Florida International University

FIU Digital Commons

$11-27-2018$

\title{
Ordered Anarchy: The Origins and Evolution of a Society of States in South America, 1864-1939
}

Nicolas Terradas

Florida International University, nterr005@fiu.edu

Follow this and additional works at: https://digitalcommons.fiu.edu/etd

Part of the International Relations Commons

\section{Recommended Citation}

Terradas, Nicolas, "Ordered Anarchy: The Origins and Evolution of a Society of States in South America, 1864-1939" (2018). FIU Electronic Theses and Dissertations. 4067.

https://digitalcommons.fiu.edu/etd/4067

This work is brought to you for free and open access by the University Graduate School at FIU Digital Commons. It has been accepted for inclusion in FIU Electronic Theses and Dissertations by an authorized administrator of FIU Digital Commons. For more information, please contact dcc@fiu.edu. 


\title{
FLORIDA INTERNATIONAL UNIVERSITY
}

Miami, Florida

\section{ORDERED ANARCHY:}

THE ORIGINS AND EVOLUTION OF A SOCIETY OF STATES

IN SOUTH AMERICA, 1864-1939

\author{
A dissertation submitted in partial fulfillment of \\ the requirements for the degree of \\ DOCTOR OF PHILOSOPHY
}

in

INTERNATIONAL RELATIONS

by

Nicolás Terradas 
To: John F. Stack, Jr.

Steven J. Green School of International and Public Affairs

This dissertation, written by Nicolás Terradas, and entitled Ordered Anarchy: The Origins and Evolution of a Society of States in South America, 1864-1939, having been approved in respect to style and intellectual content, is referred to you for judgment.

We have read this dissertation and recommend that it be approved.

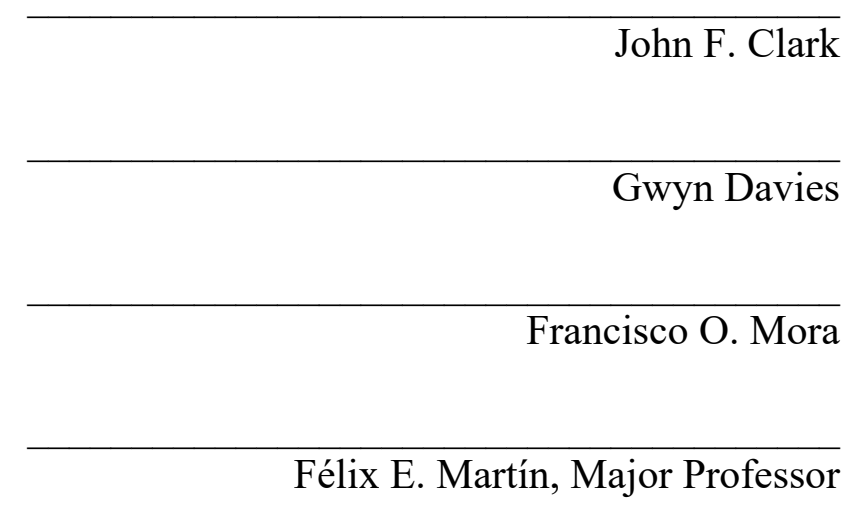

Date of Defense: November 27, 2018

The dissertation of Nicolás Terradas is approved.

John F. Stack, Jr. Steven J. Green School of International and Public Affairs

Andrés G. Gil

Vice President for Research and Economic Development and Dean of the University Graduate School

Florida International University, 2019 
(C) Copyright 2019 by Nicolás Terradas

All rights reserved. 


\section{ACKNOWLEDGMENTS}

Several individuals and institutions have supported me in the writing of this dissertation. I want to acknowledge, first and foremost, Dr. Félix E. Martín for his friendship and guidance throughout my seven years at FIU. More than simply an academic advisor or mentor, he has been like a second father to me. His legacy in terms of personal commitment, work ethics, and intellectual rigour will forever accompany me. For all his support, I am eternally grateful. I also want to acknowledge the members of my dissertation committee for their time and for their constant support of my work. Over the years, some of them have written generous letters of recommendation for a number of fellowships and grant applications. For their invaluable help, I am greatly indebted to Drs. John F. Clark, Gwyn Davies, and Frank O. Mora. Although, in the end, I was not able to officially include him in my dissertation committee, I am also immensely grateful to Dr. Miguel Á. Centeno, from Princeton University, for agreeing to be part of this project from the beginning, and for reading and commenting on my initial dissertation proposal.

From the Stephen J. Green School of Public and International Affairs (SIPA) and the Department of Politics and International Relations, I am grateful for all the support throughout the years from my professors and colleagues. In particular, I want to acknowledge the Dean, Dr. John F. Stack, Jr., for his commitment to making SIPA a research institution of the highest caliber. Similarly, for their many lessons and practical advice during my course training, I am also indebted to Drs. Thomas Breslin, John F. Clark, Ronald W. Cox, Eduardo Gamarra, Harry Gould, Paul Kowert, Mohaddin Mesbahi, and Jin Zeng. Other colleagues and friends provided support and critical advice at different stages of the project. For sharing their comments and suggestions, as well as their 
friendship, I want to thank Onur Erpul, Dr. Bibek Chand, Dr. Lukas Danner, Diego Zambrano, Nicolas Beckmann, Mike Wartenbe, Nicol Spann, Daniel Pérez, Dr. John Oates, and Dr. Erin Damman.

A very special place is reserved for Dr. Norma González and the entire staff at the Argentine Fulbright Commission, in Buenos Aires. Without their help, I would have never been able to continue my graduate education in the United States. For their support during my preparations and application process to the doctoral program at FIU, I am forever grateful. Thanks to a doctoral Fulbright Scholarship from the Department of State, I was able to fund my first two years in the Ph.D. program at FIU. Fulbright's excellent network of scholars and alumni has also left an indelible mark, allowing me to forge strong friendships all around the world.

During the research and writing process, a number of institutions also put their trust in my work. During the Fall of 2015, the Tinker Foundation awarded me, through FIU's Latin American and Caribbean Center (LACC), a generous travel grant that allowed me to conduct research in an number of key diplomatic archives in Buenos Aires and Uruguay. On two separate occasions, I also received support from the Green School through their Morris and Anita Broad Fellowships. This allowed me to visit diplomatic and national archives in Montevideo (Uruguay) and Quito (Ecuador). I also want to acknowledge the University Graduate School (UGS) at FIU for supporting me with a Dissertation Evidence Acquisition (DEA) fellowship during the Spring of 2016, which allowed me to extend my research to other diplomatic archives located in several South American countries (Argentina, Brazil, Bolivia, Chile, Paraguay, Peru, and Uruguay) for almost eleven months in total. For the Spring-Summer terms of 2018, I also received a Dissertation Year 
Fellowship (DYF) from UGS to support the writing stage of my dissertation. These grants, awards, and fellowships made possible the drafting and execution of this dissertation. For all the trust placed on me by these institutions, I am grateful, and I hope this work honors that trust.

While at the archives, several individuals made my work considerably easier and enjoyable. In Asunción, Paraguay, Juan Martínez Ávila provided invaluable assistance in my systematic perusing of the Archivo Nacional de Asunción (ANA), as well as Maria Gilda Laguardia de Llamosas and Vicente Arrúa Ávalos. Dr. Thomas L. Whigham, the world's preminent historian of the Paraguayan War, offered important comments on sources, literature, and archival "know-how" during my time in Asunción. In Buenos Aires, Analía Trouvé eased my way through the library of the Foreign Ministry, while Laura Assali and the highly-professional team working in the maintenance and (now) digitalization of the Foreign Ministry historical and diplomatic archive assisted me with the many boxes on the Paraguayan War, and other diplomatic correspondence related to the Chaco War. Graciela Sayuz and María Tarka, close family friends, generously hosted me in Buenos Aires during my research — thank you! In Bolivia, I was honored by the access granted by Sergio Elío to consult his grandfather's and father's personal archives. This not only made me the first IR scholar to have researched on these documents, but also made a substantial contribution to my understanding of the unfolding of the diplomatic negotiations during the Chaco War, helping elucidate a key aspect of the participation of the Bolivian delegation headed by Tomás Elío during the Peace Conference in Buenos Aires. Jessica Elío Mansilla, Sergio's sister, also provided crucial assistance in securing access to the archives of the Foreign Ministry in La Paz. During my visit to Santiago de 
Chile, Drs. Mauricio Rubilar Luengo, Gabriel Cid, Cristián Garay Vera, and Pablo Lacoste generously shared their time, expertise and insight, and offered relevant criticism and original ideas related to my own work. I am particularly indebted to Gabriel Cid for suggesting me to include a chapter on the War against Spain (or Guano War), as well as to Mauricio Rubilar for helping me make sense of the Chilean sources on the War of the Pacific. Cármen G. Duhart, director of the archives of the Foreign Ministry in Santiago, offered professional and efficient assistance in my perusal of the 19th-century Chilean diplomatic correspondence related to these two wars. I am also indebted to José G. Jeffs Munizaga, son of the late historian Leonardo Jeffs Castro, for sharing with me his father's doctoral dissertation - and one of the very few sources on the role of Chile during the Chaco War. Finally, while in Río de Janeiro, I profitted from the excellent team of young professionals at the Arquivo do Itamaraty, where I had the opportunity to access countless volumes of diplomatic correspondence between Brazil and its many legations around South America during the 19th century. I want to acknowledge María do Carmo Strozzi Coutinho from the Fundação Alexandre de Gusmão (FUNAG) in Rio de Janeiro, for her assistance with the valuable set of publications by the Foreign Ministry through the FUNAG.

This dissertation is dedicated to my family, who always supported me in my struggles during graduate school both in Argentina as well as in Miami. 


\title{
ABSTRACT OF THE DISSERTATION
}

\section{ORDERED ANARCHY:}

\section{THE ORIGINS AND EVOLUTION OF A SOCIETY OF STATES}

\author{
IN SOUTH AMERICA, 1864-1939
}

by

\author{
Nicolás Terradas
}

Florida International University, 2019

\author{
Miami, Florida
}

\section{Professor Félix E. Martín, Major Professor}

The present dissertation studies why South American states have fought so few wars among one another since their independence in the early 1800s, and why those wars in which they did enter were limited in intensity, casualty rates, number of battles, and overall duration. It offers an extensive review of the literature on South America's long peace and advances two critiques. First, that the existing studies have usually followed either a narrow quantitative definition of war, or a broad qualitative definition of peace. And second, that the literature tends to neglect the relevance of the 19th century in the historical formation underpinning South America's long peace. In this context, and drawing from the International Society perspective, the dissertation argues that between the mid-1860s and the late 1930s, the region developed from a mere system to a society of states through the consolidation of three key factors: first, a common interest in restraining, or taming, war in 
the region; second, the progressive institutionalization of regional order and cooperation; and third, the emergence of a pragmatic solidarity among South American neighbors when facing common threats as a region. Drawing from a large pool of primary and secondary sources collected in eight South American countries, the dissertation offers a processtracing analysis of these three causal-mechanisms across four historical case-studies: the Guano War (1864-1871), the War of the Triple Alliance (1864-1870), the War of the Pacific (1879-1884); and the Chaco War (1932-1935). For each case, six alternative hypotheses are tested in detail against both the historical record and the leading hypothesis. 


\section{TABLE OF CONTENTS}

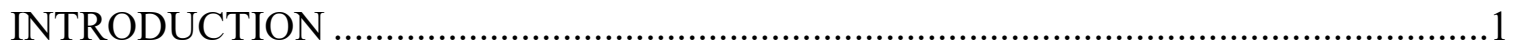

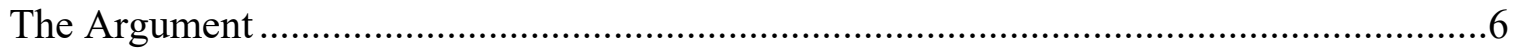

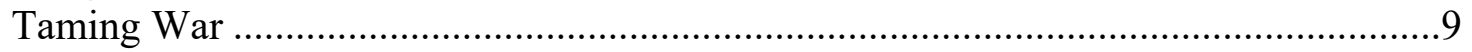

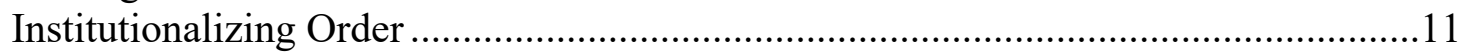

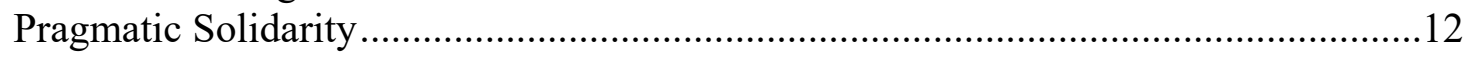

The South American Experience: 1864-1939 ………………………………….....14

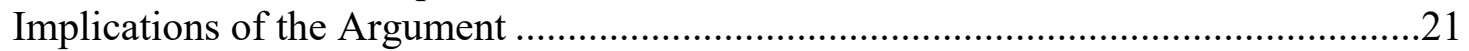

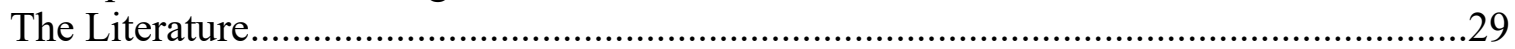

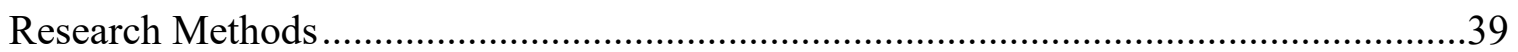

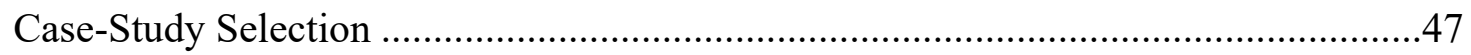

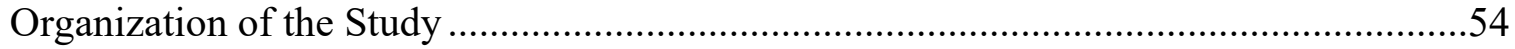

CHAPTER 1:

EXPLAINING THE LONG PEACE: CONTENDING APPROACHES …………….......62

The South American Long Peace in Context................................................................62

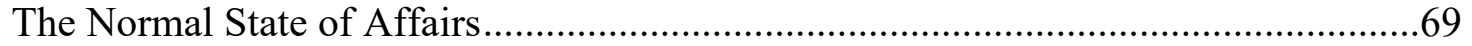

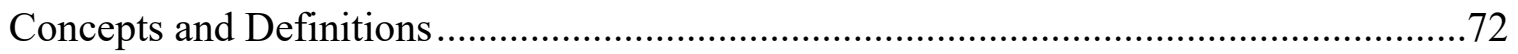

War

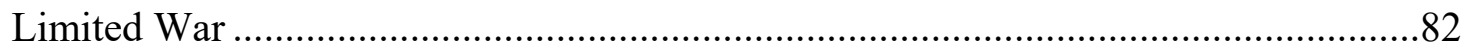

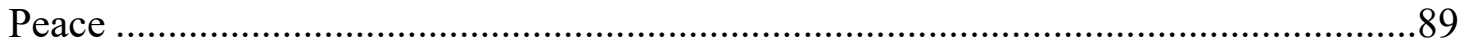

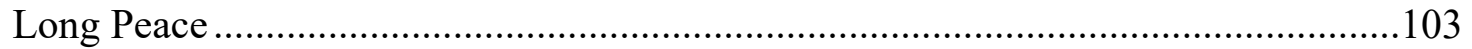

Explaining the Long Peace: Seven Contending Approaches.........................................110

(H1): South America as a Society of States .............................................................111

(H2): The United States as a Hegemonic Stabilizer...................................................119

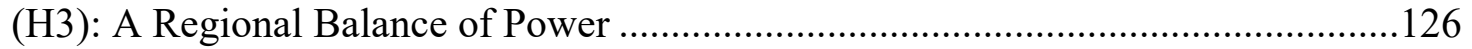

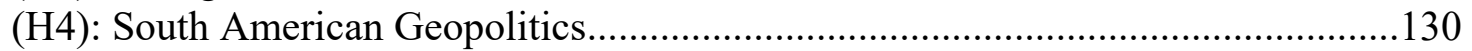

(H5): A Common Culture of Anti-Imperialism .....................................................134

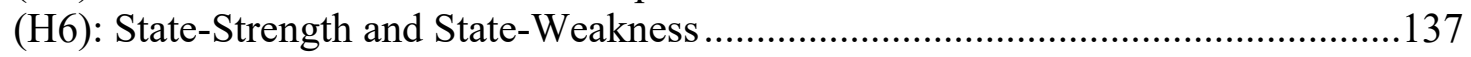

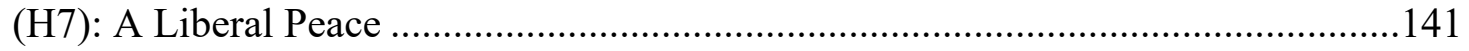

\section{CHAPTER 2:}

THE LAST STRUGGLE FOR INDEPENDENCE: WAR AND PEACE WITH THE

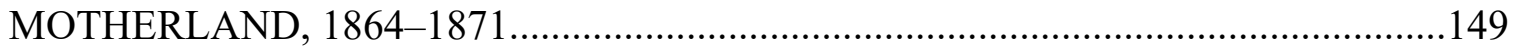

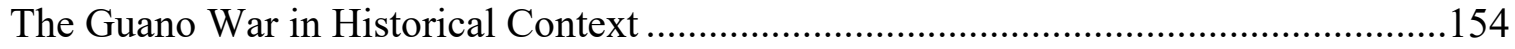

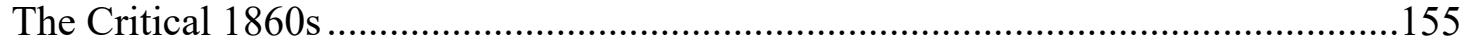

European Interventionism in the Americas........................................................158

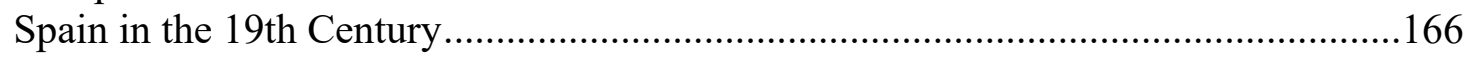

Fighting the Motherland: The First Trial of South America's Society of States..............170

Legitimacy and Restraint in the War against Spain .................................................178

Institutionalizing Order: Diplomacy and the Lima Congress of 1864 .......................188

The Quadruple Alliance: South America's Pragmatic Solidarity ................................196 


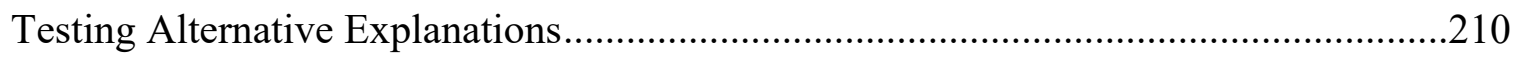

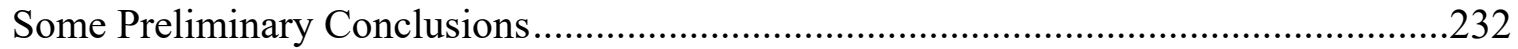

CHAPTER 3:

THE STRUGGLE FOR EQUILIBRIUM: WAR AND PEACE IN THE RIVER

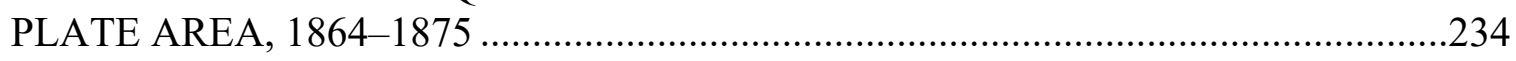

The War of the Triple Alliance: A Fight to the Death? ..................................................240

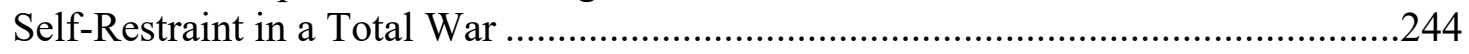

Institutionalizing a Civilized South American Order................................................28

The Consolidation of South America's Pragmatic Solidarity ..................................296

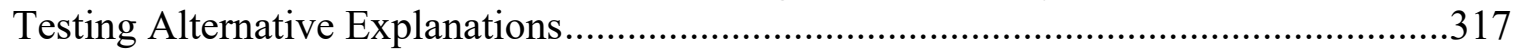

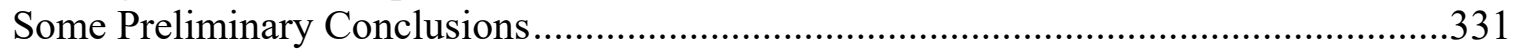

CHAPTER 4:

THE STRUGGLE FOR RESOURCES: WAR AND PEACE IN THE SOUTH

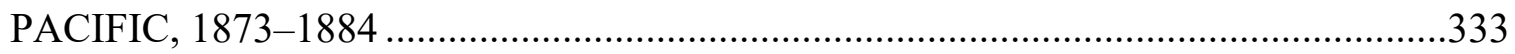

From Allies to Enemies: The Historical Context.............................................................333

The War of the Pacific: The Violent Side of Civilization ................................................336

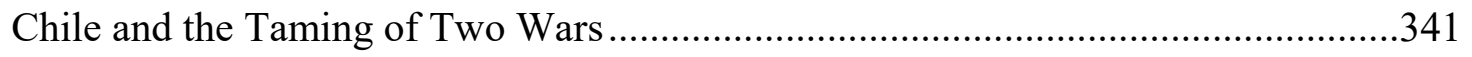

Institutionalizing Order in the South Pacific..............................................................360

Restraining Chile: Towards a Continental Pragmatic Solidarity .................................369

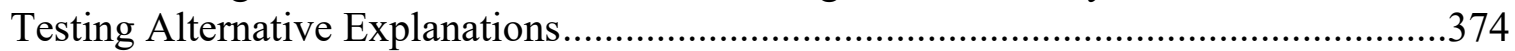

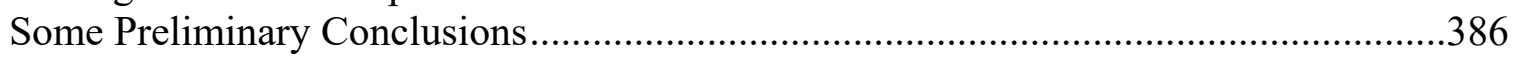

CHAPTER 5:

THE STRUGGLE FOR ORDER: WAR AND PEACE IN THE CHACO BOREAL,

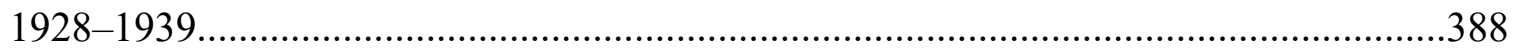

The Historical Context of the Chaco Dispute …………..............................................390

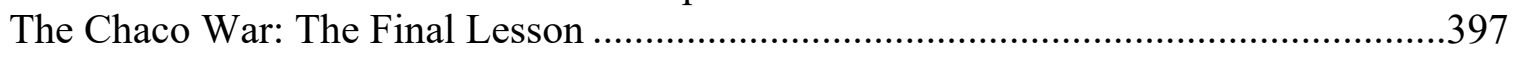

The Conduct of the Chaco War: Restraint among Friends ........................................403

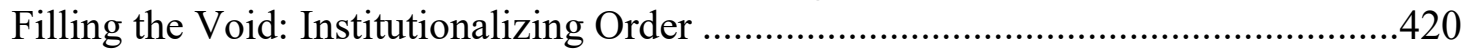

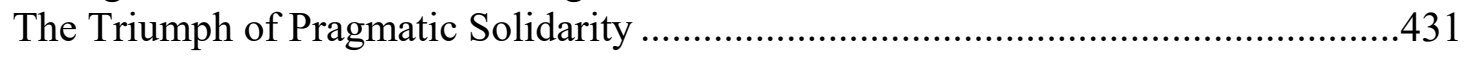

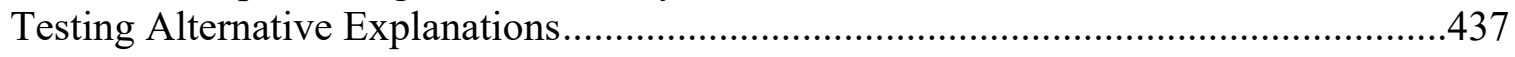

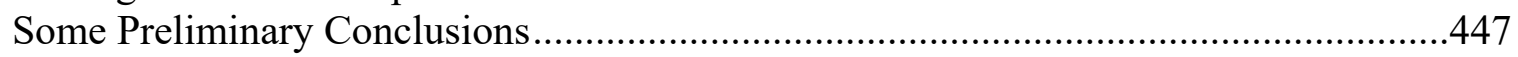

CONCLUSION: ORDERED ANARCHY IN SOUTH AMERICA ………………….....449

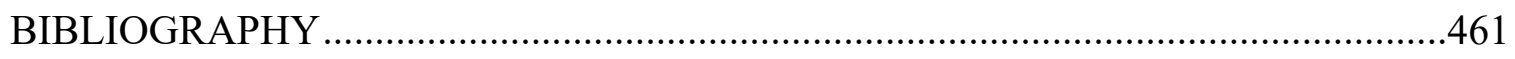

VITA ……… 


\section{LIST OF TABLES}

TABLE

PAGE

TABLE 1: Types of Tests in Case-Study Research .........................................................43

TABLE 2: Major Inter-State Wars in South America (19th and 20th Centuries) ...............80

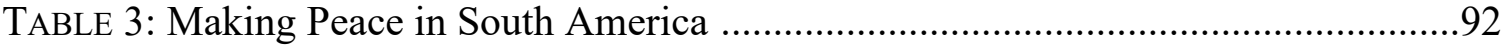

TABLE 4: Comparison of Core Arguments ....................................................................148 


\section{LIST OF MAPS}

MAP

PAGE

MAP 1: South America circa 1864 .153

MAP 2: Spain's “Scientific Expedition” to the Pacific (1862-1866).

MAP 3: Main battles in the War of the Triple Alliance (1864-1870)

MAP 4: Paraguay's borders, circa 1870

MAP 5: The Atacama region, circa 1866

MAP 6: Main battles in the War of the Pacific (1879-1884) .355

MAP 7: Main territorial gains for Chile in the War of the Pacific .368

MAP 8: The Chaco Boreal region .394

MAP 9: The Chaco War: Main forts and territorial lines (1907-1938) .395

MAP 10: Logistics of the Chaco War. .408 


\section{INTRODUCTION}

South America is unique among the regions of the world. Since achieving independence from the Spanish and Portuguese empires in the early 19th century, South American states have been at war with one another only sporadically and with restraint. No war, for example, has been fought over ideological, religious, or ethnic differences, and no state in South America has ever disappeared after being defeated in a war. Moreover, since the end of the war between Bolivia and Paraguay over the Chaco Boreal region in 1935, no new major war has broken out among South American states. This marked decline not just in the frequency but also in the intensity of the armed conflicts of the region raises an interesting puzzle for traditional theories of war and peace in the field of International Relations (IR). Although many explanations of this inter-state "long peace" have been proposed over the years, there is still little agreement about its main causes. ${ }^{1}$

\footnotetext{
${ }^{1}$ For some of the most representative works on the "long peace" in South America, see Walter Little, "International Conflict in Latin America," International Affairs, Vol. 63, No. 4 (October, 1987), pp. 589601; Jack Child, "Interstate Relations in Latin America: Peaceful or Conflictual?" International Journal, Vol. 43 (Summer, 1988), pp. 378-403; David McIntyre, "The Longest Peace: Why Are There So Few Interstate Wars in South America?" Ph.D. Dissertation, The University of Chicago (1995); Félix E. Martín González, "The Longer Peace in South America, 1935-1995," Ph.D. Dissertation, Columbia University (1998); Kalevi J. Holsti, The State, War, and the State of War (Cambridge University Press, 1996), esp. pp. 150-182; Arie M. Kacowicz, Zones of Peace in the Third World: South America and West Africa in Comparative Perspective (SUNY Press, 1998), esp. pp. 67-124; Andrew Hurrell, "Security in Latin America," International Affairs, Vol. 74, No. 3 (July, 1998), pp. 529-546; Hurrell, “An Emerging Security Community in South America?" in Security Communities, ed. by Emanuel Adler and Michael N. Barnett (Cambridge University Press, 1998), pp. 228-264; David R. Mares, Violent Peace: Militarized Interstate Bargaining in Latin America (Columbia University Press, 2001); Miguel Á. Centeno, Blood and Debt: War and the Nation-State in Latin America (The Pennsylvania State University Press, 2002); Jorge I. Domínguez, "Boundary Disputes in Latin America," Peaceworks, No. 50 (USIP, September, 2003), pp. 145; Barry Buzan and Ole Wæver, Regions and Powers: The Structure of International Security (Cambridge University Press, 2003), pp. 263-342; Andrea Oelsner, International Relations in Latin America: Peace and Security in the Southern Cone (Routledge, 2005); Félix E. Martín, Militarist Peace in South America: Conditions for War and Peace (Palgrave Macmillan, 2006); Kacowicz, The Impact of Norms in International Society: The Latin American Experience, 1881-2001 (University of Notre Dame Press, 2006); and Benjamin Miller, States, Nations, and the Great Powers: The Sources of Regional War and Peace (Cambridge University Press, 2007), pp. 306-336.
} 
What makes South America particularly unique is that, unlike other regions, it has remained free of major war in the absence of the same factors that have kept other parts of the world at peace. ${ }^{2}$ South American international relations, for example, cannot be explained by nuclear deterrence or the military presence of a preponderant power guaranteeing regional order in situ. ${ }^{3}$ Similarly, the Kantian idea of "peace among republican democracies" runs into serious empirical problems when applied to South America. During the 1930-1990 period, the region was populated by a multiplicity of authoritarian regimes, yet inter-state peace prevailed. Furthermore, one of the most enduring rivalries in 20th-century South America was precisely between two democracies, Ecuador and Peru, which also led to other limited armed confrontations in 1981 and $1995 .^{4}$

\footnotetext{
${ }^{2}$ An important recent body of literature has established that both inter-state war and inter-personal violence have been in steady decline globally since the mid-20th century. The main theoretical explanations for these general trends, however, do not apply well to the South American case. For some of the best exponents of this literature, see Steven A. Pinker, The Better Angels of Our Nature: Why Violence Has Declined (Viking, 2011); Andrew Linklater, The Problem of Harm in World Politics: Theoretical Investigations (Cambridge University Press, 2011); Linklater, Violence and Civilization in the Western States-Systems (Cambridge University Press, 2017); Joshua S. Goldstein, Winning the War on War: The Decline of Armed Conflict Worldwide (Plume, 2012); Azar Gat, The Causes of War and the Spread of Peace: But Will War Rebound? (Oxford University Press, 2017). For some of the sharpest critical reviews of this literature, $c f$. Andrew Lawler, "The Battle Over Violence," and "Civilization's Double-Edged Sword," both in Science, Vol. 336, No. 6083 (May 18, 2012), pp. 829-830, 832-833; John Gray, "Delusions of Peace," Prospect (October, 2011), pp. 40-44; Elizabeth Kolbert, "Peace in Our Time," The New Yorker, Vol. 87, No. 30 (October 3, 2011), pp. 75-78; Page Fortna, John J. Mearsheimer and Jack S. Levy, "Review Symposium: Has Violence Declined in World Politics?" Perspectives on Politics, Vol. 11, No. 2 (June, 2013), pp. 566-577; Jacqui True, “Are War and Violence Really in Decline?" Australian Journal of International Affairs, Vol. 68, No. 5 (2014), pp. 487-494; Brett Bowden, Civilization and War (Edwards Elgar, 2013); Steven A. Pinker, Bradley A. Thayer, Jack S. Levy and William R. Thompson, "The Forum: The Decline of War," International Studies Review, Vol. 15, No. 3 (September, 2013), pp. 396-419; and Michael Mann, "Have Wars and Violence Declined?" Theory and Society, Vol. 47, No. 1 (February, 2018), pp. 37-60.

${ }^{3}$ The most well-studied cases are that of Europe and the North Atlantic Treaty Organization (NATO), and that of the United States' presence with large military bases in East Asia. Other, less well-studied, cases are that of the Sub-Saharan Africa and the Norden Region. Traditional theories of IR encounter no problems for explaining the prevalence of order and peace in these cases.

${ }^{4}$ These limited armed conflicts are commonly known, respectively, as the Zarumilla-Marañón, the Paquisha, and the Cenepa disputes. For a historical overview of this enduring rivalry, see David H. Zook, Zarumilla-Marañón: The Ecuador-Peru Dispute (Bookman, 1964); Bryce Wood, Aggression and History: The Case of Ecuador and Peru (UMI, 1978); Wood, The United States and Latin American Wars, 1932-
} 
In parallel to this relative "long peace" among states, South America has also experienced high levels of intra-state armed violence for most of its history. This phenomenon, which one scholar has called the "external-peace-internal-violence paradox," ${ }^{5}$ has been particularly pronounced since the 1930s, when a wave of dictatorial regimes began to spread across Latin America. ${ }^{6}$ Indeed, the egregious record of human rights violations and protracted civil wars in Latin America has few parallels anywhere else in the world. Despite the advent of a new and more stable wave of democratic regimes in the late 1980s, Latin America still occupies today the rarest of positions: it is simultaneously one of the safest neighborhoods for the state, while also the most violent and dangerous region for the individual citizen. ${ }^{7}$

This aspect of the region, however, challenges not only popular ideas about the impact of the type of regime on the achievement, maintenance, or deepening of regional

1942 (Columbia University Press, 1966), pp. 167-342; and David R. Mares and David S. Palmer, Power, Institutions, and Leadership in War and Peace: Lessons from Peru and Ecuador, 1995-1998 (University of Texas Press, 2012). In 1932, Peru was also engaged in a border dispute with Colombia, which is commonly known as the Leticia dispute. For a brief history of this dispute, see Wood, The United States and Latin American Wars, pp. 167-251; Juan M. Bákula, La política internacional entre el Perú y Colombia (Bogotá: Temis, 1988); Alberto Donadío, La guerra con el Perú (Hombre Nuevo, 2nd ed., [1995] 2002); Ronald Bruce St. John, La política exterior del Perú (AFSDP, 1999), pp. 162-185; Juan C. Restrepo Salazar and Luis I. Betancur, Economía y conflicto colombo-peruano (Villegas, 2001); and Carlos Camacho Arango, El conflicto de Leticia (1932-1933) y los ejércitos de Perú y Colombia (Universidad Externado de Colombia, 2016).

${ }^{5}$ The concept was first introduced in 1998 by Martín, "The Longer Peace in South America," pp. 367-368. See also Martín, Militarist Peace in South America, pp. 163, 179, 6, 7, 149. A similar dynamic is identified in Centeno, Blood and Debt, pp. 66, 262-264; Kacowicz, The Impact of Norms in International Society, p. 10; and Kacowicz, Zones of Peace in the Third World, p. 70.

${ }^{6}$ See, e.g., Stanislav Andreski, "On the Peaceful Disposition of Military Dictatorships," Journal of Strategic Studies, Vol. 3, No. 3 (1980), pp. 3-10. The number of coups d'état in Latin America has always been high. In the 20th century, however, military rule became a more stable phenomenon. For an excellent discussion of this trend, see Walter Little, "Military Power in Latin America: An Overview," Working Paper No. 4 (University of Liverpool, Institute of Latin American Studies, 1986), pp. 1-91.

${ }^{7}$ See, e.g., Daniel M. Goldstein and Enrique D. Arias, eds., Violent Democracies in Latin America (Duke University Press, 2010); David Luhnow, "Latin America is World's Most Violent Region," The Wall Street Journal, April 11, 2014; and Amanda Erickson, "Latin America is the World's Most Violent Region: A New Report Investigates Why,” The Washington Post, April 25, 2018. 
peace, but also other popular types of explanations. Cultural explanations, for example, which highlight Latin America's relative homogeneity in language, religion, customs and cultural identity as a factor conducive to peace, have equally failed to account for the region's persistent low levels of political and economic integration, as well as the problematic coexistence of high levels of intra-state violence amid international peace. All of these factors make South America's "long peace" an exceptionally hard regional test for traditional theories about the causes of war and the conditions for peace.

In this context, this dissertation examines the most fundamental puzzle confronting those who seek to explain enduring types of regional order. The type of questions addressed in this study are the following: What are the main causes of stable regional order? More specifically, what explains South America's regional order in the absence of traditional sources of international peace and the presence of enduring intra-state insecurity? What are the historical preconditions that made such a paradoxical regional order possible in the first place? In short, what are the historical causes of South America's "long peace"? These questions arise from the distinctive and challenging nature of South America as a regional case study in IR. While other prominent instances of stable regional order have been wellstudied through major theoretical approaches, South America continues to resist similar explanations. ${ }^{8}$

Although the study of this long regional peace has generated a rich and ongoing academic debate, it remains a highly contested area of research. Scholars often disagree

\footnotetext{
${ }^{8}$ Despite its relevance as a regional case study, attention to this topic is still poor. One of the best recent contributions to regional studies from an IR-theory perspective, for example, barely makes any reference to Latin America - apart from mentioning the word "MERCOSUR" only three times in one chapter. See Tazha V. Paul, ed., International Relations Theory and Regional Transformation (Cambridge University Press, 2012).
} 
over concepts as foundational as war or peace, and still continue to dissagree on the characteristics and periodization of the "long peace" itself. In this sense, attention is often paid almost exclusively to either quantitative definitions of war, or to qualitative definitions of peace. Additionally, while some works focus only on the inter-state side of the debate, others recognize its coexistence with factors like domestic armed violence and dictatorial regimes, yet no general explanation has emerged to support an academic consensus on the causes of the "long peace." What is perhaps most disconcerting about the academic "debate" is the fact that scholars have only rarely addressed each other's arguments directly, avoiding for the most part to engage with other specific contending explanations. ${ }^{9}$

Despite the absence of an academic consensus, policy commentary often takes the "peaceful" nature of the region largely for granted. ${ }^{10}$ The risks of such declarations, however, are multiple. Apart from fueling a problematic sense of optimism in viewing the region as an already consolidated "zone of peace," similar ideas regularly influence foreign policy and decision-making across the region. South America is thus often presented as a "model" or an "example" for other regions to follow and imitate. ${ }^{11}$ These popularized views may give a false impression of the region as "inherently peaceful," and thus draw attention away from the examination of the intra-state dimension of the problem-a dimension that upon closer scrutiny evokes more concern than admiration. A failure to

\footnotetext{
${ }^{9}$ While some contributions do contrast their arguments with major IR theories of war and peace, no single study directly engages the specific contending arguments for the "long peace" in South America per se. For a critical review of the debate, see Nicolás Terradas, "El dilema de la seguridad en América del Sur: Una revisión del debate sobre la 'larga paz' sudamericana," M.A. Thesis, Universidad Torcuato Di Tella (2010). ${ }^{10}$ See, e.g., the "Proclamation of Latin America and the Caribbean as a Zone of Peace," Havana, Cuba, IV RMRE Doc. 3.3, January 27, 2014.

${ }^{11}$ Only a limited number of contributors has raised awareness of the potential dangers of such claims. See, e.g., Centeno, Blood and Debt, pp. 264, 99-100; Martín, Militarist Peace in South America, pp. 181-182; Mares, Violent Peace; and Kacowicz, Zones of Peace in the Third World, pp. 69-70.
} 
understand the importance of deriving good policy from good diagnosis could have negative consequences for the future of the region itself. By uncritically assuming that both the external and internal aspects of this "long peace" can be kept analytically separate, for example, as if both factors were mutually independent from one another, policy-makers could come to implement policies that in the longer run may end up undermining - rather than upholding - the present regional order. In this context, developing a good historical diagnosis emerges an indispensable task required before any policy is responsibly suggested, promoted, or consciously followed.

\section{The Argument}

The central argument of this dissertation is that the "long peace" in South America is the result of a historical process of formation and consolidation of a regional society of states. The progressive consolidation of such a society has alleviated the intensity of security competition among South American states and, thereby, made war less frequent and less intense over time. When states see themselves as members of a society of states they develop a sense of common strategic interests through which their conceptions of the "national interest" (or raison d'état) are intertwined with the larger interest of the group of states as a whole. When their strategic interests so converge, the society of states strengthens and security competition substantially relaxes, giving way to a more enduring regional order. When such interests do not converge, or do so only minimally, purely selfish conceptions of the national interest come to predominate and the society of states 
weakens. Under these conditions, security competition is stressed and war becomes a more frequent and intense regional phenomenon. ${ }^{12}$

A society of states (or international society) exists when a group of states becomes conscious of certain common interests and values. Thus, member states come to conceive themselves to be bound by a common set of rules in their relations with one another and share in the working of common institutions. ${ }^{13}$ States, however, do not have minds of their own and can only be considered "to act" or "to have interests" at all via the thoughts and actions of those individuals located in key positions of power with enough authority to design and implement policies in the name of the states and societies over which they preside. ${ }^{14}$ In an empirical sense, therefore, a society of states is characterized by the presence of national elites in charge of foreign policy and diplomacy who come to perceive their own nations' strategic interests and values as inescapably interdependent with the interests and values of the overall society of states. In this context, when national interests are perceived in this particular way by enough states in a certain region, it is possible to speak of these elites as upholding a raison de système in how they conceive, plan, and execute foreign policy. A raison de système (or "visión de conjunto") is thus not an outright rejection of the logic of raison d'état that characterizes traditional power politics, but

\footnotetext{
${ }^{12}$ On these aspects of international society, see Hedley Bull, The Anarchical Society: A Study of Order in World Politics (Columbia University Press, 1977), pp. 8-16; and Martin Wight, "Western Values in International Relations," in Diplomatic Investigations: Essays in the Theory of International Politics, ed. by Herbert Butterfield and Martin Wight (Harvard University Press, 1966), pp. 102-104. On the general implications for Bull's approach to the study of "anarchical orders" in general, see Nicolás Terradas, "The Quest for Order in Anarchical Societies: Anthropological Investigations," International Studies Review [forthcoming], https://doi.org/10.1093/isr/viy078.

${ }^{13}$ See Bull, The Anarchical Society, p. 13.

${ }^{14}$ On the understanding of "states" via the thoughts and actions of their key decision-makers, this study follows the well-known formulation by Robert H. Jackson, The Global Covenant: Human Conduct in a World of States (Oxford University Press, 2000), esp. pp. 130-134.
} 
simply a more encompassing understanding of the long-term "true interests" of the state. As Adam Watson eloquently put it, raison de système can be defined as "the belief that is pays to make the system work." ${ }^{15}$ Conceiving, articulating, and ultimately pursuing strategies under the belief that a state's national interest cannot be fully disentangled from the interests (and survival) of the system of states as a whole leads to different types of behavior and regional dynamics than the ones hypothesized by more traditional theoretical approaches to IR.

When a strong society of states forms, therefore, three fundamental aspects characterize the international relations of its members: (a) the use of force is restrained or tamed, and traditional power competition acquires a less extreme tone and character; (b) members of a society of states increasingly institutionalize their relations, creating a "thicker" set of rules and norms that can be reinforced by developing formal regional organizations; and (c) states display a tendency towards "pragmatic solidarity," usually in the form of a collective defense of regional order, but also in efforts towards the prevention of war and the preservation of peace among members of a society of states. Overall, although the use of force is not wholly eliminated, it is severely restrained, institutionalized, and regulated.

\footnotetext{
${ }^{15}$ See Adam Watson, Diplomacy: The Dialogue Between States (Routledge, 1983), pp. 201ff; Watson, "Systems of States," Review of International Studies, Vol. 16, No. 2 (1990), p. 104; Watson, The Evolution of International Society: A Comparative Historical Analysis (Routledge, 1992), p. 14; Watson, The Limits of Independence: Relations Between States in the Modern World (Routledge, 1997), pp. 95-105, 149-50. See also Herbert Butterfield, "Raison d'État: The Relations Between Morality and Government," The First Martin Wight Memorial Lecture delivered in the University of Sussex on 23 April 1975; and Alberto R. Coll, The Wisdom of Statecraft: Sir Herbert Butterfield and the Philosophy of International Politics (Duke University Press, 1985).
} 


\section{Taming War}

In a society of states, "raw" power politics gives way to diplomatic accommodation, as state survival and other existential concerns become secure. This change can be most clearly seen in the way in which states exercise force towards other members of the society of states, on the one hand, and towards extra-regional states or non-members, on the other. ${ }^{16}$ War is thus "tamed" in the sense that it is only invoked and practiced collectively against a common threat (either from within or without the region) or in cases of strict selfdefense. ${ }^{17}$ War is also tamed in the sense that members will mutually recognize certain limits in the application of organized armed violence against one another by accepting shared standards of normative and procedural restraint — standards that are largely followed even during war and which are further institutionalized in treaties, legal conventions, and regional organizations. States will take prisoners, instead of mercilessly killing the captured enemy troops; they will abide by commonly agreed legal and cultural practices of international military etiquette and "civilized" behavior; states will also try to prevent wars among neighbors from happening, or to stop them once they break out, instead of actively promoting them or rapaciously taking advantage of the neighboring belligerent states. Consequentially, states will collectively reject offensive war and agree to use force only in a proportionate and legitimate manner. The taming of war among members, therefore, not

\footnotetext{
${ }^{16}$ A further distinction can also be made between different types of members within the same society of states. Such was the case of Latin America, for instance, during the early decades after independence vis-àvis the European society of states. For a good analysis of this dynamic, see Carsten-Andreas Schulz, "Civilisation, Barbarism and the Making of Latin America's Place in 19th-Century International Society," Millennium, Vol. 42, No. 3 (2014), pp. 837-859; and Cristian Cantir, "'Savages in the Midst':

Revolutionary Haiti in International Society (1791-1838)," Journal of International Relations and Development, Vol. 20, No. 1 (January, 2017), pp. 238-261.

${ }^{17}$ See Bull, The Anarchical Society, pp. 19-20; and Wight, "Western Values in International Relations," pp. 92-111.
} 
only narrows the scope of issues over which a legitimate war can be fought, but also moderates the extent of violence that participants and non-participants are expected to use in a reciprocal manner.

Although occasional violations of formal and informal procedures of restraint can certainly happen, violators will go to great lengths in trying to justify their acts as "legitimate" ones. In such cases, states will try to convince others that their use of force is still in accordance with the rules and values of international society, or that it is an exception that should be considered. In a society of states, unlike in a mere system, these efforts in justification and legitimation-even when constituting outright "lies"-are an important aspect of the functioning of diplomacy and the society of states as a whole. Losing the legitimacy game, for instance, could trigger a collective repudiation (or even concerted action) against the violator itself. Under these circumstances, states will care a great deal about gathering support for their cause and being identified by others as just, moderate, or responsible international actors. The extent to which states make frequent and costly efforts in justifying their international behavior to others is a good indicator of the level of "maturity" (or strength) of a society of states. It also expresses an interest in behaving in concert with others by taking into account their interests and opinions regarding what is considered by all as legitimate, responsible, and acceptable behavior.

It is important to underscore that these efforts are done not out of a sense of selfless altruism, but as a well-conceived strategy for advancing what is perceived by the ruling elites as the long-term national interest of the state. Understanding South America as a society of states, rather than a mere regional "balance of power," or "zone of peace," or "security community," as in the extant literature, helps to recapture the crucial role that the 
use of force can have in upholding regional order when fundamentally threatened or contested. In short, it avoids treating war (or the use of force, more generally) only as a destabilizing factor or as something to be eradicated in order to achieve regional peace.

\section{Institutionalizing Order}

A second fundamental change that occurs when a society of states forms is that traditional inter-state competition takes on a more institutionalized character-both formally and informally. In a society of states, foreign policy is channeled through sustained institutional practices, such as the upholding of a "conscious" (or intended) balance of power, the primacy of diplomacy, and the honoring of international law and agreements. There is also an implicit recognition of those members deemed capable and willing to uphold the system's interest when threatened. That is, the strongest states (both economically or militarily) will be expected to be the "outstanding citizens" of the society of states, and will be held accountable by others for it. Thus, regional "great powers" become the "great responsibles" by taking on more roles and responsibilities than the other members in relation to the protection and effective functioning of the society of states itself. It is important to note that states do not abandon their sovereignty, giving way to a "centralized" or hierarchical society - or a supranational state. States, in fact, continue to jealously defend their respective autonomies and resist any pulls for supranational unification or political integration, as well as against other centripetal forces pulling towards greater fragmentation and national autarky. They form, in the proper sense of the term, an "anarchical society" of states. By conferring larger roles and responsibilities to the the strongest regional powers, the subyacent assymetries of power can be stabilized and 
managed more peacefuly by implicating every member in a binding association forged by common interests in the preservation of each others' autonomies and independence.

When such arrangements take root, international relations can also develop more formal institutions. Apart from the traditional sustained normative practices identified above, regional organizations and other fora, like amphictyonic congresses or international conferences, emerge as common diplomatic machanisms where the general interest of the regional system is invoked and discussed multilaterally_rather than imposed unilaterally by some preponderant power. In sum, states acknowledge the limits of autarky and recognize each other's in-dependence as well as inter-dependence; they commit to respect their mutual sovereignty and international agreements, and to further subject themselves to certain limitations in the use of force towards one another, according to agreed standards of "civilized" behavior. ${ }^{18}$

\section{Pragmatic Solidarity}

When a society of states forms and consolidates, war declines in frequency and intensity. The use of force becomes a highly-regulated activity to be employed only in exceptional circumstances and according to legitimate reasons. The third fundamental change, therefore, is reflected in the way in which neighboring states react to challenges and threats

\footnotetext{
${ }^{18}$ The use of the word "civilized" is quite pertinent here not simply because it is part of the conceptual "tool-box" of the international society approach, but also because it was widely employed throughout the 19 th century (and even in the early decades of the 20th) by diplomats, foreign-policy executives and decision-makers, as well as the wider population, public intellectuals, and the press. For the best-known contemporaneous example, see Domingo F. Sarmiento, Facundo; o civilización i barbarie en las pampas arjentinas (Buenos Aires: [n/d], 4th ed., [1845] 1868). For a modern reflection, see Maristella Svampa, Civilización y barbarie: El dilema argentino (Buenos Aires: Taurus, 2010). On the more general aspects of civilizational views in the 19th century, see Brett Bowden, The Empire of Civilization: The Evolution of an Imperial Idea (The University of Chicago Press, 2009).
} 
to regional order. When force is employed in illegitimate ways, or when it is used by an extra-regional power against a member of the society of states, neighboring states will display a sense of "pragmatic solidarity" by identifying the threat as a collective one, common to all-even when not directly involved in the conflict per se (see Chapters 2-5 of this dissertation). In short, the strategic awakening that entails developing a raison de système and forming a society of states affects how threats to the regional order are collectively perceived and dealt with.

In this context, when a society of states is weak, neighboring states will interpret their national interests in a purely selfish way and will react towards regional threats with indifference and calculated opportunism. For example, when states fail to conceive themselves as members of a society of states, they will often take strategic advantage of a war occurring between two neighbors, or between a neighbor and an extra-regional great power. Such purely self-serving acts will take the form of more than a simple declaration of neutrality, which would already imply a set of rules and expected behaviors defining what the roles and responsibilities of a neutral state would be. Instead, these acts would normally take the form of assistance to the aggressing state, or even a direct aggression against the weaker side in a dispute. In other words, a state would take advantage of a neighbor's misfortunes in war to further its own selfish short-term national interest.

On the contrary, when a sense of society among states is strong, national interests are unavoidably connected to the common interest and fate of the overall regional system. In this case, states cannot afford to be indifferent to such critical situations as, for example, a major war or a foreign intervention in their same regional neighborhood. The reason is simple: Cold and calculated indifference, or mere proclamations of neutrality, can become 
extremely costly for other actors beyond the belligerents themselves. A major war can potentially destabilize the functioning of the entire regional order, and thus undermine the security and survival of all the other states combined. A society of states, therefore, develops on the basis of a shared sense of common strategic interests, while simultaneously being affected by a geographical identification given by spatial and historical proximity. The use of force is thus only tolerated when employed for the enforcement, or protection, of the legitimate interests of the society of states itself. ${ }^{19}$

\section{The South American Experience: 1864-1939}

In the case of South America, in the span of less than sixty years, relatively new and unexperienced states established from the rubble of the independence wars a highly complex regional system of states. ${ }^{20}$ This system imported not only industrialized products and people from Europe and elsewhere, but also ideas, culture and diplomatic standards to cope with their rapidly growing domestic and regional political scenarios. If the 1810-1830 was a period of wars of emancipation and state-formation, the 1830-1880 was one of stateconsolidation — both internally as much as internationally. During this period, states became strongly "inward-looking," as they focused on achieving internal order against indigenous communities, recalcitrant caudillos and other regional leaders, who violently resisted the growing political and territorial encroachment by centralizing "national"

\footnotetext{
${ }^{19}$ See Wight, "Western Values in International Relations," pp. 92-102; Wight, Systems of States (Leicester University Press, 1977), esp. pp. 21-45; Bull, The Anarchical Society, pp. 8-14, 24-27, 40-51.

${ }^{20}$ For an excellent overview of the process, see Charles C. Griffin, "The States of Latin America," in The New Cambridge Modern History, Vol. XI, ed. by Francis H. Hinsley (Cambridge University Press, 1962), pp. 516-541; Centeno, Blood and Debt; and Adam Watson, "New States in the Americas," in The Expansion of International Society, ed. by Hedley Bull and Adam Watson (Clarendon Press, 1984), pp. $127-141$.
} 
governments throughout the region. The simultaneity of each state-building project, however, created externalities for the development of a region that escape the classical Tillyan dialectic between state-making and war-making. ${ }^{21}$ The stabilization of an "external" order, in short, became as important as the maintenance of the "internal" one. ${ }^{22}$ In 19th-century South America, diplomatic practices and institutions were transposed and copied directly from European standards of the time. These standards, moreover, played a crucial role in framing their common struggle for independence and, later, their wars of state-formation and consolidation between the $1860 \mathrm{~s}$ and the late $1880 \mathrm{~s}$. This also gave birth to a strong regional interest in the maintenance of order inter se, partly as a safeguarding mechanism against interventions from European powers, and partly as a reassurance of the stabilization of their respective domestic orders. In the context of that century, for example, republicanism (as a relatively new form of government) had not yet acquired an established international status. For this reason, several European powers pressured and coerced weaker nations on a regular basis throughout the 19th century in the hopes of reasserting themselves in the Americas via the infamous practice of "gunboat diplomacy." 23

\footnotetext{
${ }^{21}$ See Charles Tilly, ed., The Formation of National States in Western Europe (Princeton University Press, 1975), pp. 3-83, 601-638; Tilly, "War Making and State Making as Organized Crime," in Bringing the State Back In, ed. by Peter B. Evans, Dietrich Rueschenmeyer and Theda Skocpol (Cambridge University Press, 1985), pp. 169-191; and Tilly, Coercion, Capital and European States, AD 990-1990 (WileyBlackwell, rev. and enlarged ed., [1990] 1992). For a self-critique, see Tilly, "States, State Transformation, and War," in The Oxford Handbook of World History, ed. by Jerry H. Bently (Oxford University Press, 2011), pp. 176-194. Other influential works in a same line are Michael Mann, States, War and Capitalism: Studies in Political Sociology (Basil Blackwell, 1988); and Bruce Porter, War and the Rise of the State (The Free Press, 1994).

${ }^{22}$ On this dynamic, see Centeno, Blood and Debt; and Fernando López-Alves, "The Latin American Nation-State and the International," in Thinking International Relations Differently, ed. by Arlene B. Tickner and David L. Blaney (Routledge, 2012), pp. 161-180.

${ }^{23}$ See, e.g., Hilda Sábato, "Arms and Republican Politics in Spanish America: The Critical 1860s," in American Civil Wars: The United States, Latin America, Europe, and the Crisis of the 1860s, ed. by Don
} 
Although a common interest in securing internal and regional order was present from the very beginning of the post-independence period, as evoked by some of its most renowned national heroes, such as Simón Bolívar, Bernardo O’Higgins, or José de San Martín, it was not until the internal unification of major South American states was finally achieved that a shared sense of regional interest (or raison de système) could successfully develop and shape diplomatic relations in South America. Before the 1860s, for example, permanent diplomatic representations were almost non-existent among most Latin American nations. ${ }^{24}$ It was not until internal order was secured that an order among neighbors could become a viable strategic concern and a stable basis for interaction. As South American states soon came to understand, sometimes at the heavy cost of losing blood and treasure in a major war, the protection of the one was inextricably linked to the creation and maintenance of the other.

By the end of the 1880s, therefore, South America had experienced a quick process of state-consolidation that left on its path the most violent conflicts of its shared history. Even after this process was over, several border and territorial issues remained unresolved and the focus of intense diplomatic disputes and negotiation during the early decades of the 20th century. As Chapter 4 shows, for example, although the War of the Pacific between

H. Doyle (The University of North Carolina Press, 2017), pp. 185-203; Carmen Mc Evoy and Ana M. Stuven, eds., La república peregrina: Hombres de armas y letras en América del Sur, 1800-1884 (Lima: Instituto Francés de Estudios Andinos; Instituto de Estudios Peruanos, 2007); Joaquín Fermandois and Mariana Perry, "El factor internacional en la conciencia del estado-nación: Chile entre Argentina y Brasil, 1889-1902," in Estado y nación en Chile y Brasil en el siglo XIX, ed. by Ana M. Stuven and Marco A. Villela Pamplona (Santiago: Ediciones Universidad Católica de Chile, 2009), pp. 209-226. See also John F. Cady, Foreign Intervention in the Rio de la Plata, 1838-50: A Study of French, British, and American Policy in Relation to the Dictator Juan Manuel Rosas (AMs Press, 1969); and Joseph Smith, Illusions of Conflict: Anglo-American Diplomacy Toward Latin America, 1865-1896 (University of Pittsburgh Press, 1979).

${ }^{24}$ See Robert N. Burr, By Reason or Force: Chile and the Balancing of Power in South America: 18301905 (University of California Press, 1965); and Watson, "New States in the Americas." 
Chile and the Peru-Bolivia alliance officially ended in 1884 with the signing of the Treaty of Valparaíso by Bolivia ${ }^{25}$ several provisions of the final agreements remained controversial and unfulfilled. This soon created new sources of diplomatic tension that lasted for more than four decades. Similarly, the end of the War of the Triple Alliance against Paraguay in 1870, examined in Chapters 3 and 5, opened a series of controversies regarding the territorial borders between Paraguay (utterly defeated in the war) and neighboring Bolivia (later defeated in the War of the Pacific). This long-standing and equally unresolved dispute between Bolivia and Paraguay over the demarcation and ownership of the Chaco Boreal region generated tensions that lasted for more than fifty years and that finally erupted in the largest South American war of the 20th century: the Chaco War of 1932-1935.

These major armed conflicts, therefore, are profoundly interconnected one with the other and cannot be properly studied from an IR perspective as anything but as episodes in a long and complex historical process - rather than as discrete and self-enclosed conflicts. The traditional approach by Latin American historians has been to produce erudite, but partial, histories of each of these major wars through the eyes of one, or a few, of the states involved in the war. These "national histories," however, are rarely framed in a proper global perspective, nor do they contextualize the war itself as part of a larger historical evolution of the region itself. Although attention is often paid to the military-diplomatic aspects of these wars, no IR theory or theoretical approach is ever employed to approach these conflicts from a regional or global perspective. At best, historiographical work

\footnotetext{
${ }^{25}$ Peru had signed the Treaty of Ancón in 1883.
} 
remains confined to erudite "diplomatic histories" which pay little attention to theoretical, or more abstract, sets of explanations. ${ }^{26}$

In sum, during its historical evolution, South America became a society of states that progressively regulated and tamed the use of force as a tool of statecraft and diplomacy. The further institutionalization of this society and the reinforcement of a common interest in order made regional dynamics less violent and more stable over time. Although in many instances war could not be prevented in South America, as the case studies in this dissertation show, the presence of a society of states had an important impact on how those wars were waged and, ultimately, resolved. International society has had an additional direct impact on the reduction in the number and intensity of wars in the regionspecifically underpinning the region's "long peace" during the 20th century. Upon closer scrutiny, South America's major wars show that these were not simply violent encounters among bitter or irreconcilable enemies, bent on utterly destroying or annihilating one another a la romana, nor conflicts waged without any standards of conduct and restraint in the extent of the means of violence employed. As shown in the four case studies, the political objectives of these wars were typically limited - and so was also the way wars were fought in South America. ${ }^{27}$

\footnotetext{
${ }^{26}$ See, inter alia, Efraím Cardozo, Hace 100 años: Crónicas de la guerra de 1864-1870 (Asunción: El Lector, 2nd ed., [1967] 2010). 4 vols.; Ramón J. Cárcano, Guerra del Paraguay: Orígenes y causas (Buenos Aires: Viau, 1939); Cárcano, Guerra del Paraguay: Acción y reacción de la Triple Alianza (Buenos Aires: Viau, 1941). 2 vols.; Thomas L. Whigham, La guerra de la Triple Alianza (Asunción: Taurus, 2010-2012), 3 vols.; Juan J. Fernádez Valdés, Chile y Perú: Historia de sus relaciones diplomáticas entre 1819 y 1879 (Santiago: Cal \& Canto, 1997); Fernádez Valdés, Chile y Perú: Historia de sus relaciones diplomáticas entre 1879 y 1929 (Santiago: RIL; ADICA, 2004); and Juan M. Bákula, Perú, entre la realidad y la utopía: 180 años de política exterior (Lima: Fundación Academia Diplomática del Perú, 2002). 2 vols.

${ }^{27}$ On the issue of "limited war" as a resultant of the existence of a society of states, see Ian Clark, Waging War: A New Philosophical Introduction (Oxford University Press, 2nd ed., [1988] 2015), esp. pp. 13-32, 51-68; and Bull, The Anarchical Society, pp. 184-199.
} 
It is to other factors beyond simply the type of war, therefore, that one should direct attention to account for the proverbial high costs of South America's major wars in terms of "material" effects and in human lives. It is factors such as pandemics, dehydration, or the immediate implementation on the battle-field of constant technological innovations, and the lack of reliable information, capacity or military professionalism, that actually account for as many as two-thirds of the casualties in the War of the Triple Alliance, the War of the Pacific, and the Chaco War. That so many people died in each of these armed conflicts seems to have had less to do with the brutality or intensity of the actual fighting than with the impact of poor strategic planning and preparedness, as much as the high level of foreign-policy improvisation and the lack of reliable information by those who conducted the military operations. In such a global and regional context, standards of "civilized" and restrained behavior must be given a serious recognition, for they played an equally important role in taming war, institutionalizing politics, and fostering solidaritythus, also underpinning regional order.

South America's traditional tolerance for political violence changed dramatically in the 1860 s. ${ }^{28}$ Violence was common, for example, during national or local elections, often directed against the political opposition, or even during open civil war. Upon defeat in a civil war, enemies were regularly assassinated, tortured, and later desecrated. These were accepted practices that were progressively abandoned towards the second half of the 19th century. This change, however, also took place in the way states conducted diplomatic

\footnotetext{
${ }^{28}$ For an authoritative analysis of this change, see Sábato, "Arms and Republican Politics in Spanish America," pp. 185-203; and Sábato, "La fuerza de las armas: Estado, sangre y revoluciones en la Argentina de la década de 1860," in El poder y la sangre: Guerra, estado y nación en la década de 1860, ed. by Guillermo Palacios and Érica Pani (México DF: El Colegio de México, 2014), pp. 259-277.
} 
relations and war with one another. During the major armed conflicts of the 19th century in South America, for example, central governments grappled with "dual threats" to their internal and external orders. ${ }^{29}$ In this complex scenario, efforts were increasingly made to abide by contemporary regional and international standards regarding what was seen as proper or "civilized" conduct in relation to the use of force — both at home and abroad. This dramatic change in regional attitudes is indispensable in any analysis of the consolidation of a society of states given that a strong sense of "insiders" and "outsiders" developed precisely along the same lines of so-called "civilized" and "barbaric" behavior, in accordance with the prevailing cultural views of the time. Those considered part of the society of states were seen as "civilized" and enjoyed the benefits of reciprocal rights, privileges and duties - which were simultaneously denied to the "un-civilized." Those located outside the society of states were thus seen as "barbaric" and considered a threat to regional order and contemporary notions of "progress."

During the 19th century, South American states also made persistent efforts in institutionalizing their international relations through a series of regional congresses and diplomatic conferences. As early as 1826 , for instance, the Congress of Panama showcases the region's initial preference for diplomatic and institutionalized forms of interactionrather than unabashed power-political competition. Several congresses were celebrated

\footnotetext{
${ }^{29}$ For authoritative studies of the major South American wars, that pay some attention to this specific aspect, see Whigham, La guerra de la Triple Alianza; Whigham, "Aspectos claves de la larga resistencia paraguaya: Disciplina militar, cohesión burocrática, y la ego manía del Mariscal López," in A 150 años de la guerra de la Triple Alianza contra el Paraguay, ed. by Juan G. Garavaglia and Raúl O. Fradkin (Buenos Aires: Prometeo, 2016), pp. 11-52; William F. Sater, Chile and the War of the Pacific (University of Nebraska Press, 1986); Sater, Andean Tragedy: Fighting the War of the Pacific, 1879-1884 (University of Nebraska Press, 2007); Carmen Mc Evoy, Guerreros civilizadores: Política, sociedad y cultura en Chile durante la guerra del Pacífico (Santiago: Universidad Diego Portales, 2011); Mc Evoy, "Chile en el Perú: Guerra y construcción estatal en Sudamérica, 1881-1884," Revista de Indias, Vol. 66, No. 236 (2006), pp. 195-216; and David H. Zook, The Conduct of the Chaco War (Bookman, 1964).
} 
during the rest of the century: in Lima in 1848 and 1864, and in Santiago in 1857, to discuss regional strategic matters, such as common defense, the issue of war, and the development of diplomacy and law on a continental level. The shared necessity of consolidating their newly acquired status as independent nations vis-à-vis Spain (and Europe as a whole) further incentivized collective efforts in concert diplomacy ("concertación") and commondefense arrangements against extra-regional aggressions-mostly by European monarchies up until the 1860s, but also by the United States during the 1850s and the 18901920 s. $^{30}$

\section{Implications of the Argument}

There are many implications of the central argument introduced above, which touch on some of the existing works on the long South American peace, as well as on other historical and theoretical contributions. The main implication is that a regional order can be expected to be more stable and long-lasting when a society of states (or international society) is stronger. That is, if the level of awareness of common interests that make up an international society is high among the national elites in charge of foreign policy and diplomacy, then their international relations will display a decline in the frequency and intensity of the use of force over time. A growth in prominence of regional institutions and organizations will also take place, accompanied by a more pronounced pragmatic solidarity

\footnotetext{
${ }^{30}$ Although multiple types of aggressions by European monarchies took place after Latin America's independence from Spain, three in particular stand out in the 1860s. In Mexico, France instituted a monarchical regime between 1862 and 1867, while Spain itself occupied the Dominican Republic in 1861, and then again coerced Peru by occupying three islands rich in guano in 1864 and bombarding a civilian Chilean port in 1866. The United States, for its part, played a mixed role, first supporting filibustering activities throughout the 1850s in Central America, and then after its civil war ended, waged a war against Spain in Puerto Rico, Cuba, Guam, and the Philippines. At the turn of the century, the U.S. took control of the Panama Canal.
} 
towards the protection of the region's systemic interest—-thus, further dampening conflict. On the contrary, when the level of awareness of common interests declines and there is little (or no) convergence of such interests, regional instability will rise, leading to a higher level of apathy towards others' uses of force in the region, and to a higher frequency and intensity in the employment of armed force to solve diplomatic disputes. If, and when, a common sense of legitimate norms and standards of conduct breaks down, then a further consequence is a decline in the use of institutional mechanisms for conducting intraregional diplomatic relations and restraining power competition.

A second implication of the international society argument indicates that, in a society of states, wars will become limited not just because of geopolitical obstacles or the lack of technological and material capabilities. The development of a raison de système is an additional factor that must also be considered. Strongly institutional-organizational and materialistic accounts of South America's long peace explain it as the "incapacity" of South American states to fight "the right kind of wars," in the sense first identified by Charles Tilly in his classical study of the European experience. ${ }^{31}$ In this context, an international society argument can also contribute an important factor to the classical formulation regarding "state-weakness" as an explanation of the long South American peace. Specifically, it can help identify an additional source of limitation that is more qualitative (self-restraint) than the classical institutional-organizational argument (state-weakness). Although the state-weakness argument applies quite well to the 19th century, when most

\footnotetext{
${ }^{31}$ On these issues, see Centeno, Blood and Debt; López-Álves, "The Latin American Nation-State and the International"; and Cameron Thies, "War, Rivalry, and State Building in Latin America," American Journal of Political Science, Vol. 29, No. 3 (July, 2005), pp. 451-465.
} 
"states" were weak and poorly consolidated, it requires further qualification when applied to: (a) the independence wars, when the states were at their weakest, yet successful expeditions were carried out over vast geographical distances and across the Andes by both Bolívar and San Martín; and (b) the bulk of the 20th century, given that most states grew considerably in strength and capacity, yet major wars have not occurred. ${ }^{32}$

Miguel Centeno's classical argument about state-formation in Latin America, therefore, can be supplemented by a parallel process of regional-society-formation, considering elements of self-restraint, the role of common interests and institutional arrangements, in order to capture not just the incapacity of states to fight large wars, but also their political willingness to collectively limit the use of force inter se. Under these circumstances, although force remains a valid instrument of statecraft, it is important to understand how the formation of a society of states played a crucial role in making war progressively more institutionalized, less intense, and less frequent over time: War is thus tamed or limited, yet not eliminated. The international society perspective adds an important nuance that complements, rather than supersedes, Centeno's formulation by simultaneously exploring the mirror-image of his central argument. That is, it moves the focus away from the dialectic interaction of "state and war" (à-la Tilly) and delves deeper into the role of other reciprocal effects between "international society and war" (à-la Bull) at the regional level. In short, it looks into the parallel and dual processes of state-formation

\footnotetext{
${ }^{32}$ The one exception would be the Chaco War, which (quite tellingly) was waged by the two weakest states in the region in the 1930s: Bolivia and Paraguay. On this point, see Kacowicz's and Mares' critiques of Centeno's argument: Kacowicz, "Blood and Debt [review]," Estudios Interdisciplinarios de América Latina y el Caribe, Vol. 15, No. 2 (julio-diciembre, 2004), pp. 214-216; and Mares, "Making War to Make the State [review]," Georgetown Journal of International Affairs, Vol. 4, No. 1 (Winter/Spring, 2003), pp. 143-146. For a different application of the "state-weakness" argument to South America, $c f$. Holsti, The State, War, and the State of War.
} 
and consolidation, on the one hand, and region-formation and consolidation, on the other, as component parts of a continuous historical dynamic. This is why the international society approach takes special interest in studying the interaction and reciprocal influences between the major wars and their impact on the region's tendency towards varying levels of indifference/solidarism, as well as the content and direction of institutional efforts towards the taming of war and the preservation of order.

One of the more theoretical implications of the argument is related to the claim that South America formed in the mid-19th century not only a system, but also a society of states. ${ }^{33}$ The main difference between one and the other is that in a society of states, members engage in more than just recurrent, almost mechanical or automatic, strategic interactions that could be more or less violent. Members of a society of states not only input the existence and intentions of others into their own power calculations, ${ }^{34}$ but also frame those social interactions through an acquired sense of common interests and values-a "strategic awakening" of sorts-which they further support by creating rules and institutions to govern those interactions. ${ }^{35}$ Regional institutional dynamics are thus consciously designed and maintained, rather than mere unintended products (or "outputs") of systematic interactions. ${ }^{36}$ Seen in this light, therefore, a society of states does not replace

\footnotetext{
${ }^{33}$ For the standard view of South America as a "system" of power politics, see Robert N. Burr's three masterful contributions: "The Balance of Power in Nineteenth-Century South America: An Exploratory Essay," The Hispanic American Historical Review, Vol. 35, No. 1 (February, 1955), pp. 37-60; The Stillborn Panama Congress: Power Politics and the Chilean-Colombian Relations during the War of the Pacific (University of California Press, 1962); and By Reason or Force.

${ }^{34}$ Cf. Kenneth N. Waltz, Theory of International Politics (Reading, MA: Addison-Wesley, 1979).

${ }^{35}$ See Bull, The Anarchical Society.

${ }^{36}$ For well-established definitions of "system" in IR in this sense, $c f$. Robert Jervis, System Effects: Complexity in Political and Social Life (Princeton University Press, 1997); and Waltz, Theory of International Politics. For a definition of the concept of "society of states," as employed in this dissertation, see Bull, The Anarchical Society, pp. 46-51, 8-14, 40; Wight, "Western Values in International Relations";
} 
or transcend a system of states; it builds upon its foundations and profoundly shapes how actors interact. ${ }^{37}$

An additional theoretical implication also touches on the issue of culture. The sharing of a pre-existing common culture (as in the South American case) does not determine, although it may facilitate, the working of a society of states. A common language, religion, customs, or tradition can help states communicate and understand one another better, making it easier for a system to transition to a society of states, and thus share in the construction of common institutions. In most Constructivist accounts of the long peace, the idea of a "shared culture" acquires a central role and is commonly presented in the form of a "security community." 38 Contrary to this view, a society of states differs from a security community in that interactions are still mainly driven by "interests" and not just by transformations of collective identity towards peace. Equally important is the fact that in a security community threats are expected from outside the community — that is, there should be a pooling of sovereignty to collectively project force outwards, not inwards. In a society of states, force is not eradicated, as it remains a fundamental component of the protection and maintenance of order. Unlike a security community, there is no "cultural" transformation from "enmity" to "rivalry" to "friendship." 39

\footnotetext{
Wight, Systems of States; and Watson, The Evolution of International Society. For critical reviews of the use of both terms in IR, see Buzan and Little, International Systems in World History: Remaking the Study of International Relations (Oxford University Press, 2000), pp. 15-110; Alexander Wendt, Social Theory of International Politics (Cambridge University Press, 1999); and Nicholas G. Onuf, World of Our Making (Routledge: [1989] 2012).

${ }^{37}$ Bull, The Anarchical Society, pp. 13-14.

${ }^{38}$ Emanuel Adler and Michael N. Barnett, eds., Security Communities (Cambridge University Press, 1998).

${ }^{39}$ This is a direct reference to Wendt, Social Theory of International Politics, where the triad enmityrivalry-friendship is conceptualized as "role identities."
} 
The implications are important, for in a Constructivist sense South American nations should be expected to become an "amalgamated security community" over time, in the sense first advanced by Karl Deutsch. ${ }^{40}$ That is, they should logically unite into one supra-national entity. Of all the regions in the world, South America should be the strongest case for this perspective, given the extent of its cultural and identitary commonalities. But despite a strong shared cultural heritage from their common colonial past, South American nations remain politically and territorially divided, and states fiercely defend their autonomy not simply against extra-regional great powers, such as the United States, but also against one another. In this regional society of states, ultimately, the legitimate use of force is kept as an institution that protects "order" itself from one another, as much as from extra-regional interference. The persistent resistance of South America's society of states to further integrate into a larger supra-national regional entity shows that shared "cultural" factors may perhaps assist in the functioning of common institutions and organizations, but do not determine how international relations in the region come to be in the first place, or how they actually unfold in practice. In this sense, as well, the creation of regional organizations should not be interpreted as stepping stones towards a future political unification or integrated supra-national state.

Similarly, the international society argument advanced in this dissertation differs in important ways from the Liberal approach. While the Liberal argument maintains that

\footnotetext{
${ }^{40}$ See Karl W. Deutsch, et al., Political Community and the North Atlantic Area: International Organizations in the Light of Historical Experience (Princeton University Press, 1957); and Adler and Barnett, Security Communities. See also Alexander Wendt, "Why a World State is Inevitable," European Journal of International Relations, Vol. 9, No. 4 (2003), pp. 491-542, who works as a perfect example of how, from a Constructivist point of view, integration into a single political unit over time is the most logical end-point of the Constructivist teleology.
} 
democracies "of the right kind" (that is, republican democracies) do not fight wars with one another, it strictly associates one type of regime with external pacifying effects for the (regional or global) system as a whole. It claims, in other words, that a society of states can only form among democracies. The international society approach, however, refuses to associate only one specific type of regime as the indispensable component for the formation a society of states. In fact, it argues that societies of states can form and sustain themselves even among a pluralist set of states governed by different types of regimes. As with the cultural arguments, the sharing of a similar type of regime among neighbors can perhaps facilitate the working of common institutions and rules, but it is not a sine qua non for the formation and consolidation of a society of states itself.

The South American case offers a good way to test this proposition, given that during most of the 19th century the issue of the type of regime was a relevant one for the newly independent republics. The history of these young republics shows that coexistence with the Brazilian Empire (a monarchical regime between 1822 and 1889) was not an impediment in the creation and maintenance of a regional society of states in South America. Despite deep-seated suspicions and animosities regarding the Brazilian Empire during most of the 19th century, the South American republics consistently entered into alliances, signed treaties, and established formal diplomatic relations with Brazil when necessary. Local caudillos and regional chieftains in Argentina and Uruguay, moreover, often invoked - and promptly received - the financial and military support of the neighboring monarchical regime in their multiple revolts and political uprisings. The history of Brazil's relations with the South American republics of the 19th century is, in 
fact, a history of accommodation, progressively peaceful resolution of disputes, growing mutual respect, and diplomatic tolerance. ${ }^{41}$

In sum, both Constructivist and Liberal perspectives face a challenging puzzle when trying to account for the paradoxical aspect of South America's long peace. For both approaches, the values embedded in the domestic orders of states (e.g., types of regime) must correspond with their international behavior towards other similarly-organized states. While Liberals confine their analysis to inter-democratic societies, Constructivists would apply a similar logic for any pairings of types of regime — as long as they are similar to one another. Thus, not only an inter-democratic peace is possible, but also an inter-autocratic peace, inter-monarchical, etc. But in this sense, however, South America's high levels of internal violence amid an ongoing stable peace among states is quite incompatible with explanations based on the congruence between a state's sense of identity and its external behavior.

For the international society approach, the type of regime of a state should not necessarily correspond to any particular effect regarding international or regional order. In pluralistic societies of states, where differences in the type of regime matter little (or not at all), or when the consensus over the "thickness" of the common interests is rather shallow, the coexistence of external peace and internal violence does not present similar

\footnotetext{
${ }^{41}$ See Leslie Bethell, "Brazil and Latin America," Journal of Latin American Studies, Vol. 42, No. 3 (August, 2010), pp. 457-485; Leslie Bethell and José Murilo de Carvalho, "Brazil from Independence to the Middle of the Nineteenth Century," in The Cambridge History of Latin America, ed. by Leslie Bethell (Cambridge University Press, 1985), Vol. 3: pp. 679-746; Luís C. Villafañe Gomes Santos, "Brasil: Americano, Latino-Americano ou Sul-Americano?" Cuadernos del CLAEH, Año 28, Vol. 1, No. 90 ( $2^{\mathrm{a}}$ serie, 2005), pp. 87-107; Villafañe Gomes Santos, "Identities in the Empire of Brazil: Constructing the Other," in Explorations on Subjectivity, Borders, and Demarcation: A Fine Line, ed. by Raúl A. Galoppe and Richard Weiner (University Press of America, 2005), pp. 25-46; and Ori Preuss, Bridging the Island: Brazilians' Views of Spanish America and Themselves, 1865-1912 (Iberoamericana Vervuert, 2011).
} 
logical or theoretical problems. In fact, this is precisely why such divergence between the internal and external orders can be sustained over time, for the inter-state peace and stability can act as an "insulator" for what goes on inside a country's borders. International societies can, however, develop into more solidaristic forms, in which the internal compositions of states (sets of values, norms, and even culture) can be an active component of the consensus over common interests among states. ${ }^{42}$ In other words, in the international society argument, common interests can be strong ("thick") or weak ("thin") depending on the type of normative content that makes up the consensus among member states.

\section{The Literature}

Since South America represents a theoretical puzzle for mainstream IR theories, most works on the region's long peace have traditionally adopted two concrete positions. The large majority agrees in characterizing South America as anomalous or puzzling, emphasizing the region's uniqueness and often elevating it to an exemplary status worthy of imitation by other regions. ${ }^{43}$ There are multiple explanations offered for the long South American peace within this first group, ranging from the traditional Liberal triangulation

\footnotetext{
${ }^{42}$ In present day international politics, for example, the post-Cold War international system has evidenced a strong solidarism on issues of human rights violations, which in turn have taken the form of intervention in the face of genocide and blatant human-rights abuses by states against their own civilian population. On this debate, see Hedley Bull, ed., Intervention in World Politics (Clarendon Press, 1984); R. John Vincent, Nonintervention and International Order (Princeton University Press, 1974); Vincent, Human Rights and International Relations (Cambridge University Press, 1986); Nicholas J. Wheeler, Saving Strangers: Humanitarian Intervention in International Society (Oxford University Press, 2000); and Jackson, The Global Covenant.

${ }^{43}$ For some of the works characterizing South America's international relations as an "anomaly," an "exception," or a "puzzle," see Holsti, The State, War, and the State of War, pp. 150, 161, 149; Buzan and Wæver, Regions and Powers, pp. 304, 391; McIntyre, "The Longest Peace," pp. 170-171; Kacowicz, Zones of Peace in the Third World, pp. 67-124; Martín, Militarist Peace in South America, pp. 2, 24, 177, 179, 181; and Centeno, Blood and Debt, pp. 168, 1, 9, 11, 16, 17, 155, 261, 262. Cf. Mares, Violent Peace, pp. xi, xii, 51.
} 
of peace (democracy, economic inter-dependence, and institutions), ${ }^{44}$ or the hegemonic role of the United States, ${ }^{45}$ to the relative weakness/strength of the state, ${ }^{46}$ the roles of military confraternities ${ }^{47}$ and shared cultural identities, religion, language, and a common anti-monarchical past, ${ }^{48}$ and, finally, the construction of a "zone of peace" and a pluralistic security community. ${ }^{49}$

A smaller group, however, takes a more provocative position that denies any truly "peaceful" condition for the region. Although agreeing that South America is an exceptional case and a "microcosm," this second group tends to highlight the

${ }^{44}$ See, e.g., Mark Peceny, “The Inter-American System as a Liberal 'Pacific Union'?” Latin American Research Review, Vol. 29, No. 3 (1994), pp 188-201; Arie M. Kacowicz, "Stable Peace in South America: The A.B.C. Triangle, 1979-1999," in Stable Peace Among Nations, ed. by Kacowicz, et al. (Rowman \& Littlefield, 2000), pp. 200-219; Kacowicz, Zones of Peace in the Third World, pp. 67-124. Cf. Farid Kahhat, "Balance of Power, Democracy and Foreign Policy in South America's Southern Cone," Documentos de Trabajo del CIDE, No. 103 (diciembre, 2003), pp. 1-21.

${ }^{45}$ See Michael C. Desch, "Why Latin America May Miss the Cold War," in International Security and Democracy: Latin America and the Caribbean in the Post-Cold War Era, ed. by Jorge I. Domínguez (University of Pittsburgh Press, 1998), pp. 245-265; Martin Sicker, The Geopolitics of Security in the America: Hemispheric Denial from Monroe to Clinton (Praeger, 2002); and Harold Molineu, U.S. Policy Toward Latin America: From Regionalism to Globalism (Westview Press, 2nd ed., [1986] 1990).

${ }^{46}$ See Centeno, Blood and Debt; Holsti, The State, War, and the State of War; Thies, "War, Rivalry, and State Building in Latin America."

${ }^{47}$ See Martín, Militarist Peace in South America; Little, "Military Power in Latin America"; Andreski, "On the Peaceful Disposition of Military Dictatorships."

${ }^{48}$ See Cameron Thies, "The Construction of a Latin American Interstate Culture of Rivalry," International Interactions, Vol. 34, No. 3 (2008), pp. 231-257; Miller, States, Nations, and the Great Powers; Michael Barletta and Harold Trinkunas, "Regime Type and Regional Security in Latin America: Toward a 'Balance of Identity' Theory," in Balance of Power: Theory and Practice in the 21st Century, ed. by Tazha V. Paul, James J. Wirtz and Michel Fortmann (Stanford University Press), pp. 334-359; Nicola Foote and René D. Harder Horst, eds., Military Struggle and Identity Formation in Latin America: Race, Nation, and Community during the Liberal Period (University Press of Florida, 2010).

${ }^{49}$ See Adler and Barnett, Security Communities; Hurrell, "An Emerging Security Community in South America?"; Andrea Oelsner, "Pluralistic Security Communities in Latin America," in Routledge Handbook of Latin American Security, ed. by David R. Mares and Arie M. Kacowicz (Routledge, 2016), pp. 173-184; Oelsner, International Relations in Latin America; Daniel Flemes, "Creating a Regional Security Community in Southern Latin America: The Institutionalisation of the Regional Defence and Security Policies," Working Papers: Global and Area Studies, Deutsches Übersee-Institut [Hamburg], No. 13 (December, 2005), pp. 1-35; Buzan and Wæver, Regions and Powers, pp. 304-340. Cf. Charles Tilly, "International Communities, Secure or Otherwise," in Security Communities, pp. 397-412. 
commonalities of the region with other cases around the world, thus relegating its "peaceful" characteristics to mere methodological technicalities or ideological artifice. ${ }^{50}$ This group argues that states have always used force, although for limited objectives, and that this trend has continued throughout the entire 20th century. ${ }^{51}$ In this particular view, the region's geopolitical dynamics have typically favored the defense à-la Clausewitz, due to its large geographical extensions, low population densities, and difficult—sometimes unsurmountable - terrains. Since the geography of the region has not fundamentally changed, scholars within this group tend to be pessimistic about the idea of South America as a "zone of peace" where the use of force has entirely disappeared as an instrument of diplomacy. ${ }^{52}$

Both groups, and each of their specific types of explanations, will be addressed in detail in Chapter 1, which presents them as formal testable propositions in contention with the international society argument. Beyond their initial differences in diagnosis, however, both groups entail a number of problems that must be addressed. The literature, for example, tends to focus on the study of South America exclusively in the post-1935 period - after the last major war in the region. With few exceptions, the search for a potential explanation is reserved to the study of what has happened within the period of the "long peace" itself (i.e., from 1935 up to now). This neglects, therefore, the study of the

\footnotetext{
${ }^{50}$ See, e.g., McIntyre, “The Longest Peace," pp. 2, 167; and Mares, Violent Peace, pp. 32-35.

${ }^{51}$ See Mares, Violent Peace; Mares, Latin American and the Illusion of Peace (Routledge, 2012); and Mares, "Regional Conflict Management in Latin America: Power Complemented by Diplomacy," in Regional Orders, pp. 195-218.

${ }^{52}$ See McIntyre, "The Longest Peace"; Philip Kelly, Checkerboards and Shatterbelts: The Geopolitics of South America (University of Texas Press, 1997); Mares, Violent Peace; Jack Child, Geopolitics and Conflict in South America: Quarrels among Neighbors (Praeger, 1985); Child, "Interstate Relations in Latin America"; and Mares, Latin American and the Illusion of Peace.
} 
historical preconditions and alternative potential explanations located before the 1935 benchmark. ${ }^{53}$ To a large extent, the popular focus on "the last war" as the standard criterion to set the clock for the South American peace can be explained by the long-lasting influence of the Correlates of War project (COW) in how most scholars approach the study of war and peace in IR. According to this widely consulted database, there has been only one major interstate war in South America in all of the 20th century: The Chaco War, from 1932 to 1935. ${ }^{54}$ Other minor armed conflicts, such as those between Peru and Colombia in 1932 or the recurrent military confrontations between Peru and Ecuador in 1941, 1981, and 1995, are thus dropped from the analysis. The cow project establishes certain strict criteria for considering an armed conflict as a "war." One of these criteria is the 1,000 battle-related casualties indicator. Following this criterion, therefore, the Peru-Colombia and PeruEcuador disputes fall below the threshold and are not considered as wars. ${ }^{55}$ This single statistical finding from the 1980s gave a somewhat exaggerated sense of the extent to which South America could be considered "peaceful," and further established the study of the region as an "anomaly." Despite its many limitations, the COW project gave a valuable

\footnotetext{
${ }^{53}$ One of the exceptions is Centeno's landmark study, Blood and Debt, which takes a historical view of the region's "long peace" since the achievement of independence, instead of only after 1935.

${ }^{54}$ See Melvyn Small and David J. Singer, Resort to Arms: International Wars and Civil Wars, 1816-1980 (Sage, 1982), esp. pp. 50, 55-56, 597-599. See also the supplementary online website for the Correlates of War Project (COW), accessible at http://www.correlatesofwar.org. Cf. Monty G. Marshall, Third World War: System, Process, and Conflict Dynamics (Rowman \& Littlefield, 1999), p. 196. For other widely used databases for war and peace studies in the field of IR, see the Uppsala Conflict Data Program (UCDP), accessible at http://www.pcr.uu.se/research/UCDP; the Stockholm International Peace Research Institute's (SIPRI) database, accessible at http://www.sipri.org/databases; and the Center for International Development and Conflict Management (CIDCM), accessible at http://www.cidcm.umd.edu.

${ }^{55}$ Armed conflicts that fall below that threshold are typically studied as Militarized Interstate Disputes (MID). Mares' Violent Peace makes extensive use of this dataset, instead of the traditional Cow project on major war. Unsurprisingly, Mares finds that Latin America has been much more violent than what most studies of the "long peace" suggest. While Mares' contribution introduces some useful correctives to the debate, it also contains many serious flaws that will be discussed more extensively in the next Chapter.
} 
impetus to a growing academic interest in the development of concrete explanations for this South American "statistical" puzzle.

The study of the marked infrequency in inter-state war in South America, therefore, has necessarily have to take place on the fringes of the major theoretical approaches in IR. It has pushed students to develop new and creative explanations to confront the South American "anomaly," for mainstream IR theories have been unable to provide much guidance for the South American case. As one student of the region has eloquently put it, South America's long peace

[...] appears to defy the logic and explanatory power of the two most prominent schools of thought in international relations: Political Realism and International Liberalism. Expressed succinctly, the causes of war presupposed in realism were present in South America, yet interstate war did not erupt. Conversely, the causes of peace assumed in liberalism were absent, but interstate peace has prevailed in this subregion. ${ }^{56}$

More specifically, as Kalevi Holsti maintains:

Presently available theories of international politics do not explain the South American case. Neo-realist predictions are not borne out by the record; dependency theory would emphasize the economic roots of many of South America's conflicts, but there have also been conflicts where economic stakes were minimal; and liberal-institutionalist theories do not take us very far because until recently there have been only low levels of integration and successful multilateral institution-building in the region. Deutsch's theories of integration do not hold either because rich communication flows, democratic governments, and a common external threat have not been important features of the regional system. ${ }^{57}$

Influenced by this particular framing of the issue, a major difficulty for scholars trying to tackle the long South American peace has been their inability to move beyond the simple

\footnotetext{
${ }^{56}$ Martín, Militarist Peace in South America, p. 2 (see also p. 177). A similar point is made by McIntyre, "The Longest Peace," p. 24.

${ }^{57}$ Holsti, The State, War, and the State of War, p. 161. Similar arguments are also found in Mares, Violent Peace, p. xii; Miller, States, Nations, and the Great Powers, pp. 326-327; and Buzan and Wæver, Regions and Powers, pp. 304-340.
} 
"counting" of wars. The overall peacefulness of the region is evidenced not simply by the declining number of major inter-state wars (in cow terms), but also by the increasingly limited nature of the wars that were actually fought. In this sense, South America's long peace is not only longer in duration (almost two-hundred years) than what most studies acknowledge, but also must be defined in more than purely quantitative or materialistic terms. As the works of Miguel Á. Centeno, Andrew Hurrell, and Charles A. Jones suggest, beyond the relative absence of major war during most of the 20th century and beyond, even when South American states were involved in wars with one another these conflicts were limited in duration, scale and political objectives. As Centeno puts it, "[...] in general, Latin America has experienced low levels of militarization, the organization and mobilization of human and material resources for potential use in warfare. Latin Americans have frequently tried to kill one another, but they have generally not attempted to organize their societies with such a goal in mind." 58 Additionally, he argues, "[n]o countries have fought one another as representatives of an ideology or a religious faith." 59 The wars of South America, Centeno concludes,

have also been relatively short and with simple linear narratives. Most have been settled by one or two decisive battles [...]. Bibliographic accounts are remarkably simple. There is often no need for more than one strategic map, battles can be described in a single paragraph, and whole wars summarized in a few pages. Not surprisingly, by contemporary standards, the wars involved relatively few men and minimal equipment. ${ }^{60}$

\footnotetext{
${ }^{58}$ Centeno, Blood and Debt, p. 35 [italics in the original]. See also Charles A. Jones, "Foundations of South American International Society," paper presented at the APSA Meeting, Boston (August, 2008), pp. 1-38; and Andrew Hurrell, "Working with Diplomatic Culture: Some Latin American and Brazilian Questions," paper presented at the ISA Annual Convention, Montreal (March, 2004), esp. p. 4.

${ }^{59}$ Centeno, Blood and Debt, p. 52.

${ }^{60}$ Ibid., p. 53.
} 
As Centeno acknowledges, an important exception is the War of the Triple Alliance (18641870), which had devastating effects for the overall male population in Paraguayalthough an important qualification on this point is added in Chapter 3 of the present study. An additional problem is the overall neglect of the study of the historical preconditions underpinning the long peace in South America. ${ }^{61}$ This has translated into a sustained neglect of the 19th century as a relevant source for developing a consensual explanation. Scholars often black-box this period as "violent" or "conflictual," and readily concede its explanation to Realist theories - thus rendering almost half of the period of the "long peace" as unworthy of closer inspection. ${ }^{62}$ This generalized neglect of the historical conditions under which the region's decline in the frequency and intensity of war took place is problematic because it assumes there is nothing important to learn from the more

${ }^{61}$ The implicit idea of a longer "long peace" in the region is present in Centeno, Blood and Debt, esp. p. 34; and Jones, "Foundations of South American International Society," who understand South America's long peace as a two-hundred-year long period. In contrast, most other approaches mark the beginning of the regional peace in 1935. For a shorter view of the long peace that identifies a fundamental turning point in the 19th century, see Holsti, The State, War, and the State of War, pp. 150, 152, 154, 161, 155; Domínguez, "Boundary Disputes in Latin America," p. 20; Miller, States, Nations, and the Great Powers, p. 324; Martín, Militarist Peace in South America, pp. 1, 7; Kacowicz, Zones of Peace in the Third World, pp. 7175; McIntyre, “The Longest Peace," pp. 1-2; Little, "International Conflict in Latin America," pp. 594, 593; Barletta and Trinkunas, "Regime Type and Regional Security in Latin America"; and Hurrell, "Security in Latin America," pp. 531-533.

${ }^{62}$ For works that concede the entire explanation of 19th-century international relations in South America to Realist theories and characterize it as "normally" more violent and bloody, see Holsti, The State, War, and the State of War, pp. 154-165; Kacowicz, Zones of Peace in the Third World, pp. 71-72; Kacowicz, The Impact of Norms in International Society, p. 48; Burr, "The Balance of Power in Nineteenth-Century South America," pp. 37-60; Burr, By Reason of Force; Ron L. Seckinger, "South American Power Politics during 1820s," The Hispanic American Historical Review, Vol. 56, No. 2 (May, 1976), pp. 241-267; João Resende-Santos, "Anarchy and the Emulation of Military Systems: Military Organization and Technology in South America, 1870-1930," in Realism: Restatements and Renewal, ed. by Benjamin Frankel (London: Frank Cass, 1996), pp. 93-260; Resende-Santos, Neorealism, States, and the Modern Mass Army (Cambridge University Press, 2007); Randall L. Schweller, Unanswered Threats. Political Constraints on the Balance of Power (Princeton University Press, 2006), esp. pp. 85-102; and Barletta and Trinkunas, "Regime Type and Regional Security in Latin America," pp. 334-359. Other scholars, despite their exclusive focus on the 20th century, still find that balance-of-power and hegemonic-stability theories do not account well, or in its entirety, for South America's 19th century international relations. See, e.g., Kacowicz, Zones of Peace in the Third World, pp. 89-98; Miller, States, Nations, and the Great Powers, pp. 327, 334; and Buzan and Wæver, Regions and Powers, pp. 308-9, 319. 
systematic study of the region's historical evolution. Moreover, since "causes" must logically precede "effects," they run the risk of reducing the analysis of the long peace to a mere description of the "symptoms," rather than a full excavation of the anteceding causes. Such is the case of the three major armed conflicts in the history of South America, which occurred in the 1860s, 1880s, and 1930s, but which are normally left unstudied, as they are seen as part of the "normal" conflictual nature of traditional international relations prior to the advent of the long regional peace.

Confronted by these factors, in the 1990s and 2000s a series of studies have advanced several hypotheses to explain South America's historical pattern of war and peace. However, none has been able to account unproblematically for this regional long peace in all its complexities. At best, some contributions have helped in understanding temporal segments or specific aspects and manifestations of the dynamics of regional peace, while still leaving the South American case in need of an encompassing explanation. That is, an account not simply "from the last war forward," but in terms of the historical roots and preconditions that made the decline in the number and intensity of war-fighting possible in the first place. At worst, some contributions have advanced highly-original arguments that as a whole are logically incompatible or methodologically incommensurable inter se. The proliferation of such contributions, however, has hindered the construction of a unified explanation of the region's evolution as a historical process.

One of the central problems of the existing literature is the rather uncritical adoption of mainstream theoretical assumptions about immediate and underlying causes of war and peace, which typically lead them to conclude that the South American condition is "anomalous." The value of this popular assertion, however, cannot be productively 
ascertained in the absence of a larger discussion of what is to be considered the "normal" state of affairs. A lack of engagement with this important issue has led scholars to a rather unsatisfying conclusion, whereby a theoretical puzzle is left partially unexplained, or rather "explained away," as an exception to a normality that is kept unexposed and unquestioned. ${ }^{63}$ This is connected to another problem, which is the normalization of the recurrence of war. By leaving the theoretical assumptions about war and peace dynamics unchallenged, peace is seen as "anomalous" when uninterrupted by war for several decades. This, once again, normalizes war and makes a "long peace" among states an exception; a rare non-event in need of explanation due to its abnormality. It is unsurprising, therefore, that explanations armed with this particular type of analytical tools have struggled so much to come up with an encompassing argument for South America's case.

Two final problems are also worth mentioning. One of them is the lack of consensus on some core definitions, which has led to a problematic set of periodizations of the same historical phenomenon. This has been fueled by a narrow disciplinary understanding of war and peace in IR, both in quanti- as well as in qualitative terms. While most works tend to "count" how many wars have occurred in the region and then proceed to focus on historical developments within the period of "no-war" (or "negative peace"), others have over-reacted by adopting a strictly qualitative understanding of peace that commits the mirrored mistake of narrowly focusing on one of the two factors at play, losing sight of the

\footnotetext{
${ }^{63}$ This was the main conclusion in a prior work on the academic debate on South America's "long peace," which tried to expose the Realist concept of the "security dilemma" as the main (hidden) referent object behind almost all contributions to the debate. See Terradas, "El dilema de la seguridad en América del Sur”; and Terradas, “The 'Long Peace' in Latin America: Transcending the Security Dilemma?" CLAS TriUniversity Graduate Student Conference, Miami (March, 2018), pp. 1-33.
} 
interplay between both. ${ }^{64}$ Thus, the study of war and peace in South America has remained compartmentalized and unsystematic, advancing on parallel and independent tracks: some works focusing exclusively on the study of the number of wars and their material effects, while others on the type and quality of peace.

Finally, a problem has emerged in the form of a recent tendency to resolve the regional puzzle via "patchwork" theorization — that is, the attempt to artificially connect one path (quantitative study of war) with the other (qualitative study of peace) in stages or according to a linear historical sequence of "progress." This is an artificial, and in the end unproductive, solution simply because instead of reconciling the existing problems in search of a superior synthesis, it creates an internally inconsistent larger explanation where each theoretical "path" is reserved a partial (historically contingent) explanatory role at different moments of the evolution of the region. In this way, explanations that are at their core incommensurable and mutually exclusive are distributed longitudinally across the history of the region and assigned "pockets" or "patches" of explanation. No successful attempt is seriously done, however, in linking all the patched explanations into one macro, "eclectic" theoretical argument- this is, in part, because ultimately the particular explanations employed cannot be internally reconciled inter se. ${ }^{65}$

\footnotetext{
${ }^{64}$ See, e.g., Jorge M. Battaglino, "The Coexistence of Peace and Conflict in South America: Toward a New Conceptualization of Types of Peace," Revista Brasileira de Política Internacional, Vol. 55, No. 2 (JulyDecember), pp. 131-151; Kacowicz, "Stable Peace in South America"; and Oelsner, International Relations in Latin America.

${ }^{65}$ For prominent examples of this type of "patchwork" explanations, see Norrin M. Ripsman, "Two Stages of Transition from a Region of War to a Region of Peace: Realist Transition and Liberal Endurance," International Studies Quarterly, Vol. 49, No. 4 (December, 2005), pp. 669-694; Kacowicz, Zones of Peace in the Third World; Kacowicz, The Impact of Norms in International Society; Holsti, The State, War, and the State of War, pp. 150-182; Buzan and Wæver, Regions and Powers, pp. 304-340; Oelsner, International Relations in Latin America; Hurrell, "An Emerging Security Community in South America?"; and Miller, States, Nations, and the Great Powers.
} 
Only rarely has the literature provided a more in-depth analysis of the region in its historical complexity, providing justice to the often non-linear evolutionary paths and important pre-1935 foundational "stepping stones" that opened the way for a stable peace in later decades. This is precisely what this dissertation aims to do, by way of focusing not on the post-1935 period, but on the historical period immediately preceding it (1860s1930s) - between the consolidation of most states' independence and sovereignty, and the end of the last major inter-state war in 1935.

\section{Research Methods}

The method used in this dissertation is theory-informed process tracing, supplemented by historical analysis and multi-site archival research. ${ }^{66}$ Process tracing is a well-established methodology in the social sciences that attempts to identify an intervening causal process (or causal mechanism) between an independent variable (IV) and the outcome of the dependent variable (DV). ${ }^{67}$ It implies "the tracing of any causal process by which initial

\footnotetext{
${ }^{66}$ On the method of process tracing, see Gary King, Robert O. Keohane and Sidney Verba, Designing Social Inquiry: Scientific Inference in Qualitative Research (Princeton University Press, 1994), pp. 226228; Stephen Van Evera, Guide to Methods for Students of Political Science (Cornell University Press, 1997), pp. 30-34, 64-67; Alexander L. George and Andrew Bennet, Case Studies and Theory Development in the Social Sciences (MIT Press, 2005), pp. 205-232; Jeffrey T. Checkel, "Process Tracing," in Qualitative Methods in International Relations: A Pluralist Guide, ed. by Audie Klotz and Deepa Prakash (Palgrave Macmillan, 2008), pp. 114-127; Andrew Bennett, "Process Tracing and Causal Inference," in Rethinking Social Inquiry: Diverse Tools, Shared Standards, ed. by Henry E. Brady and David Collier (Rowman \& Littlefield, 2nd ed., [2004] 2010), pp. 207-219; David Collier, "Understanding Process Tracing," PS: Political Science and Politics, Vol. 44, No. 4 (2011), pp. 823-830; James Mahoney, "The Logic of Process Tracing Tests in the Social Sciences," Sociological Methods \& Research, Vol. 41, No. 4 (2012), pp. 570-597; Derek Beach and Rasmus B. Pedersen, Process-Tracing Methods: Foundations and Guidelines (The University of Michigan Press, 2013); Andrew Bennett and Jeffrey T. Checkel, eds., Process Tracing: From Metaphor to Analytic Tool (Cambridge University Press, 2015); Beach and Pedersen, Causal Case Study Methods: Foundations and Guidelines for Comparing, Matching, and Tracing (The University of Michigan Press, 2016), esp. pp. 302-336. On the method of historical analysis, see Clayton Roberts, The Logic of Historical Explanation (The Pennsylvania State University Press, 1996).

${ }^{67}$ George and Bennet, Case Studies and Theory Development, p. 206; and Andrew Bennett and Jeffrey T. Checkel, "Process Tracing: From Philosophical Roots to Best Practices," in Process Tracing, pp. 6-7, 9.
} 
conditions are translated into outcomes." ${ }^{68}$ Following the metaphor of falling dominoes, process tracing forces the investigator to consider the alternative paths through which the outcome could have occurred (that is, to take equifinality into account), as it explores a chain of events or decision-making processes by which initial case conditions lead to particular outcomes. That is, it asks "how" and "why" the row of dominoes fell. The metaphor, however, is limited in that is says little about the direction and timing of the chain reaction itself.

The cause-effect link that connects the IV and the DV is thus unpacked and divided into smaller steps in which the investigator looks for observable evidence of each individual step. ${ }^{69}$ The emphasis on "unwrapping" causal mechanisms provides stronger mechanistic evidence of causal relationships between specific causes and outcomes, for each part of the mechanism is traced empirically. As Beach and Pedersen argue, "tracing mechanisms in a case also sheds light on how a given theoretical cause (or set of causes) produces an outcome." ${ }^{\prime 70}$ This evidence, in turn, can take the form of testimony by the actors themselves, reflecting or commenting on their actions, or it can also be acquired from the structure and sequence of events. ${ }^{71}$

However, as Bennett and Checkel point out, the investigator must not confuse the metaphor with the logic of process tracing itself, for an IV could also be producing the intervening causal mechanisms themselves that then lead to the outcome of a DV. In these

\footnotetext{
${ }^{68}$ Van Evera, Guide to Methods, p. 52, fn. 9 [italics in the original].

${ }^{69}$ George and Bennett, Case Studies and Theory Development, p. 207; Van Evera, Guide to Methods, p. 64; and Bennett and Checkel, "Process Tracing," p. 4.

${ }^{70}$ Beach and Pedersen, Causal Case Study Methods, p. 302 [italics in the original].

${ }^{71}$ See King, Keohane, and Verba, Designing Social Inquiry, p. 227; George and Bennett, Case Studies and Theory Development, p. 6; and Van Evera, Guide to Methods, p. 65.
} 
situations, the intermediate events are simply "diagnostic evidence" that show the kind of process tracing taking place, but add no causal power to the intervening variables. The type of intervening variables or causal mechanisms that matter in process tracing are those that temporally or spatially are not fully determined by the IV, for "these events do have independent effects on the nature, timing, or magnitude" of the DV. ${ }^{72}$ With this important caveat in mind, process tracing can be understood as "the analysis of evidence on processes, sequences, and conjunctures of events within a case for the purpose of either developing or testing hypotheses about causal mechanisms that might actually explain the

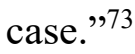

There are two main reasons why process tracing is suitable for the present study. First, process tracing generates numerous observations within a single case. This is extremely useful in cases, such as the long South American peace, that are rare or unique in the larger universe of cases. ${ }^{74}$ Process tracing, however, is not just particularly suited to study deviant or unique cases, for it can also be applied to other common (or "large-n") cases when involving other levels of analysis. ${ }^{75}$ The value of breaking a single case into smaller within-case studies is that it allows the investigator to link these smaller cases in ways that help construct an explanation for the larger case. A second reason is that process tracing offers a powerful way to make causal inferences in singular cases where other methods (e.g., controlled comparison) are not possible. ${ }^{76}$ In this sense, process tracing

\footnotetext{
${ }^{72}$ Bennett and Checkel, "Process Tracing," p. 7 [italics in the original].

${ }^{73} \mathrm{Idem}$

${ }^{74}$ See George and Bennett, Case Studies and Theory Development, p. 215.

${ }^{75}$ See Bennett and Checkel, "Process Tracing," pp. 5-6.

${ }^{76}$ See Beach and Pedersen, Causal Case Study Methods, pp. 18, 304-305; and George and Bennett, Case Studies and Theory Development, pp. 213, 214.
} 
helps avoid the dual problems of indeterminacy and confirmation-bias (or "story-telling"), for it offers the strongest type of inferential tests available in case-study research. ${ }^{77}$

"Good" process-tracing analysis, therefore, must also involve attempts to test and eliminate alternative (or rival) causal processes or mechanisms that could, in principle, lead to the same observable outcome. This is why it is so important to identify causal mechanisms that are not exclusively caused by the IV hypothesized by just one of the approaches, for in those cases the testing of alternative hypotheses would be rendered meaningless as the chosen IV would leave no room for potential alternative explanations that also employ those same intervening causal mechanisms. It would fail to account, in other words, for the problem of equifinality. In order to check for these factors, Stephen Van Evera identified a set of tests that measure the level of strength and type of predictions expected from the hypotheses and causal processes employed. Strong tests are those "whose outcome is unlikely to result from any factor except the operation or failure of the theory." ${ }^{78}$ These tests can be either certain and unequivocal, or unique and particular. The more certain and unique the prediction, the stronger the test. A "certain" prediction is one that is found in the empirical evidence, but which is also shared by other competing hypotheses. A "unique" prediction, on the contrary, is one that is found in the empirical record but which is only shared by few (or none) of the competing hypotheses.

\footnotetext{
${ }^{77}$ See Mahoney, "The Logic of Process Tracing Tests in the Social Sciences," pp. 571; and George and Bennett, Case Studies and Theory Development, pp. 224-232. In Van Evera's terms, process tracing offers the strongest types of tests, in the form of "smoking-gun tests" with a high level of "uniqueness." See Van Evera, Guide to Methods, p. 64.

${ }^{78}$ Van Evera, Guide to Methods, p. 31.
} 
As TABLE 1 (see infra) illustrates, the first type of test, called the "hoop test," evaluates predictions of high certitude, but of no uniqueness. Although passing this test is a necessary requirement for competing hypotheses to remain under consideration, it adds little support to any one of them in particular. The second type of test is the "smoking-gun test," which evaluates the reverse condition: high uniqueness, but no certitude. Passing this test corroborates the hypothesis, but casts little doubt on those explanations that fail. A third type is the "doubly-decisive test," which evaluates predictions of high uniqueness and high certitude. Passing this test decisively corroborates an explanation, while failing it eliminates it altogether. A final type is the "straw-in-the-wind test," which evaluates predictions of low certitude and low uniqueness. These are indecisive tests that cannot add strong corroboration to any one explanation. ${ }^{79}$

\section{TABLE 1. Types of Tests in Case-Study Research}

\begin{tabular}{|c|c|c|c|}
\hline & \multicolumn{2}{|c|}{ CERTITUDE } \\
\hline & & High & Low \\
\hline \multirow{2}{*}{ 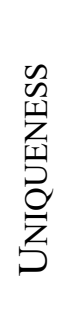 } & 해몸 & "doubly-decisive test" & "smoking-gun test" \\
\hline & 3 & "hoop test" & "straw-in-the-wind test" \\
\hline
\end{tabular}

\footnotetext{
${ }^{79}$ For a more detailed analysis of these tests, see Van Evera, Guide to Methods, pp. 30-34; Mahoney, "The Logic of Process Tracing Tests in the Social Sciences," pp. 570-597; Beach and Pedersen, Process-Tracing Methods, pp. 100-107; and George and Bennett, Case Studies and Theory Development, pp. 217-222.
} 
The dissertation follows a theory-informed type of process-tracing analysis not only because of the singular nature of the case study in question, but also because the international society argument contains an implicit causal chain mechanism that has been unexplored in regional case studies and untested against alternative competing arguments. ${ }^{80}$ For all its self-professed attention to history, political philosophy, and international law, the international society approach has demonstrated in practice a tendency to indulge in simplistic historical narratives and "story-telling" in ways that preclude the systematic testing and comparing vis-à-vis other cases and approaches. ${ }^{81}$ Works within the international society approach usually offer, at best, taxonomical theories that create and define concepts well, but which rarely systematize variables and hypotheses, operationalize causal mechanisms, or advance formal and testable propositions. It also offers comparative cases that, nevertheless, do not discuss any of the methodological aspects inherent to comparative case-study research, nor present clear and testable parameters to guide their comparison. ${ }^{82}$ In this dissertation, the international

\footnotetext{
${ }^{80}$ In this sense, this study uses what Beach and Pedersen term "theory-building process-tracing." See Beach and Pedersen, Process-Tracing Methods.

${ }^{81}$ This is one of the strongest and most common critiques levelled at the international society approach in IR. See Dale C. Copeland, "A Realist Critique of the English School," Review of International Studies, Vol. 29, No. 3 (July, 2003), pp. 427-441; and Martha Finnemore, “Exporting the English School?" Review of International Studies, Vol. 27, No. 3 (July, 2001), pp. 509-513. For an important exception to the rule, see Richard Little, "British Neutrality versus Offshore Balancing in the American Civil War: The English School Strikes Back," Security Studies, Vol. 16, No. 1 (2007), pp. 68-95. In this article, Little uses archival research and historical analysis to advance an international society critique of Neorealism's "offshore balancing" proposition regarding Great Britain's foreign policy during the United States' civil war.

${ }^{82}$ Prominent examples of this trend are Wight, Systems of States; Bull, The Anarchical Society; Bull and Watson, The Expansion of International Society; and Watson, The Evolution of International Society. Modern contributions still fiercely defend this "methodological" position. See Andrew Hurrell, "Keeping History, Law and Political Philosophy Firmly within the English School," Review of International Studies, Vol. 27, No. 3 (July, 2001), pp. 471-488; Cornelia Navari and Daniel M. Green, eds., Guide to the English School in International Relations (Wiley-Blackwell, 2014); and almost all the chapters in Cornelia Navari, ed., Theorising International Society: English School Methods (Palgrave, 2009). For a pioneering contribution that teases out the underlying causal mechanism implicit in Bull's argument, see Kalevi J.
} 
society argument is presented and operationalized with a formal hypothesis and a set of testable propositions. It is then tested via the process-tracing method against the historical record and other competing hypotheses.

With these considerations in mind, two other methods are used to reinforce the process testing. First, this study makes complementary use of historical analysis as a way to contextualize each of the within-case studies both analytically and in time, and to frame the alternative competing hypotheses by making use not just of the IR-theory literature, but also of the main historiographical debates relevant for each case study. Relying on an extensive survey of the historical literature, this dissertation offers an analysis of four within-case studies and identifies the areas of contestation that remain open among historians themselves. Incorporating some of these debates is important for exploring other hypotheses beyond the ones typically debated in the South American "long peace" debate, or in IR theory itself. The premise is to sacrifice some degree of depth on the altar of inclusiveness, for it is much preferable to err on the side of comprehensiveness than on that of narrow precision. ${ }^{83}$

In this study, historical analysis is also supported by more than simply a wide selection of secondary sources. It also makes use of multi-site archival research, with more than eighteen historical and diplomatic archives consulted in situ in eight different South American countries: viz., Argentina, Bolivia, Brazil, Chile, Ecuador, Paraguay, Peru, and

\footnotetext{
Holsti, "Theorising the Causes of Order: Hedley Bull's The Anarchical Society," in Theorising International Society, pp. 125-147.

${ }^{83}$ On the merits of following this principle in process-tracing analysis, see Derek Beach, "It's All About Mechanisms-What Process-Tracing Case Studies Should Be Tracing," New Political Economy, Vol. 21, No. 5 (2016), pp. 463-472.
} 
Uruguay. Apart from the archives of the respective Ministries of Foreign Affairs and other national archives, access to many national public and private libraries offered the unique possibility of consulting some of the best historical works from each country—-for the most part, inaccessible from abroad. The simultaneous use of primary and secondary sources, therefore, helps to avoid the problems of incomplete, selective, or biased contextualization of the actors' own words and actions in process-tracing analysis. It also acts as a corrective against many of the profoundly nationalistic, ideologized, or polemical history books that still pervade much of the historiographical production in Latin America. By using a healthy mix of primary and secondary sources the investigator can rely more confidently on the causal inferences made for each causal mechanism tested, and insulate its work from the most common distortions affecting process-tracing analysis.

In sum, the bonus of conducting archival research in almost all the countries of South America is that the investigator can acquire a better grasp and develop a wellgrounded expertise on the subject matter to discern more intelligently between "good" and "bad" secondary sources. ${ }^{84}$ This helps avoid what some scholars have called the "parasitic" use of history, which reduces historical complexity to a few simple variables relevant only to the researcher ${ }^{85}$ Finally, the combined use of primary and secondary sources helps

\footnotetext{
${ }^{84}$ The only archives not consulted were the ones in Venezuela and Colombia. The lack of access to the archives of these two countries, however, is somewhat compensated by their own minor roles in the historical case studies selected in this study.

${ }^{85}$ This is one of John L. Gaddis' main criticisms against most works in IR employing history to test social science theories. See, e.g., Gaddis, "History, Science and the Study of International Relations," in Explaining International Relations since 1945, ed. by Ngaire Woods (Oxford University Press, 1996), pp. 32-48; Gaddis, "History, Theory, and Common Ground," International Security, Vol. 22, No. 1 (Summer, 1997), pp. 75-85; and Gaddis, The Landscape of History: How Historians Map the Past (Oxford University Press, 2002). For an important rejoinder, cf. Marc Trachtenberg, The Craft of International History: A Guide to Method (Princeton University Press, 2006).
} 
discern sloppy, polemical or unreliable historical work from the best examples of wellresearched and well-documented analysis. Since historiography in Latin America remains a highly politicized activity, direct access to primary sources critically assists in correctly identifying and balancing among historians' own contending national views.

\section{Case-Study Selection}

There are not many historical cases of regional long peace, such as the one in South America. Those other cases, however, have been successfully explained using major IR theories, such as Neorealism's balance-of-power theory, Liberalism' inter-democratic and institutionalist theories, or Constructivism's security communities. The most well-studied case is the European regional order post-1945, which finds in the overarching military presence of the United States via NATO a powerful security deterrent against any aggressor-from within or without Europe. The bipolar structure of the Cold War and the presence of nuclear armed powers also constitute an additional deterrent to maintain such stable regional order in place. The consolidation of republican democracies across the European Union is also commonly invoked as a major explanation to account for Western Europe's stability and the longevity of its regional peace. ${ }^{86}$ The so-called Scandinavian

\footnotetext{
${ }^{86}$ On the "long peace" in Europe, see John L. Gaddis, "The Long Peace: Elements of Stability in the Postwar International System," International Security, Vol. 10, No. 4 (Spring, 1986), pp. 99-142; Gaddis, The Long Peace: Inquiries into the history of the Cold War (Oxford University Press, 1987); Charles W. Kegley, ed., The Long Postwar Peace: Contending Explanations and Projections (Harper Collins, 1991); John Mueller, Retreat from Doomsday: The Obsolescence of Major War (Basic Books, 1989); Mueller, Quiet Cataclysm: Reflections on the Recent Transformation in World Politics (Harper Collins, 1995), esp. pp. 27-39; Sean M. Lynn-Jones, ed., The Cold War and After: Prospects for Peace (MIT Press, 1991); John S. Duffield, "Explaining the Long Peace in Europe: The Contributions of Regional Security Regimes," Review of International Studies, Vol. 20, No. 4 (October, 1994), pp. 369-388; and Kenneth N. Waltz, "The Stability of a Bipolar World," Deedalus, Vol. 93, No. 3 (Summer, 1964), pp. 881-909. Cf. Dale C. Copeland, "Neorealism and the Myth of Bipolar Stability: Toward a New Dynamic Realist Theory," in Realism: Restatement and Renewal, pp. 29-89. For an analysis of the implication of the end of bipolarity for international security, see John J. Mearsheimer, "Back to the Future: Instability in Europe after the Cold
} 
peace, for its part, has also been associated to social democracy and high-standards of living for sustained periods of time. Being part of the European system has also been a contributing factor, coupled with "cultural" arguments highlighting a common culturalhistorical past, and the sharing of similar linguistic and religious characteristics. ${ }^{87}$ The case of Sub-Saharan Africa, moreover, has been unproblematically explained by mainstream IR theories as one of the legacies of the colonial period, where territorial boundaries remained stable and largely uncontested, while insecure governments remained threatened by transnational ethnic and religious hatreds, as well as by civil war, paradoxically occurring within and across those same stable borders. ${ }^{88}$

Unlike these other regional cases, South America defies most of the traditional IR theory expectations. Seen in this aggregate level of analysis, South America can be seen as a "deviant case"; but in the context of this dissertation, however, the focus is placed on four within-case studies of major regional diplomatic disputes that later evolved into a major

\footnotetext{
War," International Security, Vol. 15, No. 1 (Summer, 1990), pp. 5-56; Mearsheimer, "Why We Will Soon Miss the Cold War," The Atlantic Monthly, Vol. 266, No. 2 (August, 1990), pp. 35-50. For a similar argument applied to Latin America, see Desch, "Why Latin America May Miss the Cold War." For a critical view, see Little, "International Conflict in Latin America," pp. 589-601.

${ }^{87}$ On the Scandinavian case, see Clive Archer, "The Nordic Area as a 'Zone of Peace'," Journal of Peace Research, Vol. 33, No. 4 (1996), pp. 451-467; Clive Archer and Pertti Joenniemi, eds., The Nordic Peace (Ashgate, 2003); and Laust Schouenborg, The Scandinavian International Society: Primary Institutions and Binding Forces, 1815-2010 (Routledge, 2013). For a critical review of the literature, cf. Anders Wivel, "What Happened to the Nordic Model for International Peace and Security," Peace Review, Vol. 39, No. 4 (2017), pp. 489-496; and for a comparative study of the Nordic region and the Southern Cone of South America, see Dylan W. Roberts, "Create, Establish, Maintain: Comparing Zones of Peace in the Nordic Area and the Southern Cone," M.A. Thesis, Miami, FL: Florida International University, 2014.

${ }^{88}$ See Jeffrey Herbst, States and Power in Africa: Comparative Lessons in Authority and Control (Princeton University Press, 2nd ed., [2000] 2014); Robert H. Jackson, Quasi-states: Sovereignty, International Relations and the Third World (Cambridge University Press, 1993); Herbst, "War and the State in Africa," International Security, Vol. 14, No. 4 (Spring, 1990), pp. 117-139; and Robert H. Jackson and Carl G. Rosberg, "Why Africa's Weak States Persist: The Empirical and the Juridical in Statehood," World Politics, Vol. 35, No. 1 (October, 1982), pp. 1-24. For a comparative study with South America, see Kacowicz, Zones of Peace in the Third World.
} 
war. Each successive historical chapter looks at four different wars and the negotiated peace agreements that followed them. The first three cases are from the 19th century: (a) the "Guano War" of 1864-1871; (b) the War of the Triple Alliance of 1864-1870; and (c) the War of the Pacific of 1879-1884; while the last case is from the early 20th century: (d) the Chaco War of 1932-1935. Although there are other minor armed conflicts in the history of the region, these four cases represent key milestones in the history of South America's international relations. They left enduring legacies of intra-regional power disparity and hierarchies of prestige; they molded national histories, shaped cultural stigmas and selfimages, and reinforced economic and financial patterns of dependency among neighbors. Most importantly, they left a geopolitical "footprint" that still continues to affect the foreign policies of the victors and defeated alike.

In the 19th century, there were many conflicts in South America. None, however, had the scale or importance of the four cases selected for this study. An important antecedent to the War of the Pacific (1879-1884), for example, was the War of the PeruBolivian Confederation (1836-1839), which also confronted Chile with Peru and Bolivia - temporarily unified under the leadership of Andrés de Santa Cruz. Against the background of this war, also, one must contextualize the "Guano War" (1864-1871) which is the focus of Chapter 2. In these two conflicts, former enemies fought together some thirty years later against the Spanish Empire, only to become rivals once again in the War of the Pacific (1879-1884). Other conflicts, such as the multiple confrontations during the mid19th century involving Peru, Ecuador and Colombia were minor border conflicts that developed on the fringes of ongoing civil wars and regional caudillo rivalries. Although these conflicts also serve as a historical context for the disputes between Peru-Ecuador 
(1941, 1981, 1992) and Peru-Colombia (1932), their "limited" aspect renders them less useful ("weaker tests") for analyzing the potential impact of international society on the progressive taming of war in South America.

At this point, two clarifications are in order. One is chronological, regarding the timeframe of this study; and the other spatial, regarding the geographic scope of the argument. Since the present study traces the origins and evolution of South America's society of states, it focuses on the 1860s-1930s period. This has two main reasons: First, given that a "society" of states presupposes a "system," the analysis must necessarily start with the emergence and consolidation of a system of states itself before any consideration of a society can be even attempted. This explains why, in the interest of tracing the origins of South America's society of states, the study begins in the $1860 \mathrm{~s}$ and not before. Prior to this critical decade for South America, states were not consolidated and a system of states - properly defined — had not yet been established. At best, one can speak of a system in formation between the achievement of independence (1820s) and the $1860 \mathrm{~s} .{ }^{89}$

Second, the study's interest in the historical evolution of this society, and its subsequent impact on the "long peace" phenomenon, creates the need to engage with the history of South America's international relations in a longitudinal approach that covers several decades and identifies crucial moments along the way. The in-depth study of the entire history of the region, however, would not be practical or truly possible under one single volume. This dissertation, therefore, evaluates only the initial period (that between 1860s and 1930s) of the region's complete historical evolution (1810-2018). A second

${ }^{89}$ Cf. Burr, By Reason or Force; and Ron Seckinger, "South American Power Politics during 1820s." 
(future) volume could not only incorporate some of the other possible within-case studies not included in this dissertation, but also continue temporally from the 1940s until the present time. This second volume could build upon the present study's focus on "origins" and "evolution," and concentrate on the further "consolidation" (or maturation) of the society of states after the emergence of more formal institutional arrangements, such as the OAS, UNASUR, or other economic integration projects, such as MERCOSUR.

As far as the geographic scope of the study is concerned, it is necessary to explain why the argument is limited only to South America, and not simply Latin America. Although many existing discussions talk indistinctively about South and Latin America, the distinction between both is of paramount importance. First of all, in purely empirical terms the "long peace" obtains only in the South America sub-region of the American continent. The twelve countries that now compose this sub-region (including Argentina, Bolivia, Brazil, Chile, Colombia, Ecuador, Guyana, Paraguay, Peru, Suriname, Uruguay and Venezuela) constitute together not just a discrete geographical space, but also display a distinctive "self-image" that has been well-documented over the years by regional specialists and historians. ${ }^{90}$ Separated from the Caribbean and Central American subregions by more than vast distances, South America shares a unique sense of self, forged in a common history of anti-Spanish colonialism that differs from its neighboring regions in term of their distance from the United States, the lesser influence and type of French, British and Dutch colonialism, as well as higher economic, developmental conditions and overall standing in the world. Most importantly, South American nations have always

\footnotetext{
${ }^{90}$ See, inter alia, G. Pope Atkins, Latin America and the Caribbean in the International System (Westview Press, 4th ed., [1989] 1999).
} 
enjoyed a higher level of regional semi-isolation and autonomy vis-à-vis the rest of the Western Hemisphere. While a professed Latin American "brotherhood" (or "hermandad”) has always been part of the intellectual arsenal of Latin American prominent historical figures (such as intellectuals, poets, revolutionaries, politicians, and philosophers), there has always been in practice a stronger sense of belonging among those countries most immediately proximate. The international relations of Central American and Caribbean nations, moreover, escape the paradoxical nature of South America's "long peace" entirely. ${ }^{91}$ It is for all these aspects that South America must be studied separately.

Studying the "long peace" by referring to Latin America can dramatically alter the analysis. Including Central America, for example, can blind observers from clearly identifying the distinctive nature of the South American experience. This is why Miguel Centeno, Félix Martín, Arie Kacowicz, and many other contributors to the long peace focus exclusively on South American international relations. A problematic case, however, is that of David R. Mares, who in his study of the long peace not only includes the whole of Latin America, but also lowers the threshold for what should be considered a waremploying the MID dataset instead of the traditional COW project database on war. Mares' double move biases the analysis in favor of conflictivity and thus fails to appreciate the important differences in the patterns found in each sub-region of the Americas. As this study shows, a "society of states" formed only in South America in the mid-1860s, both in terms of self-images and self-references as a "region," as well as in terms of the levels of

\footnotetext{
${ }^{91}$ See Centeno, Blood and Debt, p. 1: fn. 1; Robert H. Holden, Armies without Nations: Public Violence and State Formation in Central America, 1821-1960 (Oxford University Press, 2004); cf. Holsti, The State, War, and the State of War, p. 174.
} 
identification and solidarism evoked by what were considered "threats" and "common" problems. ${ }^{92}$ The focus on interests in the international society approach, contrary to the identitary and cultural focus of other approaches, can explain better these intra hemispheric differences in solidarity and threat-perception as the 19th century gave way to the 20th. Patterns of interaction that obtained in South America among neighbors were of a distinctively different nature than those between these and Mexico or other Central American or Caribbean nations.

Finally, it is also important to explicitly state the reasons why the four chapters deal with "wars," while the larger interest of the study is in explaining a "long peace." The objective of each chapter is not to explore the military aspects of these conflicts per se, but to focus on them as parts of a larger regional diplomatic interaction, and to evaluate their impact on the construction and further consolidation of states (internally), as well as of a society of states (regionally), in the context of a larger explanation for the region's long peace. In this sense, each war is studied in conjunction with the difficult, but parallel, efforts at cooperation and peaceful resolution of each crisis, both practiced by the belligerents themselves as much as by those regional neighbors not directly involved in the conflict. The emphasis put here on such "double efforts" at negotiation and peace during such difficult times for regional order offers a unique opportunity to contrast and study in proper depth how war and peace, as inextricably linked phenomena, interact as part of a

\footnotetext{
${ }^{92}$ In the case of 19th-century Mexico, which suffered a French monarchical occupation during the 1860s, South American nations reacted in solidarity only selectively and in a feeble manner, demonstrating a weaker sense of belonging than when Peru was aggressed by Spain in 1864, or Venezuela in 1903, or when Colombia lost control of the Panama Canal to the United States. The dramatic changes in Mexican foreign policy in the 1990s, however, definitely consolidated the perceived place of Mexico as a North-American nation, rather than a Central or South American one.
} 
single dynamic process affecting order-formation and consolidation at the regional level. Additionally, and perhaps most crucially, the case studies trace and compare the "dialogue" and "action" of the main statesmen and decision-makers at the time, from belligerents and neutral countries alike. This facilitates the testing of a sense of "awareness" of common interests and the potential for "strategic learning" by political elites regarding the longerterm national interests towards a well-ordered and peaceful regional neighborhood.

\section{Organization of the Study}

The four cases studied in this dissertation represent the largest and most impactful wars in the history of South America. Their selection offers "stress tests" for the competing hypotheses presented in Chapter 1-and a remarkably strong test for the international society argument in particular. It is in these critical moments of extreme danger, when newly independent nations faced the open-ended phenomenon of war, that national survival is most at stake. For South American nations in the 19th century, only a handful of decades in existence after de facto independence from the Spanish and Portuguese empires, the three major wars of the 19th century represented decisive challenges for popular sentiments of "American brotherhood" and sense of belonging to a region of autonomous republican states. If there was any sense of membership in an international society (or society of states) at the time, as hypothesized in this study, then its effects should be particularly observable in such difficult instances of war.

At the same time, these instances of heightened risk offer a fair test for Realist hypotheses, which can be said to be at their best in such circumstances, given their focus

on survival, security and power as driving motivations for states. Liberal hypotheses are 
equally tested in their focus on regime type, for republicanism played an important role in the framing of international relations in the region. Wars among similar regime types are not expected, nor are alliances between monarchies and republics. The Liberal argument is also tested in their focus on the "pacifying" effects of economic inter-dependence, for many conflicts involved disputes over resource-rich areas. Constructivist approaches find also important tests in these four cases, for a strong cultural, linguistic and "Americanist" identitary congruence has always been present in the region, yet integration levels remain very low-both politically as well as economically. If regional peace responds to how a whole society (including its leaders and decision-makers) changes its identity, then the external-peace-internal-peace paradox presents a hard empirical challenge that contradicts the core logic of the Constructivist argument.

In this context, the first two cases are particularly informative for at least two main reasons. First, because they occurred almost simultaneously in the mid-1860s; and second, because the so-called "Guano War" confronted the alliance of Chile, Peru, Ecuador and Bolivia against the former Motherland, Spain. Pre-existing sentiments of regional belonging or membership were thus tested among South American nations in a confrontation with an extra-regional, European monarchy. Spain was seen as threatening not only the independence of one South American nation (Peru), given the Spanish seizure of the Chincha Islands, but also the very independence, autonomy and republicanism-if not the regional order - of the entire American continent. Chile, Bolivia and Ecuador entered the war in a solidarist move to protect Peru from Spanish aggression, when the latter seized three Peruvian islands rich in guano deposits. Since at the time there was no formal treaty between Peru and Spain ratifying the former's independence, this potentially 
represented a major threat to Peru's own existence as a sovereign state. In sum, the Guano War, which is the main focus of attention of Chapter 2, is a good test for corroborating sentiments of intra-region "solidarity," as well as moderation and restraint in the use of force during a situation of "life and death" for these young republics. Peru, after all, had been a terrible neighbor for Chile and Ecuador during the previous four decades. The convocation of a regional diplomatic Congress in Lima, in January 1864-four months prior to the Spanish aggression — offered a perfect opportunity to try to articulate "a common front" once the dispute with the Spanish Armada broke out.

In parallel, while the Quadruple Alliance (Bolivia, Chile, Ecuador and Peru) successfully fended off Spain in the South Pacific region, in the River Plate area, on the eastern side of the sub-continent, Paraguay and the Triple Alliance (composed of Argentina, Brazil, and Uruguay) waged the most destructive international war in the history of the Americas. ${ }^{93}$ This war, which is the focus of Chapter 3, entailed what was seen at the time as an incompatible or "unnatural" alliance between Argentina, a republic, and the Brazilian Empire, a monarchy. This alliance, moreover, was formed against Paraguay: a "sister republic."

The contrast between both wars, one in the South Pacific and the other in the Atlantic area, offers a multiplicity of opportunities for testing several of the propositions advanced by the international society approach and by many alternative theories. Not only was the War of the Triple Alliance against Paraguay (1864-1870), for example, seen as a major offense by the other nations of the region to their shared sense of "Americanism"-

\footnotetext{
${ }^{93}$ With the obvious exception, perhaps, of the civil war in the United States. Despite its civil character, many historians often consider it an international conflict as well.
} 
in particular, by the nations of the South Pacific - but also by the major powers of the world, such as Great Britain and the United States. Both great powers tried to offer their mediation at several instances during the war, trying to put an end to a conflict that was negatively affecting their commercial and strategic interests in the River Plate area. Moreover, the War of the Triple Alliance could have easily meant the end of Paraguay as an independent nation. It was, both to its leaders as much as the Paraguayan people, a "total war" for survival. Paradoxically, however, it also showcases an important test for the idea of "restraint" on the part of the allies, for despite Paraguay's monumental human losses, its existence as a sovereign nation was ultimately preserved after the war by the very own countries that had waged a brutal war against her for over five years. Its territorial loses, for example, affected only areas formerly under dispute - and not yet established as Paraguayan territory - and in a scale inferior to the pre-war demands made by both Argentina and the Brazilian Empire. The war-debt, as well, was ultimately pardoned by the allies after the war.

The simultaneous development of these two conflicts also offers the possibility of testing two case studies that were influenced by similar global developments and trends, as well as by each other. These include, for example, European imperialism and colonialism (in Asia and Africa), the problematic impact of the Civil War on the United States' foreign policy in the 1860s, and the wider effects of technological transformations in war-fighting, telecommunications, medicine, resource-extraction, finance, and trade during the second half of the 19th century. Unfortunately, the study of the interaction of these two conflicts 
inter se has been tried only rarely and in a limited manner. ${ }^{94}$ However, the proper study of their mutual effects is a crucial component of the present study, for it uncovers dynamics of South America's international relations previously overlooked or understudied, but of great importance.

Chapter 4 focuses on the 1879-1884 war between Chile and the Peru-Bolivia alliance over the control of the Atacama and Tarapacá desserts area in the South Pacific. This conflict is relevant for the integrated history of the region because, among other things, it confronted three states that had been allies less than a decade before. That is, it offers a "hard test" for the international society argument, given the rather rapid change of these countries' alignments from close allies to enemies. Moreover, it offers an interesting test for the Realist argument, for Argentina made use of Chile's war with her northern neighbors to secure its control over the Patagonia region-a dispute that nevertheless remained open from a Chilean perspective until the early years of the 20th century. Unable to fight on two fronts, Chile negotiated with Argentina an "abandonment" of her claims to that region in order to focus exclusively on the conflict with Bolivia and Peru to the north. At first sight, this "opportunistic" behavior by Argentina corroborates the Realist argument; however, upon closer inspection, Argentina's moderation and restraint in how she handled the affair, using only diplomatic channels and remaining strictly neutral in the

\footnotetext{
${ }^{94}$ For three rare examples that try to weave an interconnected view of both conflicts, see Pablo Lacoste, “Americanismo y guerra a través de El Mercurio de Valparaíso (1866-1868)," Anuario de Estudios Americanos, Tomo LIV, No. 2 (1997), pp. 567-591; Lacoste, "Las guerras hispanoamericana y de la Triple Alianza: La revolución de los Colorados y su impacto en las relaciones entre Argentina y Chile," Historia, Vol. 29 (1995-1996), pp. 125-158; and Eduardo Cavieres Figueroa, "Las frustraciones de la Unión Americana: La guerra del Paraguay, estado y sociedad en los conflictos del Cono Sur, 1860-1880," in La guerra del Paraguay: Historiografías. Representaciones. Contextos, ed. by Horacio Crespo, Juan M. Palacio and Guillermo Palacios (México DF: El Colegio de México, 2012), pp. 299-322. These brief studies, however, offer only a view that is centered on 19th-century Chile, through its main newspapers and the perceptions of its political and intellectual élite at the time.
} 
War of the Pacific, also gives a strong support for the international society argument. Argentina used its diplomatic assets carefully and with a sense of responsibility, for having accepted the Peru-Bolivian repeated requests to join their alliance against Chile would have most certainly meant the extinction of Chile as an independent nation-and thus profoundly altered the regional order.

The last historical chapter focuses on the Chaco War, between Bolivia and Paraguay. This war, waged between 1932 and 1935, presents all the ingredients for a strong test among all the rival hypotheses. Starting rather informally in 1928, with minor clashes between patrol units in the Chaco area, the dispute continued until 1938, when the final peace treaty was signed — and ultimately ratified the following year. Both Bolivia and Paraguay, as defeated powers in their previous major wars, were deeply affected by those two conflicts. In an important sense, their own war was made possible, and profoundly shaped by, the way in which the War of the Triple Alliance and the War of the Pacific had been resolved. Bolivia lost all its territorial possessions abutting the Pacific Ocean, thus becoming in 1884 a de facto land-locked country with no fluvial access to world markets other than a potential outlet to the Atlantic Ocean via the Paraguay River. Paraguay, for her part, devastated by the previous war against the Triple Alliance, was forced to abandon all her claims to a number of disputed territories, including the area of Misiones to the east, the region between the rivers Pilcomayo and Bermejo to the south, and a small area to the north adjoning Brazil, as well as other parts of the "Gran Chaco" region to the west. In the Chaco War, two of the poorest nations of the sub-continent confronted one another for control of a poorly demarcated area, suspected to contain oil deposits and fertile grasslands 
for raising cattle, but most importantly providing a strategic geopolitical bridge between the western and eastern regions of South America.

The Chaco War is iconic for the present study, for it represents the most illustrative case of American "solidarism" by key neighboring states, such as Argentina, Chile and Brazil — with the early involvement of extra-regional actors, like the League of Nations and the United States itself. The continuous offers of mediation and arbitration, and other pacification efforts by the rest of the American states between 1935 and 1938, paradoxically lasted longer than the actual fighting itself (1932-1935). That is, the negotiation of peace took more years than the fighting itself. Normally considered by the specialized literature as "the lowest point" of the Pan-Americanist movement in the Western Hemisphere, the process of war and peace in the Chaco can however also be seen as a triumph of international society. Although war could not be prevented, it was effectively moderated, restrained and de-escalated by the action of neighboring states who were deeply concerned with the wider implications of the confrontation for the region's order and stability. Although economic and financial interests were essentially involved, such as the well-known Argentine "patronage" over Paraguay or Chilean and Brazilian efforts to influence Bolivia, these interconnections far from demonstrating intra-regional imperialism, or a rapaciously opportunistic behavior, actually show the effects of a strong awareness of common interests in the protection of regional order. A regional awareness, that is, premised on very real and logical common interests - and not on some idealized version of hermandad or community sentiments, in the abstract.

Apart from these historical components, the dissertation benefits from a theoretical framework previously unapplied to the study of South America's international relations. 
By adopting the international society approach, the dissertation aims to provide a coherent, consistent and systematic set of working definitions and methodological tools with which to study the origins and dynamic evolution of South America as a social system of states, progressively learning from its experiences to value regional order and stability. This methodological approach is not typically followed by other studies of the region. Not all studies of South American international relations advance and test competing hypotheses, nor pay proper attention to the 19th century. Historians, for example, despite their attention to the Society and War perspective, have produced national histories of each respective war, but no efforts have been done to inter-connect these wars to the regional and global level of analysis. The Society and War perspective has focused on the domestic effects of each war for the society as a whole, but in particular for the women, the families of soldiers, and for ethnic and socio-economic social cleavages, as well as the war's legacy in the educational system and the collective memories of the nation, creating myths and narratives of heroes and martyrs, etc. For all the positive attributes of this perspective, particularly regarding the impact of war on state-formation and consolidation, little or no attention is normally paid to the interaction between the "domestic" and the "regional" (or external) levels produced by these wars. In other words, not just how war affected the internal dynamics of the state, but also how it affected the outward-oriented interactions among states. Each national process of state-formation and consolidation, in conclusion, took place not in isolation but in specific regional and global circumstances which are too often neglected even by the best historical studies. 


\section{CHAPTER 1}

\section{EXPLAINING THE “LONG PEACE”: CONTENDING APPROACHES}

This chapter has three main objectives. First, it contextualizes the academic debate on the long South American peace by placing it in the ongoing larger theoretical discussions about war and peace in IR. Second, it defines a series of key concepts that despite giving shape to the academic debate on the long peace in South America, remain either contested or underdeveloped. A third section introduces the main contending explanations in this study and operationalizes them as formal and generalizable causal mechanisms. This final section is of critical importance for the correct application of the process-tracing method in the subsequent case-study Chapters $2-5$. In this context, for each of the contending approaches, this chapter lays out their general conceptual propositions and theoretical expectations, and assesses their concrete empirical form when applied to the historical cases.

\section{The South American "Long Peace" in Context}

South America is usually characterized by students of regional security as one of the most peaceful regions in the world. This popular view is premised on two main assumptions. The first assumption is the acknowledgment of the fact that war among states is a recurrent phenomenon of world politics. In this sense, when certain groups of states remain at peace for prolonged periods, the conventional knowledge in IR is challenged and a need for new and better explanations grows. It is important to note that the main issue is not the mere 
occurrence of peace (understood, at least minimally, as the absence of war), but the sustainability of peace over very long periods. Similarly, although the academic debate focuses mainly on the recurrence of war, the sole occurrence of peace does not necessarily contradict IR's main disciplinary assumptions. As David McIntyre put it, "[a]fter all, the South American peace is anomalous because neo-realism predicts that warfare should be a recurrent phenomenon." 95 In fact, "moments" of peace are required among "moments" of war to be able to claim that war is a recurrent, rather than an uninterrupted, phenomenon. In this context, peace must also be understood as a recurrent phenomenon in its own right. A second assumption is the recognition that different patterns of war and peace obtain when contrasting different regions of the world. Although war may be a recurrent feature of international life, it is not equally recurrent or frequent everywhere at the same time or intensity. It is in such a context that South America stands out with a record of inter-state war that is markedly lower in frequency and intensity than any other regionespecially during the 20th century. War and other forms of organized violence among human collectivities (e.g., empires, tribes, nations, city-states, etc.) have always been a recurrent aspect of international relations. Peace, however, as historian Michael Howard argues, seems to be a modern invention. ${ }^{96}$

\footnotetext{
${ }^{95}$ McIntyre, “The Longest Peace,” p. 170.

${ }^{96}$ Michael Howard, The Invention of Peace and the Reinvention of War (Profile Books, 2001). The idea was taken by Howard from Sir Henry Maine, who in 1888 wrote in his famous treatise, International Law, "War appears to be as old as mankind, but peace is a modern invention." For a critical assessment of the view of peace as a "modern" phenomenon, see Kurt A. Raaflaub, ed., Peace in the Ancient World: Concepts and Theories (Wiley-Blackwell, 2016); Raaflaub, ed., War and Peace in the Ancient World (Wiley-Blackwell, 2006); Kurt A. Raaflaub and Nathan Rosenstein, eds., War and Society in the Ancient and Medieval Worlds: Asia, the Mediterranean, Europe, and Mesoamerica (Harvard University Press, 2001).
} 
Although the idea of war as a recurrent phenomenon was already implicit in Thucydides' work, who wrote his story "as a possession for all time," it was Kenneth N. Waltz who first problematize the recurrence of war itself. According to Waltz, it is the "anarchic" context of politics among human collectivities trying to survive what best explains the continuous resurgence of armed conflict in international relations ${ }^{97}$ In Theory of International Politics, one of the discipline's most canonical texts, Waltz argues that "[w]hether in the family, the community, or the world at large contact without at least occasional conflict is inconceivable; and the hope that in the absence of an agent to manage or to manipulate conflicting parties the use of force will always be avoided cannot be realistically entertained. Among men as among states, anarchy $[\ldots]$ is associated with the occurrence of violence." $" 98$ Yet, as he later clarified, "[t]he recurrence of war is explained by the structure of the international system. Theorists explain what historians know: War is normal."${ }^{.99}$

In this context, given that the traditional knowledge in the discipline of IR "normalizes" both the occurrence and recurrence of war, while making the maintenance of peace for prolonged periods of time "exceptional," the case of South America acquires a central importance for the study of war and peace in a general sense. If the South American case reveals itself as more than a mere "absence of war" for a handful of decades, it could be of great value for the study of the same phenomenon in other regions of the world. But

\footnotetext{
${ }^{97}$ See Kenneth N. Waltz, Man, the State, and War (Columbia University Press, 1959); Waltz, Theory of International Politics; and Waltz, "The Origins of War in Neorealist Theory," Journal of Interdisciplinary History, Vol. 18, No. 4 (Spring, 1988), pp. 615-628.

${ }^{98}$ Waltz, Theory of International Politics, p. 102 [italics added].

${ }^{99}$ Waltz, "The Origins of War in Neorealist Theory," p. 620 [italics added].
} 
if war returned to South America, then it would also be considered as a return to "normalcy," and any lessons learned from the study of its collapsing peace would lose some of its potency; faith in its wider applicability would certainly diminish.

Although the study of war and peace has always been at the heart of the discipline of IR, it has been far more common to focus on war rather than peace. As William T. R. Fox famously put it, "[w] hat makes wars end ('the causes of peace') and what makes wars from ending ('the conditions of war') has been much less studied than what makes wars start ('the causes of war') and what keeps wars from starting ('the conditions of peace')."100 This generalized war-bias in the academic study of international relations has profoundly shaped how traditional approaches to security have treated war and peace as noncomplimentary and discrete phenomena. ${ }^{101}$ During the Cold War, for instance, to study security almost unequivocally meant to focus on nuclear deterrence and the balance of power among the great powers - particularly among the Soviet Union and the United States - in detriment to other aspects, like the environment, human security, gender, or issues not directly related to the survival of the state itself, or its type of regime. ${ }^{102}$ Towards the end of the 20th century, however, new issues and "sectors" gained ground in the

\footnotetext{
${ }^{100}$ William T. R. Fox, "The Causes of Peace and Conditions of War," Annals of the American Academy of Political and Social Science, Vol. 392 (November, 1970), p. 1. For a recent restatement of the same logic through the levels-of-analysis approach, see Jack S. Levy, "The Causes of War and the Conditions for Peace," Annual Review of Political Science, Vol. 1 (1998), pp. 139-165.

101 This bias is most evident in mainstream approaches to international security. There is a growing body of literature, however, which has consistently challenged this type of approach since, at least, the end of the Cold War. Unfortunately, these new critical approaches have not yet been systematically used to study the South American case. For a general overview of this alternative literature, see Ken Booth, ed., Critical Security Studies and World Politics (Lynne Rienner, 2005); Columba Peoples and Nick Vaughan-Williams, Critical Security Studies: An Introduction (Routledge, 2nd ed., [2014] 2015); and Keith Krause and Michael C. Williams, eds., Critical Security Studies (University of Minnesota Press, 1997).

102 On this aspect, see Arnold Wolfers, Discord and Collaboration: Essays in International Politics (The Johns Hopkins University Press, 1962), esp. ch. 10.
} 
international security agenda over the more traditional systemic approaches.

Simultaneously, the so-called "new agenda" gave way to a more regionally-minded

perspective in the study of international security. ${ }^{103}$

The study of distinct patterns of war and peace through the regional lens has grown exponentially since the end of the Cold War, becoming today the most established way of framing global security studies. One of the important innovations of this approach has been the focus on "Regional Security Complexes" (RSC), which are characterized by the role of key regional states (such as "buffer" or "pivotal" states), the particularities of their geopolitical outlook, and the security dynamics of each region after the Cold War. ${ }^{104}$ Viewed in this light, all sorts of distinctive regional aspects were identified, leading to the analysis of regions strictly in terms of "zones of peace" or "zones of conflict," depending on which patterns seemed to prevail. ${ }^{105}$ One of the positive aspects of this approach was

\footnotetext{
${ }^{103}$ Although the literature is vast, some representative and pioneering studies on the regionalization of security studies are Barry Buzan, People, States and Fear: An Agenda for International Security Studies in the Post-Cold War (Lynne Rienner, 1991); Louise Fawcett and Andrew Hurrell, eds., Regionalism in World Politics: Regional Organization and International Order (Oxford University Press, 1994); Andrew Gamble and Anthony Payne, eds., Regionalism and World Order (Palgrave, 1997); David A. Lake and Patrick M. Morgan, eds., Regional Orders: Building Security in a New World (The Pennsylvania State University Press, 1997); Etel Solingen, Regional Orders at Century's Dawn: Global and Domestic Influences on Grand Strategy (Princeton University Press, 1998); Adler and Barnett, Security Communities; Buzan and Wæver, Regions and Powers; Paul F. Diehl and Joseph Lepgold, eds., Regional Conflict Management (Rowman \& Littlefield, 2003); Douglas Lemke, Regions of War and Peace (Cambridge University Press, 2004); Miller, States, Nations, and the Great Powers, States, Nations, and the Great Powers, pp. 306-336; Amitav Acharya, "The Emerging Regional Architecture of World Politics," World Politics, Vol. 59, No. 4 (July, 2007), pp. 629-652; Andrew Hurrell, "One World? Many Worlds? The Place of Regions in the Study of International Society," International Affairs, Vol. 83, No. 1 (2007), pp. 151166.

${ }^{104}$ On RSC theory, see Buzan, People, States and Fear; Arthur A. Stein and Steven E. Lobell, "Geostructuralism and International Politics: The End of the Cold War and the Regionalization of International Security," in Regional Orders, pp. 101-122; and Buzan and Wæver, Regions and Powers.

${ }^{105}$ One of the first works framing the study of regional security in such terms was Max Singer and Aaron Wildawsky, The Real World Order: Zones of Peace, Zones of Turmoil (Chatham House, rev. and enl. ed., [1993] 1996). Later studies, on a similar line, are Kacowicz, Zone of Peace in the Third World; Arie M. Kacowicz, et al., Stable Peace Among Nations (Rowman \& Littlefield, 2000); Robert D. Kaplan, The Coming Anarchy: Shattering the Dreams of the Post-Cold War (Random House, 2000); Alexander Kozhemiakin, Expanding the Zone of Peace? Democratization and International Security (Palgrave, 1998);
} 
that it generated an immense growth in comparative case-study research around the world. In the case of South America, the region has attracted mostly the interest of scholars of security studies and IR, but also that of international historians, sociologists, and comparativist political scientists. Yet, given the strong anti-theory bias of most of these contributors to the study of Latin America in general, it should not come as a surprise the rather unsystematic and presentist nature of their studies of South America's long peace. ${ }^{106}$ These usually take the form of succinct chapters or journal articles, which rarely give way to a sustained debate or serious academic exchanges among the scholars studying South America's long peace. For most of the Cold War, therefore, South-American studies lagged behind more systemic or "global" phenomena, focused on nuclear proliferation, deterrence and their impact on European regional stability. With the end of the bipolar confrontation between the Soviet Union and the United States, however, the study of South America went through an "academic re-discovery." In the 1990s, the region attracted the attention of multiple IR scholars interested in the region's "puzzling" pattern of prolonged inter-state peace amid high levels of intra-state violence, giving shape for the very first time to a more serious engagement with the paradoxical nature of the region's prolonged peace.

\footnotetext{
Vassilis K. Fouskas, Zones of Conflict: U.S. Foreign Policy in the Balkans and the Greater Middle East (Pluto Press, 2003); Robert Cooper, The Breaking of Nations: Order and Chaos in the Twenty-First Century (Atlantic Books, 2003).

${ }^{106}$ For a general overview of these problematic aspects, see Arlene B. Tickner and Mônica Herz, "No Place for Theory? Security Studies in Latin America," in Thinking International Relations Differently, ed. by Arlene B. Tickner and David L. Blaney (Routledge, 2012), pp. 92-114; Tickner, "Latin America: Still Policy Dependent after All These Years?" in Arlene B. Tickner and Ole Wæver, eds., International Relations Scholarship Around the World (Routledge, 2009), pp. 32-52; and Nicolás Terradas, "El dilema de la seguridad en América del Sur: Una revisión del debate sobre la 'larga paz' sudamericana," M.A. Thesis, Universidad Torcuato Di Tella, 2010.
} 
The traditional study of peace and war on simultaneous, but separate, tracks however has deepened the inability of major IR approaches to account for the region's relative absence of major war among states, and has created the need for a careful qualification of the popular idea depicting South America as "the most peaceful region." Understanding peace as the absence of war, for example, becomes problematic —or at least insufficient—when trying to assess the long-peace phenomenon in South America. Although several works have paid close attention to this "paradoxical" aspect of the region, a general consensus over the main explanations and the central concepts of the debate remains elusive, showing a series of other important weaknesses.

Regional studies, for example, usually acknowledge the "anomalous" nature of South America's international relations, but rarely revise the assumptions on which those theories rest. Put differently, they take for granted the "normal" state of affairs on which the main IR theories are based. This particular take on the issue both normalizes the recurrence of war and rarifies even the mere occurrence of peace. While war, therefore, has received much more attention than peace, it is uncritically accepted as a "natural" and expected phenomenon. Peace, on the other hand, is made exceptional, fragile, and ultimately presumed incapable of long life. It is only under such a way of framing the problem that it becomes possible for scholars to argue — as most do — that a regional long peace, such as the one in South America, is an "anomaly." 107 Critical discussions about these important assumptions, however, are almost non-existent in the literature.

\footnotetext{
${ }^{107}$ For a good example, see Figure 1.1 in Martín, Militarist Peace in South America, p. 16, and the entire discussion from pp. 13-17 on the "anomalous" nature of peace in the region.
} 


\section{The "Normal" State of Affairs}

In order to understand the partial and segmented accounts of South America's "anomalous" international relations, it is necessary to uncover and discuss a particular set of underlying assumptions in the literature regarding what is the "normal" states of affairs in IR. If South America's long peace constitutes an anomaly, then it is essential to assess what is to be considered the standard. The argument advanced in this dissertation is that the main works on South America's long peace showcase a heavy reliance on two core assumptions imported to IR theory directly from the field of political philosophy, but which are rarely questioned, problematized, or adapted to the subject matter in question.

In this sense, traditional approaches in IR converge on two important assumptions which a priori frame the entire debate. The first assumption is the belief that the anarchical condition of interstate relations resembles a "state of nature," as famously portrayed by Thomas Hobbes (1588-1679). The absence of a central government, as the English philosopher argued in 1651 , constitutes a fundamental obstacle to orderly, peaceful and enduring productive social relations. ${ }^{108}$ In this view, therefore, the state is portrayed as preceding society, for without a Leviathan all aspects commonly associated to community, society and orderly relations cannot take hold, and soon wither away. As Hobbes famously put it:

In such condition [i.e., the state of nature], there is no place for Industry; because the fruit thereof is uncertain: and consequently no Culture of the Earth; no Navigation, nor use of

\footnotetext{
${ }^{108}$ For Hobbes' main view on both domestic and international anarchy as comparable "state-of-nature" conditions in the sense alluded above, see his Leviathan, ed. by Richard Tuck (Cambridge University Press, 1996), esp. ch. 13 and 17. Although Plato had already talked about "war" as the normal state of affairs in The Laws, it was Hobbes who most consistently explored its implications domestically and, by analogy, also internationally. Furthermore, it is Hobbes who also extended this "state-of-nature" analogy into a fullfledged political philosophy about the necessity of the state as the procurer of social order among imperfect, greedy, and fearful individuals.
} 
the commodities that may be imported by Sea; no commodious Building; no Instruments of moving, and removing such things as require much force; no Knowledge of the face of the Earth; no account of Time; no Arts; no Letters; no Society; and which is worst of all, continual fear, and danger of violent death; And the life of man solitary, poor, nasty, brutish, and short. ${ }^{109}$

In the case of the relations among sovereign states, a comparable condition of anarchy is widely recognized by most contemporary students of IR as the "permissive cause" of war, generating the expectation that states will not be able to avoid violent conflict and war among one another for too long a period. Such an expectation, as pointed out above, "cannot be realistically entertained." 110

A second assumption is the widely held belief in a concrete set of factors expected to "tame" the international state of nature. Put differently, anarchy is seen as a problematic condition that breeds conflict and works against any meaningful cooperation or trust among states; anarchy, therefore, is seen as something states should work against, mitigate, or curb. While Constructivism, for example, highlights shared inter-subjective identities (like culture, language, ideology, or religion) as anarchy-taming variables, other approaches (e.g., Realism) focus more on the momentarily pacifying effects of fighting against a

\footnotetext{
${ }^{109}$ Hobbes, Leviathan, p. 89 [sic]. Although Hobbes' philosophy is developed across several works, Leviathan is the one most widely consulted in IR for his "state of nature" analogy. For two powerful critiques of Hobbes' overall view of domestic anarchy, as well as the problematic (although popular) importation of this argument to IR theory discussions of international anarchy, see Hedley Bull, "Hobbes and the International Anarchy," Social Research, Vol. 48, No. 4 (Winter, 1981), pp. 717-738; and Beate Jahn, The Cultural Construction of International Relations: The Invention of the State of Nature (Palgrave, 2000). For a more recent assessment of Hobbes' specific argument about international anarchy, see David Armitage, Foundations of Modern International Thought (Cambridge University Press, 2013), pp. 59-74.

${ }^{110}$ Waltz, Theory of International Politics, p. 102. For the classical formulation of anarchy as a permissive cause of war, see Waltz, Man, the State and War. See also Geoffrey Blainey, The Causes of War (Macmillan, 1973). For a critical review of Waltz's classical proposition, see Hidemi Suganami, "Understanding Man, the State, and War," International Relations, Vol. 23, No. 3 (September, 2009), pp. 372-388; Suganami, On the Causes of War (Oxford University Press, 1996); J. David Singer, "International Conflict: Three Levels of Analysis," World Politics, Vol. 12, No. 3 (April, 1960), pp. 453461; and Michael W. Doyle, Ways of War and Peace: Realism, Liberalism, and Socialism (Norton, 1997).
} 
common enemy, or the automatic operation of a balance-of-power dynamic, the mitigation of the security dilemma, and the role of geopolitics. Liberalism, for its part, tends to emphasize the intervening role of (Liberal) international institutions and values (like democracy, republicanism, economic interdependence and the free-market economy) in incentivizing cooperation, peace, trust, and economic prosperity among states. ${ }^{111}$ For many different reasons, therefore, several approaches to IR can logically accommodate a limited prolongation of peace among states through the mitigation anarchy. But in endorsing such perspectives, each of the approaches standardizes Hobbes' idea of the state of nature as the normal condition of all political life under anarchy. These diverse approaches, moreover, differ only in degree, for they are cast against the same basic Hobbesian canvas identified above. In short, although a "long peace" is possible in theory, it is often viewed as exceptional and studied with profound suspicion.

From these initial assumptions, traditional IR theories typically derive two other important interrelated generalizations that profoundly affect how scholars frame the study of regional order. On the one hand, they tend to "normalize" war and "rarefy" peace. That is, they create the expectation of much more conflict in anarchical political systems than in centralized ones. War is presented, therefore, as a historical recurrence that can be

\footnotetext{
111 The literature on the "taming of anarchy" is extensive. For some of the most representative contemporary works in this area of research, $c f$. on the role of norms, identity and culture: Karl Deutsch, et al., Political Community and the North Atlantic Area (Princeton University Press, 1957); Adler and Barnett, Security Communities; and Alexander Wendt, Social Theory of International Politics (Cambridge University Press, 1999); on the role of geopolitics and the balance of power: Hans J. Morgenthau, Politics among Nations: The Struggle for Power and Peace (Knopf, 5th ed., [1948] 1973); Waltz, Theory of International Politics; John J. Mearsheimer, The Tragedy of Great Power Politics (Norton, 2001); and on the role of Liberal values and institutions: Bruce M. Russett and John R. Oneal, Triangulating Peace: Democracy, Interdependence, and International Organizations (Norton, 2001); Kenneth A. Oye, ed., Cooperation Under Anarchy (Princeton University Press, 1986); and Amitav Acharya and Alastair I. Johnston, eds., Crafting Cooperation: Regional International Institutions in Comparative Perspective (Cambridge University Press, 2007).
} 
explained by the nature of international relations itself. ${ }^{112}$ On the other hand, since in the Hobbesian view the state "precedes" society, traditional IR theories treat anarchy and order as problematic bedfellows. They expect stable and long-lasting order only in societies with a centralized government or authority, but not in anarchical ones. The South American case, given its condition of stable order "despite" anarchy, emerges as a direct theoretical and empirical challenge to the established literature in IR, for it forms an "ordered anarchy" in the sense discussed by classical political anthropologists. ${ }^{113}$ Since the way in which scholars frame the discussion plays such a relevant role in how they go about looking for an explanation of the South American peace, it is important to focus on the terminology employed and the distinct interpretations that are often adopted. The next section reviews some of the main concepts used in the South American long peace debate and critically assesses the main problems with adopting traditional, yet insufficient, definitions.

\section{Concepts and Definitions}

Apart from the underlying assumptions framing the debate, there is a second layer of disagreement among students of South America concerning the definition of key concepts. Some of these disagreements are fundamental, for adopting a specific definition can set the analysis and framing the study of the long South American peace on different (often times incompatible) epistemological, ontological or methodological paths. For these reasons,

\footnotetext{
112 This is most clearly argued in Waltz, "The Origins of War in Neorealist Theory," pp. 615-628; Waltz, Man, the State and War, pp. 159-238; and Waltz, Theory of International Politics, pp. 102-114. For two excellent critical reviews of the main causes of war in IR, see Dale C. Copeland, The Origins of Major War (Cornell University Press, 2000); and Jack S. Levy and William R. Thompson, Causes of War (WileyBlackwell, 2010).

${ }^{113}$ See Terradas, "The Quest for Order in Anarchical Societies."
} 
attention is paid in this section to four main concepts: "war," "limited war," "peace," and "long peace," given their relevance for the existing academic debate as well as for the present study. Each concept is assessed according to the most common uses employed in the specialized literature, with the intention of highlighting the often implicit analytical "trade-offs" incurred by scholars when taking different theoretical stances.

War

The first important concept to consider is war. Most scholars involved in the study of the South American long peace commonly follow the well-known Correlates of War Project's (COW) definition. In doing so, however, certain problems arise. For example, scholars typically end up adopting a definition of war that is too quantitative or "materialist," focusing on the number of casualties and the duration of an armed conflict in order to consider it as a "war." Similarly, the reliance on these two factors, although attracting the attention of many researchers around the world interested in "solving" the "no-war" puzzle in South America, also puts too much emphasis on the frequency of war and disregards other equally important factors. According to this view, for instance, war is a declared armed conflict between two or more neighboring states (if not sharing a common border, at least located in the same region) that produces at least 1,000 battle-related casualties (including civilians) in the span of at least a year. ${ }^{114}$ Although this dataset is one of the most well-known and widely-used resources by contemporary students of regional security, reflected in the adoption of its categories by the vast majority of the contributions

\footnotetext{
${ }^{114}$ See Melvyn Small and David J. Singer, Resort to Arms: International Wars and Civil Wars, 1816-1980 (Sage, 1982). Also see the related website: $<$ http://correlatesofwar.org $>$.
} 
to the study of the "long peace," it presents a number of additional difficulties to the ones highlighted above when employed too uncritically.

One of these difficulties arises from the rather arbitrary threshold of 1,000 battlerelated casualties. This often leads scholars to develop an exaggerated sense of "peacefulness" in a region that is otherwise plagued by a plethora of civil wars and limited border disputes - an aspect that lingers even in the early decades of the 21 st century, with a regional preponderance of democratic rule. Similarly, a misleading impression is commonly created regarding the periodization of this regional long peace. Following the COW Project's criterion, for example, only the Chaco War (1932-1935) between Bolivia and Paraguay can count as a "war" in South America in the entire 20th century — separated by its most immediate antecedent, the War of the Pacific of 1879-1884, by almost fifty years. On one hand, other armed conflicts, like those between Peru and Colombia in the 1930s or between Peru and Ecuador in the 1940s (with approximately 860 and 550 casualties, respectively), are simply lost for the analysis of the region's security dynamics. And on the other hand, most scholars problematically assume that between 1884 and 1932 the region experienced a fundamentally "peaceful" period. This is showcased by the general disinterest in the study of the decades between the War of the Pacific and the Chaco War, or in the popular view of the Chaco War as an "exception."

These problems are most clearly visible, for example, in the work of one of the main contributors to the "long peace" debate, Arie M. Kacowicz, who marks the beginning of the South American long peace in the year 1883 - instead of 1935 or even 1941. This is a problematic choice that Kacowicz has nevertheless reiterated in all his studies on South America. In a peculiarly worded manner, Kacowicz consistently refers to the long South 
American peace as a period spanning from 1883 to the present "with the exception of two international wars." 115 The point becomes problematic when those "exceptions" are the rather important Chaco War (1932-1935) and the Zarumilla-Marañón dispute (1941). The first case left between 80,000 and 90,000 casualties, being the most impactful war of the entire Western Hemisphere in the 20th century, whereas the second fell short of the 1,000casualty threshold of the COW Project, but only by a small margin. Equally surprising is the lack of proper consideration for the Leticia dispute of 1932, which also left an important (although "statistically insignificant") number of casualties, but which at least constituted a "near miss" in the COW dataset for major wars. In this view, it counts only as a Militarized Interstate Dispute (MID).

Despite these methodological and historical quibbles, the majority of scholars commonly marks the beginning of the regional peace in 1935-when the last major war ended (according to the Cow Project), or in 1941, when the Peru-Ecuador dispute ended (according to the MID dataset). ${ }^{116}$ By insisting upon this arbitrary date, Kacowicz and those following him unnecessarily exaggerate the duration of the South American long peace in two specific ways: First, by artificially adding almost fifty years to the period of peace; and secondly, by dismissing the Chaco War, the Leticia and the Zarumilla-Marañón disputes, considering them only as "exceptions." The South American long peace is thus premised as running from 1883 to the present — although the official end of the War of the Pacific is

\footnotetext{
${ }^{115}$ See Kacowicz, Zones of Peace in the Third World, pp. 20, 67, 68; Kacowicz, The Impact of Norms in International Society, pp. 10-12.

${ }^{116}$ See, e.g., Holsti, The State, War, and the State of War; Martín, Militarist Peace in South America; Miller, States, Nations, and the Great Powers; Mares, Violent Peace; Buzan and Wæver, Regions and Powers.
} 
in 1884, not 1883. Kacowicz's defense of the "impact" of international norms on regional peace seems to lead him to adopt this questionable proposition in order to pair his analysis with the deeper involvement of the United States in hemispheric relations vis-à-vis the creation of the Pan-American Conferences (and later the OAS), and its rise to great-power status after the war with Spain over Puerto Rico, Cuba, Guam and the Philippines in 1898 thus substantiating a role for the United States and the OAS as one of the main propellers of international norms of peace and security on a hemispheric level. ${ }^{117}$

In this context, the works by McIntyre, Mares, and Domínguez have criticized the use of the COW dataset as the main criterion for the study of the region. Their claim is that it usually leads scholars to an unnecessary exaggeration of the duration and intensity of the "long peace" in South America. Lowering the threshold to 500, for example, as Mares and Domínguez have suggested, can make more visible the continued willingness to use force by South American decision-makers throughout the entire 20th century-despite ultimately not escalating to the level of war. This leads Mares to conclude that scholars need to be alert of the pros and cons of the statistical criteria employed before jumping to conclusions that might be too optimistic regarding the region's condition of, or potential for, stable peace. ${ }^{118}$ McIntyre, for his part, is even more categorical about it:

South America is not especially peaceful if one uses a broader definition of "war." South American states occasionally fought low-level hostilities, but they did not attempt to conquer an adversary. Their objective was generally to occupy a piece of the defender's territory before the defender could offer resistance. South America is "peaceful" because their border conflicts often did not result in sufficient casualties to qualify as a "war." [...] South America's tranquility is in part an artifact of the definition of "war." [...] Using the COW definition, South America is peaceful in its international relations. [However] The

\footnotetext{
${ }^{117}$ See Kacowicz, The Impact of Norms in International Society, pp. 54, 44, 52ff.

${ }^{118}$ See Mares, Violent Peace, esp. pp. 32-35; Mares, Latin America and the Illusion of Peace; Domínguez, "Boundary Disputes in Latin America."
} 
threshold of 1,000 is completely arbitrary; alternative thresholds of 5,000 or 999 or 100 are equally defensible. If the cutoff point were lowered, South America might become almost as war-prone as other regions in the world. Unfortunately, [a] lower number of low-level conflicts is [still] undocumented. ${ }^{119}$

For all the above reasons, other works have tried to employ a more qualitative definition of war, less dependent on its material effects (casualty rates and duration) and defined in terms of the types of political objectives behind the decisions to use of force against a neighboring state. The problem with a strictly typological approach to war, however, is that in South America almost the totality of armed conflicts has been characterized by a rather homogeneous type of objective: namely, territorial and border disputes, involving in certain instances the additional incentive of securing some strategic resource (like guano, nitrates, or access to strategic waterways). Since there is no relevant variance in the type of war in South America, the typological approach which was popular in the 1980s has now been almost entirely abandoned for analyzing the region. ${ }^{120}$ Although many of these contributions had generated an unjustified sense of pessimism regarding the decaying character of the regional peace in the 1980s and early 1990s, the return to democracy and the new wave of cooperative arrangements in South America in the 1990s (like, for example, via MERCOSUR) clearly showed the deficiencies of those pessimistic assessments.

\footnotetext{
${ }^{119}$ David McIntyre, “The Longest Peace: Why Are There So Few Interstate Wars in South America?" Ph.D. Dissertation, The University of Chicago (1995), pp. 2, 167.

${ }^{120}$ The most representatives works are Wolf Grabendorff, "Tipología y potencial de conflictos en América Latina," Nueva Sociedad, No. 59 (marzo-abril, 1982), pp. 39-46; Grabendorff, "Interstate Conflict Behavior and Regional Potential for Conflict in Latin America," Journal of Interamerican Studies and World Affairs, Vol. 24, No. 3 (August, 1982), pp. 267-294; Michael A. Morris and Víctor Millán, eds., Controlling Latin American Conflicts (Westview, 1983); Gregory F. Treverton, "Interstate Conflict in Latin America," in The United States and Latin America in the 1980s, ed. by Kevin J. Middlebrook and Carlos Rico (University of Pittsburgh Press, 1986), pp. 565-590; Child, "Interstate Relations in Latin America." For a sharp critique of this literature, see Little, "International Conflict in Latin America."
} 
Other scholars, however, marked the advent and consolidation of democratic regimes in the region as a "deepening" or "upgrading" factor for the regional peace. ${ }^{121}$

Given the multiple and important limitations of these approaches to war, a different qualitative perspective has been suggested more recently by sociologist Miguel Centeno. He argues that "[w]ar is not simply acts of military violence or banditry (Latin America has had more than enough of both). Rather, it is a special form of organized violence with clear political goals." In this sense, Centeno adds, "war is 'a substantial armed conflict between the organized military forces of independent political units' $[\ldots]$ and is different from other violence acts in that it involves the 'existence, the creation, or the elimination of states'."122 Although this definition builds off the example of political anthropology in the 1960s, and can be critiqued for its implicit built-in statism—potentially not allowing, for example, for civil wars - it resonates well with more contemporary anthropological and sociological understandings of "war" as, by nevessity, a phenomenon among organized political groups (such as the state, although not exclusively limited to it). Other, less organized and smaller political units are simply not capable to produce the type of organized political violence commonly associated with large-scale war. ${ }^{123}$

Historian Lawrence Freedman points out that, its original form, "war is about a miserable condition and that is how it is still commonly and understandably viewed. But it

\footnotetext{
${ }^{121}$ See Kacowicz, Zones of Peace in the Third World; Battaglino, "The Coexistence of Peace and Conflict in South America"; Oelsner, "Pluralistic Security Communities in Latin America."

${ }^{122}$ Centeno, Blood and Debt, p. 34 [italics in the original].

${ }^{123}$ See Miguel Á. Centeno and Elaine Enriquez, War and Society (Polity, 2016). Cf. Lawrence H. Keeley, War Before Civilization: The Myth of the Peaceful Savage (Oxford University Press, 1996); Keith F. Otterbein, The Anthropology of War (Waveland, 2009); Otterbein, How War Began (Texas A\&M University Press, 2004); Azar Gat, War in Human Civilization (Oxford University Press, 2006); and Simon Harrison, The Mask of War: Violence, Ritual and the Self in Melanesia (Manchester University Press, 1993).
} 
is a condition which is often knowingly entered because not doing so carries its own miseries and dangers." ${ }^{124}$ In this view, war is about both "a purposive activity, geared to the demands of personal, group, and national security," as well as the grim consequences of conflict itself. "War is a bad thing to happen but, at least on occasion, a good thing to do. States continue to prepare for war while professing to wish to legislate it out of existence, promising only to fight for the most righteous of reasons, as a last resort, and in the most civilized manner." 125

This alternative perspective helps one to move away from the simple "counting" of wars to qualify the "peacefulness" of a region, drawing inferences only from the study of the frequency of war in a particular period of time. It centers the discussion back on the political, sociological and institutional factors concerning the organization for violence and the capacity for the execution of political and strategic plans to that effect. At the same time, it illuminates the fact that the levels of intensity during war (measured by more than simply the number of casualties) equally matter. Rather than serve as an arbitrary threshold to discard from a statistical list those conflicts that fall below a given threshold, the consideration of different levels of intensity can help identify better the progressive decline in war-fighting ferocity in South America from the 19th to the 20th centuries ${ }^{126}$ [see infra TABLE 2].

\footnotetext{
${ }^{124}$ Lawrence Freedman, "Defining War," in The Oxford Handbook of War, ed. by Julian Lindley-French and Yves Boyer (Oxford University Press, 2012), p. 17.

${ }^{125}$ Ibid., pp. 17-18. For a similar perspective, see Clark, Waging War; Brett Bowden, Civilization and War (Edwards Elgar, 2013); Bowden, The Empire of Civilization: The Evolution of an Imperial Idea (The University of Chicago Press, 2009); and Holsti, The State, War, and the State of War, pp. 1-18.

${ }^{126}$ Intensity is measured partially through casualty rates, but also through amounts of spending, level of involvement and type of participation of the civilian population, as well as the degree of adherence to normative and ethical standards of war, and types of political objectives followed by the belligerents.
} 
TABLE 2 - Major Inter-State Wars in South America (19th and 20th Centuries)

\begin{tabular}{|c|c|c|c|c|}
\hline Duration & Name & Belligerents & Motives & Casualties* \\
\hline $1825-1828$ & "Cisplatine War" & $\begin{array}{l}\text { Argentina } \\
\text { Brazilian Empire }\end{array}$ & $\begin{array}{l}\text { Territorial } \\
\text { (River Plate's Eastern } \\
\text { Bank) }\end{array}$ & 8,500 \\
\hline $1836-1851$ & $\begin{array}{l}\text { "River Plate War" } \\
\text { (or "Guerra Grande") }\end{array}$ & $\begin{array}{l}\text { Argentina, } \\
\text { Banda Oriental } \\
\text { Brazilian Empire } \\
\text { GREAT BRITAIN } \\
\text { FRANCE }\end{array}$ & $\begin{array}{l}\text { Territorial } \\
\text { (River Plate's Eastern } \\
\text { Bank) }\end{array}$ & 10,000 \\
\hline $1836-1839$ & "War of the Confederation" & $\begin{array}{l}\text { Bolivia } \\
\text { Chile } \\
\text { Peru }\end{array}$ & Territorial & 8,000 \\
\hline 1841 & "Peru-Bolivian War" & $\begin{array}{l}\text { Bolivia } \\
\text { Peru }\end{array}$ & Territorial & 2,000 \\
\hline 1863 & "Ecuador-Colombian War" & $\begin{array}{l}\text { Colombia } \\
\text { Ecuador }\end{array}$ & Territorial & 1,500 \\
\hline $1864-1866$ & $\begin{array}{l}\text { "The Chincha Islands War" } \\
\text { (or "Guano War") }\end{array}$ & $\begin{array}{l}\text { Bolivia } \\
\text { Chile } \\
\text { Ecuador } \\
\text { Peru } \\
\text { SPAIN } \\
\end{array}$ & $\begin{array}{l}\text { Territorial + Resources } \\
\text { (Guano) }\end{array}$ & 1,000 \\
\hline $1864-1870$ & $\begin{array}{l}\text { "War of the Triple Alliance" } \\
\text { (or "Paraguayan War") }\end{array}$ & $\begin{array}{l}\text { Argentina, } \\
\text { Uruguay } \\
\text { Brazilian Empire } \\
\text { Paraguay } \\
\end{array}$ & $\begin{array}{l}\text { Territorial } \\
\text { (River Plate estuary) }\end{array}$ & 420,000 \\
\hline $1879-1884$ & "War of the Pacific" & $\begin{array}{l}\text { Bolivia } \\
\text { Chile } \\
\text { Peru }\end{array}$ & $\begin{array}{l}\text { Territorial + Resources } \\
\text { (Nitrates and Guano) }\end{array}$ & 55,000 \\
\hline $1932-1935$ & "Chaco War" & $\begin{array}{l}\text { Bolivia } \\
\text { Paraguay }\end{array}$ & $\begin{array}{l}\text { Territorial } \\
\text { (Chaco Boreal Region) }\end{array}$ & 90,000 \\
\hline $1932-1933$ & "Leticia Dispute" & $\begin{array}{l}\text { Colombia } \\
\text { Peru }\end{array}$ & Territorial & 860 \\
\hline 1941 & $\begin{array}{l}\text { "Zarumilla-Marañón } \\
\text { Dispute" }\end{array}$ & $\begin{array}{l}\text { Ecuador } \\
\text { Peru }\end{array}$ & Territorial & 550 \\
\hline 1981 & "Paquisha Dispute" & $\begin{array}{l}\text { Ecuador } \\
\text { Peru }\end{array}$ & Territorial & 150 \\
\hline 1982 & "Malvinas/Falklands War" & $\begin{array}{l}\text { Argentina, } \\
\text { GREAT BRITAIN }\end{array}$ & Territorial & 900 \\
\hline 1995 & "Cenepa Dispute" & $\begin{array}{l}\text { Ecuador } \\
\text { Peru }\end{array}$ & Territorial & 150 \\
\hline
\end{tabular}

Sources: Table based on Centeno, Blood and Debt, p. 44; Mares, Violent Peace, pp. 33-34, 45-46; Little, "International Conflict in Latin America," p. 592; McIntyre, "The Longest Peace," pp. 173-174; Child, "Interstate Relations in Latin America," p. 383; David F. Marley, Wars of the Americas: A Chronology of Armed Conflicts in the New World Since 1492 to the Present (A.B.C.-CLIO, 1998); Sater, Andean Tragedy, pp. 348-349; Thomas L. Whigham and Barbara Potthast, "The Paraguayan Rosetta Stone: New Insights into the Demographics of the Paraguayan War, 1864-1870," Latin American Research Review, Vol. 34, No. 1 (1999), pp. 174-186; and Zook, The Conduct of the Chaco War.

References: $(*)$ : Approximate total casualties—including civilians. (SMALL CAPS): Extra-regional powers. 
In this specific sense, South America is in relative harmony with ongoing global trends regarding the progressive decline in the number, as well as intensity, of inter-state wars around the world. ${ }^{127}$

Contrary to the prevailing view, which tends to emphasize the absence of war (or "negative peace") among states, Andrew Hurrell adds an important nuance: "[W]hat is most interesting about the use of force in the region," he argues, "is not its frequency or infrequency, but rather its particular character." ${ }^{128}$ If anything, it is the world that is becoming increasingly more like South America, rather than the other way around. The "anomaly" is thus quickly revealing itself as the new norm.

Centeno is the only contributor to the "long peace" debate to have elaborated further on this point, and thus it is important to carefully consider his argument in more depth:

The type of war appears to make an insignificant difference on its effects. [...] All major Latin American wars may be characterized as involving territorial swaps motivated by fairly simple geopolitical competition. While the territorial adjustments made to the colonial map have been relatively small, the acquisition and defense of territory has been the dominant historical trope. [...] No countries have fought one another as representatives of an ideology or a religious faith. [...] The wars have also been relatively short and with simple linear narratives. Most have been settled by one or two decisive battles [...]. Not surprisingly, by contemporary standards, the wars involved relatively few men and minimal equipment. [...] It often appears as if participants and observers had already accepted the marginality of their actions. ${ }^{129}$

\footnotetext{
${ }^{127}$ See, apart from the works listed on fn. 2, Monty G. Marshall and Ted R. Gurr, Peace and Conflict 2005 (University of Maryland, CIDCM, May 2005), esp. pp. 11-15; and Monty G. Marshall, Third World War: System, Process, and Conflict Dynamics (Rowman \& Littlefield, 1999). Cf. Centeno, Blood and Debt, p. 35 (see esp. the graphs in pp. 36, 38-43).

${ }^{128}$ Andrew Hurrell, "Working with Diplomatic Culture: Some Latin American and Brazilian Questions," paper presented for the ISA Annual Convention, Montreal (March, 2004), p. 4. Cf. Holsti, The State, War, and the State of War, pp. $150 \mathrm{ff}$.

${ }^{129}$ Centeno, Blood and Debt, pp. 34, 52, 66 [italics in the original]. As Centeno accepts, however, a major exception to this view is the Triple Alliance War (1864-1870). For a discussion of this war as an "exception," see Chapter 3 of the present dissertation.
} 
In this context, as Hurrell concludes, "we need to look beyond positivist correlations across a large number of cases and examine the quality and internal constitution of a particular relationship and the causal mechanisms that may explain the emergence of stable peace."130 To focus on these aspects, however, means that closer attention must be paid to the related concept of "limited war," which is central to the notion of war-as-institution in the international society approach—-followed in the present study—and which by definition re-incorporates the role of the historical context in which war takes place-so often neglected in so-called "scientific" approaches to war through statistical correlation and large- $n$ studies. ${ }^{131}$

\section{Limited War}

If war is to be studied as a phenomenon that is inextricably linked to peace, one must necessarily embrace a broader qualitative understanding of both concepts, as Centeno, Freedman, Hurrell, and others, suggest. This understanding, however, must be based not on arbitrary methodological criteria, useful perhaps for a specific dataset, but on a more widely-applicable sociological criterion that pays attention not just to the frequency of war but also to the related issues of intensity and type. This criterion must also clarify those aspects of war that make it susceptible to be studied as an "institution"- and not just as an uncontrollable torrent of collective violence. ${ }^{132}$ The study of was-as-institution, therefore,

\footnotetext{
${ }^{130}$ Andrew Hurrell, “An Emerging Security Community in South America?” p. 229.

${ }^{131}$ Freedman, "Defining War," p. 27.

${ }^{132}$ For three excellent surveys of the sociological approach to the study of war, see Andreas Wimmer, "War," Annual Review of Sociology, Vol. 40 (2014), pp. 173-197; Hans Joas and Wolfgang Knöbl, War in Social Thought: Hobbes to the Present (Princeton University Press, 2013); and Hans Joas and Kenneth B. Woodgate, "The Classics of Sociology and the First World War," Thesis Eleven, Vol. 27, No. 1 (1990), pp. 101-124.
} 
builds upon the classical Clausewitzian understanding of war-as-politics and becomes a crucial component of any discussion of the role of restraint in war (either legal, organizational, or moral). If war is a political phenomenon, it has to be approached also as an institution with its own customs, standards and cultural practices, and not in virtual isolation or trans-historically. ${ }^{133}$

As Freedman argues, the major weakness of the so-called "scientific" approaches (like the cow Project) is that their search for correlations between facts and events is carried out by ignoring the historical context and the presence of other factors which may explain the character of war in specific regions. Ultimately, "[w]hether a particular war occurs will still depend on the decisions of individuals, which may depend as much on factors of personality, cognition, and group dynamics as underlying 'causes'." 134 Given that most armed conflicts in South America have been of the limited type, in the sense outlined above, it is important to define more specifically what is meant by "limited war" in the context of the present study.

Following Centeno, Holsti, and Clark, limited wars are understood as armed conflicts between states, or other similarly organized political groups, that have a short duration overall and that may be characterized by isolated moments of ferocity, although these moments will take place mostly at the individual level, although not at the collective

\footnotetext{
${ }^{133}$ For a view of war as a political institution, touching on the issue of collective self-restraint, see Michael Howard, "War as an Instrument of Policy," in Diplomatic Investigations, pp. 193-200; Adam Roberts, "Against War," in The Oxford Modern History of War, ed. by Charles Townshend (Oxford University Press, 2nd ed., [1997] 2005), pp. 317-340; Howard, "Constraints on Warfare," and Paul Kennedy and George J. Andreopoulos, "The Laws of War: Some Concluding Reflections," both in The Laws of War: Constraints on Warfare in the Western World, ed. by Michael Howard, George J. Andreopoulos and Mark R. Shulman (Yale University Press, 1994), pp. 1-11, 214-225.

${ }^{134}$ Freedman, "Defining War," p. 27.
} 
one. One of its main components is that the belligerents share a background culturalideological profile that can emanate from a common historical experience, such as a shared colonial past, or from other factors, such as language, customs or religion. These types of war, as Centeno argues, can only lead to limited conflicts over contained agendas, such as economic resources or frontier clashes, but will not (or only rarely) escalate to all-out or "total" wars. Contrary to these, limited wars involve only a portion of the population, either by implicating a small section of the professional army or by producing limited effectsspecifically in terms of civilians being negatively affected by the conflict. In this sense, the mobilization of the population for war remains minimal or is severely restricted. ${ }^{135}$

Any proper understanding of "limited war," however, must also take into account the institutional aspects of war as a political activity carried out by individual decisionmakers in the name of their respective states. Following Machiavelli and Clausewitz, Ian Clark distinguishes the crucial role that political objectives play in limiting war, setting it apart from other conceptions, such as the "Just War" tradition. ${ }^{136}$ Thus, wars are not marked by an initial "big-bang" dynamic of violence, that once unleashed cannot be contained or controlled by political objectives. On the contrary, wars are typically curbed by the political leaders directing them. "War," as Clark argues, "is located in a real political universe, and is shaped both by its original causes as well as by its continuing goals."137 War is thus a purposive activity that carries wider social implications than simply the unabashed killing, destroying, or maiming of an opponent—or in Holsti's more graphic

\footnotetext{
${ }^{135}$ See Centeno, Blood and Debt, pp. 20-22. See also Centeno and Enriquez, War and Society, pp. 4-30; and Holsti, The State, War, and the State of War, pp. 28-32.

${ }^{136}$ See Clark, Waging War, pp. 51-68, cf. 33-50.

${ }^{137}$ Clark, Waging War, p. 55.
} 
terms, "orgies of uncontrolled violence." 138 Even in contemporary political anthropology, the idea of war as caused by a biological "urge" or "pulsion" towards aggression has been widely rejected and abandoned. Earlier works on so-called "primitive war" as a ritualized sport-like activity have been equally discredited in favor of a more accurate view of war as a collective, complex social institution with multifaceted purposes.

The sociological approach highlights that war is more than simply a force of material destruction, as it also provides creative or constructive social functions. "Limited war" contains a duality that is often either forgotten, or only mentioned in passing by most students of war in Latin America, without much careful consideration. ${ }^{139}$ The duality of war points out, beyond its "destructive" aspects, its more constructive potentials. ${ }^{140}$ This tension between the tragic and the purposive sides of war, as Lawrence Freedman argues, "is evident in the persistent efforts to acknowledge war's political function as the ultimate arbiter of disputes while containing it as a social institution and mitigating its harmful effects." ${ }^{\prime 41}$ One of the key components of limited war is, therefore, the restraining role that political, normative and institutional frameworks play in erecting barriers to the eventual resort to war and in setting up standards for its conduct. While these barriers cannot entirely erase some of the most brutal aspects of war, such as the actual killing of people and the psychological trauma suffered by those engaged in war, they can have a meaningful impact in terms of its political and material effects by narrowing the scope and type of the political

\footnotetext{
${ }^{138}$ Holsti, The State, War, and the State of War, p. 29.

${ }^{139}$ For an exception to this rule, see Miguel Á. Centeno, Warfare in Latin America (Ashgate, 2007). 2 vols.

${ }^{140}$ See Centeno and Enriquez, War and Society, pp. 118-145; Centeno, Blood and Debt, pp. 22-26. On p. 23, Centeno offers a useful table comparing the "bellicist" and the "limited war" (Latin American) models.

${ }^{141}$ Freedman, "Defining War," p. 18.
} 
objectives for which a war can be legitimately invoked and carried out—with important effects for the control of the frequency and intensity of war overall. ${ }^{142}$

But limited war is also a form of conversation. ${ }^{143}$ Through the institutionalization of war as a political activity, states agree on common standards of proper or accepted behavior, and thus narrow the scope of objectives for which the use of force can be legitimately invoked. ${ }^{144}$ The legitimacy of the situation, as well as the process of mutual recognition as "belligerents," establishes a conversational dynamic by which parties can signal one another not only a set range for their objectives, but also an acceptance of the implicit "rules of the game" and its boundaries. As Hedley Bull eloquently put it: "War is not simply a clash of forces; it is a clash between the agents of political groups who are able to recognize one another as such and to direct their force at one another only because of the rules that they understand and apply." ${ }^{145}$ War, therefore, cannot happen in the absence of a social milieu giving both sides a sense of meaning and common understanding upon which customs and standards of restraint (apart from war itself) can develop. It is only within this framework that belligerents can come to understand, through a process of reciprocity and proportionality, the advantages of practicing self-restraint in war. Charles Jones nicely illustrates the point:

Faced with overwhelming military superiority, the insurgent forces resort to sabotage and assassination. The occupiers respond by interspersing non-combatants in their convoys as a human shield or killing them at some arbitrary tariff, perhaps two for every one of their

\footnotetext{
${ }^{142}$ See Bull, The Anarchical Society, pp. 184-199; Centeno and Enriquez, War and Society, pp. 118-145; Clark, Waging War, p. 57-61; and Freedman, "Defining War," pp. 18-19.

${ }^{143}$ Charles A. Jones, "War in the Twenty-first Century: An Institution in Crisis," in The Anarchical Society in a Globalized World, ed. by Richard Little and John Williams (Palgrave Macmillan, 2006), p. 166.

${ }^{144}$ See Ian Clark, Legitimacy in International Society (Oxford University Press, 62005), pp. 11-30.

${ }^{145}$ Hedley Bull, "Recapturing the Just War for Political Theory," World Politics, Vol. 31, No. 4 (July, 1979), pp. 595-596.
} 
troops killed. It seems that one breach of the war convention has led to a second, and that the abyss beckons. Yet as often as not the display of calculated abnormality is a way for the two belligerents to signal to each other the mutual advantage of a return to compliance with tacit norms. Alternatively, a step too far by one's opponent may be exploited to strategic effect: "See, the true face of the enemy!" Writ large, war is a field of expression and representation as well as an exercise of violence, just as politics may provide a field of enmity and compulsion in the absence of violence. ${ }^{146}$

In the study of South America's long peace, apart from the few exceptions pointed out above, war is only given a superficial attention as part of a broader statistical collection of "data-points." Experts on South America's security often do not express much consideration for discussions over the main causes, characteristics, and the politicoeconomic and diplomatic effects of each major South American war. In the rare occasions when these wars are considered, the analysis is often painfully superficial, brief, and stereotypical, demonstrating sometimes a lack of accurate information about these wars and the historiographical debates surrounding them. Such studies also show a larger disinterest in the role that war has played - and continues to play-in South America's international relations. ${ }^{147}$

A more qualitative approach to war is also rarely seen, as the analysis often focuses exclusively on the material and human effects, relying on the frequency of war, rather than also considering the overall "limited" character of armed conflicts in South America. Wars

\footnotetext{
${ }^{146}$ Jones, "War in the Twenty-first Century," pp. 166-167.

147 The Chaco War, the War of the Pacific, and the War of the Triple Alliance (the Guano War traditionally receives no attention at all, despite its importance) are commonly treated in an extremely succinct and general way in the literature. See, e.g., Kacowicz, Zone of Peace in the Third World, pp. 20-21, 68, 71-78; Oelsner, International Relations in Latin America, pp. 90-97; Kacowicz, The Impact of Norms in International Society, pp. 82ff; Martín, Militarist Peace in Latin America, pp. 73-74. Two important exceptions are René De La Predaja's volumes: Wars of Latin America, 1899-1841 (McFarland, 2006); Wars of Latin America, 1948-1982: The Rise of the Guerillas (McFarland, 2013), and Wars of Latin America, 1982-2013: The Path to Peace (McFarland, 2013); and Robert L. Scheina, Latin America's Wars (Brassey 2003), 2 vols.
} 
like the Chaco War, or the War of the Triple Alliance, for example, are categorized as major wars mostly on the basis of the large amount of material and human destruction that they produced (more than 80,000 deaths in the first case, and over 400,000 in the second). Much less attention (if any) is given to the many efforts towards peace before, during and after these major armed conflicts; and barely any careful consideration is given to the specific ways in which war was actually waged according to political and cultural standards and practices of the time. More often what occurs is that contemporary students superimpose modern terminology and ideologies on 19th-century conflicts, qualifying these as "genocides" or "holocausts," and to pass judgment and dispense accusations and responsibilities on specific contemporary actors, personalities, or groups. ${ }^{148}$

David Mares, one of the strongest advocates against the idea of considering the region as a "zone of peace," while correct in pointing out the persistence of many territorial disputes in 20th century and beyond, pays less attention to the factors surrounding the limited character of those conflicts that keep afflicting the region. Put simply, Mares challenges the very existence of a "long peace" in South America by highlighting that although war may have declined, the willingness to use of force has not. ${ }^{149}$ Yet, no truly satisfactory explanation is provided for why those lingering rivalries and border disputes have not ultimately escalated to full-scale inter-state war. Mares' contribution is a healthy reminder of the limitations of existing explanations, but a poor substitute as to the reasons why war in South America has consistently declined both in frequency as well as in

\footnotetext{
${ }^{148}$ For a prominent example in the case of the War of the Triple Alliance, see Julio J. Chiavenatto, Genocídio americano: A guerra do Paraguai (São Paulo: Brasiliense, 1979). See also Silvânia De Queiróz, Revisando a revisão: "Genocídio americano: a guerra do Paraguai” (Porto Alegre: FCM editora, 2014).

${ }^{149}$ See Mares, Violent Peace; and esp. Mares, Latin America and the Illusion of Peace.
} 
intensity since the mid-19th century. His exclusive attention to the second-half of the 20th century — and to the Peru-Ecuador conflict in particular-further blinds him to the more profound trend of peace in the region, characterizing South America's international relations since at least the mid-19th century.

\section{Peace}

A second concept in contention is that of peace itself. In relation to the prior discussion, scholars have commonly approached the concept of peace merely as the absence of war. Realist approaches to peace, for example, see it as an interval or truce between moments of war. Peace is characterized, at best, as the unintended balance of power resulting from great power competition. As Arnold Wolfers put it, "[a]lthough no state is interested in a mere balance of power, the efforts of all states to maximize power may lead to equilibrium. If and when that happens, there is 'peace' or, more exactly, a condition of stalemate or truce. Under the conditions described here, this balancing of power process is the only available 'peace' strategy." 150 In Realist terms, therefore, peace is better understood as the absence of war, or as a "non-event." 151 A considerable number of studies about South

\footnotetext{
${ }^{150}$ Arnold Wolfers, Discord and Collaboration: Essays in International Politics (The Johns Hopkins University Press, 1962), p. 83. See also Geoffrey Blainey, The Causes of War (Macmillan, 1973), pp. 3-32; Raymond Aron, Peace and War: A Theory of International Relations (Doubleday, 1966), p. 151; Mearsheimer, The Tragedy of Great Power Politics. Cf. Oliver P. Richmond, Peace in International Relations (Routledge, 2008), pp. 40-57; and Marc D. Trachtenberg, "The Question of Realism: A Historian's View," Security Studies, Vol. 13, No. 1 (Autumn, 2003), pp. 156-194.

151 The idea of peace as a "non-event" was coined by John Mueller, who referred to the Cold War's "long peace" as "the greatest non-event in human history." See John Mueller, Retreat from Doomsday: The Obsolescence of Major War (Basic Books, 1989), p. 3.
} 
America conceptualizes peace in precisely these terms, irrespective of it being framed as the starting point of the analysis, or as the permanent ("normal") condition of the region. ${ }^{152}$ In reaction to this minimalist view of peace, prevalent in mainstream IR theory, a group of scholars from the 1990s and early 2000s developed a typology of peace that ranges from "cold" to "warm" to "hot"—or from "negative" to "positive"-peace, in an attempt to capture different gradations in the levels of stability of the regional (inter-state) peace. In this view, peace acquires an identity in and of itself, implying a qualitative change in how actors come to understand "violence" in general, and "war" in particular, as a social construction that should be eradicated from social interactions. As Emanuel Adler has explains, "peace as the absence of war is an oxymoron; we cannot positively define something as the opposite of something else." 153 Thus "enemies" can become "friends," and formerly bitter rivals can come to learn to trust one another and live peacefully. ${ }^{154}$ The construction of this social mentalities can, in turn, lead to qualitatively different types of stable relations - so stable, in fact, that war can become "unimaginable" among "friends." In these so-called "security communities," states stop perceiving one another as threats and,

\footnotetext{
${ }^{152}$ See, e.g., Mares, Violent Peace; McIntyre, "The Longest Peace"; Martín, Militarist Peace in South America; Child, "Interstate Relations in Latin America," pp. 378-403.

${ }^{153}$ Adler, “Condition(s) of Peace,” Review of International Studies, Vol. 24, No. 5 (December, 1989), p. 166.

${ }^{154}$ See Andrea Oelsner, "Friendship, Mutual Trust and the Evolution of Regional Peace in the International System," Critical Review of International Social and Political Philosophy, Vol. 10, No. 2 (June, 2007), pp. 257-279; Oelsner, "Procesos de paz y no-democracias: La estabilización de la paz en el Cono Sur," Revista Argentina de Ciencia Política, No. 7/8 (septiembre, 2004), pp. 67-72; Oelsner, “(De)Securitisation Theory and Regional Peace: Some Theoretical Reflections and a Case Study on the Way to Stable Peace," EUI Working Papers, RSCAS No. 27 (October, 2005), pp. 1-31; Cameron Thies, "The Construction of a Latin American Interstate Culture of Rivalry," International Interactions, Vol. 34 (2008), pp. 231-257; Johan Galtung, "Violence, Peace, and Peace Research," Journal of Peace Research, Vol. 6 (1969), pp. 167-191; Kenneth Boulding, Stable Peace (University of Texas Press, [1978] 1984); cf. Mark Peceny, "The InterAmerican System as a Liberal 'Pacific Union'?” Latin American Research Review, Vol. 29, No. 3 (1994), pp. 188-201; Richmond, Peace in International Relations, pp. 21-39.
} 
instead, collectively project their fears, uncertainties and security concerns outwardly. Short of fusing together into a larger supranational unit or regional state, a security community would typically remain within the boundaries of a "pluralistic" security community. ${ }^{155}$

Since the early 1990s, the majority of studies on South America's "long peace" has represented the evolution of the region in terms of steps or stages, ranging on one end of the spectrum from an early period of recurrent conflict, unstable balances of power, and intense security competition (1810s-1880s), to a condition called "positive" or "stable" peace, where war is eradicated from regional politics and meaningful cooperation between neighboring states is reaffirmed (post-1980s), at the very end of the spectrum. These stages, however, vary in degree and characteristics depending on the author, with various inbetween stages, types of peace, and periodizations that merit a closer and comparative view (see TABLE 3 infra).

In this general view, studies tend to generically clump together the entire 19th century as a conflictual or violent period, categorizing it as an unproblematic stage, unworthy of more serious consideration. ${ }^{156}$ The focus is put, instead, on the 20th century

\footnotetext{
${ }^{155}$ For representations of South America as a security community in these terms, see Hurrell, "An Emerging Security Community in South America?" in Emanuel Adler and Michael Barnett, eds., Security Communities (Cambridge University Press, 1998), pp. 228-264; Charles A. Kupchan, How Enemies Become Friends: The Sources of Stable Peace (Princeton University Press, 2010); Andrea Oelsner, "Pluralistic Security Communities in Latin America," in Routledge Handbook of Latin American Security, ed. by David R. Mares and Arie M. Kacowicz (Routledge, 2016), pp. 173-184; Daniel Flemes, "Creating a Regional Security Community in Southern Latin America: The Institutionalization of the Regional Defence and Security Policies," Working Papers No. 13, German Overseas Institute (December, 2005), pp. 1-36. The classical statement remains Karl Deutsch, et al., Political Community and the North Atlantic Area (Princeton University Press, 1957). Cf. Joseph M. Parent, Uniting States: Voluntary Union in World Politics (Oxford University Press, 2011).

${ }^{156}$ See, e.g., Holsti, War, the State, and the State of War, pp. 151-152, 156-157; Hurrell, "Security in Latin America," pp. 531-532; Hurrell, "An Emerging Security Community in South America?" p. 228; Little, "International Conflict in Latin America," p. 593; Domínguez, "Boundary Disputes in Latin America," pp.
} 
where "positive peace" is identified as taking hold in the early 1990s. The consolidation of several democratic governments throughout the entire region at this time is also seen in the literature as a most welcome, positive enhancement for this "stable peace."157

\section{TABLE 3 - Making Peace in South America}

\begin{tabular}{|c|c|c|}
\hline & "Negative Peace" & "Positive Peace" \\
\hline & $\begin{array}{l}\text { "War is normal" } \\
\text { (19th century) }\end{array}$ & $\begin{array}{l}\text { "War is unthinkable" } \\
\text { (20th century) }\end{array}$ \\
\hline Miller & $\begin{array}{r}\text { "Cold War" "Cold Peace" } \quad \underline{\text { "Hot }} \\
\text { ("Normal Peace" }\end{array}$ & $\begin{array}{l}\text { P e a c e" } \\
\text { "High-Level Peace") }\end{array}$ \\
\hline Kacowicz & "Negative Peace" & "Pluralistic Security Community" \\
\hline Holsti & "Hobbesian Floor" & "Kantian Ceiling" \\
\hline Buzan and Wæver & "Conflict Formation" & "Security Community" \\
\hline Hurrell & "Zone of Conflict" & "Pluralistic Security Community" \\
\hline Oelsner & "Fragile Peace" "Unstable Peace" "Cold Peace" & "Stable Peace" "Pluralistic Security Community" \\
\hline Kupchan & "Hobbesian/Lockean International Politics" & $\begin{array}{c}\text { "Zone of (Stable) Peace" } \\
\text { ("Rapprochement”-“Security Community"-“Union") }\end{array}$ \\
\hline
\end{tabular}

Sources: Miller, States, Nations, and the Great Powers; Kacowicz, Zones of Peace in the Third World; Holsti, War, the State, and the State of War; Buzan and Ole Wæver, Regions and Powers; Hurrell, "An Emerging Security Community in South America?"; Oelsner, "(De)Securitisation Theory and Regional Peace"; and Kupchan, How Enemies Become Friends.

References: (Red text) indicates the position of South America in relation to the Security Dilemma, according to each author.

According to Buzan and Wæver, for instance, "South America has traditionally been [...] a conflict formation for most of its history." ${ }^{158}$ In similar fashion, Miller argues that 19century South America "was an area of chronic war and armed intervention [...]. More

1-42; Buzan and Ole Wæver, Regions and Powers, 304-339; and Kacowicz, Zones of Peace in the Third World, pp. 67-124. Cf. Centeno, Blood and Debt, pp. 1-100.

${ }^{157}$ See, e.g., Kacowicz, Zones of Peace in the Third World; Holsti, War, the State, and the State of War. Cf. Oelsner, "(De)Securitisation Theory and Regional Peace"; Oelsner, "Procesos de Paz y No-Democracias."

${ }^{158}$ Buzan and Ole Wæver, Regions and Powers, p. 337. 
precisely, six postcolonial wars took place between 1825 and 1883, in addition to some undeclared confrontations." ${ }^{159}$ For Kacowicz, "in its formative period South America was a typical zone of conflict, characterized by international and civil wars, military interventions, political instability, changing alliances, struggles for subparamountcy in the Atlantic and River Plate basin that involved two wars and the creation of Uruguay, and a parallel struggle in the South Pacific area among Chile, Bolivia, and Peru, leading to the Chilean hegemony there following the Pacific War of 1879-83."160

Partly in reaction to the limitations of studying regional order solely through the prism of war, many of the new contributions have approached South America's puzzle influenced by the classical studies of Kenneth Boulding, Alexander George, and Karl Deutsch. These new studies have tried to solve the mystery of South America's prolonged interstate peace by looking not at the duration of the peace, defined minimally as an enduring absence of war, but at the evolution of the "quality" of peace in the region since the consolidation of democracy in the 1990s. ${ }^{161}$ It is important to point out that this newfound interest in peace came right after a decade where most regional experts were expecting a return to "normalcy"- that is, a return to traditional power-political competition, rivalries, and intra-regional war in a 19th-century style. ${ }^{162}$ It is for this reason that the new peace-studies literature was also infused with a fresh air of triumphalism and

\footnotetext{
${ }^{159}$ Miller, States, Nations, and the Great Powers, p. 317. See also Holsti, War, the State, and the State of War, pp. 151-154.

${ }^{160}$ Kacowicz, Zones of Peace in the Third World, p. 72.

${ }^{161}$ See Boulding, Stable Peace; Alexander L. George, "From Conflict to Peace: Stages Along the Road," United States Institute of Peace Journal, Vol. 6, No. 6 (December, 1992), pp. 7-9; and Deutsch, Political Community and the North Atlantic Area.

${ }^{162}$ For a good analysis of this "pessimistic" literature in the 1980s, see the excellent article by Walter Little, "International Conflict in Latin America," International Affairs, Vol. 63, No. 4 (October, 1987), pp. 589601. See also the contributions to Morris and Millán, Controlling Latin American Conflicts.
} 
optimism that added further impetus to some of their main claims, although now in retrospect they may sound somewhat exaggerated or overstated.

The attention, however, has been put not just on the elaboration of "types of peace," as illustrated above, but also on the interconnexion between peace and democracy. The connection with the return of democratic rule in the region is potentially important as it happened during the rapid changes in the institutional and normative contexts of the Western Hemisphere towards the end of the Cold War, in favor of the peaceful resolution of conflicts and the protection of human rights in general. In sum, the literature offers a reconstruction of the many stages of peace in a lineal path of progress through which South American states are seen as moving from a period of chronic conflict and war, to a period of "stable peace," with several intermediary phases. The argument that Liberal democracies "do not fight one another," however, is one of the most contested hypothesis in IR theory. At best, the proposition points to a correlation between democracies and international peace inter se-although an actual explanation is still to be provided.

Buzan and Wæver, for instance, argue that "the security community in the Southern Cone can hardly be seen as an instance of 'democratic peace'. It was not solid democracies that generated peace. It was the potential loss of democracy that motivated security measures." ${ }^{163}$ Holsti, for his part, also agrees that "[t]he growth of democracy fails to explain the change from a classical anarchical system of international politics to a no-war system. Most governments in South America during the period up to the 1980s were not democracies. And, as we have seen, the incidence of crises and wars does not correlate

\footnotetext{
${ }^{163}$ Buzan and Wæver, Regions and Powers, p. 325.
} 
with type of regime." ${ }^{164}$ David McIntyre offers a similar view on the issue: "[a]lthough no one has argued that the [inter-democratic peace] theory explains the South American 'long peace', many authors have recently used the theory to predict that the democratization will make Latin American relations less conflictual." ${ }^{\text {165 }}$

Despite these limitations, many contributors to the study of South America's long peace maintain that the return and consolidation of democratic regimes in the region after the 1980 s is a key component to explain the "deepening" of the type of peace. ${ }^{166}$ Different authors disagree about what is the stage at which the region is located at present (these positions are marked in red in TABLE 3), whether it is closer to "positive peace" or notand thus, whether war has been finally eradicated. As a general point, the so-called "return to democracy" of the late 1980s is commonly considered as a qualitative "upgrade" for the region, but this implies an acceptance of the Liberal proposition in IR connecting republican democracy with peaceful international effects via a process of "spill-over" that remains theoretically contested in IR. Beyond the many attributes that a democratic type of government can have for the welfare, freedom and security of its citizens, when compared to other types of regime, this position implies a claim about "outward effects" that are not yet backed-up by the empirical record. ${ }^{167}$

\footnotetext{
${ }^{164}$ Holsti, The State, War, and the State of War, pp. 171-172.

${ }^{165}$ McIntyre, The Longer Peace," p. 37.

${ }^{166}$ See, e.g., Kacowicz, Zones of Peace in the Third World, pp. 7-13, 20-21, 70-83; Kacowicz, et al., Stable Peace Among Nations, pp. 15-24, 200-219; Oelsner, "(De)Securitisation Theory and Regional Peace," p. 18. Lacking a theoretical consensus over how exactly democracy "produces" peace, it is controversial — at best — to claim that it may have "deepening" effects on regional peace.

${ }^{167}$ For a representative sample of studies ascertaining some type of "consolidating" effect of democracy in achieving higher levels of peace in South America, see Kacowicz, Zones of Peace in the Third World, pp. 81-89, 123-124; Solingen, Regional Orders at Century's Dawn, pp. 119-164; Oelsner, "Procesos de paz y no-democracias," pp. 67-72; Oelsner, "(De)Securitisation Theory and Regional Peace," p. 18; Miller, States, Nations, and the Great Powers, pp. 336, 327, 420-421; Michael Barletta and Harold Trinkunas,
} 
In conclusion, this evolutionary view of South America towards stable or positive peace is premised on a typology that runs from an early "pre-peace" stage, characterized by recurrent conflict and war (typically, 1810-1935), to an initial condition of fragile or unstable peace, where war remained a constant possibility, although states did not initiate one (between 1935 and 1982). This second stage of minimal peace (as a "no-war" period) can nevertheless regress at any moment back into chronic war - that is why many scholars refer to it as a "fragile" or "unstable" peace. Only when this negative peace is maintained for longer and other contingent factors come into play-so the argument goes-can "higher" stages of peace develop. Among those contingent factors, scholars often point out the potentially supporting role of extra-regional powers when they refrain from intervening (or avoid incentivizing further conflict) in the region. Another factor commonly mentioned is the presence of regional or global multilateral organizations helping to resolve through peaceful means pending legal or territorial disputes among states. ${ }^{168}$

\footnotetext{
"Regime Type and Regional Security in Latin America: Toward a 'Balance of Identity' Theory," in Balance of Power: Theory and Practice in the 21st Century, ed. by Tazha V. Paul, James J. Wirtz and Michel Fortmann (Stanford University Press), pp. 334-359; and Philippe C. Schmitter, "Change in Regime Type and Progress in International Relations," in Progress in Postwar International Relations, ed. by Emanuel Adler and Beverly Crawford (Columbia University Press, 1993) pp. 89-127. For a critical perspective, cf. Holsti, The State, War, and the State of War, pp. 157-161; Buzan and Wæver, Regions and Powers, p. 337, 325-326; Martín, Militarist Peace in South America, pp. 117-148; Charles A. Jones, "Foundations of South American International Society," paper presented at the annual meeting of the American Political Science Association, Boston, July, 2008, pp. 1-38; Andrew Hurrell, "Security in Latin America," International Affairs, Vol. 74, No. 3 (July, 1998), pp. 529-546; Hurrell, “An Emerging Security Community in South America?" pp. 228-264; Jorge I. Domínguez, "Boundary Disputes in Latin America," Peaceworks, No. 50 (USIP, September, 2003), pp. 16, 29-32.

${ }^{168}$ On the role of extra-regional powers, see Miller, States, Nations, and the Great Powers, pp. 306-336; Kacowicz, Zones of Peace in the Third World, pp. 94-96; Buzan and Wæver, Regions and Powers, pp. 263-342. On the role of regional organizations, see Domínguez, "Boundary Disputes in Latin America," pp. 1-45; Domínguez, "International Cooperation in Latin America: The Design of Regional Institutions by Slow Accretion," in Crafting Cooperation: Regional International Institutions in Comparative Perspective, ed. by Amitav Acharya and Alastair I. Johnston (Cambridge University Press, 2007), pp. 83-128.
} 
This alternative "qualitative" approach to peace in South America, however, runs into an additional set of important limitations. One issue with this approach is the suggested link between interstate peace and democracy. As highlighted above, this runs in the face of very sharp criticisms about the spuriousness of the correlation, as well as the lack of an effective way to truly test the specific hypothesis - particularly across longer periods of time when the actors' own understanding of "democracy" changes. ${ }^{169}$ The tendency, for example, to dismiss the Peru-Ecuador confrontations during the 20th century for being conflicts between two "not-democratic-enough" states, raises problems for the effective applicability of the Liberal hypothesis to concrete historical circumstances. ${ }^{170}$ A related problem is the fact that democracy has only been a stable factor of domestic politics in Latin America since the late 1980s and early 1990s. Since 1935, when the last major war ended in South America, democratic and authoritarian regimes have alternated powerwith a clear predominance of the latter. ${ }^{171}$ This leaves almost the entirety of the "long

\footnotetext{
${ }^{169}$ On the inter-democratic peace hypothesis, see Michael W. Doyle, "Kant, Liberal Legacies, and Foreign Affairs," Philosophy and Public Affairs, Vol. 12, No. 3-4 (Summer-Fall, 1983), pp. 205-235, 323-353; Doyle, "Liberalism and World Politics," American Political Science Review, Vol. 80, No. 4 (December 1986), pp. 1151-1169; Bruce M. Russett, Grasping the Democratic Peace (Princeton University Press, 1993); Russett and Oneal, Triangulating Peace. For general criticisms, $c f$. Kenneth N. Waltz, "Structural Realism After the Cold War," International Security, Vol. 25, No. 1 (Summer, 2000), pp. 5-41; John J. Mearsheimer, "Back to the Future: Instability in Europe after the Cold War," International Security, Vol. 15, No. 1 (Summer, 1990), pp. 5-56; Christopher Layne, "Kant or Cant: The Myth of the Democratic Peace," International Security, Vol. 19, No. 2 (Fall, 1994), pp. 5-49; Sebastian Rosato, "The Flawed Logic of Democratic Peace Theory," American Political. Science Review, Vol. 97, No. 4 (November, 2003), pp. 585-602; Rosato, "Explaining the Democratic Peace," American Political. Science Review, Vol. 99, No. 3 (August, 2005), pp. 467-472; David E. Spiro, "The Insignificance of the Liberal Peace," International Security, Vol. 19, No. 2 (Fall, 1994), pp. 50-86; and Joanne Gowa, Ballots and Bullets: The Elusive Democratic Peace (Princeton University Press, 1999).

${ }^{170}$ On this, see Scott Gates, Torbjørn L. Knutsen and Jonathon W. Moses, "Democracy and Peace: A More Skeptical View," Journal of Peace Research, Vol. 33, No. 1 (February, 1996), pp. 1-10; and Christopher Layne, "Kant or Cant: The Myth of the Democratic Peace," International Security, Vol. 19, No. 2 (Fall, 1994), pp. 5-49.

${ }^{171}$ For a good analysis of this process in the context of the long peace debate, see Martín, Militarist Peace in South America, pp. 117-182, see esp. tables 6.1 and 6.2 on pp. 120-121. See also Walter Little,
} 
peace" period in need of an explanation, and raises concerns regarding the real explanatory power and validity of the democratic peace hypothesis as a main approach for the study of the region.

If, as Kacowicz and others have argued, democracy must be given only complementary status—as an "upgrading" or "deepening" factor of stable peace—then the more encompassing explanation must also be provided a priori. In short, without a central explanation, what is it that democracy is "upgrading" in the first place? What exact theoretical mechanisms and causes of peace is democracy actually enhancing? The answers to these questions have failed to contribute a truly encompassing solution (both geographically as well as temporally), for some apply only to post-1980s South America, while others do so to the Southern Cone in particular - and not to South America as a whole. ${ }^{172}$

Another problem with the qualitative peace approach is that it is usually unclear in its separation of causes and effects. That is, it often leads to teleological, linear reconstructions of the history of South America that run the risk of escaping true explanation, and that at best provide mere historical description. The distinction is crucial. Authors like Kacowicz, Kupchan, Hurrell, Holsti, and Oelsner, for example, tend to think about regional peace in stages that are usually little more than thick descriptions of the state or condition of the region at different moments in its history. These authors, however, rarely (or only with great difficulty) address the issue of causes or "driving factors" that

\footnotetext{
"Military Power in Latin America: An Overview," Working Paper No. 4 (University of Liverpool, Institute of Latin American Studies, 1986), pp. 1-91.

${ }^{172}$ Cf. Kacowicz, Zones of Peace in the Third World, p. 99; Buzan and Wæver, Regions and Powers, p. 325; Miller, States, Nations, and the Great Powers; Oelsner, International Relations in Latin America.
} 
are said to propel the region from one stage to the next. These "explanations" are never presented in ways that clearly distinguish the empirical reality described from the specific factors said to be "causing" that reality in the first place. Early stages of peace, for example, are typically described as chaotic, violent, or unstable. Several characteristics are thus pointed out — such as "war remains a valid instrument of policy"-but no theoretical explanation is provided, or empirical tested, for why the region may have "transitioned" to the next stage of "no-war." Whereas an account of what happened is by itself insufficient, a detailed description of how it happened is only half the story. A fuller account must ultimately also try to address the why question. Otherwise, the concept of "negative peace" is merely implied from the historical fact of a decline of war in the region, but since the absence of war cannot be its own cause, then a teleological argument leads to a tautological explanation - and thus the South American puzzle remains unresolved.

With this assessment in mind, existing explanations based on a qualitative approach to peace must therefore provide more than simple rationalizations and a "black-boxing" of stages and types of peace according to what the historical record already shows. They must offer a theoretical explanation to give meaning and direction to the historical information presented. ${ }^{173}$ Perhaps the best attempts at overcoming this problem have come from works adopting the theoretical framework of "security communities," as initially developed by Deutsch and later refined by Adler and Barnett, and the so-called Copenhagen School of IR. $^{174}$

\footnotetext{
${ }^{173}$ See Nicholas G. Onuf, The Republican Legacy in International Thought (Cambridge University Press, 1998), p. 235.

${ }^{174}$ See, e.g., Kupchan, How Enemies Become Friend, pp. 122-134; Arie M. Kacowicz, "Stable Peace in South America: The A.B.C. Triangle, 1979-1999," in Stable Peace Among Nations, ed. by Kacowicz, et al. (Rowman \& Littlefield, 2000), pp. 200-219; Hurrell, “An Emerging Security Community in South
} 
Although these studies fill in the theoretical void identified above with the wellknown concept of the security community, they run against two additional challenges. First, the region has "failed" to integrate further, either politically or economically, beyond rather superficial levels, and thus it has failed to finally transition even to a "pluralistic security community" (the first of the two hypothesized conditions in the security communities literature). During the 1990s, the case of MERCOSUR was often invoked as a strong indication that the sub-region of the Southern Cone was finally transitioning towards a true stable peace — where war among states would be "unthinkable." These high hopes for the Southern Cone, although still alive in some recent studies, have become more moderate and at times even turned pessimistic after decades of "underperformance" by this and other similar regional trading blocs—-both economically and politically. ${ }^{175}$ A second challenge for the security-community literature has been its inability to explain why South American states have maintained separate national armies and developed no meaningful regional framework to tackle threats common to the region as a whole. As a logical component of any advanced security community, members are expected to develop in time a common understanding of the types of threats to their shared security and elaborate common institutions and organizations with which to face those challenges together, as an "amalgamated security community" (the second condition in the literature). In a security

\footnotetext{
America?" pp. 228-264; Charles A. Kupchan, How Enemies Become Friends: The Sources of Stable Peace (Princeton University Press, 2010); Oelsner, "Pluralistic Security Communities in Latin America," pp. 173-184; Oelsner, International Relations in Latin America, pp. 3-49.

${ }^{175}$ Cf. Kupchan, How Enemies Become Friends, pp. 122ff; Andrea Oelsner, "Consensus and Governance in Mercosur: The Evolution of the South American Security Agenda," Security Dialogue, Vol. 40, No. 2 (2009), pp. 191-212; Oelsner, "Procesos de paz y no-democracias"; Buzan and Wæver, Regions and Powers, pp. 263-342; Oelsner, International Relations in Latin America: Peace and Security in the Southern Cone (Routledge, 2005), passim, but esp. pp. 184-191.
} 
community, a region so culturally homogeneous as South America would be expected to develop a rather easy and expedient pooling of sovereignty given that war among member states is said to be "unthinkable" and threats would emanate only from outside the region. Put differently, member states should project force outwards, not internally. The historical record in South America has demonstrated the limits of this explanation, even when cast as a mere description of the current condition of South America's security architecture. ${ }^{176}$ Attempts at explaining South America's long peace as an instance of a "higher" peace, overall, have thus failed to elicit a convincing theoretical argument beyond mere historical description. Efforts in framing the explanation in terms of a security community, for their part, although filling in (in principle) part of the explanatory deficiency of the contributions from peace studies, still remain problematic when confronted with an empirical historical reality that does not conform to most of the framework's key expectations. Quite tellingly, South American states remain at peace with one another, while the individual citizen lives violently in almost all of the capitals and metropolitan cities of the region.

Contrary to these approaches, a more pragmatic view of the interconnection between war and peace can be articulated from the international society perspective by shifting the discussion from one about "war" or "peace" to another based on "order." A perspective centered around the notion of (regional) order can more easily accommodate concerns about war and peace without pitting one as the direct opposite of the other. Following the contributions by Hedley Bull and others to the international society

\footnotetext{
${ }^{176}$ See, inter alia, Mares, Latin America and the Illusion of Peace; Hurrell, "Security in Latin America"; Domínguez, "Boundary Disputes in Latin America."
} 
approach, a focus on order can help the researcher avoid the twin problems of either "counting" wars as a mark of a region's peaceful character, as well as the arbitrary construction of types of peace that may describe, yet not explain, the driving forces behind the South American case across time.

Conjoining the discussions over war and peace in a larger framework focused on the issue of "order" can also illuminate areas of research previously overlooked—such as the role that war can play in creating, sustaining, or challenging a certain regional order; or the role that peace can play in creating incentives to employ force in defense of values, norms and legitimate standards. These issues may appear counterintuitive at first, or outright unimaginable, for scholars committed to the existing theoretical frameworks as they apply to South America. While a concern with order does not avoid discussions about the role of war in maintaining peace, the otherwise "mixed" or contested empirical record faced by traditional approaches can be productively accommodated in a larger theoretical framework that helps explain the intricate interconnection between war and peace as a social institution.

Until now, the literature discussed has tried to tackle the South American puzzle either from the quantitative study of war, or the qualitative study of peace-with only rare exceptions acknowledging the possible permutations between these two phenomena. In the following section, the chapter looks at one final concept that, despite being the centerpiece of the whole debate, remains deeply contested. 


\section{Long Peace}

The fourth, and final, concept to consider is that of the "long peace" itself. The prior discussions about the contrasting quanti- and qualitative understandings of war and peace in the literature serve as an excellent background to comprehend why those who have studied in detail the long South American peace still disagree over so fundamental a concept as that of the "long peace."

There are three main positions regarding South America's long peace. On one hand, scholars like Centeno, Jones, or Buzan and Wæver, maintain that its duration extends for a period of roughly two-hundred years, since the achievement of independence against the Spanish Empire. ${ }^{177}$ As Centeno put it: "Since independence in the early nineteenth century, Latin America has been relatively free of major international conflict. In the twentieth century, the record is truly remarkable, especially in light of the experience of other regions of the world." And he continues:

$[\ldots]$ There is no question that Latin Americans have tried to kill each other. There are too many examples of brutal and bloody conflicts for this to be denied. [...] Yet in general, Latin America has experienced low levels of militarization, the organization and mobilization of human and material resources for potential use in warfare. Latin Americans have frequently tried to kill one another, but they have generally not attempted to organize their societies with such a goal in mind. [...] Latin American states have only rarely fought one another. ${ }^{178}$

\footnotetext{
${ }^{177}$ For the implicit view of a long "long peace," see Centeno, Blood and Debt, esp. p. 34; Charles A. Jones, "Foundations of South American International Society," American Political Science Association Meeting, Boston (August, 2008), pp. 1-38; Jones, American Civilization (Institute for the Study of the Americas, University of London-School of Advanced Study, 2007); Grabendorff, "Interstate Conflict Behavior," esp. pp. 270-271; and Marshall, Third World War, p. 196.

${ }^{178}$ Centeno, Blood and Debt, pp. 34-5, 37. [Italics in the original]. See also p. 47. Although Centeno writes Latin America, he is in fact referring to South America (plus Mexico). See ibid., p. 1: fn. 1.
} 
A second group of scholars, on the other hand, holds a truncated view of South America's long period of peace as a theoretical "anomaly," marked by a pivotal change somewhere between the turn of the century and the ending of the Chaco War in $1935 .{ }^{179}$ As Domínguez put it, "Latin America has seen war relatively infrequently since the late nineteenth century, although wars had been common before then." ${ }^{180}$ Similarly, Little opines that, in historical perspective, "the striking fact about post-independence Latin America is the frequency and intensity of conflict in the sixty years up to 1880 and its relative peacefulness thereafter."181

Finally, Holsti adds that looking at 19th-century South America, “one can identify certain patterns of peace and war marked by intervention, territorial predation, alliances, arms-racing, and power-balancing quite similar to those found in eighteenth-century Europe." He concludes:

[T]he international politics of South America have changed substantially since the late nineteenth century. [...] South America clearly is not yet a zone of peace, much less a pluralistic security community. Nevertheless, it has been a no-war zone in which the probabilities of armed conflict are substantially lower than they were in the nineteenth century [...]. For South America, then, the twentieth century has been an era of relative peace. $^{182}$

Independent from their disagreements about the periodization of the long peace in South America, there is a consensus over the theoretical status of the region as a whole. That is,

\footnotetext{
${ }^{179}$ For examples of this shorter view of the "long peace," see Holsti, The State, War, and the State of War, pp. 150, 152, 154, 161, 155; Domínguez, "Boundary Disputes in Latin America," p. 20; Miller, States, Nations, and the great Powers, p. 324; Martín, Militarist Peace in South America, pp. 1, 7; Kacowicz, Zones of Peace in the Third World, pp. 71-75; McIntyre, "The Longest Peace," pp. 1-2; Little, "International Conflict in Latin America," pp. 594, 593; and Hurrell, "Security in Latin America," pp. 531533.

${ }^{180}$ Domínguez, "Boundary Disputes in Latin America," p. 20. Italics added.

${ }^{181}$ Little, "International Conflict in Latin America," p. 594.

${ }^{182}$ Holsti, The State, War, and the State of War, pp. 152, 154, 161, 155.
} 
there is a wider agreement about its "anomalous," or exceptional, condition which also touches on the assumptions identified at the beginning of the present chapter. ${ }^{183}$ David McIntyre, for example, argues that South America is especially anomalous because according to the common wisdom of IR theory, the internal characteristic of South American states should have made them prone to war. The states should have been warprone because they had low levels of economic interdependence; were generally undemocratic; had unstable regimes; and had a lack of civilian control over their militaries. $^{184}$

Miller, for his part, adds an important distinction: "Alternative explanations for the peacefulness of South America in the twentieth century are undermined because the causal factors that supposedly produced peace according to these explanations were also present in the nineteenth century; yet these factors did not succeed in preventing the frequent wars in that period and in producing peace." ${ }^{185}$ Whereas for Holsti, the region is anomalous because of its unique pattern of no-war among states amid relatively high intra-state levels of violence. "Looking at the nineteenth-century South America," he concludes,

[t]his region would thus lend support to neorealist, structural characterizations of international politics as a game of conflict, war struggle, and survival. [...] Overall, then, the international politics of twentieth-century South America fit poorly with neo-realist characterizations and predictions. Waltz's famous recurrent outcomes of an anarchic system (war, balancing, absence of relative gains) do not apply to this area. ${ }^{186}$

\footnotetext{
183 The view of the long peace in South America as an "anomaly" is widely-shared among the students of the region. See, e.g., Martín, Militarist Peace in South America, pp. 2, 24, 177, 179, 181; Holsti, The State, War, and the State of War, p. 161; Buzan y Wæver, Regions and Powers, p. 304; Kacowicz, Zones of Peace in the Third World, pp. 67-124; McIntyre, “The Longest Peace”, pp. 170-171.

${ }^{184}$ McIntyre, "The Longest Peace," p. 24.

${ }^{185}$ Miller, States, Nations, and the Great Powers, p. 326.

${ }^{186}$ Holsti, The State, War, and the State of War, pp. 155, 157. For an attempt at explaining why Waltz's theory does not apply to the case, see McIntyre, "The Longest Peace."
} 
Given these aspects of the region, Holsti argues that South America is "[c]ompletely at odds with other areas, [since] there has been no war between [...] states since 1941. South America is an intriguing anomaly."187

Charles Jones contributes two additional aspects to the distinctiveness of the region in comparison with the rest of the world. In his view, the region is a "microcosm" characterized by its own historical path and experiences ${ }^{188}$ that, apart from its sharp decline in the incidence of war among states and the relative low level of intensity of the conflicts that actually took place throughout its history, also showcases a tendency (a) not to form balances of power, and (b) to have reached a continental or hemispheric "unipolarity" (under the United States' hegemony) much earlier than the rest of the world. "[O]ne may conclude," Jones argues, "that the history of relations between American states is distinctive in a number of ways, and that Europeans may gain from studying what may be past history for the Western hemisphere, but is now current reality for a wider world"189

A third, and final, group does not think much of the idea of South America either as a "zone of peace" or as a "security community." This smaller group, in fact, argues that a long peace does not really exist in South America. According to Mares, the idea of Latin America as a region of stable peace is a problematic proposition, both theoretically as well as pragmatically, given the particularly arbitrary ways in which the definitions of "war," "peace," or "democracy" are commonly employed in the debate. Empirically, Mares

\footnotetext{
${ }^{187}$ Holsti, The State, War, and the State of War, p. 150.

${ }^{188}$ Charles A. Jones, "International Relations in the Americas: Microcosm or Exception?" unpublished paper, September 2004, pp. 1-13. David Mares also refers to Latin America as a "microcosm." See his Violent Peace, pp. xi-xii.

${ }^{189}$ See Jones, "International Relations in the Americas," p. 13. For a similar point, see Centeno, Blood and Debt, pp. 71, 100.
} 
argues, the use of force in the region has suffered from a war-bias which has blinded the analysis of the multiple instances of uses of force (or the threat of use) throughout the 20th century in all of Latin America. Analytically, the heavy reliance on the cow Project's definition of war, as well as the focus only on South-instead of Latin-America, lead Mares to conclude that the idea of the region as a "zone of peace" is but an illusion based on capricious conceptual and methodological commitments. ${ }^{190}$

Mares believes that Latin America "represents a theoretical puzzle for the study of international relations" and that IR analysts "are usually attracted to the region because of its purported 'long peace'." However, a detailed examination of the empirical record-he adds - "indicates that there has not been a long peace in the region, whether one defines peace as the absence of 'war' (defined by at least 1,000 battlefield-related deaths), or the absence of serious military confrontations. [T] he use of violence across national boundaries has been a consistent trait of Latin America's international politics. In fact, violence in the region escalates to war in much the same proportion as in the rest of the world, with the exception of the Middle East." ${ }^{\text {"191 }}$ For Mares, Latin America is nevertheless a "microcosm" although for different reasons: not because of its pattern of infrequent war, but because of the limited character of the region's armed conflicts, which almost never escalate to war. Mares suggests that the explanation for such a limited character has to be based on the reform of the character of the region's security institutions and the many multilateral and legal regional mechanisms for building mutual trust, confidence, and stable civil-military relations at the domestic level. This institutional architecture, he concludes, cannot

\footnotetext{
${ }^{190}$ See Mares, Violent Peace, and Mares, Latin America and the Illusion of Peace.

${ }^{191}$ Mares, Violent Peace, pp. 3, 28.
} 
continue to rely on the assumption that democracies will not fight one another, of that "satisfied" states will not threaten or use force as a legitimate tool of statecraft. ${ }^{192}$

Although both Mares ${ }^{193}$ and McIntyre ${ }^{194}$ maintain that the long peace in South America obtains only when the arbitrary threshold of casualties is kept high, at the 1,000 mark, and when the analysis if confined solely to South America, their argument also suffers from some serious limitations. First, the idea that by simply lowering the threshold, say to 500 as in the MID dataset, the "peaceful" condition of the region disappears, is contradicted by these authors own recognition of the fact that countries in South America (yet not so in Central America) have managed to maintain crises, rivalries, and minor armed disputes limited, avoiding escalation into a major war. This contradiction in how both authors portray the theoretical problem simultaneously as a puzzle in need of explanation and as a "normal" condition, is most evident in the way in which Mares and McIntyre struggle to make their own contributions to the debate relevant or meaningful. Critics could easily revert their argument on its head and dismiss Mares' and McIntyre's contributions by pointing out that too-low a threshold can run the mirror problem of “counting" almost every minor border dispute as a relevant security event — and thus, create an equally distorted or biased image of the region as more violent than what other experts would agree. But this also leads to a related set of problems.

\footnotetext{
${ }^{192}$ See, e.g., David R. Mares, "Constructing Real Peace and Security in Latin America: Minimizing the 'Moral Hazard' Character of Security Institutions," Pensamiento Propio, Vol. 36-37, Año 17 (JulioDiciembre, 2012), pp. 157-174; and Mares, "Interstate Security Issues in Latin America," in Routledge Handbook of Latin American in the World, ed. by Jorge I. Domínguez and Ana Covarrubias (Routledge, 2015), pp. 420-433.

${ }^{193}$ Mares, Latin America and the Illusion of Peace, pp. 12-25; Mares, Violent Peace, pp. 28-51, esp. 32ff.

${ }^{194}$ McIntyre, “The Longest Peace,” pp. 2, 167.
} 
Second, therefore, the extension of the analysis from South to Latin America amplifies the geographical scope of the analysis at the expense of clumping together the security dynamics of two, largely different, sub-regions of the American continent. Analyzing the "long peace" as a hemispheric phenomenon not only blurs the important geographical distinctions between two distinct regions (i.e., South and Central America), but also superimposes trends and dynamics of one of them onto those of the other. Central America's extremely high levels of civil violent conflict, for example, which is a distinctive aspect of most of its history, is mixed with the relatively more peaceful condition of South America's civilian populations. Similarly, the inter-state stability of South America is superimposed on the Central American armed conflicts during the Cold War, further confusing trends of different regions as if one. This problematic approach leads to the exaggeration of the level of violence, as essentially localized Central American trends are attributed as a problem of the whole, instead of just of one of its parts. Additionally, this also leads to the exaggeration of the "external-peace-internal-violence paradox," which characterizes most of South America, but not Central America where both intra- and interstate violence remain the norm. ${ }^{195}$

In the following, and concluding, section of this chapter, the main contending approaches to the long peace are grouped into sets of theoretical arguments and are then presented in a more formal theoretical and testable form.

\footnotetext{
${ }^{195}$ See, e.g., Daniel M. Goldstein and Enrique D. Arias, eds., Violent Democracies in Latin America (Duke University Press, 2010); and Holden, Armies without Nations.
} 


\section{Explaining the "Long Peace": Seven Contending Approaches}

Many of the explanations of South America's long period of inter-state peace have been presented by not just by IR theorists and political scientists, but also by historians, sociologists, and other regional experts. In this dissertation, their different explanations are grouped in seven contending approaches and are then operationalized and discussed according to their empirical implications - given both their relevance and their popularity in contemporary discussions. The main approach for this study is (H1) the international society argument, already presented in the Introduction, but formally operationalized here. The rest of the contending approaches focus on $(\mathrm{H} 2)$ the role of the United States as a hegemonic stabilizer; (H3) a regional balance of power; $(\mathrm{H} 4)$ the unique geopolitical features of South America; (H5) the role of common culture, extra-regional threats and imperialism in fostering regional peace; (H6) the level of state-strength; and (H7) the interplay between the type of regime and economic interdependence with a set of common institutions and norms.

Most of these explanations correspond in large extent with some of the main theoretical approaches to IR, such as Realism or Constructivism, although that is not the main selection criteria followed. Other explanations are based on well-known hypotheses advanced by historians, sociologists and students of the region that follow no explicit theoretical approach. These explanations, for their part, can nevertheless be easily grouped into one of the identified sets according to the type of argument implied, although this requires a personal level of interpretation of the argument which may be open to interpretation. The criterion employed here is that even when not formally stated, all arguments carry an implicit theoretical or abstract understanding about "causes" and 
"outcomes" that can be, more or less, formalized and associated with some of the existing theoretical approaches in IR.

This section of the chapter, therefore, introduces each group of explanations, identifies its main arguments, and further operationalizes the formal explanations and variables at play in each instance. More importantly, it elaborates on the precise application of each set to the specific case-studies and distills from these a concrete set of predictions or expectations for each of the within-cases. These theoretical expectations are relevant because they will be contrasted with the historical record in each case-study chapter, as well as against each other, by way of the process-tracing method.

\section{(H1) South America as a "Society of States"}

The main hypothesis of this study is that the South American states formed over the course of the mid-19th and early 20th centuries a regional "society of states" (or international society), and that this, in turn, had a direct and positive impact upon the emergence and endurance of a regional order that underpins a "long peace" among South American states. The hypothesized "impact" of South America's international society on the quality of the international relations in the region generates a series of theoretical and concrete practical expectations. On the theoretical side, this study focuses on three key processes: the progressive limitation (or taming) of war; the growing number and importance of the regional institutions and multilateral organizations; and the pragmatic character of the region's inter-state solidarism when the regional order is threatened or disturbed from within or without. Expressed in a more formal or theoretical language, the international society argument identifies the "society of states" as the independent variable (IV) 
explaining the South American long interstate peace (DV). This relationship, however, is associated through three particular mechanisms identified above as (a) limited war, (b) the institutionalization of order, and (c) the prevalence of a pragmatic solidarism among states. Of great importance for this study is the fact that these are processes or mechanisms that are not exclusively hypothesized only in the international society approach, but are also part of the arguments in all of the competing approaches.

When applied to the South American case, therefore, the society of states can take several values in a continuum based on "strength" or "maturity." That is, a society of states can be seen as "strong" (thick), or "weak" (thin), in relation to the level of identifications experienced by states (via key decision-makers and elites) with a sense of strategic awareness regarding the interconnectivity between the individual national interests and the general interests of the regional system as a whole. This level of awareness and sense of belonging to a "society" of states is identified here with the emergence of a raison de système - as opposed to the traditional raison d'état —in how states carry out their mutual diplomatic relations. But for simplicity, the continuum can be reduced to the mere presence of absence of a society of states. Similarly, the level of awareness and the element of a raison de système can be simplified as the "background conditions" of the approach (see infra FIGURE 1). 


\section{FiguRE 1: The International Society Argument}

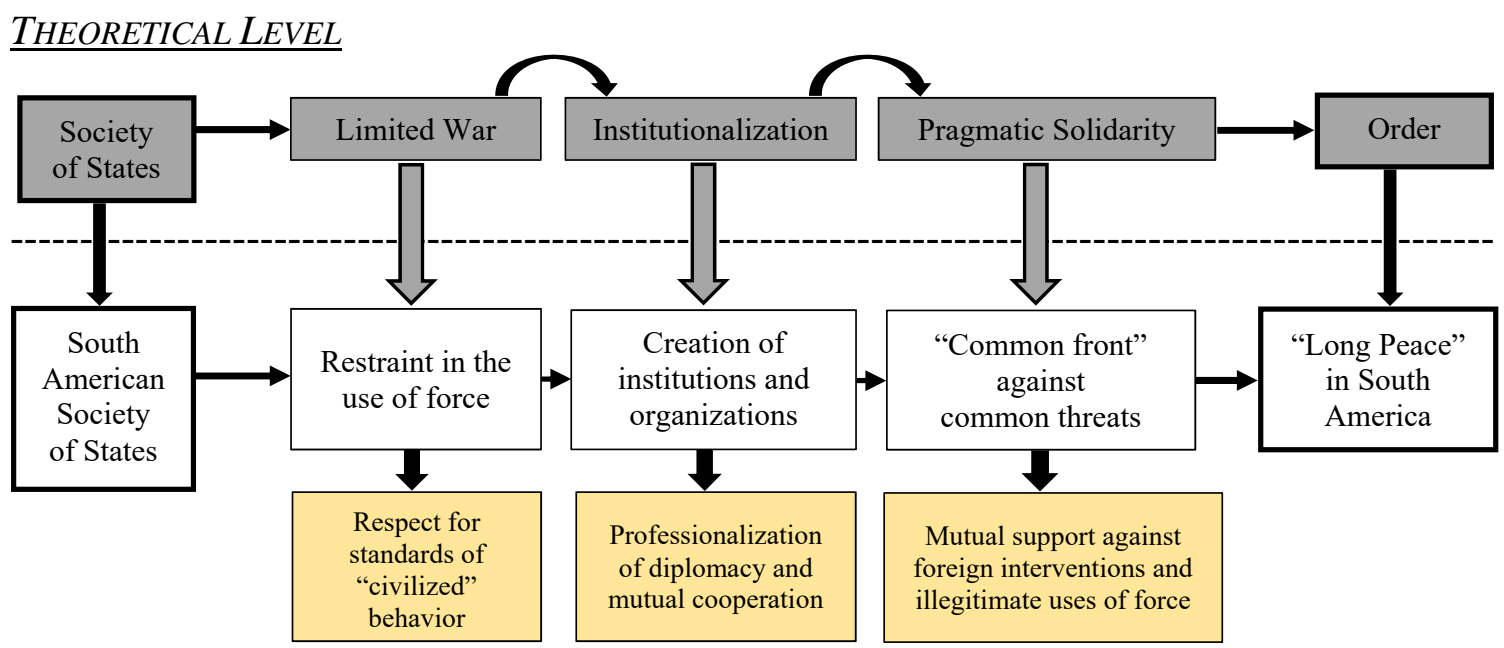

\section{EMPIRICAL LEVEL}

References: "Bold Arrows" indicate direct inferences; "Shaded Arrows" indicate (secondary) inferences; "Shaded Boxes" indicate what is actually being traced; "Golden Boxes" indicate the empirical "facts" of the historical case.

When a society of states is present, the incidence of war (both frequency and intensity) declines among members of the same society of states. Regional international relations also take on a more institutionalized manner, giving way to both formal and informal institutions to maintain and reassure the regional order. As members thus come to regard the survival, security and fate of each fellow member as intimately connected to their own's, a particular sense of pragmatism leads states to exercise solidarity with fellow members when their own fate and survival threatens the securities and stabilities of all. Thus, neutrality, indifference and predatory behaviors give way to a sense of "pragmatic solidarism" premised not on selfless altruism, but on the notion of erecting "common fronts" against common threats to regional order.

In Figure 1, the argument of the international society approach is schematized according to the process-tracing method, considering two concrete dimensions: the 
theoretical and empirical levels. On the first level, located on the top, the theoretical argument is represented in shaded boxes connecting the IV ("society of states") to the DV ("order") through three particular causal mechanisms ("limited war," "institutionalization," and "pragmatic solidarity"). Although in practice these three mechanisms could appear as temporally interchangeable or susceptible to alternation without any particular order in the chain of mechanisms identified, in truth they do entail a particular sequence that can only become visible when each mechanism is defined and properly linked analytically with one another. In this sense, when a society of states forms, the first concern in how states (i.e., states leaders) come to embrace a raison de système is how to "tame" or limit war among themselves and in their regional system as a whole. Without a proper consensus over this initial aspect, no meaningful discussion about how to institutionalize those arrangements that make up the consensus over common interests and values can realistically emerge. That is, until the use of force is not "legitimized" according to a set of standards and rules that states voluntarily uphold, the second hypothesized mechanism of institutionalization cannot logically develop.

In turn, the second mechanism reinforces the minimal elements of order that limiting war has created and further structure how the agreed set of "rules of the game" will govern the relations among member states and become institutionalized in formal organizations where collective problems are resolved in a legitimate manner. The third mechanism, therefore, concerns the sense of orientation that security collaboration, mutual assistance, and alliance (of both formal and informal nature) adopt in protection of the regional order. In order for any type of "solidarity" to develop, a minimal control over the content and nature of war and its institutionalization and control must be already in place 
among members. This solidarity will unequivocally take a "pragmatic" character in a society of states where members remain jealous of their autonomy and security, and actively work against any delegation of sovereignty to a central power-both intra- or extra-regional in nature. In this context, the long peace emerges out of the accumulated long-term effects of the first, second, and third mechanisms, as their effects can only be seen across a relatively long period of time. The study of 20th-century peace in South America, therefore, cannot remain "block-boxed" in that century; it must unavoidably entail an investigation of its underpinnings and causes located in the 19th century.

On the lower level, the empirical components of the argument are introduced according to the historical case studies. Thus, the concrete empirical level represents a process that moves from the inferred existence of a South America's society of states (IV) hypothesized as leading to regional "long peace" (DV) via three concrete processes or mechanisms taking the following historical form: First, the progressive limitation of the frequency and intensity of armed conflict in the region through the narrowing of the scope of the legitimate reasons to declare and engage in war (ad bellum), and the effort to behave according to what actors" own perceptions dictate as "civilized" and restrained behavior (in bello). These efforts in limitation of the frequency and intensity of war among South American states can be reflected in many empirical manifestations. For the purposes of this study, only some of the most relevant manifestations will be traced more systematicallyalthough reference to other equally valid manifestations can be pointed out on the side, according to the specifics of each case study. These are, first, the actors' effort at justifying and explaining their actions as "legitimate," trying to win the support not only of their own civilian populations and the public opinion, but also that of other extra-regional actors, 
such as the European great powers and the United States, which could tilt with their moral and legal support the outcome of a conflict towards a particular national cause - and away from its rivals. Second, the limitation of war can also be traced in the way in which legal and moral/civilizational principles are systematically respected (or violated) among the belligerents. Included in this second manifestation must be the treatment of prisoners of war, the respect of international and regional standards of "civilized" conduct, such as the respect of legal rights conferred to civilians and other non-combatants, and the respect of the rights of neutrals.

Second, the successful limitation of war assists in the transition from a system to a society of states, and thus helps develop a professional diplomacy that emerges on the empirical level as a set of semi-permanent congresses, conferences, and other multilateral organisms that regulate and reinforce regional order. As the society of states "strengthens," that is as it moves from the first to the second mechanism, these informal institutions such as congresses and conferences are replaced by more formal and permanent regional organizations - as in the case of the OAS (1948). The difference in practice between "institutions" and "organizations," as they are used in this study, are not simply a matter of degree of formality or informality, but also of substance: while institutions are particular patterned practices created and maintained by states, organizations are bureaucraticspecific multilateral actors that have a separate existence from its component units (states), yet remain fundamentally bound by their membership, interests and power. In 19th-century South America, it was a recurrent feature of regional international relations to form congresses ("congresos americanos") to deal with security threats and common problems, 
as well as to develop a legal set of norms and rules to govern regional diplomatic and political relations. ${ }^{196}$

Contrary to the Portuguese case, the legacies of the former Spanish rule over most of the region had left almost no institutional "know-how" at the level of the elites now in charge of domestic and foreign affairs in each independent country. These Congresses ranged from the early 1820s, with the famous Panama Congress convoked by Simón Bolívar, and the two congresses in Lima (1840s and 1860s), and in Santiago (1850s). Towards the end of the century, these congresses changed both their format, scope and ambition with the forceful introduction of the United States to the rank of great-power status after the defeat of Spain in the Caribbean and the Philippines. The presence of the United States, and its newfound active role in the American continent as a whole, opened the door to regional conferences (“conferencias panamericanas"), which established a more regular schedule for the meetings and counted on the moral prestige and material support of the United States to create - for the first time - a permanent organizational framework to regulate peace and security in the continent, and to foster economic exchange and commerce among American countries.

Third, when members of the society of states go through a qualitative change in how they come to perceive the interconnectedness of their own individual national interests and the interests of the regional system/society, they also develop a sensibility towards the limitation of their behavior (inter se) through the progressive abandonment of policies of

\footnotetext{
${ }^{196}$ Since this study covers only the origins and evolution of South America's international society, it only covers a portion of the history of South America's long peace, and thus does not come to study the role that the OAS has played, and continues to play, in the maintenance of regional order. The study of these and other factors will have to wait a future second volume to complete the history of the "origins" and "evolution" with its "consolidation."
} 
"strict neutrality" and detachment when regional instances of war or foreign invasion, or other types of regional threats, disturb their shared regional order. Typical predatory behavior, such as the ones exercised in Europe (Nazi Germany) and East Asia (Imperial Japan) in the first half of the 20th century, which are normal in a system of states, is replaced in a society of states by "pragmatic solidarism." That is: a sense of solidarity towards other members of the same society of states that is based not on altruistic, ideological, cultural, or selfless behavior, but on a pragmatic view of the longer-term interests and values of each individual country in relation to the whole - that is, by the appreciation of the interconnections between the logics of raison d'état and of raison of système.

In the case studies presented in Chapters $2-5$, the argument is tested against the empirical record during the four largest armed conflicts ever to take place in the region, as well as against a set of competing hypotheses and causal mechanisms. It is important that proper attention is paid to how these other approaches present alternative possibilities for achieving the same outcome: regional "long peace." It is necessary to look into at these approaches both in general and in concrete form in South America through potentially similar paths and causal mechanisms that each of them hypothesizes. This is also relevant to control for the twin dangers of equifinality and confirmation-bias present in any historical argument analyzed through the process-tracing method. 
(H2) The United States as a Hegemonic Stabilizer

The idea that peace and stability can be produced by the presence of a preponderant power is a well-known argument in the fields of IR and political science. ${ }^{197}$ In the field of international economics, ${ }^{198}$ so-called Hegemonic Stability Theory (HST) became widely applied to the study of international order in world politics towards the late 1970s and early 1980s, as the United States' own hegemony was faced also with the prospects of its own eventual decline. ${ }^{199}$ Its main argument is premised on the Hobbesian idea that "anarchy" creates severe obstacles to meaningful and long-lasting cooperation among self-interested actors, such as states, who just like Rousseau's stag hunters, face conflicting incentives that push them away from achieving meaningful cooperation towards common and mutually beneficial goals. Facing such obstacles, cooperation under conditions of anarchy is considered weak and feeble, and is expected to have a rather short life. ${ }^{200}$

\footnotetext{
${ }^{197}$ The classical statement was offered by Hobbes, Leviathan, who provided a philosophical argument in defense of the need for a strong, centralized power to create and maintain political order. For a recent reinterpretation of the same logic, but applied to international relations, see G. John Ikenberry, Liberal Leviathan (Princeton University Press, 2011).

${ }^{198}$ See Robert O. Gilpin, "The Rise of American Hegemony," in Two Hegemonies: Britain 1846-1914 and the United States 1941-2001, ed. by Patrick K. O'Brien and Armand Clesse (Ashgate, 2002), pp. 165-182.

${ }^{199}$ For the original argument of the stabilizing role of a hegemonic power in the field of international economics, see Charles P. Kindleberger, The World in Depression, 1929-1939 (University of California Press, 1973). For a later refinement, see Kindleberger, "Dominance and Leadership in the International Economy: Exploitation, Public Goods, and Free Rides," International Studies Quarterly, Vol. 25, No. 2 (June, 1981), pp. 242-254. See also John A. C. Conybeare, "Public Goods, Prisoner's Dilemmas, and the International Political Economy," International Studies Quarterly, Vol. 28, No. 1 (March, 1984), pp. 5-22; Barry Eichengreen, "Hegemonic Stability Theories of the International Monetary System," in Can Nations Agree? Issues in International Economic Cooperation, ed. by Richard N. Cooper, et al. (The Brookings Institution, 1989), pp. 255-298; Robert Pahre, Leading Questions: How Hegemony Affects International Political Economy (The University of Michigan Press, 1999).

${ }^{200}$ Robert Keohane coined the term "hegemonic stability theory" seven years after Kindleberger first put forth the original idea, and also included Gilpin's and Krasner's formulations as part of the same theory. See Robert O. Keohane, "The Theory of Hegemonic Stability and Changes in International Economic Regimes, 1967-1977," in Change in the International System, ed. by Ole R. Holsti, Randolph M. Siverson and Alexander L. George (Westview Press, 1980), pp. 131-162; Keohane, After Hegemony: Cooperation and Discord in the World Political Economy (Princeton University Press, 1984), esp. ch. 3. See also Robert G. Gilpin, U.S. Power and the Multinational Corporation (Basic Books, 1975); Gilpin, War and Change in
} 
In the presence of a central hegemonic power, however, international cooperation both in economic and security terms is expected to thrive as the hegemon can take up the role of "leader." A hegemon or leader can thus provide certain key services and fulfill specific roles and functions that no other individual state has either the capacity or the right incentives to serve otherwise. ${ }^{201}$ In sum, a hegemonic leader can create peace and stability by helping overcome the "free-rider" and the "collective action" problems, while also acting as "lender of last resort" in cases where the financial system is at risk of collapsing. As David Lake clarifies, "Kindleberger's contribution is merely to extend these functions to the international economy and to remind us that none of the attributes of international stability exist naturally or of their own accord. Rather, they must be created and actively maintained." ${ }^{202}$

Although theories of hegemonic stability come in different colors and sizes, ranging from Realist to Liberal interpretations and applications to international politics, at the very core they all uphold at least two basic ideas: first, that a stable and open international system is best served by the active presence of a hegemon; and second, that once

World Politics (Cambridge University Press, 1981); Gilpin, The Political Economy of International Relations (Princeton University Press, 1987); Stephen D. Krasner, "State Power and the Structure of International Trade," World Politics, Vol. 28, No. 3 (April, 1976) pp. 317-347.

${ }^{201}$ In concrete terms, there are four functions that need to be served by a hegemon to perform a stabilizing role: to provide a market for distress goods; to produce a steady, if not countercyclical, flow of capital; to maintain a rediscount mechanism for providing liquidity when the monetary system freezes in panic; and to provide a degree of coordination of domestic monetary policies.

${ }^{202}$ See David A. Lake, "Leadership, Hegemony, and the International Economy: Naked Emperor or Tattered Monarch with Potential?" International Studies Quarterly, Vol. 37, No. 4 (December, 1993), pp. 463. For other prominent revisions and critiques of HST, $c f$. Helen Milner, "International Political Economy: Beyond Hegemonic Stability," Foreign Policy, No. 110 (Spring, 1998), pp. 112-123; Joanne Gowa, "Rational Hegemons, Excludable Goods, and Small Groups: An Epitaph for Hegemonic Stability Theory?" World Politics, Vol. 41, No. 3 (April, 1989), pp. 307-324; Duncan Snidal, "The Limits of Hegemonic Stability Theory," International Organization, Vol. 39, No. 4 (Autumn, 1985), pp. 579-614; Michael C. Webb and Stephen D. Krasner, "Hegemonic Stability Theory: An Empirical Assessment," Review of International Studies, Vol. 15, No. 2 (April, 1989), pp. 183-198. 
established, the decline of the hegemon will generate systemic instability, increase economic fragmentation and heightened security competition. When applied to the field of IR, the HST argument becomes also a logical framework to understand periods of so-called "hegemonic power-transitions," in which the existing hegemon may be in decline in relation to one or a set of rising challengers. These periods are typically characterized by great tension and instability, and are often seen as the prelude to a major or systemic war. ${ }^{203}$

When applied to the regional level, and in particular to South America, the idea of a hegemonic stabilizer finds powerful resonance in the historic place that the United States has occupied in the Western Hemisphere. Since its independence in 1776, the United States has always cast a very large shadow over its sister American republics to the south—and in particular, over those in the Caribbean and Central America. Its federal constitution and Republican type of government influenced since early age how other Latin American governments framed their own legal and political systems. In the early 19th century, moreover, exactly as the wave of revolutionary wars was coming to a successful end in most of the continent, the United States announced specific foreign policy doctrines—such as the Monroe Doctrine - that further earned the admiration and respect of the different governments looking not just for international legal recognition — which the United States

\footnotetext{
${ }^{203}$ See Gilpin, War and Change; Paul M. Kennedy, The Rise and Fall of the Great Powers (Random House, 1981); Abramo F. K. Organski, World Politics (Alfred Knopf, 2nd ed., [1958] 1968); Abramo F. K. Organski and Jacek Kugler, The War Ledger (The University of Chicago Press, 1980) Ronald L. Tammen, ed., Power Transitions: Strategies for the 21st Century (CQ Press, 2000). For an important critique, cf. Charles Kupchan; Emmanuel Adler; Jean-Marc Coicaud and Yuen Foong Khong, Power in Transition: The Peaceful Change of International Order (United Nations University Press, 2001).
} 
was quick to grant—-but also a sense of protection from expected European monarchical encroachments on their newly acquired sovereign status. ${ }^{204}$

The hegemonic-stabilizer argument, therefore, can generate important predictions and insights into the potential role of the United States as a "leader" in the Americas, which by wielding its preponderant power can secure order and peace in the continent. The premise is that it can intervene, pressure, or even coerce militarily its weaker neighbors to the south whenever they threaten one another, the regional system itself, or the entire hemispheric balance. Equally, a hegemon can "inoculate" the entire region from foreign intervention and imperialism, removing additional sources of instability and threat for each individual regional state. The precise ways in which this "pacification from above" can occur range from mere diplomatic pressure and de-legitimization of certain actors, to the offering of mediation and "good offices" (buenos oficios) to conflicting parties. It can even further use (or threaten to use) force against one or all of the conflicting parties in order to catalyze a final solution to a dispute. The interests of a hegemon for peace, however, as could well be the case of the United States in the Americas, cannot be always taken for granted.

\footnotetext{
${ }^{204}$ There are many excellent studies of the early history of the United-States-Latin America early international relations. For two excellent brief surveys, see James Dunkerley, "The United States and Latin America in the Long Run (1800-1945)," in The United States and Latin America: The New Agenda, ed. by Victor Bulmer-Thomas and James Dunkerley (Harvard University Press, 1999), pp. 3-31; and Dunkerley, "U.S. Foreign Policy in Latin America," in U.S. Foreign Policy, ed. by Michael Cox and Doug Stokes (Oxford University Press, 2008), pp. 292-314. For a classic study of the determinants of U.S. foreign policy during the early decades of the 19th century towards Latin America, see John J. Johnson, A Hemisphere Apart: The Foundations of United States Policy towards Latin America (The Johns Hopkins University Press, 1990); and Thomas R. Shurbutt, ed., United States-Latin American Relations, 18001850: The Formative Generations (University of Alabama Press, 1991). For a good study of the tensions between British and U.S. policies towards the region, see Joseph Smith, Illusions of Conflict: AngloAmerican Diplomacy toward Latin America, 1865-1896 (University of Pittsburg Press, 1979). Another good study focused mostly on the 20th century is Peter H. Smith, Talons of the Eagle: Latin America, the United States, and the World (Oxford University Press, 3rd ed., [1996] 2008).
} 
Although there are powerful incentives for a preponderant power to keep its own regional neighborhood in order, as laid out by the HST proposition, it is important to note that at times hegemons can also become more detached, or simply come to think they can benefit from not acting as a referee of last resort in the provision of order. When, for whatever reasons - be they domestic politics, ideological, or otherwise - a hegemon acts in a detached and isolated way, then the predictions derived from the argument are that conflict will rise in the region, leading potentially to more wars which may undermine any sense of "long peace" or stability among states. In such situations, both the frequency of war, as well as the intensity of the rivalries and the actual fighting, are expected to grow. ${ }^{205}$ In this context, it is expected that in moments of strategic retrenchment by the United States from the international relations of the continent, South American inter-state power competition will intensify, leading to diplomatic and territorial disputes, and potentially more frequent and intense war.

In light of the main argument offered here, about the positive impact of a regional society of states in South America, the hegemonic-stabilizer argument offers a powerful alternative for understanding whether the taming of war, the growth in institutionalization, and the eventual pragmatic solidarity among states correlate better with the idea of a society of states in the region, or whether these emanate from the overseeing presence of the United States as an arbiter and regulator of conflict in the region. Firstly, limited war in South

\footnotetext{
${ }^{205}$ This is the argument, for example, in Michael C. Desch, "Why Latin America May Miss the Cold War," in International Security and Democracy: Latin America and the Caribbean in the Post-Cold War Era, ed. by Jorge I. Domínguez (University of Pittsburgh Press, 1998), pp. 245-265; Ahsan I. Butt, "Anarchy and Hierarchy in International Relations: Examining South America's War-Prone Decade, 1932-41," International Organization, Vol. 67, No. 3 (Summer, 2013), pp. 575-607; and Martin Sicker, The Geopolitics of Security in the America: Hemispheric Denial from Monroe to Clinton (Praeger, 2002).
} 
America could (in theory) also be the result of the pressure exercised by the United States over the South American governments - this is particularly important, for example, for the periods when military rule was the norm in the region (particularly post-1930s). Secondly, the rise in institutionalization transcends the scope of South America alone, as became a feature of the entire continent after 1948. The United States has played a crucial role in further formalizing into multilateral organizations (like the OAS) the multiple pre-existing institutions that had governed and given a sense of stability to South American international relations during most of the 19th century. ${ }^{206}$

After the isolationist hiatus produced by the Civil War in the 1860s, the United States embarked on a new, more active, foreign policy towards the Americas. ${ }^{207}$ In the course of the second-half of the 19th century, therefore, the United States offered its mediation and tried to be actively involved in the peaceful resolution of every major armed conflict and diplomatic dispute in the continent—and particularly, in South America, where the major wars happened. Although it never participated in any of the "American congresses"-in part because its participation was largely unwanted by the South

\footnotetext{
${ }^{206}$ For a good historical analysis of the institutional component of U.S.-Latin American relations during the 19th and early 20th centuries, see J. Lloyd Mecham, The United States and Inter-American Security, 1889-1960 (University of Texas Press, 1965).

${ }^{207}$ For three classic studies of this phase in U.S. foreign policy towards the Americas, see Lars Schoultz, Beneath the United States: A History of U.S. Policy toward Latin America (Harvard University Press, 1998); Brian Loveman, No Higher Law: American Foreign Policy and the Western Hemisphere since 1776 (The University of North Carolina Press, 2010); and Smith, Talons of the Eagle. Of particular importance is Walter LaFeber's detailed study: The New Empire: An Interpretation of American Expansion, 1860-1989 (Cornell University Press, 1963). Both Schoultz and LaFeber are very critical of the "imperialistic," paternalistic and racist tones that U.S. foreign policy adopted between the 1860s and the 1930s - when the Good Neighbor Policy was finally implemented, thus changing the course towards the opposite direction. Other important studies in a similar line are David M. Pletcher The Awkward Years: American Foreign Relations under Garfield and Arthur (University of Missouri Press, 1975); Alice F. Tyler, The Foreign Policy of James G. Blaine (University of Minnesota Press, 1927); and Milton Plesur, America's Outward Thrust: Approaches to Foreign Affairs, 1865-1890 (Northern Illinois University Press, 1971).
} 
American states - the United States tried to foster economic, cultural, and socio-political ties with the South American nations, and was always an advocate of creating an "American system" addressing law, security, and economic aspects of inter-American relations.

It was during the 1860s, while the Civil War impeded a unified and coherent foreign policy towards the continent, that the French invasion and later occupation of Mexico occurred. It was also in this decade that two important conflicts erupted in South America - and the subject of Chapters 2 and 3-while the Spanish Empire briefly occupied the Dominican Republic after a short pro-Spanish domestic revolution took control over the country. This rise of conflictivity in the continent while the United States was going through its civil war contrast with the mark decline in conflictivity of later decades, particularly after the U.S. victory in its war against Spain in 1898. Between the 1890s and 1930s, however, it was the United States itself who became the center of criticism for its imperialistic foreign policy towards the Caribbean, Central America, and East Asia. With the changing of course in the 1930s, characterized by the "Good Neighbor Policy," a mix record emerged. While the United States was now willing to play a more active role in defense of hemispheric order, it could not prevent or stop three armed conflicts in the region: the Chaco War (1932-1935), and the Leticia (1932) and the Zarumilla-Marañón (1941) disputes. ${ }^{208}$

\footnotetext{
${ }^{208}$ See Bryce Wood, The United States and Latin America Wars, 1932-1942 (Columbia University Press. 1966); Wood, The Making of the Good Neighbor Policy (Norton, 1967); Wood, The Dismantling of the Good Neighbor Policy (University of Texas Press, 1985); Butt, "Anarchy and Hierarchy in International Relations."
} 
In each of the case studies (Chapters 2-5), the hegemonic-stabilizing role of the United States is contrasted with the international society approach to uncover the actual way in which the causal mechanisms identified in FIGURE 1 are connected to one another, moving the argument forward towards the outcome of a "long peace."

\section{(H3) A Regional "Balance of Power"}

An alternative approach is the exact opposite of the hegemonic-stabilizer argument. The idea of a regional "balance of power" suggests that a long peace can be produced "from below." Although the term balance of power has been used to explain many different situations, and has therefore adopted multiple meanings over time, the most common use in IR, political science, and history is that of "a rough equilibrium of forces." ${ }^{209}$ In this context, the concept stipulates that order and stability are better served when there is an equilibrium of forces between competing states-and not when one of them is preponderant. It is important to distinguish, however, between two main understandings that are often present in the literature, and which are critically important for the present study.

One is the Neorealist conception of balance of power as an "outcome," which is the unintended result of the competing actors' relentless search for security and power. ${ }^{210}$ This is the view commonly identified with Kenneth Waltz and his classical study Theory of International Politics, and later extended by John J. Mearsheimer in The Tragedy of Great

\footnotetext{
${ }^{209}$ On the multiple meanings that the notion of the balance of power has adopted over the years, see Ernst B. Haas, "The Balance of Power: Prescription, Concept, or Propaganda," World Politics, Vol. 5, No. 4 (July, 1953), pp. 442-477.

${ }^{210}$ The most iconic work in this line is, perhaps, Morgenthau, Politics among Nations.
} 
Power Politics. The balance of power, in the Neorealist view, is a fragile mechanism by which the great powers can maintain a semblance of order based on the protection of each other's autonomy and independence. This notion of the balance of power, however, should not be confused with the notion of "concert." 211 Peace, in this view, is only a secondary concern, since oftentimes the balance of power requires the use of force by one or several powers to counter-balance the effects of a rising threatening state. Given that this is viewed as a semi-automatic mechanism, Neorealists expect a balance of power (or equilibrium) to emerge overtime independently of the actors' intentions, designs, ideology, or internal arrangements. It is the international structure of power which will eventually "push and shove" states to conform to a pattern of behavior that will diffuse any concentration of power inter se, and thus perpetuate the anarchical condition of international politics. ${ }^{212}$ The process is commonly described as one in which relatively weaker powers will either coalesce against a common threatening power, or develop enough internal capabilities to shorten the power gap between them and the threatening power/s. ${ }^{213}$

Another way of conceptualizing the balance of power, however, is to treat it not as an outcome, but as an "idea." Contrary to the Neorealist interpretation, the idea of the balance of power can only have concrete observable effects when those individuals who

\footnotetext{
${ }^{211}$ For a Realist take on the notion of "concert" and its differentiation from the "balance of power," see Robert Jervis, "From Balance to Concert: A Study of International Security Cooperation," World Politics, Vol. 38, No. 1 (October, 1985), pp. 58-79; and Jervis, "A Political Science Perspective on the Balance of Power and the Concert," The American Historical Review, Vol. 97, No. 3 (June, 1992), pp. 716-724. See also Richard Little, The Balance of Power in International Relations: Metaphors, Myths and Models (Cambridge University Press, 2007).

${ }^{212}$ See Waltz, Theory of International Politics.

${ }^{213}$ This is what Waltz calls "external" and "internal" balancing strategies, respectively. External balancing will take the form of formal military alliances, while internal balancing that of emulation of the most successful strategies and organization in the system.
} 
make decisions in the name of the state, or other political groups, think in terms of the balance of power. ${ }^{214}$ This implies that the achievement of a rough equilibrium of power among states can (or cannot) form depending on whether the decision-makers hold some notion of the balance of power in their heads. In this view, balances of powers may fail to form (i.e., to become "outcomes") not because of military or strategic underperformance, or the failure to perceive a common threat, ${ }^{215}$ but simply because the idea of a balance of power may not have played a role at all in how states conceived their strategic options in a given environment. ${ }^{216}$

The international society approach holds a view of the balance of power closer to the latter interpretation and, therefore, treats the notion of a balance of power not only as an idea but also as an institution (that is, as a patterned and sustained practice). From this vantage point, a balance of power can be expected to form only when states share common notions, principles and values conducive to the practice and perpetuation of a balance or equilibrium of power among one another. Hedley Bull, for example, identifies two main contrasting views of the balance of power which roughly correspond with the distinction made above: one which sees it as a "fortuitous," and another which sees it as a "contrived," institution. A fortuitous balance of power "arises without any conscious effort on the part

\footnotetext{
${ }^{214}$ For this conception of the balance of power, see Wight, "The Balance of Power"; and Butterfield, "The Balance of Power," both in Butterfield and Wight, Diplomatic Investigations. See also Bull, The Anarchical Society, pp. 103-106.

${ }^{215}$ This is the view, for example, in Randall L. Schweller, Unanswered Threats: Political Constraints on the Balance of Power (Princeton University Press, 2006), which presents a theory of "under-balancing"; and in Fareed Zakaria, From Wealth to Power: The Unusual Origins of America's World Role (Princeton University Press, 1998), which presents a theory of domestic constraints that may produce a strategic "lag" in how a state perceives and takes advantage of the opportunities presented by the international context.

${ }^{216}$ On these type of "failures," see, for example, Stuart J. Kaufman, Richard Little and William C. Wohlforth, eds., The Balance of Power in World History (Palgrave, 2007).
} 
of either of the parties to bring it into being." A contrived one, on the other hand, "owes its existence at least partly to the conscious policies of one or both sides."217

In the context of the South America experience after independence, the present study evaluates the first notion of the balance of power (as an "outcome") as an alternative argument, given that the second notion is already contemplated within the international society approach as part of the central hypothesis (H1). The contrast between these two contending conceptions of the balance of power, however, is extremely important for the empirical tests and the final evaluation of the strength and validity of each separate competing argument in the historical case studies. In the Neorealist view, states are expected to clash with one another over access and control of scarce resources, as well as over security and power considerations. Although more or less offensively inclined, depending on whether the state vies for "security" (Waltz) or "power" (Mearsheimer), the common expectation is for power politics to develop according to distinctively fierce competitive and largely opportunistic behavior. As part of this "mechanistic" and "automatic" understanding of the balance of power as an outcome, moreover, states will engage in strategic alliances only when in need of confronting a common threatening power. Since this type of behavior also bears resemblance to the "pragmatic solidarity" identified in the international society approach, a clarification is in order.

The main difference between a Neorealist understanding of alliances and the international society approach's understanding of solidarism is that alliances are expressions of military solidarity that are premised on immediate security threats, and

${ }^{217}$ See Bull, The Anarchical Society, p. 104. 
which will end as soon as the "common enemy" is placated or defeated. ${ }^{218}$ In this logic, as well, military alliances are merely tactical associations that are short-lived, fluent and dynamic by definition. On the contrary, the international society interpretation alludes to a type of solidarism that goes beyond the mere military realm, touching on the issue of legitimacy, institutionalization and regional identity. In this other view, therefore, states' "pragmatic solidarity" cannot be short-lived because geography plays an important constraining role framing regional dynamics within a confined (regional) geopolitical space. In short, unlike in multilateral alliances which can form among diverse actors and across different regions of the world, the type of pragmatic solidarisms expected among members of a regional "society of states" has a distinctively limited and rigid dynamic, shaped by proximity, and shared interests and value considerations. The regional factor, and the actors' strategic awareness of it, thus plays a crucial role in the creation of rather stable patterns of limited rivalry and competition along predictable lines over time. In the international society perspective, although these rivalries and patterns cannot be mechanically predicted a priori, once historically set in motion they can be assessed according to the region's own dynamics.

\section{(H4) South American Geopolitics}

An alternative hypothesis points to the distinctive role of geopolitics in South America and its impact upon patterns of war and peace in the region. In this view, extremely popular

\footnotetext{
${ }^{218}$ For a view of alliances as instruments of the balance of power, see Stephen M. Walt, The Origin of Alliances (Cornell University Press, 1987); Glenn Snyder, Alliance Politics (Cornell University Press, 1997); and Waltz, Theory of International Politics. Cf. Ole R. Holsti, P. Terrence Hopmann and John D. Sullivan, eds., Unity and Desintegration in International Alliances: Comparative Studies (John Wiley \& Sons, 1973), esp. pp. 31-39.
} 
between the 1890s and the early 1980s, the peculiarities of the region's topography are the main reasons behind the South American "long peace." As David McIntyre concluded in his doctoral dissertation, "South America has been so peaceful because its geography deters war. The states do not seek to conquer one another because geographic factors of terrain, transportation, and depth discourage attempts to conquer other states." ${ }^{219}$ Philip Kelly, for his part, also attributes the "peaceful" nature of the region to its insulated and compartmentalized geopolitics:

Checkerboards and shatterbelts have formed the basic structure of South American geopolitics since colonial times [...]. The predominant checkerboard kept the continent's geopolitics largely focused inwardly on frontiers, resources and development, and the prevention of two-front wars and an escalation of conflict. There are no longer any shatterbelts in South America, but they have left [it] divided, isolated, and dependent on foreign resources and technology. ${ }^{220}$

For Jack Child, who has studied the geopolitics of the region as well as the "geopolitical thinking" of the South American militaries, there are other factors beyond the mere topography (i.e., its vast territories, strategically unsurmountable obstacles like the Andes, the Amazon jungle, or scorching deserts) that play a role in explaining the region's peculiar international relations. Other factors, such as the colonial legacy of the placement of the capital cities - far away from territorial borders and sources of dispute - and the type of socio-economic models of development geared towards resource-extraction and exportation to world markets, also help explain the peaceful disposition of the South

\footnotetext{
${ }^{219}$ McIntyre, “The Longest Peace," p. 167.

${ }^{220}$ Philip Kelly, Checkerboards and Shatterbelts: The Geopolitics of South America (University of Texas Press, 1997), p. 209.
} 
American states inter se. ${ }^{221}$ Child's list of factors nevertheless remains within the "hardware" type of explanations, centered on material state capacities and tangible geographic obstacles preventing or limiting conflict.

In this competing hypothesis, the main theoretical expectation is to find that states in 19th-century South America, after trying to wage European-style war on each other, over time found it strategically unsound and counterproductive, if not outright impossible, to sustain. The progressive "taming" of war, therefore, would be expected to come not from the formation of a raison de système and the consolidation of a regional "society of states" over time, but from the material incapacity to overcome real physical and space-related obstacles. War, in this view, would be impractical and thus its decline in frequency and intensity would a logical conclusion for states and its decision-makers.

The factor of the institutionalization of order would also be expected to emerge as a result of the common necessity to redefine, consolidate and police the vast spaces separating each individual state, together with their extended large borders. Absence the traditional option of war as an instrument to solve disputes, as in most of the European history, South American states_-presumably_would have no other real choice but to play out their differences in institutional and organizational-bureaucratic fora. This would help explain, at least in part, the record-high number of instances of arbitration and mediation to solve disputes in a region famous for its otherwise peaceful international relations. ${ }^{222}$

${ }^{221}$ See Jack Child, Geopolitics and Conflict in South America: Quarrels among Neighbors (Praeger, 1985), pp. 5-6, 8-10; and Child, "Interstate Relations in Latin America."

${ }^{222}$ See Kacowicz, The Impact of Norms in International Society; and Domínguez, "Boundary Disputes in Latin America." 
Lastly, the factor of pragmatic solidarity would be explained through two main developments. On one hand, the geopolitical argument suggests the necessity to maintain stable intra-regional relations in order to be able to perform well on the external commercial front - as producers of strategic primacy products to Europe, the United States and (later) Asia. On the other hand, since this is a shared condition of all the South American countries, competition for markets abroad would make more sense than costly inter-state war in the region. Viewed in this framework, therefore, the long South American peace would be the product of the type of geopolitical outlook of the region and its related way of development under the aegis (or tyranny?) of a logic of world markets that creates further incentives not to fight wars among neighbors, but to collectively focus on internal peace through an embryonic model of export-oriented development.

Unlike other trade-related hypotheses-some of them analyze below-the geopolitical argument is carries severe deterministic overtones that cannot be ignored. Contrary to similar-sounding arguments, the geopolitical thesis finds in the unique topographical outlook of the region the main source of both the patterns of (no-)war and peace in the region, as well as the nature of South America's economic and commercial place in a larger world market. The main problem with such deterministic and linear arguments is that other factors, such as technology, which can dramatically alter the ways in which geography affects politico-economic relations among states, is never given due attention in this debate. The clearest example of the a priori limitations of this perspective can be seen when trying to account for the decline in war and its intensity before and after the 1930s. If the South American geography has remained essentially the same over several millennia, then what explains the rapid change towards peace? Absence supplementary 
factors like technology, or knowledge/information, the strictly geopolitical arguments can offer limited assistance in solving the South American puzzle.

\section{(H5) A Common Culture of Anti-Imperialism}

One of the most popular views regarding the history of Latin America is the idea that all its "nations" formed a "family of nations" which was subsequently fragmented by the workings of foreign interests and ideologies. ${ }^{223}$ In this view, the struggles for independence gave birth to one single Latin-American nation that shared similar Americanist interests and formed a collective identity. This identity is thus premised on the fact that most peoples in the continent have always had similar ideological aspirations - such as freedom and equality—as well as a strong sense of belonging to the "New World." This general perspective early on also included the United States, whose foreign policy doctrines and Republican type of government were either praised, admired or imitated throughout the continent in the 19th century. Most importantly, a common history of emancipation from the Spanish and Portuguese empires left cultural legacies that shaped how Latin Americans came to perceive and define their own collective identity and place in the world. Some of these legacies, for example, relate to a common—or similar—language, religion, ethnic, and socio-economic associations.

Exploited by foreign capital, so the argument goes, armed conflicts (both civil and international) are explained mainly by the interference of extra-regional interests who, like Machiavelli advised to his prince, were taken advantage though classical divide et imperia

\footnotetext{
${ }^{223}$ For two prominent examples of this view, see Jorge A. Ramos, Historia de la nación latinoamericana (Buenos Aires: Peña Lillo, 2011); and Eduardo Galeano, Las venas abiertas de América Latina (Buenos Aires: Siglo XXI, 26th ed., [1971] 2006).
} 
tactics. In this light, therefore, the war against Spain after its seizure of the Peruvian Chincha islands showcases the last attempt by the former "Motherland" to recuperate prestige and effective possessions in the American continent. The solidarity displayed by Chile, Ecuador and Bolivia towards Peru, in this case, responds to the power of those primordial sentiments of Americanism first sparked by the process of emancipation in 1810. An underlying, and pre-existing, common culture-and not merely tactical selfinterested power calculations - are said to explain why states "ally" with one another against the "imperialism" of great powers, such as Spain, France, England, or even the United States.

The War of the Triple Alliance, which took place almost simultaneously with the war against Spain, also showcases the interplay between a common regional culture and the workings of imperialism. In this case, the argument is that collaborating elites can also replicate regionally — and do the "dirty work" for the extra-regional powers - the same patterns of imperialism practiced abroad by European powers. Thus, advocates of this view, see in the war against Paraguay a form of intra-peripherical imperialism carried out by the Brazilian Empire, with the connivance of Argentina and the Banda Oriental (modern day Uruguay). ${ }^{224}$

In the case of the War of the Pacific, a similar argument is presented. The foreign commercial interests of the European great powers, such as England and France, are seen

\footnotetext{
${ }^{224}$ For exemplary works in this light, see León Pomer, La guerra del Paraguay: Estado, política y negocios (Buenos Aires: Colihue, 3rd ed., [1968] 2008); Julio J. Chiavenatto, Genocídio americano: A guerra do Paraguai (São Paulo: Brasiliense, 1979); José M. Rosa, La guerra del Paraguay y las montoneras argentinas (Buenos Aires: Punto de Encuentro, [1973] 2008); and Galeano, Las venas abiertas de América Latina. For two well-documented critiques of these (still) widely popular views, $c f$. Thomas L. Whigham, La guerra de la Triple Alianza (Asunción: Taurus, 2010-2012), 3 vols.; and Francisco Doratioto, Maldita guerra: Nova história da guerra do Paraguai (São Paulo: Companhia Das Letras, 2nd ed., [2002] 2015).
} 
as part of a larger semi-conspiracy towards war in the South Pacific_-pitting Chile against Peru and Bolivia over the resource-rich areas of the Atacama and Antofagasta deserts, where guano, salt peter, and other strategic minerals were spread across the shared borders of these three nations. ${ }^{225}$ On the Chaco War, the argument specifically points fingers at two international oil companies: the Standard Oil Co. (U.S.A.), and the Schell Co. (The Netherlands). These companies, so the argument goes, pushed the respective governments of Bolivia and Paraguay to consider the Chaco Boreal region as a potentially oil-rich area of exploitation. Continuing with the colonial, and then post-independence, narrative of a dependent relationship between servile export-oriented economies and foreign powers, authors like Chiavenatto and Ortega see the Chaco War as only the latest example of the armed violence in South America that is provoked by the forces of imperialism - and intraperipheral imperialism. ${ }^{226}$

In each of these important conflicts, the common-culture/anti-imperialism hypothesis expects all cases of solidarism, collaboration, or alliances, to come from a feeling of (Latin) Americanism among the "peoples" of the continent against the extra-

\footnotetext{
${ }^{225}$ See, e.g., Heraclio Bonilla, Guano y burgesía en el Perú (Lima: FLACso, 3rd ed., [1974] 1994); Bonilla, Un siglo a la deriva: Ensayos sobre el Perú, Bolivia y la guerra (Lima: Instituto de Estudios Peruanos, 1980); Luis Ortega, "En torno a los orígenes de la guerra del Pacífico: Una visión desde la historia económica y social," Asian Journal of Latin American Studies, Vol. 19, No. 4 (2006), pp. 27-58; Ortega, "Nitrates, Chilean Entrepreneurs and the Origins of the War of the Pacific," Journal of Latin American Studies, Vol. 16, No. 2 (November, 1984), pp. 337-380; and Enrique Amayo, La política británica en la guerra del Pacífico (Lima: Horizonte, 1988). For a critical perspective of these interpretations, employing a wide arrange of primary sources, $c f$. William F. Sater, Chile and the War of the Pacific (University of Nebraska Press, 1986); Roberto Querejazu Calvo, Guano, salitre, sangre: Historia de la guerra del Pacífico (La Paz: GUM, 3rd ed., [1979] 1998); Querejazu Calvo, Bolivia y los ingleses (1825-1948) (La Paz: Los Amigos del Libro, 1973); and Querejazu Calvo, Aclaraciones históricas sobre la guerra del Pacífico (La Paz: Juventud, 1995).

${ }^{226}$ Julio J. Chiavenatto, A guerra do Chaco (leia-se petróleo) (São Paulo: Brasiliense, 1980). Cf. Roberto Querejazu Calvo, Masamaclay: Historia política, diplomática y militar de la guerra del Chaco (La Paz: GUM, 4th ed., [1965] 2008); and Querejazu Calvo, Aclaraciones históricas sobre la guerra del Chaco (La Paz: Juventud, 1995).
} 
regional forces of imperialism and economic domination. The cases of competition and strife, on the contrary, are blamed on the intermittent success of those anti-American forces, which instill mistrust, enmity, and push towards intra-regional competition among the otherwise peacefully-inclined nations of the continent. This particular type of "solidarism" emanating from feelings of common-culture, when triumphant, would logically lead to deepening levels of institutionalization and organization on a regional scale.

Lastly, the issue of war, in this view, however, is not simply to "tame" or curb collective violence, but to eradicate it as a whole. Contrary to the international society approach, therefore, which treats the use of limited force as an instrument for the preservation of order, the common-culture/anti-imperialism approach would interpret the three causal mechanisms identified in FIGURE 1 as spitting stones towards a further integration of the Latin American countries into a whole continental "nation"- as it is said it was in the very beginning.

\section{(H6) State-Strength and State-Weakness}

One of the strongest alternative hypotheses suggested for the long South American peace is that related to the relative (in)capacity of the state to fight large-scale wars. There two central views on this issue: The first position, associates the "strength" of a state to its level of autonomy vis-à-vis its own society. That is, it focuses on the level of elite cohesion and their capacity to make decisions relatively "free" from political, economic and ideological 
constraints from the society over which they preside. ${ }^{227}$ The second position, and the one that has made the largest contribution to the long peace debate, measures the "strength" or "weakness" of a state by its capacity to extract resources from its society, mobilize its population, and reorganize its internal institutions in light of external threats, challenges, or concrete strategic objectives presented by the regional or international environment. ${ }^{228}$

Given their contrasting focuses, the arguments from the two positions regarding the potential for long peace in the region generate different expectations. ${ }^{229}$ Proponents of the first view, like Holsti, expect that it in the presence of "weak" states the region will become more prone to (inter-state) war. The inability of governments to contain internal conflicts would inevitably lead to "spill-over" effects that would drag in neighboring or even extraregional actors into the internal conflict. This, in time, acts "by contagion" making what was originally a localized and limited armed conflict into a regional, generalized war. ${ }^{230}$ When applied to South America, this view seems to perform well when trying to explain the prevalence of international conflict in the 19th century, when states were at their weakest. The argument, however, is less clear when applied to the 20th century, given that the extent of the state "strength" is contested by regional experts.

\footnotetext{
${ }^{227}$ For a good example of this position, see Michael Desch, "War and Strong States, Peace and Weak States?" International Organization, Vol. 50, No. 2 (Spring, 1996), pp. 237-268; and Holsti, The State, War, and the State of War.

${ }^{228}$ Examples of this second position are Centeno, Blood and Debt; and Thies, "War, Rivalry, and State Building in Latin America."

${ }^{229}$ For a discussion of the implications of both positions when applied to the case of South America's long peace, see Mares, "Making War to Make the State [review]," Georgetown Journal of International Affairs, Vol. 4, No. 1 (Winter/Spring, 2003), pp. 143-146; and Kacowicz, "Blood and Debt [review]," Estudios Interdisciplinarios de América Latina y el Caribe, Vol. 15, No. 2 (julio-diciembre, 2004), pp. 214-216.

${ }^{230}$ See Holsti, The State, War, and the State of War, passim, but esp. pp. 126ff.
} 
Proponents of the second view, on the contrary, defend the opposite argument. It is when states are stronger that a region becomes more stable and war declines in both frequency and intensity. For scholars like Centeno, for example, the weakness of the Latin American state helps account for all the "paradoxes" of the long peace. First, it explains the prevalence of limited war in general-including the limited character of most 19th century wars. Second, the continued weakness of the state in the 20th century also helps understand the endurance of the region's long peace. ${ }^{231}$ While scholars like Holsti would expect less conflict in South America, as the region moves from the 19th to the 20th century - under the assumption that the state became stronger - in Centeno's view, the state has remained fundamentally weak vis-à-vis the technological changes affecting the capacities and efficiency of the modern Latin American state.

A related perspective, offered by Benjamin Miller, overlaps on this issue. For Miller, the key factor explaining the relative war- or peace-proneness of a region is what he calls the "state-to-nation balance."232 This balance is defined as the level of congruence between a state's territory and its ethno-national identity. In this view, a state is strong when there is high congruence in the state-to-nation ratio, and weak when this balance is out of phase. When an entire region is populated by "strong" states in this sense, then stable peace ensues. When it is not, then chronic conflict and armed violence become the norm. ${ }^{233}$

\footnotetext{
${ }^{231}$ See Centeno, Blood and Debt, esp. pp. $262 \mathrm{ff}$.

${ }^{232}$ See Miller, States, Nations, and the Great Powers, esp. pp. 306-336.

${ }^{233}$ Miller offers as contrast for these two types of regions, on the one hand, South America, and the Middle East, on the other. Cf. Miller, States, Nations, and the Great Powers, pp. 129-255, 306-336. Miller also contemplates the level of involvement and intervention by extra-regional powers as modifiers or enhancers - although not as determiners — of these patterns of regional peace or conflict.
} 
The general perspective on the levels of state "strength" or "weakness," therefore, creates three specific expectations regarding the causal mechanisms identified by the international society approach. The limitation or "taming" of war would respond not to the evolution of a "societal" perspective among states, but to the institutional and bureaucratic incapacity of the state to wage and sustain a large-scale war against another state. In Centeno's view, the limited capacity of the typical Latin American state is one of the main factors that explain its limited capacity to engage in wars of the type experienced in Europe during its own state-formation period. In sum, all sources of restraint emanate from structural and institutional problems, yet not credit is given to other sources-such as the ones identified by the international society argument.

A second related expectation is that the progressive institutionalization of the region would be the result of the need of structurally weak — and indebted — peripheral states to compensate or scaffold their many deficiencies. In this view, South America's record-high level of multilateral agreements and regional organizations could be explained very well as an external legal-institutional architecture created and maintained to supplement the fragile regional peace created by the weakness of its states.

Finally, another expectation is that related to the prevalence of some form of solidarism among South American states. A logical conclusion from this competing argument is that "weak" states, when faced with a constraining international environment or context, will coalesce in semi-stable alliances, as well as in regional and international multilateral organizations, as a common protection for their shared condition. No "ideational" or "cultural" component is necessary in this explanation, as the focus remains centered on the (shared) condition of weakness of the region's state. Explanations such as 
these, for example, can help account for the cooperation among democracies (post-1980s) as much as that among authoritarian regimes (1930s-1980s) in Latin America. ${ }^{234}$

\section{(H7) A “Liberal Peace”}

A final contending approach is one most commonly known as the Kantian "triangulation of peace. ${ }^{235}$ In this view, three factors converge to produce stable or enduring peace. First, the presence of republican-democratic regimes in a region. ${ }^{236}$ Second, the prevalence of higher levels of economic interdependence, marked by free-trade economics and Liberal values. ${ }^{237}$ And third, the creation of multilateral institutions, regimes, or organisms, that promote and defend the first and second factors. ${ }^{238}$ The central argument put forth by Russett and Oneal integrates the traditional three hypotheses from the Liberal approach to IR, and further claims that these produce peace only when seen in interaction with one another-yet not separately. This "virtuous circle" between democracy, interdependence

\footnotetext{
${ }^{234}$ See, e.g., Martín, Militarist Peace in South America; Stanislav Andreski, "On the Peaceful Disposition of Military Dictatorships," Journal of Strategic Studies, Vol. 3, No. 3 (1980), pp. 3-10; and Walter Little, "Military Power in Latin America: An Overview," Working Paper No. 4 (University of Liverpool, Institute of Latin American Studies, 1986), pp. 1-91.

${ }^{235}$ The term was popularized by the landmark study of Russett and Oneal, Triangulating Peace.

${ }^{236}$ For prominent examples of this part of the triangle, see Doyle, "Kant, Liberal Legacies, and Foreign Affairs"; Russett, Grasping the Democratic Peace; and Russett and Oneal, Triangulating Peace, pp. 43124.

${ }^{237}$ On the contribution of free-trade and interdependence to the triangulation of peace, see the classical arguments by Keohane, After Hegemony; Robert O. Keohane and Joseph S. Nye, Power and Interdependence (Longman, 4th ed., [1977] 2011); and Russett and Oneal, Triangulating Peace, pp. 125 156.

${ }^{238}$ For this side of the argument, see Robert O. Keohane, International Institutions and State Power: Essays in International Relations Theory (Westview, 1989); Keohane, After Hegemony; and Russett and Oneal, Triangulating Peace, pp. 157-196.
} 
and institutions can thus be applied to the study of regional "zones of peace," where war becomes "unthinkable."239

When applied to the South American case, this integrated Liberal approach picks up and develops Immanuel Kant's framework, formulated more than two centuries ago, and argues that a regional stable peace can be expected when there is an interaction of a similar type of regime and Liberal values (such as democracy and republicanism), the growth of economic interdependence (free-trade), and the creation of regimes and institutions (such as political and economic multilateral organizations) on a regional scale. The first factor, has been a relevant issue since the early post-independence years for most South American nations. The elites who came to predominate in the newly independent states in the Americas soon established the republican type of government as the normeven if tolerating neighboring countries still governed by the monarchical type: i.e., the Brazilian Empire from 1822 to 1889 . Although authoritarian regimes were established across the region during most of the 20th century, peace prevailed. This period, however, created a stronger sense of commitment and appreciation for the virtues of Liberal values, like democracy, republican government, and wider social freedoms. Although these authoritarian regimes trumped several Liberal principles during their rule, it is worth mentioning that in many instances South American dictators and military juntas selfjustified their involvements in politics as a "protection" of the very Liberal and democratic values they were assaulting. Moreover, during their rule, authoritarian regimes were

${ }^{239}$ See Russett and Oneal, Triangulating Peace, pp. 9-42, 197-238; Kacowicz, Zones of Peace in the Third World, pp. 1-65, 177-207; and Kacowicz, Stable Peace Among Nations. 
fanatical adherents to the free-trade, or "capitalist," doctrine of international economic relations.

The second factor, that of economic interdependence, has always been a problematic proposition in Latin America. All Latin American nations, and particularly those of Central America and the Caribbean, have traditionally been net exporters of primary products with low levels of added value and industrialization. Most of these, in fact, being producers and exporters of one, or a limited few, strategic resources, like oil, gas or minerals. ${ }^{240}$ This situation has also characterized South America, although this region has had a somewhat more flexible set of options, with territorially larger countries with more diverse trade portfolios. But countries like Argentina, Brazil, or Uruguay, for example, have also had to face a common condition to all Latin American countries in the form of competition for markets abroad. Being the producers of relatively similar products for the most advanced industrial economies of the world, economic inter-dependence has been relatively low throughout most of the region's history. Put differently, foreign markets—not their neighbors - have been historically more important for commercial, financial, and developmental reasons. ${ }^{241}$ In this particular context, the economic interdependence side of the Liberal "triangle of peace" seems to be a priori affected by the proverbial peripheral and dependent integration of Latin America as a whole to the global dynamics of trade, growth and development—raising doubts about the validity or applicability of the Liberal argument to the case.

\footnotetext{
${ }^{240}$ See, e.g., Fernando H. Cardoso and Enzo Faletto, Dependency and Development in Latin America (University of California Press, 2nd ed., [1971] 1979).

${ }^{241}$ See Juan C. Puig, Integración latinoamericana y régimen internacional (Caracas: Universidad Simón Bolívar, 1987).
} 
The third factor, that of the role of international institutions and organizations, appears prima facie to have a sounder basis in South America's historical trajectory. This is due to two aspects: First, because the region stands high in the world rankings regarding the recourse to arbitration and mediation, as well as the creation, membership and regular use of international legal and institutional agreements to coordinate economic-, politicaland security-related policies. ${ }^{242}$ And second, specifically in the area of regional security, South American nations have developed since their very early existence as independent nations in the early 1800 s a set of then innovative practices-such as continental congresses and conferences - to face common problems of war and peace. In this process, South Americans became pioneers in several important areas, such as international law, institutional (regional) governance, and peaceful solution of disputes. ${ }^{243}$ These institutions, as Jorge Domínguez put it, developed through s process of "slow accretion," lacking "a crafting moment or a master architect."244

\footnotetext{
${ }^{242}$ See, e.g., Arie M. Kacowicz, "Compliance and Non-compliance with International Norms in Territorial Disputes: The Latin American Record of Arbitrations," in The Impact of International Law on International Cooperation: Theoretical Perspectives, ed. by Eyal Benvenisti and Moshe Hirsch (Cambridge University Press, 2004), pp. 194-215; Domínguez, "Boundary Disputes in Latin America"; Domínguez, "International Cooperation in Latin America"; and Kacowicz, The Impact of Norms in International Society.

${ }^{243}$ For an excellent view of the region's contributions to these fields, see Juan P. Scarfi, The Hidden History of International Law in the Americas: Empire and Legal Networks (Oxford University Press, 2017); Arnulf Becker Lorca, Mestizo International Law: A Global Intellectual History 1842-1933 (Cambridge University Press, 2014); Charles A. Jones, "Exile as an Institution of South American International Society, 1808-1881," paper presented at the III Global International Studies Conference of the World International Studies Committee, Porto, August 17-20, 2011, pp. 1-46; Jones, "Another American Social Science: International Relations in the Western Hemisphere," in Cooperation and Hegemony in U.S.-Latin American Relations: Revisiting the Western Hemisphere Idea, ed. by Juan P. Scarfi and Andrew R. Tillman (Palgrave, 2016), pp. 33-70; and Fernando Murillo Rivera. "La solidaridad americana en el pensamiento internacionalista de Andrés Bello," in Quinto Centenario, No. 10 (Madrid: Editorial Universidad Complutense, 1986), pp. 19-61.

${ }^{244}$ Domínguez, "International Cooperation in Latin America," p. 83.
} 
The "Liberal peace" argument, therefore, holds several promising areas for the South American long peace case. Its distinctive relation with multilateral regimes and institutions, together with the early association with republican and Liberal values, places the region in an ideal position to be analyzed through this approach. It is only the second "leg" of the triangle which raises some doubts and requires further elaboration. That is, the economic inter-dependence side of the argument is more problematic than what the Liberal argument seems to maintain. The peripheral condition of South America affects the relation neighboring states have towards one another-leading to more competition, rather than cooperation - as well as with the wider world-leading to similarly embryonic and dependent forms of externally-oriented development strategies. In the 19th century, in particular, the struggles for the consolidation of a centralized "national" government, and thus also a state, translated in a rise in internal violence and civil war, as diverging visions of socio-economic development clashed inter se: one Liberal, mercantile and "modernizing"; the other more conservative, aristocratic and federalist. Although Russett and Oneal maintain that the "triangulation" of these three factors leads to stable peace, and not the separate logics in isolation, this study will nevertheless test the applicability of the whole approach versus the historical case studies. In part, this is justified because several historians and regional experts continue to employ these arguments to study the regional peace, but also because the a priori applicability of two of the three factors of the triangle of peace seem to be very high in light of the history of the region.

Contrary to the international society argument, therefore, the Liberal approach to South America's long peace raises a series of distinctive expectations. One of them is that the "taming" of war would emanate not from the construction of a "society of states" in the 
region, but from the states' democratic and republican identities. These types of regimesand only this ones-will be expected to create a "democratic" society of states that will self-identify with the Liberal values so strongly that inter se will cancel all armed or violent forms of solving disputes. In this framework, war is expected to vanish and wither away, instead of simply remain limited or "tamed." The overlap with the common-culture argument, as with the international society one, are only apparent, however. In the first case, the common-culture argument goes beyond the mere similarities in regime typetouching on "deeper" issues of culture, language, and collective social identity. In this view, as well, any type of regime - as long as the region is populated with the same onecan produce meaningful cooperation and stable peace. The argument would also apply to other entities and social groups beyond simply "states." In the Liberal approach, however, stable peace can only form among republican democratic regimes, who will also further their institutional (international) political and economic relations through the protection of a free-trade international regime and Liberal multilateral organizations.

In the second case, beyond the already mentioned contrasts in regard to limited war and type of government, the international society approach envisions a society of states that in principle can form among a plurality of regimes - and not necessarily among democratic ones. While the Liberal view will tend towards the creation of a "zone of peace" in South America, and the common-culture/identity one towards a "security community," the international society argument holds a more practically minded and "realistic" view of an anarchical society where threats remain multidirectional and the use of force is limited yet never eradicated. Another distinctive difference is that in the international society approach, countries of different regime type can enter and maintain alliances and display 
pragmatic solidarity towards one another - such as in the case of Argentina and Uruguay with the Empire of Brazil during their war against Paraguay (1864-1870).

The progressive institutionalization of regional international relations, in turn, are expected to develop according to the Liberal criterion seeing "institutions" as facilitators of information, transparency, and thus also of meaningful cooperation among states. In this view, the 19th century remains somewhat of a puzzle, since only informal and nonpermanent forms of institutional cooperation took place. The argument, however, seems to gather strength when looking at the mid-20th century, when under the direction of a more assertive United States the region developed more permanent and regular meetings, which eventually led to the creation of the Organization of American States (OAS) in 1948. It was only in the late 20th century (1990s onwards) that other economic and trade-related regional projects materialized and the democratic type of regime became enshrined in the respective carta magna of every international institutional organizations. ${ }^{245}$ Part of the interesting challenge of studying 19th-century South America is, indeed, that the limitation of war, the institutionalization of order, and a sense of pragmatic solidarity developed in the absence of an overarching regional institutional architecture, such as that of the OAS.

To summarize the competing arguments, TABLE 4 offers a comparison of the main explanations according to: the main hypothesis proposed (why), the background conditions (when and whether), and the suggested causal mechanisms (how).

\footnotetext{
${ }^{245}$ See Jean-Michel Arrighi, La oEA y el derecho internacional (México DF: Porrúa, 2015); Arrighi, "The 'Democracy Clause' in the Americas," in The Limits of International Law: Essays in Honour of Joe Verhoeven (Brussels: Bruylant, 2015), pp. 223-236; Rubén M. Perina, "Los desafíos de la Carta Democrática Interamericana," Estudios Internacionales, Año 44, No. 173 (septiembre-diciembre, 2012), pp. 7-36.
} 
TABLE 4 - Comparison of Core Arguments

\begin{tabular}{|c|c|c|c|c|}
\hline Explanation & $\begin{array}{l}\text { Why? } \\
\text { (cause) }\end{array}$ & $\begin{array}{c}\text { Whether? } \\
\text { (background) }\end{array}$ & $\begin{array}{l}\text { When? } \\
\text { (trigger) }\end{array}$ & $\begin{array}{c}\text { How? } \\
\text { (mechanisms) }\end{array}$ \\
\hline $\begin{array}{c}(\mathrm{H} 1) \\
\text { Society } \\
\text { of States }\end{array}$ & $\begin{array}{l}\text { Common Interest } \\
\text { in Order } \\
\rightarrow \text { "Long Peace" }\end{array}$ & $\begin{array}{l}\text { Far-sighted elites } \\
\text { (raison de système) }\end{array}$ & $\begin{array}{c}\text { Strategic } \\
\text { Awakening }\end{array}$ & $\begin{array}{l}\text { 1. Taming of War } \\
\text { 2. Institutionalization } \\
\text { 3. Pragmatic Solidarity }\end{array}$ \\
\hline $\begin{array}{l}(\mathrm{H} 2) \\
\text { Hegemonic } \\
\text { Stability }\end{array}$ & $\begin{aligned} & \text { Hegemony } \\
\rightarrow & \text { "Long Peace" }\end{aligned}$ & $\begin{array}{l}\text { Preponderance } \\
\text { of Power }\end{array}$ & $\begin{array}{l}\text { Hegemonic } \\
\text { Willingness to } \\
\text { Lead }\end{array}$ & $\begin{array}{l}\text { 1. Suppression of War } \\
\text { 2. Institutional Tutelage } \\
\text { 3. Solidarity with the Hegemon }\end{array}$ \\
\hline $\begin{array}{l}(\mathrm{H} 3) \\
\text { Balance } \\
\text { of Power }\end{array}$ & $\begin{aligned} & \text { (Unintended) } \\
& \text { Equilibrium } \\
& \rightarrow \text { "Long Peace" }\end{aligned}$ & $\begin{array}{l}\text { Short-sighted elites } \\
\text { (raison d'état) }\end{array}$ & $\begin{array}{c}\text { Threats to State } \\
\text { Survival }\end{array}$ & $\begin{array}{l}\text { 1. War as Regulating Mech. } \\
\text { 2. Mutual Fear } \\
\text { 3. Dynamic Alliances }\end{array}$ \\
\hline $\begin{array}{c}(\mathrm{H} 4) \\
\text { Geopolitics }\end{array}$ & $\begin{array}{c}\text { Fixed or } \\
\text { Unchanging } \\
\text { Geography } \\
\rightarrow \text { "Long Peace" }\end{array}$ & $\begin{array}{l}\text { Topographic } \\
\text { Constraints }\end{array}$ & $\begin{array}{l}\text { War Costs } \\
\text { Outweigh } \\
\text { Technology }\end{array}$ & $\begin{array}{l}\text { 1. Impossibility of War } \\
\text { 2. Institutions as Coping Mech. } \\
\text { 3. Shatterbelts / Checkerboards }\end{array}$ \\
\hline $\begin{array}{l}\text { (H5) } \\
\text { Common } \\
\text { Culture }\end{array}$ & $\begin{array}{c}\text { Security } \\
\text { Community } \\
\rightarrow \text { "Long Peace" }\end{array}$ & $\begin{array}{l}\text { Common Legacy of } \\
\text { Anti-Imperialism }\end{array}$ & $\begin{array}{l}\text { Extra-regional } \\
\text { Intervention }\end{array}$ & $\begin{array}{l}\text { 1. Eradication of War } \\
\text { 2. Re-unification } \\
\text { 3. Ideological Solidarity }\end{array}$ \\
\hline $\begin{array}{l}(\mathrm{H} 6) \\
\text { State-Strength/ } \\
\text { Weakness }\end{array}$ & $\begin{array}{l}\text { State-Incapacity } \\
\rightarrow \text { "Long Peace" }\end{array}$ & $\begin{array}{l}\text { Domestic } \\
\text { Constraints }\end{array}$ & $\begin{array}{c}\text { Mutual Security } \\
\text { Externalities }\end{array}$ & $\begin{array}{l}\text { 1. Incapacity for Major War } \\
\text { 2. Institutions as Supplements } \\
\text { 3. Avoidance of Externalities }\end{array}$ \\
\hline $\begin{array}{c}(\mathrm{H} 7) \\
\text { Liberal Peace }\end{array}$ & $\begin{array}{l}\text { Liberal values } \\
\rightarrow \text { "Long Peace" }\end{array}$ & $\begin{array}{l}\text { Republican } \\
\text { Democracy, Free- } \\
\text { trade, and Liberal } \\
\text { Institutions }\end{array}$ & $\begin{array}{l}\text { Convergence of } \\
\text { Liberal Interests } \\
\text { and Values }\end{array}$ & $\begin{array}{l}\text { 1. Eradication of War } \\
\text { 2. Liberal Institutionalization } \\
\text { 3. Inter-Democratic Solidarity }\end{array}$ \\
\hline
\end{tabular}




\section{CHAPTER 2}

THE LAST STRUGGLE FOR INDEPENDENCE:

WAR AND PEACE WITH THE MOTHERLAND, 1864-1871

"Los hermanos sean unidos, porque esa es la ley primera; tengan unión verdadera en cualquier tiempo que sea, porque si entre ellos pelean los devoran los de ajuera." 246

In the morning of April 14, 1864, a Spanish squadron commanded by Admiral Luis Hernández Pinzón seized three small islands off the coast of Peru known for their vast guano deposits - a mineral produced by the sedimented excrement of seabirds and bats with applications both as a fertilizer and in the making of gunpowder. These islands, known as the Chinchas, had been the main source of public revenue in Peru since at least the 1840s, when the deposits were discovered and a market boom erupted around the exportation of guano. In 1864, Peru's revenue from the exportation of guano represented more than two-thirds of the government's budget. For these reasons, the Chincha Islands soon became coveted objectives of European imperialism during the second-half of the 19th century. The Spanish act of aggression generated, therefore, not only a political and financial crisis in Peru, but also a diplomatic one that rapidly escalated into a military

\footnotetext{
246 José Hernández, La vuelta de Martín Fierro (Buenos Aires: Librería del Plata, 1879), XXXII: 1160. ["Brothers, stand by each other, Because this is the first law. Keep a true bond between you always, At every time, Because if you fight among yourselves, You'll be devoured by outsiders.’]
} 
conflict between Spain and a quadruple alliance formed by Peru, Chile, Ecuador, and Bolivia.

Given the great political importance of this conflict both for Spain and the newlyindependent South American states, the so-called "Guano War" occupies a special place in the history of the international relations of the region. "The War with Spain," as it was known in the allied nations, ${ }^{247}$ marked the beginning of the end of European interventions, covert aggressions, and gunboat diplomacy in the Americas. Spain's 19th-century “foreign policy of prestige," in particular, received a knock-out blow from which it never fully recovered. ${ }^{248}$ The final collapse of Spain's colonial presence in the continent came in 1898 as a result of the war with the United States. But the Guano War also showed the limits of the Monroe Doctrine itself, for the United States' civil war (1861-1865) critically impaired the implementation of this hemispheric policy during the $1860 \mathrm{~s}$, when a series of new European interventions in the Americas occurred.

For Peru, the war with Spain created such a profound internal convulsion that a political revolution soon erupted, deposing the conciliatory Juan A. Pezet administration and replacing it with the more resolute of Mariano I. Prado's dictatorship, who later declared war on Spain by joining the Quadruple Alliance with Chile (a former enemy during the war of 1836-1839), Ecuador (a troubling "buffer state" between Peru and Colombia), and Bolivia (a traditional ally of Peru, but with strained relations with Chile after the collapse of the Peru-Bolivian Confederation in 1839). At the time of the Spanish

\footnotetext{
${ }^{247}$ In Spain, it is known simply as the "War of the Pacific."

248 José A. S. González Pizarro, La política de España en América bajo Isabel II (Navarra: Newbook, 1999), pp. 11-12.
} 
seizure of the Chincha Islands, Peru and Spain had no formal treaty recognizing Peru's independence, and bilateral diplomatic relations were at a historic low since the late $1820 \mathrm{~s}$, when the very last Spanish troops were forced out of Lima—once the proudest possession of the Spanish empire in the Americas. This aspect aggravated the diplomatic crisis because the unclear legal status of the Spanish aggression had the potential of becoming accepted by other great powers and neighboring states as a legitimate act of "revindication" by the Spanish monarchy over one of its former colonial territories.

In this context, the main objective of this chapter is to study the diplomatic and military conflict between Spain and the Quadruple Alliance through the lens of the international society approach. In particular, the chapter presents an analysis of three key aspects of the conflict that go beyond the traditional (mostly military) accounts of the war. First, the chapter explores the role of diplomatic standards of conduct prevalent at the time and assesses their importance for the control, minimization, and progressive de-escalation of the war. Secondly, it presents an analysis of the role of rules and formal channels for conducting more stable and professional diplomatic relations. The establishment of the Lima Congress (1864-1865), for example, which was invoked by Peru in January of 1864 , became active during the crisis between Peru and Spain and played an important role in opening alternative diplomatic channels of communication with the Spanish Admiral during the initial stages of the conflict.

Lastly, the chapter offers an analysis of the process by which South American states attempted to erect a "common front" against Spain, the former Motherland. This was a relevant development because Spain had maintained strong socio-cultural, political, and economic connections with most South American nations after their independence. The 
Quadruple Alliance is analyzed, therefore, in its two main facets: that is, both as a type of "pragmatic solidarism" between Peru and its allies against the Spanish aggression, but also in its external aspect, as it attempted to erect a continental diplomatic bulwark against all types of European aggressions throughout the Americas, beyond a merely ad hoc alliance against Spain alone. In this same sense, and quite importantly, the Quadruple Alliance tried to mediate in the War of the Triple Alliance (Argentina, Brazil, and Uruguay versus Paraguay), which was unfolding simultaneously in the Platine region on the other side of the continent. These efforts by the Quadruple Alliance to intervene diplomatically and stop the war against Paraguay offer a unique opportunity to evaluate the impact of international society on the self-perception of elites and decision-makers at the time, who viewed the Spanish aggression as more than simply a bilateral affair between Peru and Spain, and instead insisted on framing the conflict as an "American question" affecting not just Peru's national interest but the region's common interest as a whole.

The chapter contains four sections. In the introductory section, the Guano War is placed in a historical context, highlighting the most immediate antecedents, and the general aspects of Spain's foreign policy at the time. In the second section, the chapter applies the international society framework to understand the evolution of the conflict by emphasizing the three factors identified above. In the third section, the chapter explores a number of process-tracing "tests" to evaluate the relative strength of the competing hypotheses vis-àvis the international society argument. A final section summarizes the main findings and offers a set of preliminary conclusions regarding the role of international society in explaining the case. 
MAP 1 - South America circa 1864.

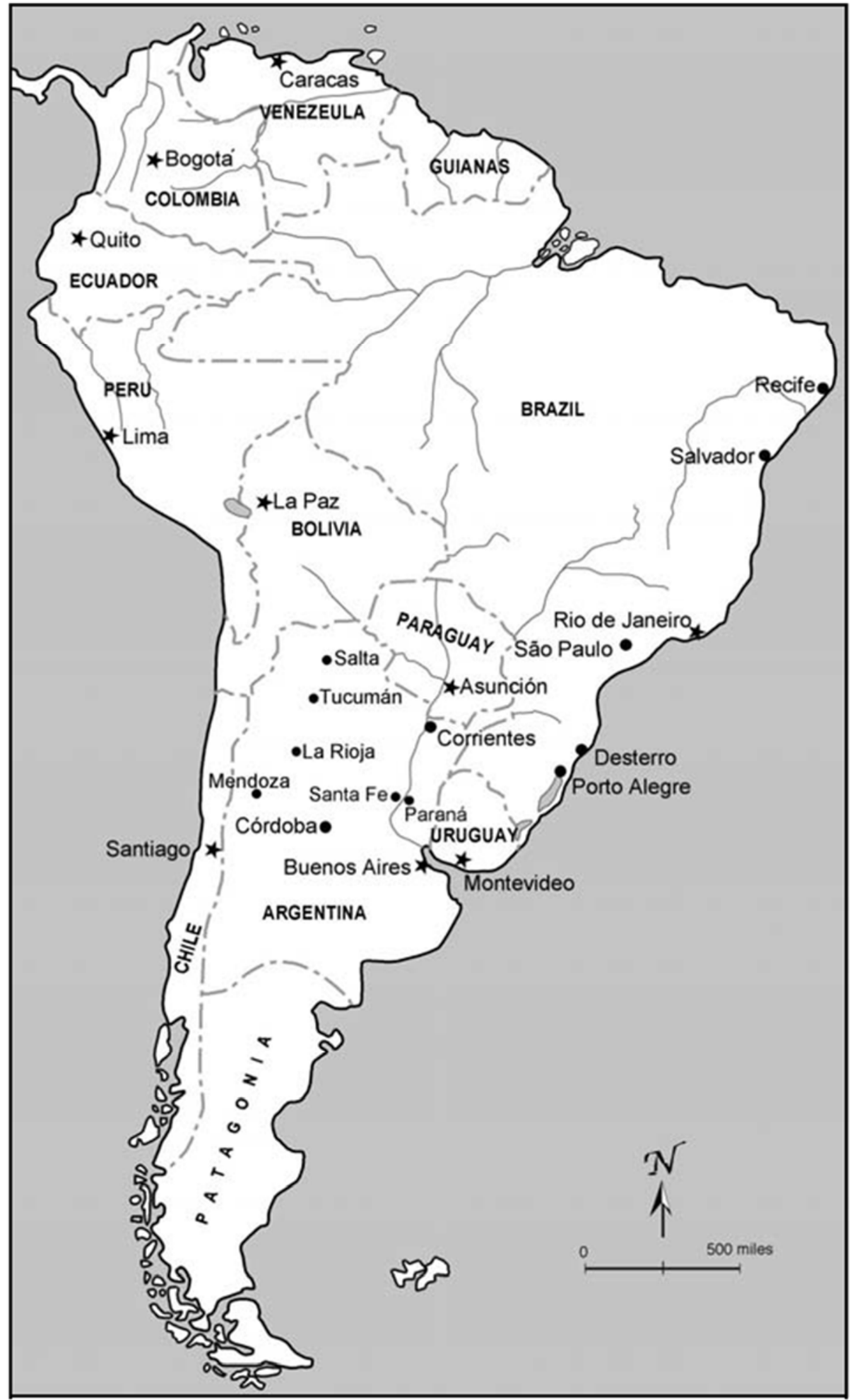

Source: Hendrick Kraay and Thomas L. Whigham, eds., I Die with My Country: Perspectives on the Paraguayan War, 1864-1870 (University of Nebraska Press, 2004), p. 3. 


\section{The Guano War in Historical Context}

After the achievement of independence, South America emerged to an international context of unique characteristics. With the end of Spanish and Portuguese colonialism, which had extended from 1492 to the late 1820 s, the new independent political entities of South America grappled with a multiplicity of problems emanating both from within and without.

Internally, the first forty years of independence were characterized by a series of violent political and military confrontations over the formation of central "national" governments. These disputes tried to establish which local power or caudillo would direct the process of creation and expansion of the new central authority. Other related issues were the protracted discussions over the type of government or regime, the forms of tax collection, placement of the capital city, access to strategic ports, waterways, and canals, as well as the distribution of state resources and its population, and the control over commercial revenues, among other contentious issues. Therefore, between the late $1820 \mathrm{~s}$, when the wars of independence were coming to a close, and the early 1860 s, when the general process of state-formation ended, South America was in a state of violent flux that was marked by high levels of internal political contestation and violence. This "anarchy" that came to predominate in early South American countries also constituted an important impediment for the establishment of well-organized and stable international relations in the region.

Externally, therefore, the decades preceding the 1860s were also remarkably dynamic. The United States, for example, self-proclaimed protector of the free republics of the Western Hemisphere against the imperialist ambitions of European powers, entered in the 1860 s into a fierce civil war which temporarily opened a window of opportunity for 
Spain, England and France to intervene in the continent to regain former colonial possessions, or as in the cases of the Netherlands, Italy, and Prussia, to establish new ones. Technologically, the international context of the early decades after independence was marked by rapid change, an exponential number of innovations and transformative applications to the productive sectors of the economy, and to faster and more reliable types of communication, navigation, and scientific discoveries. When applied to statecraft, these had an enormous impact on the capacity and effectiveness of the South American states to govern the vast territories inherited from the collapse of the Spanish colonies, to create a more professional state bureaucracy, to provide an increasing number of social services, and most crucially to consolidate a regular, standing military.

\section{The Critical 1860s}

Contemporary historians agree on the fact that the 1860 s represent a tipping point in the history of the Western Hemisphere in general, and of South America in particular. ${ }^{249}$ The first, and perhaps most distinctive, aspect of the 1860 s is the end of the period of internal "anarchy" that so characterized the preceding decades. Although some historical cases took longer than others, by 1862 most countries in South America were already consolidated as distinct national political entities. ${ }^{250}$ Except for Brazil, which attained independence in

\footnotetext{
${ }^{249}$ For two edited works on the importance of the 1860s for the American continent, see Don H. Doyle, ed., American Civil Wars: The United States, Latin America, Europe, and the Crisis of the 1860s (The University of North Carolina Press, 2017); and Guillermo Palacios and Érica Pani, eds., El poder y la sangre: Guerra, estado y nación en la década de 1860 (México DF: El Colegio de México, 2014).

${ }^{250}$ See Christon I. Archer, ed., The Wars of Independence in Spanish America (Wilmington, DE: Scholarly Resources, 2000); Miguel Á. Centeno, "Latin American Independence and the Double Dilemma," Latin American Politics and Society, Vol. 50, No. 3 (Fall, 2008), pp. 147-161; and David A. G. Waddell, "International Politics and Latin American Independence," in The Cambridge History of Latin America, ed. by Leslie Bethell (Cambridge University Press, 1985), Vol. 3: pp. 197-228.
} 
1822 and remained a monarchy until 1889, all other South American states self-identified as "republics." ${ }^{251}$ A second aspect of the 1860 s is that, with the final consolidation of central governments, regional diplomatic relations became possible on a scale, level of regularity, and intensity unimaginable until then. ${ }^{252}$ The achievement of internal order, coupled with the rapid technological changes of the time, also created favorable conditions for the development of a regional system of states characterized by practices and standards largely imported from Europe's own regional experience. ${ }^{253}$ For South American countries, following the European example of diplomacy and international relations played an important role in securing international recognition as legitimate and autonomous "civilized" sovereign nations. ${ }^{254}$ Once achieved, recognition by the established powers of Europe and the United States offered an opportunity to access world markets and acquire financial loans with which to further each national "modernization" project involving

\footnotetext{
${ }^{251}$ See Hilda Sábato, Republics of the New World The Revolutionary Political Experiment in NineteenthCentury Latin America (Princeton University Press, 2018); and Sábato, "Arms and Republican Politics in Spanish America: The Critical 1860s," in American Civil Wars: The United States, Latin America, Europe, and the Crisis of the 1860s, ed. by Don H. Doyle (The University of North Carolina Press, 2017), pp. 185203.

${ }^{252}$ On this point, see Robert N. Burr, "The Balance of Power in Nineteenth-Century South America: An Exploratory Essay," The Hispanic American Historical Review, Vol. 35, No. 1 (February, 1955), pp. 3760; and Burr, By Reason or Force: Chile and the Balancing of Power in South America: 1830-1905 (University of California Press, 1965), pp. 9-11, 107-116. Cf. Ron L. Seckinger, "South American Power Politics during the 1820s," The Hispanic American Historical Review, Vol. 56, No. 2 (March, 1976), pp. 241-267.

${ }^{253}$ Despite the predominance of the monarchical type of government in Europe, and the generalized rejection of it in the Americas, the European diplomatic system was nevertheless considered as an unavoidable example to follow. Even the United States, for example, in spite of its Founding Fathers' skeptical views of traditional European standards, such as the balance of power, eventually recognized the utility and practical functions that the European "model" offered. See David Armstrong, Revolution and World Order (Clarendon Press, 1993), pp. 42-78, 299-310.

${ }^{254}$ See Burr, By Reason or Force, p. 1; and Mikulas Fabry, Recognizing States: International Society and the Establishment of New States Since 1776 (Oxford University Press, 2010).
} 
capital-intensive investments, such as the extension of railways or the professionalization of the armed forces.

A related aspect of "the critical $1860 \mathrm{~s}$ " is that technological advancements soon gave way to a fast-paced revolution in warfare and the conduct of military affairs. New types of weaponry, modes of transportation, and tactics, coupled with a rapid growth in population size and composition in most South American nations, made inter-state war possible on a scale never-before-seen in the history of the continent. The civil war in the United States, for example, where the latest technological innovations were more systematically introduced, remains a gruesome but important reminder of the new realities created by "modern" warfare in the 19th century. ${ }^{255}$ Since technological advancements in other areas, such as battle medicine, were progressing more slowly than those in the weaponry sector, the number of casualties grew exponentially during this century, quickly becoming the new norm. ${ }^{256}$ Importantly, this also put a stress on how statesmanship and diplomacy could accommodate the use of force and war as part of receding paradigm of tradition "power politics" á-la Europe. In this context, moreover, pandemics and other health-related problems soon became established as one of the main drivers of death in war-often accounting for two-thirds of the total number of casualties in most 19-century wars. Such was the case, for example, of the Crimean War and the U.S. civil war, as well as the two major armed conflicts of South America: The War of the Triple Alliance and

\footnotetext{
${ }^{255}$ For a brief, but erudite, analysis of these transformations in 19th-century military technology amidst other simultaneous socio-economic revolutions, see Julian Lindley-French and Yves Boyer, eds., The Oxford Handbook of War (Oxford University Press, 2012); and Charles Townshend, ed., The Oxford Modern History of War (Oxford University Press, 2nd ed., [1997] 2005).

${ }^{256}$ See Tanisha N. Fazal, "Dead Wrong? Battle Deaths, Military Medicine, and Exaggerated Reports of War's Demise," International Security, Vol. 39, No. 1 (Summer, 2014), pp. 95-125.
} 
the War of the Pacific. However, although they were important features of 19th-century war, other factors (like thirst, hunger and pandemics) continued to be important even in the early decades of the 20th century, as the Chaco War between Paraguay and Bolivia amply demonstrated.

A final, yet equally relevant, aspect of the 1860 s was the progressive rejection of offensive war and armed violence as the main form of solving political disputes. It was a global phenomenon from which South America was not exempted. The creation of the Red Cross in 1864 is, perhaps, one of the most iconic developments in this regard. In South America, where even domestic politics since independence was commonly characterized by violence against political opponents, a growing intolerance for war progressively translated into a slow process of attrition through which civilian governments partially displaced military leaders and caudillos from politics, as they began to share power more evenly. In 1860s South America, as Juan B. Alberdi famously proclaimed, war was quickly becoming "a crime" that all civilized nations worthy of that title should come to control, reject, and eventually eradicate. ${ }^{257}$

\section{European Interventionism in the Americas}

In this context, the 1860 s presented for many European powers a unique opportunity to gain control over portions of a vast territory from which most of them had been largely excluded during Spanish and Portuguese rule. On two concrete occasions in the early

${ }^{257}$ See Juan B. Alberdi, El crimen de la guerra. Edición crítico-genética de Élida Lois (San Martín: Universidad Nacional de San Martín, [1870] 2007). 
1860s, in fact, European monarchies partially succeeded in establishing new dominions in the Americas: one in Santo Domingo; the other in Mexico.

The reincorporation of Santo Domingo to the Spanish crown occurred towards the end of 1860 . Local political elites, using as a pretext a potential aggression by neighboring Haiti, forged in connivance with Madrid the annexation of Santo Domingo to the Spanish Empire. The president of the country, Pedro Santana, with the support of other promonarchical political leaders and aristocratic families, was one of the most visible promoters of the reincorporation. The opposition, however, did not remain idle and quickly mobilized to depose Santana and thwart his plans. In a manifest signed by "A Thousand Patriots," the people of Santo Domingo were called to arms against Santana and his "criminal partners." ${ }^{258}$ By March 1861, nevertheless, the annexation had triumphed, and Santo Domingo proclaimed as part of the Spanish Empire. Less than a month later, Spanish troops disembarked on Dominican soil giving way to a reactionary war of national liberation. The civil war lasted four years under the leadership of several generals (such as Rojas, Cabral, Manzueta, Pimentel, and Luperón), and victory against Spain was finally attained in April 1865. ${ }^{259}$

From the very beginning of the intervention, the South American nations did not remain indifferent to the aggression. The Peruvian government, for example, through its

\footnotetext{
${ }^{258}$ See El Federalista, 2/1/1861.

${ }^{259}$ On the annexation of Santo Domingo, see José de la Gándara, Anexión y guerra de Santo Domingo (Madrid: Correo Militar, 1884), 2 vols.; Jaime de Jesús Domínguez, La anexión de la República Dominicana a España (Santo Domingo: Editora de la Universidad Autónoma de Santo Domingo, 1979); Richard Pattee, La República Dominicana (Madrid: Cultura Hispánica, 1967); and González Pizarro, La política de España en América, pp. 248-277. Also cf. Francisco Febres-Cordero Carillo, "La anexión y la guerra de restauración dominicana desde las filas españolas (1861-1865)," Ph.D. Dissertation, Río Piedras: Universidad de Puerto Rico (2008).
} 
Foreign Minister, José F. Melgar, issued an official protest against the "reconquest" of Santo Domingo, calling it an "attack on the independence of one of the hispano-american republics" and a direct affront on the sovereignty of all others. It was essential, according to Melgar, for South American nations to embark on a "solidaristic defense" of Santo Domingo. ${ }^{260}$ The occupation of Santo Domingo, said Melgar in his Circular Note, has pushed "my government, faithful to the honorable tradition of liberty and consequently also the policy of cooperation with the rest of the states of the continent each time that America has faced a common threat or its independence has been endangered, to issue a protest, after a mature deliberation by the Ministers of the Cabinet, against the reincorporation of the Republic of Santo Domingo to the Spanish Crown.” He continued: "Consequently, Peru does not recognize the legitimacy of this act; solemnly protests against it, and condemns the damaged intentions that make possible to suppose are held by Madrid towards the republican America." ${ }^{261}$ Despite the claims made by the Peruvian minister, a sense of alarm remained high in the region, no effective project for collective defense ever materialized in support of Santo Domingo. ${ }^{262}$

The second case of European interventionism was significantly more serious and involved a joint operation in 1861 by France, England, and Spain during the Mexican civil war. Compared to the intervention in Santo Domingo or the Spanish seizure of the Chincha

\footnotetext{
260 “Circular a los gobiernos de América,” Lima, August 24, 1861, in Ricardo Aranda, Colección de los tratados [...] (Lima, 1907), Vol. 11:, pp. 870-874.

261 Ibid.

${ }^{262}$ For the set of replies from Santo Domingo and other states in the region, see Aranda, Colección de los tratados, Vol. 11:, pp. 875ff. For more historical context, see also Alberto Wagner de Reyna, Historia marítima del Perú: La intervención de las potencias europeas en Latinoamérica, 1864 a 1868 (Lima: Instituto de Estudios Histórico-Marítimos del Perú, 1981), p. 62.
} 
islands and the subsequent war against the four allied countries of the South Pacific, the intervention in Mexico is a case of much more global strategic importance, for it entailed the establishment of a European monarchy on American soil and the creation of a "Mexican Empire" under the protection of Napoleon III of France. Influenced by controversial plans to construct an interoceanic canal in Nicaragua, as well as other factors, such as ideology, religion and economic interests in Mexico itself, the invasion of Mexico was part of a larger plan to erect a double barrier: first, against the expansion of the United States towards Central America; and second, against Spain itself. ${ }^{263}$ The simultaneous development of the war of secession in the United States and the civil war in Mexico offered the right opportunity for such an ambitious plan. As in Santo Domingo, moreover, there were local political factions in Mexico eager to assist the French in the establishment of an American monarchy, which many thought would offer better prospects for long-term stability and security in Mexico - a country chronically affected by crippling external debt and protracted civil war.

Initially, the joint intervention was supported by France, England, and Spain as a coercive measure against Mexico for the non-payment of its external financial obligations. However, when two of the intervening powers backed-down after securing promises of repayment, France continued alone with a military occupation of the country. ${ }^{264}$ After an initial confrontation with Mexican forces in 1863, between 1864 and 1867 Mexico was

\footnotetext{
${ }^{263}$ See Wagner de Reyna, La intervención de las potencias europeas, pp. 48-53; and Edmundo A. Heredia, El imperio del guano: América Latina ante la guerra de España en el Pacífico (Córdoba: Alción, 1998), pp. 15-30.

${ }^{264}$ For an analysis of Spain's position regarding the French intervention in Mexico, see González Pizarro, La política de España en América, pp. 277-303; James W. Cortada, "España y Estados Unidos ante la cuestión mexicana: 1855-1868," Historia Mexicana, Vol. 27, No. 3 (enero-marzo, 1978), pp. 387-426.
} 
ruled by Ferdinand Maximilian, Archduke of Austria (Habsburg), who was proclaimed Emperor of Mexico. Throughout his troubled reign, Maximilian I of Mexico grappled with the relentless armed resistance of Benito Juárez's forces, which refused to recognize the legitimacy of any monarchical rule in Mexico. In June 1867, the liberation forces led by Juárez were finally victorious; Maximilian was captured and executed; and the republic was soon reestablished.

During the early stages of the joint intervention in Mexico, Peru—once againplaced itself at the forefront of an "Americanist" effort to showcase solidarity with Mexico's cause. With this objective in mind, in March 1862 Peru sent J. Nicolás Corpancho to Mexico as chargé d'affaires. ${ }^{265}$ President Juárez overlooked diplomatic protocol by attending the ceremony of reception of the Peruvian diplomat — thus sending a clear signal of appreciation for the Peruvian attempts at breaking the increasing isolation of Mexico imposed by France and other European monarchies. But despite this gesture of interAmerican solidarity, Peru failed to organize a coalition of South American countries to come to the aid of Mexico during the period of French invasion. ${ }^{266}$ Before 1863, many countries, such as Argentina and Uruguay, were still involved in internal conflicts over the formation of a central state, and were thus practically unable to exert any meaningful role

\footnotetext{
${ }^{265}$ On this important Peruvian mission, see Genaro Estrada, Las relaciones entre México y Perú: La misión de Corpancho (México DF: Archivo Histórico Diplomático Mexicano No. 4, Secretaría de Relaciones Exteriores, 1923); and Mario F. Real de Azúa, "La misión diplomática el peruano Manuel Corpancho, 1862-1863," Historia Mexicana, Vol. 28, No. 1 (julio-septiembre, 1978), pp. 62-81.

${ }^{266}$ See Robert W. Frazer, "Latin-American Projects to Aid Mexico during the French Intervention," The Hispanic American Historical Review, Vol. 28, No. 3 (August, 1948), pp. 377-388; Estrada, Las relaciones entre México y Perú; Guillermo Palacios, "Brasil y el sur hispanoamericano ante la intervención francesa," in El poder y la sangre, pp. 395-417; Rubén Ruiz Guerra, Más allá de la diplomacia: Relaciones de México con Bolivia, Ecuador y Perú, 1821-1994 (México DF: Secretaría de Relaciones Exteriores, 2007); and Palacios, "De imperios y repúblicas: Los cortejos entre México y Brasil, 1822-1867," Historia Mexicana, Vol. 51, No. 3 (enero-marzo, 2002), pp. 559-618.
} 
in the Mexican question. ${ }^{267}$ The South American nations, however, despite their ongoing troubles, were not entirely indifferent to the French intervention, doing what was within their means at the time. Setting an important precedent, they collectively refused to recognize Maximilian I as the legitimate ruler of Mexico. Only Argentina and Chile, believing Mexico's independence was not truly at risk, initially held Mexico responsible for its difficulties. ${ }^{268}$ In time, however, most South American nations broke all diplomatic relations with the Mexican Empire and never ceased to express their profound discontent and concern for the occupation of Mexico and the establishment of a European monarchy on American soil. It was not until the civil war in the United States ended that a more effective pressure by the United States was able to convince France to desist and withdraw all support for Maximilian, leading to his eventual downfall. ${ }^{269}$

Apart from these two well-known cases in Central America and the Caribbean, South America itself had in previous decades been the subject of similar monarchical plots. During the late 1840s, for example, similar developments in Ecuador raised the alarm of the republics of the continent regarding the still fragile and insecure condition of their mutual independence. Sectors of the Ecuadorean political elite saw in the reincorporation of Ecuador to the Spanish empire a safer route to protect the survival of the state against the recurrent invasions and hostilities from neighboring Peru and Colombia. Although courting on several occasions with the idea of a Spanish-supported invasion, all plans were

\footnotetext{
${ }^{267}$ See Guillermo Palacios and Ana Covarrubias, Historia de las relaciones internacionales de México, 1821-2010. Vol. 4: América del Sur (México DF: Secretaría de Relaciones Exteriores, 2011), pp. 67-99.

${ }^{268}$ See Frazer, "Latin-American Projects to Aid Mexico," pp. 378-379.

${ }^{269}$ See Marcela Terrazas, “¿Dónde quedó la Doctrine Monroe? Estados Unidos ante la intervención francesa en México," in El poder y la sangre, pp. 367-393; Wagner de Reyna, La intervención de las potencias europeas, pp. 52-53; and Cortada, "España y Estados Unidos ante la cuestión mexicana."
} 
eventually thwarted in time and never came to fruition. But on two occasions, however, pro-monarchical forces in Ecuador came really close to achieving their goals. In 1846, Juan J. Flores, an Ecuadorean General who had been deposed as president the previous year, received the tacit support of the Queen of Spain and organized a military expedition to establish the monarchical type of government in his own country. ${ }^{270}$ Several South American countries_-but particularly neighboring Peru, Chile and Colombia-reacted immediately by publicly denouncing Flores' plans, dispensing financial and military support to Ecuador, and even drafting plans to resist the foreign-backed invasion, if it ever materialized. Thanks to these concerted efforts, Flores' vessels, weapons and troops never left British ports thanks to the collaboration of England in delaying and ultimately undermining the projected invasion.

A second attempt occurred only some years later. In 1859, Gabriel García Moreno, then president of Ecuador, arranged the support of Spain and France in an attempt at securing its political survival against his internal opposition. Although it was not one of the main conditions of the support offered, García Moreno had contemplated changing Ecuador's status to that of a "protectorate," and even to adopt the monarchical type of government if necessary. Neighboring Peru, through its Foreign Minister, asked the Ecuadorean government for explanations on the issue, considering the rumors of potential projects to "surrender the autonomy of Ecuador" to European monarchies as an affront on

\footnotetext{
${ }^{270}$ On Flores' plans, see Wagner de Reyna, La intervención de las potencias europeas, pp. 53-62; González Pizarro, La política de España en América, pp. 198-237; Ralph W. Haskins, "Juan José Flores and the Proposed Expedition against Ecuador, 1846-1847," The Hispanic American Historical Review, Vol. 27, No. 3 (August, 1947), pp. 467-495; and Mark J. Van Aken, King of the Night: Juan José Flores and Ecuador: 1824-1864 (University of California Press, 1989), pp. 209-233.
} 
the autonomy of all others in the Americas. ${ }^{271}$ Although García Moreno denied all charges and dismissed all accusations, his attitude during the French invasion of Mexico showcases a level of ambivalence not seen in other South American countries at the time. That is, although Ecuador withdrew their chargé d'affaires from Mexico, just like many other South American nations did, García Moreno avoided any demonstration of antipathy against France and did not partake in the public condemnation of the invasion itself. ${ }^{272}$

During the early decades after independence, therefore, domestic and intra-regional dynamics of political competition characterized most of South America's international relations. These, in turn, allowed European monarchies to play individual countries, and their caudillos, against one another and to implement ambitious plans of neo-colonial or subordinate rule in the Americas. Such was the international political context of the 1860s, where prominent and dangerous antecedents, such as those of Mexico, Santo Domingo and the failed attempts in Ecuador, had created a regional sense of profound insecurity among the newly-independent South American republics. Not only the continuity of the republican type of government seemed at risk, but also their very survival as autonomous political units was at stake. It was under these conditions that news of a Spanish "Scientific Expedition" to the Pacific reached the continent and soon raised the alarm of all South American nations - and of Peru in particular, given its diplomatic anti-European activism and the still non-recognition by Spain of its independence.

\footnotetext{
${ }^{271}$ See Pattee, Gabriel García Moreno y el Ecuador de su tiempo, pp. 195-206, 339-414; Pattee, "García Moreno y la política internacional ecuatoriana," Boletín de la Academia Nacional de la Historia (Quito), Vol. XVII, No. 50-53 (enero-junio, 1939), pp. 185-208; and Peter V. N. Henderson, Gabriel García Moreno and Conservative State Formation in the Andes (University of Texas Press, 2008).

${ }^{272}$ See Wagner de Reyna, La intervención de las potencias europeas, pp. 54, 55.
} 


\section{Spain in the 19th Century}

The 1860s found Spain in political and financial turmoil. The reign of Queen Isabel II had been grappling with the perennial problems of administering Spain's long-term international decline. ${ }^{273}$ This decline was first ignited by Napoleon's invasion of the country and the removal of Fernando VII, which in turn led to the loss of the Spanish colonies in the New Continent. For several decades since the early 19th century, therefore, the Spanish Crown had been virtually excluded from money markets and was thus heavily indebted. The economy was quickly de-industrializing and its people was on the verge of social revolt. ${ }^{274}$ During the late 1850 s and early 1860 s, Spain tried to implement a new foreign policy which would put Spain back among the first-rate powers of the world. This thus-called "foreign policy of prestige" was shared by the two main political parties at the time: the Unión Liberal, led by Leopoldo O'Donnell, and the Partido Moderado, led by Ramón M. Narváez. These parties alternated power in the cabinet of Isabel II and put into place a series of innovations to reactivate the economy and boost productivity, as well as other administrative reforms. Among the most prominent of these was the reform of the Royal Navy. Spain's foreign policy was thus reset to serve the more immediate domestic interests of the Crown. ${ }^{275}$

In the course of the $1860 \mathrm{~s}$, however, the search for an actively interventionist foreign policy based on regaining a sense of "lost prestige" did not produce much benefit-

\footnotetext{
${ }^{273}$ See José María Jover, Política, diplomacia y humanismo popular en la España del siglo XIX (Madrid: Turner, 1976), pp. 84-138; and James W. Cortada, "Spanish Foreign Policy, 1846-1875," in Spain in the Nineteenth-Century World, ed. by James W. Cortada (Greenwood Press, 1994), pp. 23-43.

${ }^{274}$ William C. Davis, The Last Conquistadores: The Spanish Intervention in Peru and Chile, 1863-1866 (The University of Georgia Press, 1950), p. 3.

${ }^{275}$ See Heredia, El imperio del guano, pp. 15-30.
} 
neither in terms of economic gain, nor in prestige itself. The series of interventions carried out by Spain abroad, in fact, damaged rather than solidified Spain's image oversees and served more as a temporary distraction for the general public and the popular media than a real solution to the monarchy's crippling troubles. ${ }^{276}$ Whereas in 1859 the Spanish invasion of Morocco lasted for six months, cost Spain nearly 7,000 lives (two-thirds of them lost to cholera), and produced no long-term strategic gains for the Crown, the ill-fated intervention in Santo Domingo (1861-1865) cost Spain 10,000 lives and created an enormous burden on an already meager treasury—without counting the immense disrepute to its international image as a would-be first-rate European power. ${ }^{277}$

It was in this pressing context that a sector within the administration, implicated in the restructuring of the Spanish Navy, decided in March 1860 to put together a "Scientific Expedition" to South America. The launch of the expedition, however, suffered from a two-year delay due to multiple internal problems in the implementation of such an ambitious project during so difficult a time. In August 1862, the squadron finally left Spain. It consisted of two frigates: the flagship Resolución and the Triunfo-both of 42 cannons. Upon arrival at the River Plate, other vessels joined up, such as the schooners Covadonga and Vencedora - of three cannon each. After the diplomatic crisis with Peru had already taken place (April 1864), other powerful ships came to reinforce the naval expedition in December of that year, coming from the Spanish naval station in the Caribbean: these were the frigates Berenguela, Blanca and Villa de Madrid. The objectives of the so-called

\footnotetext{
${ }^{276}$ See Davis, The Last Conquistadores, pp. 1-8. With the final debacle of the intervention in the Chincha Islands in Peru, and the costly war that this generated, the reign of Isabel II ended in 1868 when a revolution replaced the monarchical regime with a republic.

${ }^{277}$ See González Pizarro, La política de España en América, pp. 248-276.
} 
"peaceful expedition" were to take a small number of Spanish naturalists to the Americas to gather specimens, fossils, samples and all sorts of artifacts to reinvigorate the study of the sciences in Spain upon their return. ${ }^{278}$ The composition of the naval squadron, however, suggests that other-more political—objectives were equally, if not more, important. ${ }^{279}$

Given the peculiar composition of the squadron sent by Spain, made of mainly heavily-armed military vessels, and the most recent adventures abroad in Morocco, Cochinchina, Santo Domingo and Mexico, the "real" objectives behind Spain's expeditionary force to the Pacific seemed less peaceful than what was at the time proclaimed. First, the main aim of Isabel's cabinet was to display Spain's military might in an area of the world where the Spanish flag had been lately associated with colonial oppression and war. Spain's presence in the region would thus serve as a reminder of the renewed standing and prestige of Spain in the world. Second, the expedition itself was led by a military officer, Admiral Pinzón, ${ }^{280}$ and not by any of the members of the scientific commission sent to the Americas. A closer attention to the "confidential" instructions given to Pinzón, moreover, shows that the main objective was-after all—to re-ascertain a foreign policy of prestige for Spain. The "scientific" aspect of the expedition was, at the

\footnotetext{
${ }^{278}$ See Leoncio López-Ocón Cabrera and Miguel Á. Puig Samper Mulero, "Los condicionantes políticos de la Comisión Científica del Pacífico: Hispanoamericanismo y nacionalismo en la España bajoisabelina (1854-1868)," in Estudios sobre historia de la ciencia y de la técnica, Vol. 2 (Valladolid: Junta de Castilla y León, 1988), pp. 615-629; and López-Ocón, "La comisión científica del Pacífico: De la ciencia imperial a la ciencia federativa," Bulletin de l'Institut Français d'Études Andines, Vol. 32, No. 3 (2003), pp. 479515.

279 Pedro de Novo y Colson, Historia de la guerra de España en el Pacífico (Madrid: Fortanet, 1882), pp. 84-87, 509-510; and Davis, The Last Conquistadores, pp. 9-19; and Agustín R. Rodríguez González, La campaña del Pacífico: España frente a Chile y Perú (Madrid: Real del Catorce, 2nd ed., [1999] 2016), pp. 29-39.

${ }^{280}$ Pinzón was related to the renowned conquistador of the same name who sailed to the Americas with Christopher Columbus in 1492, as captain of the Niña.
} 
very best, of secondary concern. According to these instructions, the squadron was to represent Spain diplomatically in each of the countries visited during the expedition and to establish good diplomatic relations with the republics of South America, paying special attention to the resolution of all pending legal, criminal, and financial issues involving subjects of the Crown living on the continent. ${ }^{281}$

Although there was a profound sense of opportunism implicit in the confidential instructions to Pinzón, there was no real or explicit plan of invasion or "re-conquest" against any of the South American countries. In the majority of works on this war written by Latin American historians, however, the "Scientific Expedition" is often portrayed as part of a well-conceived, almost conspiratorial, plan to seize the Peruvian islands and establish a new Spanish control in the region. ${ }^{282}$ The controversy over the confidential instructions emanates from the open-ended and at times contradictory objectives, leaving ample room for interpretation in controversial cases, such as Peru, where a final treaty of independence had not been signed.

\footnotetext{
${ }^{281}$ See Davis, The Last Conquistadores, pp. 9-12, 17-18; cf. Novo y Colson, Historia de la guerra de España en el Pacífico, pp. 86-87.

${ }^{282}$ See, e.g., Juan del Campo Rodríguez, Por la república y por la Reina: Una revisión del conflicto de 1864-1871 entre España y la alianza peruano-chilena ([Lima]: AFDA, [2003]); Fermín Toro Jiménez, Una misión diplomática en Venezuela (1866) (Caracas: Facultad de Derecho, Universidad Central de Venezuela, 1971); and Agustín Sánchez Andrés, "La intervención española en el Pacífico sur en el contexto de la política latinoamericana de España, 1863-1866," in El poder y la sangre, pp. 339-364.
} 


\section{Fighting the Motherland: The First Trial of South America's Society of States}

The war between Spain and the Quadruple Alliance had its most immediate origins in a domestic incident, occurred in August 1863, in a northern Peruvian estate called Talambo. As the result of a pressing labor dispute between the owner of the hacienda and a group of Basques who had migrated to Peru in 1859 to work in the cotton fields, a series of intimidations and threats between the Basques workers and the owner of the estate escalated to an open-ended brawl in which handguns were involved, several people were wounded, and two individuals died. One a Peruvian, the other a Basque. ${ }^{283}$

News of the Talambo incident reached Pinzón when the Spanish squadron was making its way back from San Francisco (see MAP 2 infra). Pinzón had already received new instructions from Madrid to move the squadron to Cuba to reinforce the naval station in the Caribbean. After hearing about the Talambo incident and in particular about the slow and inefficient way in which the Peruvian Judiciary system was handling the affair, Pinzón decided to postpone his new instructions and instead station the squadron in the Peruvian port of Callao in order to offer diplomatic representation and assistance to the Spanish citizens involved in the affair. ${ }^{284}$ On the way to Callao, however, Eusebio Salazar $y$ Mazarredo - a special emissary sent by the Spanish Crown to Peru to re-establish diplomatic relations-joined the squadron. Upon arrival at the Peruvian port, Pinzón

\footnotetext{
${ }^{283}$ On the issue of the Talambo estate, see Rodolfo Aguado Cantero, "El precedente de la hacienda de Talambo en el conflicto hispano-peruano de la segunda mitad del siglo XIX," Estudios de Historia Social y Económica de América, No. 3-4 (1988), pp. 165-174; La cuestión Talambo ante La América (Lima: Imprenta del Comercio, 1864); Davis, The Last Conquistadores, pp. 21-32; Novo y Colson, Historia de la guerra de España en el Pacífico, pp. 131-160; and Pizarro, La política de España en América, pp. 387403.

${ }^{284}$ From L. Pinzón to Minister of Navy, Callao, December 29, 1863, in Pizarro, La política de España en América, p. 391: fn. 14.
} 
received protests from a certain group of influential Spanish agents residing in Peru, such as the Count of San Isidro, who together with Salazar y Mazarredo instigated Pinzón to do something drastic and exemplary to protect the Her Catholic Majesty's subjects. ${ }^{285}$ Surrounded by such influential opinions, Pinzón was introduced to a final and more definitive piece of information which convinced him of seizing the Chincha Islands as a way of exemplary punishment (or extorsion) of the Peruvian government. Salazar y Mazarredo, who had joined the squadron in Panama, carried two sets of instructions: one regular, which he immediately showed to Pinzón, and another "confidential," which he concealed from the Admiral. Salazar y Mazarredo first claimed he had misplaced the second instructions, without even indicating their "confidential" status.

Only after Pinzón's insistent requests, Salazar y Mazarredo conveyed the content of those instructions verbally_-which Pinzón, lacking any other option, was forced to take at face value. The confidential instructions were later found by Pinzón on his desk, mixed with his own private papers, inside a book that Pinzón had announced to Salazar y Mazarredo that he was going to read next. This suggested to him that Salazar y Mazarredo had carefully placed them there before returning to Madrid, and that he had also mocked and manipulated him all along. ${ }^{286}$

\footnotetext{
${ }^{285}$ See Heredia, El imperio del guano, pp. 42-45.

${ }^{286}$ See Novo y Colson, Historia de la guerra de España en el Pacífico, pp. 169-171; Davis, The Last Conquistadores; González Pizarro, La política de España en América, pp. 400-401; and Wagner de Reyna, La intervención de las potencias europeas, pp. 174-175.
} 


\section{MAP 2 - Spain's "Scientific Expedition" to the Pacific (1862-1866).}

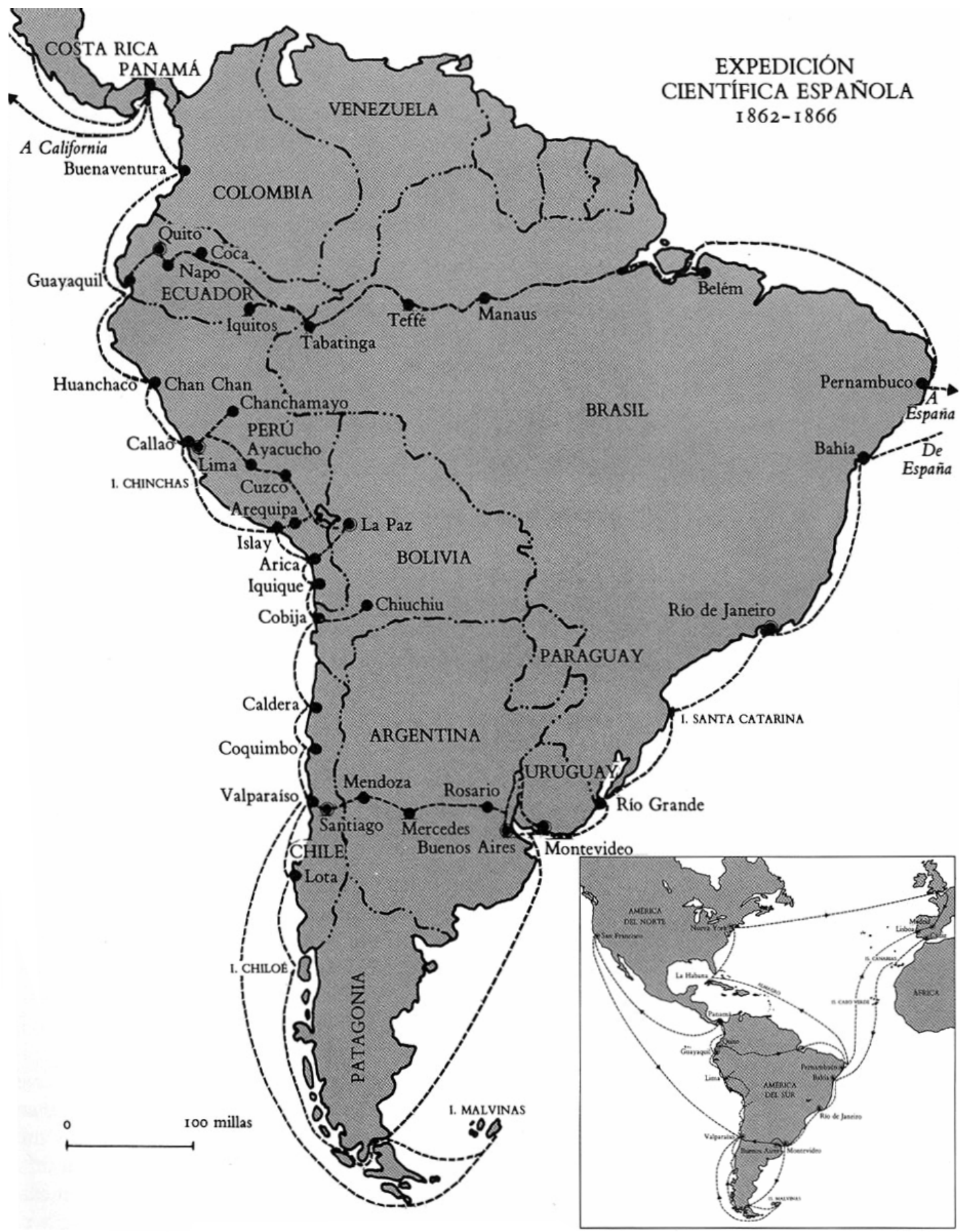

Source: López-Ocón, "La comisión científica del Pacífico: De la ciencia imperial a la ciencia federativa," Bulletin de l'Institut Français d'Études Andines, Vol. 32, No. 3 (2003), p. 495. 
Months later, this episode evolved into a bitter dispute between the two Spanish representatives once both were back in Madrid, which eventually led to a special investigation by the Naval Admiralty over the incident, given its crucial importance for clarifying who exactly made the fateful decision to seize the Chincha Islands in the first place. Given Salazar y Mazarredo's powerful political connections in the cabinet and his extended professional experience in the Chancellery, it is not surprising that the Admiralty found Pinzón as solely responsible for igniting the diplomatic crisis. Despite the Navy's final decision, a closer reading of Pinzón's own log side by side with the important revelations offered by Salazar y Mazarredo's personal secretary, Mr. Fidelo E. Cerruti, reveal that it was Salazar y Mazarredo who designed, plotted, and even at times publicly boasted about the seizure of the islands as his plan. Despite the strong evidence concerning Salazar y Mazarredo's responsibility, some historians have recently insisted that it was Pinzón who solely decided the occupation of the islands. ${ }^{287}$

The first instructions brought by Salazar y Mazarredo directly from Madrid conveyed the effective, and "true," role he was sent to play: as "Special Commissary" to Peru. For several weeks before his official meeting with the Peruvian government, Salazar y Mazarredo had been in Peru in secrecy and under a pseudonym, as a spy trying to incite

\footnotetext{
${ }^{287}$ See, e.g., González Pizarro, La política de España en América, pp. 387-403; and José A. González Pizarro and Daniel Parodi Revoredo, "Una gesta común: La alianza peruana-chilena contra España, 18641866," in Las historias que nos unen: Episodios positivos en las relaciones peruano-chilenas, siglos XIX y XX, ed. by Sergio González and Daniel Parodi (Santiago: RIL, 2013), pp. 105-149. However, cf. Fidelo E. Cerruti, Peru and Spain, being a Narrative of the Events Preceding and Following the Seizure of the Chincha Islands, with an Analysis of the Despatch of Señor Salazar y Mazarredo [...] (London: Williams and Norgate, 1864); Luis Hernández Pinzón, Diario de la navegación practicada al Océano Pacífico con las fragatas y goleta Resolución, Triunfo y Covadonga (Madrid: Museo Naval de Madrid, [1864]), Doc. No. 976, Code of Ref.: BMDB20160046090); and Wagner de Reyna, La intervención de las potencias europeas, pp. 90-107.
} 
anti-Peruvian sentiments among Spanish communities living in Peru. ${ }^{288}$ According to his instructions, he was expected to present his credentials to the Pezet administration "at a convenient time" and, upon acceptance, begin to work on the reestablishing of peaceful and harmonious diplomatic relations between Spain and Peru. The second ("confidential") instructions were directed at Pinzón and indicated the objectives and priorities of the Admiral's mission: he was to support Salazar y Mazarredo in his diplomatic negotiations. Most importantly, he was reminded that his mission was above all "a peaceful one." The confidential instructions to Pinzón were so detailed and extensive that they even contemplated potential future scenarios where the need to employ force to protect the Spanish citizens' interests could emerge—although this option was reliant on the attitude adopted by the Peruvian government. Only if such an extreme case materialized was Pinzón to present an ultimatum "days in advance," as well as to consider using force only after that first step had been taken, "at his own discretion." 289 The idea of momentarily seizing the islands was not on the table — although the instructions did mention the potential bombardment of a South American port, if needed, as an intimidating display of force.

Since Pinzón still seemed disinclined to use force, a new reason (or excuse) was concocted by Salazar y Mazarredo to convince the Admiral of the importance of taking immediate control of the Guano-producing islands as the most valid measure of protecting

\footnotetext{
${ }^{288}$ For a description of Salazar y Mazarredo's and other agents' earlier roles as incognito agitators in Peru, see Davis, The Last Conquistadores, pp. 33-50; Cerruti, Peru and Spain; and Heredia, El imperio del guano, 21-30, 37-54.

${ }^{289}$ For a detailed analysis of the instructions to Pinzón, see Alfonso Cerda Catalán, "La guerra entre España y las repúblicas del Pacífico, 1864-1866. Primera Parte: Antecedentes diplomáticos, militares y económicos," Revista Histórica [Santiago], Año LXXI, Tomo XLIX, No. 145-147 (noviembre, 1977), pp. 69-74; González Pizarro, La política de España en América, pp. 387ff; Davis, The Last Conquistadores, pp. 10-19; and Novo y Colson, Historia de la guerra de España en el Pacífico, pp. 86-87.
} 
Spain's honor and prestige. This opportunity finally came when the "Special Commissary" presented his credentials to the Peruvian government. After the main protocolary customs had been honored, the Peruvian Minister of Foreign Affairs, Juan A. Ribeyro, made the passing clarification that, given the uncommon title of "Special Commissary," which was not accepted by international treaties and conventions at the time, the Peruvian government would recognize him as "Confidential Agent" instead. The title "Commissary" was particularly problematic because it was a remnant of previous colonial titles in the Americas, such as "Royal Commissary" (or Comisario Regio), as it was commonly used by the Spanish authorities to negotiate with the local tribes and communities in the Americas. The use of such title could therefore be seen as a veiled, and quite insulting, diplomatic provocation. To avoid any embarrassments or potential misunderstandings, Ribeyro remarked, Salazar y Mazarredo could maintain his title as it was on paper but added the important caveat that "by 'Special Commissary' the Peruvian government understands 'Confidential Agent'.,'290

The fact that Salazar y Mazarredo purposefully hid these second instructions to Pinzón and "delivered" them only after the capture of the Chincha Islands had already been decided by the Admiral upon his suggestion, indicates several potential reasons behind the initiation of the diplomatic conflict. First, as most historians agree, this shows that Salazar y Mazarredo was actively looking for an issue of enough importance to "justifiably" trigger a crisis that could work as a pretext for the seizure of the Peruvian islands. In a private

\footnotetext{
${ }^{290}$ The most accurate analysis of the problem with the credentials and title of Salazar y Mazarredo is offered by Wagner de Reyna, La intervención de las potencias europeas, pp. 90-107. In subsequent correspondence with the Peruvian authorities, Salazar y Mazarredo also added the term "Extraordinary" to the already controversial "Special Commissary" title, despite the absence of that word in his official letter of credential.
} 
correspondence to the Spanish Minister of Foreign Affairs, Joaquín Pacheco, penned two days before the occupation of the islands, Salazar y Mazarredo had already laid out his entire plan. In it, for example, he confessed his long-held dream of purchasing back the Rock of Gibraltar from England. This could be achieved — he thought—with the enormous revenue generated by the guano islands off the coast of Peru. To accomplish such a fantastical plan, Salazar y Mazarredo had been planning for the longest time the "isolation of Peru from America and the separation of its government, blaming it for every hostile act against Spain, and proposing the execution of a military plan to Pinzón and his officers.”291 Salazar y Mazarredo was a Spanish citizen who had been born in Lima, and whose obsession with these guano-producing islands was only matched by his disdain of the Peruvian people, culture and government. He considered Peru unworthy of such riches, and the main responsible for the squandering of the guano as a strategic resource. ${ }^{292}$

After his meeting with Ribeyro, Salazar y Mazarredo summoned Pinzón—who was at the time in Valparaíso, Chile - to rendezvous near the Chincha Islands. To hide his intentions, Salazar y Mazarredo left Callao that same night with a north-bound trajectory. However, some minutes later, after losing sight of the port, his vessel turned immediately south towards the Chincha Islands, where he had planned to meet Pinzón beforehand. Once both had reached the islands, Salazar y Mazarredo put up a simulation which few could at first entirely believe. As his boat was approaching the Resolución, he was already trying to loudly inform Pinzón of the Peruvian government's "refusal to meet him." As one of the

\footnotetext{
${ }^{291}$ From E. Salazar y Mazarredo to J. Pacheco, Lima, April 12, 1864, in Cerda Catalán, "La guerra entre España y las repúblicas del Pacífico," (noviembre), pp. 45-46, 47: fn. 59.

${ }^{292}$ See Heredia, El imperio del guano, pp. 45-54; and Cerda Catalán, "La guerra entre España y las repúblicas del Pacífico," (noviembre), pp. 46ff.
} 
linguists on board of the Resolución, who later became Salazar y Mazarredo's personal secretary during his return trip to Spain, details:

On the 14th of April, at 10:30 am, the fleet being at the time within six miles of the Chincha Islands, we sighted the Spanish sloop of war "Covadonga," having on board Señor Salazar y Mazarredo. On drawing nearer, a boat was lowered from the latter vessel into which the envoy descended, and who was so childishly anxious to communicate the intelligence with which he was busting, that he stood up in the gig as it approached the flag-ship, and shouted to those on board to go and tell the Admiral that "they had refused to receive him." Two minutes afterwards, he came up the side and in an excited manner explained to the Admiral that the Peruvians had refused to grant him an audience. The result of their conversation was an order to have the vessels prepared for action! $!^{293}$

Salazar y Mazarredo was not, however, an isolated instigator. He was, together with local Spanish agents in Peru and other private individuals, largely instrumental to Spain's “foreign policy of prestige.” A closer scrutiny of Salazar y Mazarredo’s writings, memoirs, official and personal correspondence, as well as his actions, show that they were in harmony with the popular opinion in Madrid, as disclosed by the printed press and vividly discussed in the Spanish Courts at the time. ${ }^{294}$ This relative, yet uncoordinated, convergence between diplomats and military officers "on the ground" and Spain's cabinet back in Madrid is most evident by the ambiguous official position taken by Spain regarding the seizure of the islands by the Admiral of the "peaceful" Scientific Expedition to the Pacific. ${ }^{295}$ Although Spain's initial reaction was to publicly regret the decision to seize the islands, the official return of the islands was never issued by Madrid, who tried to leverage

\footnotetext{
${ }^{293}$ Cerruti, Peru and Spain, p. 8.

${ }^{294}$ For an exposition of this harmony of interests, see Heredia, El imperio del guano, p. 52; González Pizarro, La política de España en América, pp. 412ff; Del Campo Rodríguez, Por la república y por la Reina, pp. 51-71; Juan Antonio Inarejos Muñoz, "De la guerra del guano a la guerra del godo: Condicionantes, objetivos y discurso nacionalista del conflicto de España con Perú y Chile (1862-1867)," Revista de Historia Social y de las Mentalidades, Vol. 14, No. 1 (2010), pp. 137-170; and González Pizarro and Parodi Revoredo, "Una gesta común," pp. 105-149.

${ }^{295}$ See Heredia, El imperio del guano, pp. $52 \mathrm{ff}$.
} 
its momentary possession of the guano-producing islands to negotiate a favorable treaty with Peru over pending issues since the Peru's de facto declaration of independence in 1826. This hesitant position by Madrid played an important role early on in the conflict, for several South American nations_-including Chile, Argentina, and Ecuador-initially refused to come to Peru's aid against Spain, speculating that Spain would eventually discredit the royal agents' decision, return the islands, and then reestablish normal diplomatic relations.

\section{Legitimacy and Restraint in the War against Spain}

The Spanish occupation of the Chincha Islands on April 14, 1864 made a profound impression on the rest of the South American nations. The unexpected nature of it, coupled with the outrageous reasons invoked by the Spanish agents and the illegality of the form of the occupation itself (and perhaps also the geographical proximity of the incident), made possible what past European interventions in other areas of the American continent had not: the formation of a common front of South American nations against an extra-regional power. Peru, which had been at the forefront of past official protestations against Spain for its occupation of Santo Domingo, the surreptitious attempts in Ecuador, and its role in the Mexican case, was now at the receiving end of Spain's overseas policy of prestige and intimidation. Peru tried, therefore, to present the Spanish aggression as a continental issue in the hope that the involvement of the other South American nations would exert pressure on Spain's ambitions and induce some restraint on its foreign policy.

Despite a prominent history of rivalry between Chile and Peru over the hegemonic control of the South Pacific region, after the seizure of the guano islands major popular 
expressions of outrage against Spain and of solidary towards Peru erupted in Chile, Bolivia, and other countries, including parts of Argentina and Ecuador. Initial suspicions had been focused on Peru itself for its own irresponsibility in not having properly clarified its relations with Spain after independence and for the poor condition of its governmental budget and finances. ${ }^{296}$ These critiques, however, soon turned into unabashed expressions of popular support and official offers of mediation and assistance for the "sister republic" of Peru. For all the problematic aspects of Peru as a neighbor, none compared with its being taken advantage by Spain when it captured the heart of Peru's source of revenue and future prosperity. ${ }^{297}$

Between April and August 1864, the Pezet administration in Peru was thus caught in a complicated web of overlapping interests. Pressured by crippling financial difficulties, which were hard to explain to its own population given the bonanza of the guano market, it was also threatened by a relentless political opposition organized around both chambers of Congress. Pezet tried to simultaneously negotiate a peaceful solution to the conflict with Spain while also avoiding appearing weak or unpatriotic to Peruvian public opinion and political opposition. The Peruvian people demanded war against Spain, and so did Congress, who authorized the Executive by law to declare war. But Pezet was well aware of the relative weakness of the Peruvian "navy"-which at the time consisted only of a handful of wooden vessels that were no match for the Spanish squadron in the Pacific. Two

\footnotetext{
296 See Miriam Salas Olivari, El presupuesto, el estado y la nación en el Perú decimonónico y la corrupción institucionalizada, 1823-1879 (Lima: Instituto de Estudios Histórico-Marítimos del Perú, 2016); and Salas Olivari, Historia marítima del Perú. Vol. 11(4): “La República: 1879 a 1883 ” (Lima: Instituto de Estudios Histórico-Marítimos del Perú, 2011), esp. pp. 63-191.

${ }^{297}$ Robert Burr illustrates well how Chile came to see its own interest as imbricated with the defense of Peru's autonomy in the Chincha Islands incident. See Burr, By Reason or Force, pp. 90-106.
} 
modern ships had been commissioned in Europe by the previous administration but waiting for their completion was not a viable option. ${ }^{298}$

In this early stage of the conflict, therefore, an important source of restraint came from Peru itself given its incapacity to employ force effectively against the Spanish squadron. This incapacity, however, was not only material in the form of limited warfighting assets, but also immaterial in the form of political capital. Both the Peruvian Congress's pressure and public opinion, incensed and clamoring war in the streets of Lima, would have made it relatively easy for Pezet to declare war on Spain and put into practice some type of diversionary war. This would have at the same time distracted the domestic audiences from well-known corruption scandals and pressing financial debacle, as well as forced the hand of neighboring Chile and Ecuador into coming to Peru's aid. The political decision, however, was made by Pezet not to employ force against the Spanish vessels in the hope of negotiating diplomatically a peaceful resolution to the crisis. With this in mind, Pezet redoubled the administration's efforts to arrange a meeting in Madrid to nullify and redress the occupation, and to secure the safe return of the islands to Peru through diplomatic channels only. These negotiations, however, soon failed after the intransigence and dilatory tactics of the Spanish government. ${ }^{299}$

\footnotetext{
${ }^{298}$ Pezet's own reflections on this critical period were published some years later, after his removal from power. See Juan A. Pezet, Exposición del General don Juan Antonio Pezet, ex-Presidente del Perú (Paris: Berger, 1867). See also Antonio J. Chang Huayanca, "Entre la espada y la pared: La administración del Gral. Juan Antonio Pezet frente a la crisis diplomática con España (1863-1865)," Lic. Thesis, Lima: Universidad Nacional Mayor de San Marcos, 2013; and Luis Mesónes, La diplomacia y el Congreso (Turin: Imprenta de l'Italie, 1864).

${ }^{299}$ See Wagner de Reyna, La intervención de las potencias europeas, pp. 173-176, 156-159; Heredia, El imperio del guano, pp. 62-65; and Mesónes, La diplomacia y el Congreso.
} 
A related problem for Pezet was, therefore, the need to balance a peace with Spain, which he attempted on a bilateral basis through several Peruvian agents in Europe, with the successful framing of the occupation of the islands as an "American issue." ${ }^{300}$ On this important matter, Chile was the first of Peru's neighbors to come to its aid. Its support, however, came out not of "fraternal love" among both nations, but merely from the recognition by a group of clear-eyed Chilean politicians of the unacceptable precedent that the Spanish occupation would establish in the region. ${ }^{301}$ Through its diplomatic representative in Lima, J. Nicolás Hurtado, Chile tried to act as a chief mediator via the Diplomatic Corps in Lima between Admiral Pinzón and the Pezet administration. ${ }^{302}$

This effectively involved, at least initially, the representatives of other great powers, such as England, the United States, and France, in the ongoing diplomatic crisis. The Diplomatic Corps in Lima was led by Cristopher Robinson (U.S.), Thomas R. Elredge (Hawaii), W. M. Stafford Terringham (Great Britain), and J. Nicolás Hurtado (Chile). The representative of France, Ferdinand M. de Lesseps, however, given the absence of a Spanish representative, had a double role also as a representative of Her Catholic Majesty until an official Spanish representative was finally accredited in Lima. For this reason, de Lesseps voluntarily stayed aside from all the negotiations initiated by the Diplomatic Corps

\footnotetext{
${ }^{300}$ See Heredia, El imperio del guano, pp. 64-65; and Wagner de Reyna, La intervención de las potencias europeas, pp. 159-167.

${ }^{301}$ On this aspect of Chilean foreign policy towards Peru, see Alberto Wagner de Reyna, "La ocupación de las islas de Chincha y las relaciones chileno-peruanas," Boletín de la Academia Chilena de la Historia, Vol. 17, No. 50 (1954), pp. 5-70; Wagner de Reyna, Las relaciones diplomáticas entre el Perú y Chile durante el conflicto con España, 1864-1867 (Lima: Sol, 1963); Juan J. Fernández Valdés, Chile y Perú: Historia de sus relaciones diplomáticas entre 1819 y 1879 (Santiago: Cal \& Canto, 1997), pp. esp. 249-260; and Burr, By Reason or Force.

${ }^{302}$ See J. Nicolás Hurtado, La legación de Chile en el Perú desde abril hasta setiembre de 1864 i el conflicto peruano-español (Santiago: Librería del Mercurio, 1872); Fernández Valdés, Chile y Perú, pp. 252-257; and Wagner de Reyna, Las relaciones diplomáticas entre el Perú y Chile, pp. 15-91.
} 
with the two Spanish agents. During the first months after the occupation, therefore, Pezet was technically unable to use effective force against Spain and remained heavily dependent for political survival and domestic stability upon the rapidly deteriorating "public image" of his administration. The intervention of the Diplomatic Corps represented, in this context, an important lifeline after the unsuccessful attempts at negotiations in Europe and Madrid. Accordingly, Peru's Minister of Foreign Affairs, Juan A. Ribeyro, sent a letter to the Diplomatic Corps on April 16, 1864, protesting the Spanish occupation and requesting their involvement and support. ${ }^{303}$

After the occupation of the islands, Pinzón and Salazar y Mazarredo issued a memorandum to offer an explanation for their sudden and unannounced move. This statement was delivered on April 16 (two days after the occupation) by the chargé d'affaires of France acting as a momentary representative of Spain. The memorandum surprised everyone because in an important passage it claimed that the seizure of the Chincha Islands had been done as an "act of revindication" of former Spanish territory, given the current state of "truce" between both nations, and had been decided as a more peaceful alternative to what their instructions contemplated initially (the bombardment of Peruvian ports). ${ }^{304}$ The Diplomatic Corps rejected the claim of revindication and further indicated that their respective governments would continue to regard the islands as Peruvian territory. ${ }^{305}$ Notes of sympathy were sent by Argentina, Brazil, Chile, Bolivia,

\footnotetext{
${ }^{303}$ From J. Ribeyro to Agents of the Diplomatic Corps, Lima, April 16, 1864, in Cuestión entre el Perú y la España (Lima: Imprenta del Gobierno, 1864), pp. 60-62.

${ }^{304}$ See Wagner de Reyna, La intervención de las potencias europeas, pp. 122-124.

${ }^{305}$ See Davis, The Last Conquistadores, pp. 68-69; and Wagner de Reyna, La intervención de las potencias europeas, p. 125.
} 
Colombia, Costa Rica, El Salvador, France, Guatemala, Nicaragua, and Venezuela. ${ }^{306}$ The general reaction indicated that all South American states expected Madrid to disavow the occupation, recall its agents and the squadron, and establish formal relations with Peru after the return of the islands.

Taking advantage of this generalized sentiment, Ribeyro wrote directly to Pinzón on April 16, demanding explanations for the unprovoked aggression and expressing the administration's concern for the claim of revindication issued in the memorandum. Ribeyro further raised the issue that the Peruvian government could not realistically entertain the fact the Madrid could have approved a priori, or even reaffirm later, the seizure of the islands under any legal form or excuse. Ribeyro closed his letter by saying:

Whatever be henceforward your conduct, you may safely trust that the Spanish subjects which today reside in Peru will continue enjoying the most complete security in their persons without any danger of being insulted while they follow peaceably and honestly their own business. Sufficient advance in civilization has been made by Peru through the independence from what once was her mother country, to render unnecessary the taking of hostages as a security against her; it was reserved for you to revive a warlike custom which terminated with the times of barbarism and which is far from honoring the chief of the squadron of a nation pretending to be civilized. ${ }^{307}$

In this context, a second source of restraint came in the form of the web of legal and diplomatic entanglements to which Spain and its agents in the region were forced to confront. Both Peru and its allies, in great part due to their military weakness, employed international law and diplomacy, as well as claims about the "higher duties of all civilized nations" and international reputation, as alternative tools to try to restraint, contain, and

\footnotetext{
${ }^{306}$ See Peru, Ministerio de Relaciones Exteriores, Memoria del Ministerio de Relaciones Exteriores del Perú (1864), pp. 117-139; Davis, The Last Conquistadores, pp. 69-72; and Wagner de Reyna, La intervención de las potencias europeas, pp. 144-155.

${ }^{307}$ From J. Ribeyro to L. Pinzón, Lima, April 16, 1864, in Peru, Memoria del Ministerio de Relaciones Exteriores del Perú(1864), pp. 99-101.
} 
eventually repel Spain's interventionist foreign policy—short of declaring open war. At this early stage, the main channel for the implementation of this strategy was the set of negotiations conducted by the Diplomatic Corps in Lima, and incentivized by the Chilean representative in Lima, Nicolás Hurtado. But given de Lesseps's double diplomatic role, he soon distanced himself from all communications issued by the Diplomatic Corps itself. The representatives of the United States and of Great Britain, while expressing their support for the mediatory role adopted by the Diplomatic Corps, warned that their respective countries would not be ready to exert any further pressure on the matter. With them, all hopes for getting any of these great powers involved into the conflict dissipated. ${ }^{308}$ After receiving Ribeyro's note, the Diplomatic Corps met and soon agreed (upon Hurtado's insistence) to issue a collective statement aimed at the Spanish agents in repudiation of their occupation of the islands, which, according to the note, had been done in violation of international law principles. The importance of the Diplomatic Corps' note was that, unlike Ribeyro's first letter of protest to Pinzón, it focused on the truly substantive issue of the "revindication" of the islands, as initially claimed by Pinzón and Salazar y Mazarredo. As Wagner de Reyna correctly points out, "if Spain revindicated a part of the territory that once belonged to the monarchy, it could then invoke this same argument against any other; thus, all of South America would be threatened." ${ }^{309}$ The issue of the occupation of the Chincha Islands was, therefore, formally widened in scope as a regional concern, instead of being merely a bilateral one. With this move, as well, the Diplomatic

\footnotetext{
${ }^{308}$ See Hurtado, La legación de Chile en el Perú, pp. 9-31; and Wagner de Reyna, La intervención de las potencias europeas, pp. 124-126.

${ }^{309}$ Wagner de Reyna, La intervención de las potencias europeas, p. 126.
} 
Corps involved other considerations related to the violation of the Monroe Doctrine by Spain-in an attempt of interesting also the United States in the dispute.

The intervention of the Diplomatic Corps had, at least, two additional effects. First, it forced Pinzón and Salazar y Mazarredo to abandon their initial claim of "revindication" and issue a correction indicating that what they had actually meant was "reprisal." 310 Second, this relative success in forcing the Spanish agents to redact and tone down their claims had a more problematic indirect effect for Peru. The change in the Spanish agents' justifications unintendedly weakened Peru's efforts in presenting the occupation of the islands as an American issue. The change from revindication to reprisal, in other words, turned the issue back to a bilateral nature, as it was intended all along by Pinzón and Salazar y Mazarredo. For this reason, Ribeyro was forced to disavow the efforts by the Diplomatic Corps and distance the Peruvian government from their otherwise valuable negotiation efforts. With this, as well, Peru lost the potential for involving foreign great powers into the affair as an indirect way of constraining Spain's aspirations.

The neighboring countries, for their part, did not have any interest in risking a war with Spain who, in spite of being considered a second-rate power by most of them, was nevertheless a formidable opponent for the poorly-armed "navies" of South America. Not even the prospects of a combined naval force between Chile, Peru, Ecuador, Bolivia, and Argentina could seriously present a challenge to the relatively modern vessels of the Spanish squadron deployed in the Pacific. ${ }^{311}$ These vessels could also at any time be

\footnotetext{
${ }^{310}$ See Heredia, El imperio del guano, pp. 55ff; and Wagner de Reyna, La intervención de las potencias europeas, pp. 127-131.

${ }^{311}$ See Rodríguez González, La campaña del Pacífico, esp. pp. 20-34.
} 
reinforced with more frigates from the Caribbean station in Cuba. The only hope now rested in the avoidance of war altogether.

With this in mind, a plan was first conceived by Chile as a strategy of denial of access to all Spanish vessels to the main ports on the continent. ${ }^{312}$ The main idea was to isolate the squadron from all sources of fuel, food, water, and other resources, like coal and powder. But for this plan to be effective all South American states would have to come to understand that a defense of Peru's interest was also in South America's common interests as a region. Although Chile's plan for a regional alliance against Spain was only partially successful in recruiting South American states for the cause (only Ecuador and Bolivia joined in), it was ultimately a sufficient and effective way to present a "common front" against Spain and its foreign policy ambitions in the South Pacific region. All four allies, including Bolivia at the time, had ports on the Pacific Ocean, and could thus offer a concerted front in the most immediate area of the conflict forcing the Spanish squadron to rethink its own strategy. This championing of the South American regional interest, however, would also cost Chile dearly, for it eventually dragged the country into a direct confrontation with Spain the following year, with the subsequent bombardment and destruction of its main commercial port in the city of Valparaíso in March 1866 as a reprisal for its sustained diplomatic and material support to Peru. ${ }^{313}$

\footnotetext{
${ }^{312}$ See Carlos Grez Pérez, Los intentos de unión hispano americana y la guerra de España en el Pacífico (Santiago: Nascimento, 1928), pp. 233ff; and Fernández Valdés, Chile y Perú, pp. 302-303.

${ }^{313}$ See Alfredo Cerda Catalán, "La guerra entre España y las repúblicas del Pacífico, 1864-1866. Segunda Parte: La lucha armada," Revista Histórica [Santiago], Año LXXV, Tomo LIII, No. 160-162 (abril, 1982), pp. 75-90; and Rodríguez González, La campaña del Pacífico, pp. 67-74.
} 
The Chilean popular fervor was so strong in support for Peru's cause that, despite issuing a declaration "to all governments of America," Minister of Foreign Affairs, Manuel A. Tocornal, was forced to step down in early May, 1864, for not taking a resolute enough stance against the Spanish aggression. ${ }^{314}$ Álvaro Covarrubias, who's "Americanist" credentials were impeccable, was immediately sworn in as the new foreign minister. As part of a more invigorated diplomatic action, Covarrubias re-appropriated for South America the principles of the Monroe Doctrine, originally proclaimed unilaterally by the United States four decades earlier. In this sense, it proclaimed "[South] America for Americans. ${ }^{315}$

In early May, therefore, a new attempt at mediation by the Diplomatic Corps, this time led by Jerningham, pressured the Spanish agents for the immediate return of the islands, the exchange of salutes to the Peruvian and Spanish flags, the designation of new representatives in Lima and Madrid, and the re-establishment of formal diplomatic relations between both countries. This second diplomatic intervention had the important (yet unintended) effect of creating a split between Pinzón from Salazar y Mazarredo. Although initially both took responsibility for the act of occupation, Pinzón soon realized the manipulation to which Salazar y Mazarredo had subjected him in order to seize the islands in contravention of his (written) "confidential" instructions-hidden from him by Salazar y Mazarredo until the latter sailed back to Madrid. After all, from the vantage point

\footnotetext{
${ }^{314}$ See M. Tocornal, "Circular a los gobiernos de América," Santiago, May 4, 1864, in Chile, Ministerio de Relaciones Exteriores, Memoria del Ministerio de Relaciones Exteriores de Chile (1864), pp. 69-72; Davis, The Last Conquistadores, pp. 68ff; and Alberto Wagner de Reyna, "La misión Martínez ante el gobierno de Pezet (mayo-octubre de 1865)," Revista Histórica [Lima], Vol. 20 (1953), pp. 326-338.

${ }^{315}$ Chile, Memoria del Ministerio de Relaciones Exteriores de Chile (1864), pp. 5-29.
} 
of the cabinet in Madrid, Pinzón had decided to ignore his last instructions to move the squadron to Cuba. With the promise of helping explain his decisions upon his return to Madrid, Salazar y Mazarredo resigned his post and immediately sailed back to Spain to report in person about events. Pinzón, aware of his predicament, asked Madrid on repeated occasions to remove him from his post. He even threatened to resign himself before the Courts in Madrid had reached any decision-so as to facilitate Spain's diplomatic negotiations. ${ }^{316}$ Although Pinzón's wishes were fulfilled as soon as Salazar y Mazarredo reached Spain, the diplomatic crisis with Peru (and potentially its neighbors) was still active with little prospect of resolution any time soon. Moreover, diplomatic negotiations would get more complicated for Spain as the Diplomatic Corps soon gave way to the opening of sessions of the regional Congress, in Lima.

\section{Institutionalizing Order: Diplomacy and the Lima Congress of 1864}

One of the most remarkable developments of the 1860s in South America was the extent and frequency with which regional powers tried to formalize their diplomatic relations. Since the early decades after independence, and beginning with the first Congress of Panama in 1826, South American nations tried on several occasions to institutionalize their diplomatic relations, further regulating the use of force and war, as well as developing legal arrangements to coordinate common defense efforts against internal or external aggressions. ${ }^{317}$ Facing a rise in foreign interventions in the 1840 s and 1850 s in the form of

\footnotetext{
${ }^{316}$ Davis, The Last Conquistadores, pp. 77, 81-82.

317 See, e.g., Samuel Guy Inman, Inter-American Conferences 1826-1954: History and Problems (University Press, 1965); Germán A. De la Reza, El ciclo confederativo: Historia de la integración latinoamericana en el siglo XIX (Lima: Fondo Editorial de la Universidad Nacional Mayor de San Marcos, 2012); Grez Pérez, Los intentos de unión hispano americana, pp. 13-85, 152-168; Jesús M. Yepes, Del
} 
filibustering expeditions in Central America and parts of the South Pacific region, South American states met for a second time in Lima, in 1847-1848, and then again in Santiago in 1856 , with the main objective of articulating a common regional front, developing new legal principles to that effect, and in securing the popular "American" feeling of solidarity among the newly free nations of the continent. ${ }^{318}$

With this important precedent in mind, in early 1864 , Peru issued a convocation for a second Lima Congress, to meet later that year, to concretize a regional institutional scheme of common defense. This can be interpreted both as a "natural" development for the region, in continuation of past meetings, but also a far-sighted move on the part of Peru in anticipation of the arrival of the Spanish "scientific expedition." The main objectives of the meeting, according to Ribeyro, were "to declare that all American nations [...] form a single family linked by the same principles and identical interests," which are: "to sustain their independence, their rights to autonomy, and national existence."319

Although most American governments were formally invited, the Empire of Brazil was excluded. Ribeyro's note also avoided Central and North American nations. Argentina,

Congreso de Panamá a la Conferencia de Caracas, 1826-1954: El genio de Bolívar a través de la historia de las relaciones interamericanas (Caracas: Cromotip, 1955); Peru, Ministerio de Relaciones Exteriores, Congresos americanos de Lima: Recopilación de documentos precedida de Prólogo por Alberto Ulloa (Lima: Archivo Diplomático del Perú II-III; Imprenta Torres Aguirre, 1938); Enrique V. Corominas, Historia de las conferencias interamericanas, desde el Congreso de Panamá hasta la Conferencia Interamericana de Caracas, en 1954 (Buenos Aires: Propulsión, 1959); and Francisco M. Cuevas Cancino, Del Congreso de Panamá a la Conferencia de Caracas, 1826-1954 (Caracas: [n/d], 1976).

${ }^{318}$ Germán A. De la Reza, "La asamblea hispanoamericana de 1864-1865, último eslabón de la anfictionía," Estudios de Historia Moderna y Contemporánea de México, No. 39 (enero-junio, 2010), pp. 71-91; De la Reza, “¿Necesidad o virtud? Razones y alcances de los tratados continentales hispanoamericanos de 1856," Histórica, Vol. 38, No. 1 (2014), pp. 61-83; and De la Reza, "La dialéctica del fracaso: el Congreso americano de Lima (1847-1848) y su desenlace," Cuadernos Americanos, Vol. 134, No. 4 (octubre-diciembre, 2010), pp. 11-26.

${ }^{319}$ From J. Ribeyro to Chile's Minister of Foreign Affairs, Lima, March 26, 1864; and from J. Ribeyro to Bolivian Minister of Foreign Affairs, Lima, April 5, 1864, both in Peru, Congresos americanos de Lima, vol. 1, pp. 363-364, 373-378. 
for its part, participated with a delegate, Domingo F. Sarmiento, but delayed giving him full powers. Sarmiento, therefore, although present in the deliberations, had no vote in the assembly. Thus, with the exception of Brazil, all South American nations invited reacted positively to Peru's note of convocation. ${ }^{320}$ According to the Peruvian chancellor, the invited countries shared a sense of "proximity" and "common interests" that were lacking between other states. ${ }^{321}$ In the case of Brazil, a lingering suspicion dating as far back as the first Congress of Panama regarding the only monarchical government in the region, poisoned the diplomatic waters between Peru and Brazil in the 1850s. ${ }^{322}$ The outbreak of the war against Paraguay in December 1864 further strained these bilateral relations in the 1860 s and 1870s. In the midst of the Spanish aggression, for example, relations deteriorated so rapidly that Brazil's declared neutrality in the war with Spain would eventually lead to a break in diplomatic relations between Brazil and Peru over the final demarcation of their common border in the Amazon region. ${ }^{323}$

\footnotetext{
${ }^{320}$ See the reaction notes in Peru, Congresos americanos de Lima, vol. 1.

321 "Nota circular de invitación al Congreso," Lima, January 11, 1864, in Peru, Congresos americanos de Lima, vol. 1, pp. 337-342.

322 On the persistent suspicions by Latin American republics about monarchical Brazil (1822-1889), see Thomas Millington, Colombia's Military and Brazil's Monarchy: Undermining the Republican Foundations of South American Independence (Greenwood Press, 1996); Ron L. Seckinger, The Brazilian Monarchy and the South American Republics, 1822-1831: Diplomacy and State Building (Louisiana State University Press, 1984); Leslie Bethell, "Brazil and Latin America," Journal of Latin American Studies, Vol. 42, No. 3 (August, 2010), pp. 457-485; Luís C. Villafañe Gomes Santos, "Brasil: Americano, LatinoAmericano ou Sul-Americano?" Cuadernos del CLAEH, Año 28, Vol. 1, No. 90 (2a serie, 2005), pp. 87-107; and Ori Preuss, Bridging the Island: Brazilians' Views of Spanish America and Themselves, 1865-1912 (Iberoamericana Vervuert, 2011).

${ }^{323}$ See Luís C. Villafañe Gomes Santos, O Império e as repúblicas do Pacífico: As relações do Brasil com Chile, Bolívia, Peru, Equador e Colômbia (1822-1889) (Curitiba: Editora UFPR, 2002); Villafañe Gomes Santos, "As consequências da guerra da Tríplice Aliança na definição da identidade brasileira," Militares $e$ Política, No. 3 (julho-dezembro, 2008), pp. 42-58; and Richard Graham, "Brazil from the Middle of the Nineteenth Century to the Paraguayan War," in The Cambridge History of Latin America, Vol. 3: pp. 747794.
} 
Although the Spanish occupation occurred in mid-April of 1864, and the Lima Congress would not formally meet until November, during the in-between months the presence of distinguished personalities arriving from neighboring countries in Lima for the Congress created a second opportunity for Pezet's administration to channel the Chincha Islands question as a regional, instead of merely a bilateral, issue. Contrary to the Diplomatic Corps' early interventions, however, this time Peru would be an integral member of the delegations in the regional Congress and, thus, also a part in the negotiations themselves. ${ }^{324}$ The delegates to the Lima Congress were experienced and well-respected personalities from neighboring countries. Most prominently among them were Manuel Montt from Chile, Domingo F. Sarmiento from Argentina, Juan de la Cruz Benavente from Bolivia, Justo Arosemena from Colombia, Vicente Piedrahíta from Ecuador, Pedro Alcántara Herrán representing El Salvador, Antonio L. Guzmán from Venezuela, and José G. Paz Soldán from the host country. The Congress was invoked with a larger and more encompassing agenda than the resolution of the Spanish occupation, including telecommunications, international arbitration, border or limit agreements, postal conventions, among other issues. The main concerns, however, were common defense, regional identity, and the peaceful resolution of disputes inter se. The Lima Congress, however, saw itself as legally and political competent to intervene diplomatically in the issue of the Spanish occupation of the Peruvian islands. Between the months of November, 1864 , and January of the following year, in fact, the "Spanish question" absorbed almost all the attention of the delegates. ${ }^{325}$

\footnotetext{
${ }^{324}$ Davis, The Last Conquistadores, pp. 115-118.

${ }^{325}$ De la Reza, "La asamblea hispanoamericana de 1864-1865," pp. 71-91.
} 
The first, and perhaps most relevant, consequence of the involvement of the Lima Congress in the Chincha Islands issue was the legitimation of the Peruvian claim of the incident as an American affair. ${ }^{326}$ This important diplomatic "victory" for Peru, however, ran against an unexpected move by Madrid. While the rest of the South American nations waited for a direct and unambiguous disavowal of the Spanish agents' fateful decision before deciding on which foreign policy strategy to adopt towards Peru, the dismissal order was never issued. Coinciding with the formal establishment of the Lima Congress in November 2, 1864, Spain finally decided to recall Pinzón and replace him with Vice Admiral José M. Pareja. This signaled that Isabel II's cabinet was redoubling its efforts and taking the Chincha Islands incident more seriously. With Pinzón and Salazar y Mazarredo out of the picture, Pareja took control not only of the Spanish squadron but the legal representation of Spain in the entire Pacific region as well. That is, his instructions gave him ample powers that surpassed even the diplomatic missions of other representatives, such as San Salvador de Tavira, chargé d'affaires in Santiago since $1848 .{ }^{327}$ Pareja was, in other words, a super-representative of Spain with wide margins of decision in situ, given the vast distances and the time-sensitivity of many diplomatic negotiations expected to take place. This had been, after all, one of Salazar y Mazarredo's excuses in Madrid, claiming that the vast distances and their impact on communications had forced him and Pinzón to make expedient and resolute decisions on the ground. In this context, however, Spain was

\footnotetext{
${ }^{326}$ Davis, The Last Conquistadores, pp. 117, 146; and Wagner de Reyna, La intervención de las potencias europeas, pp. 201-231.

${ }^{327}$ See Heredia, El imperio del guano, p. 74.
} 
sending with Pareja an even more hard-liner agent than the preceding ones, to defend and extend Spain's prestige abroad.

The arrival of the new naval commander, therefore, acted as a bulwark against the renewed diplomatic efforts by the groups of South American delegates gathered in the Lima Congress. Unlike Pinzón, for example, Pareja showed the most inflexible diplomatic stances, re-focusing on the importance for Spain of receiving a 21-gun salute to the Spanish flag before accepting to seat down to negotiate the devolution of the islands to Peru. Peru, as it was expected, refused to this article, explaining that Spain should first recreate the status quo ante before initiating negotiations. The bilateral negotiations, unsurprisingly, stalled once again. Thus, although the Lima Congress was successful in consolidating the Spanish occupation as an aggression against the autonomy and interest of all South American nations, little else was possible — short of using force against the squadron. The opportunity for this presented itself on November 25, 1864, when one of the main vessels, the Triunfo, accidentally caught fire during the night and was destroyed. The Spanish squadron's lost with it half of its fire capacity. Extensive debates over whether to initiate an attack or not against the weakened Spanish squadron at the heart of the Lima Congress were finally inconclusive, and soon the window of opportunity for any kind of bold action passed. With this, as well, the Congress passed the buck and the full weight of the negotiations with Pareja returned, once again, to Pezet's administration.

Facing an increasingly ardent and war-mongering citizenry, on which the opposition in the Peruvian Congress tried to capitalize, Pezet decided to close the legislative body and incarcerate several opposition political leaders. Attacks by the printed press accused the administration of treason and a number of conspiratory claims inflamed 
the political climate in Lima. Pressured by the situation, Pezet decided to change his entire cabinet in an attempt to alleviate the popular pressure on his government, which was utterly impotent in the face of the Spanish squadron. After replacing J. Ribeyro with Toribio Pacheco, in a sudden attempt at recovering the islands - something he had promised one night after a popular uprising outside the government palace demanding war-Pezet commissioned General Vivanco, a long-time personal friend and an experienced political ally with a positive image in Madrid, to negotiate with Pareja a final treaty to resolve the incident peacefully once and for all.

Pressed between a tumultuous domestic scenario and an optionless international front, Pezet tried to involve neighboring states and present the issue as an American affair. Yet, the speculative diplomatic stance of Pezet's administration of avoiding bilateralism while simultaneously trying to avoid the use of force to cut a deal with Spain directly, ultimately damaged Peru's relations with Argentina, Ecuador, Chile, and Uruguay. In this context, the Vivanco-Pareja Treaty, signed on January 27, 1865, while it secured the return of the islands (effective on February 3), it also accepted multiple clauses that the Peruvian newspapers and public opinion in general considered offensive, derogatory, and infamous to Peru's national honor. One of the most controversial "demands" by Pareja was the payment of 3 million pesos (pesos fuertes españoles). The popular outcry in Lima and elsewhere was so severe that a political revolution immediately ensued and in a matter of months the Pezet administration was violently removed from power by a civil-military coalition formed in the southern regions of the country and led by Manuel I. Prado. By the end of 1865, once Prado had secured a victory, the Vivanco-Pareja Treaty was declared null and void, and all other articles included in the agreement were rejected. Not soon after, 
Spain was forced to declare war on Peru for the violation of the treaty, while insinuating that a re-occupation of the islands could take place. ${ }^{328}$ But before any decisive action was agreed against Peru, Spain refocused its attention on Chile.

Given the open-ended nature of the revolution, Spain decided not to engage with Peru first to avoid getting dragged into an unfolding civil war for which it was not prepared logistically nor diplomatically. While Pareja, with a keen strategic eye for the situation, chose to wait for most of the second half of 1865 for Prado to consolidate his power, Chile became his new center of attention. During the early months of the occupation, Tocornal's rather timid circular note to all the South American nations denouncing the seizure of the islands as an act of aggression with no basis in international law, and an affront to all civilized nations, had nevertheless created a negative image of Chile in Madrid. The fatal error of Tocornal's note, which cost him his post due to the animosity of the Chilean public opinion, was that it was not stern and committed enough. The circular was, in fact, an offer of mediation rather than an implied ultimatum to Spain and a "call to arms," as the Chilean people demanded. ${ }^{329}$ After Tocornal's removal, the more combative and "Americanist" Covarrubias reaffirmed Chile's overall critical tone regarding Spain's actions in the Pacific while abandoning any pretensions (or hopes) of maintaining intact Chile's relations with Spain. ${ }^{330}$

\footnotetext{
${ }^{328}$ See Grez Pérez, Los intentos de unión hispano americana, pp. 169-186; Davis, The Last Conquistadores, pp. 145-169, 189-207; Wagner de Reyna, La intervención de las potencias europeas, pp. 225-250; and Novo y Colson, Historia de la guerra de España en el Pacífico, pp. 227-269.

${ }^{329}$ See Wagner de Reyna, La intervención de las potencias europeas, pp. 141-144; and Davis, The Last Conquistadores, pp. 171-172.

${ }^{330}$ Davis, The Last Conquistadores, pp. 139, $189 \mathrm{ff}$.
} 
With the change in the Foreign Ministry in Chile, Pareja considered that the more conciliatory efforts by Spain's representative in Santiago also needed to change. With this in mind, Tavira was asked to contact Covarrubias to ask for a detailed set of explanations for Chile's foreign policy behavior during the Chincha Islands question. Pareja wanted to hold Chile accountable for the formally "neutral," yet informally partial, diplomatic position towards Spain during the crisis with Peru. Apart from Tocornal's circular note and Covarrubias' subsequent efforts in championing a regional alliance against Spain in the Pacific, Chile had also declared coal and other food products as "war contraband" items. Hiding behind such a partial "neutrality," Pareja believed, Chile was specifically hurting Spain, since Peru had no proper navy to fuel nor sailors to feed. ${ }^{331}$

\section{The Quadruple Alliance: South America’s Pragmatic Solidarity}

Although Chile's traditional foreign policy since the 1830s had been the prevention of the interference of extra-regional powers in South American affairs (and particularly in the South Pacific), ${ }^{332}$ the animosity against Spain had played a crucial role in its overall diplomatic initiative of closing off all Pacific ports to the Spanish squadron. As part of this strategy, Chile's declaration of the trading of coal and food as contraband - that is, as warsensitive materials, was a direct provocation to Pareja. This, as well, coming from a "neutral" state, had two immediate implications. First, it implied that for Chile the Spanish occupation of the islands equated to "a war" between Spain and Peru. Second, despite

\footnotetext{
${ }^{331}$ For an excellent analysis of the complexity of the situation, which was rapidly deteriorating, between Spain and Chile, see Heredia, El imperio del guano, pp. 72-90; and Wagner de Reyna, La intervención de las potencias europeas, pp. 273-275, 279ff.

332 See Burr, By Reason or Force.
} 
Chile's claims to "neutrality," Spain could not consider its foreign policy as truly neutral, but as antagonistic. Behind Pareja's demands for explanations, therefore, was a veiled effort at intimidation to further isolate Peru from any regional network of support. This was increasingly important if Pareja wanted to re-negotiate with Prado a new treaty, and to avoid a new occupation of the guano islands.

Salvador de Tavira, Spain's representative in Santiago, in an attempt to prevent a war between Chile and Spain, came to an agreement with Covarrubias, which was officially signed on May 13, 1865. Despite his multiple positive notes sent to Madrid trying to ease the diplomatic tension, Pareja's instructions had given him power to override Tavira, if so needed. Set on extricating an official apology from Chile itself, Pareja rejected the TaviraCovarrubias agreement and directed the squadron south. On behalf of the Vice Admiral, Tavira was then recalled to Madrid, leaving no other intermediary between the squadron and Chile than Pareja himself. ${ }^{333}$ By early September, 1865, the Spanish vessels were already outside Valparaíso. Pareja decided to lay anchor in front of the Chilean port precisely on the 17th, a day of national festivities in Chile, as the country celebrated its independence from Spain(!). Upon arrival, and mediating no other communication beforehand, Pareja sent Covarrubias an ultimatum on September 18, in which he reviewed all the acts of animosity towards Spain over the previous year, and closed with a pretentious demand for an official apology and a 21-gun salute to the Spanish flag. After a heated exchange of notes with Pareja, in which the Chilean Minister of Foreign Affairs outright rejected all such demands and intimidation tactics, Covarrubias followed through with a

\footnotetext{
${ }^{333}$ Davis, The Last Conquistadores, p. 217.
} 
sudden declaration of war on the 24th of that month. "Chile," said Covarrubias, "will never purchase peace at the cost of her dignity and her rights. ${ }^{\prime 334}$ In over a year after the Spanish occupation of the Chincha Islands, Chile was now engaged in a declared international war with the former Motherland, Spain, even before Peru itself, where the whole crisis had originally begun. Since Prado's administration had counted on Chile's support during the uprising that deposed Pezet from power, the worst scenario imagined by Pareja was now coming to fruition: Peru and Chile had become natural allies. By early 1866, Peru issued its own declaration of war against Spain and a defensive military alliance between both countries was finally established.

In order to erect a truly effective "common front" against Spain, however, Chile and Peru needed to secure at the very least the support of Bolivia and Ecuador, the other two other countries with ports on the Pacific coastline. With this objective, Chile put in motion an aggressive multipronged diplomatic initiative that included the entire hemisphere. Covarrubias' first move was to stall Pareja, to delay for as long as possible the squadron from taking military action— given Chile's military powerlessness. Covarrubias tried to gain time, for example, by involving the Diplomatic Corps in Santiago, and U.S. representative Thomas H. Nelson in particular. Faced with a sudden war that few diplomats in Santiago foresaw or imagined, the Diplomatic Corps tried to encourage their own respective governments to intervene directly with Madrid in order to refrain Pareja from taking any military action. ${ }^{335}$ These dilatory tactics were ultimately successful, for Pareja's

\footnotetext{
${ }^{334}$ From Á. Covarrubias to J. Pareja, Santiago, September 23, 1865, in Chile, Memoria del Ministerio de Relaciones Exteriores de Chile (1866), pp. 16-17. See also

${ }^{335}$ Wagner de Reyna, La intervención de las potencias europeas, pp. 341-354.
} 
deadline was crossed without any violent act on behalf of the Spanish squadron until March 1866. Although these negotiations eventually failed, Covarrubias gained important extra time for the creation of a second front. This alterative front involved the active deployment of a set of Chilean diplomatic missions to all the countries in the region, and including the United States, in an attempt to secure their support, if not their outright addition to the Chile-Peru alliance.

Special envoys were sent out, first to Venezuela, Peru, Bolivia, and Ecuador, but then also to Argentina, Uruguay, and Brazil. The Chilean mission to Venezuela was important because of the country's ports on the northern part of the region, which could play an important role in harassing Spanish vessels in the Caribbean and in delaying them from coming to reinforce the squadron in the Pacific. ${ }^{336}$ Although Manuel A. Matta's mission to Caracas failed to secure Venezuela's official alliance, it managed to undermine Spain's image in that country and rattle up the public opinion in Caracas in favor of the American allies, reflected in the printed press, cultural events, and in other displays of public opinion. ${ }^{337}$

The Chilean mission to Peru had the objective to further coordinate with the Prado administration the combination of both countries' navies. ${ }^{338}$ The mission was ultimately a success, for a coordination with Peru's forces was achieved and by early 1866 both

\footnotetext{
${ }^{336}$ On the Chilean mission to Caracas, see Fermín Toro Jiménez, Fermín. Una misión diplomática en Venezuela, 1866 (Caracas: Facultad de Derecho, Universidad Central de Venezuela, 1971).

${ }^{337}$ See, .e.g., El Federalista, January 19, 22, 24, and 25, 1866.

${ }^{338}$ On the mission to Lima, see Alberto Wagner de Reyna, "La misión Santa María en el Perú (octubre 1865-enero 1866)," Apartado del Boletín de la Academia Chilena de la Historia (Santiago: Imprenta Universitaria, 1952), pp. 1-48; Wagner de Reyna, Las relaciones diplomáticas entre el Perú y Chile, pp. 167-216; and Fernández Valdés, Chile y Perú, pp. 305-309.
} 
countries officially declared war on Spain. Peru's contribution was crucial for Chile because the combined navies could present a more viable military plan of resistance against the Spanish squadron than either of them in isolation. ${ }^{339}$ Domingo Santa María, Chile's special envoy, met with Pacheco, Peru's Minister of Foreign Affairs in the new Prado administration, and an Offensive and Defensive Treaty of Alliance was signed on December 5, 1865 (and ratified the very next month by both governments). ${ }^{340}$

The Chilean missions to Ecuador and Bolivia, for their part, secured their incorporation to the alliance during the early months of $1866 .{ }^{341}$ With the joining of these two Pacific countries, Chile achieved a strategic, as well as a symbolic, victory. It was strategic because with their collaboration now all major ports on the Pacific coastline could be denied to the Spanish squadron, which would have to utilize distant bases to remain operational — this also meant that supply lines could be harassed by the much smaller allied fleet without having to engage directly with the powerful Spanish frigates. But it was also

\footnotetext{
${ }^{339}$ On the negotiation and composition of the allied navy, see Wagner de Reyna, Las relaciones diplomáticas entre el Perú y Chile, pp. 288-309.

340 "Tratado de alianza ofensiva y defensiva," Lima, December 5, 1865, in Aranda, Colección de los tratados, Vol. 4: pp. 70-72.

${ }^{341}$ On the Bolivian incorporation to the alliance, see Juan Siles Guevara, "Juan de la Cruz Benavente y la participación de Bolivia en la cuádruple alianza contra España de 1866," in Revisiones bolivianas (La Paz: José Camarlinghi, 1969), pp. 77-101; Davis, The Last Conquistadores, pp. 266-267; and Bolivia, Ministerio de Relaciones Exteriores, Memoria que el ex-Secretario General de Estado y actual Ministro de Gobierno, Justicia y Relaciones Exteriores de la República de Bolivia presenta a la Asamblea Nacional Constituyente reunida en 1868 (La Paz: Imprenta Paceña, [1868]), pp. 100-154. On Ecuador's joining to the alliance, see Richard Pattee, "García Moreno y la política internacional ecuatoriana," Boletín de la Academia Nacional de Historia [Quito], Vol. 17, No. 50-53 (enero-junio, 1939), pp. 199-206; Pattee, Gabriel García Moreno y el Ecuador de su tiempo (México DF: Jus, 2nd ed., [1941] 1944), pp. 339-357; Jorge W. Villacrés Moscoso, Historia diplomática de la República del Ecuador (Guayaquil: Programa Editorial de la Biblioteca de la Muy Ilustre Municipalidad de Guayaquil, 3rd ed., [1989] 2007), Vol. 2: pp. 21ff; Villacrés Moscoso, "El rol del Ecuador en el ofrecimiento de la mediación de la cuádruple alianza de la guerra entre el Paraguay y la Triple Alianza," Boletín de la Academia Nacional de Historia [Quito], Vol. 51, No. 112 (julio-diciembre, 1968), pp. 200-202; Davis, The Last Conquistadores, pp. 265-266; and Exposición del Ministerio del Interior y Relaciones Exteriores dirigida a las Cámaras Legislativas del Ecuador en 1865 (Quito: Imprenta Nacional, 1865), pp. 31-36, I-XXVII.
} 
a symbolic victory because, although neither Ecuador nor Bolivia had an effective navy or army to increase the allied military capacity, both contributed with supplies and military equipment useful for combined navies of Chile and Peru. Ecuadorean forces even participated in the defense of the Peruvian port of Callao later that year. ${ }^{342}$ With this participation, therefore, the Quadruple Alliance was formed and the war against Spain was now formally declared. ${ }^{343}$

The Chilean mission to the River Plate countries, unlike the preceding ones, was headed by only one individual, José V. Lastarria. His mission was to reach out to Argentina, Uruguay, and Brazil, and try to secure their collaboration in the allies' war effort, if not join them altogether. This was, perhaps, the most important and ambitious mission for Chile, for Argentina and Uruguay were being used as alternative ports by Pareja to bypass the closing of all ports in the Pacific. ${ }^{344}$ But these three countries, as well, had been involved in a war with Paraguay since December 1864; and no clear end was in sight at the time. Lastarria had, thus, a tremendously important mission on his hands, for securing a coalition of countries against Spain on both sides of the region, the Pacific as well as the Atlantic, would have certainly accelerated the end of Spain's plans and forced the squadron

\footnotetext{
${ }^{342}$ On the Ecuadorean contribution to the battle of May 2, 1866 in Callao, see Alfredo Luna Tobar, El Ecuador en la independencia del Perú (Quito: Banco Central del Ecuador, 1986), Vol. 2: pp. 303-314.

${ }^{343}$ Although Colombia was also sought out by Chile to join the alliance, little progress could be achieved due to an ongoing civil conflict at the time. The Colombian press and public opinion, however, were amply in favor of the allied cause. See Yoer J. Castaño Pareja, “'La diplomacia secreta': La participación de Colombia en el conflicto entre Perú y España por las islas guaneras," Historia y Sociedad, No. 24 (enerojunio, 2013), pp. 189-214.

${ }^{344}$ See Carlos J. Larraín de Castro, La misión Lastarria, 1865-1866 (Santiago: El Imparcial, 1940); Burr, By Reason or Force, pp. 99-104; Pablo Lacoste, "Americanismo y guerra a través de El Mercurio de Valparaíso (1866-1868)," Anuario de Estudios Americanos, Tomo LIV, No. 2 (1997), pp. 567-591; and Juan J. Fernández Valdés, La República de Chile y el Imperio del Brasil: Historia de sus relaciones diplomáticas (Santiago: Bello, 1959), pp. 44-62.
} 
to return to Spanish waters. A related aspect of Lastarria's mission was to get approval by the Argentine and Uruguayan authorities for Chile's issuing of letters of marque in the Atlantic, in order to extend the harassment tactics against Spanish supply vessels beyond the South Pacific region and into the South Atlantic - and possibly into the Caribbean as well. ${ }^{345}$ Despite Chile's participation in the Declaration of Paris of 1856, where privateering had been outlawed, the official authorities in Santiago deemed it necessary to begin issuing letters of marque as a justified (legal) strategic option, given the allies' virtual incapacity to wage naval warfare against the Spanish squadron. Explaining Chile's position, Covarrubias argued that since Spain was not a party to the Paris declaration, privateering was still a valid tactic against Spanish vessels. ${ }^{346}$

Lastarria's mission to the River Plate countries met with a complex scenario in that region of South America, as the Argentina-Uruguay-Brazil alliance was entering a middle phase in its bitter war with Paraguay, and each of the allies had stable relations with Spain at the time. Argentina, for example, had just finished negotiating a treaty in Madrid not only reassuring its independence, but also the legal status and rights of Spaniards born on Argentine soil. ${ }^{347}$ During their initial voyage towards Chile and Peru, the Spanish "Scientific Expedition" had made stops in Brazilian, Uruguayan, and Argentine ports, in which Pinzón had been received with full honors and wide approval by the printed press

\footnotetext{
345 See Heredia, El imperio del guano, pp. 101-102.

${ }^{346}$ See Great Britain, Foreign Office, Correspondence Respecting the War Between Chile and Spain: Confidential F.O. 420: 21 [HC-PP] (London: Harrison, 1866), pp. 20-41; Lacoste, "Americanismo y guerra," p. 576; and Davis, The Last Conquistadores, pp. 275-277.

347 See Mario Belgrano, "La cuestión de la nacionalidad y el tratado con España de 1863," Anuario de Historia Argentina, Vol. 2 (1940), pp. 47-64.
} 
and the general public. ${ }^{348}$ During the stage of open war between Spain and the Quadruple Alliance, the River Plate allies were accused on several occasions of providing assistance to supply vessels under non-Spanish flag but which were known to be assisting Pareja's squadron in the Pacific. In Uruguay, for its part, Lastarria was caught in a diplomatic crossfire between his Foreign Ministry in Santiago and Montevideo over the issue of privateers in the River Plate area. After a confusing exchange of accusations and denials, Uruguay revoked Lastarria's credentials and his diplomatic mission in that country was thus bluntly interrupted. ${ }^{349}$ Coupled with their refusal to accept Chile's issuing of letters of marque and the practice of privateering in the Atlantic area, the mission entrusted to Lastarria cannot be categorized as anything but a total disaster for the cause of the allies in the Pacific.

One of Chile's most ambitious diplomatic missions was the one sent to the United States itself, and led by Benjamín Vicuña Mackenna. The objectives of the mission were to have a positive impact on the printed press and help reinforce an already pro-Chilean public opinion in order to excerpt pressure on the U.S. Department of State and thus precipitate the involvement of the U.S. and the invocation of the Monroe Doctrine against Spain. A secondary objective was to help fund and radicalize private individuals eager to

\footnotetext{
${ }^{348}$ Cerda Catalán, "La guerra entre España y las repúblicas del Pacífico," (abril), pp. 1-48; Miguel Á. De Marco, La armada española en el Plata (1845-1900) (Rosario: Universidad Católica Argentina, 1981); and Emilio Esteban-Infantes y Marín, Expediciones españolas: Siglo XIX (Madrid: Instituto de Cultura Hispánica, 1949).

${ }^{349}$ For the exchanges between Uruguay and Chile, leading to the expulsion of the Chilean Minister from Montevideo, see Uruguay, Ministerio de Relaciones Exteriores, Negociaciones entre el gobierno oriental del Uruguay i el ministro diplomático de Chile sobre el consulado chileno en Montevideo y la venta de presas (Buenos Aires: Imprenta de Buenos Aires, 1866); J. G. Courcelle Seneuil, La guerra entre España i Chile: Los neutrales i el derecho de jentes (Santiago: Imprenta de la República, 1866); and Larraín de Castro, La misión Lastarria, 1865-1866. See also Uruguay, Ministerio de Relaciones Exteriores, Publicación oficial del negociado entre el Ministerio de Relaciones Esteriores y el Sr. Enviado Estraordinario y Ministro Plenipotenciario de la República de Chile, con motivo de su pretensión sobre venta de presas que las fuerzas navales chilenas pudieran hacer a la España (Montevideo: La Tribuna, 1865).
} 
organize rebellions in Cuba against the Spanish rule on the island. Mackenna's mission was doomed to failure the moment that the U.S. government arrested him for espionage and released him months later under Chile's claim that he was, after all, acting in official capacity as a diplomatic envoy to the U.S. - despite not having been declared as such from the beginning. The failure of Mackenna's mission left Chile with the only option of redoubling its efforts in re-stating the principles contained in the Monroe Doctrine and make them an intricate component of a foreign policy of regional cooperation against Spain. $^{350}$

After Pareja's ultimatum to Chile and the formal declaration of war, a new phase in the Guano War began. The combined navies of Chile and Peru, while avoiding direct confrontation with the Spanish vessels, managed to open a military front previously unimagined by Pareja. The Spanish squadron, in order to make their demands more credible, instituted a blockade of all the Pacific ports—but particularly Valparaíso. This decision, however, was a grave mistake. In practical terms, it divided the squadron into smaller groupings of ships in charge of blockading each individual port along an extensive 4,000-mile coastal line stretching from Chile to Ecuador. This opened up an opportunity for the less numerous allied vessels to harass each group of Spanish ships individually and on a more even basis. In one such encounter, the allied "navy" managed to capture the schooner Covadonga, which was immediately added to the allied forces. After this important turn of events, Spain was reduced to a total of 217 guns, while the allied navy

\footnotetext{
${ }^{350}$ On Mackenna's mission to the U.S., see Benjamín Vicuña Mackenna, Diez meses de misión a los Estados Unidos de Norte América como ajente confidencial de Chile (Santiago: Imprenta de la Libertad, 1867). 2 vols. See also Cristián Guerrero Yoacham, "La misión de Vicuña Mackenna a los Estados Unidos (1865-1866), Atenea, Vol. 454 (1986), pp. 239-275; Heredia, El imperio del guano, pp. 87-89, 107-108; and Davis, The Last Conquistadores, pp. 284-289.
} 
was upgraded to 130 guns. The Covadonga was the second vessel lost since the beginning of the expedition in 1863, after the fire accident on board the Triunfo. Faced with this new reality, Pareja felt so deeply embarrassed and humiliated — an embarrassment, one must add, bolstered by his own sense of cultural superiority - that, upon receiving news of the loss of the Covadonga, he decided to take his own life on board of the flagship Villa de Madrid on November 28, 1865, while stationed in front of the port of Valparaíso. ${ }^{351}$

Casto Méndez Núñez, captain of the Numancia, replaced Pareja as commander of the squadron. Compelled by the situation and the need to re-establish Spain's honor after such unfortunate blows to the squadron (both moral and material), Méndez Núñez decided to carry on with Pareja's earlier ultimatum and after a hiatus of several months, on March 31, 1866, he decided to bombard and destroy Valparaíso-an unarmed, civilian, commercial port. ${ }^{352}$ The act was so outrageous according to the legal standards of the time that not only other South American nations outside the formal Quadruple Alliance, which had been ambiguously "neutral" (like Argentina and Brazil) and even antagonistic (like Uruguay), announced their public indignation at the bombardment and the most adamant condemnation of such a "barbarous act." 353 Argentina's Minister of Foreign Affairs, Rufino de Elizalde, issued a harsh letter of protest claiming that Argentina would break their friendly relations if the Spanish squadron persisted in using force against civilian

\footnotetext{
351 The whole episode is well explained in David J. Woods, The Bombardment of Paradise (Geneva: WTA Publishing, 2011).

352 Davis, The Last Conquistadores, p. 264.

${ }^{353}$ See Cerda Catalán, "La guerra entre España y las repúblicas del Pacífico," (abril), pp. 75, 48, 3, 50, 52: fn. 78, 58; Mariano Varela, et al., "Bombardeo de Valparaíso: Protesta de la prensa de Buenos Aires," La Revista de Buenos Aires, Vol. IX, Año III, No. 34 (febrero, 1866) pp. 321-324; Bombardment of Valparaiso (Documents Officiels) suivi du Combat du Callao (Paris: 2nd ed., corrected and enlarged, 1866); Davis, The Last Conquistadores, pp. 304, 245-259; and Novo y Colson, Historia de la guerra de España en el Pacífico, pp. 327-362.
} 
towns and ports. ${ }^{354}$ In Bolivia and Ecuador, spontaneous popular manifestations broke out in the streets against Spain and its citizens, and in "Americanist" solidary with Chile, thus turning the tables in favor of Bolivia's expedient entry into the alliance. ${ }^{355}$ Lastly, Brazil maintained a cautious neutrality which privileged its ongoing war with Paraguay and its good relations with fellow monarchical Spain. Its chargé d'affaires in Santiago, Francisco Adolfo Varnhagen, however, created a little controversy by joining the Diplomatic Corps in Chile in its expressions of condemnation for the bombardment of Valparaíso. After recalling Varnhagen back to Rio de Janeiro, Brazil signaled a much more restrained approach to the incident. This cold, yet not opportunistic, foreign policy would cost Brazil dearly in terms of damaged relations with Chile for at least a decade, and a much more problematic relation with Peru, who broke relations with Brazil after the war. ${ }^{356}$

\footnotetext{
${ }^{354}$ For the correspondence between Elizalde and Chile's Minister of Foreign Affairs, as well as with Mariano Balcarce, the Argentine representative in Europe, see the excellent essay by Mario Belgrano, "España y el conflicto del Pacífico, 1864-1867," in Contribuciones para el estudio de la historia de América: Homenaje al Doctor Emilio Ravigniani (Buenos Aires: Peuser, 1941), pp. 515-549. For Elizalde's revealing communications with Domingo F. Sarmiento, the Argentine representative in Chile and Peru, see Domingo F. Sarmiento, Obras (Buenos Aires: Imprenta Mariano Moreno, 1900), Vol. 34; and Néstor T. Auza, La misión Sarmiento en Chile y Perú y el Congreso Americano, 1864-1865 (Buenos Aires: Histórica, 2007). The original documents were consulted at the Archivo del Ministerio de Relaciones Exteriores y Culto, Argentina, Boxes AH051, No. 42-77: "Misión Sarmiento en Chile," and "Misión Sarmiento en Perú."

${ }^{355}$ See Protesta del pueblo orureño contra el ultraje inferido a la soberanía nacional del Perú, a nombre de la Reina de España, por su escuadra, al mando del Almirante Pinzón (Oruro: Vargas, 1864); Gran comicio popular, reunido con motivo del bombardeo de Valparaíso en la ciudad de Potosí a 23 de abril de 1866 ([Potosí]: Tipografía del Progreso, [1866]); Villacrés Moscoso, "El rol del Ecuador en el ofrecimiento de la mediación...," pp. 201-202; and Siles Guevara, "Juan de la Cruz Benavente y la participación de Bolivia."

${ }^{356}$ On the Varnhagen mission and the controversies that the Guano War created for Brazilian relations with the Pacific countries, see José A. Ribas Miranda, "Peso da neutralidade: Varnhagen e o Governo Imperial ante a crise das ilhas Chincha (1864-1865)," Anais Eletrónicos do X Encontro Internacional da ANPHLAC, 2012, pp. 1-11; Ribas Miranda, “'Diplomata mais amante do seu paiz que das suas commodidades': Atuação de Francisco Adolfo de Varnhagen nas Repúblicas do Pacífico, 1863-1865," M.A. Thesis, Porto Alegre: Pontifícia Universidade Católica do Rio Grande do Sul, 2013; and Luís C. Villafañe Gomes Santos, "Varnhagen e a América do Sul," in Varnhagen (1816-1878): Diplomacia e pensamento estratégico, ed. by Sérgio E. Moreira Lima (Brasília: Fundação Alexandre de Gusmão, 2016), pp. 199-242. Varnhagen's diplomatic correspondence has been published in Brazil, Ministério das Relações Exteriores and Fundação
} 
Also other European great powers, and even the United States itself, issued harsh criticisms of Spain's actions and questioned its activities in the region. ${ }^{357}$ The end of the civil war in the United States several months before the bombardment of Valparaíso helped fuel a sense of urgency on the part of Spain in solving its ongoing conflict with the republics of the Pacific in an attempt to suppress the need for the U.S. to invoke the Monroe Doctrine unilaterally and exert diplomatic pressure in Madrid to end the war. ${ }^{358}$ As historian William Davis points out, the U.S. adopted a slightly more active attitude after the Spanish debacle in Valparaíso, and quite importantly stopped signaling its neutrality to Madrid, as in previous decades. Still, the U.S. remained unwilling to assume the role of mediator until the conflict had practically ended. ${ }^{359}$

Faced with international outcry and public condemnation, Méndez Núñez decided to change his strategy. The blockading of ports ceased and the squadron now only concentrated on Valparaíso. But after two months, he decided to bring the same kind of retribution to Peru's port of Callao, which was well-fortified. In May 2, 1866, a battle ensued at Callao involving all the vessels of the Spanish squadron against a set of batteries

\footnotetext{
Alexandre de Gusmão. A missão Varnhagen nas repúblicas do Pacífico 1863 a 1867 (Rio de Janeiro, 2005).

${ }^{357}$ Cf. "The Bombardment of Valparaiso: Letter from an American Naval Officer," The New York Times, May 5, 1866; Rear-Admiral Denman, Mr. Layard, The Bombardment of Valparaiso (Liverpool: 1866); Bombardment of Valparaiso: Speech of the Spanish Minister for Foreign Affairs; together with the Diplomatic Circulars, Report of the Spanish Admiral, etc. (London: Schrader, 1866); and Great Britain, Foreign Office, Correspondence Respecting the War Between Chile and Spain: Confidential F.O. 420: 21 [HC-PP] (London: Harrison, 1866), pp. 306ff.

358 This delayed sense of "self-imposed" pressure on the part of Spanish officials in Madrid regarding the Monroe Doctrine is well documented in Heredia, El imperio del guano, pp. 103-112, 118-126; Davis, The Last Conquistadores, pp. 278-310; and González Pizarro, La política de España en América.

${ }^{359}$ See Davis, The Last Conquistadores, pp. 325: fn. 4, 326, 327: fn. 12; 329, 331-332. See also Peru, Ministerio de Relaciones Exteriores, Correspondencia diplomática relativa a la cuestión española, publicada por orden de S. E. el Jefe Supremo Provisorio para ser presentada al Congreso Constituyente (Lima: El Imprenta del Estado, 1867), pp. 403-479; Chile, Memoria del Ministerio de Relaciones Exteriores de Chile (1867), pp. 21-49.
} 
emplaced by Prado's administration and reinforced with several civilian volunteers from Lima, Quito and Santiago. ${ }^{360}$ The Battle of Callao, or the Battle of May 2 as it is popularly known in Peru, represented the last significant episode of the war. ${ }^{361}$ Suggestively, its ending had no clear military victor; it was a political and diplomatic "victory" for the South American allies, in so far as the squadron—severely damaged after the day-long combat— abandoned the Pacific for good. But it was celebrated as a victory also in Madrid when the "Scientific Expedition" squadron finally returned to Spain. For several years, until a final armistice was signed in 1871 in Washington, fears and rumors of commissioned "corsair" vessels arranged by Chile and Peru wreaked havoc in the minds of Spanish commanders in the Caribbean and the Atlantic. ${ }^{362}$ No new confrontation or crisis, however, erupted after Callao. Following the end of Isabel's reign in Spain, in 1868, a new and more conciliatory policy towards the South American nations managed not only to secure the final armistice but also to formalize relations with Peru. ${ }^{363}$

The outbreak of the war with Spain, therefore, was a crucial moment for the region. It helped forge a sense of regional awareness among the political elites and decision-makers in charge of the foreign policy of each Pacific state. This sense of awareness of was largely imposed on the reality of South America's international relations by the necessity to

\footnotetext{
${ }^{360}$ See Luna Tobar, El Ecuador en la independencia del Perú, Vol. 2: pp. 303-314.

${ }^{361}$ See "The Bombardment of Callao, Spanish Barbarism," The New York Times, June 1, 1866.

362 Heredia, El imperio del guano, pp. 115-118.

363 The treaty of armistice was signed in Washington in 1871, but the final Treaty of Peace was signed bilaterally between Spain and each of the fours allied Pacific nations. Madrid signed the peace with Peru and Bolivia in 1879; with Chile in 1883; and with Ecuador as late as 1885(!). On an interesting note, all of these treaties were signed during the War of the Pacific (1879-1884) that involved three of the four allies. Thus, the war between Chile against Peru and Bolivia would signal not only the complete reversal of the sentiments of common interest and "Americanism" between these countries and its peoples, but also represented a propitious opportunity for Spain to consolidate a final peace agreement with each country individually in such hour of need for the South American nations.
} 
coordinate their foreign policies against an arrogant and belligerent foreign power. This incipient emergence of a raison de système, however, was only partially successful, for Lastarria's mission to the River Plate countries failed to lock-in key geopolitical members into a "continental" alliance. Thus, only half of the region-propelled in part by a sense of common danger but also by a strong sense of regional community and common interest in order - managed to create a common front in the Pacific to defend the region's "common interest" in resisting and fending off one last time the incursions of the former Motherland. Confronting this extreme situation, four countries allied to repel Spain's aggression (Peru, Chile, Ecuador, and Bolivia), bypassing important short-term strategic interests and risking open war with a European power. Ecuador, for example, by joining the alliance, declared war on its prime consumer of cacao - the main product for export from Ecuador at the time. ${ }^{364}$ Similarly, Ecuador was coming to the aid of Peru, a persistently antagonistic neighbor which had supported insurgencies and military expeditions prepared by Ecuadorean caudillos sheltered in Peruvian territories. Bolivia, for its part, in order to come to Peru's aid rushed the conclusion of a border treaty with Chile, in 1866, creating a "generous" arrangement—-known as medianería — by which both countries would share a strip of land as the limit between both nations, instead of a single line. Inside this strip or zone, both countries would enjoy the revenues and profits from the mineral resources located there. This controversial, and never-before-seen, treaty was going to play a fundamental role in the 1879-1884 war between Chile, Bolivia and Peru. ${ }^{365}$

\footnotetext{
${ }^{364}$ Davis, The Last Conquistadores, p. 266.

${ }^{365}$ On the general aspects of the allies' individual foreign policies and motives for joining or remaining "strictly neutral" during the Guano War, see Heredia, El imperio del guano, pp. 149-209; and David, The Last Conquistadores, pp. 265-270.
} 


\section{Testing Alternative Explanations}

The case of the Guano War offers the chance to evaluate many of the hypotheses identified in Chapter 1. In relation to the three mechanisms associated with the international society approach (H1), namely: "tamed war," "institutionalization," and "pragmatic solidarity," the six competing approaches $(\mathrm{H} 2-\mathrm{H} 7)$ offer important alternative interpretations of related causes and chained-mechanisms that could also lead to the progressive reduction of conflict and consolidation of regional order in South America but through alternative causal-chain mechanisms. Although not all of them pass the initial, and most basic, test (the "smokinggun test"), an exploration of the contrast between each hypothesis' expected patterns of state-behavior (or case-specific "predictions") and the historical record is necessary to evaluate the strength or weakness of the competing arguments.

\section{H2: The U.S. as a Regional Hegemonic Stabilizer}

The first alternative hypothesis (H2), concerned with the role of the United States in limiting war and institutionalizing regional peace, fails to pass the first ("smoking gun") test. The experience of the U.S. civil war (1861-1865) practically "removed" the hegemon from regional or hemispheric strategic picture for almost a decade. In fact, its absence could help explain the outbreak of conflict — rather than peace. Even the "return" of the U.S. once the civil war was over does not correlate neatly with the decline in conflictivity in the South Pacific area and the end of the military operations between Spain and the Pacific allies. On the contrary, although the U.S. civil war had effectively ended by mid-May 1865, it was precisely in that year that the diplomatic relations between Spain and the Chile-Peru alliance deteriorated sharply. U.S. diplomacy was unable to exert any serious influence on 
Spain's foreign policy during the immediate post-war period (1865-1866), the year when actual military confrontation between Spain and the allies intensified. The U.S. representative in Valparaíso, Thomas H. Nelson, could not even interest the U.S. Department of State in invoking the Monroe Doctrine principle to prevent the bombardment of Valparaíso, announced well in advance, nor to intercept, let alone deter the Spanish vessels from using force against the unfortified Chilean port. The same applies in the case of Peru some months after the bombardment of Valparaíso, during the battle of Callao (May 2, 1866).

Some historians, such as Davis or Heredia, do find some relevance in the form of a reestablished U.S. international image after the end of the civil war. However, as they also notice, the U.S. made no real effort in acting as mediator during the Guano War. The conflict resolved itself by dissipating into a delicate armistice in 1871 that eventually found its way towards a set of separate treaties of peace with Spain during crucial moments of extreme duress during the War of the Pacific between the former allied Pacific nations. Failing this first test is critically damning because it technically disqualifies the core premise of this hypothesis for testing this specific case-study. In short, if the U.S. was not exercising any international role as a regional or hemispheric "hegemonic stabilizer," regardless of whether it did not intend to or was incapable of doing so, then the hegemonic stabilizer argument cannot be properly evaluated against the case of the Guano War.

\section{H3: A South American "Balance of Power"}

The second alternative hypothesis, concerned with the balance of power (H3) as understood in power-political terms, also runs into some initial difficulties. Although it passes the basic 
"smoking-gun" test, for South American nations were certainly interested in maintaining a regional balance of power inter se by protecting their respective independence and autonomy, this aspect is not unique to this hypothesis. That is, it transforms into a "hoop test" (low uniqueness and low certitude). That is, this characteristic is shared, at least in principle, with the $\mathrm{H} 1$ (international society) and $\mathrm{H} 4$ (geopolitics) hypotheses. To distinguish between these interpretations, it is critical to clarify what is expected in each case and what are the precise background conditions and triggers that differentiate one interpretation of the balance of power dynamic from the other.

In the first instance, the balance-of-power approach (H3) generates three precise expectations: First, that war will serve as a regulating mechanism (via deterrence) to reduce the overall level of conflictivity in the region. Second, that the regional balance of power created out of this dynamic will be based on mutual fear and suspicion, and would therefore not translate into stable institutional arrangements (that is, it only minimally maintain a fear-based balance of power). And third, that the nature of regional alliances would be dynamic and multifaceted, changing at any time and according to short-term strategic calculations of power-maximization and opportunism. In other words, there would be no rigid or static sets of alliances and patterns of enmity/friendship identifiable over time. With this in mind, these predictions are expected to raise in prominence as certain background conditions also grow in importance historically. The main background condition for $\mathrm{H} 3$ is the fact that states are will engage more firmly in such balance-ofpower behavior when their survival is at stake. This leads to elites and decision-makers who cannot afford to develop far-sighted views about the regional system they inhabit. In 
sum, raison d'état reigns supreme and the "national interest" is understood by the historical actors narrowly, and in short-term, material or survival-specific considerations.

When applied to the Guano War case, several important factors come to the fore. First, the Spanish intervention in Peru happened at a critical moment in Peru's life as a sovereign nation. Without a formal treaty with Spain recognizing its independence, Peru's survival was truly on the line. Chile and Argentina, as well as Ecuador and other neighbors, had already signed, or were on the verge of signing, treaties with the ex-Motherland and thus had their formal independence well-established and secure. Despite this important factor, Pezet's administration did not behave according to a short-sighted view of the national interest, according to which it would have been expected of Peru to ally immediately with regional allies (the weaker side) to confront Spain (the stronger side) militarily in every opportunity available. According to the H3 hypothesis, as well, Peru should have tried to involve as many European powers as possible to the balancing effort against Spain—including, perhaps, the U.S. In practice, however, Pezet avoided the use of force at every turn possible. Peru's diplomatic efforts in European courts were limited only to influencing Madrid to disavow the Spanish agents' actions in the Pacific, but little more. No solicitation for assistance, or "protection," nor even a military alliance, was seriously considered.

Suggestively, it was Chile, and not Peru, who led a region-wide campaign to erect a common front against Spain — an effort that eventually dragged the country into the war itself. Contrary to the $\mathrm{H} 3$ expectations, Pezet tried to peacefully negotiate an agreement in Madrid and only when that option collapsed did he try to rely on the intermediary role of two diplomatic bodies: the Diplomatic Corps in Lima and the Lima Congress of 1864. The 
first, however, although influential in creating a rift between the Spanish agents, Pinzón and Salazar y Mazarredo, ultimately backfired as it undermined Peru's efforts in presenting the affair as an American or regional one. The second body, although important in institutionalizing a regional interest in order, not only by incorporating Peru in the negotiations but also by implicating Argentina (which had been reticent throughout to antagonize with Spain), was unable to crack the hard shell of the new commander, Vice Admiral Pareja, nor induce any change in the Spanish demands. It was not until the bombardment of Valparaíso and the specter of similar action at Callao weeks after, that Argentina, a key strategic power in the Atlantic, hardened its position against Spain.

Interesting, as well, is to observe the behavior of Chile in this affair. It was, in principle, easier for Chile to let Spain exert some pressure on Peru, its historical rival in the South Pacific region since the end of the wars of independence in the 1820s. The power competition between Peru and Chile not only erupted into a major war between 1836 and 1839, in which Chile defeated the Peru-Bolivian Confederation, but also had implications for the border disputes with Bolivia over the southern frontier of the Atacama Desert. It was in Chile's most immediate interest, therefore, to have Peru suffer at the hands of the Spanish squadron, for this would have allowed Chile to pressure Bolivia more effectively - a traditional ally of Peru — and with the potential control of the nitrate and mineral rich area obtained from Bolivia's medianería agreement, outperform Peru in economic and military terms. On the contrary, however, Chile not only disregarded these short-sighted calculations regarding Bolivia and Peru, but actually embarked on a multidirectional diplomatic campaign (that involved even the United States) to create a common front against any European encroachment on the continent, like the one Spain was 
exercising in the Chincha Islands. This also dragged Chile and Peru to reach out to the Atlantic powers, Argentina, Brazil, and Uruguay, to mediate in and bring to an end their ongoing war with Paraguay. Although this diplomatic initiative ultimately failed, it shows how much Chile was prepared to put aside diplomatically (and even territorially) to protect a sense of regional order and autonomy against Spain's ambitions. These Chilean concessions included a partial relaxation of its claims over the disputed territories with Argentina over the Andean frontier and the ownership of Patagonia to the south—which the Lastarria mission to Buenos Aires was also instructed to negotiate.

Bolivia, for its part, failed to follow the expected patterns of traditional balance-ofpower politics. The pre-existing rivalry with Chile was so intense than when Bolivia effectively entered the Quadruple Alliance in June, 1866, it made little sense from a purely power-political vantage point. Bolivia, according to this view, should have played one neighbor against the other, allowing Spain to coerce Peru while also containing Chile from coming to Peru's aid, while also negotiating an anti-Chilean alliance with Argentina. This was the pattern that Bolivia tried to follow during the 1836-1839 war of the Peru-Bolivian confederation, led by Bolivian caudillo Andrés de Santa Cruz. Achieving such strategy in the 1860s could have helped tilt the balance in Bolivia's favor over the demarcation of its shared border in the Atacama Desert (with Chile) and the Andean region to the south (with Argentina). Instead, Bolivia, led by caudillo Melgarejo, and out of a distinctive "Americanist" fervor and solidarity towards all South American nations, rushed to an agreement with Chile over their southern border - thus creating an unprecedented, shared medianería frontier - that was excessively generous to Chile, but which recorded little gains for Bolivia. Furthermore, this unique agreement cleared the way for both countries 
to join Ecuador in aiding Peru against Spain by way of closing all ports on the Pacific to the Spanish squadron, and by effectively resolving (if only momentarily) a critical pending dispute between neighbors.

Lastly, Ecuador was the third country to join the alliance. Emanating from its condition as a buffer-state between Peru and Colombia, Ecuador had suffered historically the interference of its neighbors in its internal affairs, supporting factions and caudillos, destabilizing the internal order, and delaying its chances to play a more mature regional role. Peru's strategy of disturbing Ecuador's domestic and international politics was well known at the time. An armed confrontation between both countries, in fact, had just been resolved less than a decade prior to the Spanish intervention in the Peruvian islands. For these reasons, Ecuador, and not only Chile or Bolivia, had profound short-term security interests in seeing Peru suffer at the hands of the Spanish squadron. The Chincha Islands question represented a unique opportunity for Ecuador to take advantage of Peru's weakening international status and take revenge for all the constant antagonizing over the years. But apart from an initial declaration of "strict neutrality," however, Ecuador did not take advantage of Peru's troubles in an opportunistic way, and instead joined the Quadruple Alliance championed by Chilean diplomacy — thus countervailing all "logical" expectations derived solely from a balance-of-power approach. This is also a particularly important case because Ecuador had a history of pro-monarchical conservative political elites and leaders, such as Flores and García Moreno, who in the 1840s and 1850s had attempted to transform the Republic of Ecuador into a protectorate of the Spanish and French crowns. By declaring war on Spain, as well, Ecuador was forgoing other commercial interests related to its cacao exports—of which Spain was the prime consumer. 
The Lima Congress of 1864, as well, makes little sense when seen through the H3 perspective. Although cotemporaneous with the Spanish intervention, it had been invoked to deal with larger, more regional, interests related to general patterns of European interventions across the continent seen in the preceding decades, as well as intra-regional political and commercial affairs. Although mainly concerned with regional security, the Lima Congress of 1864 was conceived more in line with a regional tradition of multilateral congresses than with mere balancing arrangements inter se. In sum, far from constituting an unintended, almost spontaneous, "equilibrium" of forces in South America against Spain, the repeated efforts at diplomatic coordination and the principles invoked in each specific congress show a more conscious and political intended effort (even if only partially successful in the end) in linking the national interests of each participating state with those of the region as a whole in a stable manner and according to commonly-agreed principles of diplomatic conduct. A region characterized by a mere balance-of-power dynamic based on mutual fear and suspicion would have found no utility in such diplomatic arrangements in the short as well as in the long term.

\section{H4: South American Geopolitics}

The geopolitical hypothesis expects a rather unchanging set of patterns to evolve in South America as long as the geography does not vary. Although the geography in itself has not changed, the discovery of guano deposits in the 1840s certainly played an important role in stimulating intra-regional rivalries and power competition for strategic resources among neighbors. The contested border between Bolivia and Chile, as much as the strategic relevance of the Chincha Islands, for example, cannot be disentangled from the role of 
guano as a key resource between the 1840s and the 1870s. The precise expectations derived from this hypothesis, therefore, would be that: First any regional peace would have to derive from the material and geopolitical impossibility of war due to topographical obstacles or a lack of any resources to fight about. Second, that institutions - if any actually develop-would act only as coping mechanisms created by states to help overcome unsurmountable geopolitical obstacles to cooperation. And finally, the idea of fixed patterns of interaction-"shatterbelts" and "checkerboards"-would eventually stabilize due to the rather static nature of geography in the region.

Regarding the first prediction, it is certainly relevant that Peru was guano-rich in the 1860 s, yet fiscally and thus materially incapable of waging war with Spain. It is also important to note that Chile's conflicting relations with Bolivia were based on disputes over areas where minerals and nitrates were abundant and accessible. The role of the congresses in South American diplomacy, including the second one in Lima (1864), could be interpreted as coping mechanisms to countervail these rather deterministic geopolitical features; that is, as concerted efforts to overcome the rigid topographical obstacles to deeper interaction in the region. As was shown before, the Lima Congress of 1864 also included agreements over areas aimed at improving the communication and interconnectivity among member states. It was these agreements, in fact, and not the security agreements for a common front against European aggressions, which received widespread congressional ratification in the respective members in the years after. However, the expected pattern of historical regional dynamics fails to corroborate the geopolitical hypothesis. 
According to the geopolitical hypothesis (H4), Peru and Chile should have continued with some form of reiteration of their past rivalry patterns, rooted in the flat and desert-like territories between them, as well as the open Pacific Ocean, which acted as conduits or "arenas" for their power competition. These shared spaces had not changed since independence or the end of the Peru-Bolivian Confederation War in the 1830s. Determined by the vast distances and the static factor of the Andes, Peru and Bolivia should have been allies (together with Argentina) aiming to curtail any Chilean plans for regional hegemony. Chile, for its part, should have allied with Brazil against this triple coalition of neighbors, lest their success over Chile could be turned against the Empire later on. But in practice, it was Chile who championed a regional defense of Peru's and South America's interests against Spain's ambitions. It was Chile who first reached out to Argentina, its other historic rival after Peru, to erect a common South American front against their former Motherland. Argentina failed to enter the alliance, and focused instead on combatting Paraguay - as part of an "uncommon" alliance with Brazil, a monarchical regime and a traditional rival of Argentina in the region.

In short, the Guano War represents a case-study that runs contrary to the main expectations of the geopolitical approach (H3) regarding potential sources of reduction in war and the use of force, as well as in potential patterns of institutionalization, or "crisscrossed" geopolitical balance-of-power relations. Most crucially, the expectation of a geographically determined set of alliance patterns in terms of shatterbelts and checkerboards did not form in the 1860s. The alliances in the South American region happened not according to two axes: one made by Chile-Brazil-Ecuador, and the other made by Peru-Bolivia-Argentina, for example, but according to other considerations 
related to a regional identification with "South America" as a bulwark against the Spanish (or any European) aggression. While the topographic aspects of the region may help illuminate some aspects of the more historic patterns of conflictivity in the region, these same dynamics seem to have had no significant effect during the Guano War in reducing conflictivity, generating processes of institutionalization, nor in shaping patterns of regional association, alliance, or solidarity in the face of common threats.

\section{H5: Common Culture}

This hypothesis is, perhaps, the most challenging of the alternative arguments. In part, this is because of its superficial similarity with the international society argument, but also because of its popularity as part of the historical "Americanist" sentiment among thinkers and historians, as well as historical figures and politicians at the time. The main premise of the H5 when applied to the South American case is that a "security community" formed out of a common history of anti-imperialist struggles in the region. This peculiar legacy is said to have fueled anti-imperialist sentiments that overshadow any other strategic consideration when foreign powers, like Spain, employ force against one of the community members (Peru or Chile). Facing this common threat, the $\mathrm{H} 5$ expects an association among South American states that effectively eradicates war inter se, and which redirects the (now collective) use of force outwards, against extra-regional powers, such as Spain (or France during the Mexican occupation). This elimination of war among community members, in turn, leads to a second expectation of progressive supranational unification that is based on common institutions and regional organizations. This is premised on the functional necessities of more efficient mechanisms for maintaining and protecting the security 
community for external threats. In essence, South America is interpreted as a security community forged in common cultural, linguistic, religious, and even ideological "unity" that was initially shattered by foreign imperialistic forces but which Latin American countries have been piecing back together since day one after independence.

In the South American case, the strong sentiments of "American unity" have always played a role in politics since the achievement of independence. With the death of Simón Bolívar in 1830, the first champion of the "Americanist" cause, this collective popular sentiment became associated most directly with Bolívar's name and political project. During the Guano War, this sentiment played a crucial role as it was very much alive in the Chilean political elite that propelled the country towards war with Spain over the occupation of three Peruvian islands. President Joaquín Pérez in Chile, as well as Tocornal's replacement, Covarrubias, and many other important figures during the Guano War-including leading diplomats Lastarria, Mackenna, Matta, Hurtado and others—were members of the political association called Unión Liberal, which defended the integrationist dreams of continental unification threatened by foreign powers and imperialism. This highly unique and certain prediction, in the correspondence with facts of the Chilean case, makes the H5 hypothesis a very powerful explanation a priori. After all, the Guano War represents the most ideal case-study for this approach, given than a foreign, European power, Spain, which happened to be the former colonial ruler of the region, initiated a direct aggression against a former colonial territory in demands of "revindication" first, and then of "reprisals" for past and present offenses.

In this context, and contrary to the $\mathrm{H} 1$ argument, the common culture hypothesis expects international institutional agreements, such as the Lima Congress of 1864, to be a 
platform for unification and solidarity based, not on common interests (H1), but on shared ideology. The Lima Congress can certainly be interpreted as an institutional extension of the Americanist "dream" held by so many Chilean public officials and other political figures of the 1860s, including Domingo F. Sarmiento, Juan B. Alberdi, Justo Arosemena, among many others. It was, as historians now agree, also the last such attempt in South America for the Americanist ideals. Although a new continental congress was invoked in the early 1880 s by Colombia, it never came to fruition. ${ }^{366}$ The Lima Congress of 1864 represented an effort in supranational unification in matters of security, with plans for a regional executive body which would take full control of the armed forces of member states in cases of external aggression. The crucial point in this development is, however, that the treaties on this aspect were never ratified by the respective legislative bodies of each member state. That is, the Lima Congress was more an aspiration towards those higher ideals than a practical reality. From a historical vantage point it is important to ask why those ideals, arguably so influential in motivating a regional defense against Spain, failed so miserably to institutionalize during such a critical period in the history of the region. Failing to pass this highly-certain, but shared, prediction regarding South America during the Guano War (that is, a "hoop test"), limits the strength of the H5 when compared to the empirical record. Similarly, the H5 hypothesis shares with the "Liberal Peace" argument (H7), discussed below, the highly distinctive expectation of the "eradication" of war, instead of just its suppression, amelioration, "taming," or impossibility/impracticability.

\footnotetext{
${ }^{366}$ For a brilliant and well-documented explanation of the reasons behind the Panama Congress' failure, see Robert N. Burr, The Stillborn Panama Congress: Power Politics and the Chilean-Colombian Relations during the War of the Pacific (University of California Press, 1962).
} 
As the other case-studies in the present dissertation show, "war" did not disappear from the region's international relations, although important changes in its execution have certainly changed over time.

A potential answer from proponents of the $\mathrm{H} 5$ hypothesis is that imperialism was ultimately triumphant in maintaining South America's fragmentation, in true Machiavellian spirit. Historically, however, other factors seem to have played a more important role. In Chile, for example, the effects of the country's involvement in the war and the bombardment of the port of Valparaíso left a political cost that was soon paid in terms of electoral defeat by the "Americanists" at the hands of more conservative political forces. In Peru and Bolivia, successive domestic political convulsions created other priorities than a supranational unification; while in Argentina, the end of the war against Paraguay also removed from power the Liberal coalition led by Bartolomé Mitre, who had initially agreed to participate in the Lima Congress of 1864 and coordinate foreign policy decisions with Chile against Spain, but later grew more skeptical about Argentina's involvement in the war.

The hypothesis of common culture also seems to partially hold when interpreting the type of solidarity followed by the American states during the Guano War. In the H5 argument, states are expected to be "solidaristic" towards one another on the basis of a "common culture" created by a shared past of fighting against imperialist European powers. It is, in short, an ideological solidarity that runs across identitary lines, more than mere interests and short-term cost-benefit calculations. This expectation, although it may fit well the motivations behind the foreign policies of Chile and Bolivia during the 1860s, cannot fully account for the behavior of other important states. Ecuador, for example, 
which was led by ultra-conservative political forces at the time, joined the Quadruple Alliance and thus put several security and commercial interests on the line. Similarly, the prediction runs into difficulties when trying to account for the non-solidarity of Argentina, Venezuela, and Uruguay, which did not join the Quadruple Alliance against Spain. These countries, and in particular Argentina and Venezuela, not only represent important strategic players in the South American region, but also carry a symbolic importance for being the birthplace of the two revolutionary movements that through epic military campaigns went on to liberate the rest of the continent from Spanish rule. ${ }^{367}$ Despite this, neither Bolívar's Venezuela, nor San Martín's Buenos Aires, joined the Quadruple Alliance in antiimperialist fervor against the former Motherland, Spain. The fact that one of the most conservative states joined the alliance, while the two states most closely associated with "Americanism" ideals did not, opens a serious wound at the heart of the "common culture" argument for explaining the progressive stabilization of regional order in South America.

\section{H6: State-Strength, State-Weakness}

The argument in $\mathrm{H} 6$ is that patterns of regional peace in South America are driven mainly by state-strength/weakness considerations. When states go through severe domestic constraints, for example in the form of armed political opposition and caudillo infighting, then the main source of potential regional peace comes from the fact that war-particularly major war-becomes impossible to practice or sustain over long periods of time. The point is that weak states can only employ minimal force (at beast) against one another. When

${ }^{367}$ See, e.g., Edmundo A. Heredia, "Primeras relaciones entre Venezuela y Argentina," Todo es Historia, No. 205 (mayo, 1984), pp. 8-28. 
faced with a crisis situation, such as the one created by the seizure of the Chincha Islands by Spain in 1864, then weak states generate externalities inter se which can only be tackled as a group, coordinating common policies through some form of institutional arrangements as a supplement to their institutional/organizational deficiencies. The background conditions are clearly present, as well, given that Latin American states in general fit well with the notion of weak-states during most of the 19th century. This state-weakness, well studied by state-formation students of the region, also highlight the "porous" nature of borders, leading in turn to transnational externalities that reinforce each state's domestic frailties and so-called "anarchy."”68

The aim of this concerted effort, therefore, is not a unification into a supranational government or the eradication of war altogether (as in H5), but simply the more limited objective of avoiding security externalities and threats. In this context, the H6 argument makes three important predictions regarding the Guano War. First, given the extremely weak government of the Pezet administration in Peru, it would have been logical for Peru to try to present the Spanish aggression as a potential problem for the rest of the South American neighboring states. Appealing to the neighbors' own interests in avoiding the externalities from the Peruvian incident, the Pezet administration would have been expected to seek regional support through institutional multilateral means. This expectation can be said to have been amply fulfilled as, in fact, something close to it occurred during the first year of the diplomatic crisis. Moreover, it was Peru's own domestic political and

\footnotetext{
${ }^{368}$ This is the focus of well-known studies, such as Miguel Á. Centeno, Blood and Debt: War and the Nation-State in Latin America (The Pennsylvania State University Press, 2002); and Kalevi J. Holsti, The State, War, and the State of War (Cambridge University Press, 1996), esp. pp. 150-182.
} 
financial crises what first ignited the Talambo incident, which was then used by Salazar y Mazarredo to convince Pinzón (and thus also Madrid) of the "necessity" of occupying the islands as a reprisal for the offenses committed against Spanish citizens on Peruvian soil.

A second prediction of the $\mathrm{H} 6$ argument relates to the role of the Lima Congress of 1864 as an institutional supplement for other neighboring states to "contain" the Peruvian problem. It was because of Peru's own weakness that a European power was now marauding the Pacific waters of South America after all. The attitudes of the Peruvian delegates to the Congress, as much as those of Chile, Bolivia, Ecuador, and Argentina, seem to confirm the view that one of the main objectives of the South American states was to limit the implications, or externalities, emanating from the Chincha Islands affair. Put differently, in their "defense" of Peru's interests they took great care in not giving Peru a diplomatic "blank check" or a free-pass for its own responsibilities in the crisis. But the Lima Congress, however, also had higher aspirations beyond mere mitigation of security externalities. As advanced by the $\mathrm{H} 5$ and $\mathrm{H} 1$ arguments, larger regional considerations were invoked in the summoning and functioning of the Lima Congress which cast a shadow over the idea that this institutional gathering was a mere "empty shell" for dealing with Peru as much as with Spain. As highlighted before, collective and regional ideals were a crucial ingredient that played a role by, first, re-appropriating the U.S. Monroe Doctrine principle as a foreign-policy objective of the region as a whole, and second, by creating a common front or bulwark against European interventions in general — and not simply against Spain. That is, the Chincha Islands occupation was regionally recast as an "American" issue that transcended purely Peruvian problems and interests. Far from an "empty shell" used for tactical purposes of quarantining Peru's problem with Spain, the 
Lima Congress was a centerpiece of long-held tradition by American states to handle their own affairs autonomously.

The avoidance of externalities, nevertheless, seems to help explain quite well the behavior of the Atlantic powers in South America: Argentina, Brazil, and Uruguay. Occupied with their own major confrontation with Paraguay, the allies could not realistically entertain a potential simultaneous confrontation with Spain. This incapacity was also premised on their own state-weaknesses (as the next chapter in the dissertation shows). Paraguay, a geographically small but militarily strong country, offered for more than five years a stubborn resistance to the combined forces of the three allies, and became a major reason why the ideal "common front" imagined by Chilean officials could not come to fruition by incorporating the Atlantic powers in the Quadruple Alliance.

Lastly, the H6 argument can be said to illuminate quite well the unexpected behavior of Chile in taking the initiative in coordinating a diplomatic regional front against Spain. Chile had, since at least the late 1830s, a well-organized domestic political system. Apart from the Brazilian Empire itself, Chile was the most stable and well-consolidated South American country by the mid-1860s. This allowed Chile to play a more active diplomatic role in the region, developing an understanding of the intricate connections between its own (short-term) "national interest" and the region's (long-term) "common interests. ${ }^{" 369}$ Seen in this light, the $\mathrm{H} 6$ argument contributes another possible explanation for the proactive Chilean diplomacy of the mid-19th century in general—and its multidirectional offensive with regards to the Chincha Islands occupation by Spain in

${ }^{369}$ This is well explained in the classical study by Burr, By Reason or Force. 
particular. Its relative strength vis-à-vis its neighbors (Peru and Bolivia specially) made possible for Chile to put into practice ingenious and creative strategies to fend off the Spanish squadron, both by closing off all Pacific ports, but also by instigating "corsairstyle" harassment tactics against all Spanish ships in the Pacific and the Atlantic, issuing letters of marque and waging all kinds of anti-Spanish propaganda campaigns abroad. The H6 argument can explain Chile's remarkably unique behavior, while also help understand the incapacity of Peru, Bolivia, Ecuador, and other South American nations to follow through with Chile's more grandiose schemes. In short, they could not perform diplomatically as well as Chile did due, in great part, to their relatively more unstable and insecure domestic fronts.

\section{H7: A "Liberal Peace" in South America?}

The final alternative argument articulates three elements: the republican and democratic type of regime, the adherence to free-trade principles, and the creation of Liberal institutions. These factors are expected to reinforce one another and together lead likeminded and like-structured states to a separate peace inter se. The background conditions, therefore, allude to the presence of such regime types, economic policy ideals, and institutional arrangements during the 1860s in Latin America. A crucial component, as well, is the convergence of these factors in order for the expectations to be tested fairly. If and when these conditions are met, then three clear expectations emerge: first, that war would disappear among states; second, that institutional arrangements will be Liberal in nature (that is, they will protect and advance political and economic Liberal values, such as market freedom and political liberty); and third, that among states organized around 
these factors an "inter-democratic" solidarity will form, based on Liberal values and ideals, and excluding war among members.

When applied to the Guano War case, the H7 argument applies only partially. Firstly, the idea that 1860 s South American states were "democratic" can be questioned on several fronts. It was not until the mid-20th century, for example, that women and the broader working masses were allowed to vote. Between 1820 and 1910, most Latin American countries self-identified with the republican type of government. However, these same states were strongly aristocratic and exclusionary of several groups, classes, and social strata, on the basis of property ownership, education, and socio-ethnic backgrounds. With this caveat, it is possible however to sustain the argument that republican/democratic values played a role in how elites and decision-makers presiding over their societies evaluated and conducted foreign relations on ideological and value-laden considerations.

The issue of type of regime, for example, was a popular one in the confrontation with Spain. Aside from the illegality of the occupation in itself, the aggressor state was a monarchy. This was an important factor in arousing the wider population and unnerving the printed press in Peru, Bolivia, and particularly in Chile. The citizens gathered in bars, cafés, and plazas, to demand from their respective governments "action" against Spain. Pezet confronted such pressures at the very doorsteps of the Governmental Palace in Lima, while Chilean authorities had to contain the mob from lynching Spanish citizens in Santiago's streets after the bombardment of Valparaíso. In Bolivia, as well, the spontaneous popular manifestations of solidarity towards Peru and Spain convinced the government of joining the Quadruple Alliance at once, forgoing important legal concessions and past animosities with both Chile and Peru. But although the "republican 
factor" played a role at the popular level, it certainly can't be said to have been a major element at the diplomatic one. Neither Pezet, not any of the allied governments, based the argument against Spain on merely ideological (republics versus monarchies) terms.

While part of the discourse at times, both official protests and negotiations were conducted on the basis of the illegality and illegitimacy of the occupation itself. That is, South American republics limited themselves to the commonly-agreed diplomatic standards of the time and never fully exploited the "regime type" angle to any significant extent. This includes, for example, their initial appeals to the U.S. potential for intervention in the affair. The Monroe Doctrine itself does not specify "monarchies" as the real threat to the American continent, but European powers in general. Lastly, and quite revealingly, in its attempt at incorporating the members of the Triple Alliance to join the Quadruple Alliance, Chile was also signaling that Brazil's monarchical type of government was in no way going to be an impediment for an alliance against Spain—another monarchy. Lastarria was charged with a tripartite mission to Argentina, Uruguay and Rio de Janeiro. In fact, it was Brazil's collaboration that Chile wanted the most, for its navy was by far the strongest and most professional of the entire continent—perhaps, only slightly behind that of the U.S., which had been modernized after the Civil War.

On the issue of free-trade principles, a more compelling picture can be painted in favor of the $\mathrm{H} 7$ argument. In the Triple Alliance war against Paraguay, Mitre's Argentina allied with Brazil despite the regime-type divergences, which suggests that other considerations were at play beyond the issue of the type of government. The sharing of a common socio-economic state-building "vision" seems to have been a much more important factor in South America in the 1860s. As part of that vision, the Liberal economic 
principles of "Order and Progress" — engraved to this day in Brazil's national flag — served as a glue for common interests forged in the defense of similar values of "civilization" (represented by Liberalism) versus the forces of "barbarism" (represented by conservatism and federalist political projects). In the Guano War case, the association with such economic and political values, although present in the public discourse of the times, does not seem to have had a direct impact in the patterns of association, alliance, and displays of solidarity among South American states. At no point, for example, South American decisionmakers considered Spain more of a threat because of its "illiberalism" because, in fact, it was a monarchy that had a special domestic political arrangement that accommodated and alternated in power political forces of the Unión Liberal. If anything, "imperialistic" emanated from Spain's foreign policy, it was paradoxically coming from its own Liberal view of the world and its attempt at reestablishing itself back into the higher ranks among the great powers of Europe.

Finally, the Lima Congress of 1864 cannot be easily interpreted as an expression of Liberal institutionalization on the regional level. In part, this is because the values and principles invoked alluded more to the "protection" of their common independence and autonomy than to the advancement of Liberal values. Although the Brazilian empire was not officially invited to the Lima Congress, this was part of a long-held suspicion on the part of Bolívar and his followers back in the 1820s against the true intentions of monarchical Brazil. By the 1860s, Brazil had already made an important shift in its foreign policy approach to the region, towards a less interventionist and more moderating or stabilizing force. The ongoing war against Paraguay, which was preceded by an intervention in Uruguay in support of one of the rival factions in that country, reawakened 
Bolivarian fears of a more expansionistic Brazil. Peru, both during the Pezet but also the Prado administrations, was at the forefront of these fears and suspicions, which reflected in large part in the Lima Congress negotiations. Apart from this fact, however, the Lima Congress represented more strongly "Americanist" ideals of continental unity than Liberal ideals of free-trade among republican democracies.

\section{Some Preliminary Conclusions}

The Guano War offers certain key preliminary points of reference that are worth reiterating before presenting the next case-study. First, it is important to consider that it was a major war that involved a European power, Spain. Second, this was not "any" European power, but the former colonial ruler, or Motherland. For South American nations, therefore, this represented both symbolically and strategically their last war for independence. It marked the end and ruin of Isabel's "foreign policy of prestige" abroad, and opened a new stage for the Americas that saw a sharp decline in European interventions thereafter. Additionally, a third point worth considering is the fact that the relative compatibility of this case study for the popular "Americanist" proposition of a united continent fragmented by foreign imperialism — a view that remains extremely popular today ${ }^{370}$ - the countries of the region did not automatically flock to Peru's aid in what many would have expected to be a continental "common front" against Spain. As some of the alternative approaches show, other type of considerations played a more consistent role in explaining the partial and highly pragmatic type of "solidarity" seen in this case.

${ }^{370}$ See, e.g., Eduardo Galeano, Las venas abiertas de América Latina (Buenos Aires: Siglo XXI, 26th ed., [1971] 2006). 
Fourth, and finally, the multifaceted nature of the Quadruple Alliance, championed by Chile, is a highly unique development in South America. This alliance not only succeeded in fending off Spain's vastly superior squadron, with little more than well-timed tactics and diplomatic activism, but also went further than the mere coordination for war. In an effort to incorporate the River Plate countries to the alliance, the Quadruple Alliance made persistent attempts to mediate in the Paraguayan War, in order to bring it to a peaceful end, and to refocus those military efforts to serve more regional, or collective, common interests. This war, and the subsequent effort at creating a bi-oceanic alliance, marked one of the most important developments in the international relations of South America in the 19th century. It bridged, to paraphrase Robert Burr, the two sub-systems of the region into one, now mutually interdependent, regional system. In doing so, it also inaugurated the first step to the consolidation of a regional society of states, with shared common interests and regional institutions. 


\section{CHAPTER 3}

\section{THE STRUGGLE FOR EQUILIBRIUM:}

WAR AND PEACE IN THE RIVER PLATE AREA, 1864-1875

"Al que es amigo, jamás lo dejen en la estacada, pero no le pidan nada ni lo aguarden todo de él. Siempre el amigo más fiel es una conduta honrada."

The War of the Triple Alliance, or Paraguayan War, ${ }^{372}$ was the longest and most destructive international armed conflict in the history of the Americas. ${ }^{373}$ In global terms, it was the longest and one of the bloodiest interstate wars of the entire 19th century, apart from the Crimean War (1854-1856). ${ }^{374}$ Experts have debated over decades the total amount of casualties produced in the war of the Triple Alliance against Paraguay, but due to the lack of sufficient documentation to establish the Paraguayan losses, the total estimates usually range from 200,000 to $800,000 .{ }^{375}$ According to the most accurate of

371 José Hernández, La vuelta de Martín Fierro (Buenos Aires: Librería del Plata, 1879), XXXII: 1150. [“To whom is your friend, Never leave him in the lurch, But don't ask him for anything, Nor expect everything from him. The truest friend is always, An honest conduct."]

${ }^{372}$ In Paraguay, it is also popularly known as Guerra Grande (great war) or Guerra Guasú in Guaraní. The name of the war is still today the subject of debate among South Americans, for by selecting one or the other, a person may be seen as implying that Paraguay or the allies were the sole responsibles for the war.

373 The U.S. civil war was not, in technical terms, an international war. Some historians, however, consider it so because of its global implications - considering the involvement of France and Great Britain, and the extraordinary amount of casualties produced by the (civil) war (over 600,000 casualties).

${ }^{374}$ See Leslie Bethell, “The Paraguayan War (1864-1870)," University of London, Institute of Latin American Studies, Research Paper No. 46 (1996), p. 1.

${ }^{375}$ Cf. John E. Fagg, Latin America: A General History (New York : Macmillan, 1969), p. 449; Vera B. Reber, "The Demographics of Paraguay: A Reinterpretation of the Great War, 1864-70," The Hispanic American Historical Review, Vol. 68, No. 2 (May, 1988), pp. 289-319; Whigham and Potthast, "Some 
these estimates, the war left approximately 420,000 casualties in the span of more than five years (from December 1864 to March 1870). ${ }^{376}$ Paraguay, defeated in the war, was devastated demographically, losing two-thirds of its population and more than 80 percent of its male population above the age of 10 due to death in battle, imprisonment, or forced migration after the end of the war. Paraguayan casualties represented almost two-thirds of the total casualties in the war. ${ }^{377}$

To understand the origins of this conflict, it is imperative to contextualize the history of the River Plate area as a whole, for although the war itself confronted Paraguay with the Argentina-Brazil-Uruguay alliance, it had deeper roots in the traditional rivalry between the Portuguese and Spanish empires over the control of the Eastern Bank (Banda Oriental - modern-day Uruguay) of the Río de la Plata. Most historians associate the beginning of the war to the inherited inter-imperial rivalry between Portugal and Spain; a rivalry that was transferred to Argentina and the Brazilian Empire after their achievement of independence.

\footnotetext{
Strong Reservations: A Critique of Vera Blinn Reber's 'The Demographics of Paraguay: A Reinterpretation of the Great War, 1864-70'," The Hispanic American Historical Review, Vol. 70, No. 4 (November, 1990), pp. 667-675; Reber, "Response to Whigham and Potthast," The Hispanic American Historical Review, Vol. 70, No. 4 (November, 1990), pp. 677-678; Reber, "A Case of Total War: Paraguay, 1864-1870," Journal of Iberian and Latin American Studies, Vol. 5, No. 1 (July, 1999), pp. 1540; Thomas L. Whigham and Barbara Potthast, "The Paraguayan Rosetta Stone: New Insights into the Demographics of the Paraguayan War, 1864-1870," Latin American Research Review, Vol. 34, No. 1 (1999), pp. 174-186; Reber, "Comment on 'The Paraguayan Rosetta Stone'," Latin American Research Review, Vol. 37, No. 3 (2002), pp. 129-136; Jan M. G. Kleinpenning, "Strong Reservations About 'New Insights into the Demographics of the Paraguayan War'," Latin American Research Review, Vol. 37, No. 3 (2002), pp. 137-142; and Whigham and Potthast, "Refining the Numbers: A Response to Reber and Kleinpenning," Latin American Research Review, Vol. 37, No. 3 (2002), pp. 143-148.

${ }^{376}$ See Thomas L. Whigham, The Road to Armageddon: Paraguay versus the Triple Alliance, 1866-70 (University of Calgary Press, 2017), p. 425: fn. 29-31; and Robert L. Scheina, Latin America's Wars (Brassey 2003), Vol. 1: p. 331.

377 Thomas L. Whigham, The Paraguayan War: Causes and Early Conduct (University of Calgary Press, 2nd ed., [2002] 2018), p. xiv; Whigham, The Road to Armageddon, pp. 424-425; and Whigham and Potthast, "The Paraguayan Rosetta Stone," pp. 181, 185.
} 
This "underlying" cause ${ }^{378}$ of the conflict helps explain, at least in part, the Argentine-Brazilian competition over political and economic influence in Uruguay during the first half of the 19th century, in which two wars occurred. The first one happened between 1825 and 1828 , and is commonly known as the "Cisplatine War." The second war took place in the 1836-1851 period, and is popularly called the "River Plate War" (or Guerra Grande, in Uruguay). The first conflict faced the Argentine Confederation with the Brazilian Empire over the control of the Banda Oriental. The strategic importance of this territory was given by the need to secure access to the interior rivers of the River Plate estuary-leading all the way up north to Bolivia and the northern Amazon region near Peru, while also cutting across Paraguay's territory. Whomever controlled both banks of the River Plate would hold a grip over the entire interior and its waterways, with the potential option of shutting down all access between the Atlantic Ocean and the hinterland of South America. For Brazil, securing the free and open navigation of the interior rivers was crucial for accessing its most remote province of Mato Grosso, located to the north of Asunción, but accessible only via the Paraguay river [see infra Map 3]. With the end of the Cisplatine War, made possible by the arbitration of Great Britain, the Banda Oriental became the Republic of Uruguay: a neutralized "buffer-state." Uruguay's independence was reassured by a treaty signed by Argentina and Brazil, with the commitment of Great Britain as the guarantor of Uruguay's independence. ${ }^{379}$

\footnotetext{
${ }^{378}$ The Argentine historian, Ramón J. Cárcano, pioneered the study of the Paraguayan War from this perspective, identifying "causas originarias" or "lejanas" (underlying causes) of the war in the long history of Spanish-Portuguese competition in the region since the early 1700s. See Ramón J. Cárcano, Guerra del Paraguay: Orígenes y causas (Buenos Aires: Viau, 1939), pp. 18ff. See also Thomas L. Whigham, The Politics of River Trade: Tradition and Development in the Upper Plata, 1780-1870 (University of New Mexico Press, 1991); and Whigham, The Paraguayan War, esp. pp. 1-73.

${ }^{379}$ See Luis A. de Herrera, La misión Ponsonby (comentario) (Montevideo: Barreiro y Ramos, 1930).
} 
MAP 3 - Main battles in the War of the Triple Alliance (1864-1870).

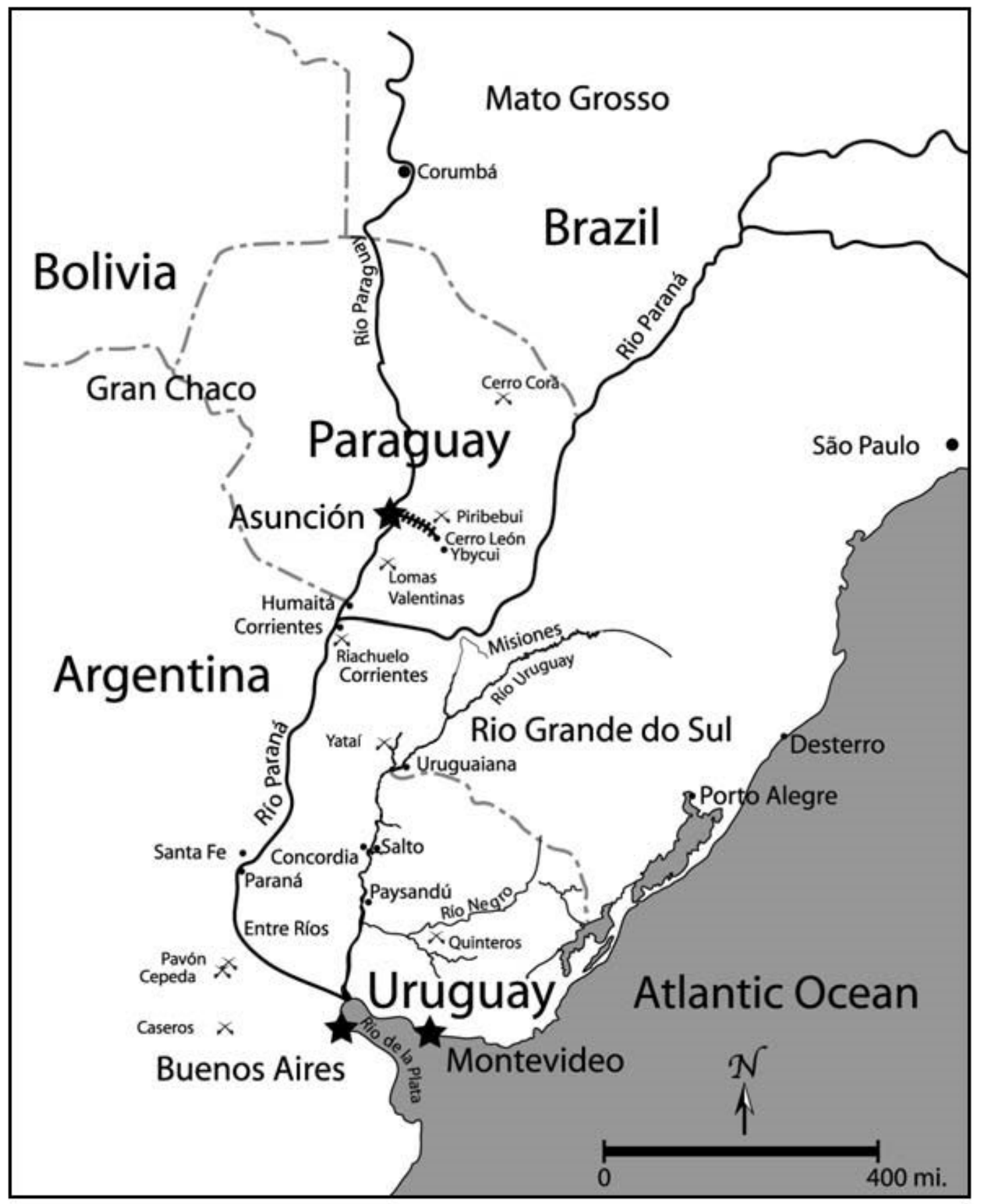

Source: Hendrick Kraay and Thomas L. Whigham, eds., I Die with My Country: Perspectives on the Paraguayan War, 1864-1870 (University of Nebraska Press, 2004), p. 8. 
The second of these conflicts, however, showed both the instability of the prior peace agreement over the Eastern Bank and the continuing ambitions of Brazil over the area. It also showed the commitment of Great Britain in reassuring the survival of Uruguay as an independent country. This war, which was an uncontained Uruguayan civil war, represented a strategic loss for the two South American powers. Brazil, for example, lost direct control over the Eastern Bank area and had to content itself with not having direct access along the northeastern River Plate. This problem, however, was compensated by Argentina's own losses. By remaining independent, Uruguay's "neutral" existence meant that Argentina would not control both banks of the river either. Since Great Britain had become the legal guarantor of this River Plate balance, by the mid-1850s Argentina and Brazil resigned themselves to accept Uruguay's de facto and de jure independence, or otherwise risk war with one of the main European powers. This meant an important change in Brazilian and Argentine foreign policy approaches towards the entire region. ${ }^{380}$

Paraguay, located upriver, acted as a default buffer-state but without any of the legal reassurances that Uruguay had already gained for itself. Considered as a "rogue province" by most Argentine political figures at the time, Paraguay understood well her fragile geopolitical situation and thus confined herself to pursuing a largely isolationist foreign policy for most of the 19th century. ${ }^{381}$ In this context, from 1811 to 1862, Paraguay

\footnotetext{
380 On these changes, see Rubens Ricupero, A diplomacia na construção do Brasil, 1750-2016 (Rio de Janeiro: Versal, 2017), pp. 169-252; Carlos Delgado de Carvalho, História diplomática do Brasil (Brasília: Edições do Senado Federal, [1959] 2016); Luis S. Sanz, "La historia diplomática desde la presidencia de Mitre, 1862, hasta 1930," in Historia argentina contemporánea, 1862-1930 (Buenos Aires: El Ateneo, 1964), Vol. 2: pp. 293-359; and Roberto Etchepareborda, "La política externa argentina, 1870-1920," Anuario del Departamento de Historia, Año II-III, No. 2 (Córdoba: Universidad Nacional de Córdoba, Facultad de Filosofía y Humanidades, 1964-1965), pp. 167-261.

${ }^{381}$ See Luis G. Benítez, Historia diplomática del Paraguay (Asunción: [n/d], 1972), pp. 63-143, 173-200.
} 
followed a cautious foreign policy of internal growth and modernization, based on the production of yerba mate, quebracho wood, and other basic agricultural products, while relying on foreign-capital investments (particularly British) for its technological modernization. ${ }^{382}$

After a failed Argentine military campaign led by Manuel Belgrano to "retake" Asunción in 1811, the country reaffirmed itself as a de facto independent nation—although the memory of a hostile Buenos Aires was never fully forgotten in Paraguay. This de facto independence, however, and the country's consequent isolation from most Platine affairs, left it highly vulnerable to political developments in Buenos Aires and Montevideo in relation to the export of its agricultural products to European markets. Similarly, Paraguay's borders with Argentina and Brazil remained undefined without formal negotiations or a treaty. In anticipation of potential diplomatic troubles, and even a war, Paraguay had been militarizing for decades prior to the outbreak of the war. ${ }^{383}$

In this context, this chapter has three main objectives. First, an initial section offers a historical overview of the main developments related to the War of the Triple Alliance. Within this general overview, it traces specific historical factors relevant for the three causal-mechanisms identified by the international society approach. In this sense, the war

\footnotetext{
382 On these aspects, see John H. Williams, "Foreign Técnicos and the Modernization of Paraguay, 18401870," Journal of Interamerican Studies and World Affairs, Vol. 19, No. 2 (May, 1977), pp. 233-257; Williams, The Rise and Fall of the Paraguayan Republic, 1800-1870 (University of Texas Press, 1979), pp. 177-193; Juan C. Herken Krauer and María I. Giménez de Herken, Gran Bretaña y la guerra de la Triple Alianza (Asunción: Arte Nuevo, 1983); Edward N. Tate, "Britain and Latin America in the Nineteenth Century: The Case of Paraguay, 1811-1870," Ibero-Americanisches Archiv, Neue Folge, Vol. 5, No. 1 (1979), pp. 39-70; and Josefina Plá, The British in Paraguay 18501870 (Richmond, 1976).

383 On Paraguay's pre-war process of militarization, see Jerry W. Cooney, "Economy and Manpower: Paraguay at War, 1864-69," in I Die with My Country: Perspectives on the Paraguayan War, 1864-1870, ed. by Hendrik Kraay and Thomas L. Whigham (University of Nebraska Press, 2004), pp. 23-43; and Luc Capdevila, Una guerra total: Paraguay 1864-1870. Ensayo de historia del tiempo presente (Buenos Aires: SB edición, CEADUC, [2007] 2010).
} 
of the Triple Alliance against Paraguay presents prima facie a challenging case-study for this particular approach, given the war's extreme effects in terms of casualties, duration, and geopolitical importance for the region as a whole. In a second section, the chapter turns to the competing arguments $(\mathrm{H} 2-\mathrm{H} 7)$ to explore their relative explanatory power vis-à-vis the main hypothesis (H1) proposed in this dissertation. A third, and final, section offers a set of preliminary conclusions.

\section{The War of the Triple Alliance: A Fight to the Death?}

The war that for more than five years confronted Argentina, Brazil and Uruguay with Paraguay raises a series of relevant points of analysis for evaluating the strength of the international society approach in explaining the evolution of order in South America. One of the most important of these is the discussion about its causes. The most well-regarded explanation points to the complexity of the River Plate area and the interaction between a colonial legacy, marked by the Luso-Spanish inter-imperial competition, and the South American states' own process of state-building and national consolidation after independence. For the proponents of this argument, the War of the Triple Alliance was a tragic and largely unintended phenomenon, produced by the interplay of historical forces of both domestic and international nature. In sum, the emphasis for explaining the outbreak of the war is put on the region's own complex dynamics. ${ }^{384}$

\footnotetext{
${ }^{384}$ See Thomas L. Whigham, "The Paraguayan War: A Catalyst for Nationalism in South America," in I Die with My Country: Perspectives on the Paraguayan War, 1864-1870, ed. by Hendrik Kraay and Thomas L. Whigham (University of Nebraska Press, 2004), pp. 178-198; Whigham, The Paraguayan War; Francisco Doratioto, Maldita guerra: Nova história da guerra do Paraguai (São Paulo: Companhia Das Letras, 2nd ed., [2002] 2015); Chris Leuchars, To the Bitter End: Paraguay and the War of the Triple Alliance (Greenwood Press, 2002); Efraím Cardozo, El Imperio del Brasil y el Río de la Plata: Antecedentes y estallido de la guerra del Paraguay (Buenos Aires: Librería del Plata, 1961); Cardozo, Vísperas de la guerra del Paraguay (Buenos Aires: El Ateneo, 1954); Cárcano, Guerra del Paraguay:
} 
A second explanation points to the role of foreign imperialism, and to Great Britain in particular, as the main culprit. In this view, British capital created a situation of intraregional competition for markets and products that pitted neighbor against neighbor. The main responsibility, therefore, lies "abroad" while the central players of this bloody drama (the Argentine, Brazilian, and Uruguayan elites) are seen as mere pawns or marionettes in the indirect service of British interests and imperialism. ${ }^{385}$ Other popular explanations, such as the intricacies of the Uruguayan civil war, the role of diplomatic intrigue and strategic misperceptions; or the aggressiveness and megalomania of Paraguay's leader, Francisco S. López, among other hypotheses, have either been convincingly discredited by recent historiography, or fit quite neatly in one of the two main explanations identified above. $^{386}$

Orígenes y causas; and Cárcano, Guerra del Paraguay: Acción y reacción de la Triple Alianza (Buenos Aires: Viau, 1941).

${ }^{385}$ See, e.g., León Pomer, La guerra del Paraguay: Estado, política y negocios (Buenos Aires: Colihue, 3rd ed., [1968] 2008); Julio J. Chiavenatto, Genocídio americano: A guerra do Paraguai (São Paulo: Brasiliense, 1979); Eduardo Galeano, Las venas abiertas de América Latina (Buenos Aires: Siglo XXI, 26th ed., [1971] 2006); José A. Fornos Peñalba, "The Fourth Ally: Great Britain and the War of the Triple Alliance," Ph.D. Dissertation, Los Angeles, CA: University of California (1979); Sergio G. Vilaboy, Paraguay: De la independencia a la dominación imperialista, 1811-1870 (La Habana: Editorial de Ciencias Sociales, 1984); José M. Rosa, La guerra del Paraguay y las montoneras argentinas (Buenos Aires: Punto de Encuentro, [1973] 2008); Mário Maestri, La guerra sin fin: La Triple Alianza contra el Paraguay. La campaña ofensiva, 1864-1865 (Asunción: Intercontinental, 2017); and Maestri, La guerra sin fin: La Triple Alianza contra el Paraguay. La campaña defensiva, 1866-1870 (Asunción: Intercontinental, 2018).

${ }^{386}$ For some of these alternative explanations, see Pelham H. Box, The Origins of the Paraguayan War (Russell \& Russell, [1930] 1967); Frank J. McLynn, "The Causes of the War of the Triple Alliance: An Interpretation," Inter-American Economic Affairs, Vol. 33, No. 1 (Autumn, 1979), pp. 21-43; Diego Abente, "The War of the Triple Alliance: Three Explanatory Models," Latin American Research Review, Vol. 22, No. 2 (1987), pp. 47-69; Hendrik Kraay and Thomas L. Whigham, eds., I Die with My Country: Perspectives on the Paraguayan War, 1864-1870 (University of Nebraska Press, 2004); Bethell, "The Paraguayan War"; Randall L. Schweller, Unanswered Threats: Political Constraints on the Balance of Power (Cornell University Press, 2006), pp. 85-102; Alex Weisiger, Logics of War: Explanations for Limited and Unlimited Conflicts (Cornell University Press, 2013), pp. 86-104; and Alfredo Da Mota Menezes, A guerra é nossa: A Inglaterra não provocou a Guerra do Paraguai (São Paulo: Contexto, 2012). 
These discussions over the main causes of the war are important for the international society approach discussed here, because they can help clarify the issue of restraint as it pertains to the narrowing of the range of political options for practicing war legitimately. If the war was justified by its main protagonists by appealing to the legal, diplomatic, and political standards of the time, then the factor of international society can be studied more directly. If, on the other hand, actors behaved according to merely imperialistic or self-aggrandizing motivations, then some of the competing hypotheses can grow in prominence as explanations for the actual development of the war.

Another important point of analysis is the simultaneity of the Paraguayan War with the Spanish intervention in the South Pacific, which provoked the Guano War. The analysis of these two wars as part of a mutually influential regional context is something only rarely seen in the current historiography. ${ }^{387}$ However, the simultaneous development of both conflicts is of crucial importance for understanding some of the constraints and concerns experienced by key decision-makers on both sides of the region. It is for these reasons that the diplomatic efforts by the Quadruple Alliance to mediate in the War of the Triple Alliance to bring the Paraguayan War to an end, become relevant in the exploration of the factor of "pragmatic solidarity" in the 1860s. This "bridge that two wars built," to borrow

\footnotetext{
${ }^{387}$ Although focused on the Chilean point of view, three valuable exceptions are Pablo Lacoste, “Americanismo y guerra a través de El Mercurio de Valparaíso (1866-1868)," Anuario de Estudios Americanos, Tomo LIV, No. 2 (1997), pp. 567-591; Lacoste, "Las guerras hispanoamericana y de la Triple Alianza: La revolución de los Colorados y su impacto en las relaciones entre Argentina y Chile," Historia, Vol. 29 (1995-1996), pp. 125-158; and Eduardo Cavieres Figueroa, "Las frustraciones de la Unión Americana: La guerra del Paraguay. Estado y sociedad en los conflictos del Cono Sur, 1860-1880," in La guerra del Paraguay: Historiografías. Representaciones. Contextos, ed. by Horacio Crespo, Juan M. Palacio and Guillermo Palacios (México DF: El Colegio de México, 2012), pp. 299-322.
} 
Burr's own phrase, has great value in the consideration of a potential sense of "strategic awakening," as hypothesized in the international society approach. ${ }^{388}$

A third point of analysis concerns the prominence of diplomacy in the outbreak, conduct, and resolution of the war itself. Most of the historiographical works on the Paraguayan War focus on reconstructing "national histories" and conveying "war experiences." 389 Yet even when collecting the histories and experiences of each participating state and producing competent narratives of the war, these works tend to overlook or underestimate the factor of diplomacy per se. This is not to say that there are no diplomatic histories of the war-in fact, these are one of the most traditional types of studies of this war. The point is that even when reconstructing the war from a "diplomatic" vantage point, no International Relations perspective is systematically employed. ${ }^{390}$ This absence of an "IR approach," for example, has led to an over-concentration on the brutality and ferocity of the war, illustrated quite graphically in studies about the soldiers' personal accounts of the atrocities of war, the psychological traumas endured, the miseries of forced recruitment and military life, etc. All diplomatic efforts related to the prevention, mitigation, and taming of the war, apart from other more concrete efforts to bring it to an

\footnotetext{
${ }^{388}$ Robert N. Burr, By Reason or Force: Chile and the Balancing of Power in South America: 1830-1905 (University of California Press, 1965), p. 97.

${ }^{389}$ See, for example, the contributions to Horacio Crespo; Juan M. Palacio and Guillermo Palacios, eds., La guerra del Paraguay: Historiografías. Representaciones. Contextos (México DF: El Colegio de México, 2012), esp. pp. 31-271.

${ }^{390}$ One minor exception is Diego Abente, who also credits Robert N. Burr, "The Balance of Power in Nineteenth-Century South America: An Exploratory Essay,” The Hispanic American Historical Review, Vol. 35, No. 1 (February, 1955), pp. 37-60, as an important exception to the rule. Two other interesting cases are Schweller, Unanswered Threat, pp. 85-102; and Weisiger, Logics of War, pp. 86-104; But the contributions of Abente, Schweller, and Weisiger, however, limit themselves to testing a narrow number of competing IR theories to evaluate the "causes" of the conflict. Yet, no attempt is made to offer a systematic reading of the war as a whole in its global and regional contexts, according to more general analytical tools available in IR.
} 
end after its outbreak, are persistently neglected in most historical accounts. Understanding the Paraguayan War through an IR lens, however, can help illuminate many instances of restraint even during the war, which are otherwise lost from perspectives that, at times, obsess over the most gruesome aspects of a "total war." It is precisely in this area that the international society argument holds the most potential for a contribution.

Lastly, the War of the Triple Alliance offers a unique opportunity to explore how the South American states involved in the war struggled with a "double dilemma" composed, on one hand, by the need to consolidate a violently contested domestic order with, on the other hand, the impositions of an international war of unprecedented scale and consequences. In this framework, the role that elit -considerations about "order," "equilibrium," "civilized behavior," and "war" played in the unfolding of this drama hint

at important clues about how the development of common interests can help forge a regional international society despite the intrinsic horrors of war itself. In so far as the role of international society can be said to have had any relevant impact on the course of the war itself, then elements of restraint and self-limitation in the use of force, the progressive institutionalization of order, and the practice of "pragmatic solidarity" in defense of regional common interests, are rescued from more popular representations of the Paraguayan War as a pure "orgy of violence" or "total war" unleashed by three powerful allies upon an isolated and relatively weaker, fellow South American republic.

\section{Self-Restraint in a "Total War"}

To explore the element of restraint in a war such as the one waged by the Triple Alliance and Paraguay, given the unprecedented number of casualties and the devastating 
demographical effects on at least one of its participants, may sound prima facie as a strange, or even futile, endeavor. After all, as a number of historians have established over the years, the Paraguayan War can be considered as the first case of "total war" in the Americassecond only to the U.S. Civil War. ${ }^{391}$ This idea has been amplified even more by revisionist historians, who often characterize the war as an "American holocaust," a "war of extermination," or even as "the war of the triple infamy," accusing the British Empire of being the main instigator behind the formation of the Triple Alliance and its so-called "genocide" of the Paraguayan people. ${ }^{392}$

There are many factors, however, that upon closer scrutiny point to a different, less categorical, conclusion. One of the main elements to consider is the fact that, of the total number of casualties produced by the war, at least two-thirds were caused by non-battlerelated factors. For all the episodes of brutality and horror experienced by the soldiers "on foot," most of their deaths were ultimately related to the incidence of other factors beyond direct "face-to-face" engagement with the enemy in battle. As historians agree, infectious diseases and pandemics, such as cholera, yellow fever, and diphtheria, as well as other health-related problems like thirst and trench-foot disease, were the main factors behind the high number of casualties produced by the War of the Triple Alliance. ${ }^{393}$ This was,

\footnotetext{
${ }^{391}$ See, .e.g., Capdevila, Una guerra total; Reber, “A Case of Total War”; Ricardo Salles, Guerra do Paraguai: Escravidão e cidadania na formação do exército (Rio de Janeiro: Paz e Terra, 1990), p. 8; Doratioto, Maldita guerra, pp. 195, 477; and John H. Williams, "A Swamp of Blood: The Battle of Tuyutí," Military History, Vol. 17, No. 1 (April, 2000), pp. 58-64.

${ }^{392}$ See Chiavenatto, Genocídio americano; Pomer, La guerra del Paraguay; Galeano, Las venas abiertas de América Latina; Fornos Peñalba, "The Fourth Ally”; and Silvânia De Queiróz, Revisando a revisão: "Genocídio americano: a guerra do Paraguai" (Porto Alegre: FCM editora, 2014). Cf. Alfredo Da Mota Menezes, A guerra é nossa: A Inglaterra não provocou a Guerra do Paraguai (São Paulo: Contexto, 2012); Doratioto, Maldita guerra; and Bethell, "The Paraguayan War," pp. 15-27.

${ }^{393}$ See Miguel Á. De Marco, "La sanidad militar argentina en la guerra con el Paraguay (1865-1870)," Revista Histórica [Buenos Aires], Vol. 3, No. 9 (julio-diciembre, 1981), pp. 55-86; De Marco, La guerra del Paraguay (Buenos Aires: Booket, 2nd ed., [1995] 2013), pp. 180-224; Yolanda C. Stewart Sellitti,
} 
after all, a common feature of most wars in the 19th century — such as the Napoleonic Wars, the Crimean War, the wars of German and Italian unification, and most prominently the U.S. Civil War. ${ }^{394}$ It is only in more recent times that technological advancements have been able to produce a change in this pattern. As Tanisha Fazal put it, "four key improvements in military medicine have driven up wounded-to-killed ratios since the nineteenth century: advances in preventive medicine; advances in battlefield medicine; improved evacuation times; and better protective armor for military personnel."395

Despite its popular characterization as a "total war," the study of the War of the Triple Alliance can, in fact, accommodate some elements of restraint and limitation in the use of force. Although every human death can be seen as unfortunate, most acts of extreme violence, brutality, and ferocity in this war came only from isolated battle engagements with the enemy. The tactical development of the war itself shows that it was waged according to separate "bursts" of violence, as each battle took place within several months of separation between one another, over a five-year period. ${ }^{396}$ This, in turn, also indicates that the most horrendous facets of the war were distributed across several years of intermittent warfare, and that interpersonal violence was relatively contained within those

\footnotetext{
Memorias del doctor Guillermo Stewart: Jefe de la Sanidad Militar durante la guerra del '70 (Asunción: Intercontinental, 2015); and Luiz de Castro de Souza, "A medicina na guerra de Paraguai: Mato-Grosso (Iv)," Revista de História, Vol. 37, No. 75 (1968), pp. 145-173; Vol. 38, No. 78 (1969), pp. 383-414; Vol. 40, No. 81 (1970), pp. 113-136; Vol. 41, No. 83 (1970), pp. 111-136; Vol. 42, No. 85 (1971), pp. 129 146.

${ }^{394}$ See Clara E. Councell, "War and Infectious Disease," Public Health Reports, Vol. 56, No. 12 (March, 1941), pp. 547-573; Charles E. Rosenberg, The Cholera Years: The United States in 1832, 1849 and 1866 (The University of Chicago Press, 1987); and James M. McPherson, Battle Cry of Freedom: The Civil War Era (Oxford University Press, 1988), pp. 487-489.

395 Tanisha N. Fazal, "Dead Wrong? Battle Deaths, Military Medicine, and Exaggerated Reports of War's Demise," International Security, Vol. 39, No. 1 (Summer, 2014), p. 97.

${ }^{396}$ See Bethell, “The Paraguayan War”; and Scheina, Latin America’s Wars, Vol. 1.
} 
episodes. Unlike contemporary notions of "total war," which imply the involvement of entire societies, and not just the use of military troops, or the constant and sustained condition of battle, the War of the Triple Alliance was in this regard remarkably contained within established cultural parameters of the time regarding notions of "civilized" conduct in war.

One of the main factors that made the war so costly, difficult, and protracted, however, was the uncharted terrain on which it unfolded. Before the war, little was known by the allies about Paraguay's unique topography. Surrounded by inhospitable tropical marshes, infested with mosquitos and other natural hazards, the terrain played an important role in support of Paraguay's stubborn resistance throughout the war. The eminent Paraguayan historian, Efraím Cardozo, argues that Francisco S. López actually considered this factor in his decision, not only to precipitate the war with Brazil, and then with Argentina, but also for refusing some of the diplomatic offers of support extended by Bolivia and the United States after the war had taken a clear turn in favor of the allies. ${ }^{397}$ Decision-makers in Buenos Aires and Río de Janeiro had no reliable maps or detailed guides to the area with which to properly plan a military campaign to Asunción. ${ }^{398}$ Since the initial diplomatic imbroglio that sparked the war involved Uruguay and its ongoing

\footnotetext{
${ }^{397}$ See Cardozo, El Imperio del Brasil y el Río de la Plata. For an extended analysis of the factors behind Paraguay's stubborn resistance and war "to the bitter end," see Weisiger, Logics of War, pp. 86-104; and Thomas L. Whigham, "Aspectos claves de la larga resistencia paraguaya: Disciplina militar, cohesión burocrática, y la ego manía del Mariscal López," in A 150 años de la guerra de la Triple Alianza contra el Paraguay, ed. by Juan G. Garavaglia and Raúl O. Fradkin (Buenos Aires: Prometeo, 2016), pp. 11-52.

${ }^{398}$ One of the first detailed descriptions of Paraguay's territory appeared in Buenos Aires as late as 1866. See Mariano A. Molar, "Descripción histórica de la antigua provincia del Paraguay," La Revista de Buenos Aires, Tomo IX, Año III, No. 33 (enero, 1866), pp. 8-22, 173-187, 300-310; Tomo X, Año III, No. 37 (mayo, 1866), pp. 47-60, 189-199, 310-319; Tomo XI, Año IV, No. 41 (septiembre, 1866), pp. 46-53, 194-208, 353-367, 472-488; Tomo XII, Año IV, No. 45 (enero, 1867), pp. 72-90, 199-224, 337-351; Tomo XIII, Año v, No. 49 (mayo, 1867), pp. 326-351, 527-537; Tomo XIV, Año V, No. 53 (septiembre, 1867), pp. 33-63; and Tomo XV, Año VI, No. 57 (enero, 1868), pp. 31-59, 157-174.
} 
civil war between Colorados and Blancos, none of the allies thought necessary at the time to procure such relevant information in the first place. Paraguay, after all, was not seriously in any Argentine or Brazilian plan for war in the early 1860s. They still were a more pressing threat to each other than a realistic danger to Paraguay, as erroneously immagined by Francisco S. López at the time.

One of the biggest ironies of the "Paraguayan" War is that in the beginning it did not contemplate Paraguay at all. The crisis that led to the war started in Uruguay, where the two main political factions reignited the civil war of earlier decades. The Blancos represented conservative and federalist ideals, and defended a decentralized national government in which the interior provinces would distribute power more equally with the capital city-port of Montevideo, where most of the customs revenue originated. When the Blancos established themselves in power in the early 1860s, the Colorados, representing centralist and Liberal values, were forced into exile in neighboring Argentina, where the Liberal party of Bartolomé Mitre offered sanctuary and turned a blind eye to Colorado political intrigue and military preparation. The leader of the Colorados, Venancio Flores, was a veteran of Argentina's own internecine wars, where he fought for Mitre's side, helping him consolidate power in a series of confrontations against the powerful caudillo from Entre Ríos, Justo J. de Urquiza. Given the particular context in which Uruguay was born as an independent republic, many of the political leaders on both sides of the River Plate shared political and ideological allegiances that played a central role in the 
transnational movement of forces that came to determine the fate of Uruguay's civil war in the mid-1860s. ${ }^{399}$

In this crisscrossed set of allegiances, the Unitarios of Argentina, led by President Mitre, supported the cause of the Colorados in Uruguay, led by Flores. But the opposite was also true. The Blancos in Uruguay, led by President Bernardo P. Berro, supported the cause of the multiple rebellious caudillos of northern Argentina-including Entre Ríosand presented a constant threat to Mitre's porteño centralizing project. Since the provincial caudillos in the north and north-east of Argentina remained defiant and, on occasion, turned to open armed revolt against Buenos Aires, the tension between the two Argentine factions was amplified by their mutual suspicions and accusations of invoking "external" (Blanco or Colorado) support. ${ }^{400}$ In this scenario, the bilateral relations between Argentina and

\footnotetext{
${ }^{399}$ For several classical studies on these transborder political-party dynamics, see José P. Barrán, Apogeo y crisis del Uruguay pastoril y caudillesco: 1839-1875 (Montevideo: Ediciones de la Banda Oriental, 1992); Juan E. Pivel Devoto, Historia de los partidos políticos en el Uruguay (Montevideo: García, 1942); Juan E. Pivel Devoto and Alcira Ranieri, Historia de la República Oriental del Uruguay (1830-1930) (Montevideo: Medina, 1966); Luis A. de Herrera, El Uruguay internacional (Paris: Grasset, 1912); Herrera, Antes y después de la Triple Alianza (Montevideo: Adroher, 1951-1952); and Eduardo Acevedo, Anales históricos del Uruguay (Montevideo: Barreiro y Ramos, 1933).

${ }^{400}$ On this phenomenon, see León Pomer, Cinco años de guerra civil en la Argentina (1865-1870) (Buenos Aires: Amorrortu, 1985); Pomer, Conflictos e intervenciones extranjeras en la cuenca del Plata (1810 1890) (Buenos Aires: Instituto Superior Dr. Arturo Jauretche, 2012); Ariel de la Fuente, Caudillo and Gaucho Insurgency during the Argentina State-Formation Process (La Rioja, 1853-1870) (Duke University Press, 2000); De la Fuente, "Federalism and Opposition to the Paraguayan War in the Argentine Interior: La Rioja, 1865-67," in I Die with My Country, pp. 140-153; Luiz A. Moniz Bandeira, La formación de los estados en la cuenca del Plata: Argentina, Brasil, Uruguay, Paraguay (Buenos Aires: Grupo Editorial Norma, 2006); Francisco Centeno, "Las montoneras: Invasión a Salta por el célebre montonero Felipe Varela," Revista de Derecho, Historia y Letras, Año XXIII, Tomo LXVIII (1921), pp. 111 119, 259-268, 366-394, 476-482; Tomo LXIX (1921), pp. 99-109, 381-403; Tomo LXX (1921), pp. 99108, 237-259; Fernando López-Alves, State Formation and Democracy in Latin America, 1810-1900 (Duke University Press, 2000); Frank J. McLynn, "The Frontier Problem in Nineteenth Century Argentina," History Today, Vol. 30 (January, 1980), pp. 28-32; McLynn, "Political Instability in Cordoba Province during the Eighteen-Sixties," Ibero-amerikanisches Archiv, Neue Folge, Vol. 6, No. 3 (1980), pp. 251-269; and McLynn, "The Ideological Basis of the Montoneros Risings in Argentina during the 1860s," The Historian, Vol. 46, No. 2 (February, 1984), pp. 235-251.
} 
Uruguay were at a low point in the early 1860 s, prior to Flores' military invasion of Uruguay in April, 1863.

Despite Paraguay's policy of self-imposed isolation between 1811 and 1862, when dictator Carlos A. López died, it played an active role in Platine affairs on at least two separate occasions. First, in the late 1850s, when Paraguay acted as a mediator in the civil war between the Confederated Provinces of Argentina, led by Urquiza, and Buenos Aires, led by Mitre. Paraguay's second deviation from its traditional policy came in 1864, in reaction to the Brazilian and Argentine involvement in Uruguay's civil war. This second Paraguayan activism in the region, however, would trigger the biggest military conflagration the region would ever come to experience.

In this complex web of transnational allegiances in the Plata region, Paraguay was not only considered by many in Buenos Aires as a "rogue" Argentine province, but was also suspected of providing support to the rebel caudillos in the interior provinces of Argentina - whose territories shared borders, customs and values with Paraguay. In the eyes of porteño elites, Paraguay represented a source of inspiration for the remaining caudillos in their federalist quest for more economic and political autonomy-if not outright de facto independence. Although Urquiza had moderated his political ambitions after his military defeat against Mitre in 1861, in the Battle of Pavón, other strong caudillos from the interior provinces were becoming impatient with Urquiza's more restrained approach. A younger generation of regional caudillos was increasingly organizing armed rebellions against Mitre and the Buenos Aires-led political project of central 
government. ${ }^{401}$ To complicate the panorama even further, a number of prominent Paraguayan exiles, declared enemies of Francisco S. López, found in Buenos Aires a hospitable place to plot the reconstruction of a more "Liberal" Paraguay after the downfall of the López pseudo-dynastic rule. ${ }^{402}$ Such was the fragile political scenario in the River Plate area before the War of the Triple Alliance erupted.

In this general context, it is important to explore in some detail three key diplomatic missions that preceded the war. These missions exemplify a concerted effort in trying to solve the crisis in Uruguay — and thus to avoid war. The ulterior failure of these missions, however, precipitated the involvement of Paraguay into the diplomatic crisis by declaring war on Brazil and Argentina for their violation of Uruguay's sovereignty. As the Paraguayan Minister of Foreign Affairs put it, their intervention in the Uruguayan civil war "disturbed the balance of power" in the Platine region, and Paraguay could not remain indifferent. ${ }^{403}$

The first two missions were sent by Argentina in mid-1863. One was led by José Mármol, and the other by the Argentine Minister of Foreign Affairs himself, Rufino de Elizalde. These missions had the objective of establishing channels of communication

\footnotetext{
${ }^{401}$ See Frank J. McLynn, “General Urquiza and the Politics of Argentina, 1861-1870,” Ph.D. Dissertation, London: University of London (1976); McLynn, "Urquiza and the Montoneros: An Ambiguous Chapter in Argentina History," Ibero-amerikanisches Archiv, Neue Folge, Vol. 8, No. 3 (1982), pp. 283-295; McLynn, "The Montoneros Risings in Argentina during the Eighteen-Sixties," Canadian Journal of History, Vol. 15, No. 1 (1980), pp. 49-66; Beatriz Bosch, "Los desbandes de Basualdo y Toledo," Revista de la Universidad de Buenos Aires, Vol. 4, No. 1 (1959), pp. 213-245; Bosch, "Urquiza y la guerra de la Triple Alianza," Boletín de la Academia Nacional de la Historia, Vol. 34, No. 2 (1963), pp. 819-835; Bosch, Urquiza y su tiempo (Buenos Aires: EUDEBA, 1971); De la Fuente, Caudillo and Gaucho Insurgency; and Julio Victorica, "Reminiscencias históricas: El General Urquiza, los Estados Unidos y el Paraguay," Revista de Derecho, Historia y Letras, Año II, Tomo VI (1900), pp. 389-402.

${ }^{402}$ See Juan B. Gill Aguinaga, La Asociación Paraguaya en la guerra de la Triple Alianza (Asunción: ServiLibro, [1959] 2011).

${ }^{403}$ From J. Berges to C. Vianna de Lima, Asunción, August 30, 1864, Paraguay, Archivo Nacional de Asunción, Colección Río Branco, Doc. I-30-24-26, No. 2975.
} 
between the ruling Blanco party — practically besieged in Montevideo — and the Colorados, led by Flores, who were in open revolt against the Berro administration and in control of large areas of the rural interior of the country. A third effort was a Brazilian mission, sent to Montevideo in mid-1863, and led by José A. Saraiva. This was a last and desperate attempt to contain the Uruguayan civil war and put an end to a number of serious security and economic externalities that had been disturbing the state of Rio Grande do Sul, in southern Brazil, since at least 1852, but which remained problematically unresolved. ${ }^{404}$

Given the delicate nature of Argentina's relations with Uruguay over the unofficial porteño support to Flores, Mitre felt it was more sensitive to first send Mármol to Río de Janeiro to reach a common understanding with the Brazilian Empire in order to avoid letting the Uruguayan crisis drag both powers into a conflict with each other. ${ }^{405}$ According to his instructions, Mármol's mission had to secure the final treaty of the Convention of 1828 concerning Uruguay's independence and territorial integrity. To achieve these goals, Mármol had to remove all possible sources of misunderstanding between Brazil and Argentina regarding their respective policies towards the ongoing civil war in Uruguay. In a critical passage of the instructions, Elizalde said to Mármol that his ulterior objective was "to reach an agreement with the Brazilian government to implement a joint action aimed at putting an end to the prevalent disorder in Uruguay through their influence and, if

\footnotetext{
${ }^{404}$ The diplomatic context leading up to the outbreak of the war is well reconstructed in Box, The Origins of the Paraguayan War, esp. pp. 70-178.

${ }^{405}$ On the Mármol mission, see Cardozo, El Imperio del Brasil y el Río de la Plata, pp. 149-167. This showed Mitre's clear-eyed foreign policy and strategic far-sightedness, trying to avoid the perpetuation of former Luso-Spanish inter-imperial rivalries in the area.
} 
necessary, the use of force." ${ }^{406}$ In a communication with Edward Thornton, the British representative in Buenos Aires, Elizalde revealed that he had instructed Mármol to

enquire of the Government of the Emperor how long they would deem it expedient to allow the continuance of the present intestine commotions in the Republic of the Uruguay by which the interests of the numerous Argentines and Brazilians resident in that country as well as the general commerce of the other two countries were so seriously prejudiced, and, if possible to come to an arrangement with the Brazilian Government for a joint intervention for the purpose of putting an end to the existing disorder in the Republic of the Uruguay, by the exertion of their influence, or if necessary, of force. ${ }^{407}$

Elizalde had a clear plan for the region. The success of Mármol's mission in securing the independence of Uruguay depended on an agreement that if either Argentina or Brazil had to use armed force in Uruguay, its territory would not be curtailed in any way. This part of Elizalde's plan, however, was not clearly transcribed to Mármol in the official instructions. This became evident when an opportunity opened up in Montevideo, but no positive result materialized. On its way to Río de Janeiro, Mármol had a brief stay in the Uruguayan capital. This opportunity was seized by William G. Lettsom, the British chargé d'affaires in Uruguay, to arrange an informal meeting over dinner between him, Mármol, and Uruguay's Minister of Foreign Affairs, Juan J. de Herrera. After five hours, little progress was made. The Argentine and Uruguayan diplomats compared accusations and denials of involvement in the civil war, and most suggestions for peace ended vaguely with promises of redacting new basis for future negotiation, but no concrete peace plan. ${ }^{408}$

\footnotetext{
${ }^{406}$ From R. de Elizalde to J. Mármol, Buenos Aires, March 2, 1864, in Ricardo R. Caillet-Bois, "1864, un año crítico en la política exterior de la presidencia de Mitre," Boletín de la Academia Nacional de la Historia, Vol. 17 (1946), p. 52.

${ }^{407}$ From E. Thornton to J. Russell, Buenos Aires, March 24, 1864, Foreign Office 6.250, Dispatch No. 35, in Box, The Origins of the Paraguayan War, p. 104.

${ }^{408}$ See Cardozo, El Imperio del Brasil y el Río de la Plata, pp. 153-154; Box, The Origins of the Paraguayan War, pp. 104-105; and Caillet-Bois, "1864, un año crítico en la política exterior de la presidencia de Mitre," pp. 52-54.
} 
With the failure of this impromptu negotiation, Mármol continued his journey to Río de Janeiro, where he arrived on April 6, 1864. Months prior to his arrival, the Chamber of Deputies in Brazil, led by a Liberal coalition, had pushed Brazilian Chancellor, João P. Dias Vieira, to adopt a harsher stance on the Uruguayan crisis. ${ }^{409}$ The Liberal party in Brazil was now voicing some of the concerns brought up by the Riograndenses towards finding an actual solution the Uruguayan civil war once and for all. This meant that the timing of Mármol's arrival was quite unfortunate, for the new political situation was not contemplated in his written instructions - although it was an option considered in Elizalde's overall plan, as it was conveyed to Thornton. The lack of clear communication between Elizalde and Mármol created a situation in which the Argentine representative in Río de Janeiro limited himself to merely signal that the Mitre administration would not view it with suspicion if Brazil felt it necessary to intervene in Uruguay to bring its domestic anarchy to a resolute end. In this first rapprochement with Brazil, although part of the original plan was attained, it generated a new danger, for now Brazil interpreted Mármol's mission as a "green light" to use force unilaterally as long as it did not alter Uruguay's territorial integrity.

With this important antecedent, the Brazilian Empire instituted a plan of increasing pressure on Montevideo, which was combined with open support for Flores' troops. There was a clear potential threat of an armed intervention if the chaos and disorder in Uruguayparticularly in the northern region-did not stop or the Berro administration did not offer

\footnotetext{
${ }^{409}$ For the communications that Mármol maintained with Mitre while in Río de Janeiro, see Argentina, Museo Mitre, Archivo del General Mitre: Documentos y correspondencia (Buenos Aires: Biblioteca de "La Nación,” 1914), Vol. 27: pp. 146-153.
} 
credible guarantees for the future. A long list of crimes and violations against Brazilian citizens and their property in northern Uruguay had gone unanswered for over a decade. Brazil's foreign policy was thus, in large part, over-reacting to the pressures of the powerful political and military leaders from the southern state of Rio Grande do Sul. This region had always had a history of contestation and intermittent uprisings against the monarchy, which on occasion had led to armed rebellions and intimations of civil war. The troubled relationship between Rio Grande do Sul and Uruguay, for its part, rested on the externalities generated from the ongoing civil war, which often resulted in the violation of Brazilian private property in estates and farms in the Uruguayan countryside, as well as the periodic loss of life, forced recruitment, and abuse of Brazilian run-away slaves caught in between the rivaling factions. ${ }^{410}$

To preempt Brazil's unilateral intervention in Uruguay, Elizalde personally embarked on a "confidential" mission to Montevideo in a desperate attempt at diffusing all animosities between Flores and Atanasio Aguirre, the new interim Uruguayan president. ${ }^{411}$ In order to render Brazil's intervention unnecessary, Elizalde took a risk by entering Uruguay incognito, traversing several miles on horseback through the rough country side. He was entering as a private citizen since diplomatic relations between Argentina and

\footnotetext{
${ }^{410}$ See Roger Kittleson, "The Paraguayan War and Political Culture: Rio Grande do Sul, Brazil, 1865-80," in I Die with My Country, pp. 105-118; Eduardo Santos Neumann and Luiz A. Grijó, org., O continente em armas: Uma história da guerra no sul do Brasil (Rio de Janeiro: Apicuri, 2010); and Vitor Izecksohn and Peter M. Beattie, "The Brazilian Home Front during the War of the Triple Alliance, 1864-1870," in Daily Lives of Civilians in Wartime Latin America, ed. by Pedro Santoni (Greenwood Press, 2008), pp. 123-145. See also Amado L. Cervo, O Parlamento brasileiro e as relações exteriores (1826-1889) (Brasília: Universidade de Brasília, 1981), pp. 94-100.

${ }^{411}$ For Elizalde's confidential letters with Mitre during this mission, see Correspondencia Mitre-Elizalde (Buenos Aires: Universidad de Buenos Aires, 1960); and Argentina, Museo Mitre, Archivo del General Mitre, Vol. 27: pp. 165-205.
} 
Uruguay had deteriorated to the point of interruption after Mármol's failed negotiation. Elizalde would later look back upon this effort in preventing the war through such unconventional ways by humorously referring to it as "Diplomacia Pampa."

Elizalde's mission was quite successful at the beginning. Upon arrival in Montevideo on June 16,1864 , he officially announced his presence, which was very much welcomed by the press. He then met with Herrera, with whom he confided that his motivation for helping Uruguay reach internal peace had been amplified by the aggression of the Spanish Admiral Pinzón in the Pacific. ${ }^{413}$ Similarly, in successive communications sent to the Argentine representative in Paris, Mariano Balcarce, Elizalde made clear his preoccupation with the Spanish aggression towards Peru in the Chincha Islands. With this in mind, he instructed Balcarce to inquiry about the true intentions of Spain in the Pacific, and to reach out to other powers, such as France and England, to contain Spanish ambitions in the region. ${ }^{414}$ This created the further necessity of putting out the fires in the Plata region in the face of a potential common danger. But Elizalde's mission came as a surprise for the Brazilian Chancellor, Dias Vieira, who had just commissioned some weeks earlier Conselheiro Saraiva to go to Montevideo to obtain the security guarantees from the Blanco government, or otherwise deliver an ultimatum in case of rejection. These two overlapping

\footnotetext{
${ }^{412}$ Caillet-Bois, “1864, un año crítico en la política exterior de la presidencia de Mitre," p. 60.

${ }^{413}$ From R. de Elizalde to B. Mitre, Montevideo, June 6, 1864, in Argentina, Museo Mitre, Archivo del General Mitre, Vol. 27: pp. 165-166.

${ }^{414}$ See Mario Belgrano, "España y el conflicto del Pacífico, 1864-1867," in Contribuciones para el estudio de la historia de América: Homenaje al Doctor Emilio Ravigniani (Buenos Aires: Peuser, 1941), pp. 515549. Several of the confidential letters between Elizalde and Balcarce were accessed through Argentina, Documentos del Dr. Rufino de Elizalde, Instituto Ravignani, Buenos Aires, section "Año 1863: Correspondencia del exterior - Correspondencia de Mariano Balcarce con Rufino de Elizalde."
} 
missions, therefore, created some rifts between Elizalde and Saraiva, as one had come to put out fires, while the other was carrying a concealed threat.

After a number of failed attempts at avoiding Elizalde, the two diplomats finally met. Saraiva was not convinced by Elizalde's framing of the regional panorama-thus minimizing Pinzón's threat for the River Plate area. However, Elizalde had more success in convincing the Brazilian representative of another threat, much closer and immediate. In an attempt at interesting Saraiva in coming to a joint understanding in favor of the necessity to prioritize order in the Plata region, the Argentine Minister showed Saraiva a series of letters and private documentation proving that the Paraguayan agent in Buenos Aires had been sending copious amounts of money to European capitals for the procurement of armaments and other war materiel. Furthermore, Mitre had received reliable information about a letter penned by the Paraguayan Minister of Foreign Affairs, José Berges, in which he pointed out Paraguay's eagerness and expectant opportunism to initiate a war with Brazil. ${ }^{415}$ It was clear to Elizalde, as he tried to convey to Saraiva, that although a Brazilian armed intervention in Uruguay would be treated by Argentina as a necessary development in order to "pacify" that country, it would most certainly also trigger a Paraguayan reaction that could engulf the entire region in an international war.

Although Elizalde's diplomatic effort in opening a channel for negotiation between Flores and Aguirre did not succeed in physically bringing both leaders to the same room or shaking hands with one another, at least it made both parties agree on a joint mediation

\footnotetext{
${ }^{415}$ See from J. Berges to L. Torres, Asunción, March 6, 1864, Paraguay, Archivo Nacional de Asunción, Colección Río Branco, I-22-12-1, No. 71. On the role that Lorenzo Torres played as an informant for Mitre on this issue, see Efraím Cardozo, Paraguay independiente (Asunción: ServiLibro, [1949] 2011), pp. 257261; Cardozo, El Imperio del Brasil y el Río de la Plata, p. 209; and Box, The Origins of the Paraguayan War, pp. 198-201.
} 
facilitated by Elizalde, Thornton, and Saraiva. ${ }^{416}$ The objectives of this tripartite mediation were initially quite successful, thanks to an improvised solution proposed by Elizalde. The parties met, in true "pampa diplomacy" style, in a commonly agreed location in the country side, near Flores' camp. The intermediaries would separately talk to Flores and the two Blanco envoys, and draft a series of concrete propositions that both parties would likely come to see favorably. After several rounds, the mediators managed to get the two otherwise stubborn and bitter rivals to agree on the fact that the Blanco administration would incorporate into a new cabinet more moderate Blanco co-religionaries, in replacement of the current party fanatics and exaltés occupying all the key Ministries. In return, Flores would stand down his forces and agree to an end of the civil war in the hope that, in the incoming electoral cycle (set for February 1864), the Colorados would be allowed to participate in Congress and vie for ministerial positions. This would have been a fantastic result for Elizalde's diplomatic mission and overall plan to pacify the Platine region. Upon return to Montevideo, however, the two Blanco negotiators found that Aguirre had succumbed to the pressure from of the hardliner members of the party, who forced him to back-track on all his earlier commitments to Flores. The situation

\footnotetext{
${ }^{416}$ The diplomatic correspondence related to the confidential Elizalde mission to Montevideo is partially reproduced in Argentina, Memoria del Ministerio de Relaciones Exteriores (1865), pp. 21-74. The Brazilian correspondence related to Saraiva's participation is partially reproduced in Brazil, Ministério das Relações Exteriores, Relatório da repartição dos negócios estrangeiros apresentado á Assambléa Geral Legislativa (Rio de Janeiro: Laemmert, 1864), Annexo 1: pp. 1-10. For Thornton's participation, see the correspondence reproduced in Great Britain, Foreign Office, Correspondence Respecting Hostilities in the River Plate: Confidential F.O. 420: 18 [HC-PP] (London: Harrison, 1865). This is nicely complemented with (previously unpublished) documentation by Juan Oribe Stemmer, El umbral de la Triple Alianza: Correspondencia de los representantes diplomáticos británicos en el Río de la Plata y documentos complementarios de la región, enero 1864 - agosto 1865 (Montevideo: Banda Oriental, 2nd ed., rev. and enlarged, [2008] 2013).
} 
deteriorated rapidly, which opened the door for Brazil, with the good will of Mitre, to pressure Montevideo one last time, before issuing an ultimatum. ${ }^{417}$

The failure of the tripartite mediation made Brazil's position uncomfortable. Saraiva, originally sent to Montevideo to put diplomatic pressure on the Blanco government, had been dragged in by Elizalde's clever and timely intervention to turn a unilateral mission of diplomatic pressure into a joint mission of peace. With the change in tone and the subsequent failure of the mediation, Herrera adopted a more dogmatic stance, invoking Uruguayan principles of independence and national honor, and flatly dismissed all of Saraiva's requests for reassurance on the northern question. Thus, Herrera brought both countries to the brink of war. ${ }^{418}$ A growing tension and set of reprimands soon followed between Saraiva and Dias Vieira, which provoked Saraiva's reassignment to Buenos Aires. The Brazilian Council of State wanted to leave the Elizalde-Saraiva connection open to reassure the good will of the Mitre administration in case of an intervention. Saraiva's replacement in Montevideo, José M. da Silva Paranhos (Viscount of Rio Branco), would further Brazil's plans of intervention by formally securing the Empire's support for Flores and his Colorado faction in the Uruguayan civil war. Unlike

\footnotetext{
${ }^{417}$ On the Saraiva mission, see Correspondencia e documentos officiaes relativos á Missão Especial do Conselheiro José Antonio Saraiva ao Rio da Prata em 1864 (Bahia, Typographia do "Diario," 1872); and Uruguay, Ministerio de Relaciones Exteriores, Documentos diplomáticos: Misión Saraiva (Montevideo: Imprenta de la Reforma Pacífica, 1864). See also Hélio Lobo, Antes da guerra (A missão Saraiva ou os preliminares do conflicto com o Paraguay) (Rio de Janeiro: [n/d], 1914); and Lobo, Ás portas da guerra: (Do ultimatum Saraiva, 10 de agosto de 1864, á Convenção da Villa União, 20 de fevereiro de 1865) (Rio de Janeiro: Imprensa Nacional, 1916).

${ }^{418}$ See Luis A. de Herrera, La diplomacia oriental en el Paraguay: Correspondencia oficial y privada del doctor Juan José de Herrera, Ministro de Relaciones Exteriores de los gobiernos de Berro y Aguirre (Montevideo: Barreiro y Ramos, 1908-1911), Vol. 1-2; and Herrera, Antes y después de la Triple Alianza, Vol. 1. For an important rejoinder, $c f$. Walter A. de Azevedo, "A 'Diplomacia Oriental en el Paraguay' do Dr. D. Luis Alberto de Herrera (Algumas notas)," Crítica Jurídica, Histórica, Política y Literaria, Tomo XVII, No. 48-50 (1928), pp. 141-151; Tomo XVIII, No. 51-53 (1928), pp. 21-35.
} 
the Blancos in Montevideo, Flores promised the Brazilian Empire that upon assuming office he would put an end to the civil war and solve all the sources of diplomatic trouble between both countries regarding the "anarchy" of the northern frontier. ${ }^{419}$

While these three missions tried to prevent the deepening of the Uruguayan civil war, the Blanco administration had not remained idle. Between the last months of the Berro administration and the interim presidency of Aguirre, the Uruguayan Minister, Herrera, had initiated a diplomatic "charm offensive" in Paraguay trying to secure an intimate alliance between both countries. Herrera sent a series of special missions to Asunción during the last months of 1863 and throughout 1864 in a desperate attempt to convince Francisco S. López and his Minister of Foreign Affairs, José Berges, of the strategic necessity of forging an offensive-and-defensive alliance. Herrera appealed to López's own sensibilities with regards to the "balance of power" in the region, which he claimed would be negatively affected by a Brazil-Argentina coordination in support of Flores. ${ }^{420}$

In early 1863, almost a month before Flores' military invasion, Octavio Lapido's mission to Asunción set in motion Herrera's strategy. Arriving after the recent death of Carlos A. López, Francisco S. López's father and former ruler of Paraguay, the Lapido

\footnotetext{
${ }^{419}$ On the Paranhos mission, see Cesar de Oliveira Lima Barrio, A missão Paranhos ao Prata (1864-1865): Diplomacia e política na eclosão da guerra do Paraguai (Brasília: Fundação Alexandre de Gusmão, 2010); Lobo, Ás portas da guerra; Doratioto, Maldita guerra, pp. 71-79; and Box, The Origins of the Paraguayan War, pp. 224ff.

${ }^{420}$ Luis A. de Herrera (Juan J. de Herrera's son) published after his father's death a series of volumes in which historical narrative is mixed with the transcription of primary documentation taken from the personal archive of J. J. de Herrera, in an attempt at reaffirming the Foreign Minister's "true" role in the outbreak of the war and clear his name in the face of accusation and smear. See Herrera, La diplomacia oriental en el Paraguay, Vols. 1-5. Although this work is a deeply partial and selective account of the events, it is nevertheless a good source of primary documentation for studying the three Uruguayan missions to Asunción, which tried to convince Paraguay to come to Uruguay's aid - and thus of crucial importance in understanding the role of Herrera (and Blanco diplomacy, in general) in precipitating Paraguay's involvement in the war.
} 
mission shows the extent of Herrera's far-sightedness and strategic awareness of the common interests linking Uruguay and Paraguay in the Platine region as "buffer states" deeply affected by the spill-over effects of party in-fighting across borders. ${ }^{421}$ Francisco S. López's recent experience in Europe in a diplomatic mission to procure engineers, military experts, and weaponry for Paraguay, had introduced him to the intricacies of European principles of diplomacy - the balance of power, in particular. ${ }^{422}$ Lapido, under Herrera's instruction, appealed to the strategic sensibility of the Paraguayan leader in order to form an alliance between both countries. Although Lapido's negotiations with Berges failed in the end to concretize such an alliance, they certainly resonated with López's well-known megalomaniac personality and his vision of a more prestigious Paraguay, called upon by history to play a central role in the Platine balance of power. ${ }^{423}$

Numerous letters exchanged between Herrera and Lapido confirm that Herrera himself also shared a similar sensibility towards the (European) principle of the balance of power. The invocation of this principle, therefore, cannot be easily interpreted as a tactic or an attempt at manipulation of the Paraguayan leader to secure his military support against Flores and his allies. It seems more plausible that both leaders shared a sincere appreciation of its applicability to their countries' similar geopolitical positions and

\footnotetext{
${ }^{421}$ An importance antecedent, however, had occurred in March 1862, when Herrera himself attempted a similar rapprochement with Paraguay's previous ruler, Carlos A. López. Herrera had tried to convince the stubbornly isolationist Paraguayan dictator of the need to join Uruguay's cause. See Whigham, The Paraguayan War, pp. 140-141.

${ }^{422}$ On López's mission to Europe and his infatuation with the principle of the balance of power in European history, see Augusto Ocampos Caballero, Emancipación y diplomacia: Misión de Solano López en Madrid (Asunción: Ricor, 1995); and Rómulo J. Yegros, Diario de viaje a Europa (1853-1854) (Asunción: Academia Paraguaya de la Historia, 2006).

${ }^{423}$ See Whigham, The Paraguayan War, pp. 141-142.
} 
common interests. ${ }^{424}$ The extent to which this first mission to Asunción played a central role in involving López in the War of the Triple Alliance is still unclear. Lapido's mission, however, was at least instrumental in either igniting or reinforcing López's framing of the Platine affairs in terms of a balance of power with interlocking common interests.

During the following year, two additional missions to Asunción made sure that a constant pressure was maintained on Paraguay's decision-makers through an insistent enticing of Paraguay to forge "a mutually beneficial alliance." Commissioned by Uruguayan Minister of Foreign Affairs, José Vásquez Sagastume and Antonio de las Carreras, two card-carrying Blancos, intrigued and conspired with López and Berges to obtain any type of commitment, verbal or otherwise, to make Paraguay intervene in the civil war on the side of the Blancos. While Lapido's activities in Asunción had at least created an atmosphere of suspicion against Argentina, suggesting at times ambitious plans of a military alliance with the Argentine provinces that opposed Buenos Aires, the roles of Vásquez Sagastume and De las Carreras raised the bet even further. The Uruguayan agents were so desperate in trying to secure Paraguay's military assistance that, when faced with López's stern reluctance, they began to spin increasingly wilder conspiracies of a "common threat" in an Argentine-Brazilian secret plan to coordinate a military invasion against both countries. Uruguay was not being "pacified," but erased. And Paraguay was next. ${ }^{425}$

\footnotetext{
${ }^{424}$ The original documents of the Lapido mission were consulted in Uruguay, Archivo General de la Nación, "Legación en el Paraguay," Box 424, File 1, No. 1-II (composed of 239 pp.). For a partial reproduction and commentary, see Herrera, La diplomacia oriental en el Paraguay, Vol. 2: pp. 380-534.

${ }^{425}$ On these two missions, see Herrera, La diplomacia oriental en el Paraguay, Vol. 3: pp. 343-393 and Vol. 5; Whigham, The Paraguayan War, pp. 118-161; Box, The Origins of the Paraguayan War, pp. 171178; Cardozo, Vísperas de la guerra del Paraguay, pp. 105-116.
} 
In the course of two years, Paraguay had been implored by successive Uruguayan diplomats to officialize a military alliance with Uruguay with a promise of reciprocity, in the case of Paraguay being the one attacked by its neighbors. From Herrera (in 1862) and Lapido (in 1863), to Vásquez Sagastume and De las Carreras (in 1864), all possible excuses were tried out: from principled appeals to balance-of-power considerations, to now more concrete accusations of mutual extermination by their neighbors. Helping Uruguay was presented, therefore, not only as in Paraguay's best interest, but also as an issue of national survival. Both countries, according to Herrera, were going to be invaded and territorially partitioned by Argentina and Brazil. Unbeknownst to López, however, Herrera was simultaneously negotiating an agreement with Elizalde, officially accepting the Argentine explanation of its policy of "strict neutrality" in Uruguay's civil war. ${ }^{426}$

In reaction to these requests and the absence of any evidence to support such accusations, Francisco S. López took a problematic decision that would eventually damage Paraguay's bilateral relations with Argentina, and soon plunge Paraguay into war. In a blunt attempt at "consulting" the Argentine government about the accusations made by Uruguayan officials, López wrote to Mitre to explore the possibility—suggested months before by Herrera —of acting as an arbiter or mediator in the ongoing civil war in Uruguay. López envisioned himself as a key strategic actor in the Platine equilibrium which, just like in Europe, would earn him and his country enormous amounts of prestige and decidedly break with decades of Paraguayan isolation. ${ }^{427}$ Although the tone of the conversation

\footnotetext{
${ }^{426}$ For these parallel negotiations between Elizalde and Andrés Lamas, the Uruguayan special representative, see Andrés Lamas, Tentativas para la pacificación de la República Oriental del Uruguay, 1863-1865 (Buenos Aires: Imprenta de la Nación Argentina, 1865).

${ }^{427}$ See Cardozo, El Imperio del Brasil y el Río de la Plata, pp. 226-229; and Box, The Origins of the Paraguayan War, pp. 179ff. The diplomatic correspondence between B. Mitre and F. S. López has been
} 
between both leaders was candid and polite, Mitre ultimately rejected López's role as a mediator. This prompted López to instruct his Minister of Foreign Affairs to communicate in parallel with Elizalde to ask for explanations regarding the accusations raised by Uruguay's agents. In a stunning decision that would shock both the Uruguayans as much as the Argentines, Berges shared with Elizalde all the correspondence between the Uruguayan agents in Asunción and his government.

This was problematic for several reasons. First, because it betrayed the confidence of a potential ally by exposing Uruguay's rebellious plans, damaging accusations, and duplicity towards Mitre. Second, because neither Mitre nor Elizalde were entirely aware at the time of the real magnitude of Uruguay's diplomacy of intrigue and hostility against Argentina. And lastly, because in the face of this new information, Mitre's policy of rapprochement towards Brazil became the most reliable option to counteract such a potential transnational alliance between Uruguay, Paraguay, and the rogue federal caudillos of northern Argentina. If these plans were true, Uruguayan diplomacy presented a conspiracy against Argentina's territorial integrity as well. ${ }^{428}$

The correspondence exchanged between Berges and Elizalde on this issue also demonstrates the extent of the damage done by Paraguay's diplomatic blunder. In what

extensively reproduced in Argentina, Museo Mitre, Archivo General Mitre, Vol. 2: pp. 9-62; and Paraguay, Ministerio de Relaciones Exteriores, Correspondencia confidencial entre el Exmo. Sr. Presidente de la República del Paraguay y el de la Confederación Argentina en 1863 y 1864 (Asunción: Imprenta Nacional, [1867] 1886).

${ }^{428}$ For this reason, Mitre reached out to his old political and military rival, Justo J. de Urquiza, a still powerful caudillo from Entre Ríos, to corroborate whether the Uruguayan plans for sedition in Argentina's northern provinces were real. Urquiza, for his part, also sent a personal envoy to Asunción to reassure López of the absence of any support to the Uruguayan plan against Buenos Aires. The correspondence between Mitre and Urquiza has been reproduced in Argentina, Museo Mitre, Archivo General Mitre, Vol. 2: pp. 63-129. See also Cardozo, Vísperas de la guerra del Paraguay, pp. 117-138. 
Berges thought to be a display of trust towards Buenos Aires, Elizalde saw an attempt at intimidation and Paraguayan involvement in "strictly Platine affairs," in which Paraguay was expected to play no meaningful role. ${ }^{429}$ Upon Berges' insistent requests for explanations regarding the veracity of the Uruguayan accusations, Elizalde stalled with promises of future letters that would clarify the whole affair. The demands for explanation were so outrageous that Elizalde had no intentions of ever providing any clarifications. In reaction to Argentina's policy of contempt, therefore, López instructed Berges to forgo all requests for explanation and brusquely declare that from then on Paraguay would follow a policy according only to its own national interest. ${ }^{430}$

By mid-1864, Blanco diplomacy in Asunción had triumphed in creating intrigue and mistrust between Paraguay and its neighbors. Although no formal military alliance had been signed, Paraguay damaged its relations with Argentina by demanding explanations about the Uruguayan intervention, while ipso facto also revealing that it was not a reliable confidante, nor a restrained strategic player. With the failure of the Argentine and Brazilian missions, therefore, the scenario deteriorated even further when Brazil's ultimatum expired and intervention soon followed. In anticipation of the use of force by Brazil, Paraguay unilaterally declared on August 30,1864, that if any military aggression against Uruguay's territorial integrity were to take place, it would elicit a similar reaction by Paraguay against

\footnotetext{
${ }^{429}$ The correspondence between Elizalde and Berges on this issue has been reproduced in Paraguay, Ministerio de Relaciones Exteriores, Correspondencia confidencial; Argentina, Memoria del Ministerio de Relaciones Exteriores (1864), pp. 281-321; and Arturo Rebaudi, La declaración de guerra de la República del Paraguay a la República Argentina: Misión Luis Caminos-misión Cipriano Ayala-declaración de Isidro Ayala (Buenos Aires: Serantes, 1924), pp. 134-162.

${ }^{430}$ From J. Berges to R. de Elizalde, Asunción, September 6, 1863, Paraguay, Archivo Nacional de Asunción, Colección Río Branco, No. 2117. See also the follow-up exchanges from October 2, 1863, No. 2164; October 21, 1863, No. 2214; December 16, 1863, No. 2336/7; December 21, 1863; No. 2356; December 31, 1863, No. 2164/5; and January 6, 1864, No. 2429.
} 
the aggressor. "The alternative of the ultimatum has left a painful impression in the opinion of [my] government," wrote Berges to César S. Vianna de Lima, the Brazilian Minister in Asunción. "No less painful [...] has been the rejection by H. E. Counsellor Saraiva to the proposition of arbitration [...]." And then added:

The Government of the Paraguayan Republic profoundly deplores that Yours had thought opportune to depart in this occasion from the policy of moderation in which it should have trusted now more than ever, after signing the Congress of Paris, but cannot look upon this matter with indifference, nor consent that, in execution of the [...] ultimatum, the Imperial armed forces of Brazil either through land or sea occupy part of the territory of the Uruguayan Republic either temporarily or permanently [...]. The Government of the Republic of Paraguay will consider any occupation of Uruguayan territory by Imperial forces $[\ldots]$ as injurious to the equilibrium of the Platine states, which is of interest to the Republic of Paraguay as a guarantee of its security, peace, and prosperity; and that it protests in the most solemn manner against such act, freeing itself from all responsibility regarding the ulterior consequences of the present declaration. ${ }^{431}$

On the very same day, Berges wrote a notably long letter to Vásquez Sagastume, the Uruguayan representative in Asunción, explaining the reasons why Paraguay had decided not to insist on a proposal for mediation or arbitration, given Mitre's earlier rejection. More importantly, Berges expressed a profound disappointed in the duplicity of Uruguay's diplomacy after receiving confirmation (partly through Mitre's correspondence with López) of Montevideo's parallel negotiations of peace with Buenos Aires. With this letter, therefore, Paraguay was declaring that it was willing to intervene militarily in defense of its own interests and principles affected by the foreign intervention in Uruguay, but without forging an alliance with Montevideo. ${ }^{432}$

\footnotetext{
${ }^{431}$ From J. Berges, to C. Vianna de Lima, Asunción, August 30, 1864, Paraguay, Archivo Nacional de Asunción, Colección Río Branco, I-30-24-26, No. 2975.

${ }^{432}$ From J. Berges to J. Vásquez Sagastume, Asunción, August 30, 1864, in Semanario, No. 540 (September 1, 1864). For the complete exchange of correspondence between Paraguay and Brazil from this point until the official break-up of diplomatic relations, see Paraguay, Ministerio de Relaciones Exteriores, Documentos oficiales concernientes a la ruptura de relaciones entre el gobierno de la República del
} 
After the collapse of the negotiations between Silva Paranhos and the Blanco government in Montevideo, Brazil proceeded with a military intervention in support of Flores. After the joint forces invaded from the north, and the major coastal cities on the River Uruguay were attacked with the assistance of the Brazilian navy, Paraguay declared war on the Empire. The first Paraguayan reaction was the seizure of the Marquês de Olinda, a Brazilian steamer passing through Asunción on its way to the northern Brazilian province of Mato Grosso, on November 13, 1864. This vessel was carrying the new governor of that province, which amplified the effects of the Paraguayan reaction, for it also involved the imprisonment of a Brazilian high official. ${ }^{433}$

The taking of the steamer and the declaration of war closed the period of diplomatic intrigue and negotiation, and set in motion the purely military phase of the war. In its early stage, the War of the Triple Alliance confronted Paraguay with Brazil—allied with Flores' Colorado faction. It was, in this regard, characterized by a Paraguayan offensive against Brazil. After receiving the confirmation of the intervention in Uruguay, López took advantage of the military buildup which he had so laboriously presided over several years before taking office. In accordance to what he and his Ministers had communicated to Argentina and Uruguay before the outbreak of the war, his first strategic decisions were taken according to Paraguay's own self-interest—and not in support of an ally. This became evident when the first Paraguayan offensive was directed north, to Mato Grosso, and not south-east, towards Uruguay to aid the Blancos fend off the invaders. Mato Grosso

\footnotetext{
Paraguay y el del Imperio del Brasil a consecuencia de la ocupación a mano armada del territorio de la República Oriental del Uruguay por fuerzas brasileras (Asunción: El Paraguayo, 1890).

${ }^{433}$ See Whigham, The Paraguayan War, pp. 160-161.
} 
was an isolated Brazilian province that was practically unreachable via land due to the thick vegetation and swampy terrain connecting that province with the rest of Brazil. The only effective way of reaching Mato Gross was via navigation of the River Paraguay, cutting across Paraguay from south to north [see infra Map 4]. Although the province offered no real military threat, López opened his military campaign with a signature move, more symbolic than strategically sound — as it later became quite evident. ${ }^{434}$

With little resistance, Paraguay was able to capture important military materiel and assets with which to initiate a second campaign towards Uruguay. During this part of the offensive, which developed all throughout 1865 , several key strategic and tactical mistakes left Paraguay technically defeated by the end of that year-despite a short series of early battle victories. On two key land operations, however, officers failed to follow López's instructions directed at maintaining the occupied cities, instead of continuing south with the offensive. The officers, emboldened by the earlier victories, nevertheless embarked on rushed and improvised attacks that eventually cost Paraguay the majority of its best regular divisions. Another fateful example was the disastrous naval attacks on the allies' ships located to the south, near the Riachuelo River, to the south of Entre Ríos. The Battle of Riachuelo would leave Paraguay without any naval capacity from there on. Before the end of the first year of the war, therefore, Paraguay was technically already defeated militarily. ${ }^{435}$ With no naval forces left, and his best troops either killed or captured during the disastrous campaign, López had only two choices: either to surrender, or to continue

\footnotetext{
${ }^{434}$ On the Mato Grosso campaign, see Doratioto, Maldita guerra, pp. 97-130; Whigham, The Paraguayan War, pp. 193-216; and Leuchars, To the Bitter End, pp. 32-37.

${ }^{435}$ On the Corrientes campaign and the Battle of Riachuelo, see Whigham, The Paraguayan War, pp. $257-$ 348; and Doratioto, Maldita guerra, pp. 130-156.
} 
fighting rather irregularly a defensive war of attrition inside Paraguay's own territory with the remaining army of recruits and conscripts brought from the farming lands of Paraguay's countryside.

The geography of the region, although on López's side in a potential defensive war, was unfavorable for an offensive war of his own. Geographical factors also played an important role in precipitating the entry of Argentina to the war. On its eastward expansion, for example, López underestimated two aspects: first, that the peculiar geography of the area would be an obstacle for any offensive campaign — not just that of Paraguay's enemies; and second, that the political geography offered an ever more complicated obstacle, for Paraguay and Uruguay shared no common border. In order to march to Uruguay to face the Brazilian troops, therefore, the Paraguayan army had to across the Argentine province of Corrientes in order to be able to invade Uruguay via the Brazilian state of Rio Grande do Sul [see infra Map 4]. The earlier invasion of Mato Grosso, combined with the geographical obstacles mentioned above, severely delayed the march of López's army towards Uruguay by several months. ${ }^{436}$ This was a fatal delay which allowed Flores to defeat the Blancos and assume power before the Paraguayan eastern offensive was fully in motion.

\footnotetext{
${ }^{436}$ While the Mato Grosso campaign began in December 1864, the invasion of Corrientes only started in April of the following year.
} 
MAP 4 - Paraguay's borders, circa 1870.

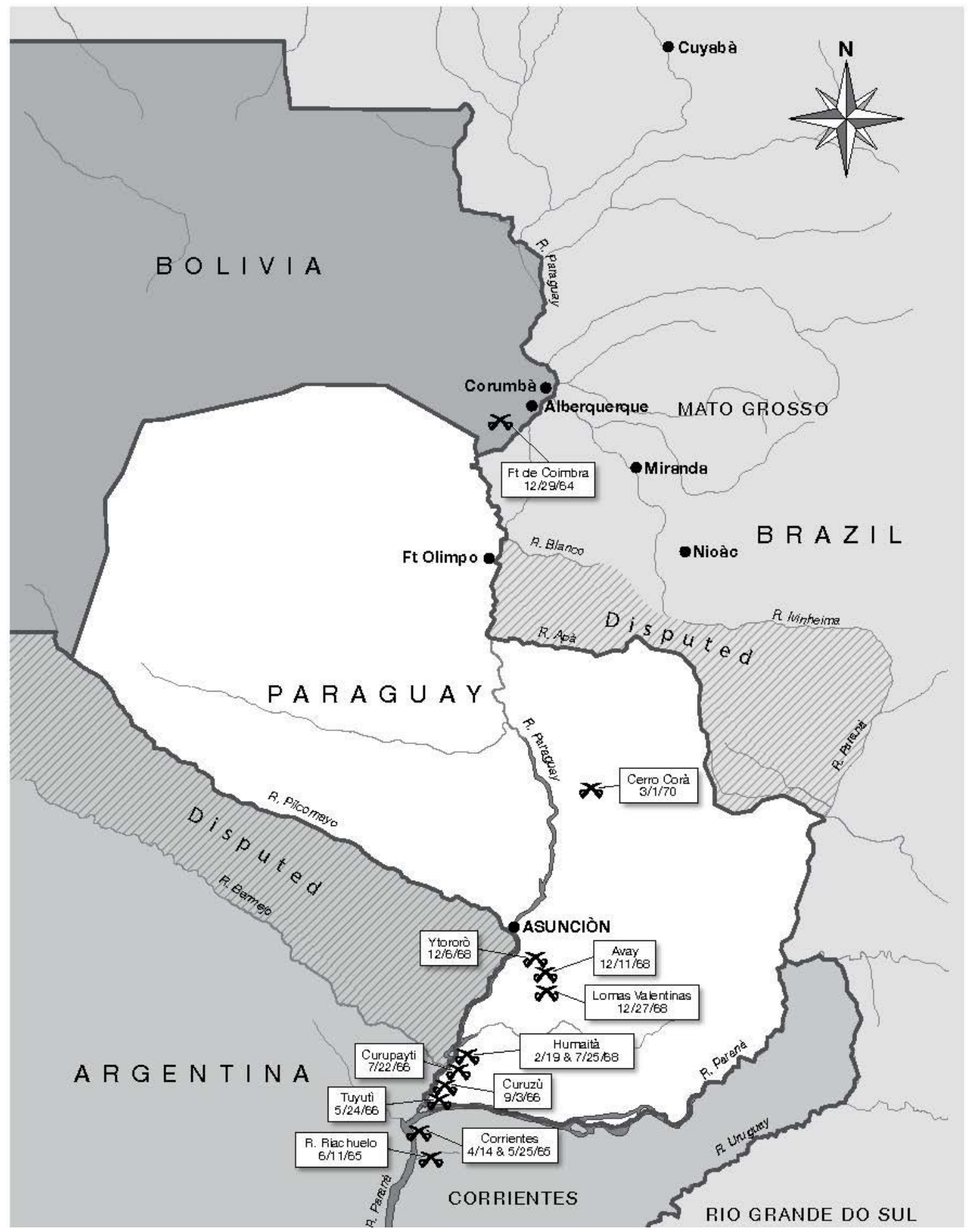

Source: Gabriele Esposito, Armies of the War of the Triple Alliance, 1864-70 (Oxford: Osprey, 2015), p. 4. 
To overcome this political barrier, therefore, Berges wrote to Elizalde requesting permission to cross Argentine territory-exclusively through Corrientes. ${ }^{437}$ The Argentine Minister replied three weeks later with a refusal based on a policy of "strict neutrality" followed by Mitre. ${ }^{438}$ Confronted with this problem, López summoned the Paraguayan Congress and, after a long speech praising the Paraguayan people and its involvement in the war against Brazil, obtained a declaration of war on Argentina. The official declaration of war was dispatched immediately, but the Paraguayan troops began to invade Corrientes days before Buenos Aires received the official letter. This scenario had been only hypothetically contemplated by Mitre and Elizalde, who thought López was bluffing and would never plunge his country into a war against both Brazil and Argentina. News of the invasion of Corrientes and the belated formal declaration of war, therefore, took Buenos Aires by complete surprise. Evidence of this is the absolute lack of Argentina's military and economic preparation before the war, or any reinforcement of the army and navy capabilities. To offer even a modicum of resistance in Corrientes, Mitre had to assemble an improvised militia in the matter of days. ${ }^{439}$

The fact that López requested permission to cross Argentine territory shows that he tried to avoid making an enemy of Argentina despite the suspicions implanted by Blanco

\footnotetext{
${ }^{437}$ From J. Berges to R. de Elizalde, January 14, 1865, in Argentina, Memoria del Ministerio de Relaciones Exteriores (1865), pp. 167-168.

${ }^{438}$ From R. de Elizalde to J. Berges, February 9, 1865, in ibid., pp. 169-173.

${ }^{439}$ The lack of military preparedness in Argentina is well documented in Juan C. Garavaglia, "Las fuerzas de guerra argentinas durante el conflicto de la Triple Alianza, 1865-1871," in A 150 años de la guerra de la Triple Alianza, pp. 105-130; Garavaglia, "Guerra y finanzas en la Argentina unificada, 1864-1872: La guerra del Paraguay y la misión De la Riestra en Londres," Quinto Sol, Vol. 20, No. 3 (septiembrediciembre, 2016), pp. 1-33; Hilda Sábato, "La fuerza de las armas: Estado, sangre y revoluciones en la Argentina de la década de 1860," in El poder y la sangre: Guerra, estado y nación en la década de 1860, ed. by Guillermo Palacios and Érica Pani (México DF: El Colegio de México, 2014), pp. 259-277; and De Marco, La guerra del Paraguay, pp. 43-179.
} 
agents that Argentina and Brazil were secretly allied. This supports a view of the Paraguayan leader as an autonomous strategist (not entirely "fooled" by the Blancos) with some appreciation for the principle of the balance of power, and respect for international law and diplomatic standards. If the ultimate goal was to break with Paraguay's traditional isolation and re-introduce it to regional politics, to earn prestige and elicit international admiration for Paraguay and himself, then a calculated respect for the norms, rules and principles of "civilized" international affairs had to be a central piece of that foreign policy strategy.

Several decades of diplomatic isolation, however, had rendered Paraguay too selfenclosed within its own political and domestic affairs. A poor network of diplomatic relations abroad and a strictly personalistic system of governance at home had hindered Paraguayan leader's ability to "read" the strategic context with more clarity. In this context, Paraguay's 1811 fears of an Argentine invasion to reclaim a rogue or lost province were still vivid in 1865. And Brazil's aggressive foreign policy towards the Banda Oriental in the first half of the 19th century was still perceived as active in 1865 , despite important changes to the contrary after 1852 . Since the most intense diplomatic rapprochement came from the desperate Blancos in Uruguay during the years preceding the war, the Paraguayan leadership had a severely skewed interpretation of the regional dynamics and its neighboring powers' true intentions.

After the defeat of the Blancos and the establishment of Flores as the head of government in Uruguay, Paraguay faced a new situation that had not been contemplated when it declared war on the Brazilian Empire. In an attempt at preventing the Empire's intervention in Uruguay, the country had come to declare war on Brazil, Argentina, and 
now also on Colorado-ruled Uruguay. Since López showed no signs of backing down, in March 1865 Brazil sent Francisco Octaviano de Almeida Rosa to replace Silva Paranhos as the special representative in Buenos Aires, to establish a formal alliance with Argentina against the new Paraguayan threat. The leaders of the three threatened countries signed a Treaty of Alliance on May 1, 1865, formalizing the Triple Alliance and consolidating the prior efforts at coordination between Argentina and Brazil, initiated by Elizalde and Saraiva in Montevideo. It was agreed that the articles and provisions of the Treaty would remain "secret"-a common practice in the 19th century—until the war was over. ${ }^{440}$

The Treaty declared that the war was not against Paraguay, as a nation, but against its government and its leader, Francisco S. López. The allies made a commitment to continue the war and maintain their military cooperation until López was effectively removed from power. A highly controversial article stipulated that after Paraguay's defeat, the allies would preside over all pending territorial disputes and resolve them in their favor. This meant that Paraguay's borders with Argentina to the south would be not on the Bermejo River, but on the Pilcomayo River. To the south-east, a portion of the province of Misiones that was disputed by Paraguay, would be consolidated as Argentine. To the north, Paraguay would concede to Brazil all disputed territories and agreed to a final demarcation line [see supra Map 4]. These provisions were not known at all by the rest of the international community.

\footnotetext{
${ }^{440}$ See Doratioto, Maldita guerra, pp. 157-162; and Whigham, The Paraguayan War, pp. 276-281. "Secret" in the context of the 19th century meant that the signatories will not publish the text during the war. The existence of the treaty itself was indeed publicly know, and even some of the Triple Alliance political objectives were extra-officially known.
} 
Despite the disastrous unfolding of the war for Paraguay, several factors allowed López to delay his capitulation and redouble Paraguay's efforts to fight to the bitter end. The war was not only technically and tactically lost by early 1866, but López's commitment not to surrender clashed with the allies' determination to remove him from power at all costs, and the war soon turned into a collective massacre with little room for a peaceful settlement. As the war grew longer and bloodier, López began to crack down on his own population, including officers, politicians, diplomats, and even members of his own family, whom he accused of conspiracy and treason. ${ }^{441}$ Towards the end of the war, López's army was making use of children and the elderly, and implementing all kinds of irregular desperate tactics in defense of Paraguay's territory. ${ }^{442}$

Two additional factors that help illuminate additional episodes of restraint took place when the war was becoming obviously ruinous for Paraguay, towards the end of the year 1865 and the beginning of 1866 . One important factor was the inability of the allies to achieve a swift and decisive military victory against López. Battles were becoming increasingly more sporadic, gruesome, and intense. As the Paraguayan offensive of 1864 1865 turned into a defensive action by mid-1866, after losing its naval power, the allied

${ }^{441}$ See Arturo Rebaudi, Guerra del Paraguay: La conspiración contra S. E. el Presidente de la República, Mariscal don Francisco Solano López (Buenos Aires: Constancia, 1917); and Thomas L. Whigham, "Court of Blood: Treason and Terror under Paraguay's Francisco Solano López," The Americas, Vol. 75, No. 2 (April, 2018), pp. 325-348. For a personal account of the blood trials and a description of the brutal punishments inflicted during López's political inquisition, see Charles A. Washburn, The History of Paraguay, with Notes of Personal Observations, and Reminiscences of Diplomacy under Difficulties (Lee and Shepard, 1871); and Paraguay, Ministerio de Relaciones Exteriores, Correspondencias cambiadas entre el Ministerio de Relaciones Esteriores de la República y el señor Charles A. Washburn sobre la conspiración fraguada contra la Patria y el gobierno en combinación con el enemigo, y el atentado de asesinato a la personal del Exmo. Señor Mariscal López por Nacionales y Extrangeros (Luque: Imprenta Nacional, 1868).

${ }^{442}$ For an excellent analysis of the human costs of López's stubborn decision to resists to the last soldier, see Whigham, The Road to Armageddon, esp. pp. 205-275. 
forces commanded by Mitre brought the war to Paraguay's own territory—eventually capturing the capital, Asunción, in 1869. However, the long forced marches and brutal battles on Paraguay's hostile and largely uncharted terrain gave López multiple opportunities to exploit strategic and political factors in Paraguay's favor. This, however, only helped prolong the inevitable. From mid-1866 until the very end of the conflict in March 1870, the war transformed into a sequence of intense battles separated by severalmonths-long pauses in between them. The allies kept on making military progress, but only at the expense of enormous material and human costs both in terms of domestic recruitment, military provisions, as well as economic and logistical issues. The increasingly oppressive recruitment tactics, in particular, sparked a growing domestic opposition to the war in Argentina, Brazil, and Uruguay, and created severe public-opinion pressure to end the war by whatever means possible. ${ }^{443}$

In this second stage of the war (1866-1870), the Paraguayan offensive turned into a desperate war of survival. Of the multiple military milestones of this period, three stand out for the study of restraint and international society proposed here. The first element refers to a failed attempt at negotiating a peace agreement between López and the allies in September 1866. The second element points to the treatment of prisoners as the war grew

\footnotetext{
${ }^{443}$ See De la Fuente, "Federalism and Opposition to the Paraguayan War in the Argentine Interior: La Rioja, 1865-67," in I Die with My Country, pp. 140-153; José A. F. Peñalba, "Draft Dodgers, War Resisters and Turbulent Gauchos: The War of the Triple Alliance against Paraguay," The Americas, Vol. 38, No. 4 (April, 1982), pp. 463-479; Wilma Peres Costa, A espada de Dâmocles: O exército, a guerra do Paraguai e a crise do Império (São Paulo: HUCITEC, 1996); and Vitor Izecksohn, "Resistência ao recrutamento para o Exército durante as guerras civil e do Paraguai: Brasil e Estados Unidos na década de 1860," Estudos Históricos, No. 27 (2001), pp. 84-109. See also Patricia S. Pasquali, “Americanismo y conflictos domésticos en el Rosario de 1864,” Res Gesta, No. 29 (1991), pp. 185-192.
} 
in intensity and ferocity. A last element is the allies' occupation of the Paraguayan capital, Asunción, and the effects generated by the sacking of the city by Brazilian troops.

In relation to the first element, in mid-September 1866, a new opportunity for dialogue and peace became possible after a major battle in Curuzú, where the allies had achieved an important victory but failed to press home their advantage. The next battle was going to be an assault on the Paraguayan fortified outpost of Curupaity. In order to gain time for the engineers to finish the construction of a trench and prepare the field, López wrote a letter to Mitre asking for a personal meeting. News about this meeting filled the allied camp with hopes of a potential Paraguayan surrender. However, the private conference between the two Generals was met with suspicion by Flores and the other Brazilian commanders who put little faith in López's true intentions to negotiate. The conference gave an opportunity for both leaders to exchange formal compliments and expressions of a shared desire to bring the war to an expedient end. They also discussed the treatment of each side's prisoners. "My presence here," said López, "is explained by the events and duties that the situation imposes on those who lead the destinies of people and are responsible for their fate." And then added:

I have made war with Brazil because I did not believe that that nation would stop after its domination of Uruguay, and that it was a threat to us all. [...] I have made war with the government of Argentina because I considered it tied to the Brazilian one in the Uruguayan question. I believe that the blood spilled so far is enough to consider easing the offense by which each one of the belligerents thought itself offended and I consider that this terrible war can be brought to an end, establishing the conditions for a solid, enduring, and honorable, peace for all. ${ }^{44}$

${ }^{444}$ Quoted in Julio C. Cháves, La conferencia de Yataity-Corá (Buenos Aires: Biblioteca Histórica Paraguaya de Cultura Popular, Vol. 2, 1958), p. 22. 
Mitre's reply highlighted similar hopes for a prompt end to the war, but also reminded López that the provisions of the Treaty of the Triple Alliance made it sine qua non that he was removed from office in order for them to consider the war finished. This point forced López to declare that the conditions of that treaty of alliance were "unacceptable" to him. ${ }^{445}$ This historic meeting between the two leaders ended with Mitre's reassurance that he would consult with the other members of the Triple Alliance, for he could not take final decisions on such an important matter on his own. Mitre told López that, while this consultation takes place, "military actions will continue in full force." The allied consultation took place between Mitre, the Brazilian generals, and Flores, who had refused to meet with López, but Mitre's reply was delayed for a day. Then, heavy rain postponed military operations for three more days, giving López the exact extra time needed to finish the trenches. ${ }^{446}$ The stipulations of the Treaty prohibited any single ally to negotiate peace with Paraguay separately, so Mitre's hands were tied due to Brazil's adamant refusal to engage in any dialogue with López. ${ }^{447}$ In this unfortunate manner, the only serious attempt by López to negotiate a peaceful negotiated end to the war-which was about to turn brutal for Paraguay_-was wasted by the stubborn resistance of Brazil and Uruguay.

The second element concerns the treatment of prisoners of war. Considering the high number of casualties produced during the war, it is important to explore other aspects that escape the merely diplomatic level, but which are still linked to how each side in the

\footnotetext{
${ }^{445}$ See ibid., pp. 22-23.

${ }^{446}$ See George Thompson, The War in Paraguay; with a Historical Sketch of the Country and its People and Notes upon the Military Engineering of the War (London: Longmans Green, 1869).

${ }^{447}$ See Adolfo J. Báez, Yatayty-Corá: Una conferencia histórica (recuerdos de la guerra del Paraguay) (Buenos Aires: Perrotti, 1929).
} 
war conceived of the boundaries between "civilization" and "barbarism," on one hand, and the realities of war itself, on the other. The question of the treatment of prisoners during the War of the Triple Alliance offers a partial window into this important phenomenon.

In 1860s South America, the relation between politics and violence was rapidly changing. At the same time as the war against Paraguay was in full swing, important new sensibilities about interpersonal and political violence were beginning to develop in society, forcing through literary critique, the printed press, and increasing popular involvement in political affairs, a corresponding change in how countries behaved towards one another during war. ${ }^{448}$

One of the main factors propelling this change was the rapid rate of technological innovation during the second half of the 19th century. The amplified range of brutality, suffering, and pain that technological weaponry made possible, amplified the always gruesome components of large-scale war. While some technological improvements were prima facie more inert, such as Brazil's test of observation balloons or Paraguay's incorporation of the telegraph, others had a much more direct impact. ${ }^{449}$ The inclusion of modern artillery, high-caliber rounds of munition, and the implementation of steampowered vessels and engines, among other innovations applied to warfare, created killing

\footnotetext{
${ }^{448}$ The most prominent example of this changing trend is Juan B. Alberdi, El crimen de la guerra. Edición crítico-genética de Élida Lois (San Martín: Universidad Nacional de San Martín, [1870] 2007). This pamphlet is a full-fledged manifest in denunciation of war as an "uncivilized" and "uncivilizing" phenomenon that mature and enlightened societies would eventually learn to eradicate from their social interactions. Alberdi's views were developed as a reaction to the horrors of the War of the Triple Alliance.

${ }^{449}$ See Thomas L. Whigham, "Brazil's 'Balloon Corps': Pride, Desperation, and the Limits of Military Intelligence in the Triple Alliance War," Luso-Brazilian Review, Vol. 52, No. 2 (2015), pp. 1-18; and F. Stansbury Haydon, "Documents Relating to the First Military Balloon Corps Organized in South America: The Aeronautic Corps of the Brazilian Army, 1867-1868," Hispanic American Historical Review, Vol. 19, No. 4 (1939): 504-517.
} 
fields of unprecedented magnitude, never-before experienced by political and military leaders forged in the smaller-scale civil and frontier wars against caudillos and indigenous populations. Important for communication across vast distances and large contingencies of soldiers, the combination of the printed press and the telegraph played a key role as a battleground of its own between the leading elites and their critics over the influence of the public discourse and opinion. By incorporating the newest technological innovations, the press became an important legitimizing force of official narratives that praised or opposed the development of the war and those conducting it. This, as well, made the horrors of the frontline more palpable and real for the civilians in the main urban centers of each belligerent country, and beyond. ${ }^{450}$

A related factor behind the change in sensibilities in the 1860 s was the advent of three international developments: the Lieber Code, signed by the President Abraham Lincoln in 1863 as a set of regulations for the soldiers of the United States to respect during combat; the creation of the Red Cross in Europe; and the celebration of the first Geneva Convention of 1864, which created new standards for the amelioration of the condition and treatment of the wounded on the field. Given the simultaneity of these developments, they did not have a serious impact on the conduct of the War of the Triple Alliance itself. Regarding the treatment of prisoners, however, individual leaders and officers on the battlefield did adjust their behavior on multiple occasions to adhere to self-imposed standards of conduct in situations of enemy surrender or capture. Despite the presence of

\footnotetext{
${ }^{450}$ For two excellent studies of the role of the press during the war, see María L. Johansson, La gran máquina de publicidad: Redes transnacionales e intercambios periodísticos durante la guerra de la Triple Alianza (1864-1870) (Sevilla: Universidad Internacional de Andalucía, 2017); and Johansson, Soldados de papel: La propaganda en la prensa paraguaya durante la guerra de la Triple Alianza (1864-1870) (Asunción: CEADUC, 2016).
} 
these incipient global standards, South American states loosely invoked or interpreted these norms on a case-by-case basis, in reference to a generic concept of "the laws of war" that was believed to separate "civilized" behavior from "barbarism." ${ }^{\text {"451 }}$ Most of these criteria were not entirely adopted until much later in the 19th century. In Argentina, for example, the Red Cross was created in 1880, during a short-lived civil war in Buenos Aires. This was its first appearance in the entire region. ${ }^{452}$

Although the issue of the treatment of prisoners of war is one of the most underexplored aspects of the Paraguayan War, the few existing studies that address the issue offer brief or partial accounts that focus only on the most brutal or inhumane episodes of the treatment of prisoners. ${ }^{453}$ For the standards of the time, however, where only a few and incipient global international frames of legal reference existed and no relevant internal army regulations or codes of conduct were available, there were certain remarkable displays of self-restraint. Although manifested on an ad hoc basis, the type of treatment of the prisoners of war usually relied on the personal and professional criterion of the officer in command at the time. It was also important whether the prisoners had surrendered or

\footnotetext{
${ }^{451}$ See Luc Capdevila, "Droit et coutumes dans la guerre de la Triple Alliance (1864-1870): Le sort des prisonniers de guerre," Nuevos Mundos, Mundos Nuevos, Debates (2006), pp. 1-17; and Adler H. Fonseca de Castro, "Los prisioneros de guerra paraguayos: La experiencia brasileña, 1864-1870," in Paraguay: Investigaciones de historia social y política. III Jornadas Internacionales de Historia del Paraguay en la Universidad de Montevideo, ed. by Juan M. Casal and Thomas L. Whigham (Asunción: Tiempo de Historia, 2013), p. 157-167.

${ }^{452}$ See Hilda Sábato, "Arms and Republican Politics in Spanish America: The Critical 1860s," in American Civil Wars: The United States, Latin America, Europe, and the Crisis of the 1860s, ed. by Don H. Doyle (The University of North Carolina Press, 2017), pp. 185-203; and Sábato, Buenos Aires en armas: La revolución de 1880 (Buenos Aires: Siglo XXI, 2008).

${ }^{453}$ See, e.g., Doratioto, Maldita guerra; Alberto del Pino Menck, "El estigma de los vencidos: Prisioneros, pasados y traidores en la guerra contra la Triple Alianza," in Paraguay: Investigaciones de historia social y política, pp. 129-146; Fonseca de Castro, "Los prisioneros de guerra paraguayos"; Thompson, The War in Paraguay; Peñalba, "Draft Dodgers, War Resisters and Turbulent Gauchos"; Chiavenatto, Genocídio americano; and Izecksohn and Beattie, "The Brazilian Home Front."
} 
had been captured after a bitter confrontation. ${ }^{454} \mathrm{~A}$ large number of prisoners, moreover, were often faced with the difficult choice presented by the Allies: either to remain in chains and be relocated to prisons back in Buenos Aires, Rio de Janeiro, or Montevideo; or join the ranks of the Allies and earn their freedom by fighting against López. ${ }^{455}$ The most infamous case of this type of "forced re-enlistment" was that of the Uruguayan commander, León de Palleja, although the Brazilian generals were also known for refilling their ranks with prisoners of war, who were treated like slaves. ${ }^{456}$ The Argentine army, unlike any of the other allies, had among its divisions a "Paraguayan Legion" formed by Paraguayan citizens exiled in Buenos Aires who, despite Mitre's reluctance, wanted to be part of the war against López. According to them, it was not a war against their own country, but against a brutal dictator and a tyrant. In this context, Mitre had a clear policy of accepting re-enlistments only for those who volunteered to join the Paraguayan division and fight alongside their fellow nationals.

Perhaps the most revealing aspect of the treatment of prisoners was the way in which the belligerents treated the wounded. This was a salient aspect that the participants themselves saw as "civilized" behavior. Although Brazil was a slaving Empire and Argentina practiced forced enlistment tactics in its interior provinces—well characterized in José Hernández's gaucho epic ${ }^{457}$ - the Paraguay of López also exercised brutal tactics

\footnotetext{
${ }^{454}$ Capdevila, "Droit et coutumes dans la guerre de la Triple Alliance," pp. 1-17.

${ }^{455}$ See Doratioto, Maldita guerra, p. 185; Izecksohn, "Resistência ao recrutamento para o exército"; Hendrik Kraay, "Slavery, Citizenship and Military Service in Brazil's Mobilization for the Paraguayan War," Slavery and Abolition, Vol. 18, No. 3 (December, 1997), pp. 228-256; and Kraay, “"The Shelter of the Uniform': The Brazilian Army and Runaway Slaves, 1800-1888," Journal of Social History, Vol. 29, No. 3 (Spring, 1996), pp. 637-657.

${ }^{456}$ See León de Palleja, Diario de la campaña de las fuerzas aliadas contra el Paraguay (Montevideo: El Pueblo, 1865-1866).

${ }^{457}$ José Hernández, El gaucho Martín Fierro (Buenos Aires: La Pampa, 1872).
} 
against anyone who was even minimally suspected of opposing López's rule. ${ }^{458}$ In the course of the war, however, Mitre and López frequently exchanged letters on the issue of the treatment of prisoners and the wounded that shed further light on the matter. In a confidential correspondence with Mitre, for example, Elizalde was clear about the importance of behaving according to all considerations of law on the subject of prisoners and their optional re-enlistment. ${ }^{459}$ And in conversation with Juan A. Gelly y Obes, the acting Vice-President, Mitre expressed his personal refusal to use prisoners to fight against their own motherland, given that, apart from violating principles of common laws of nations, the desertion rates would be enormous. Brazil, for its part, was well-known for "stealing" prisoners, officers, and runaway slaves, and reusing them in their offensives against the enemy. On the contrary, Mitre saw with great enthusiasm the reincorporation of the Paraguayan prisoners to suburban life in Buenos Aires where, he thought, they would make excellent citizens who, after enjoying the advantages of progress, would voluntarily remain in Buenos Aires after the war. ${ }^{460}$

On November 20, 1865, on the eve of the allied attack on the Paraguayan fortress of Humaitá, López and Mitre exchanged an important set of letters about the need to "regularize" and ameliorate "the evils of war." López wrote demanding Mitre's reciprocity in these matters towards the Paraguayan prisoners of war and the wounded, or otherwise he would not extend the same privileges and rights to the allied prisoners under his control:

In the unavoidable necessity in which nations and their governments find themselves, sometimes, to settle by force of arms the questions that affect their vital interests, war has

\footnotetext{
${ }^{458}$ See, e.g., Whigham, "Court of Blood."

${ }^{459}$ From R. de Elizalde to B. Mitre, Buenos Aires, September 2, 1865 in Argentina, Museo Mitre, Archivo del General Mitre, Vol. 5: pp. 82-83.

${ }^{460}$ From B. Mitre to J. Gelly y Obes, HQ in Capihiquisé, October 3, 1865, in ibid., Vol. 3: pp. 71-73.
} 
broken out between this Republic and the states whose armies you command. In such cases, it is of general and practical use among civilized nations to attenuate the evils of war by our own laws, stripping it of the acts of cruelty and barbarism that disgrace Humanity, and that stigmatize like an indelible stain the leaders who order, authorize, protect or tolerate them [...]. Thus informed, and in conscience of such duties, one of my first concerns was to order the observance of all considerations with which the prisoners of any class whatsoever were treated and kept with respect in line with their ranks; and in effect they have enjoyed of all possible commodities and even the relative freedom of their position and conduct. [...] I would like to believe, in this first international war, as Your Excellency would notify to your subordinates, that a prisoner of war does not cease to be a citizen of his own nation [...] and that, in surrendering, he stops being an enemy. ${ }^{461}$

Mitre replied five days later, agreeing on the main premises regarding the necessity of regulating war, but also pointing out that López's impression about how the Allies treated the prisoners of war was an exaggeration. After denouncing Paraguay's assault on Argentine territory without a proper declaration of war as an act of "piracy," Mitre enumerated a long list of "atrocities" and "barbaric acts" performed by the Paraguayan troops after invading Corrientes. Mitre documented these claims by referencing the personal diary of the Paraguayan Commander Estigarribia himself, acquired after his capture. Far from treating the Paraguayan prisoners with cruelty and inhumanity, Mitre argued, the prisoners and the wounded were treated with benevolence and pity, given their poor physical condition and military equipment provided by the government of Paraguay. ${ }^{462}$

These written jousts between Mitre and López, however, stopped once the course of the war became more protracted and costlier. Since the end of 1865 , until the very end of the conflict, the war grew in intensity and ferocity, and all respect for "civilized" and

\footnotetext{
${ }^{461}$ From F. López to B. Mitre, Humaitá, November 20, 1865, in ibid., Vol. 4: pp. 106-110.

462 From B. Mitre to F. López, HQ in Bella Vista, November 25, 1865, in ibid., Vol. 4: pp. 110-114.
} 
honorable behavior became increasingly more difficult to maintain by the officers on the battlefield. The bloodier the battle, the harsher the treatment of the wounded and the prisoners became. Towards the end of the war, in effect, the troops of all the belligerents made a routine out of killing the wounded laying on the fields of battle.

One last aspect of this progressive tension between exercising restraint in an increasingly "total war" became evident when the allied troops finally overcame the Fortress of Humaitá. Besieged by the Allies on November 2, 1865, and surrendered on July 25, 1868, the road to Asunción was then open. Since the crumbling Paraguayan army followed López to the mountains in the north-west of the country, where they made their very last stand, the capital city was abandoned without any resistance. The occupation of Asunción, however, showed one of the ugliest sides of the war yet, as Brazilian troops ransacked and pillaged the city, stealing furniture and other private items of value, and harassing the few remaining citizens (mostly women) who had been left behind. The Brazilian troops, given the rushed abandonment of the city by López's troops, were able to capture the entire official archives and libraries, which were kept as trophies of war until 1982, when part of the surviving original documentation was returned.

Previewing such a grotesque spectacle, the leader of the Argentine forces, Emilio Mitre, ${ }^{463}$ decided not to be part of the offensive that captured the Paraguayan capital, leaving this "honor" solely to the Brazilian troops. This far-sightedness earned the young Argentine commander the congratulations of the new President, Domingo F. Sarmiento. In a private letter to him, Sarmiento said: "I very much applaud your extremely prudent

\footnotetext{
${ }^{463}$ Bartolomé Mitre’s son.
} 
determination of not entering Asunción, leaving it to the Brazilian soldiery to pillage at will. It is not against the law of nations for the victor to take the abandoned property of the enemy. Civilization, however, condemns such barbarities. This war will take colossal proportions in history and it is good that our name remains clean of all reproach." ${ }^{464}$

\section{Institutionalizing a "Civilized" South American Order}

The concern of leaders, such as Sarmiento, with the future judgement of history was not entirely rhetorical, but also based on real political consequences. During the war, for example, the signing of the Treaty of the Triple Alliance (May 1, 1865) laid out a set of clear objectives for the allies which, at the time, were kept secret. Public knowledge about these objectives would not only have damaged their strategic achievement by providing López some crucial information about the enemy's intentions, but would have also opened up the content of the Treaty objectives for discussion by other interested states, such as the four allies in the Pacific, or even the United States. It is for these reasons that the Triple Alliance was only interested in communicating some, but not all, of their war aims. The idea of making war against Paraguay's government, yet not against its people, was just one of those objectives widely and proudly publicized in Buenos Aires, Río de Janeiro, and Montevideo. It was important for the legitimacy of the allies' cause to secure the approval of the entire world, supported by the general impression that this was a war fought reluctantly by the allies.

${ }^{464}$ From D. Sarmiento to E. Mitre, Buenos Aires, January 21, 1869, in Obras, by Domingo F. Sarmiento (Buenos Aires: 1902), Vol. 50: p. 127. 
On one occasion, the British chargé d'affaires in Montevideo, William G. Lettsom, asked Carlos de Castro, the Uruguayan Minister of Foreign Affairs, about the veracity of the rumors saying that the allies were going to partition Paraguay territorially after the war "like a South American Poland." To assuage Lettsom's curiosity, Castro showed him a copy of the treaty. When Lettsom sent a transcript to Lord John Russell, the British Prime Minister in the Chamber of Commons, he asked him to honor the trust deposited on him by Castro by not making the Treaty public. ${ }^{465}$ Lord Russell, in a calculated act of indiscretion that deeply offended the allies, decided to publish the entire text of the Treaty in one of the internal Parliamentary "Blue Books" in March 1866-almost exactly a year after the signing of the Treaty. A London newspaper picked it up soon afterwards, and a copy of the bulletin found its way back to Bueno Aires, where it was published by a proParaguay newspaper in May. The international public opinion expressed its outcry and condemnation, for up to that point the allies were commonly seen as the aggrieved parties, reacting to the Paraguayan "tyrant" and his armed invasion of the allies' territories. The Treaty's articles dealing with Paraguay's post-war territorial arrangement, in particular, opened up a serious criticism of the ulterior objectives of Brazil and Argentina regarding the integrity and autonomy of Paraguay as a sovereign nation. ${ }^{466}$ This also triggered the members of the Quadruple Alliance to write Buenos Aires, Río de Janeiro, and Montevideo, demanding explanations for the content of those articles. ${ }^{467}$

\footnotetext{
${ }^{465}$ From W. Lettsom to J. Russell, Montevideo, June 27, 1865, (No. 62, confidential), in Great Britain, Foreign Office, Correspondence Respecting Hostilities in the River Plate: Confidential F.O. $420: 19$ [HCPP] (London: Harrison, 1865) (London: Harrison, 1866), pp. 24-28.

${ }^{466}$ See Box, The Origins of the Paraguayan War, pp. 270-273.

${ }^{467}$ From B. Vigil to C. de Castro, Montevideo, May 23, 1866, in Peru, Ministerio de Relaciones Exteriores, Correspondencia diplomática relativa a la cuestión del Paraguay, publicada por orden de S. E. el Jefe
} 
The revelation of the treaty provisions not only turned domestic and international public opinion drastically against the leaders of the three allied powers, but also showed an unexpected diplomatic move by Great Britain, which up to that point had only been interested in joint mediations and the protection of the status quo in the River Plate area favorable to its commercial interests in the region. With this move, the British Empire severely damaged the image and reputation of the three allies and made their achievement of victory even more difficult. The Paraguayan citizens, and the troops in particular, found renewed impetus to keep fighting, offering a stubborn—quasi suicidal—resistance. ${ }^{468}$ This also showed to the leaders of the allied powers that acting according to the "civilized" standards of the time was not only relevant for what future historians and observers would eventually think of the war and the conduct of those who fought it, but it also carried real and more palpable consequences for their more immediate context. In other words, it was in the short-, as well as in the long-term interest of each state to act under a legitimizing framework that was accepted by everyone-including the enemy.

The consequences of winning the war, therefore, became doubly important for the allies. In Brazil, the protracted conflict demonstrated all the cracks in the social and political structure of the Empire, which still rested on slavery. The impact of the war was most strongly felt in the lower social strata, who either semi-voluntarily or by force, participated in the long campaign against López. ${ }^{469}$ After Francisco S. López's death in

Supremo Provisorio para ser presentada al Congreso Constituyente (Lima: El Progreso, 1867), pp. 24-30. See also from T. Pacheco to B. Vigil, Lima, July 9, 1866, in ibid., pp. 30-36.

${ }^{468}$ See Whigham, The Road to Armageddon, pp. 45-46.

${ }^{469}$ See Norman T. Strauss, "Brazil after the Paraguayan War: Six Years of Conflict, 1870-6," Journal of Latin American Studies, Vol. 10, No. 1 (May, 1978), pp. 21-35; and Luis C. Villafañe Gomes Santos, “As 
Cerro Corá on March 1, 1870, the Brazilian army began to play a central role in the progressive anti-slavery Liberalization of the Brazilian society as a whole, which soon translated in popular uprisings and a political crisis that eventually toppled the Monarchy in $1889 .{ }^{470}$

In Argentina, the Liberal party fractured. The faction led by Mitre faced severe criticism from the press and the society in general as the war grew more and more unpopular and costly. In the 1868 presidential elections, the political formula led by Elizalde lost to Sarmiento, who assumed the presidency for the remainder of the war. This demonstrated a split inside the Liberal porteño leadership between the old guard of former moderate caudillos, led by Mitre, and a newer generation of rising middle-class businessmen, lawyers and doctors who wanted to bring the war to an end as quickly as possible. Mitre and Elizalde, although victorious on the battlefield, lost their powerbase at home due to the widespread unpopularity of the war and the public condemnation of the treaty provisions regarding post-war Paraguay. ${ }^{471}$ Part of the outrage against the Mitre-

consequências da guerra da Tríplice Aliança na definição da identidade brasileira," Militares e Política, No. 3 (julho-dezembro, 2008), pp. 42-58.

${ }^{470} \mathrm{On}$ the role of the Brazilian armed forces in the downfall of Pedro II and the establishment of the Republic in Brazil, see Wilma Peres Costa, "Los tormentosos años 60 y la crisis de la monarquía en Brasil: Guerra, esclavitud e imaginarios políticos," in El poder y la sangre, pp. 235-257; Perez Costa, A espada de Dâmocles; Perez Costa, "Revisitando as reverberações de uma 'guerra maldita'-A guerra do Paraguai e a crise do Império," in A 150 años de la guerra de la Triple Alianza, pp. 61-94; Doratioto, Maldita guerra, pp. 471ff; Ricardo Salles, "La guerra de Paraguay, la cuestión servil y la cuestión nacional en Brasil," in Estado y nación en Chile y Brasil en el siglo XIX, ed. by Ana M. Stuven and Marco A. Villela Pamplona (Santiago: Ediciones Universidad Católica de Chile, 2009), pp. 113-138; and Izecksohn and Beattie, "The Brazilian Home Front."

${ }^{471}$ On the internal consequences of the war for Argentina, see Frank J. McLynn, "Consequences for Argentina of the War of the Triple Alliance, 1865-1870," The Americas, Vol. 41, No. 1 (July, 1984), pp. 81-98; McLynn, "The Argentine Presidential Election of 1868," Journal of Latin American Studies, Vol. 11, No. 2 (November, 1979), pp. 303-323; David Rock, "Argentina Under Mitre: Porteño Liberalism in the 1860s," The Americas, Vol. 56, No. 1 (July, 1999), pp. 31-63; and Luis F. Beraza, "Secuelas diplomáticas de la guerra de la Triple Alianza," Todo es Historia, No. 274 (abril, 1990), pp. 6-25. 
Elizalde faction was motivated by a disapproval of Elizalde's "friendship with the Empire." Unlike the case of Brazil, Mitre's war efforts at least helped professionalize the army, initiated a modernization of the navy, and helped forge a "national" image and identity previously hindered by petty "party politics" and parochial caudillo mentality. ${ }^{472}$

During the course of the war, therefore, South American political elites and decision-makers had to grapple with a multifaceted set of challenges that interconnected the external and internal fronts with their countries' political-party and Congressional dynamics. These were new challenges that Brazilian and Argentine elites handled with difficulty, achieving success in some areas, while being flatly defeated in others. Particularly on the international front, South American states were able to make substantial progress in the 1860s, advancing on their cooperation in projects such as the Congress of Lima of 1864, and successfully repelling the encroachments of Spain and other European powers in the 1850s and 1860s. The main common source of regional trouble, however, continued to be the "domestic front." This was the case in Chile, but most notably in Bolivia, Uruguay, Peru, Venezuela and Colombia. In the case of Brazil and Argentina, the Paraguayan War created a new set of priorities which also elevated their policy to a higher strategic plane. ${ }^{473}$ Having substantially "pacified" their domestic fronts after the war, and with a change in leadership in Argentina, their traditional strategic rivalry soon resumed

\footnotetext{
472 Raúl de Labougle, "Mitre y la política exterior argentina," Mayo: Revista del Museo de la Casa de Gobierno, No. 8 (1960), pp. 115-139; and Whigham, "The Paraguayan War: A Catalyst for Nationalism in South America,"pp. 178-198.

${ }^{473}$ During the decades prior to Mitre's government (i.e., pre-1861), it was common for provincial caudillos to invoke foreign assistance, such as the Brazilian Empire, to finance and back-up them against other factions, or the central government itself. Mitre and the War of the Triple Alliance put an end to this dynamic, consolidating a national "image" that reinforced for the first time a view of the armed forces under the control of a central government.
} 
over the application of the provisions of the Treaty of the Triple Alliance and the arrangement of a new government in post-war Paraguay. Lacking regional, or even hemispheric, formal institutional frameworks for doing so, the two countries had no other realistic option but to rely on the now widely unpopular ad hoc agreement signed in May 1,1865 .

Prior to assuming the presidency in Argentina, Sarmiento had accepted a diplomatic mission to the United States late in 1863. Since Sarmiento would pass through Chile and Peru on his way to Washington, Mitre and Elizalde planned to have him remain in Santiago and Lima for some months as a special representative, and to participate "as an observer" in the Lima Congress of 1864. For several decades, Argentina had no permanent diplomatic representative in any country on the Pacific, which made Sarmiento's mission to these two countries important for establishing a good communication between both sides of the region. Upon arrival in Santiago, Sarmiento was caught by surprise by the news of Pinzón's seizure of the Chincha Islands, as his mission was then substantially altered by this act of aggression against Peru. ${ }^{474}$

Since the occupation occurred on April 14, 1864, Mitre and Elizalde were still hopeful about the peaceful resolution of the Uruguayan crisis. With this in mind, they instructed Sarmiento not to intervene in the Lima Congress as a plenipotentiary, and act simply as an observer - denying him the official credentials to be accepted as a delegate in the Lima Congress. Elizalde wanted to maintain Mitre's firm conviction in a foreign policy

\footnotetext{
${ }^{474}$ For the most detailed study of Sarmiento's mission, see Néstor T. Auza, La misión Sarmiento en Chile y Perú y el Congreso Americano, 1864-1865 (Buenos Aires: Histórica, 2007). See also Edmundo A. Heredia, "Sarmiento en Lima," Boletín del Instituto Rivera-Agüero, No. 15 (1988), pp. 199-212.
} 
of "strict neutrality" in all regional affairs while the Argentine domestic front remained convulsed. Mitre's strategy tried to solve the domestic front first before implicating the country in any regional affair or association — and much less one that could potentially lead to a war with Spain(!). ${ }^{475}$

A polemic then emerged between Sarmiento, an unabashed "Americanist" who wanted to participate more actively in the Lima Congress, and the more prudent MitreElizalde approach. ${ }^{476}$ This also created an important rift in Argentina's foreign policy that sent mixed signals to the countries in the Pacific. Despite Elizalde's constraining instructions, Sarmiento gave public speeches and made personal declarations in Santiago and Lima which complicated Elizalde's "pampa diplomacy" in the River Plate area. After receiving an official admonishment by Elizalde, Sarmiento did tone down his Americanist rhetoric, but nevertheless continued advocating for a more "solidaristic" role for Argentina than the one originally intended by Mitre. ${ }^{477}$

\footnotetext{
${ }^{475}$ On Mitre's overall foreign policy during the critical 1860s, see Labougle, "Mitre y la política exterior argentina"; [G. H. S.], "El general Mitre y la guerra de Chile con España," Revista Chilena, Año IV, Tomo XI, No. 39 (marzo, 1920), pp. 432-435; Ricardo R. Caillet-Bois, "Argentina y la intervención europea en México en 1862," Historia Mexicana, Vol. 12, No. 4 (abril-junio, 1963), pp. 552-594; Caillet-Bois, "1864, un año crítico en la política exterior de la presidencia de Mitre"; Armando Braun Menéndez, Mitre y la cuestión de límites argentino-chilena (Buenos Aires: Emecé, 1957); and Sanz, "La historia diplomática desde la presidencia de Mitre."

${ }^{476}$ See Mariano Drago, "Una controversia de Mitre y Sarmiento sobre política intercontinental," Revista del Museo Mitre, No. 9 (1956), pp. 97-118. For the communications between Elizalde and Sarmiento, see Bernardo González Arrili, Vida de Rufino de Elizalde: Un constructor de la república (Buenos Aires: Colombo, 1948), pp. 211-236.

477 The official correspondence of the Sarmiento mission to Chile, Peru, and the Lima Congress, was consulted in Argentina, Archivo del Ministerio de Relaciones Exteriores y Culto, Boxes AH051, No. 4277: "Misión Sarmiento en Chile," and "Misión Sarmiento en Perú." See also Sarmiento, Obras, Vol. 34; Sarmiento-Mitre: Correspondencia, 1846-1868 (Buenos Aires: Museo Mitre, 1911); Francisco Centeno, "1864: Misión del Coronel Sarmiento a Chile y Perú," in Virutas históricas (1810-1928) (Buenos Aires: Menéndez, 1929), Vol. 1: pp. 92-100; and Auza, La misión Sarmiento en Chile y Perú, esp. pp. 47-95.
} 
Given Brazil's monarchical regime, neither Chile nor Peru held much hopes for a serious Brazilian commitment in favor of the Pacific republics or against a fellow monarchy, Spain. ${ }^{478}$ Their more serious aspirations, therefore, sought Argentina's adherence to the Quadruple Alliance and a full participation in the Lima Congress. Mitre, however, consistently refused to involve Argentina in the Spanish question and proposed, instead, to help Chile and Peru solve the affair on their own. Mitre's policy was, at first, misunderstood by the Chilean and Peruvian elite as a betrayal of "the American cause" by not only refusing to join the fight against Spain, but also allying with the Brazilian Empire against a fellow republic. To quell similar criticisms by the Argentine Congress itself, Mitre justified his policy by famously proclaiming: "Argentine first and foremost, my government will not stop being American and a good neighbor." ${ }^{\prime 49}$

It is important to point out that, although the Lima Congress was invoked in early 1864 by Peru, and began its functions later that year, neither the Uruguayan nor the Argentine leadership saw in it an opportunity to seek regional or international support of any kind. Unlike Peru, which tried to use this regional congress to institutionalize a principle of "Americanist solidarity" against European encroachment, the countries of the Atlantic developed a different perspective which, from a purely "Americanist" standpoint, would come to be seen as "defeatist," subservient to foreign imperialism, and antiAmerican. With time, however, the principles of foreign policy so consistently pursued by

\footnotetext{
${ }^{478}$ See, e.g., Juan J. Fernández Valdés, La República de Chile y el Imperio del Brasil: Historia de sus relaciones diplomáticas (Santiago: Bello, 1959); and Luís C. Villafañe Gomes Santos, O Império e as repúblicas do Pacífico: As relações do Brasil com Chile, Bolívia, Peru, Equador e Colômbia (1822-1889) (Curitiba: Editora UFPR, 2002).

${ }^{479}$ Enclosed in a letter from B. Mitre to D. Sarmiento, Buenos Aires, March 24, 1865, in Revista de La Biblioteca, Año 1, Tomo 1 (1896), pp. 279-290.
} 
Mitre and brilliantly executed by Elizalde would come to be accepted all across the American continent, before the end of the century, as the standard for sustaining a regional society of states based on a mutual respect for each other's autonomy and independence. In this sense, the more utopian aspirations of unity and "brotherhood" of Americanists like Sarmiento, Lastarria, Alberdi, Covarrubias, or Vicuña Mackenna, who for most of the 19th century propelled congress-styled diplomatic collaboration among South American states, would give way to more pragmatic multilateral conferences from 1889 to $1942 .{ }^{480}$ In 1948 , the creation of the Organization of American States (OAS) would finally crown this second perspective as the most accepted continental institutional framework in the Americas.

Mitre's foreign policy was the epitome of a restrained, responsible, and measured strategy. Quite understandably, it was a frustrating strategy for the Americanists, for in their eyes it represented the death of a glorious post-colonial potential of continental unity. However, unlike Francisco S. López, who plunged Paraguay into an unnecessary war with all of its neighbors, or Joaquín Pérez and his Minister of Foreign Affairs, Covarrubias, who recklessly dragged Chile into a war with a European power without even a basic navy or military preparations, and which led to the bombardment of its main commercial port of

\footnotetext{
${ }^{480}$ For the most canonical text of the "Americanists" of the 1860s, perhaps the last generation of Bolivarian romantics in this regard, see José V. Lastarria; Álvaro Covarrubias, Domingo Santa María and Benjamín Vicuña Mackenna, Colección de ensayos i documentos relativos a la unión i confederación de los pueblos hispano-americanos (Santiago: Imprenta Chilena, 1862). For its 20th-century equivalent, see Jorge A. Ramos, Historia de la nación latinoamericana (Buenos Aires: Peña Lillo, 2011). For a historical analysis, see Carlos E. Grez Pérez, Los intentos de unión hispano americana y la guerra de España en el Pacífico (Santiago: Nascimento, 1928); Cavieres Figueroa, "Las frustraciones de la Unión Americana"; Lacoste, "Americanismo y guerra a través de El Mercurio de Valparaíso"; Germán A. De la Reza, El ciclo confederativo: Historia de la integración latinoamericana en el siglo XIX (Lima: Fondo Editorial de la Universidad Nacional Mayor de San Marcos, 2012); De la Reza, "La asamblea hispanoamericana de 1864 1865, último eslabón de la anfictionía," Estudios de Historia Moderna y Contemporánea de México, No. 39 (enero-junio, 2010), pp. 71-91; De la Reza, "La dialéctica del fracaso: el Congreso americano de Lima (1847-1848) y su desenlace," Cuadernos Americanos, Vol. 134, No. 4 (octubre-diciembre, 2010), pp. $11-$ 26.
} 
Valparaíso, Mitre's prudent policy of "strict neutrality" tied the pacification of Argentina's chronically unstable domestic front with the avoidance of costly commitments on the external front. As Eduardo Cavieres eloquently put it, amidst an uncertain climate of apparent generalized conflict in the region, and a war with Paraguay, "the Argentine government $[\ldots]$ rested on a guessing game and on strategies considered effective for maintaining multiple balances with the rest of the states that were not involved in the war. ${ }^{, 481}$ In conclusion, the policy of Argentina in the $1860 \mathrm{~s}$, and in different measure also those of Uruguay and Brazil, generated not just a powerful wear-and-tear effect to the Americanist thought of a "Latin-American solidarity," then led by Chile, but also destroyed and fractured it for good. ${ }^{482}$

The reaction that the Argentine government gave to the Peruvian request in 1862 to join the Continental Treaty of $1856,{ }^{483}$ for example, perfectly illustrates the coherence and substance of a policy of "pragmatic solidarity" properly understood and practiced by Mitre and Elizalde, as well as by the Brazilian Empire under the prudent diplomatic hand of the Barão do Rio Branco. In the 1850s, for example, a wave of aggressions by foreign powers had put all Latin American states on alert. ${ }^{484}$ Before the Lima Congress of 1864 , therefore, a Continental Congress was summoned in Santiago de Chile to coordinate a

\footnotetext{
${ }^{481}$ Figueroa, "Las frustraciones de la Unión Americana," p. 304.

${ }^{482}$ Lacoste, "Americanismo y guerra a través de El Mercurio de Valparaíso," pp. 571-572.

${ }^{483}$ From B. Seoane to E. Costa, Buenos Aires, July 18, 1862, in Argentina, Ministerio de Relaciones Exteriores, Correspondencia cambiada con la legación del Perú en la República Argentina sobre el Tratado Continental celebrado en Santiago de Chile, en setiembre 15 de 1856 (Buenos Aires: Bernheim y Boneo, 1862), pp. 15-17.

${ }^{484}$ The most (in)famous cases were those of the filibuster, William Walker, in Nicaragua, and Aureley Antoine, "The King of the Patagonia." See Edmundo A. Heredia, "Intervencionismo, unidad latinoamericana y pensamiento liberal: La Liga Continental, 1856-1862," Ciclos, Año III, Vol. 3, No. 4 (1º semestre, 1993), pp. 75-102.
} 
common reaction by the countries of the South Pacific. ${ }^{485}$ Unlike the previous meetings in 1826 (Panama) and 1848 (Lima), or even the Lima Congress of 1864 itself, the Santiago congress contemplated a unique anti-monarchical clause in its main provisions, which also intended to exclude the United States.

In reaction to the Peruvian invitation, Elizalde brilliantly summarized the core principles that would govern Argentina's policy for decades. After rejecting the invitation, Elizalde explained that the Argentine Government did not have reasons to admit the existence of a general threat to America's independence, after the events of Santo Domingo and Mexico, that would justify the unification of the policies and principles of all the republics of the continent. Moreover, Elizalde doubted that the means suggested to fend off such a threat were not sufficient. "Independent America," he added, "is a political entity that does not exist, nor is it possible to construct it by diplomatic combination. America contains independent nations, with needs and means of self-government, that can never form a single political entity." And then concluded: "Nature and events have divided it and the efforts of diplomacy are sterile to countervene the existence of those nationalities, with all the forced consequences that derive from them. ${ }^{486}$

In reaction to the issue of the monarchical type of government and the threat of foreign powers on the continent, moreover, Elizalde counterargued that the European

\footnotetext{
485 On the thus-called "Continental Treaty of 1856," see Heredia, "Intervencionismo, unidad latinoamericana y pensamiento liberal"; Manuel Esquivel Molina, "Un caso de panamericanismo práctico: La solidaridad continental de 1856," Revista de los Archivos Nacionales [Costa Rica], Vol. 20, No. 1-6 (enero-junio, 1956), pp. 143-147; Germán A. De la Reza, “¿Necesidad o virtud? Razones y alcances de los tratados continentales hispanoamericanos de 1856," Histórica, Vol. 38, No. 1 (2014), pp. 61-83; and Gustave A. Nuermberger, "The Continental Treaties of 1856: An American Union 'Exclusive of the United States'," The Hispanic American Historical Review, Vol. 20, No. 1 (February, 1940), pp. 32-55.

${ }^{486}$ From R. de Elizalde to B. Seoane, Buenos Aires, November 10, 1862, in Argentina, Ministerio de Relaciones Exteriores, Correspondencia cambiada con la legación del Perú, p. 20.
} 
monarchies were linked commercially and culturally, by bonds of blood, that constituted the economic basis of their power. In this context, the only potential threat that could ever come from them was in the form of a League of Monarchies, which in any case would not be able to oppose the entire American continent. "If the nations of Europe ever intended any injustice against the American governments, these were isolated events that do not constitute a policy, and the American governments, if they have been subjected to them [the injustices], it has always been because of the state in which they were due to their own civil wars. [...] There is no antagonist European element of an American element." ${ }^{487}$

\section{The Consolidation of South America's Pragmatic Solidarity}

When analyzing the element of "solidarity" in the $1860 \mathrm{~s}$, therefore, it is important to consider two key factors. One factor is the role that the War of the Triple Alliance played in incentivizing a peculiar type of collaboration and understanding between Brazil and Argentina that overcame more traditional concerns with regime type, past rivalry dynamics, and pure power-political competition. This "strategic awakening" to the unavoidability of interlocking common interests in the River Plate area came to the fore most visibly in the post-war negotiations between Argentina and Brazil over defeated Paraguay. A second factor is the role that the United States played towards the end of the conflict, particularly through its diplomatic agents in Asunción and Buenos Aires. Unlike in the Guano War, the United States tried to officially mediate in the war motivated, not only by purely commercial interests, but also by a concern for reasserting "republican values" in the continent (i.e., in defense of Paraguay). A third, and extremely relevant

\footnotetext{
${ }^{487}$ Ibid., pp. 21-22.
} 
factor, was the diplomatic efforts by the members of the Quadruple Alliance in the Pacific to intervene diplomatically to stop the war and add the politico-military assets of the Triple Alliance to the "common front" erected against Spain in the Pacific. The relative success of the first factor, and the resounding failure of the other two, helps illustrate the strength of the "pragmatic" component of inter-state solidarity in South America's incipient society of states in the mid-1860s.

After the defeat of López, the provisions of the Treaty of the Triple Alliance entered into effect. Since Brazil had been at the center of the last stage of the war effort, taking Asunción and eliminating López's last pockets of resistance, it had a more favorable position over Argentina in influencing post-war developments in Paraguay. Between 1869 and 1871, therefore, negotiations between the victorious powers began with an almost insignificant role for Uruguay, which would eventually support Brazil's position. Brazil commissioned its most experienced diplomat, Silva Paranhos, who faced a new cabinet in Argentina in the Sarmiento administration. ${ }^{488}$ The new government in Argentina made a series of strategic mistakes which empowered Brazil's grip over the new Paraguayan Liberal elites.

First, Sarmiento designated a young and relatively inexperienced Minister of Foreign Affairs, Mariano Varela, who adopted a principled position that claimed "victory does not grant rights." The idea behind this diplomatic maxim was to turn Sarmiento's

\footnotetext{
${ }^{488}$ Francisco Doratioto, “Tentativas de paz na guerra do Paraguai," Navigator, Vol. 11, No. 21 (2015), pp. 119-131; and Thomas L. Whigham, "Protesta, desilusión y primeras tentativas de lograr la paz: La crítica a la Triple Alianza (1866)," in Paraguay en la historia, la literatura y la memoria: Actas de las II Jornadas Internacionales de Historia del Paraguay en la Universidad de Montevideo, ed. by Juan M. Casal and Thomas L. Whigham (Asunción: Editorial Tiempo de Historia and Universidad de Montevideo, 2011), pp. 239-249.
} 
congratulatory note for Emilio Mitre on the sacking of Asunción into a full foreign policy strategy. If successful, Sarmiento would have created a new set of costs for Brazil—costs of a "moral" nature—which in turn would have made Brazil's occupation of Paraguay unbearable. According to Bartolomé Mitre and Rufino de Elizalde, who became active critics of this new foreign policy approach, the "Varela Doctrine" meant that all the blood and treasure spent by Argentina to win the war would now be wasted away, enhancing, instead of constraining, Brazil's freedom of maneuver in Paraguay. ${ }^{489}$

The new Argentine policy facilitated Silva Paranhos job in Asunción. ${ }^{490}$ With the support of Uruguay, Brazil proceeded to negotiate separately a series of treaties with Paraguay, which gave way to the formation of a new government. This raised serious concerns in Buenos Aires about the violation of one of the Treaty articles regarding the impossibility of negotiating separately with the enemy. Varela naively thought that by accepting the composition of the new Paraguayan government while postponing a discussion with Brazil about the conditions for peace, he would save the spirit of the alliance with Brazil. However, with the ensuing wave of internal criticism in Argentina, Varela was soon forced to step down, being replaced by Carlos Tejedor. ${ }^{491}$

\footnotetext{
${ }^{489}$ See Fernando A. Bidabehere, Mitre diplomático (Buenos Aires: Porter, 2nd ed., [1966] 1967); and Bidabehere, "Un episodio diplomático en la vida de Mitre," Historia, Vol. 13, No. 47 (abril-junio, 1967), pp. $99-101$.

${ }^{490}$ See Thomas L. Whigham, "Silva Paranhos and the Construction of a Post-Lopista Paraguay," Journal of Iberian and Latin American Studies, Vol. 21, No. 3 (2015), pp. 221-241; Harris G. Warren, Paraguay and the Triple Alliance: The Postwar Decade, 1869-1878 (University of Texas Press, 1978); Augusto Tasso Fragoso, "A paz com o Paraguai despois da guerra da Tríplice Aliança," Revista do Instituto Histórico e Geográfico Brasileiro, Vol. 174 (1939), pp. 1-334; Gustavo Acosta, Posguerra contra la Triple Alianza: Aspectos políticos e institucionales (1870-1904) (Asunción: ServiLibro, 2013); and Eduardo Amarilla Fretes, La liquidación de la guerra de la Triple Alianza contra el Paraguay (negociaciones diplomáticas) (Asunción: Imprenta Militar, 1941).

${ }^{491}$ For a good overview of this period, see Bias Campos Arrudão, "Ending the War of the Triple Alliance: Obstacles and Impetus," M.A. Thesis, Austin, TX: University of Texas at Austin, 1981; Warren, Paraguay and the Triple Alliance: The Postwar Decade, 1869-1878 (University of Texas Press, 1978); Roberto
} 
With a new reality consolidated in Paraguay, Tejedor tried to mend the strategic blunders of his predecessor by negotiating with Paraguay the issue of common borders. But instead of negotiating these matter with Brazil directly, as originally stipulated in the Treaty, Argentina would now have to negotiate with a newly formed Paraguayan government that worked under the influence of Brazil. Although not entirely a "puppet" regime, the Paraguayan government would, at least, be able to maintain a stronger opposition to any Argentine demands due to Brazil's underlying support.

The tensions between Brazil and Argentina, therefore, led to a momentary breakup of the Triple Alliance in 1871, which was propelled in part by Tejedor's insistence in claiming the entire western area of Chaco in Paraguay. The rumors of a severe confrontation, and possibly war, between Argentina and the Empire prompted Sarmiento to reconsider his radical departure from Mitre's foreign policy of "strict neutrality" and pragmatic rapprochement with Brazil. Accepting his predecessor's view on the matter, Sarmiento reversed back to Mitre's original strategy and commissioned him personally in a "special mission" to Asunción and Río de Janeiro to help recompose the relation with Brazil and negotiate a new treaty for Paraguay's new borders with Argentina. ${ }^{492}$

\footnotetext{
Etchepareborda, "Enfrentamiento argentino-brasileño al finalizar la guerra del Paraguay," Investigaciones y Ensayos, Vol. 10 (enero-junio, 1971), pp. 131-158; Etchepareborda, "La política externa argentina, 18701920," Anuario del Departamento de Historia, Año II-III, No. 2 (Córdoba: Universidad Nacional de Córdoba, Facultad de Filosofía y Humanidades, 1964-1965), pp. 167-261; and Etchepareborda, Historia de las relaciones internacionales argentinas (Buenos Aires: Pleamar, 1994).

${ }^{492}$ On this important mission, which helped reestablish the Argentina-Brazil alliance, see Bidabehere, Mitre diplomático; Armado Alonso Piñeiro, La misión diplomática de Mitre en Rio de Janeiro-1872 (Buenos Aires, Institución Mitre, 1972); Ramón J. Cárcano, "La misión Mitre al Brasil (abril-diciembre 1972)," Anales de la Faculta de Derecho y Ciencias Sociales, Tomo III, $1^{\circ}$ parte (2º serie, 1913), pp. 5-189; José L. Suárez, Diplomacia universitaria americana: Argentina en el Brasil (Buenos Aires: Escoffier, Caracciolo, 1918); Tasso Fragoso, "A paz com o Paraguai despois da guerra da Tríplice Aliança"; and "Missão especial do General argentino D. Bartolomé Mitre ao Brazil em 1872: Negociação confidencial," Revista Trimensal do Instituto Histórico e Geographico Brazileiro, Tomo XL, Parte $1\left(1^{\circ}\right.$ e $2^{\circ}$ trimestres, 1897), pp. 5-74. See also Jaime Sosa, Negociaciones diplomáticas entre el Brasil, la República Argentina y
} 
Apart from the intricacies of the negotiations themselves, two other elements stand out in this period. First, Paraguay survived as an independent state after the war, for its territory was not "partitioned," as many had interpreted from the Treaty's text. As the defeated side in the war, Paraguay did suffer some territorial losses. These were, however, "disputed" territories that had never been consistently under Paraguayan control before. On this matter, therefore, it is quite revealing that despite the catastrophic defeat in the war against the Triple Alliance, Paraguay was not obliterated from the map. The allies never made "a South American Poland" of it, as many critics had feared. While Argentina and Brazil managed to settle (in their favor) all their border and territorial issues with Paraguay, one region remained open to future contention: the Chaco Boreal region between Paraguay and Bolivia. The persistent lack of solution for this question later became a core source of controversy that led to the last major armed conflict in the Americas: the Chaco War (19321935) between Paraguay and Bolivia.

A second element worthy of attention is the fact that both occupying countries in time pardoned Paraguay's war reparations and debts, thus easing Paraguay's financial burdens in its post-war reconstruction. This was an important gesture of self-restraint by the allies who, motivated by a common interest in pacifying the area, needed the new Paraguay to establish a stable domestic order that would put an end to the original causes of the war. For Paraguay, now led by a new generation of politicians that had been in exile for long periods of time, the country presented a very complex scenario. Severely depopulated, militarily occupied, and with a barren economy, the tensions between Argentina

el Paraguay: Misión del ciudadano paraguayo Jaime Sosa a Río de Janeiro (Buenos Aires: La Tribuna, 1875). 
and Brazil were used instrumentally in their favor, pitting one power against the other, and gaining concessions from both. The very fact of Paraguay's survival after the war as an independent country, however, shows the extent of the allies' policy of self-restraint in victory.

In so far as the intended participation by the United States as a mediator during the last phases of the war, it is quite telling that not only the diplomatic effort by the U.S. failed, but most importantly that it was flatly rejected by the South American leaders-including Francisco S. López(!). The details of how the offer of mediation was extended, and of how it was rebuffed, points towards the role of a regional understanding, shared by all South American leaders, who proposed "South American solutions" for "South American problems." The existence of this common sentiment regarding the illegitimacy of the United States' involvement in the region-even when advocating peace-shows something eminently distinctive about the presence of a consolidating regional society of states at the time.

The involvement of the U.S. in the war, as in the late and incipient mediation efforts during the Guano War, took place in a problematic domestic context marked by the end of its civil war. Despite this important domestic constraint on the conduct of its foreign affairs, the U.S. showed a remarkable interest in bringing about peace in this southern, and rather remote, region of the continent. The Lincoln administration was not yet ready for a full engagement in the form of a mediation, but nevertheless instructed the Secretary of State to engage in subtle diplomacy, rather than exert an overt or forceful persuasion for the achievement of a peaceful resolution of the war. Under these instructions, Secretary of 
State, William H. Seward, conceived a type of posture that would guarantee the U.S. a position of "stewardship" rather than "guardianship" over the continent. ${ }^{493}$

In this context, the official policy of the U.S. towards the War of the Triple Alliance was one of strict neutrality for almost the entire duration of the conflict. In several communications with the U.S. Minister in Asunción, Charles A. Washburn, Seward insisted that although the Paraguayan defeat could be anticipated, the war was an unfortunate event from which the U.S. should remain detached but vigilant. ${ }^{494}$ But as the war progressed, and Paraguay entered into a purely defensive mode, the pressures to present a U.S. mediation became stronger-mainly due to the increasingly impatient reports from ministers Washburn and Webb in Paraguay and Brazil, respectively. The diplomats commissioned to the River Plate, unlike cabinet members located in Washington, had a more intimate knowledge of the events and were urging the Department of State to adopt a more engaged policy before other powers, such as France or Great Britain, could step in and act as peace brokers. In other words, the war was quickly becoming not only an issue of intra-regional order and peace, but also a matter of principle for the reaffirmation of the Monroe Doctrine itself after the end of the U.S. civil war.

To reconcile these complex interests, Seward decided to adopt two main policies. First, he instructed ministers Washburn (in Paraguay), J. Watson Webb (in Brazil), and

\footnotetext{
${ }^{493}$ See Harold F. Peterson, "Efforts of the United States to Mediate in the Paraguayan War," The Hispanic American Historical Review, Vol. 12, No. 1 (February, 1932), pp. 2-17; Peterson, Argentina and the United States: 1810-1960 (State University of New Yok, 1964), pp. 194-207; and Robert C. Hersch, “American Interest in the War of the Triple Alliance, 1865-1870," Ph.D. Dissertation, New York, NY: New York University (1974), pp. 82-85.

${ }^{494}$ See Thomas L. Whigham and Juan M. Casal, comps., La diplomacia estadounidense durante la guerra de la Triple Alianza: Escritos escogidos de Charles Ames Washburn sobre el Paraguay, 1861-1871 (Asunción: ServiLibro, 2015); and Hersch, “American Interest,” p. 86: fn. 11-13.
} 
Alexander Asboth (in Argentina) "to insist" on the acceptance of a U.S. mediation. ${ }^{495}$ And second, Seward approached Brazil by offering the U.S.' unconditional support in the war in exchange for the acceptance and application of several foreign-policy principles aligned with the U.S. This clever double-play was later also extended to Argentina, with whom the U.S. indicated the value of a regional protection of all republican governments. In this intricate diplomatic approach, therefore, the U.S. tried to entice all the parties on the basis of different interests and values, with the ulterior objective of bringing about an end to the war. In communication with Seward, the American representative in Brazil stated:

If the United States do not intervene by the offer of mediation, England and France most assuredly will from necessity do so. And against such friendly interference by them we of course could not object. Under existing circumstances, then, and where the "Monroe doctrine" has been virtually admitted by the withdrawal of the French troops from Mexico, it does appear to me that the United States, without setting up any claim in the premises, should indirectly assume that it is her right to interpose in all international conflicts on this continent to the full extent that interposition from other powers is admissible. We should impress all the American governments with a conviction that it is alike their interest and their duty to look to the United States for protection and advice; protection from European interference, and friendly council and advice in regard to difficulties with their neighbors. I therefore earnestly recommend that at the earliest possible moment I be authorized to tender to Brazil and her lies, the republics of Argentine and Uruguay, our good offices and friendly interposition in the settlement of all pending questions between them and Paraguay. ${ }^{496}$

Despite this initial rapprochement, Seward's strategy ultimately fell apart as the South American nations felt manipulated and unduly pressured, and thus resented the U.S.

\footnotetext{
${ }^{495}$ From W. Seward to J. Webb, Washington DC, October 10, 1866, "Instructions," Brazil, Vol. XVI: pp. 158-159; from W. Seward to A. Asboth, Washington DC, October 15, 1866, "Instructions," Argentina, Vol. XV: pp. 259-260; from W. Seward to C. Washburn, October 17, 1866, "Instructions," Paraguay, Vol. I: p. 611, all quoted in Peterson, "Efforts of the United States to Mediate," p. 4: fn. 4.

${ }^{496}$ From W. Seward to J. Webb, Río de Janeiro, August 7, 1866, in Papers Relating to Foreign Affairs (Washington DC: Govt. Printing Office, 1866), pp. 320-321.
} 
involvement on otherwise "strictly South American matters." ${ }^{497}$ Apart from the two core principles of reasserting the Monroe Doctrine and reestablishing regional order and peace, South American nations came to resent a third implicit principle of U.S. diplomacy after the end of its civil war: its search for prestige and leadership. ${ }^{498}$ The tension was now evident, between a unilateral interpretation and application of the Monroe Doctrine by the U.S., and a more multilateral and shared interpretation by the more assertive South American nations, like Chile, Argentina, or Brazil.

The critical break occurred when the U.S. insisted that the members of the Triple Alliance accept its mediation took a rather "undiplomatic" turn, escalating into bitter exchanges between the U.S. ministers and different South American ministers of foreign affairs. ${ }^{499}$ Paraguay itself, under López's rule, was also unimpressed by U.S. offers of mediation, rejecting every opportunity presented by Washburn and his successor, Martin T. McMahon, who arrived in Asunción in November, $1868 .{ }^{500}$ According to López, the U.S. had historically done nothing truly substantial to aid Paraguay. ${ }^{501}$ However, the

\footnotetext{
${ }^{497}$ See Hersch, “American Interest," pp. 100-111; and Donald E. Willett, “Across the Andes: United States, Argentina and Chilean Diplomatic Relations, 1865-1883," M.A. Thesis, Nacogdoches, TX: Stephen F. Austin State University, 1976, passim, but esp. pp. 12-16.

${ }^{498}$ See Milton Plesur, America's Outward Thrust: Approaches to Foreign Affairs, 1865-1890 (Northern Illinois University Press, 1971); and Peterson, "Efforts of the United States to Mediate," p. 4.

${ }^{499}$ See Peterson, Argentina and the United States, pp. 194-207; Hersch, "American Interest," pp. 100ff; and Peterson, "Efforts of the United States to Mediate," pp. 11-15.

${ }^{500}$ On McMahon's mission to Paraguay, see Michael K. Huner, "Saving Republics: General Martin Thomas McMahon, the Paraguayan War and the Fate of the Americas (1864-1870)," Irish Migration Studies in Latin America, Vol. 7, No. 3 (March, 2010), pp. 323-338; Arthur H. Davis, Martin T. McMahon, diplomático en el estridor de las armas (Asunción: Litocolor, 1985); and Lawrence R. Hughes, "General Martin T. McMahon and the Conduct of Diplomatic Relations Between the United States and Paraguay," M.A. Thesis, Boulder, CO: University of Colorado, 1962.

${ }^{501}$ Two prior diplomatic incidents, first with the U.S.S. Water Witch in 1851, and then with the U.S. representative Edward A. Hopkins in 1853, had strained the bilateral relations with Paraguay and left a very negative impression in Asunción. See, e.g., Frank O. Mora and James W. Cooney, Paraguay and the United States: Distant Allies (The University of Georgia Press, 2007), pp. 7-37; and Peterson, Argentina and the United States, pp. 163-178. On the subsequent U.S. naval expedition to Paraguay, see Pablo M.
} 
overall official position was to consider the U.S. as "a friend" of Paraguay. McMahon, deepened even further these superficial expressions of friendship given the Minister's Irish background and his fervent defense of republicanism - a system of government that López claimed as a characteristic of his rule. During the very last years of fanatical resistance by Paraguay, the U.S. minister was the only foreign diplomat still present in Asunción. This angered the allies, who rejected all efforts at mediation coming from Washington. Although the South American allies tried to maintain good relations with the U.S., they made Washburn's efforts at acting as a channel of communication between López and the allies almost impossible, to the point that on one occasion, after Washburn's travelled back to Paraguay following a short visit to the U.S., his return to Asunción was effectively delayed for several months. ${ }^{502}$

In December 1866, the U.S. suggested that a conference be held in Washington to broker a final peace treaty. But although several newspapers in the allied countries showed initial interest in this proposal, the governments consistently avoided a final answer. As Harold Peterson argues, the allies "hoped to delay consideration of the proposition until the subjugation of Paraguay made mediation unnecessary. ${ }^{" 503}$ Final refusals were issued on March 30 (by Argentina), March 31 (by Uruguay), and April 26 (by Brazil), in 1867.

Ynsfrán, La expedición norteamericana contra el Paraguay, 1858-1859 (Buenos Aires: Guarania, 1954); Ynsfrán, "Sam Ward's Bargain with President Lopez of Paraguay," The Hispanic American Historical Review, Vol. 34, No. 3 (August, 1954), pp. 313-331; and Thomas O. Flickema, "The Settlement of the Paraguayan-American Controversy of 1859: A Reappraisal," The Americas, Vol. 25, No. 1 (July, 1968), pp. 49-69; Flickema, “'Sam Ward's Bargain': A Tentative Reconsideration,” The Hispanic American Historical Review, Vol. 50, No. 3 (August, 1970), pp. 538-542.

502 This episode is described in great detail in Whigham and Casal, La diplomacia estadounidense; and John H. Saunders, "Diplomacy Under Difficulties: United States Relations with Paraguay during the War of the Triple Alliance," Ph.D. Dissertation, Athens, GA: University of Georgia (1966).

${ }^{503}$ Peterson, "Efforts of the United States to Mediate," p. 8. 
Silence ensued after the reception of these rejections, until one final attempt was tried in January 1868, by the U.S. Minister in Brazil, Webb. This new proposition had a more restrained tone and tried to err on the side of impartiality. In the new offer, however, the war was near its final completion, which weakened the allies' need for a peace agreement involving an extra-regional power. Equally, a number of indiscretions—-such as the implicit idea that Brazil bore the main responsibility for the outbreak of the war-irreversibly damaged the spirit of the U.S. proposal. By mid-1868, therefore, all three allied powers had already sent their replies to the U.S. government rejecting the proposal: the replies by Argentina and Uruguay were issued in March, while Brazil's followed in late April.

In this way, the ultimate failure of the U.S. mediation in the War of the Triple Alliance reached an ignominious and embarrassing end. The lack of professionalism and diplomatic "tact" by U.S. officials and ministers affected the tone of the offers of mediation and, in turn, facilitated the allies' rejection of each proposal. In the end, the numerous attempts by the U.S. played no relevant role in the amelioration or termination of the war. At no point it can be said the allies seriously considered any of the intended "pressures" by the U.S., nor contemplated a potential coercive measure by the U.S., in how they carried out their respective war efforts and foreign policy strategies. If anything, the image of the U.S. was further tarnished by what the Allied nations perceived as an opportunistic and threatening involvement by the U.S. in a region of the Americas that was beyond the purview of U.S.' national interest.

To conclude, it is imperative to explore a second source of intended mediation during the latter stages of the war: that of the Quadruple Alliance. In the previous chapter, the process of reaching out to the Atlantic powers was treated from the perspective of Chile, 
and its diplomatic missions sent out to all South American countries - and the U.S. - to gather support in erecting a common front against Spain. In this chapter, however, the effort of the Quadruple Alliance is presented through the lens of the countries involved in the War of the Triple Alliance. Overall, the exploration of this crucial intra-regional diplomatic interaction offers significant information in support of Burr's view about the "bridging" of both sub-systems: Atlantic and Pacific, or Platine and South Pacific, which forged a common interests of the entire South American region into one single inter-state system. Beyond Burr's view, however, this chapter suggests that also a society of South American states emerged as a product.

When the news of Pinzón's occupation of the Peruvian islands reached Buenos Aires, the first reaction of the Mitre administration was to consult with Balcarce, the Argentina agent in France, to find out "from a solid source" in Madrid whether the government of Isabel II would confirm or reject the claims of "revindication" made by the Spanish agents in the Pacific. ${ }^{504}$ Mitre, well aware of President Pezet's internal scandals of corruption and mishandling of the country's finances, tried to avoid being dragged into a situation in which Peru would negotiate peace bilaterally with Spain, while Argentina, Chile and the rest of the neighbors demanded explanations and antagonized Madrid collectively. ${ }^{505}$ To avoid such embarrassment, Mitre changed Sarmiento's original instructions and reached out to the Chilean president to propose a coordination and

\footnotetext{
${ }^{504}$ Belgrano, "España y el conflicto del Pacífico," passim, but esp. pp. 515-519; and Caillet-Bois, "1864, un año crítico en la política exterior de la presidencia de Mitre."

${ }^{505}$ Francisco Centeno, "La diplomacia argentina en el Pacífico: Guerra hispano-americana de 1865," Revista de Derecho, Historia y Letras, Año XIX, Tomo LVII (1917), pp. 380-390; [G. H. S.] "El general Mitre y la guerra de Chile con España"; $c f$. Ignacio Santa María, "Chile y Argentina en 1864," Revista Chilena, Año v, Tomo XIII, No. 46 (octubre, 1921), pp. 5-32, Tomo XIII, No. 47 (noviembre, 1921), pp. $113-128$.
} 
potentially an alliance in case Madrid refused to disavow the action of its diplomatic agents. $^{506}$

Throughout the entire diplomatic crisis, as well as during the Guano War itself, Spain stalled, providing no clear or compelling answer. It neither recalled the agents, nor disavowed their claims, limiting itself only to communicate that the Cabinet in Madrid deeply regretted the situation created by the occupation of the islands. This persistent ambiguity on the part of Madrid, therefore, had to be contemplated and counterbalanced by Peru's own duplicity in its handling of the issue. The extensive communications between Mitre and Sarmiento, as well as between Elizalde and Sarmiento, and Elizalde and Balcarce, demonstrate well how this complex dual international front was handled with care by the Argentine diplomacy-considering also that the Uruguayan imbroglio was unfolding in parallel across the River Plate from Buenos Aires.

The Brazilian diplomacy also faced a similar situation, which was further compounded by its condition as a monarchy - a factor that was still a source of mistrust for many Pacific countries. The Brazilian representative in Santiago and Lima, Adolfo Varnhagen, however, handled the Brazilian neutrality with extreme care. ${ }^{507}$ Although he was assigned to both Santiago and Lima, the news of the Spanish aggression reached him while he was in Chile. Varnhagen reported accurately not only the general public sentiment

\footnotetext{
${ }^{506}$ From R. de Elizalde to D. Sarmiento, Buenos Aires, October 8, 1864, in Argentina, Documentos del Dr. Rufino de Elizalde, Instituto Ravignani, Buenos Aires, section "Correspondencia de Domingo Faustino Sarmiento con Rufino de Elizalde y otros (1858-1868).” Also available in Argentina, Archivo del Ministerio de Relaciones Exteriores y Culto, Boxes AH051, No. 42-77: "Misión Sarmiento en Chile." See also Francisco Centeno, “1864: Misión del Coronel Sarmiento a Chile y Perú,” pp. 92-100; Centeno, “Correspondencia entre Elizalde y Sarmiento," Revista de Derecho, Historia y Letras, Año IX, Tomo XXVII (1907), pp. 442-449; and Auza, La misión Sarmiento en Chile y Perú, pp. 112-114.

${ }^{507}$ Ribas Miranda, "Peso da neutralidade"; Ribas Miranda, “Diplomata mais amante do seu paiz que das suas commodidades," pp. 54-103; and Villafañe Gomes Santos, "Varnhagen e a América do Sul.”
} 
of outrage in Santiago, but also was a keen observer of the activities of the Lima Congress, gathered in Lima. Later, he was a privileged witness to the Spanish blockade and bombardment of Valparaíso-following which he wrote letters to Admiral Pareja and to the U.S. agent in Chile, Thomas H. Nelson, condemning the Spanish aggression. ${ }^{508}$

Given the vast distances and the still deficient communication technologies, the diplomatic agents of all South American nations deployed in the Pacific were endowed with ample powers - by today's standards - so they could, in the right situations, take important decisions in situ without consultation with their respective chancelleries. Varnhagen, as well as Sarmiento, made critical use of these attributes, reacting to the Spanish aggressions with official public condemnation. In both cases, however, they earned the admonishment of their respective governments, more interested in maintaining a strict neutrality on the Pacific question, given the unpredictable situation in Uruguay's civil war. In the case of Sarmiento, his own personal "Americanist" political and ideological inclinations imprinted on the Argentine diplomacy towards the region—and towards this particular war as a whole—a distinctive tone that extra-limited Mitre's and Elizalde's intended level of involvement. In the case of Varnhagen, being a historian with an extensive diplomatic experience in Portugal and in other countries of Europe, his own idiosyncrasies and professional traits also got him in trouble with Itamaraty. In reaction to the bombardment of Valparaíso, Varnhagen joined the Diplomatic Corps letter of public condemnation of the Spanish Admiral's decision, and issued statements that sent mixed signals to the Chilean government in relation to Brazil's position towards the war with

\footnotetext{
${ }^{508}$ From J. Duarte da Ponte Ribeiro to J. d'Azambuja, Lima, April 27, 1864, in Brazil, Arquivo Histórico do Itamaraty, "Legação Imperial do Brasil no Peru," No. 212/2/12.
} 
Spain. ${ }^{509}$ The initial impression of a potential Brazilian adherence to the Quadruple Alliance, was followed by an official denial from Río de Janeiro, which created a popular sentiment of resentment against Brazil that complicated the bilateral relations in during the rest of the 1860s and early 1870 s.

The members of the Quadruple Alliance had two main contentions with the Triple Alliance. The first issue was that Argentina had joined Brazil, a monarchy, to wage war on Paraguay, a country that many in the Pacific considered as a "republic," although little to nothing was really known about López himself or Paraguay's political system, due to its long history of isolation from regional affairs. This led to an implicit bias in favor of Paraguay, and in disguised hostility against Brazil, Argentina, and Uruguay. A second issue was the fact that none of the members of the Triple Alliance rushed to the protection of Peru's autonomy and independence when the Spanish squadron occupied the Chincha Islands in April, 1864. Many historical works by Chilean or Peruvian authors, for example, still maintain a skewed and negative view of the so-called "abandonment" or "betrayal" by Argentina and Uruguay of their sister republics of the Pacific. This narrative, however, ignores an important series of diplomatic risks taken by the Atlantic powers in clear support of the cause of the Quadruple Alliance. ${ }^{510}$

\footnotetext{
${ }^{509}$ From A. Varnhagen to J. Pareja, Santiago, October 10, 1865; and from A. Varnhagen to T. Nelson, Santiago, October 7 and October 9, 1865, all annexed copies a letter from A. Varnhagen to J. Saraiva, Santiago, October 12, 1865, in Brazil, Arquivo Histórico do Itamaraty, "Legação Imperial do Brasil no Peru," No. 212/2/12.

${ }^{510}$ Cf. Edmundo A. Heredia, El imperio del guano: América Latina ante la guerra de España en el Pacífico (Córdoba: Alción, 1998); Lacoste, "Americanismo y guerra," pp. 567-591; Lacoste, "Las guerras hispanoamericana y de la Triple Alianza," pp. 125-158; and Cavieres Figueroa, "Las frustraciones de la Unión Americana," pp. 299-322.
} 
As previously mentioned, in 1864 Argentina and Brazil were preoccupied with the unfolding Uruguayan crisis and the potential interjection of Paraguay into it. Nevertheless, Brazil maintained a practical neutrality in a situation where the monarchical element played an inverted constraining role. It was not the case, as the Pacific allies believed, that Brazil kept its neutrality out of solidarity with Spain as a monarchy, but in effect it maintained a neutral position in order not to antagonize the Pacific republics, who were deeply suspicious of Brazil's intentions to begin with. Brazil, moreover, had unresolved border disputes with Peru, Bolivia, and Ecuador, which Itamaraty tried to close as soon as possible. ${ }^{511}$ Argentina, for its part, not only offered Chile an early alliance-which Santiago rejected — but also made numerous diplomatic efforts via its diplomatic agent in France to propose either an Argentine mediation or a joint Anglo-French mediation to bridge the relations between Peru and Spain bilaterally. ${ }^{512}$

For example, although short of a formal endorsement of the Pacific alliance, Argentina instructed its sole representative in the European capitals to make clear Argentina saw with great concern the principles invoked by Pinzón and Salazar y Mazarredo, as well as the very means by which the occupation had been carried out. This consistent policy of pressure to force Madrid commit to a format explanation was pursued

\footnotetext{
511 Villafañe Gomes Santos, O Império e as repúblicas do Pacífico, pp. 87-109; Villafañe Gomes Santos, O Brasil entre a América e a Europa: O Império e o interamericanismo (do Congresso do Panamá à Conferência de Washington) (São Paulo: Editora UFPR, 2003); Marcos Cueto and Adrián Lerner, Indiferencias, tensiones y hechizos: Medio siglo de relaciones diplomáticas entre Perú y Brasil, 1889-1945 (Lima: Instituto de Estudios Peruanos; Embajada de Brasil en el Perú, 2012), pp. 17-63; Leonam L. Nunes da Silva, 'Relacoes na Tríplica Fronteira: A Bolívia no contexto da 'Guerra Grande' (1865-1868), M.A. Thesis, Cuiabá: Mato Grosso, Universidade Federal de Mato-Grosso, 2009; and Álvaro Pérez del Castillo, Bolivia, Colombia, Chile y el Perú: Diplomacia y política, 1825-1904 (La Paz: Los Amigos del Libro, 1980).

${ }^{512}$ See Centeno, "La diplomacia argentina en el Pacífico," pp. 380-339; [G. H. S.] "El general Mitre y la guerra de Chile con España"; Belgrano, "España y el conflicto del Pacífico"; and Caillet-Bois, "1864, un año crítico en la política exterior de la presidencia de Mitre."
} 
even at the cost of damaging the negotiation of a critical treaty between Argentina and Spain over commerce and mutual recognition. ${ }^{513}$ Mitre was, therefore, taking a serious risk by acting unilaterally towards the Spanish Court, while also proposing an alliance with Chile. The Pérez administration rejected Mitre's offer because at the very beginning of the diplomatic crisis, while Tocornal was Minister of Foreign Affairs, Chile itself had adopted - just like Ecuador - a neutral position towards the Peru-Spain dispute. Chile would later come to lament that early rejection, when its "Americanist" fervor, personified in Tocornal's replacement, Covarrubias, would come to drag Chile into a war with Spain for which it was not prepared.

Paraguay itself, during the offensive phase of its military campaign against the Triple Alliance, also rejected several offers of support and military assistance made by Bolivia — its neighbor to the west. Bolivia's foreign policy was, just like Chile's, strongly pro-Americanist and solidarist during the reign of Melgarejo. But unlike Chile, it had a chronically unstable domestic order characterized by a plethora of caudillos that ruled arbitrarily and whimsically until they were toppled by the next caudillo, who perpetuated the cycle. During the rule of Mariano Melgarejo (December 1864-January 1871), Bolivia sent three diplomatic missions to Asunción to explore the possibility of establishing an axis with López, to assist him in his fight against the Brazilians, and to potentially defuse the war on the Atlantic and, thus, "free" Argentina and Uruguay to join the Quadruple Alliance against Spain. ${ }^{514}$ Melgarejo, at one point, even offered López troops to help him fend off

\footnotetext{
${ }^{513}$ See Mario Belgrano, "La cuestión de la nacionalidad y el tratado con España de 1863," Anuario de Historia Argentina, Vol. 2 (1940), pp. 47-64.

${ }^{514}$ On this under-studied aspect of South American diplomatic relations in the 1860s, see the excellent study by Ricardo Scavone Yegros, Las relaciones entre el Paraguay y Bolivia en el siglo XIX (Asunción: ServiLibro, 2004), esp. pp. 65-122. See also David Alvéstegui, Bolivia y el Paraguay: La cuestión de
} 
the invading allied army—which he refused. ${ }^{515}$ Melgarejo's rapprochement with López had begun some time earlier, however, during the early months of the war. ${ }^{516}$ López had put too much trust in the country's difficult terrain and believed, as seen with his rejection of the Uruguayan proposals for alliance, that Paraguay could raise the costs of the war for the allies and then exploit their domestic weaknesses, as well as their lack of coordination and intra-alliance rivalries, and force them into a negotiated settlement.

Colombia, which had refused to join the Quadruple Alliance, dispensed all kinds of honors and tributes to Francisco S. López and the "heroic" defense that the Paraguayan people were undertaking for their independence and freedom. ${ }^{517}$ The Colombian people's affection towards Paraguay, however, as well as that of Venezuela and Ecuador, never went beyond a mere rhetorical identification with López's cause as a way to antagonize Brazil. No troops, money, nor any other type of resources were ever mobilized by any of the Pacific nations in support of Paraguay's war effort.

\footnotetext{
límites (La Paz: Renacimiento, 1926), esp. pp. 184-204; Fernando Cajías de la Vega, "Bolivia y la guerra de la Triple Alianza," in La guerra del Paraguay, pp. 383-397; Humberto Vázquez-Machicado, "Melgarejo y la Triple Alianza," Revista Khana, Vol. 4/5, No. 21/24 (1956-1957), pp. 226-231; and Vázquez-Machicado, "Para una historia de los límites entre Bolivia y el Brasil," in Obras completas de Humberto Vázquez-Machicado y José Vázquez-Machicado (La Paz: Don Bosco, 1988), Vol. 1: pp. 197_ 210.

${ }^{515}$ From F. Egusquiza to J. Berges, Buenos Aires, February 16, 1865, Paraguay, Archivo Nacional de Asunción, Colección Río Branco, I-30-8-60, No. 3550.

${ }^{516}$ See, e.g., from J. Berges to A. Arce, Asunción, January 31, 1865, ibid., I-22-12-1, No. 3560. See also from M. Melgarejo to F. López, La Paz, August 30, 1866, in Leonardo S. Torrents, Dívida e throphéos paraguayos e a propaganda no Brazil: Contendo alguns documentos e factos pouco conhecidos no Brazil (Rio de Janeiro: Montenegro, 1899), p. 235.

${ }^{517}$ See Ricardo Scavone Yegros, comp., Colombia ante la guerra del Paraguay contra la Triple Alianza: Documentos oficiales, artículos periodísticos y otros escritos contemporáneos (Asunción: Tiempo de Historia, 2015); Germán Cavelier, Política internacional de Colombia (Bogotá: Universidad Externado de Colombia, 1997), Vol. 2: pp. 26-37; Yoer J. Castaño Pareja, “'La diplomacia secreta': La participación de Colombia en el conflicto entre Perú y España por las islas guaneras," Historia y Sociedad, No. 24 (enerojunio, 2013), pp. 189-214; Colombia, Secretaría de lo Interior y Relaciones Exteriores, Memoria de la Secretaría de lo Interior y Relaciones Exteriores de Colombia (Bogotá: [n/d], 1865); and Juan M. Bákula, La política internacional entre el Perú y Colombia (Bogotá: Temis, 1988).
} 
Apart from Bolivia's diplomatic offer, Peru and Chile were the most serious about supporting Paraguay in reaching a peaceful and negotiated resolution in its war with the Triple Alliance. ${ }^{518}$ After the bombardment of Valparaíso and the subsequent Battle of Callao in mid-1866, the two countries led a diplomatic offensive to mediate in the War of the Triple Alliance. ${ }^{519}$ Through the Peruvian representative in the Platine capitals, Benigno G. Vigil, and the Chilean special envoy, José V. Lastarria, the Quadruple Alliance tried between 1866 and 1867 to offer favorable negotiating concessions to Argentina on the Patagonia border dispute, as well as to secure Uruguay's and Brazil's closing of their ports to the supply vessels of different nationalities used to assist the Spanish squadron with fresh water, coal, and other provisions. ${ }^{520}$ Although ex post facto the military stage of the Guano War was effectively over by the end of 1866 , Chile and its allies could not afford to remain idle, for Spain could attempt a new incursion in the near future. ${ }^{521}$ Without a professional navy to confront Spain, Chile pressed Uruguay and Argentina even further for the acceptance of the letters of marque issued by Chile and the practice of privateering in the

\footnotetext{
${ }^{518}$ From B. Vigil and G. Blest Gana to A. Flangini, Montevideo, January 2, 1867, Peru, Archivo Central del Ministerio de Relaciones Exteriores, 5-2: "Legación en Brasil." See also from J. Taborga to R. de Elizalde, F. de Almeida Rosa, and A. Flangini, Laja, July 6, 1866, in Bolivia, Ministerio de Relaciones Exteriores, Bolivia-Paraguay: Exposición de los títulos que consagran el derecho territorial de Bolivia, sobre la zona comprendida entre los ríos Pilcomayo y Paraguay, ed. by Ricardo Mujía (La Paz: El Tiempo, 1914), Vol. 2: 740-744. See the respective replies in ibid., pp. 744-750.

519 The best single source of primary information for studying the Quadruple Alliance's effort to mediate is Peru, Ministerio de Relaciones Exteriores, Correspondencia diplomática relativa a la cuestión del Paraguay, publicada por orden de S. E. el Jefe Supremo Provisorio para ser presentada al Congreso Constituyente (Lima: El Progreso, 1867). Other relevant information can be accessed at the Peruvian Archivo Central del Ministerio de Relaciones Exteriores, located in Lima, and its valuable special collection: Catálogo de documentos sobre la guerra de las repúblicas aliadas contra España: 1866 (Lima: Ministerio de Relaciones Exteriores del Perú; Red de Archivos Diplomáticos Iberoamericanos, 2012). This resource, however, offers incomplete year coverage that can only be supplemented by the Ministry's diplomatic archive itself.

${ }^{520}$ See Cristóbal Aljovín de Losada, "Perú y la guerra del Paraguay, 1864-1870,” in La guerra del Paraguay, pp. 363-382.

${ }^{521}$ Heredia, El imperio del guano, pp. 106-114.
} 
Atlantic. Lastarria, however, overplayed his hand while negotiating these concessions. Pressed by the need to steer the Atlantic powers' attention towards the Pacific, Lastarria's accusations of Uruguayan support to Spain prompted the Uruguayan government to revoke the diplomat's exequatur, which led to a serious diplomatic crisis between Chile and Uruguay. ${ }^{522}$

The tension grew higher when, in March 1866, the content of the "secret" Treaty of the Triple Alliance became publicly known. The offers of mediation, therefore, were followed by official letters of protest by Chile, Peru, and Bolivia. Ecuador, for its part, only indirectly joined the diplomatic protests by allowing the Chilean diplomatic agents to "speak for Ecuador" on this particular matter. ${ }^{523}$ Although the efforts of the Quadruple Alliance failed in getting its mediation accepted by the members of the Triple Alliance and Paraguay, and deepened ever further past intra-regional rivalries among the countries on both sides of the continent, it did signal something important. The simultaneous development of both wars in the mid-1860s, while the U.S. was undergoing its own civil

\footnotetext{
522 On this crisis, see Uruguay, Ministerio de Relaciones Exteriores, Publicación oficial del negociado entre el Ministerio de Relaciones Esteriores y el Sr. Enviado Estraordinario y Ministro Plenipotenciario de la República de Chile, con motivo de su pretensión sobre venta de presas que las fuerzas navales chilenas pudieran hacer a la España (Montevideo: La Tribuna, 1865); and ibid., Negociaciones entre el gobierno oriental del Uruguay i el ministro diplomático de Chile sobre el consulado chileno en Montevideo y la venta de presas (Buenos Aires: Imprenta de Buenos Aires, 1866).

${ }^{523}$ See Jorge W. Villacrés Moscoso, "El rol del Ecuador en el ofrecimiento de la mediación de la cuádruple alianza de la guerra entre el Paraguay y la Triple Alianza," Boletín de la Academia Nacional de Historia, Vol. 51, No. 112 (julio-diciembre, 1968), pp. 200-208; Villacrés Moscoso, Historia diplomática de la República del Ecuador (Guayaquil: Programa Editorial de la Biblioteca de la Muy Ilustre Municipalidad de Guayaquil, 3rd ed., [1989] 2007), Vol. 2: pp. 43-45; Bolivia, Ministerio de Relaciones Exteriores, Memoria que el ex-Secretario General de Estado y actual Ministro de Gobierno, Justicia y Relaciones Exteriores de la República de Bolivia presenta a la Asamblea Nacional Constituyente reunida en 1868 (La Paz: Imprenta Paceña, [1868]), pp. 274-293; Juan Siles Guevara, "Juan de la Cruz Benavente y la participación de Bolivia en la cuádruple alianza contra España de 1866," in Revisiones bolivianas (La Paz: José Camarlinghi, 1969), pp. 77-101; and Peru, Ministerio de Relaciones Exteriores, Correspondencia diplomática relativa a la cuestión del Paraguay, esp. pp. 24ff.
} 
war, introduced leaders on both sides of the region to a new strategic reality from which there was no coming back. Firstly, the momentarily orphan Monroe Doctrine had to be, necessarily, re-appropriated and defended by the South American nations themselves, as the powerful United States could not be counted on for protecting the hemisphere from European interventions. Secondly, the region's own geopolitical dynamics opened South American states to the realization of their own political, economic, and military weaknesses. Whether fighting an extra-regional power, or among themselves, South American nations awakened to the strategic necessity of the "new" costs of contemporary, large-scale international war. The experience of the Pacific nations, as well as those involved in the war against Paraguay, were able to reap few true benefits from their "victories" on the battlefield.

In conclusion, the most recent technological advancements, as well as the process of consolidation of the new independent states, brought all states together in an interlocking web of complex interests. Perhaps the most powerful realization of all was the fact that the war affected not just those directly involved, but also the stability and common interests of the entire region. Indifference increasingly ceased to be a viable, long-term strategic option. Despite the ultimate success or failure of each of the mediation efforts and diplomatic missions of peace elicited by the War of the Triple Alliance (and the same must be said about the Guano War), the subtle lessons learned during this whole period left an indelible mark in how future generations of leaders, diplomats, statesmen, and decision-makers conducted their foreign relations toward one another. The process was a painfully slow, costly, and gruesome one, but it configured the power relations and dynamics that eventually came to determine the future quality of international relations in South America. 


\section{Testing Alternative Explanations}

\section{H2: The U.S. as a Regional Hegemonic Stabilizer}

There are six alternative explanations that advance competing narratives and sets of predictions regarding the War of the Triple Alliance, or Paraguayan War. The first main alternative explanation $(\mathrm{H} 2)$ points to the role of the United States as a broker of peace in the region via the suppression of armed conflict among neighbors, the implementation of a certain institutional "tutelage" over the region, and an asymmetrical type of "solidarity" that is premised on its own hegemonic leadership, principles, and values. As with the case of the Guano War, the two background conditions identified in Chapter 1 were present, although deeply affected by the U.S. civil war. Its "power preponderance," for example, can be considered a factor that was present and effective, but hindered by a domestic conflict that focused much of the U.S. decision-makers' attention away from foreign affairs (and South America in particular). Unlike in the Chincha Islands case, however, where the main incident occurred in early 1864, in the Paraguayan War the U.S. was able to demonstrate an increasing willingness to lead as its civil war waned. This was exemplified by its insistent and, at times forceful and rude, offers of mediation beginning in the second half of 1868 , when the victory of the Union was already secured. As the present Chapter illustrated, although willing and able, the United States was successfully rebuffed by Argentina, Brazil, and Uruguay, thus making evident not only a lack of means to exert diplomatic pressure on the allies, but also a lack of political capital and legitimacy behind its actions. Even though the U.S. civil was over, the three allies felt it was within their powers and prerogatives to deny the colossus from the north any legitimate interest in what they considered a purely Platine affair. 
Although the U.S. commercial interests in the River Plate area were rather inconsequential at the time, the role of the in situ diplomatic agents Washburn and McMahon was a key piece in interesting Washington in mediating the war in such a relatively peripheral a region for the U.S. It was McMahon, in particular, who raised the cause of republicanism in favor of institutionalizing a hemispheric principle based on the sharing and protection of this particular type of government over the monarchical one, associated with ancien Europe and imperialism. The members of the Triple Alliance, however, counting a monarchy among their own ranks, rejected basing intra-regional principles of solidarity and cooperation on such standards. "Order," "progress," and the Liberal values associated with "civilization" mattered more than considerations of regime type and New-World-Old-World rivalries, as suggested by the U.S. agents - and in part also by the Quadruple Alliance in the Pacific. Paradoxically, the absence of a McMahon in Chile or Peru during the Spanish aggression shows why the U.S. considered the issue of monarchical government irrelevant in the Pacific, while important in the River Plate area.

\section{H3: A Platine Balance of Power}

Regarding the second alternative explanation, that of the traditional balance of power (H3), several elements seem to offer support for at least two of the three main theoretical expectations or predictions. Moreover, both background conditions also seem to obtain; thus, making the exploration of this hypothesis a valid and meaningful task. The first condition, that of short-sightedness by the elites in power, and the second one (the "trigger") related to the presence of threats to state survival, played a relevant role in how the Blancos in Uruguay and Francisco S. López in Paraguay perceived their strategic 
environment in the early 1860s. As the present Chapter has shown, López and the Blancos shared a view of their precarious geopolitical situation, which was seen as threatened by Brazil and Argentina. The post-independence history of the region certainly justified the Uruguayan and Paraguayan leaders' blunt interpretations and suspicions regarding their powerful neighbors. However, with the hindsight of history one can confidently see that none of their fears were realistic by the 1860s. Brazilian policy had fundamentally changed after 1828, when it accepted (although reluctantly) the independent existence of the Republic of Uruguay, which was guaranteed by the British Empire. This policy was tested throughout the civil war that engulfed Uruguay up to 1852; and yet, the Blanco leadership perceived a mortal danger from both sides. From Argentina, for example, the Blancos believed in an even more sinister threat in the form of a plot by Buenos Aires' to "reconstruct the Viceroyalty of Rio de la Plata," which would engulf both Uruguay and Paraguay into one large political unit.

Perhaps more distinctively, López saw in these conjectures and plots an existential threat for which he had been preparing Paraguay for several years, militarizing almost the whole of Paraguayan society. Randall L. Schweller, a prominent advocate of the traditional balance-of-power approach in IR, argues that López in effect "over-balanced" against Paraguay's neighbors by believing that the threat that Argentina and Brazil posed was more prominent than it really was. ${ }^{524}$ But this shows precisely the limits, rather than the strength, of the $\mathrm{H} 3$ perspective as it pertains to the case. Contrary to what the classical balance-ofpower perspective would expect, state leaders did not act upon a "real" distribution of

\footnotetext{
${ }^{524}$ See Schweller, Unanswered Threat, pp. 85-102.
} 
material power, therefore producing a balance-of-power as an outcome unintended by the actors involved. It was, in fact, the balance of power as an idea or principle - that is to say, "in their minds"-which had a real impact on the power dynamics between states. Leaders' concerns about the balance of power led them to war, rather than to stable equilibrium. In the case of the Paraguayan War, López did not "read" the situation in the Platine region in terms of a calculated strategy based on the distribution of material capabilities, or as if Paraguay could engage in offensive war because it was strong enough to dominate others by force and conquest. It was, in fact, an overreaction to a fear that was, ex post facto, simply not there. López, in short, succumbed to the Blanco framing of the situation as one in which Uruguay was going to fall first, while Paraguay would soon follow.

The idea of the "balance of power," not as an unintended resultant of offensivelyminded states, but as a learned or acquired principle of statecraft, therefore, seems to lend more credit to the $\mathrm{H} 1$ understanding of this phenomenon than the purely power-political one. López's, as well as Herrera's, strategic sensibilities to the virtues and applicability of the principle of the balance of power, based on the European experience, played a major role precisely because key individuals in key decision-making positions at key moments in time held those particular notions in their minds, and so filtered and interpreted in a similar way their strategic environment. In the end, the militarily weaker states in objective terms (Uruguay and Argentina) did not ally against the more powerful ones (Paraguay and Brazil) as it should have been expected in the traditional view of the balance of power. Paraguay clashed with a triple coalition by Argentina, Brazil, and Uruguay, over the terms of which rules and standards of foreign conduct should dominate the international relations of the River Plate area. In the end, it was the actors' concern for prestige, status, and legitimacy 
that drove their patters of balancing and counter-balancing—not the objective distribution of military power among them.

The allied leaders, although not explicitly invoking the balance-of-power principle, could also be interpreted as upholding a similar notion in the implementation of their foreign policies. The diplomatic missions prior to the outbreak of the war itself, for example, illustrate well their own sensibilities to the virtues of maintaining a balanced power relation in the Plata region, in which Uruguay's independence and autonomy would be maintained and protected. Their distinctive framing of the situation, however, led Argentine and Brazilian leaders to understand the long-term strategic necessity of "pacifying” or “ordering" Uruguay's civil war. As the Brazilian and Argentine experiences demonstrate well, the unfinished process of state-formation in the mid-1860s in the Plata region generated problematic "externalities" between one country's domestic front and another's external front $-a$ situation that was clearly unsustainable in the long run. One front had to be ordered for the other to do so as well. It is on this point that perhaps the H3 overlaps substantially with the $\mathrm{H} 1$ on the understanding of war as a "taming" or "regulating mechanism." The "facts" of the case show that "fear" and "legitimacy" concerns cannot be so clearly disentangled from one another as drivers of either understanding of war.

As part of the $\mathrm{H} 3$ proposition, one can consider the second expectation regarding the role of mutual fear as a key ordering mechanism. But although "fear" was an important factor in how Paraguay precipitated a regional war with its neighbors, it was not an overriding factor, for López not only rejected making formal alliances with the Uruguayan Blancos when it was more sensible to do so, but also rebuffed Bolivian and U.S. explicit offers of support during the worst stages of the war for Paraguay. More than fear, it seems 
López injected an important quota of self-serving egomania, concerns for prestige, and international status, that ultimately led Paraguay down a ruinous path of self-destruction.

Contrary to the $\mathrm{H} 3$ expectation, Paraguay did not "balance" by way of forming international alliances against its enemies; while Argentina and Brazil forged their rapprochement not in direct reaction to López's aggression but several months earlier as they tried to "pacify" the Uruguayan imbroglio. Their formal alliance, signed on May 1, 1865 , do certainly show a dynamic component, overlooking concerns over regime type and a past history of rivalry inter se. Nevertheless, a stronger shared view of the two country's "common interests," personified in the Elizalde-Saraiva connection, seems to have won out. Sarmiento's early mistakes in the 1870 s, abandoning this common understanding, cost Argentina dearly as Brazil was able to hold a stronger economic and political grip over post-war Paraguay for several decades until the eventual collapse of the Empire in 1899.

\section{H4: River Plate Geopolitics}

The geopolitical approach (H4), for its part, offers a different reading of the situation and the motivation behind the actors' crucial decisions. The topography of the entire area certainly played a crucial role in shaping the actors' perceptions of the power dynamics underway in the 1860 s. As it was pointed out before in the Chapter, López considered Paraguay's terrain as a power potential obstacle in case of having to fend off an invading army. This may have emboldened the Paraguayan leader in believing that, in the unlikely case of an alliance between two former bitter rivals, Argentina and Brazil, Paraguay could drag both powers into a protracted wat of attrition and irregular combat in which the allies' domestic front weaknesses could be exploited in combination with growing human and 
military costs on the battlefield. López's strategy almost triumphed towards mid-1866, after the provisions of the Treaty of the Triple Alliance was made public and international condemnation created severe difficulties to the allied governments. A series of brutal defeats for Paraguay opened a window of opportunity for López to offer a peaceful and negotiated solution to the war in September 1866. His proposal was rejected, however, as Brazil and Uruguay were adamant about fulfilling the Treaty objectives - partly as a save facing mechanism, and partly as a way to preserve the Triple Alliance.

In the case of Uruguay, as well, the shared condition of "buffer state" with Paraguay, played an important role in pushing the former to seek the latter's assistance during the early stage of the diplomatic crisis with Brazil. The proximity of all the countries' capitals, connected by an extensive waterways system in the River Plate estuary, was undeniably a central component of the dynamics of the rivalries in the area. During the time of colonial rule, these dynamics had driven Portugal and Spain against each other. The very founding of the city of Buenos Aires and later "upgrading" to the status of Viceroyalty, was an attempt by Madrid to erect a bulwark against Portugal's relentless territorial expansion towards the southern part of the region. These same dynamics, also, were transferred over the independent nations which inherited the seats of power and territories of the former colonial units. This, as was detailed above, expressed itself in Argentine and Brazilian rivalry over the Banda Oriental region from 1810 until 1852. In the 1860s, however, the War of the Triple Alliance breaks with this purely geopolitical dynamic, as Argentina and Brazil did not fight over the issue of the protracted civil war in Uruguay, but actually coordinated their efforts and polished their common understanding 
of the reasons behind Brazil's necessity to forcefully put an end to the "anarchy" and "disorder" in Uruguay.

Contrary to the three specific expectations in the geopolitical hypothesis (H4), the overall geographical outlook of the region was not a physical obstacle to war, making it practically impossible, but actually a crucial incentive for Paraguay to risk major war with its main neighbors. It also occupies a central place in the explanation of Paraguay's capacity to prologue the inevitable result of the war for four more years, after its early strategic defeat in late 1865. Much has been written in the classical and recent historiography of the war about Paraguay's brave, heroic, and courageous defense, deeply rooted in their Guaraní culture and influences. However, without the right kind of combination between a difficult and largely unknown terrain and the inadequate war technology for that type of war, one can speculate that Paraguay's resistance would most certainly have been shorter, and its defeat markedly swifter. Perhaps thousands of soldiers on both sides of the war would not had to die in such large proportions by the hand of Mother Nature.

\section{H5: A Common Culture of Anti-Imperialism}

The "common culture" perspective (H5) offers an alternative interpretation of the factors that may attenuate war, increase the institutionalization of order, and promote solidarity among states. Based on the prevalence of two main background conditions, the expectations are, first, that states will try to eradicate war among themselves; second, that states would further try to progressively unify into a larger political unit; and third, that the prior two developments will be premised on an underlying sentiment of solidarity that rests 
on ideological and cultural commonality. In the case of the Paraguayan War, as much as in the case of the Guano War, a shared legacy of a recent anti-imperialist past was clearly present in the societies and, most importantly, in the political elites and decision-makers of each country involved. Unlike the Guano War case, however, there was no extra-regional aggression which could have justified a stronger sense of "American" solidarity against a common enemy.

In this specific context, the Paraguayan war is normally considered by many South American historians as the prototypical case of foreign imperialism. The argument typically focuses on the British Empire as the main "power behind power," as the local elites in Argentina and Brazil waged war on Paraguay due to the latter's challenge to the "Liberal" capitalist model of national production. Subservient to this foreign power and its capital, the allies are seen as crushing the alternative model of autonomous national development in Paraguay. The facts of the case, however, show no empirical support for this narrative. The British Empire, in effect, had a real interest in preserving Uruguay's independence and autonomy, as well as in preventing war from ever occurring in the region. It was precisely British economic and financial interests what propelled the diplomatic agents Lettsom and Thornton to actively participate in the pre-war negotiations, facilitating as much as possible all sources of common understanding between the countries involved. After the failure of these negotiations, however, it was Lord Russell who ordered the publication of the Treaty of the Triple Alliance- a decision that was clearly intended to injure the legitimacy of the allies' cause, and augment their level of difficulties in the war. The intention was to force the allies' hand diplomatically so they would feel obliged to accept a negotiated settlement of the conflict with López. If the British Empire's interests 
were in enjoying the benefits of commerce by keeping the entire River Plate area open to international trade, it makes little sense for it to have continuously tried to prevent and then undermine the war.

Even after discarding this potential role of a foreign power "intervening" via its regional puppets, other element of the hypothesis (H5) seem to provide a poor explanation for understanding the case. Although no extra-regional intervention really occurred, a common legacy of anti-imperialism (mostly Spanish) was present. However, this did not translate into the three expectations identified above. For example, none of the participants in the war pushed for the eradication of war either prior, during, nor after the conflict itself. The "horrors of war" were certainly a factor considered by Mitre and López, as well as other prominent political figures, such as Alberdi and the members of the Unión Liberal in Chile, but practical efforts focused only on "attenuating" or alleviating the effects of war; yet not on the elimination of it as a political phenomenon. The lesson was not that modern war had to be eradicated, but that it had become so destructive, costly, and dangerous that its political objectives, justification, and effects had to be reconsidered anew in a more restrained and "civilized" manner. The practical necessity of the recourse to use force, either as a self-defense mechanism, or as a collective tool for preserving order, however, remained.

Similarly, the state leaders involved did not seek politico-economic unification or fusion as an alternative option to avoid future war. Although they all came to "fear war itself," the reaction of the Triple Alliance to the Quadruple Alliance efforts of mediation illustrate well the difference in strategic understanding of the impracticability of the Pacific nations' aspirations towards forging a larger association premised on an "American" 
identity, opposed to an "European" element. As Elizalde's reply to the Peruvian convocation to sign the 1856 treaty clearly established, the American republics were independent and if they ever were to secure their future survival as such, the only real option was to establish solid basis of coordination and cooperation that rested on pragmatic considerations of common interests, but not on passé Bolivarian dreams of continental "brotherhood" and unity. In short, the South American regional order had to be promoted and maintained not via the invocation of artificial ideological or cultural commonalities, but their more reliable overlapping interests in a stable regional order inter se, a modus vivendi of sorts.

\section{H6: State-Strength and State-Weakness in the River Plate Area}

The H6 hypothesis puts the emphasis on the states' shared condition of incapacity for engaging in large-scale war over long periods of time. Severe domestic constraints, such as "strong-men" or caudillo armed rebellions, who persistently contest the central government's authority, can indirectly affect how the South American states performed militarily in the war-and thus offering important alternative sources of limitation in the use of force. In short, the argument rests on "state-weakness or incapacity, instead of state "self-restraint." This, in turn, is expected to be amplified with a "trigger" condition in the form of mutual security externalities is present. Under these conditions, the $\mathrm{H} 6$ argument expects three concrete developments: first, that major war will not to occur, or if it does occur to be short-lived and limited; second, that formal and informal institutions will only emerge as supplements, acting as political "stretches" to compensate via regional coordination for the lack of state-capacity to face the dangers of war; and third, that inter- 
state "solidarity" will only be focused on the avoidance of externalities between regional neighbors.

The Uruguayan case fits quite nicely into this framework. The diplomatic crisis that eventually led to the War of the Triple Alliance was, in fact, sparked by the necessity felt by Brazil to put an end to the pressures of the rebellious state of Rio Grande do Sul. This southern Brazilian state had endured for several decades the spill-over effects of the Uruguayan civil war on its own territory. Even well-off hacendados with investments in northern Uruguay had experienced severe violations of their property and private rights. After Argentina's understanding of Brazil's interest in solving the Uruguayan crisis, the two found common ground enough to put aside their historical rivalry and coordinate a solution. It was Blanco party fanaticism and brutal tactics which had pushed Venancio Flores' faction of the Colorados to seek exile and support from the two neighbors. Their refusal to meet the Brazilian demands as presented by Saraiva in Montevideo, further deteriorated the situation, leaving Brazil with few options but to exert pressure and use force legitimately — with the approval, that is, of Argentina and the British Empire.

Although this hypothesis partially holds true for these early diplomatic dynamics in the River Plate area, it loses explanatory power when applied to the larger context of the war itself. Paraguay, for example, had a distinctively different domestic scenario. After decade of rearmament, technological modernization for war, and deepening of a model of power of the state centered around the figure of Francisco S. López, the Paraguayan statesociety balance was clearly tilted. In other words, the Paraguayan state was "strong" in terms of the state-strength/weakness hypothesis. This internal homogeneity, as Alex Weisiger, Randall Schweller, and Thomas Whigham, among others, have pointed out, 
allowed Paraguay to put up a dangerous offensive in the early months of the war, as well as a stubborn resistance once López's multiple strategic mistakes had wasted Paraguayan military capacity by early 1866 .

Although Paraguay's behavior gives partial support for the H6 argument, it is overshadowed by the equally impressive logistical and strategic war effort put up by the allies themselves. Neither Brazil nor Argentina were prepared for a war of such proportions. Argentina, in particular, was not ready for any war whatsoever. The opposition to the war became more intense after the publication of the Treaty in 1866 , but it had always been an important factor for Mitre due to the death of Urquiza and the new uprisings in the interior provinces. The caudillos from the northern provinces, in particular, put up a serious fight against the national government. This became so intense that by 1868 Mitre had to step down from the command of the allied forces and refocus on the upcoming election and the final "pacification" of the caudillo armed rebellions. The Argentine military participation in the war also progressively dwindled with Mitre's own political retreat from the frontline. While Uruguay, after several decades of protracted civil war, was not only materially incapable of waging an external war, but also psychological and morally exhausted. Its collaboration to the allied army was minimal, and as the allies were ready to capture Asunción, the few remaining troops returned to Montevideo.

In conclusion, the factor of state-weakness helps explain some, yet not all, the dynamics in the Paraguayan War. It helps illuminate López's overall performance, yet it cannot account for the allies' relatively weaker state-society relation and their own resilience in maintaining, despite extreme costs, the fight against López-and eventually end victorious(!). Importantly, the generalized "weakness" of the states involved, contrary 
to what $\mathrm{H} 6$ would logically expect, did not induce a restrained, limited, or short-lived type of war. In fact, this interacted with geopolitical factors, and actually helped make the war more protracted, costly, and long-lived-leading in turn to the loss of more life than otherwise expected. As the war intensified, the battles became increasingly more brutal and ferocious, and sparser in between. It was precisely in those long months of "pause" or truce between each battle that pandemics and disease made their profound impact on the enormous casualties for which the war is so infamously remembered today.

\section{H7: A “Liberal” Peace?}

The final alternative hypothesis to evaluate is that of the so-called "triangulation of peace" (H7). Based on the notion of an inter-democratic peace, the sharing of "Liberal values" can offer an alternative explanation for certain dynamics of the Paraguayan War. The issue of type of regime was certainly a center piece of the Treaty of the Triple Alliance, which explicitly declared that the war was not against Paraguay but against its leader, Francisco S. López and his tyrannical rule.

Despite this important aspect, however, the allies were not bound by their sharing of a "democratic" republic system of government. Considering the peculiarities of those concepts and their meaning in the 1860 s, however, it is clear from the participation of monarchical Brazil that although stated in the treaty text it was not a crucial component in the dynamics of the war itself. The Pacific countries, for instance, did not see López's Paraguay as a tyranny, but as a "fellow republic." This, coupled with their necessity in bringing Argentina and Brazil to their side against the Spanish intervention, led the Quadruple Alliance to undermine their own efforts in mediation by taking a priori a biased 
stance in favor of Paraguay. While important for them, it was relatively secondary or unimportant for the Triple Alliance powers.

What seems to hold a better promise for the H7 hypothesis, however, is the more loosely defined "Liberal values" that the porteño Unitarios in Buenos Aires did share with the Liberals in Dom Pedro II's court in Río de Janeiro. This connection, however, was more ideological than interest-driven, and thus cannot be clearly associated to a "defense" of a type of regime, or the creation of Liberal regional institutions. The only possible connection that can be made is that between Argentina's and Brazil's interests in "pacifying” the River Plate area in order to secure the free navigation of the interior rivers and waterways. In so far as their common interest can be interpreted in terms of repressing López's disruptive strategy for international free-trade, then one of the three factors identified in $\mathrm{H} 7$ can be said to have played a significant role. Seen in this light it is interesting to note that, although Paraguay and Uruguay had recurrent fears of a potential "closing up" of the River Plate estuary if either Brazil or Argentina controlled the margins of the River Plate and isolating the interior provinces and ports to international trade, it was Argentina and Brazil who waged a war with both countries in order to maintain the free navigation of those waterways. After all, it was Paraguay which seized the Marquês de Olinda when it was on its way upriver to the Brazilian province of Mato Grosso.

\section{Some Preliminary Conclusions}

The War of the Triple Alliance against Paraguay offers what at first sight would be an easy case in support of the common culture (H5) hypothesis, centered on the region's past in resisting anti-imperialism, as well as in support of the state-weakness/strength argument 
(H6), centered on Paraguay's distinctive internal socio-cultural and political cohesion and its capacity for engaging in "proper" European-style war. Similarly, prima facie, the main hypothesis defended in this dissertation (H1) seems to face a harder tests than the rest. The specifics of the case, however, show that although the final evaluation of the relative strengths of the different alternative explanations is mixed, the best-performing arguments are those which expect some form of "amelioration" or "taming" of war (H1, H2, H3, and $\mathrm{H6}$ ), yet not the more ambitious "eradication" or "impossibility" of war ( $\mathrm{H} 4, \mathrm{H} 5$, and $\mathrm{H} 7)$.

A combination of some of the hypotheses' expectations, for its part, can help illuminate different aspects of the war, yet none seems to consistently and convincingly offer a general explanation for the attempts at minimizing the effects, as well as the political objectives, of the war, that is superior to the $\mathrm{H} 1$ proposition. Nor does any of the competing arguments seem to articulate a good explanation for the alliance between Argentina, a republican government, with Brazil, a monarchical one-compounded by the fact that these were bitter rivals in the prior decades, after independence. 


\section{CHAPTER 4}

THE STRUGGLE FOR RESOURCES:

WAR AND PEACE IN THE SOUTH PACIFIC, 1873-1884

$Y$ al que le toca la herencia Donde quiera halla su ruina.

Lo que la suerte destina No puede el hombre evitar. Porque el cardo ha de pinchar

Es que nace con espina. ${ }^{525}$

\section{From Allies to Enemies: The Historical Context}

The story of the War of the Pacific (1879-1884) is the story of how three of the four allies in the War against Spain turned into bitter enemies in one of the most important large-scale military conflicts of the 19th century. To understand how former allies, bonded so uniquely in "Americanist solidarism" in the 1860 s, became engulfed in a war that lasted more than five years it is essential to explore the confluence of several factors. First and foremost, the colonial legacy left behind by Spain created a situation not conducive to stable, long-term diplomatic relations between the Pacific countries of South America. Undefined borders inherited from the former Viceroyalties of Peru and Nueva Granada were transferred after independence to Chile, Bolivia, and Peru. The problem was further compounded by the

\footnotetext{
525 José Hernández, La vuelta de Martín Fierro (Buenos Aires: Librería del Plata, 1879), III: 355. [“And he who is born to an inheritance, Anywhere finds his ruin. What Fate has in store, He cannot avoid. For a thistle pricks you, It is made with thorns."]
} 
application of the uti possidetis principle, by which the new territorial borders would respect follow the territorial divisions previously maintained by the Spanish empire.

This unclear demarcation problem interacted with a second factor, that of vast territories separating each country's capital city and centers of power. The discovery of guano deposits in the area in 1842 added an explosive combination of empty spaces with disputed borders and the presence of new strategic resources coveted by everyone. The entire area from northern Chile to the southern Peruvian provinces of Tacna and Arica, therefore, became the center of geo-economic and political tensions in the second half of the 19th century, centered around Chile, Bolivia and Peru.

A third factor, worthy of mention here, is the fact that during this tense period the domestic orders in Bolivia and Peru were deeply unstable. In contrast, since the 1830s, the Portalian era of stable and efficient administration in Chile had created a sense of normalcy in politics that allowed the country to articulate a steady and clear-eyed foreign policy towards the region. ${ }^{56}$ Victory in the War of the Peru-Bolivian Confederation further consolidated Chile's vision of "a balance of power in its favor" in the South Pacific. ${ }^{527}$ In Bolivia, however, the contrast was abysmal. Since independence, internal politics had been characterized by the rule of the "caudillos bárbaros." ${ }^{28}$ Government in Bolivia was violent and unstable, dominated by regime survival and party mentality, rather than by a national

\footnotetext{
${ }^{526}$ See Simon Collier and William F. Sater, A History of Chile, 1808-2002 (Cambridge University Press, 2nd ed., [1999] 2004) pp. 51-103; and Elliott A. Marcus, "Chile and Hispanic-American Solidarity, 18101830," The Americas, Vol. 7, No. 4 (April, 1951), pp. 463-474.

${ }^{527}$ Robert N. Burr, By Reason or Force: Chile and the Balancing of Power in South America: 1830-1905 (University of California Press, 1965), pp. 3, 17; and Burr, "Commentary on the Papers of Professors Hann and Bader," Proceedings of the Pacific Coast Council on Latin American Studies, Vol. 3 (1974), pp. 55-72. ${ }^{528}$ Alcides Arguedas, "Los caudillos bárbaros," in Obras completas, Tome II, Book V (Mexico: Aguilar, 1959).
} 
vision coherently articulating the domestic and external fronts into one grand strategy. The successive replacement of one caudillo by another left Bolivia with a chronically inwardlooking political elite who could only afford to concentrate in self-help, survival, and shortterm strategic objectives - spelling doom for the country in the long run. In Peru, the market boom created by the discovery of guano met with a corrupt and inept political class that squandered for over two decades most of this financial bonanza and soon faced a violent reality check from its own citizens and political opposition. The context in which the Spanish aggression occurred, therefore, was prima facie propitious for such an enterprise. The Pezet administration was on the verge of collapse in early 1864, and none of the neighboring countries - except perhaps Chile - was in condition to articulate a serious regional effort to protect Peru and South America's common interest. ${ }^{529}$

The importance of "the critical 1860s," therefore, is not only evident when studying the two simultaneous wars that erupted on both sides of the continent, but also for understanding the political dynamics of the entire second-half of the 19th centuryincluding the War of the Pacific. The war between Chile and the Peru-Bolivia alliance offers a good example of the dark and violent side of a "civilizational" view, which was so predominant at the time, but which underpinned the formation of South America's society of states in the long run. As with the case of the Paraguayan War, where Argentine and Brazilian leaders took upon themselves that task of "pacifying" the region by intervening in the internal affairs of a neighboring country, Chile also took upon itself to pursue a

${ }^{529}$ See Burr, By Reason or Force; Marcus, "Chile and Hispanic-American Solidarity, 1830-1865," The Americas, Vol. 9, No. 2 (October, 1952), pp. 177-200. 
foreign policy that would put an end to the chronic problems of instability emanating from its northern neighbors.

In doing so, however, it became quite clear that the construction of a regional consensus over the common interests of the region also had a violent side. If order was to be secured, it required the commitment to employ force when necessary. The coexistence of differently consolidated states with different levels of internal order, and sharing a common regional space, was unsurprisingly conflictual and unstable. However, the lessons acquired from this period would leave an important mark in the history of the region that would later become, quite paradoxically, the basis for more stable and orderly relations.

In this context, the present chapter reviews the War of the Pacific from the international society perspective, exploring the role of its three main causal mechanisms: the taming of war, the institutionalization of order, and pragmatic solidarity. While these aspects are explored in the first section, a second part offers an evaluation of the alternative competing arguments $(\mathrm{H} 2-\mathrm{H} 7)$, and their relative explanatory strengths. This is followed by a concluding section with some preliminary remarks for the case.

\section{The War of the Pacific: The Violent Side of "Civilization"}

Before the Spanish aggression to the Peruvian islands in the Pacific and the forging of the Quadruple Alliance, Chile, Bolivia, and Peru had a convoluted history of geopolitical rivalry and competition for power and prestige in the Pacific. The 1840s added to this mix the element of strategic natural resources. Before the inclusion of guano and salitre (saltpeter or sodium nitrate), the power dynamic in the South Pacific was distinctively traditional and self-contained. In the late 1830s, for example, the Bolivian caudillo Andrés 
de Santa Cruz finally achieved the historic dream of many fellow caudillos of uniting Peru and Bolivia into one political entity. ${ }^{530}$ This constituted an obvious threat to Chilean interests, which had historically competed with Peru over Bolivia's role in the balance of power of the Pacific.

With Chile's victory in 1839, the Peru-Bolivian Confederation was finally undone and, in an exemplary display of restraint, Chile contented itself with a simple redress to the status quo ante. It reinstituted Bolivia's independence and autonomy from Peru, and vice versa. Bolivia's coastline at the time, although neglected by La Paz, was crucial for Chile, for it acted as a "buffer" between Peru and Chile. An independent Bolivia, thus, made possible for the two rivals to compete almost exclusively by developing their navies. The tensions between Chile and Peru, therefore, emanated from the placement of their respective major ports: Chile's port of Valparaíso, for example, enjoyed a strategic advantage over Peru's port of Callao due to its proximity to the Magellan Strait, which connected the entire South Pacific region to Europe. The Argentine border with Chile was

\footnotetext{
${ }^{530}$ On the history of the Peru-Bolivian Confederation (1836-1839), see Peru, Ministerio de Relaciones Exteriores, Confederación Perú-Boliviana (1835-1839). Recopilación y prólogo de Carlos Ortiz de Zevallos Paz-Soldán (Lima: Archivo Diplomático del Perú IX, 1972-1974); Roberto Querejazu Calvo, comp., Oposición en Bolivia a la Confederación Perú-boliviana: Cartas del vicepresidente Mariano Enrique Calvo y el presidente Andrés Santa Cruz (Sucre: Excma. Corte Suprema de Justicia de la Nación, 1996); Cristóbal Aljovín de Losada, "La Confederación Perú-boliviana, 1836-1839: Política interna o externa," Investigaciones Sociales, Año v, No. 8 (2001), pp. 65-79; Gabriel Cid, "Entre el diseño interno y la amenaza externa: La oposición al régimen portaleano y la Confederación Perú-boliviana," Revista Histórica (separata) [Santiago], Tomo XLV (2011-2012), pp. 69-96; Cid, La guerra contra la Confederación: Imaginario nacionalista y memoria colectiva en el siglo XIX chileno (Santiago: Universidad Diego Portales, 2011); Carlos Donoso Rojas and Jaime Rosenblit B., eds., Guerra, región y nación: La Confederación Perú-boliviana, 1836-1839 (Santiago: Universidad Andrés Bello; Centro de Investigaciones Diego Barros Arana, 2009); Álvaro Pérez del Castillo, Bolivia, Colombia, Chile y el Perú: Diplomacia y política, 1825-1904 (La Paz: Los Amigos del Libro, 1980); Natalia Sobrevilla Perea, The Caudillo of the Andes: Andrés De Santa Cruz (Cambridge University Press, 2011); and Phillip T. Parkerson, Andrés de Santa Cruz y la Confederación Perú-Boliviana, 1835-1839 (La Paz: Juventud, 1984).
} 
also a contending, unsettled issue, which further complicated Chile's foreign policy by implicating the country's interests on too many fronts. ${ }^{531}$

Although the early historiography recreated "national theses" about the causes of the war, typically accusing one country or another for precipitating the conflict, ${ }^{532}$ modern works by professional historians, although qualitatively superior in the use of primary sources and overall information, have not been able to entirely break with the mold of investigating the war from the vantage point of one or two of the belligerents. ${ }^{53}$ Two exceptions that present a more general view the war, however, only focus on the military aspects of the war. ${ }^{534}$

\footnotetext{
${ }^{531}$ Burr, By Reason or Force, pp. 260-263.

${ }^{532}$ See, inter alia, Tomasso Caivano, Storia della guerra D'America fra il Chilì il Perù e la Bolivia (Torino: Loescher, 1882-1886), 2 vols.; Charles V. de Varigny, La guerra del Pacífico (Santiago: Cervantes, [1881] 1922); Benedetto Spila da Subiaco, Il Chilì nella guerra del Pacifico: Missionario emerito del Chili (Roma: Cuggiani, 2nd ed., enlarged, [1883] 1886); Mariano F. Paz Soldán, Narración histórica de la guerra de Chile contra el Perú y Bolivia (Buenos Aires: Imprenta y Librería de Mayo, 1884); José M. Valega, Causas i motivos de la guerra del Pacífico (Lima: La Moderna, 1917); Víctor M. Maúrtua, La cuestión del Pacífico (Lima: Imprenta Americana, 1919); Gonzalo Bulnes, Chile and Peru: The Causes of the War of 1879 (Santiago: Imprenta Universitaria, 1920); Bulnes, Guerra del Pacífico (Valparaíso: Universo, 1912-19), 3 vols.; Benjamín Vicuña MacKenna, Historia de la campaña de Tacna y Arica, 1879-1880 (Santiago: Rafael Jover, 1881); Vicuña MacKenna, Historia de la campaña de Tarapacá (Santiago: Rafael Jover, 1880), 2 vols.; Vicuña MacKenna, Historia de la campaña de Lima, 1880-1881 (Santiago: Rafael Jover, 1881); Sergio Villalobos, Chile y Perú: La historia que nos une y nos separa, 1535-1883 (Santiago: Editorial Universitaria, 2nd ed., [2002] 2004); Jorge Basadre, Historia de la República del Perú (1822-1933) (Lima: El Comercio, 2005); and Basadre, Reflexiones en torno a la guerra de 1879 (Lima: Campodónico, 1979).

${ }^{533}$ See, e.g., Mc Evoy, Guerreros civilizadores: Política, sociedad y cultura en Chile durante la guerra del Pacífico (Santiago: Universidad Diego Portales, 2011); William F. Sater, Chile and the War of the Pacific (University of Nebraska Press, 1986); Roberto Querejazu Calvo, Guano, salitre, sangre: Historia de la guerra del Pacífico (la participación de Bolivia) (La Paz: GUM, 3rd ed., [1979] 1998); Richard S. Phillips, "Bolivia in the War of the Pacific, 1878-1884," Ph.D. Dissertation, Charlottesville, va: University of Virginia (1973); Jacinto López, Historia de la guerra del guano y el salitre; o guerra del Pacífico entre Chile, Bolivia y el Perú (De Laisne \& Rossboro, 1930); and William S. Coker, "The War of the Ten Centavos: The Geographic, Economic, and Political Causes of the War of the Pacific," The Southern Quarterly, Vol. 7, No. 2 (1969), pp. 113-129.

${ }^{534}$ See William F. Sater, Andean Tragedy: Fighting the War of the Pacific, 1879-1884 (University of Nebraska Press, 2007); Bruce Farcau, The Ten Cents War: Chile, Peru, and Bolivia in the War of the Pacific, 1879-1884 (Praeger, 2000); Francisco A. Machuca y Marín, Las cuatro campañas de la guerra del Pacifico (Valparaíso: Victoria, 1926-1930), 4 vols.; and James Dunkerley, Orígenes del poder militar: Bolivia, 1879-1935 (La Paz: Plural, 2006). There still is no equivalent for the War of the Pacific to what
} 
The academic discussion about the causes of the War of the Pacific have recurred over the years, falling into three main groups. A first thesis argues that the responsibility for the war rests on Chile's ambitions towards the coastal territories of Bolivia and Peru in the Atacama dessert. Unsurprisingly, this explanation has been most consistently elaborated by Peruvian and Bolivian authors, who believe Chile had a premeditated strategy. This strategy was put into action several years in advance by populating the areas of guano and salitre production with Chilean citizen-workers and penetrating with Chilean and foreign capital. ${ }^{535}$

A second thesis maintains that the main responsibility for the war relies on Peru and Bolivia. Chilean authors, in particular, put the emphasis on a "secret" treaty signed by both countries in 1873, which Bolivia activated during a crisis with Chile in 1878 to drag Peru into the fight. In this view, the war erupted because Bolivia's caudillo, Hilarión Daza, feeling reassured by this treaty in case of a war, provoked Chile into war; while Peru instigated Bolivia into a clash with Chile over the possession and exploration rights over the export of guano and salitre in the Atacama Desert. From this vantage point, therefore, Chile was the victim, surrounded by neighbors that were planning its demise. Most Chilean

Thomas L. Whigham has done for the Paraguayan War. See, e.g., his masterful multi-volume study, first published in toto in Spanish: Whigham, La guerra de la Triple Alianza (Asunción: Taurus, 2010-2012).

${ }^{535}$ See Enrique Aramayo, La política británica en la guerra del Pacífico (Lima: Horizonte, 1988); Heraclio Bonilla, Guano y burguesía en el Perú (Lima: FLAcso, 3rd ed., [1974] 1994); Bonilla, Un siglo a la deriva: Ensayos sobre el Perú, Bolivia y la guerra (Lima: Instituto de Estudios Peruanos, 1980); Victor Kiernan, "Foreign Interests in the War of the Pacific," The Hispanic American Historical Review, Vol. 35, No. 1 (February, 1955), pp. 14-36; Luis Ortega, "En torno a los orígenes de la guerra del Pacífico: Una visión desde la historia económica y social," Asian Journal of Latin American Studies, Vol. 19, No. 4 (2006), pp. 27-58; Ortega, "Nitrates, Chilean Entrepreneurs and the Origins of the War of the Pacific," Journal of Latin American Studies, Vol. 16, No. 2 (November, 1984), pp. 337-380; John Mayo, "Before the Nitrate Era: British Commission Houses and the Chilean Economy, 1851-80," Journal of Latin American Studies, Vol. 11, No. 2 (November, 1979), pp. 283-302; and Mayo, "A 'Company' War? The Antofagasta Nitrate Company and the Outbreak of the War of the Pacific," Boletín de Estudios Latinoamericanos y del Caribe, No. 28 (Junio de 1980), pp. 3-11. 
writers, moreover, see the War of the Pacific as a war strictly between Chile and Peru, with Bolivia as Lima's puppet. ${ }^{536}$

The most recent, and well respected, literature on the causes of the war has dealt with this dichotomy quite problematically. The tendency has been either to repeat one of these theses but with more supporting documentation, or to ignore the discussion about the causes of the war entirely and focus on other aspects - such as the soldiers' experience, domestic cultural factors, the role of the church, the role of women, the local press, etc. ${ }^{537}$ The current consensus, however, associates the post-colonial territorial legacies with the struggle for resources as the main driver of the war. In other terms, it was a "tragedy." 538

No study has yet been performed on the placement of the War of the Pacific in the context of 19th-century South America in terms of a regional system - and much less as a society of states. Although not entirely neglecting the important military and powerpolitical aspects that shaped the war itself, it is also important to explore a view of the conflict that rescues the diplomatic efforts that preceded the war and which tried to "tame" or curb its potential effects, as well as frames the "civilizational" values that came to dominate Chilean leadership and society. It is important to look into the efforts at

\footnotetext{
${ }^{536}$ See, e.g., Juan J. Fernández Valdés, Chile y Perú: Historia de sus relaciones diplomáticas entre 1819 y 1879 (Santiago: Cal \& Canto, 1997); Bulnes, Chile and Peru; and Fabián Berríos, Orígenes: Las causas de la Guerra del Pacífico (Santiago, Legatum, 2017).

${ }^{537}$ See, inter alia, David Home, Los huérfanos de la guerra del Pacífico: El "Asilo de la Patria," 18791885 (Santiago: LoM; Centro de Investigaciones Diego Barros Arana, 2006); Carmen Mc Evoy, Armas de persuasión masiva: Retórica y ritual en la guerra del Pacífico (Santiago: Centro de Estudios Bicentenario; Universidad Andrés Bello, 2010); and Carlos Donoso Rojas and Gonzalo Serrano del Pozo, eds., Chile y la guerra del Pacífico (Santiago: Centro de Estudios Bicentenario; Universidad Andrés Bello, 2011).

${ }^{538}$ See Coker, "The War of the Ten Centavos"; Sater, Chile and the War of the Pacific; Phillips, "Bolivia in the War of the Pacific"; and Mauricio Rubilar Luengo, "La política exterior de Chile durante la guerra y postguerra del Pacífico (1879-1891): Las relaciones con Estados Unidos y Colombia. Diplomacia, opinión pública y poder naval,” Ph.D. Dissertation, Valladolid: Universidad de Valladolid (2012).
} 
institutionalizing the conduct of the war itself through the offers of mediation by the United States, and other related aspects, such as the treatment of prisoners, and the difficulties that arose after Chile occupied Peru's capital for three years.

\section{Chile and the Taming of Two Wars}

Despite its victory over the Peru-Bolivian Confederation in 1839, which meant a politically separate and independent Peru and Bolivia, Chile could not avoid the frequent collaboration between these two neighbors. When the Spanish squadron occupied the Chincha Islands, however, the Chilean leadership at the time had to balance between tolerating the presence of a European power in the Pacific or assist the weakened Peru in its struggle for independence. The temptation was strong, for a prostrated Peru would give Chile more freedom of action to pressure Bolivia. The pro-Americanist sentiments of the political elite in Santiago, however, prevailed and Chile decided to momentarily put aside all animosities with Peru and Bolivia in order to serve a higher set of regional interests.

Bolivia, at the same time, took the Spanish aggression with surprise and was forced to redefine its international strategy up to that point. Since the early 1840 s, the relations between Bolivia and Chile had been deteriorating as a rapid pace due to the overlapping commercial interests of Chilean private interests in the exportation of guano and salitre in the region of Atacama, backed by foreign capital — mostly British. ${ }^{539}$ The confluence of the Spanish aggression and the need to pool all regional efforts into a "common front," pushed both Bolivia and Chile to seek an agreement on the disputed border between the two

\footnotetext{
${ }^{539}$ See Ortega, "Nitrates, Chilean Entrepreneurs and the Origins of the War of the Pacific"; Amayo, La política británica en la guerra del Pacífico; Bonilla, Guano y burguesía en el Perú; and Mayo, “A 'Company' War?"
} 
nations - now containing important strategic resources. At least for a short while, therefore, the more elevated strategic necessity of collaborating for a "higher cause" forced Chile and Bolivia to bypass decades of rivalry and mistrust, and try to solve their lingering disputes in order to forge the Quadruple Alliance in early 1866.

In August 1866, Bolivia and Chile exercised mutual self-restraint by signing a treaty of unique characteristics, known as "treaty of the medianería" (or Mutual Benefits Zone). The Bolivian dictator, Mariano Melgarejo, pressed by his internal opposition and a crippling national debt, saw in this agreement a way to assuage Chile in its problematic "re-population" strategy in the Bolivian portion of the Atacama Desert, as well as a good way to secure a steady source of revenue for Bolivia. ${ }^{540}$ The treaty was subscribed on August 10, 1866, and represented an enormous risk by Melgarejo. Although Bolivia needed external peace to confront internal opposition, the concessions could also potentially lead to territorial adjustments in Chile's favor in the long run. ${ }^{541}$ The uniqueness of the medianería relied in an absolutely unprecedented agreement that determined a "mutual benefits" zone or band, instead of a single line, as a demarcation border between both countries. The zone comprised the area between parallels $25^{\circ} \mathrm{S}$ and $23^{\circ} \mathrm{S}$, and was divided in half by the parallel $24^{\circ} \mathrm{S}$. Furthermore, the medianería allowed Chilean capital and manpower to exploit Bolivian natural resources inside the zone, thus granting Chile semisovereign rights over the southern strip, between parallels 24 and 25. [see infra Map 5].

\footnotetext{
${ }^{540}$ From Á. Covarrubias to A. Vergara, Santiago, March 2, 1866, Chile, Archivo Histórico del Ministerio de Relaciones Exteriores, Oficio No. 4 [en copiador]; and the reply from A. Vergara to Á. Covarrubias, La Paz, March 26, 1866, ibid., "Legación de Chile en Bolivia," Oficio No. 2.

${ }^{541}$ On the 1866 treaty of medianería, see Roberto Querejazu Calvo, Aclaraciones históricas sobre la guerra del Pacífico (La Paz: Juventud, 1995), pp. 25-27; Fernández Valdés, Chile y Perú, pp. 380-389.
} 
MAP 5 - The Atacama region, c. 1866.

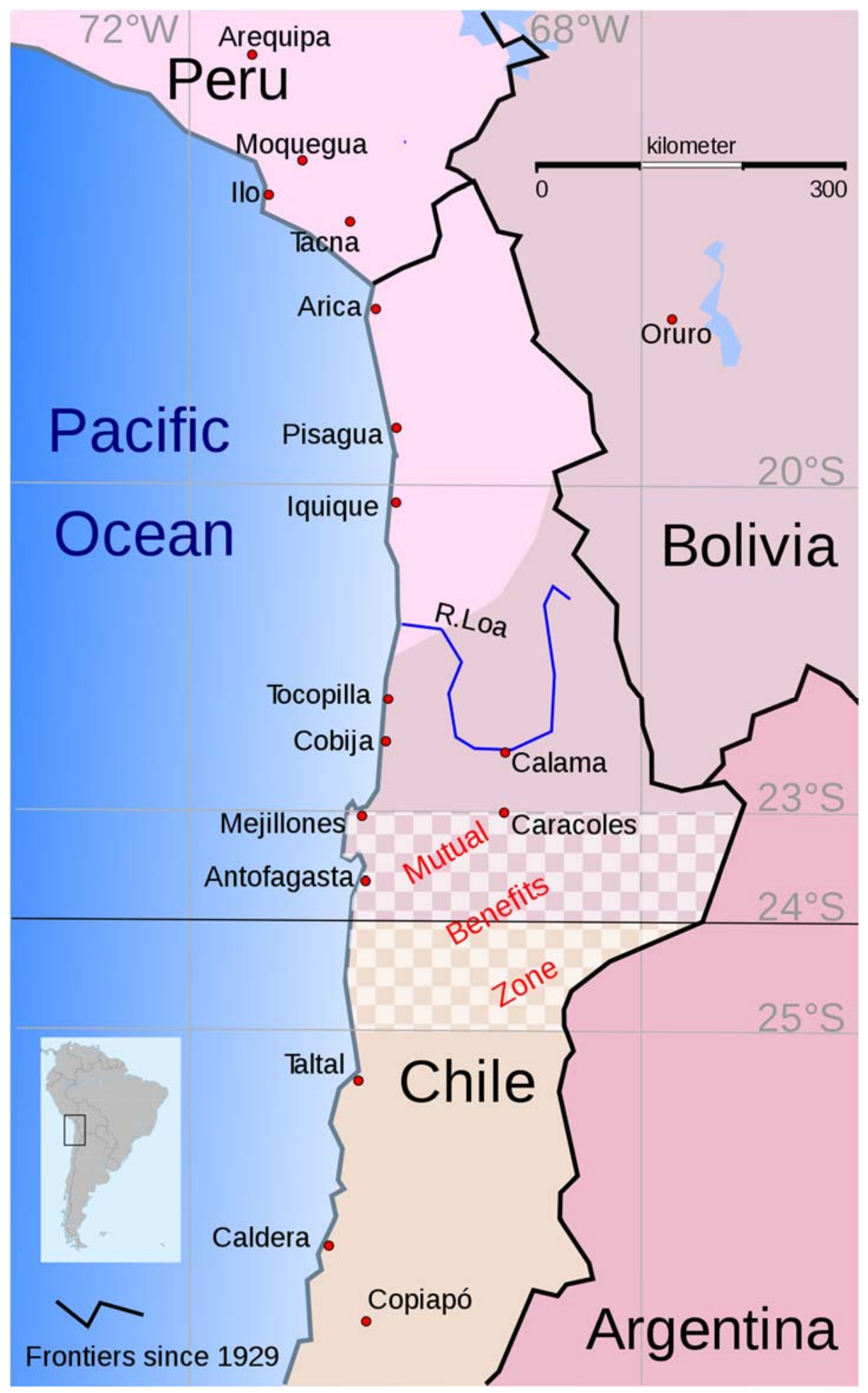

Source: Wikimedia Commons [https://upload.wikimedia.org/wikipedia/commons/f/fe/MBT.en.svg] 
During the struggle of the Quadruple Alliance against Spain in the Pacific, this strange arrangement by Bolivia momentarily cleared the way for the collaboration between Chile and Bolivia in the alliance. However, Bolivia's chronic domestic anarchy and recurrent civil wars led to the deposition of Melgarejo in 1871. He was replaced by Agustín Morales, another caudillo bárbaro. ${ }^{542}$ During his rule, the Chilean government became anxious about the future of Melgarejo's "generous" ${ }^{543}$ concession and commissioned the construction of two ironclads that would give Chile naval superiority in the Pacific. Once again, Chile's relations with Bolivia were triangulated with Peru's foreign policy in order to balance one against the other and thus keep them separate. At the time of the agreement, Peru had four ironclads, Chile had only two older ones, while Bolivia had no navy at all.

A serious dispute emerged when new guano deposits were found in the early 1870 s. Rich mines were discovered in Mejillones and Caracoles, in Bolivian territory, but their location was quite unfortunate. The location of the mine in Caracoles was almost exactly on the northern limit of the medianería zone (parallel $23^{\circ} \mathrm{S}$ ), which prompted Chile to pressure Bolivia to include it as part of the 1866 agreement. Bolivia refused, claiming the mine was actually located north from the parallel, but this was disputed by Chile. It soon became apparent that Bolivia, unable in terms of infrastructure and manpower to exploit its own littoral resources, would have to face more forcefully the continuous Chilean expansion inside the zone of medianería.

\footnotetext{
${ }^{542}$ See Ramón Sotomayor Valdés, La legación de Chile en Bolivia desde setiembre de 1867 hasta fines de 1870 (Santiago: Imprenta Chilena, 1872). Sotomayor Valdés was stationed in Bolivia at the time and offers one of the most detailed accounts of the internal political dynamics of the country during the time of Melgarejo's rule and the subsequent transition to Morales' government.

${ }^{543}$ Querejazu Calvo, Aclaraciones históricas, p. 25.
} 
By 1872, the Guano War against Spain was already over and a peace with Spain guaranteed. ${ }^{544}$ Bolivia, therefore, started to resent the provisions of the 1866 treaty. The traditional caudillo infighting had created new financial restrictions, and the government was desperate for new sources of revenue. A diplomatic campaign was then put in motion to reach out to Peru, whose own mineral production in the Tacna and Arica provinces competed with Chile's, to secure an alliance in case Chile decided to take by force part of Bolivia's territory. These negotiations led to the signing of a "secret" treaty in 1873 by which Peru and Bolivia committed to come to each other's defense in case of aggression, and to further extend this pack with other neighboring states (i.e., Argentina). ${ }^{545}$

The rumors of the existence of this pact reached Santiago fairly early, however there was no confirmation of its existence. Since Chile had an ongoing dispute still pending with Argentina over the Patagonia region and the Magellan Strait, President Pérez sent a special representative to La Paz to negotiate a treaty with Bolivia. The Chilean agent's mission was to negotiate a new treaty that maintained as much as possible the commercial benefits carved out from Melgarejo in 1866. While this negotiations were underway, Daza

\footnotetext{
${ }^{544}$ Although the armistice between the Quadruple Alliance was signed in 1871, the final treaties of peace were signed bilaterally with Spain. Madrid signed the peace with Peru and Bolivia in 1879; with Chile in 1883; and with Ecuador in 1885.

${ }^{545}$ On the controversial 1873 "secret" treaty, see Roberto Querejazu Calvo, "El tratado de alianza defensivo perú-boliviano de 1873 y la misión de Serapio Reyes Ortiz de 1879," Historia y Cultura, Vol. 3 (1978), pp. 245-257; Pedro Yrigoyen, La adhesión de la República Argentina al tratado de alianza defensiva perúboliviano de 1873 (Lima: Sanmartí, 1919); Yrigoyen, La alianza perú-boliviana-argentina y la declaratoria de guerra de Chile (Lima: Sanmartí, 1921); José M. Echenique Gandarillas, El tratado secreto de 1873: Su documentación (Santiago: Cervantes, 1921); José Pardo y Barreda, Historia del tratado "secreto" de alianza defensiva entre el Perú y Bolivia (Lima: Milla Batres, 1979); Juan J. Fernández, La República de Chile y el Imperio del Brasil: Historia de sus relaciones diplomáticas (Santiago: Bello, 1959), pp. 63-108; Fernández, Chile-Perú..., pp. 371-444; and Percy Cayo, Perú y Bolivia: Una historia común (Lima: Universidad del Pacífico, 2010), pp. 104-189.
} 
sent the Bolivian Minister of Foreign Affairs, Serapio Reyes Ortiz, to Lima in a special mission to sign a treaty of alliance with Peru. ${ }^{546}$

Considering the gravity of the Bolivian request, Peru's Minister of Foreign Affairs, José de la Riva Agüero, wrote to his peer in Santiago expressing his concern for the developments in the Bolivian littoral. Peru feared the occupation of the zone, which had provoked the Bolivian government to adopt a tougher stance on the matter. If Chile were to occupy Mejillones or Antofagasta, said Riva Agüero, "Peru could not stand as an indifferent spectator and would be forced to back Bolivia in guard of its own interests which are common, for we could not allow Chile, by breaking the American balance, to appropriate a littoral that does not belong to it." The message ended with a warning: Peru would offer its mediation, and if it were not accepted by Chile and then continued to occupy the littoral, the inevitable and necessary consequence would be that Peru would seek to ally Bolivia. $^{547}$

The assassination of the Bolivian president, Agustín Morales, in November of 1872, led Tomás Frías - the interim president — to adopt a more conciliatory approach towards Chile. On December 5, Bolivia and Chile signed the Lindsay-Corral protocol to fix the lingering problems of the execution and application of the 1866 treaty. Since this protocol was ill-received by the Bolivian public opinion, Chilean authorities expected the agreement to be revoked by Congress at some point. The expectation of more immediate

\footnotetext{
546 The prominent Bolivian historian, Roberto Querejazu Calvo, in his article "El tratado de alianza defensivo," refuted the Chilean version of the treaty as initiated by Peru. Querejazu Calvo found in the archives of the Universidad de San Andrés, in La Paz, crucial documentation proving the secret treaty of 1873 was a Bolivian initiative. See also Querejazu Calvo, Guano, salitre, sangre, pp. 88-100.

${ }^{547}$ Quoted in Arturo García Salazar, Resumen de historia diplomática del Perú: 1820-1884 (Lima: Sanmartí, 1928), pp. 163-164.
} 
troubles with Chile prompted Bolivia to finally secure the 1873 Treaty with Peru, which was signed on February 6 of that year. One way or another, Bolivia was trying to guarantee its territorial possession of the Atacama region against the encroachment of Chilean policy.

In this triangular drama of the Pacific, however, there was a fourth actor crucial for the Bolivian strategy: Argentina. As indicated above, one of the provisions of the 1873 treaty considered the need to extend the treaty to other states to join the alliance. Although the text did not explicitly specify which state, it was obvious to everyone that this meant Argentina — for the treaty was aimed specifically against Chile. In this context, Argentina had a unique opportunity to join the "secret" treaty between Bolivia and Peru and thus pressure Chile to make important concessions on the Patagonia and Magellan Strait questions. Well aware of the cataclysmic effects that its participation would have had for Chile, Argentina did not break with its traditional policy of strict neutrality — thus saving Chile from one of the most dangerous regional scenarios imaginable by Santiago's elites. ${ }^{548}$ The Argentine Minister of Foreign Affairs, Carlos Tejedor, offered a series of reasons for looking upon this alliance with reluctance. First, it was not clear to him that the proposed alliance was simply defensive. Although Peru defended the pact as a way to neutralize Chile and thus guarantee peace, Tejedor believed this could dangerously corner Chile into an overreaction — which by all means had to be avoided. Second, Argentina and Bolivia had also an unresolved territorial dispute of their own, whose resolution the Argentine Congress raised as a sine qua non for advancing with the proposition of alliance.

\footnotetext{
548 The Peruvian mission to Argentina was led by Manuel Yrigoyen, who arrived on July 7, 1873. See Enrique M. Barba, "La alianza secreta de 1873 entre Bolivia y Perú: Tentativa para obtener la anexión argentina," Revista de Historia de América, No. 22 (diciembre, 1946), pp. 273-351; Ricardo R. CailletBois, Cuestiones internacionales (1852-1966) (Buenos Aires: EUDEBA, 1970), pp. 31-60; and Yrigoyen, La adhesión de la República Argentina; and Yrigoyen, La alianza perú-boliviana-argentina.
} 
Since neither Bolivia nor Argentina would cede on this matter, the prospect of Argentine participation went dead cold. If the true objective of the treaty, said Tejedor, was to protect the territorial integrity of Bolivia — and not to organize an aggression against Chile — then Argentina could join immediately a separate alliance only with Peru. Finally, Tejedor feared that joining the Peru-Bolivian alliance would elicit a reaction by Brazil, who would ally with Chile to counterbalance Argentina. As the negotiation with Brazil over post-war Paraguay was becoming terse, Sarmiento and Tejedor did not want to provoke Brazil further. ${ }^{549}$

With the failure to include Argentina, Peru suggested that Bolivia try to renegotiate the 1866 treaty of medianería once again, reinforcing the 1872 protocol. In 1874, therefore, a new treaty secured the 24th parallel as the new definitive border between Bolivia and Chile. This was a painful concession of territory to Chile, but one deemed necessary given the military weakness of Bolivia and the fact that after all Chile's productivity and investments reaped benefits for both governments.

Article 4 of the 1874 treaty stipulated that Chilean citizens, capitals, and property would not be subjected to further contributions (i.e., taxes) beyond the ones already established. This provision would hold for twenty-four years. In 1866, Melgarejo had granted to two prominent Chilean citizens the concession of certain lands in Antofagasta, which were transferred in 1868 to the Antofagasta Nitrate and Railroad Company to exploit the resources in the area. The privileges were so great that the Bolivian public opinion put

\footnotetext{
549 Ramón J. Cárcano, "La diplomacia de la Triple Alianza," Revista Americana, Ano I, No. 2 (novembro, 1909), pp. 161-178; Cárcano, "La misión Mitre al Brasil (abril-diciembre 1972)," Anales de la Faculta de Derecho y Ciencias Sociales, Tomo III, $1^{\circ}$ parte ( $2^{\circ}$ serie, 1913), pp. 5-189; and Tasso Fragoso, "A paz com o Paraguai despois da guerra da Tríplice Aliança."
} 
increasing pressure on Daza and the Congress to modify the situation. In early 1878, the conditions of the agreement were reviewed and the taxes were raised by 10 cents per quintal of exported saltpeter. This new gravamen sparked the protest of multiple sectors in Chile, from the wider populace to the most directly affected miners and financiers involved in the exportation of nitrates and guano in the region. ${ }^{550}$

Daza's violation of the 1874 treaty meant that the original 1866 agreement and its subsequent protocol of 1872 were no longer valid. On February 10, 1878, therefore, the Bolivian caudillo put into effect a new law, approved by Congress, establishing the new tax requirement. Then, an ultimatum was issued to the Antofagasta Nitrate and Railroad Company, which was partially owned by Chilean and British capital, indicating that noncompliance with the new regulations would be met with a public auction. Since this option was absurd, for no private citizen had enough money to put forth even a first bet for the whole value of the Company, Daza's policy was obviously a move to eventually expropriate the Company. On February 14, 1879, just before the Bolivian ultimatum expired, Chilean troops landed on the Bolivian coast and occupied the city of Antofagasta in anticipation of the threat of expropriation by Bolivia. On March 1, Bolivia declared war on Chile, and the latter reciprocated a month later, declaring war on both Bolivia and Peru. The War of the Pacific had started.

A good indication of Chile's anticipation of the possibility of a war, although the country was not ready for one, is the fact that after the Bolivian new tax was announced

\footnotetext{
550 "Protestas de la Compañía del Salitre y Ferrocarril," Chile, Archivo Nacional de Chile, November 8, 1879, December 31, 1880, and August 1882, 1882, "Fondos Varios," Vol. 419. See also Ortega, "Nitrates, Chilean Entrepreneurs and the Origins of the War of the Pacific"; Kiernan, "Foreign Interests in the War of the Pacific"; and Mayo, "A 'Company' War?"
} 
but before the expiration date of the ultimatum, Chile reached out to Argentina to negotiate peacefully their pending territorial disputes. Neither Argentina or Chile really desired a war, despite a constant pressure from their society and public opinion. ${ }^{551}$ In Chile, President Aníbal Pinto was strongly criticized for its "weak" policy towards Bolivia, trying to strike deals since 1866 instead of adopting a more forceful approach. When the agreement with Argentina was finally achieved, the popular outcry was enormous, and Pinto was accused by the political opposition in Congress of betraying the national interest of Chile by "conceding the Patagonia" to Argentina and only partially securing control over the Magellan Strait—crucial for Chile's commercial interests in Europe.

The Fierro-Sarratea Treaty, signed on December 1878, represented both a sign of self-restraint on part of Chile as well as a necessary strategic move in preparation for a potential Bolivian aggression in the Atacama region. Chile was forced to tame two potential wars at once, for which Pinto decided to secure Argentina's implicit neutrality and concentrate on the Bolivian question. By the time Bolivia declared war on Chile, in March of 1879, therefore, Chile had at least secured one of its two problematic fronts. As Robert N. Burr explains, the diplomatic maneuvering prior to the war "clearly demonstrated the ushering in of a new era in intra-South American relations. [...] Under the influence of their integration into the world economy, they had become rivals for influence over lesser states. At the same time, they had become loosely bound together by a network of interlocking interests." ${ }^{\circ 52}$

\footnotetext{
${ }^{551}$ Sater, Chile and the War of the Pacific, p. 7; Burr, By Reason or Force, p. 134; and Querejazu Calvo, Guano, salitre, sangre, pp. 98-100.

${ }^{552}$ Burr, By Reason or Force, p. 136.
} 
During the early months of the war, an important factor demonstrated Peru's interest in preventing the conflict between Bolivia and Chile. This display of restraint by Lima officials, who tried to avoid being dragged into a war by the activation of the 1873 treaty of alliance with Bolivia, ultimately ended in utter failure due to the fact that the "secret" treaty had created in Pinto and his cabinet a larger effect than the one intended originally by Peru and Bolivia in 1873. For Peru, the treaty's objective had been to prevent war all along, not to encircle Chile and provoke a military confrontation. However, the secrecy clause and the persistent denial by both Peruvian and Bolivian officials had undermined Chile's confidence in the behavior of Peru. The earlier attempt to incorporate Argentina to the pact also played a powerful role. ${ }^{553}$

In this context, when Peru sent one of its most reputable diplomats, José A. de Lavalle, to Santiago to offer Peru's mediation on March 5, 1879, ${ }^{554}$ public opinion as well as the President received the Peruvian envoy with profound reluctance and suspicion. Prior to his departure, however, Lavalle had a meeting with Mariano I. Prado, the Peruvian President; Manuel Yrigoyen, the Minister of Foreign Affairs; and Serapio Reyes Ortiz, the Bolivian Minister of Foreign Affairs and special representative in Lima. According to

\footnotetext{
${ }^{553}$ Querejazu Calvo, Guano, salitre, sangre, p. 98.

${ }^{554}$ On the Lavalle mission to Santiago, see José A. de Lavalle, Mi misión en Chile en 1879 y anexos (Lima: Instituto de Estudios Histórico-Marítimos del Perú, 1994); and La misión Lavalle en Chile y el tratado secreto de 1873: Correspondencia oficial del enviado extraordinario y ministro plenipotenciario del Perú en Chile, don José A. de Lavalle, con el ministro de relaciones de ese país, durante su misión cerca del gobierno de Chile, en 1879, según los documentos originales que existen en el archivo del Ministerio de Relaciones Exteriores (Santiago: Imprenta Nacional, 1924). See also Querejazu Calvo, Guano, salitre, sangre, pp. 241-249; Jorge Basadre, "Antecedentes de la guerra con Chile," in Historia del Perú. Vol. 7: "Perú republicano" (Lima: Mejía Baca, 1980), pp. 96-160; cf. Alejandro Ríos Valdivia, "La misión Lavalle," Anales de la Universidad de Chile, Año 2, Serie 2 (enero-diciembre, 1924), pp. 413-559, 8561002.
} 
Lavalle, none of them raised the issue of the 1873 treaty in their conversations, thinking that he was well aware of its existence and provisions — which he was not. ${ }^{555}$

Once in Santiago, where he arrived on March 4, 1879, Lavalle was received by Aníbal Pinto, who conveyed to him the difficulties for his government to accept the peace after Bolivia's declaration of war. Although Pinto was prudent and desired no armed conflict with Bolivia, he also feared that if he backed down he would be forcefully removed from power either by the mob in the streets or by the fierce political opposition in Congress. ${ }^{556}$ For this reason, Lavalle's conditions for the mediation could not be seriously met. The Peruvian offer of mediation required that Chile retreated from the occupied territories so a peace negotiation could take place. In their multiple conversations, Pinto and his close adviser Domingo Santa María—who would later succeed Pinto in the presidency - interrogated Lavalle about the existence and content of the 1873 treaty. Lavalle, in full honesty, claimed that he had no instructions on that regard and that he would have to consult with Lima. Later, the Chilean officials asked Lavalle about the undergoing naval rearmament in Peru, to which Lavalle—once again—answered evasively. ${ }^{557}$ This interaction fueled Chile's fears and suspicions that Peru's mediation was an insincere act meant to gain time for Peru to prepare militarily to join the fight as Bolivia's ally. ${ }^{55}$

Chile detained Lavalle and proceeded to declare war on both Bolivia and Peru. The Lavalle mission had spectacularly failed precisely at the moment when it was most needed

\footnotetext{
${ }^{555}$ Lavalle, Mi misión en Chile en 1879, pp. 21-22.

${ }^{556}$ Sater, Chile and the Wat of the Pacific, pp. 10-12; and Pinto's reflections in "Apuntes," Revista Chilena, Tomo XIV (1922).

${ }^{557}$ Lavalle, Mi misión en Chile en 1879, pp. 59ff. See also Ahumada Moreno, Guerra del Pacífico, Vol. 2: pp. 10ff; Vol. 4: p. 4.

${ }^{558}$ See Ríos Valdivia, “La misión Lavalle,” p. 432.
} 
for all the belligerents. In reaction, Chile dispatched two diplomatic missions, one to Argentina, led by Manuel Balmaceda, and a second one to Brazil, led by José V. Lastarria. These two missions represented for Chile the crowning of its far-sighted diplomacy of stability and order in the region, during an extremely difficult period of its history. ${ }^{559}$ Balmaceda was successful in identifying the constant pressure on the Argentine government by anti-Chilean groups, as well as Sarmiento's reluctance to engage them, which was exemplified in Argentina's eventual refusal of the Peruvian invitation to join the 1873 treaty. ${ }^{560}$ Lastarria, for his part, was even more successful in coordinating with the representative in Buenos Aires and securing the Brazilian implicit "good will" for Chile's cause in the upcoming war. It was through the Argentine delegate in Buenos Aires that Chile was finally able to confirm the existence of the 1873 treaty and to read its articles and provisions. ${ }^{561}$ Since the bilateral relations with Chile had not been positive during the Paraguayan War, Brazil was trying to win Chile's support to counteract Ecuadorean, Bolivian, and Peruvian border disputes still pending with the Brazilian Empire. ${ }^{562}$

\footnotetext{
${ }^{559}$ See Geoffrey Smith, "The Role of José M. Balmaceda in Preserving Argentina Neutrality in the War of the Pacific," The Hispanic American Historical Review, Vol. 49, No. 2 (May, 1969), pp. 254-267; and Burr, By Reason or Force, pp. 144-146.

${ }^{560}$ See Barba, "La alianza secreta de 1873 entre Bolivia y Perú"; and Caillet-Bois, Cuestiones internacionales, pp. 31-60.

${ }^{561}$ On the Brazilian proposition of a "true and sincere alliance" with Chile, and its sharing of the contents of the treaty with Chile, see the diplomatic correspondence in Chile, Archivo Nacional de Chile, "Legación de Chile en las Repúblicas del Plata y Brasil, 1874-1876," No. 5, January 19, 1874; No. 10, February 14, 1874; No. 12, February 16, 1874 [confidential]; and Brazil, Arquivo Histórico do Itamaraty, "Legação Imperial do Brasil no Chile, Reservados e confidenciais, 1860-1878," No. 231/1/2, Valparaíso, January 24, 1874 [reserved No. 1]; and February 17, 1874 [reserved No. 2].

${ }^{562}$ See Luís C. Villafañe Gomes Santos, O Império e as repúblicas do Pacífico: As relações do Brasil com Chile, Bolívia, Peru, Equador e Colômbia (1822-1889) (Curitiba: Editora UFPR, 2002), pp. 120-125; Alfredo Valladão, Brasil e Chile na época do Império, amizade sem exemplo (Rio de Janeiro: Olympio, 1959); Juan J. Fernández, "El tratado secreto peruano-boliviano de 1873 y la diplomacia brasileña," Boletín de la Academia Chilena de la Historia, Año XXIII, No. 55 ( $2^{\circ}$ semestre, 1956), pp. 5-18; and Fernández, La República de Chile y el Imperio del Brasil, pp. 68, 76ff.
} 
The development of the war spanned from April to April, between 1879 and 1884 . During the first months of the conflict, the character of the war was strictly naval between Peru and Chile. In October of 1879, however, the capture of Peru's flagship, the monitor Huáscar, dealt a deadly blow to the Peruvian navy, for the naval balance was now tilted in Chile's favor. With this naval superiority, Chile was able to quickly move north, capturing almost the entire Atacama and Tarapacá regions in a matter of a few months, and before the end of $1879^{563}$ [see infra Map 6]. In 1881, Lima was captured, unravelling a political crisis in Peru that for almost three years saw two civilian governments, one supported by the occupying Chilean force, and another "legitimate" one in hiding in the countryside. Under the command of Andrés A. Cáceres, surviving Peruvian troops waged a "brokenbacked" war of attrition against the Chilean troops in $\mathrm{Lima}^{564}$-inflicting serious casualties on them. In 1884, following the signing of a treaty of peace by Peru, Bolivia also officially surrendered, thus putting an end to the purely military stage of the conflict.

\footnotetext{
${ }^{563}$ For a good military account of the stages and campaigns of the war, see Sater, Andean Tragedy; and Farcau, The Ten Cents War, pp. 47-117. See also Gabriele Esposito, Armies of the War of the Pacific, 1879-83: Chile, Peru and Bolivia (Osprey, 2016), pp. 7-18.

${ }^{564}$ Farcau, The Ten Cents War, p. 171.
} 
MAP 6 - Main battles in the War of the Pacific (1879-1884).

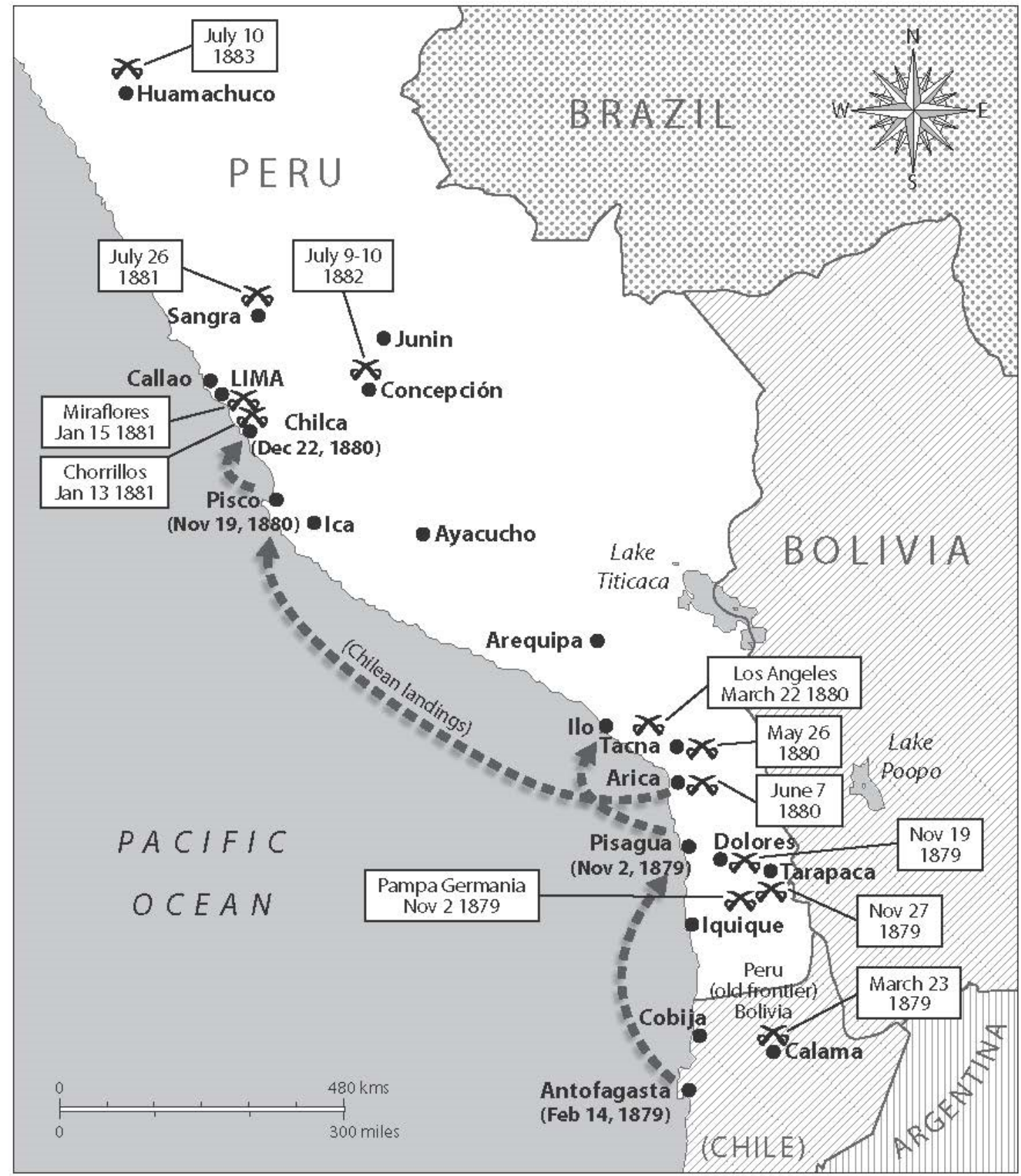

Source: Gabriele Esposito, Armies of the War of the Pacific, 1879-83: Chile, Peru and Bolivia (Osprey, 2016), p. 11. 
A new period had opened with the occupation of Lima by the Chilean troops, for this military presence soon turned into a fiscal, administrative, and moral burden for the Chilean state. As historian Carmen Mc Evoy notably put it, the Chilean state was effectively duplicated or "unfolded" onto the Peruvian space, thus creating an unprecedented situation for the troops, officers, and those directing the war from Santiago. ${ }^{565}$ This heavy burden was compounded by a growing tension between the civilian leadership back in the capital city, and the military commanders on the field — who at some point acted as Chilean "proconsuls" in Lima. ${ }^{566}$

During Chile's rule of Lima, three army veterans governed the enemy's capital: Manuel Baquedano, Cornelio Saavedra, and Pedro Lagos. However, it fell on Patricio Lynch, a ruthless military commander of both the navy and the army, to continue the operations against the Piérola "government in the shadows" and the irregular army organized by Andrés Cáceres and still resisting in the countryside. Back in Santiago, the new president Domingo Santa María, also felt a similar omnipotent power emanating from the occupation and effective administration of the former enemy's finances, governmental activities, and-partly-even its foreign affairs. ${ }^{567}$ This feeling of superiority led the Chilean authorities to re-conceive of their role in the occupied territories as a "civilizing"

\footnotetext{
${ }^{565}$ Mc Evoy, Guerreros civilizadores, pp. 335-405; and Mc Evoy, "Chile en el Perú: Guerra y construcción estatal en Sudamérica, 1881-1884,” Revista de Indias, Vol. 66, No. 236 (2006), pp. 195-216.

${ }^{566}$ Sater, Chile and the War of the Pacific, pp. 35-61.

${ }^{567}$ From D. Santa María to A. Pinto, Santiago, February 6, 1880, Chile, Archivo Nacional de Chile, "Fondos Varios," Vol. 416, p. 74. In a letter to Lynch, Santa María expressed the "true moral authority" of eliminating "all source of resistance" in order to the Chilean civilization to reach its full potential in Peru. From D. Santa María to P. Lynch, Santiago, August [n/d], 1882, Chile, Archivo Nacional de Chile, "Fondos Varios," Vol. 414, p. 273.
} 
mission, as if almost ordained by God, and to develop mythical tales about the war and its campaigns as an epic, with heroes and martyrs. ${ }^{568}$

During this new phase of the war, the issue of the "civilized" conduct during war rose to prominence. An important element to consider for exploring the taming of war in the Pacific, therefore, is the issue of the treatment of prisoners as a relevant factor in the conduct of the war itself. Unlike the case of the War of the Triple Alliance, the war between Chile and its neighbors unfolded in an international context where the "laws of war" and the "civilized" conduct of the belligerent armies was incipiently developed and more widely accepted. During the 1879-1884 war, therefore, the Chilean political elite took upon itself to protect the legitimacy of its cause by behaving according to the standards of the "civilized nations" at the time. This included accepting the Lieber Code. In this context, two elements became relevant for the war. One element pointed to the legal boundary defining what type of combatant was included under the category of belligerent, and thus also who could be considered as legally "protected" by certain rights and duties during war. Another element pointed to the humane and legal treatment of prisoners of war. Those combatants who did not respect these same rules and standards were considered as outside the purview of the laws of war and were thus not granted the same treatment or rights granted to others. In this non-protection fell upon those waging guerrilla or irregular war.

Beyond the Lieber Code, Chile and Bolivia also subscribed to the 1864 Geneva Convention in July 1879 , relevant for the treatment of those wounded in battle. Before their

\footnotetext{
${ }^{568}$ On these aspects, see Mc Evoy, Guerreros civilizadores; Mc Evoy, "De la mano de Dios: El nacionalismo católico chileno y la guerra del Pacífico, 1879-1881," Revista Histórica [Lima], Vol. 28, No. 2 (2004), pp. 83-136; Mc Evoy, Armas de persuasión masiva; and William F. Sater, The Heroic Image in Chile: Arturo Prat, Secular Saint (University of California Press, 1973).
} 
subscription, however, Peru had unilaterally signed the Convention, which was considered at the time as a very risky decision for it would have bounded Peruvian troops to a selfrestraint that at the time had not been reciprocated by the enemy. ${ }^{569}$ Incorporated in each belligerent army's code of conduct, therefore, each country was compromised in the fair and human treatment of the wounded and the prisoners of war. When the situation allowed it, those wounded in battle had to be picked up and transported to medical unit for treatment regardless of their nationality. These and other humanitarian dispositions were distributed and publicized in Chile, for example, in a document titled El derecho de la guerra según los últimos progresos de la civilización. ${ }^{570}$

Although these legal and normative regulations were practically applied only inconsistently by the soldier on foot and the officer corps, it signals an incipient recognition of the willingness of all the belligerents to incur in self-restraining behavior during warsometimes even unilaterally, as in the early case of Peru. Unlike the previous wars in the continent, and in particular the Paraguayan War, the War of the Pacific took place in a "thicker" normative international framework in which the three belligerent countries voluntarily entered, procuring the creation of battle-ambulances, campaign hospitals, and military chaplains. ${ }^{571}$ The abundance of correspondence kept in the archives of all the countries involved shows that the prisoners were, at least, not prohibited to communicate

\footnotetext{
${ }^{569}$ See Boletín de las leyes i derechos del Gobierno: Año 1879: Suplemento al Libro XLVII (Santiago: Núñez, 1882).

${ }^{570}$ See El derecho de la guerra según los últimos progresos de la civilización (recopilación oficial) (Santiago: [n/d], 1879). See also Jus, La guerra de Chile ante el Derecho de Gentes (Valparaíso: Julio Real y Prado, 1880).

${ }^{571}$ See, e.g., Fernando González del Riego, Donde triunfó el sentido humanitario: Depósitos de prisioneros en la guerra del Pacífico. El caso de San Bernardo (Santiago: Sociedad del Canal de Maipo, 2013); Elvira Cárdenas Román, Las ambulancias en la guerra del Pacífico: Obra de Zenón Dalence y Patricio Orureño (Oruro, Garza Azul, 2012).
} 
with their families and friends. Moreover, security was lax, as shown by the frequent instances of prisoner escapes and breakouts. ${ }^{572}$ Although several excesses have been well documented throughout the war, two episodes stand out above all: one is the Chilean occupation of Lima in 1881 and the subsequent sacking and violation of property carried out; and a second episode is the imprisonment of the interim Peruvian President and his family, Francisco García Calderón, and his relocation to Chile after the war. ${ }^{573}$

Towards the end of the war, the occupation of Lima by Chilean troops and the support for the puppet government of García Calderón for almost three years strained Chile-Peru relations. From the countryside and the mountainous regions of Peru, Andrés Cáceres, a hero of the war, continued to resist the Chilean occupation via guerrilla tactics and irregular war. This tenacious resistance not only prolonged the presence of the Chilean army in Lima, but also complicated the negotiation of a final peace treaty, for as long as Cáceres presented battle, the government of García Calderón would remain overshadowed by the parallel "legitimate" government of Nicolás de Piérola, which sided with Cáceres and refused to capitulate. ${ }^{574}$ During the most bitter periods of the war, excesses were reported by battlefield medics and surgeons, who after some battles found that certain wounded soldiers had been killed. This is what some called at the time as "el repase," which consisted in the "review" of the field and the killing of those laying mortally

\footnotetext{
${ }^{572}$ Perhaps the most famous of these was the one in San Bernardo. See González del Riego, Donde triunfó el sentido humanitario. See also Ahumada Moreno, Guerra del Pacífico, Vol. 7: p. 64.

${ }^{573}$ For García Calderón's own view of the experience, see his Memorias del cautiverio (Lima: Librería Internacional del Perú, [1938] 1949). See also "Detalles de la prisión de García Calderón y su Ministro Manuel M. Gálvez," in Pascual Ahumada Moreno, Guerra del Pacífico (Valparaíso: Imprentas del Mercurio; Americana; Progreso, 1884-1891), Vol. 6: pp. 286ff.

${ }^{574}$ See Memorias del Mariscal Andrés A. Cáceres (Lima: Milla Batres, 1986); Mc Evoy, Chile en el Perú; and Puente Candamo and De la Puente Brunke, El estado en la sombra.
} 
wounded on the field. These episodes, however, were rare and occurred only sporadically after some particularly bitter or hard-fought battle. ${ }^{575}$

The War of the Pacific, although brutal and with excesses as most wars in the 19th century, cannot be categorically seen as a "war of extermination" or "all-out war," for the parties involved engaged in frequent capture and exchange of prisoners, treatment of the wounded, and even conceded certain liberties of communication and mobility within the cities occupied. As one historian put it, the key is "to distinguish between what happened during battle from what occurred after. ${ }^{n 576}$

\section{Institutionalizing Order in the South Pacific}

As the Chilean army approached Lima, two international efforts tried to further institutionalize the war into commonly agreed and more pacific channels. Both initiatives, however, were stillborn. The first effort was that of the United States, which in late 1880 tried to mediate in the war. The improvised and unprofessional cadres occupying the diplomatic posts in Lima and Santiago, however, set in motion a negotiation that was bound to fail given the multiple mistakes by the U.S. agents in bridging the two belligerents' positions prior to the negotiations. The second effort came also in late 1880 , as an initiative by Colombia to summon a new "American Congress" in the style of the prior ones from 1826, 1848, 1856, and 1864. The simultaneous occupation of Lima prompted Chile to

\footnotetext{
${ }^{575}$ See, e.g., Zenón Dalence, Informe histórico del servicio prestado por el cuerpo de ambulancias del Ejército boliviano (La Paz: 1881); and Cárdenas Román, Las ambulancias en la guerra del Pacífico. See also the many reports compiled by Ahumada Moreno, Guerra del Pacífico, Vol. 1: p. 511; Vol. 2: pp. 71, 109, 129; Vol. 8: p. 225.

576 Patricio Ibarra Cifuentes, "Vivir la guerra en cautiverio: Prisioneros en la guerra del Pacífico (1879_ 1883)," in Chile y la guerra del Pacífico, ed. by Carlos Donoso Rojas and Gonzalo Serrano del Pozo (Santiago: Universidad Andrés Bello; Centro de Estudios del Bicentenario, 2011), pp. 155-174.
} 
relentlessly undermine this international gathering by actively disincentivizing Central American countries to participate or by trying to pre-arrange their objectives. Chile feared that the Panama Congress invoked by Colombia would turn into a regional forum for judging the Chilean occupation of Lima and its overall territorial gains secured as part of the military victory over Peru and Bolivia. Argentina's acceptance of the Colombian invitation was the last reason needed by Chile to boycott the initiative. ${ }^{577}$

Before the end of the 19th century, therefore, the U.S. had a second opportunity to reassert its international prestige as "the champion of peace in the Americas" after the diplomatic debacle in the Paraguayan War. The role of the U.S. was initially driven by a generic economic interest in securing the assets of U.S. citizens and companies located in either of the belligerent countries. As the war progressed, however, Washington feared that through Chile's victory in the war interests of other European powers - mainly Great Britain — were being served. This was deemed unacceptable by the U.S., for it clashed with the U.S.' interpretation of the principles of the Monroe Doctrine. Popular opinion in the U.S., reflected in the vast majority of newspapers, believed that the eventual defeat of Chile was a certainty, however. ${ }^{578}$ Despite popular inclinations towards the allied cause (i.e., to

\footnotetext{
${ }^{577}$ For a well-documented study of this international meeting, see Robert N. Burr, The Stillborn Panama Congress: Power Politics and the Chilean-Colombian Relations during the War of the Pacific (University of California Press, 1962). For Argentina's position, see Néstor T. Auza, "Apertura de relaciones diplomáticas en el Pacífico: Misión Cané en Venezuela y Colombia," Revista Histórica [Buenos Aires], Tomo VI, No. 17 (1991), pp. 165-236; María L. Cochetti, La neutralidad "activa" argentina en la guerra del Pacífico: La promoción del tráfico de armas hacia los ejércitos de Bolivia y Perú (Buenos Aires: FLACSO; Universidad de San Andrés; Universidad de Barcelona, 2006); and Ricardo Sáenz Hayes, Miguel Cané y su tempo (1851-1905) (Buenos Aires: Kraft, 1955), esp. pp. 157-259.

${ }^{578}$ See also Juan Ortiz Benites, comp., El New-York Herald y la guerra del Pacífico (Lima: La Casa del Libro Viejo, 2013).
} 
Peru and Bolivia), the official U.S. government position at the very beginning of the hostilities was one of "strict neutrality." 579

Although the economic interests of the U.S. in the South Pacific were small, much like its economic interests in Paraguay and the River Plate basin earlier, the enormous leverage that British and French companies enjoyed in the exploitation of the mineral trade in the region, soon became an important source of concern for the U.S. in its quest for reasserting its presence in the entire continent while also shielding the region from all European strategic interests. As Millington put it, “[a]lthough certain European nations had far more at stake in the Pacific War from an economic point of view, the United States hastened to assume the lead as champion of neutral rights and as defender against intervention. ${ }^{" 580}$ The past effort at mediation by the U.S. in the war against Spain in 1871 had left a positive opinion of the U.S. in Chile and Peru. The U.S. tried, therefore, to cash in that diplomatic check and reinvest it in the present war between the two former allies.

The U.S. position tried to reconcile the principles of the Monroe Doctrine with the respect by the three belligerents of the rights of neutral commercial powers active in the region. ${ }^{581}$ This came as a prime directive from the Secretary of States, William M. Evarts, to the U.S. Minister in Peru, Isaac P. Christiancy, because as part of the military conflict among these neighboring states, a parallel commercial war (potentially affecting sea trade

\footnotetext{
${ }^{579}$ Herbert Millington, American Diplomacy and the War of the Pacific (Columbia University Press, 1948), pp. 30-33. See also Sater, Chile and the United States, pp. 35-50.

${ }^{580}$ Millington, American Diplomacy, p. 34.

${ }^{581}$ On the role of the Monroe Doctrine in the U.S. calculations for intervening in the war, see Peru, Ministerio de Relaciones Exteriores, Memorándum sobre la actitud del gobierno de los Estados-Unidos de Norte-América en el Pacífico, presentado a las cancillerías del Plata por la legación peruana (Buenos Aires: Coni, 1882); and The South American War and the United States as Arbitrators (Ilsley \& Marx, 1881), p. 7.
} 
routes) was quickly emerging. ${ }^{582}$ As the war started to affect international trade and property, pressure mounted in the U.S. to intervene in a more direct manner. But presented with the options of mediation or military intervention, the Hayes administration decided for the former. ${ }^{583}$

A critical development in the war, however, threatened this traditional plan for mediation. Despite the popular support in the U.S. for this policy, U.S. ministers in Bolivia, Peru, and Chile largely ignored such principles and, without waiting for official authorization from Washington, issued promises and reassurances to the respective governments to whom they had been deployed. They conveyed the impression that the U.S. would support their causes if mediation was officially requested. ${ }^{584}$

As the conflict intensified and Peru's early naval defeat represented a virtual strategic loss, Peru and Bolivia started to seriously consider involving the U.S. into the conflict as a way to constrain Chile. Chile, for its part, had accepted an early offer of mediation from Great Britain, thus raising the stakes of the role of European powers as influential diplomatic actors in the dispute. ${ }^{585}$ Therefore, Peru and Bolivia declined Great Britain's offer, in a clear gesture towards the U.S. The inflexibility of the U.S. commitment to non-intervention, however, started to erode the confidence of the allies, as the Chilean armed forces kept marching north towards Lima. ${ }^{586}$ When the Bolivian territory Atacama and the Peruvian province Tarapacá were effectively occupied by Chile towards the end of

\footnotetext{
${ }^{582}$ From W. Evarts to I. Christiancy, December 26, 1879, in Millington, American Diplomacy, p. 38.

${ }^{583}$ See Kenneth W. Crosby, "The Diplomacy of the United States in Relation to the War of the Pacific, 1879-1884," Ph.D. Dissertation, Washington DC: George Washington University (1949), pp. 45-80.

${ }^{584}$ See “Apuntes de Don Aníbal Pinto," pp. 259-280; and Millington, American Diplomacy, p. 54.

${ }^{585}$ See Ahumada Moreno, Guerra del Pacífico, Vol. 1: pp. 205-206.

${ }^{586}$ Sater, Chile and the War of the Pacific, p. 200.
} 
1880, a new issue emerged for the would-be mediator. The U.S.' hopes for a pacifying role had become reliant on its ability to broker a peace treaty between the three belligerents that could simultaneously reassure the return of these occupied regions to Bolivia and Peru. ${ }^{587}$

Onboard the U.S.S. Lackawanna, in October 1880, the representatives of Chile, Peru and Bolivia met with the three U.S. Ministers accredited to each respective country. ${ }^{588}$ The U.S.-sponsored conference, however, had been arranged despite clear indications to Isaac Christiancy by the Chilean President, Aníbal Pinto, that Chile was firm in its decision not to concede the Atacama region (including the medianería with Bolivia), nor any of the occupied Peruvian territories. Christiancy thought he could persuade Chile to rethink this point while at the negotiating table. However, his failure to do so condemned the Lackawanna conference to utter failure. After the meetings, in fact, each country issued public memoranda putting the entire blame for the failure of the negotiations on the other party. In this sense, the amateur approach by the U.S. agents had deepened, rather than assuaged, Peru-Chile relations. In the U.S. itself, public opinion turned on the incumbent

\footnotetext{
${ }^{587}$ I. Christiancy to W. Evarts, Lima, June 20, 1880, in United States of America, Department of State, Papers Relating to the War in South America and Attempts to Bring About Peace. Executive Document No. 79, 47th Congress, 1st Session (Washington DC: Government Printing Office, 1882), pp. 373-374. See also Querejazu Calvo, Guano, salitre, sangre, pp. 428ff.

${ }^{588}$ On the Arica Conference, see Las conferencias en Arica: Documentos relativos a la mediación ofrecida por el gobierno de los Estados Unidos de Norte América para poner fin a la guerra entre Chile, Peru i Bolivia (Santiago: Imprenta Nacional, 18800); Cornelius A. Logan and Francisco García Calderón, Mediación de los Estados Unidos de Norte América en la guerra del Pacífico (Buenos Aires: Imprenta de Mayo, 1884); Bolivia, Ministerio de Relaciones Exteriores, Mediación de Estados Unidos en la guerra del Pacífico: Bolivia (La Paz: Imprenta de la Unión Americana, 1880); Chile, Ministerio de Relaciones Exteriores, Las conferencias en Arica: Documentos relativos a la mediación ofrecida por el gobierno de los Estados Unidos de Norte América para poner fin a la guerra entre Chile, Perú i Bolivia (Santiago: Imprenta Nacional, 1880). See also Jorge Gumucio Granier, Estados Unidos y el mar boliviano: Testimonios para la historia (La Paz: Plural; Instituto PRISMA, 3rd ed., [1985] 2005), pp. 101-136; Sater, Chile and the United States, pp. 35-50; Millington, American Diplomacy, pp. 53-81; Sater, Chile and the War of the Pacific, pp. 200-204; Percy Cayo, "Las conferencias de Lackawanna," Revista Histórica [Lima], Vol. 32 (1979), pp. 73-97; and Querejazu Calvo, Guano, salitre, sangre, pp. 428-459.
} 
administration for, as an editorial of the New York Herald put it, "[ $[$ the half-hearted attempt [onboard the Lackawanna] made American diplomacy the laughing-stock of the South American continent. ${ }^{.589}$

The failure of U.S. mediation left a clear road for Chile's advance towards Lima and reinforced its occupation of the Bolivian and Peruvian territories even further. The subsequent occupation of Lima by Chilean troops in 1881 changed the tone of all future negotiations entirely. For the parties involved, and above all for Peru, no other involvement other than a forceful U.S. ultimatum to Chile would now be realistic. The balance of power among the belligerents was so broken that Peruvian hopes were now placed on the promises that were irresponsibly extended by the U.S. ministers some months before, but which were now less realistic than when they were first uttered. In the U.S., incoming Secretary of State, James G. Blaine (March 7, 1881), tried to further Evart's policy of mediation in the war but, unlike his predecessor, he interpreted the war as one of "Chilean aggression." 590 This implied a more interventionist view of mediation that the one dubbed in the U.S. as "pugilistic diplomacy." 591

\footnotetext{
${ }^{589}$ New York Herald, January 31, 1881.

${ }^{590}$ See David Healy, James G. Blaine and Latin America (University of Missouri Press, 2001), p. 64; Sater, Chile and the War of the Pacific, pp. 209-213; Millington, American Diplomacy, p. 82-83; and Berry W. Smith, "James G. Blaine and the United States Mediation in the War of the Pacific," M.A. Thesis, East Lansing, MI: Michigan State College of Agriculture and Applied Science, 1955.

${ }^{591}$ For a general overview of James Blaine's controversial, yet brief, time in office and his approach to the War of the Pacific, see Healy, James G. Blaine and Latin America, pp. 54-99; Russell H. Bastert, "A New Approach to the Origins of Blaine's Pan American Policy," The Hispanic American Historical Review, Vol. 39, No. 3 (August, 1959), pp. 375-412; William S. Robertson, The Pan-American Policy of James G. Blaine (University of Wisconsin, 1899); A. Curtis Wilgus, "James G. Blaine and the Pan American Movement," The Hispanic American Historical Review, Vol. 5, No. 4 (November, 1922), pp. 662-708; Alice F. Tyler, The Foreign Policy of James G. Blaine (Archon Books, 1965); and Humberto VázquezMachicado, "James G. Blaine y la guerra del Pacífico," in Obras completas de Humberto VázquezMachicado y José Vázquez-Machicado (La Paz: Don Bosco, 1988), Vol. VII: pp. 281-288.
} 
With the occupation of Lima, chaos ensued and two Peruvian governments formed.

One was a collaborationist government supported by the occupying Chilean force, and was led by García Calderón, while the other was established "in the shadows," and was led by Nicolás de Piérola ${ }^{592}$ Christiancy one again acted in a controversial manner, recognizing De Piérola's government as the legitimate one. However, running against the Minister's advice, Blaine decided on its own account to officially recognize García Calderón's government instead. Behind Blaine's assertiveness was a strong commitment to the traditional policy of the Monroe Doctrine, through which he intended to thwart British imperialism in South America. Since the perception in Washington was that Chile was backed-up by Great Britain, a support for the collaborationist García Calderón in Lima was expected to win the sympathies of Chile for the U.S. diplomatic efforts. However, the appointment of new Ministers to Chile and Peru—Judson Kilpatrick and William H. Hurlbut, respectively—created an embarrassing episode which would seal the fate of U.S. mediation efforts in the war for good.

In an apparent miscommunication between Blaine and Hurlbut, the latter issued a proposal to Chile indicating the U.S.' willingness to concede to the Chilean demands for

\footnotetext{
592 See José A. de la Puente Candamo and José De la Puente Brunke, eds., El estado en la sombra: El Perú durante la ocupación chilena. Documentos administrativos (diciembre de 1881-julio de 1882) (Lima: Fondo Editorial de la Pontificia Universidad Católica del Perú, 2016); and Carmen Mc Evoy, Chile en el Perú: La ocupación a través de sus documentos, 1881-1884 (Lima: Fondo Editorial del Congreso del Perú, 2016). For an account of the occupation from the perspective of the British and French diplomatic agents in Lima, see Celia Wu Brading, Diplomacia y cañones en la guerra del Pacífico: Testimonios británicos de la ocupación de Lima, enero de 1881 (Lima: Biblioteca Nacional del Perú, 2016); and Eugène Le Léon, Souvenirs d'une mission à l'armée chilienne: Batailles de Chorrillos et de Miraflores (avec un résumé de la guerre du Pacifique et des notes) (Paris: Baudoin, 1883). For an account of the reaciton in Buenos Aires, see Gerardo Trillo Auqui, "Buenos Aires y la guerra del Pacífico: Actores subalternos en la ocupación de Lima,” Diálogo Andino, No. 48 (2015), pp. 55-64.
} 
territory only if Peru could not pay an indemnity. ${ }^{593}$ Since this "offer" implied the adoption of a semi-protectorate of Peru (at least in the handling of its foreign relations), the Chilean government, enraged, rejected all proposals noting that South American countries could very well resolve their disputes "without foreign tutelage." ${ }^{" 594}$ After this incident, Blaine term as Secretary of State was short-lived. He was soon replaced by Frederick Frelinghuysen, who redressed Blaine's more confrontational instructions issued to the ministers in Chile and Peru. ${ }^{595}$ Two new ministers were appointed, and Chile became once again free to impose on Peru the peace of the victors. In February 1882, the fate of Tarapacá was finally sealed, becoming Chilean territory. In October, 1883, the Peruvian "guerrilla army" was finally defeated and thus, free from all opposition, a final treaty of peace was signed, effectively terminating the war. Soon after, Bolivia also agreed to an armistice and signed separately "a truce" in $1884 .{ }^{596}$

\footnotetext{
${ }^{593}$ On this polemic, see William H. Hurlbert, Meddling and Muddling: Mr. Blaine's Foreign Policy: Being a Review of his Nine Months' Tenure of the State Department, in a Letter to the Editor of The New York Herald (Gérardmer, France: [Private Printing], 1884).

${ }^{594}$ Sater, Chile and the War of the Pacific, p. 209.

${ }^{595}$ See Russell H. Bastert, “Diplomatic Reversal: Frelinghuysen's Opposition to Blaine's Pan-American Policy in 1882," The Mississippi Valley Historical Review, Vol. 42, No. 4 (March, 1956), pp. 653-671; and Millington, American Diplomacy, p. 121-143.

${ }^{596}$ On this less-well studied episode of the war, see Joaquín Aguirre Lavallén, Guerra del Pacífico: Pacto de tregua 1884. Documentos reservados inéditos (La Paz: Los Amigos del Libro, 1987); Nataniel Aguirre, Bolivia en la guerra del Pacífico (Cochabamba: El Heraldo, 1883); Phillips, "Bolivia in the War of the Pacific," pp. 316-331; and Daniel Parodi Revoredo, La laguna de los villanos: Bolivia, Arequipa y Lizardo Montero en la guerra del Pacífico (1881-1883) (Lima: Institut Français d'Études Andines; Fondo Editorial de la Pontificia Universidad Católica del Perú, digital ed., [2001] 2015).
} 
MAP 7 - Main territorial gains for Chile in the War of the Pacific.

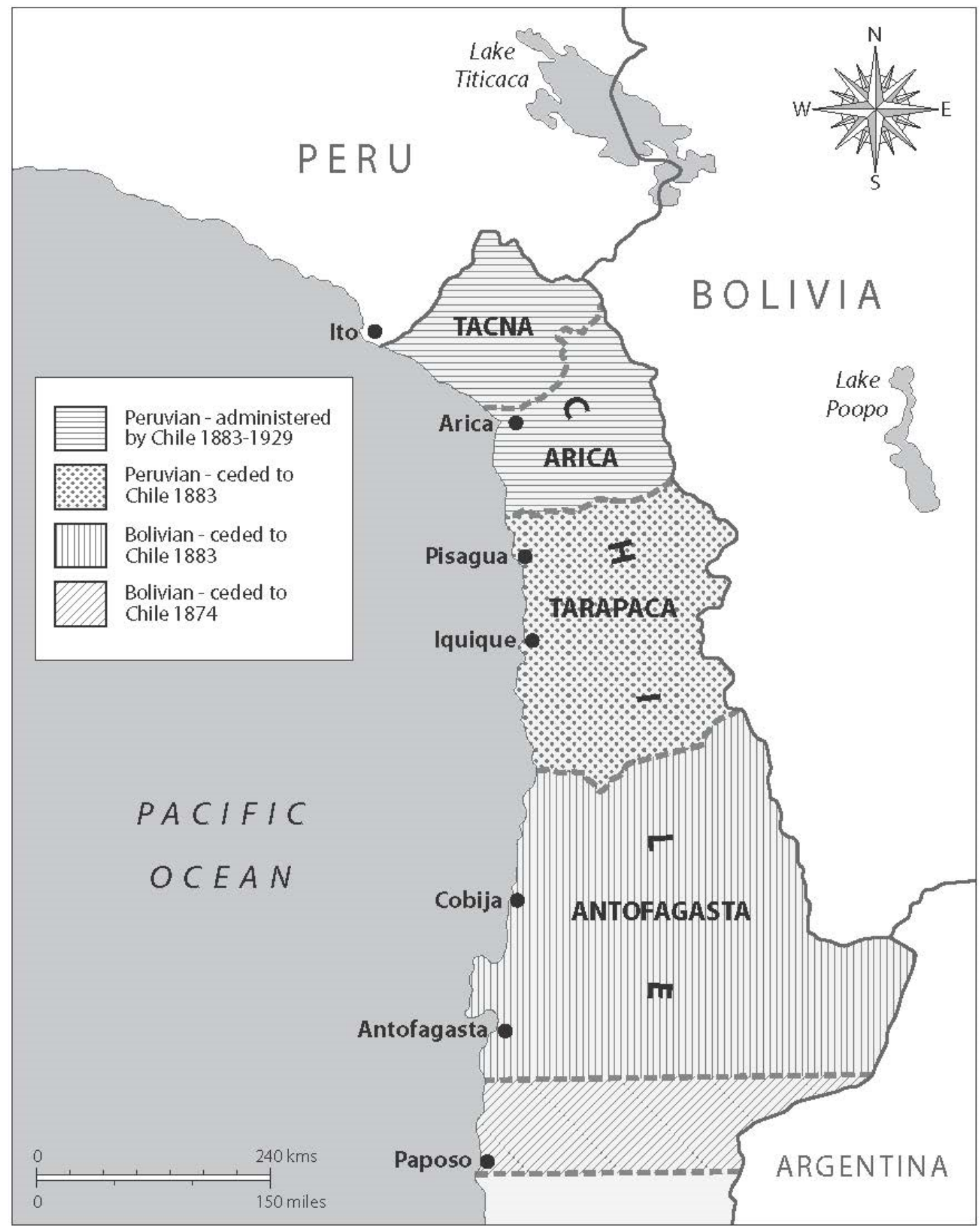

Source: Gabriele Esposito, Armies of the War of the Pacific, 1879-83: Chile, Peru and Bolivia (Osprey, 2016), p. 18. 
The victory for Chile was total. Its army had marched all the way north up to Peru, occupying its capital for almost three years [see supra Map 7]. Bolivia, for its part, lost its most western provinces, and with them as well all access to the Pacific Ocean. Although Chile signed separate peace treaties with Peru and Bolivia, the final territorial and legal arrangements would not be settled until 1929, when a final treaty sealed the fate of Bolivia's former Pacific provinces, and settled with Peru the most contentious aspects of the Tacna and Arica dispute. ${ }^{597}$

\section{Restraining Chile: Towards a Continental Pragmatic Solidarity}

Unlike the previous two major armed conflicts in the region, which occurred almost simultaneously in the mid-1860s, the Chilean victory in the War of the Pacific was followed closely by all the neighboring states and even the United States. Chile's occupation of Bolivian and Peruvian territories far beyond the initially disputed zone of medianería and the subsequent occupation and administrative control of Lima alarmed Argentina - with whom Chile had a pending dispute over the Patagonia region. For Colombia, who convoked the second Panama Congress in late 1880, the Chilean victory

\footnotetext{
${ }^{597}$ For this extended set of negotiations after the war, see William J. Dennis, Documentary History of the Tacna-Arica Dispute (Kennikat Press, 1927). For as assessment of the role of U.S. diplomacy during this process, see also Dennis, Tacna and Arica: An Account of the Chile-Peru Boundary Dispute and of the Arbitrations by the Unites States (Yale University Press, 1931); Don M. Coerver and Linda B. Hall, Tangled Destinies: Latin America and the United States (University of New Mexico Press, 1999), pp. 74 103; Fredrick B. Pike, Chile and the United States, 1880-1962: The Emergence of Chile's Social Crisis and the Challenge to United States Diplomacy (University of Notre Dame Press, 1963); Sater, Chile and the United States, pp. 69-91; Joe F. Wilson, The United States, Chile and Peru in the Tacna and Arica Plebiscite (University Press of America, 1979); Michael G. Varley, "Aftermath of the War of the Pacific: A Study in the Foreign Policy of Chile, 1891-96," Ph.D. Dissertation, Cambridge: University of Cambridge (1969); and A. Nayland. Page, "United States Diplomacy in the Tacna-Arica Dispute, 1884-1929," Ph.D. Dissertation, Norman, OK: The University of Oklahoma (1958). For a comparative study of British diplomacy, see William F. Beck, "A Comparison of British and United States Relations with Chile, 18791883: A Study in Diplomatic History,” Ph.D. Dissertation, Pittsburgh, PA: University of Pittsburgh (1942).
} 
became an additional source of concern after the growing U.S. involvement in the Panama Canal. Since one of the main topics in the agenda of the Congress was the issue of permanent arbitration to negotiate regional disputes, the continental congress turned into an important regional forum where both concerns could be debated and regional dynamics of collaboration, solidarity, and resistance, could form.

Chile's neighbors, despite their concern for its growth in power, did not rush to form a counter-balancing coalition. Countries like Argentina and Peru, however, did try to use the Panama Congress to create a common institutionalized front within which curtail in legal and diplomatic ways the post-war gains made by Chile at Bolivia's and Peru's expense. The Congress was successful in channeling a regional interest in establishing "mandatory arbitration" as a formal practice in South America, but due to Peruvian and Bolivian protests against Chile's occupation, the whole issue was seen as extremely sensitive by Chile's officials as it would have been the main focus of the debate and commentary by the rest of the region. Eventually, this sealed the fate of the Congress, which had a poor beginning and an ignominious end. Delegates from all the invited states either failed to arrive on time, or simply speculated and stalled, but never made it to the meetings. ${ }^{598}$

\footnotetext{
${ }^{598}$ See Colombia, Documentos referentes a la reunión en Panamá del Congreso Americano, iniciada y promovida por el Gobierno de Colombia en favor de la institución del arbitraje (Bogotá: Rivas, 1881). See also Burr, The Stillborn Panama Congress, pp. 87-11; Rafael Núñez, "El Congreso Internacional de Panamá," in La reforma política en Colombia: Colección de artículos publicados en "La Luz" de Bogotá, "El Porvenir" y "El Impulso" de Cartagena, de 1878 a 1884 (Bogotá: La Luz, 1886), pp. 38-43; Gustavo Otero Muñoz, Un hombre y una época: La vida azarosa de Rafael Núñez (Bogotá: Biblioteca de Historia Nacional, Vol. LXXXIII, 1951); and Jesús M. Yepes, El Panamericanismo y el derecho internacional (Bogotá: Imprenta Nacional, 1930), pp. 90-104.
} 
During the War of the Pacific, Colombia's relations with Chile were strained by the transfers of arms, munition, and other provisions, through the canal-then under Colombian control. The chaotic and profoundly decentralized domestic front in Colombia created "parallel diplomacies" by the Colombian national government and some of the coastline states, further complicating the effectiveness of Chile in interrupting the flow of war contraband in support of Peru during the Lima occupation. ${ }^{599}$

Argentina's own growth in power across the Andes also raised Chile's concern. Argentina's final solution to the tensions with Brazil over the arrangement of post-war Paraguay allowed the government to refocus on its pending disputes with Chile, with whom several rounds of negotiations in the course of the 1870s had produced no tangible results on the Patagonia and Magellan Strait issues. ${ }^{600}$ Despite this growing tension, Argentina's foreign policy towards post-war Chile was resoundingly prudent and restrained. When the Peruvian diplomacy reached out to suggest its incorporation to the "defensive" 1873 treaty with Bolivia, Argentina could have dealt a devastating blow to Chile's foreign policy,

\footnotetext{
${ }^{599}$ On these aspects, see Celestino A. Araúz, Panamá y sus relaciones internacionales (Panamá: Editorial Universitaria, 1994), Vol. 1: pp. 46-55; Celestino A. Araúz and Patricia Pizzurno Gelós, El Panamá colombiano (1821-1903) (Panamá: Primer Banco de Ahorros; Diario La Prensa de Panamá, 1993), esp. pp. 279ff; and Araúz and Patricia Pizzurno Gelós, Relaciones entre Panamá y los Estados Unidos: Historia del canal interoceánico desde el siglo xvi hasta 1903 (Panamá: Autoridad del Canal de Panamá, 1999). For an excellent study of the Chilean perspective of the diplomatic crisis, see Burr, The Stillborn Panama Congress; Burr, By Reason or Force, pp. 157-158; Mauricio E. Rubilar Luengo, "Chile, Colombia y Estados Unidos: Sus relaciones internacionales durante la guerra y postguerra del Pacífico, 1879-1886," Tzintzun: Revista de Estudios Históricos, No. 42 (julio-diciembre, 2005), pp. 49-86; Rubilar Luengo, "Guerra y diplomacia: Las relaciones chileno-colombianas durante la guerra y postguerra del Pacífico (1879-1886)," Universum, Vol. 19, No. 1 (2004), pp. 148-175; and Rubilar Luengo, "La política exterior de Chile durante la guerra y postguerra del Pacífico (1879-1891).

${ }^{600}$ See, inter alia, Robert N. Burr, "Argentina and Chile," in Conflict in World Politics, ed. by Steven L. Spiegel and Kenneth N. Waltz (Winthrop, 1971), pp. 155-176; Burr, By Reason or Force, pp. 145-146, 153-155; 171-172, 184-186, 195-197, 204-208, 210-227; Donald E. Willett, "Across the Andes: United States, Argentina and Chilean Diplomatic Relations, 1865-1883," M.A. Thesis, Nacogdoches, TX: Stephen F. Austin State University, 1976, passim, but esp. pp. 1-28; Caillet-Bois, Cuestiones internacionales, pp. 19-29, 61-108; and Armando Braun Menéndez, Mitre y la cuestión de límites argentino-chilena (Buenos Aires: Emecé, 1957).
} 
opening a second front that would have produced a complete strategic encirclement of Chile by the end of the 1870 s. It was the Brazilian timely reaction, as identified above, that ultimately saved Chile from such a fate, for by confirming the existence of the "secret" treaty to the Chilean agent in Buenos Aires, a new tacit alliance was born between Chile and Brazil. The dynamic was simple: Brazil had an interest in seeing Chile remain powerful after the War of the Pacific to help counter-balance Argentina's growing influence in the River Plate. Also, a more assertive Chile would help Brazil triangulate more favorably all its negotiations with the Andean republics, Peru, Bolivia, and Ecuador, over the common Amazonian borders.

And so, it was that, at the expense of the weaker states in the region, a strategic triangle emerged in South America. The War of the Triple Alliance and the War of the Pacific, in sum, forged a dual balance of power in the region by which the three countries became local "great powers" and custodians of the status quo. Although the stabilization of this balance created tensions in the transition to the 20th century, eliciting a naval arms race between the three countries, it soon gave way to a three main improvements in the quality of the region's international affairs. First, it consolidated the internal and external fronts of the three main actors in the region-thus, also, contributing to an overall pacification of South America. Second, it made clear which states would bear the higher costs and bear the heaviest burdens of "responsibility" for upholding the regional order. And third, it cleared the way for an important-although imperfect-dynamic of coordination under the notion of the "A.B.C." triangle, which played a meaningful role in several diplomatic initiatives in the Americas since the later 1890s, after Brazil's transition to the republican form of government. The importance of the Argentina-Brazil-Chile 
cooperation can be seen in the multiple initiatives in Central America and the Caribbean in the 1910s and 1920s, as well as in the last major war of the Americas, the Chaco War between Bolivia and Paraguay. It is also a tacit common understanding underpinning the "May Pacts" between the three states, which offers voluntarily display of self-restraint by three (at the time) competing, rising powers. ${ }^{601}$ Lastly, it represented the last obstacle for Brazil's foreign policy to be finally "accepted" into the larger continental consensus of Latin American republics. It thus helped solve one of Brazil's most perennial problems of the 19th century: its identity as an "American" country. ${ }^{602}$

One major issue, however, was left unaddressed in this new regional order. The two weakest links in the South American chain, that is: the defeated countries in the previous wars, viz. Bolivia and Paraguay, would come to challenge this entire diplomatic architecture one last time. Their unresolved dispute over the ownership of the Chaco Boreal region, problematically brewing in the background since the very end of the Paraguayan War in 1870, escalated to war in the 1930s testing not only the strength and underlying stability of the "society" of states forged under the A.B.C. triangulation of power, but also the resolve of the United States and the newly-formed League of Nations, in their frantic attempt at bringing the war to an end. This tension between a nascent international legal

\footnotetext{
${ }^{601}$ See Jorge Huneeus, La amistad chileno-argentina: El verdadero origen de los Pactos de Mayo. Datos para la historia (Santiago: Barcelona, 1908); Pablo Lacoste, "Argentina, Chile y los Pactos de Mayo (1902)," Diplomacia, No. 91, (abril-junio, 2002), pp. 107-136; Oscar Espinosa Moraga, "Los Pactos de Mayo," Boletín de la Academia Chilena de la Historia, Vol. 19, No. 46 (1 ${ }^{\circ}$ semestre, 1952), pp. 5-52; and Juan J. Fernández, "Los Pactos de Mayo y la diplomacia británica," Boletín de la Academia Chilena de la Historia, Vol. 32, No. 73 ( $2^{\circ}$ semestre, 1965), pp. 99-131; and Beatriz R. Solveira de Báez, El A.B.C. como entidad política: un intento de aproximación entre la Argentina, Brasil y Chile a principios de siglo, Ciclos, Año II, Vol. 2, No. 2 (1ºmestre, 1992), pp. 157-183.

${ }^{602}$ See Villafañe Gomes Santos, “Brasil: Americano, Latino-Americano ou Sul-Americano?” pp. 87-107; and Preuss, Bridging the Island.
} 
framework for conflict resolution, plus the resolute willingness of the United States to intervene in the dispute, clashed with this incipient regional consensus among South American nations interested in finding their own solutions to their own problems.

\section{Testing Alternative Explanations}

The case of the War of the Pacific offers another chance to evaluate many of the competing hypotheses identified in this dissertation. In relation to the three mechanisms associated to the international society approach $(\mathrm{H} 1)$, six alternative approaches $(\mathrm{H} 2-\mathrm{H} 7)$ offer a set of contrasting interpretations of the chained causal-mechanisms that may have affected the progressive reduction of conflict and consolidation of regional order in South America in the 1880s. An exploration of the contrast between each hypothesis' case-specific "predictions" and the historical record is required to evaluate the strength or weakness of all the competing arguments, including the main one (H1).

\section{H2: The U.S. as a Regional Hegemonic Stabilizer}

The role of the United States in limiting war and institutionalizing regional peace is premised on two background conditions: its preponderance of power and its willingness to lead. Both conditions are met for the present case. Passing the "hoop text," therefore, allows one to continue with an evaluation of the distinctive case-specific predictions. In relation to the expectations of the "suppression of war," the first causal-mechanism, the War of the Pacific shows that not only the United States failed to prevent, ameliorate, or terminate the war, but actually it helped incentivize the Chilean advancement in late 1880 . The diplomatic performance of the U.S. agents in each of the countries involved shows that 
U.S. diplomacy was uncoordinated, unprofessional, and irresponsible. While the agents in Peru and Bolivia gave false impressions of a determined U.S. support to their host governments, thus defying the main foreign-policy stance outlined by the Department of State, the interaction with the U.S. agent in Santiago made the negotiations onboard the U.S.S. Lackawanna stillborn and with no real chances of success. This blunder made the Peru-Chile bilateral relations even more antagonistic, while also damaging the U.S. reputation as a "broker of peace" in the process.

On the issue of institutionalization of order, the sudden change of Secretary of State in Washington, precipitated in part by the assassination of the U.S. President, but also by the lack of regional expertise of the Secretary of States themselves, produced a similar end result as in the previous War of the Triple Alliance. In the War of the Pacific, however, some of the belligerents (Peru and Bolivia) readily accepted the U.S. offer of mediationwhereas in the Paraguayan War none of the contenders, including López, accepted the legitimacy of the U.S. ambition to arbitrate the dispute. Furthermore, the British diplomatic backing of Chile's foreign policy in the war triggered U.S. concerns about the Monroe Doctrine which ultimately undermined its position as an impartial regional moderator. The Chilean, Peruvian, and Bolivian interpretations of the Doctrine were substantially more multilateral than the unilateral view defended by Washington. While the former signaled assistance, collaboration, and solidarity, the latter implied tutelage and imposition. In sum, while the expectation of U.S. "suppression of war" was tried out in practice, it failed to deliver its intended effects.

The third prediction in the $\mathrm{H} 2$ argument indicates that the belligerents will flock in solidarity under the hegemon's wings for protection from one another. Of the three states 
involved, only two looked for the Washington for protection. However, this coincided with the downturn in the military balance, thus indicating that only the losing side tried to open the door to the U.S. involvement in the dispute. Chile, however, theoretically on the losing side before the outbreak of hostilities and threatened from two fronts, did not seek an early rapprochement with the U.S., and instead appeased Argentina with important concessions over the Patagonia dispute, and moved on to secure the tacit collaboration of Brazil to contain both Argentina and the other neighboring Andean nations. As indicated by Sater and other historians, as well, Chile and the U.S. were early rivals in the South Pacific since the closing of the Guano War. The inaction of the U.S. navy during the Spanish bombardment of Valparaíso during that war had left an indelible impression in the Chilean elite that a solid foreign policy could not rest on the U.S. for support. If the Monroe Doctrine was to be upheld, it was Chile itself who should do it. In conclusion, the H2 generates three very "unique" predictions, which do not find high "certitude" in the socalled facts of the case.

\section{H3: A "Pacific" Balance of Power}

The second alternative hypothesis is concerned with the balance of power (H3) as understood in traditional power-political terms. Since the publication of Robert N. Burr's classic studies of Chile's foreign policy during the 19th century, a multitude of Chilean historians and foreign affairs experts normally take the idea of Chile as "the champion of the balance of power" in South America as a given. A closer reading of these key studies, however, reveals that the idea of "equilibrium" or "balance" in Burr's work is not treated as an outcome - that is, as an expectation of a situation among states — but as an idea in the 
minds of those individuals in power, taking decisions, and using this principle as a guiding compass. This, therefore, indicates that Burr's diplomatic history supports the international society interpretation of the balance of power, instead of the contemporary "Realist" approach to IR. Put differently, 19th century Chile is not a "posterchild" for offensive realism, as delineated by John J. Mearsheimer, nor even a model defensive realist state, as originally suggested by Kenneth Waltz.

Contrary to such realist perspectives' expectations, Chile pursued a rather restrained foreign policy for most of its history. While it is certainly true that Chile occupied and maintained territories previously undisputed, from Bolivia and Peru alike, it is also true that the war was thrust upon it by the reckless and fearful Peru-Bolivian diplomatic arrangements, who tried to encircle Chile by reaching out to Argentina and the U.S. to reduce Chile's power to a minimum expression. It is also correct to notice that the source of Bolivia's international troubles, repeatedly losing parts of its territory throughout the 19th century, is more directly associated to its own domestic anarchy and chronic caudillo in-fighting than to the rapacious behavior of its neighbors. Diplomacy matters. Yet, in order to exercise an effective defense of a country's interests and values, domestic order had to be a reality first.

Burr's work, therefore, makes any discussion about the presence of the H3 background conditions quite unnecessary. Both Bolivia and Chile felt mortally threatened in the 1860 s, after the costly victory over Spain—from which Bolivia came out almost unaffected. Chile, on the other hand, had learned an invaluable lesson about unabashed, principled "Americanist" solidarism: a lesson which the same Chilean leadership that had 
presided over the Spanish aggression to Peru and Chile (of the likes of Santa María, Pinto, Vicuña Mackenna, Lastarria, etc.) did not fail to remember a decade later.

In this context, the $\mathrm{H} 3$ generates three discrete predictions. First, the expectation of "war" as a regulating mechanism among mutually-fearing neighbors. This is a prediction shared in part with other approaches, so it adds little value to its explanatory strength ( $c f$. H1). It simply passes the "smoking-gun" test. The expectation of "mutual fear" as a potential driver of regional institutionalization, however, does entail a higher degree of uniqueness in this case. The "facts of the case" seem to strongly support this second prediction, as exemplified in Bolivia's post-1866 foreign behavior and the Peru-Bolivia alliance of 1873 . Both efforts were clearly driven by the fear of Chilean growing economic interests (and population!) in the zone of medianería. Peru feared not just for its traditional ally, Bolivia, but also for its own guano and sodium nitrate export markets which contained enormous economic potential. ${ }^{603}$ Fear also seems to have driven Chile into the appeasing of Argentina particularly on the Patagonia issue, in order to deal with the more immediate and concerning threat from Bolivia's expropriation and Peru's naval and commercial rivalry.

The case seems to corroborate one of the first two predictions of the balance of power approach. Since this is a highly "unique" prediction, its explanatory power is partially strengthened. The third prediction, related to the formation of "dynamic" alliances, is also unique, but finds only partial support in the case-study. The "dynamic"

\footnotetext{
${ }^{603}$ A recent study found that, had Peru and Bolivia not lost their territories to Chile in the war, their "government revenues could have been at least double their historical levels" today. See Richard Sicotte, Catalina Vizcarra and Kirsten Wandschneider, "The Fiscal Impact of the War of the Pacific," Cliometrica, Vol. 3 (2009), p. 97-121.
} 
element alludes to the fact that in a purely power-political region, states can only form a system, yet not a society, of states. One of the main reasons is that in a realist context, states can only "afford" to be shortsightedly self-centered. The decentralized condition of their environment rewards only that kind of behavior. This also implies that when alliances form, a dynamic component will play an important role: that is, today's friends will be tomorrows enemies. Thus, predictable geopolitical patterns should not emerge in the region, for although geography does not change, the interests of states do.

In the War of the Pacific, however, this highly unique expectation seems to run against the rather patterned set of alliances at play. The Chile-Brazil-Ecuador group tends to counter-balance the Argentina-Peru-Bolivia one in a semi-geopolitical fashion. That is, partly determined by their geo-spatial placement in the region system of states. In the H1 approach, on the contrary, the alliances are expected to partially follow a geographical factor or proximity that is correlated with a sense of proximity ins values and interests as well. In the $\mathrm{H} 1$, therefore, alliances are better understood as patterns of "pragmatic solidarism" determined by the confluence of a common interest in order-not just by mutual fear of a common threat.

\section{H4: Geopolitics of the South Pacific}

The geopolitical hypothesis (H4) is premised on a rather static set of patterns that should endure as long as the geography does not vary. The War of the Pacific, paradoxically, shows that rather than an obstacle to war, the vast arid deserts over which the war was fought, were readily bypassed by Chile's early achievement of supremacy at sea. This allowed Chile to mobilize troops directly to distant ports and key strategic places- 
including Lima—without having to suffer the full operational caos of the inhospitable Atacama and Antofagasta deserts. Peruvian and Bolivian forces, however, were constrained to land operations, which they failed miserably to coordinate or employ effectively.

In this context, the two background conditions of $\mathrm{H} 4$ are met, for the topography did present serious obstacles for war operations, and in this sense the costs seemed to outweigh the benefits. Nevertheless, both Chilean and allied forces managed to mobilize and battle over a vast open space, with little technological advantages, and even without some basic supplies, like water or proper medical equipment. The "facts of the case," therefore, seem not to support the first prediction: that of the impossibility of war. Secondly, only minor efforts were made to prevent the war or attenuate its effects by appealing to regional formal institutions. The Panama Congress of 1880 was proposed by Colombia, not Peru or Bolivia, and it was never directly aimed at stopping the War of the Pacific, but in fact it was invoked to consider the status of "mandatory arbitration" in the Americas - aimed, at the same time, to the developments in the Panama Canal. It only became an option for Peru when the U.S. mediation failed and its capital was on the verge of falling into the invading Chilean troops. Yet, this effort was ultimately unsuccessfully.

Perhaps the most important contribution from the $\mathrm{H} 4$ argument is the element of geographically-driven alliance patterns. Contrary to H1, these alliances are completely determined by geography, which gives to this prediction a stronger level of uniqueness. The idea of shatterbelts and checkerboards, in fact, does seem to explain quite well the patterns of alliances formed prior and during the war. 


\section{H5: Common Culture}

The H5 hypothesis is premised on two background conditions, which are only partially met. The idea of a common legacy of anti-imperialism is certainly a factor in understanding the war; however, when employed, it seems to lead to the opposite effect. Instead of acting as a coalescing and moderating force, its acted as a catalyzer for war. Historians and experts who have written about the war from an anti-imperialist perspective, such as Bonilla, Mayo, Amayo, and others, in fact invoke either British or U.S. "imperialism" as a motivating force for Chile and Peru respectively to push the other side further down the path to war. Foreign capital and commercial interests, the argument goes, made each country's government greedy to expand into a largely unexploited region where abundant strategic resources were accessible and unprotected. In this narrative, anti-imperialism played no ameliorating role at all.

Interestingly, it was the U.S., and not any of the involved states, who via its unilateral interpretation of the Monroe Doctrine during Blaine's tenure in the Department of State, tried to cast Chile's victory as the servant of British interests. With the U.S. failure to mediate and the short-lived administration of Blaine himself, the initiative receded into the background - and so did the relative explanatory strength of the H5 hypothesis. Beyond the U.S., neither Argentina or Brazil, nor any other powers in the region, behaved according to the three main expectations of this approach. For example, no international effort was made to "eradicate war" from the region. Chile's growth in power raised alarms among its neighbors, but neither war itself nor foreign imperialism were seen as the real source of the problem. The second prediction, that of a push for unification, also did not obtain, for the factor of regional common-cultural "solidarity" did not play a significant role. The absence 
of a direct extra-regional aggressor, as in the Guano War case, helped undermine its effects. Furthermore, the War of the Pacific was par excellence a war for resources among fellow South American neighbors. Despite certain interpretations to the contrary, there was no one to blame but the belligerents themselves both for unleashing an international war with unpredictable consequences as well as for failing to prevent it in time.

\section{H6: State-Strength and Weakness}

The argument in H6 suggests that patterns of regional order in South America are mainly driven by state-strength/weakness dynamics. The background conditions do seem to obtain, for all actors involved suffered in one degree or another of domestic constraints and thus generated security externalities onto one another. This argument is perhaps at its strongest when analyzing the 1866 treaty of medianería subscribed by Chile and Peru under a very particular moment in the region. More importantly, these are highly unique predictions, for which the level of certitude could potentially be a key determinant of the whole argument's strength.

When confronted with the historical case, however, these very promising background conditions fall short of delivering a "highly certain" (or "doubly-decisive test"). The first prediction, for instance, points to the "incapacity" to wage war. Yet, both Chile and Peru, crippled by domestic crises at the time, managed to organize in relatively short period and practice large-scale war for at least one year-until Peru's loss of the Huáscar towards the end of 1879 . This seems to indicate two things. On one hand, that even poor and crisis-stricken states can mobilize and practice international war; but on the

other, that these same weak states will only be able to wage high-stakes war efficiently for 
either very short periods of time, or by intermittent "chapters"- just like the War of the Triple Alliance. The Peruvian resistance, coupled with Chile's capacity to secure an early naval superiority yet failing to "finish off” the irregular army of Andrés A. Cáceres or direct a campaign across the Andes to La Paz, demonstrate that international war among weakstates can actually prolong, rather than muffle or diffuse, war. It is only moderately comforting, at least, that in their shared condition all belligerents were sensitive to the standards of "civilization" of the time, which in turn, helped practice some modicum of restraint during the actual conduct of the war. Less optimistic, perhaps, is the acknowledgement of the fact that the same "civilizational" standards also set the rules of the games (of war) for the belligerents, and in that, also sanctioned and legitimized certain forms of violence-instead of none.

In this framework, the second prediction of institutionalization as supplementary to the inability of states to contain problematic neighbors, offers at least a partial interpretation of the case. Bolivia, the most unstable and erratic of the countries involved in the war, quickly becomes the center of the whole drama. It was Bolivia's rebellious domestic (dis-)order which generated capricious and unchecked leaders, such as Mariano Melgarejo, who drove Bolivia into the abyss. It was his successors, too, who sparked no only the ambitions of entrepreneurial Chilean interests into the Antofagasta region, but also the clumsy treaties and agreements which were later dishonored by Hilarión Daza in 1878. Bolivia is, for this case, the problematic weak-neighbor par excellence. However, Chile, who also was transitioning a period of internal fiscal constraint and popular unrest, was able to perform much better than Bolivia or Peru—showing and interest variance across weak-states. Chile's more solid, institutional domestic political order allowed its leadership 
to strategize with an eye on the long-term, thus negotiating the right kind of deals with specific neighbors, at the right time. This, moreover, helped Chile overcome what was, otherwise, an objective disadvantage in pure power (material) terms.

The fateful 1873 treaty, which contemporary historians "blame" for the War of the Pacific, when seen under this light seems to indicate a validation of the H6 hypothesis in terms of Bolivia's and Peru's attempts at avoiding the externalities that they themselves were producing for Chile. Peru's externality came from its own sodium nitrates bonanza, which further incentivized Chile to develop its own. Bolivia's externality, too, through the strange and unstable medianería pact of 1866, and mended in 1872 and 1874, and the virtual "free hand" that is produced for Chile within the shared zone itself. Bolivia's failure in handling the dual need of extricating more benefits from the Antofagasta mines without antagonizing Chile is what, in the end, caused the war-instead of preventing it. As it seems, the factor of the quality of a country's diplomacy and political leadership was key.

\section{H7: A “Liberal Peace” in the South Pacific?}

The final alternative hypothesis articulates three specific predictions, premised on two distinctive conditions. It expects that when the Liberal values, like republicanism, freetrade, and (Liberal) institutions are present, they will converge in three ways: first, by an inter-republican eradication of war; second, by the construction of Liberal institutions to help maintain and protect this "separate" peace; and third, by displaying solidarity among republican democracies. In the case at hand, only Chile could be regarded as a republicaccording to the standards of the time. Neither Bolivia nor Peru had any substantial republican form of government. As pointed out above, Bolivia was ruled by alternating 
caudillos bárbaros who governed with an iron fist and sought mainly political survival. Peru was only "democratic" in a superficial sort of way, with recurring military leaders, like Mariano I. Prado in the late 1870s, giving way to other civilian—but equally undemocratic—leaders like Nicolás de Piérola in the early 1880s.

Although the predictions of $\mathrm{H} 7$ do not seem to offer any important information about the case, it is relevant to point out that "the masses"—as it was often put—did played a role in how political opposition managed to put pressure on the incumbent administration - particularly in Chile. In Peru and Bolivia, public opinion also mattered, but in a more uncontrolled or un-channeled way, for there were no strong political opposition to capitalize on it. Thus, political opponents often recurred to violence to remove from office their political rivals, instead of Congress or wait for the next round of elections.

In conclusion, a related theme: that of sameness of type of regime, seems to have played no role in how Chile and Brazil came to forge their implicit alliance. Thanks for this important linkage between one Pacific and one Atlantic power, South America was able to overcome one of the traditional patterns of earlier periods. It was the first time states from different margins of the continent established a non-confrontational relation. As pointed out above, this was Brazil's baptism of fire which officially introduced it to the regional "society" of states in South America. Chile's induction allowed Brazil to begin to play a more stabilizing and assertive role in the 20th century and, most distinctively, actively participate in regional congresses and conferences for the very first time in the history of the Americas. 


\section{Some Preliminary Conclusions}

The War of the Pacific is an important chapter in the history of South America's society of states. Its unfolding during the $1879-1884$ period is deeply rooted in several decades of rivalry and cooperation between the same countries. Allies in the 1810 in their common struggle for independence against Spain, then enemies in the late 1830s, and then again allies in their "second war of independence" in the 1860s. During the 1870 s, intra-regional dynamics of state- and nation-consolidation interacted with new discoveries of strategic resources in a common space connecting geographical the three states to one another as well as to the Pacific Ocean. Internal dynamics, as well, spiraled out of control producing a pervasive cycle of mutual fear and security externalities, which eventually sparked in a war between Chile and the alliance Peru-Bolivia. The circle was complete, beginning in the $1830 \mathrm{~s}$, it relied upon Chile once again to disjoint the two allies in the $1870 \mathrm{~s}$.

Those involved directly in the war, as well as those observing from the sidelines, picked up valuable lessons from the war. Chile, for example, found in Brazil an important ally with whom, thanks to not sharing any common borders, it was easy to find common ground in constraining Argentina and Peru. Moreover, its experience during the occupation of Lima also left the indelible impression of the costs of war-even when victorious! The "unfolding" of the Chilean state onto Peru's territory created fiscal, administrative, and moral burdens on Chile which deeply affected the post-war "return to normalcy." Argentina and Brazil, over their tense negotiations in post-war Asunción, experienced a similar learning process. In both instances, the victorious occupants counted the minutes and the seconds to leave their unwelcoming hosts. 
It became clear for all South American states that, even when victorious, large-scale international war was more a burden than a tangible asset. It created a more fervent domestic opposition, in was opposed by the independent press, and it was more often than not condemned internationally. Further, it opened the regional door to unwelcomed powers, like the United States, to extend their "good offices" and international mediation. Well socialized by the recent common struggle against Spanish and Portuguese rule, however, South American elites and public intellectuals soon learned the best way to avoid external meddling and interference was to have their house in order: both domestically and regionally. 


\section{CHAPTER 5}

\section{THE STRUGGLE FOR ORDER:}

WAR AND PEACE IN THE CHACO BOREAL, 1928-1939

Atención pido al silencio Y silencio a la atención, Que voy en esta ocasión, Si me ayuda la memoria, A mostrarles que a mi historia Le faltaba lo mejor. ${ }^{604}$

Of all the wars in Latin America, the Chaco War is the most relevant one. Its importance is not given by the number of casualties produced, the size of the territory that was lost or gained, or the duration of the conflict itself. On that regard, in fact, it was quite a prototypical South American war. The distinctive factor of the Chaco War is that it was the last major armed conflict between states in the continent. It is, in other words, a tipping point in the history of the entire region - a history with a plethora of lessons learned.

The Chaco War also represents the clash between the two weakest countries in the region in terms of military and economic power. After its territorial losses in the war with Chile, confirmed by the 1884 "Pact of Truce," Bolivia became a land-locked country almost overnight. Its particular topography, making it simultaneously an Andean and a valley country, had always made it difficult for either La Paz or Santa Cruz, the two main

${ }^{604}$ José Hernández, La vuelta de Martín Fierro (Buenos Aires: Librería del Plata, 1879), III: 355. ["Attention I ask for silence, And silence for attention, That on this occasion, If my memory allows, I will show you that my story, Was still missing the best part."] 
centers of power, to reach the littoral region with infrastructure, people, or goods. Its ports on the Pacific Ocean, however, were incipient centers of commercial activity together with some Peruvian ports to the north. After the loss of this territory, Bolivia was left with two uneven options: since sparking a new war with Chile was - for the foreseeable futureruled out, the only realistic option for Bolivia at the turn of the century was to search for an outlet to the Atlantic Ocean through the Paraguay River. ${ }^{605}$

Paraguay, for its part, defeated in the War of the Triple Alliance, was forced to abandon its former territorial claims in favor of Brazil and Argentina, and become a de facto "buffer state" between both neighbors. Post-war Paraguay, therefore, returned to a more traditional moderate and isolationist foreign policy of its earlier decades in the 19th century. Powerful Argentine and Brazilian commercial interests penetrated the country in the second half of the 19th century, further deepening its dependence on foreign trade and investments for its productivity and growth.

In this context, the present chapter explores the war between Bolivia and Paraguay from the international society perspective, making focus on three key causal-mechanism related, first, to the sources of restraint and moderation in war, and the taming of the use of force; second, to the progressive institutionalization of regional order; and lastly, to the consolidation of a "pragmatic" version of solidarism among South American states which is different from the more traditional view of "Bolivarian solidarism" most popularly association to Pan-Americanism and inter-American unity.

\footnotetext{
${ }^{605}$ See J. Valerie Fifer, Bolivia: Land, Location, and Politics since 1825 (Cambridge University Press, 1972); Herbert S. Klein, Historia de Bolivia (La Paz: Juventud, 3rd ed., rev. and enlarged, [1992] 2002); Ronald B. St. John, "Hacia el mar: Bolivia's Quest for a Pacific Port," Inter-American Economic Affairs, Vol. 31, No. 3 (Winter, 1977), pp. 41-73; and St. John, "Same Space, Different Dreams: Bolivia's Quest for a Pacific Port,” The Bolivian Research Review, Vol. 1, No. 1 (July, 2001), pp. 1-21.
} 


\section{The Historical Context of the Chaco Dispute}

The origins of the war are firmly set in the mid-19th century before Paraguay's defeat at the hands of the Triple Alliance and Bolivia's defeat in the War of the Pacific. Although both of these wars had a more immediate effect on the Paraguayan and Bolivian foreignpolicy objectives in the early 20th century, the first source of concern by both states about the Chaco Boreal region emerged out of a treaty signed in 1852 between Paraguay and the Confederated Provinces of Argentina. Part of the agreement specifically stated that Paraguay owned its homonymous river "from bank to bank," thus casting a shadow of doubt on Bolivia's official borders with Paraguay over that river. Although Bolivia issued several protests and demanded an official clarification, Argentina's own internal convulsions at the time between the Confederated Provinces, led by Justo J. de Urquiza, and Buenos Aires, led by Bartolomé Mitre, postponed a final resolution of the dispute until the mid-1860s.

During the War of the Triple Alliance (1864-1870), Bolivia maintained a vigilant eye on the fate of Paraguay. Months into the war, the Bolivian President, Mariano Melgarejo, not only extended its personal sympathies to Francisco S. López, the Paraguayan President, but also offered him military support in the form of 12,000 soldiers and "an offensive alliance against the common enemy." ${ }^{\text {"606 }}$ At this time, Bolivia was not yet part of the Quadruple Alliance against Spain, so the possibilities for Melgarejo to join

\footnotetext{
${ }^{606}$ This was reported by the Paraguayan confidential agent in Buenos Aires to his Minister of Foreign Affairs. See from F. Egusquiza to J. Berges, Buenos Aires, February 16, 1865, Paraguay, Archivo Nacional de Asunción, Colección Río Branco, I-30-8-60, No. 3550.
} 
forces with López was a real one. ${ }^{607}$ In January 1865, the Paraguayan Minister of Foreign Affairs, José Berges, wrote to Aniceto Arce, the Bolivian representative in Asunción, insinuating that Paraguayan troops were ready to initiate an offensive on the Brazilian province of Mato Grosso and that this was perhaps "a propitious moment" for Bolivia to revindicate its territories and rights usurped by Brazil in this area. "It is about time that we understand each other on this issue and that you have ports on the Paraguay River." ${ }^{608}$ After a hiatus of several months, explained by the difficulties of communication in the area between both countries, Arce replied in mid-October, congratulating "Paraguay's heroic struggle. ${ }^{" 609}$ The pressing Bolivian concern for the unsettled border with Chile, which was pushing both countries to the verge of war, was abruptly solved by Melgarejo's pact of medianería and the adherence to the Quadruple Alliance against Spain. Although Melgarejo remained in power until January of 1871, no official reply to Berges' proposal nor follow-up conversation about the promised 12,000-strong column was ever issued.

In the course of the war, Bolivia extended to Paraguay and all the members of the Triple Alliance its offer of mediation in conjunction with Chile and Peru. ${ }^{610}$ After the publication of the Treaty of the Triple Alliance in March of 1866, Bolivia joined its allies

\footnotetext{
${ }^{607}$ Ramón Sotomayor Valdés, La legación de Chile en Bolivia desde setiembre de 1867 hasta fines de 1870 (Santiago: Imprenta Chilena, 1872), pp. 98-99.

${ }^{608}$ From J. Berges to A. Arce, Asunción, January 31, 1865, Paraguay, Archivo Nacional de Asunción, Colección Río Branco, I-22-21-1, No. 3560.

${ }^{609}$ From A. Arce to J. Berges, Potosí, October 17, 1865, ibid., I-30-6-65, No. 4102.

${ }^{610}$ See Peru, Ministerio de Relaciones Exteriores, Correspondencia diplomática relativa a la cuestión del Paraguay, publicada por orden de S. E. el Jefe Supremo Provisorio para ser presentada al Congreso Constituyente (Lima: El Progreso, 1867); Bolivia, Ministerio de Relaciones Exteriores, Memoria que el exSecretario General de Estado y actual Ministro de Gobierno, Justicia y Relaciones Exteriores de la República de Bolivia presenta a la Asamblea Nacional Constituyente reunida en 1868 (La Paz: Imprenta Paceña, [1868]), pp. 274-293; and Ricardo Scavone Yegros, Las relaciones entre el Paraguay y Bolivia en el siglo XIX (Asunción: ServiLibro, 2004), esp. pp. 69-79, 95-104.
} 
in issuing an official protest to the governments of the Triple Alliance concerning the content of certain provisions and articles included in the treaty. In particular, Bolivia expressed concern about the projected re-distribution of Paraguay's eastern territories after the war. ${ }^{611}$ Rufino de Elizalde, the Argentine Minister of Foreign Affairs, true to his style, stalled with promises and reassurances that Bolivia's rights on the west bank of the river would be protected. ${ }^{612}$

Over the course of the second half of the 19th century, therefore, Bolivia followed closely the Argentine-Brazilian execution of the Treaty of Triple Alliance. To further assuage Melgarejo's anxieties, in February of 1867, the Brazilian Empire commissioned Felipe Lópes Neto to La Paz to broker an agreement on the portion of the post-war settlement concerning both countries. In less than two months, the crafty negotiator managed to sign a treaty of limits, commerce, and navigation that sealed another territorial loss for Bolivia - this time on the northern fraction of the River Paraguay. ${ }^{613}$ The BoliviaBrazil rapprochement infuriated López, who now regarded Melgarejo with disappointment and contempt. ${ }^{614}$

In June 1867, Bolivia sent Quintín Quevedo to the River Plate republics and Brazil to follow the allies' negotiations more closely, as the end of the war was becoming clearer.

\footnotetext{
${ }^{611}$ From J. Taborga to R. de Elizalde, F. de Almeida Rosa, and A. Flangini, Laja, July 6, 1866, in Bolivia, Ministerio de Relaciones Exteriores, Bolivia-Paraguay: Exposición de los títulos que consagran el derecho territorial de Bolivia, sobre la zona comprendida entre los ríos Pilcomayo y Paraguay, ed. by Ricardo Mujía (La Paz: El Tiempo, 1914), Vol. 2: 740-744.

${ }^{612}$ From R. de Elizalde to J. Taborga, Buenos Aires, August 18, 1866, ibid., pp. 744-746.

${ }^{613}$ See José R. Gutiérrez, La cuestión de límites entre Bolivia y el Brasil (La Paz: Imprenta Paceña, 1868); Walter A. Sotomayor, Relaciones Brasil Bolivia: La definición de las fronteras (La Paz: Plural, 2013), pp. 92-115; Humberto Vázquez-Machicado, "Melgarejo y la Triple Alianza," Revista Khana, Vol. 4/5, No. 21/24 (1956-1957), pp. 226-231; and Sotomayor Valdés, La legación de Chile en Bolivia, pp. 99ff. ${ }^{614}$ From F. López to J. Berges, Paso Pucú, April 11, 1867, Paraguay, Archivo Nacional de Asunción, Colección Río Branco, I-30-13-2, No. 4355.
} 
The Bolivian diplomacy became increasingly active once López's death in Cerro Corá was confirmed, and the articles of the Triple Alliance entered into effect. In 1872, therefore, Mariano Reyes Cardona was commissioned as new plenipotentiary and special envoy to Argentina, Uruguay, and Paraguay, in order to try to involve Bolivia in the post-war negotiations. Facing the resistance of Carlos Tejedor, the new Argentine Minister of Foreign Affairs in the Sarmiento administration, Bolivia turned to Río de Janeiro, where he found only word of reassurance that the stipulations of the treaty of alliance would not damage the interest of Bolivia over the Chaco region. Not yet satisfied with the allies' verbal promises, Reyes Cardona wrote to Salvador Jovellanos, the new Paraguayan President, saying:

The Chaco question cannot be negotiated between [Argentina] and Paraguay, with the exclusion of Bolivia, without making the treaty radically nulled and compromising the bilateral relations between my Government and Yours. No man of common sense could entertain the possibility of a final territorial agreement disputed among three nations that is carried out without the presence of all three. ${ }^{615}$

Despite the numerous efforts of Quevedo and Reyes Cardona, nothing tangible was achieved by Bolivia. Without Bolivia at the negotiating table, Argentina and Paraguay reached an agreement on February 3, 1876. The region known as "Chaco Boreal" was divided into three sections. The "Central Chaco," between the rivers Bermejo and Pilcomayo, was conceded to Argentina [see infra Maps 8 and 9].

${ }^{615}$ From M. Reyes Cardona to S. Jovellanos, Petrópolis, May 21, 1873, Bolivia, Archivo Central Histórico del Ministerio de Relaciones Exteriores y Culto, "Legación en Brasil," received, Vol. 2 (1870-1873). 
MAP 8 - The Chaco Boreal region.

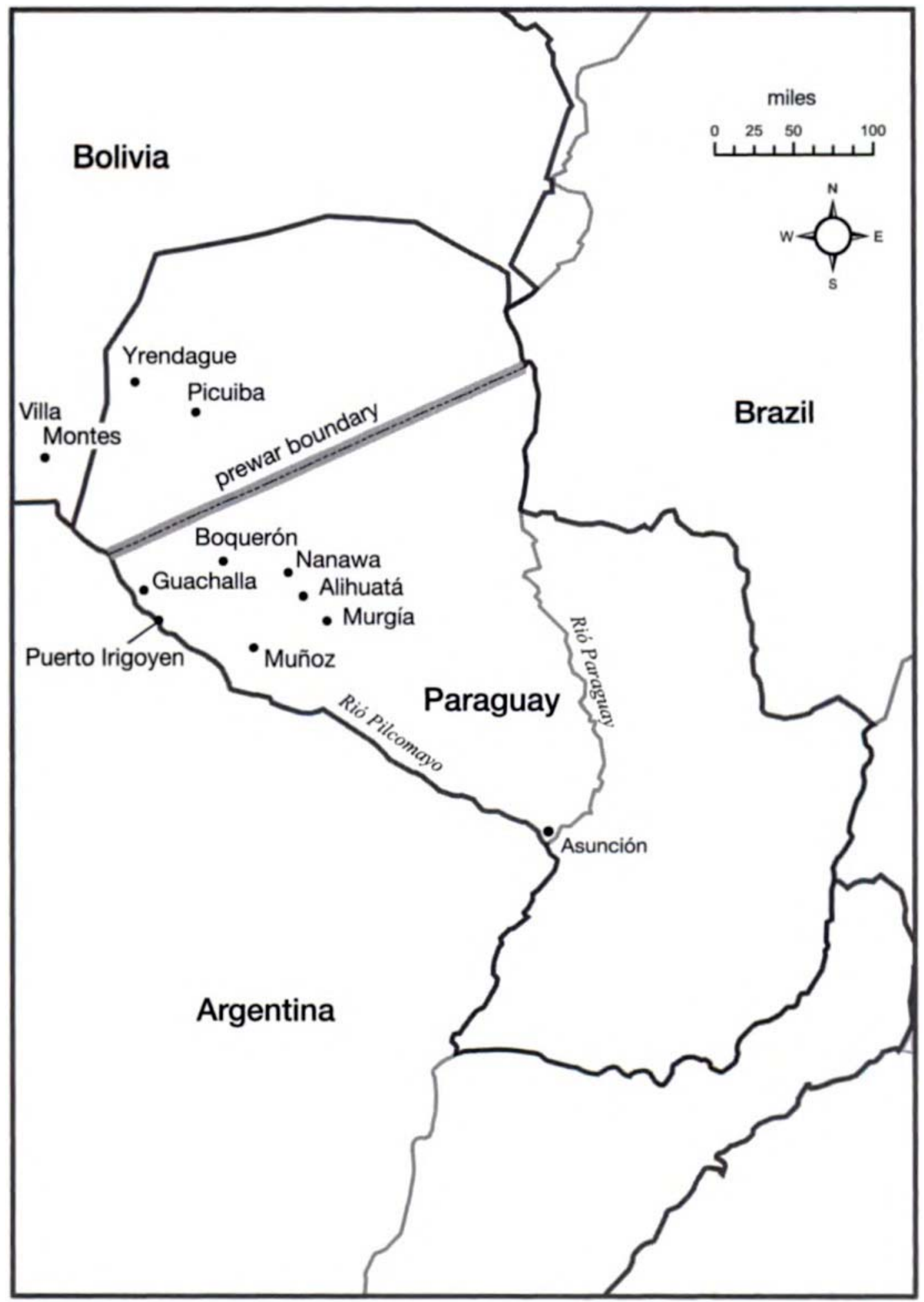

Source: Ann Zulawski, Unequal Cures: Public Health and Political Change in Bolivia, 1900-1950 (Duke University Press, 2007), p. 55. 


\section{MAP 9 - The Chaco War: Main forts and territorial lines (1907-1938).}

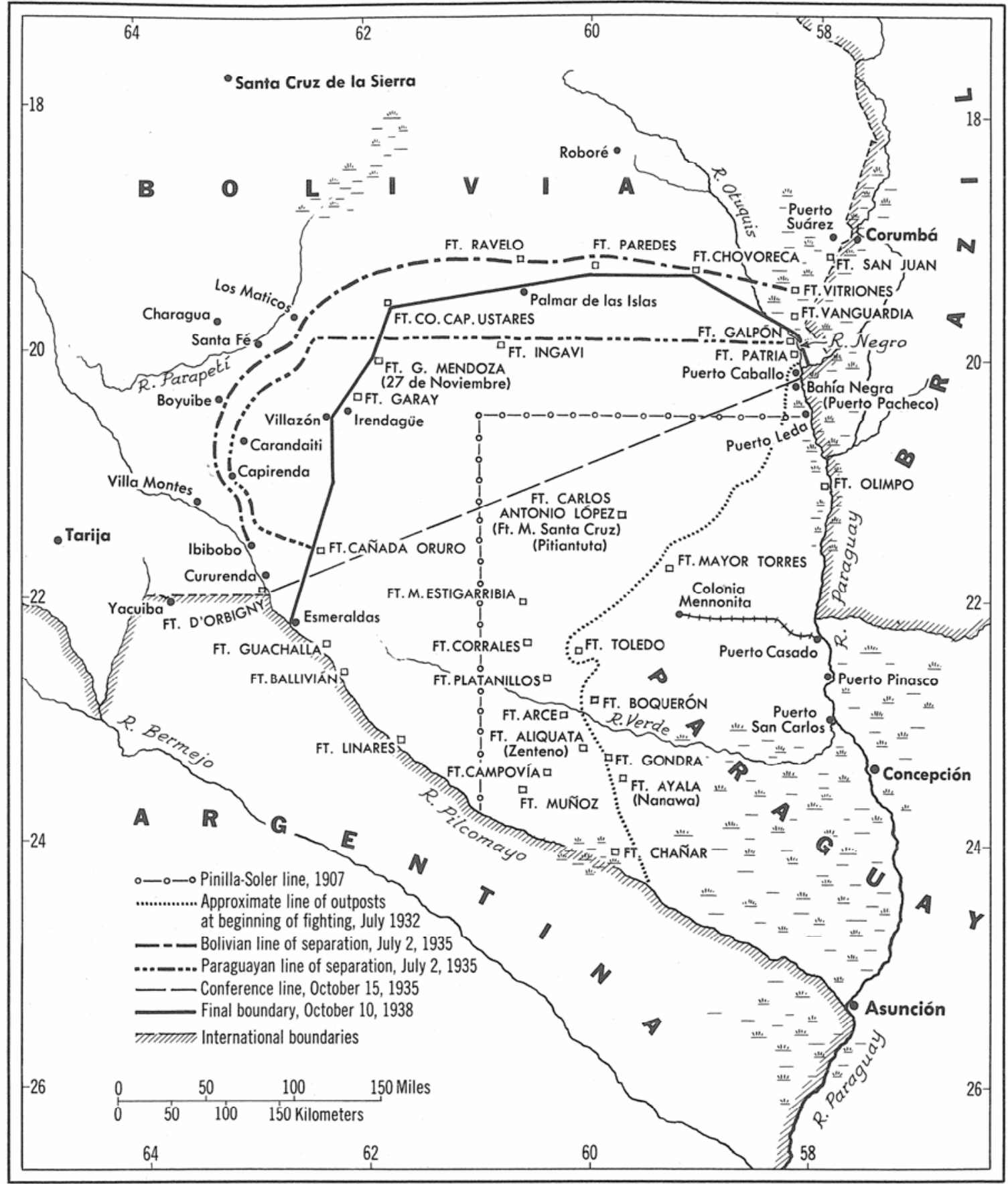

Source: Bryce Wood, The United States and Latin American Wars, 1932-1942 (Columbia University Press, 1966), Appendix. 
The treaty also stated that Argentina officially abandoned any claim to the Bahía Negra port (in the north) and the Verde River (in the center) [see supra MAPS 8 and 9]. The rest of the territory between that point and the Pilcomayo River would be deferred to the arbitration of the U.S. President, Rutherford B. Hayes. Although Bolivia tried to pass a memorandum to re-ascertain its rights on the Chaco Boreal region, the Secretary of States, William Evarts, refused to include the Bolivian petition as valid documentation. On November 12, 1878, Hayes issued his final decision: Paraguay would have legal rights to the entire area between the Verde and Pilcomayo rivers. This also included the Villa Occidental, formerly owned and controlled by Argentine commercial interests.

By 1879, therefore, Paraguay had affirmed all its territorial borders with its main neighbors - except Bolivia. But given the outbreak of the War of the Pacific, between Chile and the alliance Bolivia-Peru, a treaty of limits between Bolivia and Paraguay was eventually approved by Hilarión Daza, the Bolivian President, and signed on October 15, 1879. Between this year and 1894, numerous treaties and protocols were agreed and then not ratified by one or both of the respective congresses, thus postponing the definition of the frontier between Bolivia and Paraguay into the 20th century. ${ }^{616}$

\footnotetext{
${ }^{616}$ For a review of these negotiations, see David Alvéstegui, Bolivia y el Paraguay: La cuestión de límites (La Paz: Renacimiento, 1926); Humberto Vázquez-Machicado, "Un litigio de fronteras en la América del Sud: Bolivia-Paraguay," in Obras completas de Humberto Vázquez-Machicado y José Vázquez-Machicado (La Paz: Don Bosco, 1988), Vol. 7: pp. 167-237; Miguel Mercado Moreira, El Chaco Boreal: Litigio boliviano-paraguayo (La Paz, Atenea, 1929); Mercado Moreira, Historia diplomática de la guerra del Chaco (La Paz: [n/d], 1966), pp. 7-21; Enrique Finot, Nuevos aspectos de la cuestión del Chaco (La Paz: Renacimiento, 1931); Efraím Cardozo, Paraguay independiente (Asunción: ServiLibro, [1949] 2011), pp. 363-413; Carlos R. Centurión, El conflicto del Chaco Boreal: Gestiones diplomáticas (Asunción: La Colmena, 1937); Vicente Rivarola, "El litigio paraguayo-boliviano," Revista Chilena, Año 12, No. 93-94 (enero-febrero, 1928), pp. 47-67; and Scavone Yegros, Las relaciones entre el Paraguay y Bolivia, pp. $123 \mathrm{ff}$.
} 
At the turn of the century, Paraguay and Bolivia had settled all their international borders with their respective neighbors, except with each other. In the case of Paraguay, the country had been achieved this moderate progress despite extreme internal and diplomatic conditions generated by the prolonged occupation and the fiscal constraints produced by the war with the Triple Alliance. In the case of Bolivia, the resolution of its international borders had come via defeat in war, after the loss of an outlet to the Pacific Ocean and the entire region of Antofagasta - rich in guano and sodium nitrates. The importance of this territorial loss is evidenced by the fact that after the War of the Pacific, and until the end of the century, more than half of Chile's governmental revenue came from the exportation of minerals produced in former Bolivian and Peruvian territories. ${ }^{617}$

\section{The Chaco War: The Final Lesson}

In this general historical context, it is important to explore the Chaco War from three interrelated perspectives. First, from the diplomatic point of view, related to the pre-1932 efforts in preventing the conflict. Second, from the more military-political angle, related to the conduct of the war itself. Diplomatic efforts by other South American countries continued in parallel to those of the United States and the League of Nations. All of these initiatives were ultimately ineffective in stopping the war between 1932 and 1935; however, the combination of politico-economic exhaustion by the belligerents and the relentless efforts of the neighboring countries (the A.B.C.P group) ultimately made an armistice possible in June, 1935. Lastly, the chapter explores the angle of "pragmatic solidarity" among South

${ }^{617}$ Richard Sicotte, Catalina Vizcarra and Kirsten Wandschneider, "The Fiscal Impact of the War of the Pacific," Cliometrica, Vol. 3 (2009), p. 97-121. 
American nations and contrasts it with the U.S.-led effort under the doctrine of the "GoodNeighbor" policy to invoke Pan-Americanism and the Monroe Doctrine as a hemispheric basis for collaboration and intra-hemispheric peace.

Discussions about the causes of the Chaco War have always been surrounded by impassioned rhetoric and polemics. Part of the reason for this is that many of the individuals involved in the peace negotiations before, during, and after the war wrote memoirs and pamphlets, and revealed private documentation that expressed some of their own personal as well as national idiosyncrasies. It should come as no surprise, for example, that in both countries there still exists a strong national sentiment of having lost the war. In Bolivia and Paraguay, moreover, there is a general impression that succeeding administrations during the 1930s made either military or diplomatic blunders that lost them the war on the battle field or the negotiating table, respectively.

The voluminous literature on the war, therefore, tends to focus either on the military aspects of the war, ${ }^{618}$ or the equally long period of peace negotiations that followed it. ${ }^{619}$

\footnotetext{
${ }^{618}$ See David H. Zook, The Conduct of the Chaco War (Bookman, 1964); Aquiles Vergara Vicuña, Historia de la guerra del Chaco (La Paz: Imprentas Unidas, 1940-1944), 7 vols; Carlos J. Fernández, La guerra del Chaco (Buenos Aires/Asunción: [n/d], 1955-1987), 7 vols; Eduardo Arze Quiroga, Documentos para una historia de la guerra del Chaco: Archivo Daniel Salamanca (La Paz/Cochabamba: Don Bosco/Universitaria, 1951-1974), 4 vols.; René de la Pedraja, Wars of Latin America, 1899-1841 (McFarland, 2006), pp. 325-392; José F. Estigarribia, The Epic of the Chaco (University of Texas Press, 1950); Bruce W. Farcau, The Chaco War: Bolivia and Paraguay, 1932-1935 (Praeger, 1996); James Dunkerley, Orígenes del poder militar: Bolivia, 1879-1935 (La Paz: Plural, 2006), pp. 203-267; and Elizabeth Shesko, "Conscript Nation: Negotiating Authority and Belonging in the Bolivian Barracks, 1900-1950,” Ph.D. Dissertation, Durham, NC: Duke University (2012).

${ }^{619}$ See Leslie B. Rout, Politics of the Chaco Peace Conference, 1935-1939 (The University of Texas Press, 1970); Tomás M. Elío, La guerra y la paz del Chaco (La Paz: Plural, 2nd ed., [1959] 2011); Tomás G. Elío, La paz del Chaco, una decisión política (La Paz: Plural, 2nd ed., [1988] 2011); J. Isidoro Ramírez, La paz del Chaco: Defensa de la línea de hitos (Asunción: Intercontinental, [1942] 2011); Bautista Saavedra, El Chaco y la conferencia de paz de Buenos Aires (Santiago: Nascimiento, 1939); Félix Paiva Alcorta, La paz del Chaco: Documentos para el estudio de las tratativas que concluyeron en el Tratado de Paz, Amistad y Límites con Bolivia (Archivo Dr. Félix Paiva) (Asunción: El Lector, 1983); Víctor Ayala Queirolo, Paz del Chaco: Gestión Dr. Gerónimo Zubizarreta (Asunción: La Casa del Libro, 1976-1996), 2 vols.; José M. Zubizarreta Ugarte, La paz del Chaco. Tomo I: “Antecedentes del conflicto” (Buenos Aires: Buschi, 1974);
} 
However, few scholars have produced synthesizing accounts of the war from a more holistic perspective. ${ }^{620}$ The existing literature, most commonly produced in Bolivia, Paraguay, or Argentina, is largely out-of-print today and access to some of the primary documentation is difficult even for those living in these countries. Similarly, there is very little academic production in English or in other languages beyond Spanish, that makes the study of the Chaco War (1932-1935) and its subsequent Peace Conference (1935-1938) quite a taxing process. ${ }^{621}$

Since the deepest roots of the dispute over the Chaco Boreal can be traced as further back as the colonial period, when the Spanish "Royal Audiencia of Charcas" exercised jurisdiction over the entire area, many legal experts from Paraguay and Bolivia made important contributions to thicken the files that both countries used to employ to legally justify possession, control, or jurisdiction over the Chaco Boreal. These experts, however, colloquially dubbed "doctores del Chaco" (or "Ph.D.s in the Chaco Question"), have been unable to overcome the basic limitations of the uti possidetis principle in the Americas: that is, the problem of overlapping credentials and documents. ${ }^{622}$

Marco A. Laconich, La paz del Chaco: Un pueblo traicionado (Montevideo: Editorial Paraguay, 1939); Mercado Moreira, Historia diplomática de la guerra del Chaco; Sandra Pérez Stocco, La paz del Chaco: Carlos Saavedra Lamas y la participación de la Cancillería argentina (1932-1938) (Mendoza: Jagüel, 2014); and Bryce Wood, The United States and Latin America Wars, 1932-1942 (Columbia University Press. 1966), pp. 17-166.

${ }^{620}$ See, e.g., Roberto Querejazu Calvo, Masamaclay: Historia política, diplomática y militar de la guerra del Chaco (La Paz: GUM, 4th ed., [1965] 2008).

${ }^{621}$ In preparation for this chapter, the author consulted three Bolivian archives: the Archivo Central Histórico del Ministerio de Relaciones Exteriores y Culto; the Archivo de La Paz, located in the Universidad Mayor de San Andrés, in La Paz, which holds the entire documentation of the Bolivian Delegation to the Buenos Aires Peace Conference; and the Papers of the Elío Family, in La Paz. Access to the personal papers of Tomás Manuel Elío, head of the Bolivian delegation during the peace negotiations, was generously provided by Sergio Elío, his grandson. In Argentina, the author also consulted the Archivo del Ministerio de Relaciones Exteriores y Culto, in Buenos Aires.

${ }^{622}$ See, inter alia, Carlos E. Grez Pérez, La agresión de Bolivia en el Chaco y el "uti possidetis” (Santiago: Neupert, 1932); J. Isidoro Ramírez, El panamericanismo, el arbitraje y la agresión boliviana en el Chaco: 
The main discussions about the causes of the Chaco War, therefore, have typically centered on the more contemporaneous disputes about the competition for the placement of small garrisons or out-posts, called fortines, over the vast $297,000 \mathrm{~km}^{2}$ uninhabited space of the Chaco Boreal. The climate is extremely hostile throughout the year, alternating from arid, scorching-hot and dry weather between May and November, to swampy, mosquitoinfested and densely humid throughout the rest of the year. Seasonal tropical storms flood the central and eastern plains, whereas the sloping western region irrigate the windy areas of the valley. As a prominent Bolivian historian graphically put it, the interior Chaco alternates between "an ocean of mud" and "an ocean of fire." ${ }^{223}$ Parts of the eastern Chaco, however, were crucially important for Paraguay. ${ }^{624}$ In this largely inhospitable region, Bolivia and Paraguay, two of the poorest countries at the beginning of the century, clashed over the effective control of those few areas most susceptible to become arable lands, located near or around sources of fresh water.

The traditional historical accounts, therefore, put the responsibility of the war in the expansionist ambitions of both countries. Those who blame Bolivia, for example, point to the perennial quest for a port as an outlet to the Atlantic Ocean via the Paraguay River. ${ }^{625}$ Those others who see Paraguay as the main culprit, however, point to Paraguay's

Un examen documental (Santiago: [n/d], 1933); Efraím Cardozo, Aspectos de la cuestión del Chaco (Asunción: Imprenta Nacional, 1932); Cardozo, El Chaco en el régimen de las intendencias: La creación de Bolivia (Asunción: Imprenta Nacional, 1930); and Cardozo, El Chaco y los virreyes: La cuestión paraguayo-boliviana según documentos de los archivos de Buenos Aires y de Río de Janeiro (Asunción: Imprenta Nacional, 1934).

${ }^{623}$ Vázquez-Machicado, "Un litigio de fronteras," p. 172.

${ }^{624}$ The areas of the Chaco most proximate to the Paraguay River, for example, provided almost a third of Paraguay's pre-war public revenues. The Bolivian side of the Chaco had little intrinsic value.

${ }^{625}$ See Fifer, Bolivia; Klein, Historia de Bolivia; St. John, "Hacia el mar"; St. John, "Same Space, Different Dreams"; and William L. Krieg, Bolivia's Quest for the Sea (U.S. Department of State Report, Department of State, Washington DC: Office of External Research, 1993). 
nationalism, reinvigorated in the earliest decades of the 20th century by the indirect cultural and political patronage of Argentina ${ }^{626}$ Some historians place the responsibility in the Bolivian oil fields, located on its valley region in the western part of the disputed Chaco area. The expectations of finding more oil in the rest of the Chaco Boreal, according to this view, propelled both countries to compete for its control and occupation. ${ }^{627} \mathrm{~A}$ popular hypothesis proposed by Argentine, Brazilian, and Paraguayan authors, reverses the argument and suggests that it was Bolivia's ambition for oil what precipitated the war. ${ }^{628}$ More drastically, some authors point to the role of international oil corporations, like the Standard Oil Co. and the Dutch Schell Co., as "master puppeteers" behind both countries' interests in the Chaco. These multinational corporations are viewed as pushing Bolivia to

\footnotetext{
${ }^{626}$ See María Oliveira-César, "La política cultural de la Argentina en el Paraguay en los años previos a la guerra del Chaco," América: Cahiers du CRICCAL, No. 39 (2010), pp. 147-156; Liliana M. Brezzo and Beatriz J. Figallo, La Argentina y el Paraguay: De la guerra a la integración (Rosario: Instituto de Historia, Facultad de Derecho y Ciencias Sociales del Rosario; Pontificia Universidad Católica Argentina, 1999); Figallo, "Espacios nacionales y regionales: Conflictos y concertaciones en las fronteras chaqueñas de Argentina, Bolivia y Paraguay," Anuario de Estudios Americanos, Tomo LX, No. 1 (2003), pp. 183-212; Figallo, "Militares, poder y política exterior: El Paraguay y la Argentina entre la paz del Chaco y la Segunda Guerra Mundial," Res Gesta, No. 35 (enero-diciembre, 1996), pp. 45-69; and Figallo, "La Argentina frente a la rivalidad boliviano-paraguaya: Relaciones internacionales y estrategicas económicas, 1920-1945, in La Argentina y el mundo del siglo XX, ed. by Nilsa Alzola and Dinko Cvitanociv (Bahía Blanca: Universidad Nacional del Sur, 1998), pp. 260-269.

${ }^{627}$ On the impact of oil in the Chaco War, see Ronald S. Kain, "Behind the Chaco War," Current History, Vol. 42, No. 2 (August, 1935), pp. 468-474; Herbert Klein, "American Oil Companies in Latin America: The Bolivian Experience," Inter-American Economic Affairs, Vol. 18, No. 2 (Autumn, 1964), pp. 47-72; Herbert Klein and José A. Peres-Cajías, "Bolivian Oil and Natural Gas under State and Private Control, 1920-2010,” Bolivian Studies Journal, Vol. 20 (2014), pp. 141-164; Alfredo M. Seiferheld, Economía y petróleo durante la guerra del Chaco: Apuntes para una historia económica del conflicto paraguayoboliviano (Asunción: El Lector, 1983); Stephen C. Cote, "A War for Oil in the Chaco, 1932-1935," Environmental History, Vol. 18 (October, 2013), pp. 738-758; Cote, "Bolivian Oil Nationalism and the Chaco War," in The Chaco War: Environment, Ethnicity, and Nationalism, ed. by Bridget M. Chesterton (Bloomsbury, 2016), pp. 157-176; Cote, Oil and Nation: A History of Bolivia's Petroleum Sector (West Virginia University Press, 2016); and Alonso Baldrich, "El problema del petróleo y la guerra del Chaco," Revista Americana de Buenos Aires (septiembre, 1934), pp. 9-46. Cf. also Emily L. Meierding, "Dismantling the Oil Wars Myth," Security Studies, Vol. 25, No. 2 (2016), pp. 258-288; and Meierding, "Do Countries Fight Over Oil?" in The Palgrave Handbook of the International Political Economy of Energy, ed. by Thijs Van De Graaf (Palgrave Macmillan, 2016), pp. 441-460.

${ }^{628}$ See, e.g., Geoffrey LaCasse, "Trace of Oil: The Search for the Initiating Factor of the Chaco War," M.A. Thesis, Burnaby, BC: Simon Fraser University, 1987.
} 
war in the late 1920s over control of a potentially oil-rich area. In this view, it is imperialism, not local national ambitions, what caused the war. ${ }^{629}$

The Chaco War spanned two years and nine months (September 9, 1932 - June 12, 1935). Its preceding decade was equally important, for a preview of the war took placealthough it was successfully defused for a time by the diplomatic intervention of the United States and the Argentine government, and the early collaboration of the League of Nations. After the war, in 1935, a diplomatic conference of unprecedented importance and scale in the history of the Americas took place in Buenos Aires - eventually bringing the war to a stable end. Paradoxically, the Buenos Aires peace conference lasted longer than the war itself (June 12, 1935 - July 21, 1938). In the rear-mirror of history, the Chaco War was one of the most anticipated armed conflicts, with decades in the making, and yet it could not be prevented. It left behind close to 90,000 deaths and two economically devastated societies. ${ }^{630}$ Throughout the war, as well as the preceding and following peace negotiations,

${ }^{629}$ See Julio J. Chiavenatto, A guerra do Chaco (leia-se petróleo) (São Paulo: Brasiliense, 1980); and Ricardo M. Setaro, Secretos de Estado Mayor (Buenos Aires: Claridad, 1936), pp. $51 \mathrm{ff}$. Cf. Klein, "American Oil Companies"; and Kain, "Behind the Chaco War," pp. 473-474.

${ }^{630}$ Although different studies provide a wide variation regarding the total number of casualties in the Chaco War, the most reliable assessments agree on a total between 60,000 and 130,000 casualties. Cf. Vergara Vicuña, Historia de la guerra del Chaco, Vol. 7: p. 683; Zook, The Conduct of the Chaco War, pp. 240241; Paul H. Lewis, "Paraguay since 1930," in The Cambridge History of Latin America, ed. by Leslie Bethell (Cambridge University Press, 1991), Vol. 8: p. 234; Farcau, The Chaco War, p. 230; Margaret La Foy, The Chaco Dispute and the League of Nations (Bryn Mawr, 1941 [1946]), p. 134; Wood, The United States and Latin America Wars, p. 95; and Spencer C. Tucker, The Roots and Consequences of 20thCentury Warfare: Conflicts that Shaped the Modern World (A.B.C.-CLIO, 2016), p. 137. In a recent study, Matthew Hughes argues that: "With casualty rates equivalent to those of the powers that fought the First World War, the Chaco War, 1932-35, was South America's bloodiest inter-state conflict of the twentieth century. In a war in which both sides fielded armies totalling almost 400,000 men, Bolivia lost about 2 percent of its population (56-65,000 dead) and Paraguay approximately 3.5 percent (36,000 dead)." See Matthew Hughes, "Logistics and the Chaco War: Bolivia versus Paraguay, 1932-1935," The Journal of Military History, Vol. 69 (April, 2005), p. 412. For a critical review of such widely different estimates, see the meticulous work by Elizabeth Shesko, "Mobilizing Manpower for War: Toward a New History of Bolivia's Chaco Conflict, 1932-1935," Hispanic American Historical Review, Vol. 95, No. 2 (2015), pp. 303-305. 
however, several important political and diplomatic factors show that neither Bolivia or Paraguay faced one another as bitter enemies or with profound cultural-ideological contempt. As many of the soldiers' and officer's own accounts show, this was a technical war, fought for purely strategic reasons, between two rather similar societies and political cultures. As was the case with the Paraguayan War and the War of the Pacific, the soldiers who fell in battle were outnumbered 2:1 by the number of deaths from thirst, famine, exhaustion, or pandemics. ${ }^{631}$ By any standards, however, the Chaco War pales in comparison with the levels of brutality experienced in the two most prominent wars of the 20th century.

\section{The Conduct of the Chaco War: Restraint among Friends}

During the first decade of the 20th century, Argentina and Paraguay subscribed to a final agreement over their shared border-now established on the Pilcomayo River. Although the substantive issue was settled, the more practical aspects of its in-situ demarcation reopened the debate. The Pilcomayo River has several branches along the frontier, so both countries had an interest in settling which one was the stronger branch to serve as the definitive border line. In 1907, after many years of unsuccessful negotiations, the PinillaSoler Protocol was finally signed between Bolivia and Paraguay, thus establishing their first Chaco frontier [see supra MAP 9]. The new agreement included "a mutual commitment not to finance or extend the existing positions." A debate soon arose over whether the respective Ministers of Foreign Affairs had meant to say "positions" or

${ }^{631}$ Ann Zulawski, Unequal Cures: Public Health and Political Change in Bolivia, 1900-1950 (Duke University Press, 2007), pp. 52-85, esp. 61-64; and Farcau, The Chaco War, pp. 230-231. 
"possessions." ${ }^{632}$ Although the treaty was later defeated in the Bolivian congress, the Paraguayan government considered that a certain status quo had been reached between both nations. ${ }^{633}$

In Bolivia, as well as in Paraguay, the first decades of the 20th century came with profound internal unrest and civil war. ${ }^{634}$ Several political factions, from Liberals, to nationalists, to conservatives - and even the armed forces - all became active political players vying for power in a context of economic crisis. This dynamic reinforced Paraguay's disdain for Bolivia's internal politics, although this eventually brought the chief architect of the non-ratification of the 1907 treaty, Daniel Salamanca, to power. ${ }^{635}$

In Paraguay, an internal split within the Liberal party broke out into civil war in 1921. ${ }^{636}$ These common internal convulsions not only damaged the government's finances but would also hinder their handling of foreign policy. Under these constraints, the perceptions of the domestic political actors that could articulate Argentine or Brazilian support were a destabilizing factor, for these perceptions turned local elites more intransigent when dealing with peace negotiations either abroad or internally. This dynamic made them more prone to challenge the establish authorities via the support of an external

\footnotetext{
${ }^{632}$ Farcau, The Chaco War, p. 10.

${ }^{633}$ See Paraguay, Ministerio de Relaciones Exteriores, Informe del Plenipotenciario Dr. Manuel Domínguez acerca de las negociaciones Domínguez-Cano, posteriores al ajuste Soler-Pinilla de 1907 (Asunción: Imprenta Nacional, 1929).

${ }^{634}$ See, e.g., Doratioto, "En busca del equilibrio: La política exterior paraguaya entre 1920 y 1925," Cena Internacional, Vol. 8, No. 1 (junho, 2006), pp. 4-19; and Manuel E. Contreras, "Debt, Taxes, and War: The Political Economy of Bolivia, c.1920-1935," Journal of Latin American Studies, Vol. 22, No. 2 (May, 1990), pp. 265-287.

${ }^{635}$ See Moisés Alcázar, Drama y comedia en el Congreso: Cónicas parlamentarias (La Paz: Juventud, 3rd ed., rev., [1957] 1980); and David Alvéstegui, Salamanca: Su gravitación sobre el destino de Bolivia (La Paz: Patiño, 1962), Vol. 3: pp. 35-116.

${ }^{636}$ On the Paraguayan civil war and crisis of the Liberal ("Colorado") party, see Manuel Peña Villamil, Eusebio Ayala y su tiempo (Asunción: [n/d], 1993), esp. pp. 123-186.
} 
ally. Thus, the domestic politics of Paraguay was "internationalized" by the mere perceptions and calculations of the elites in their disputes for power. ${ }^{637}$ During the Paraguayan civil war, moreover, the government completely neglected the Chaco area, recalling units back to the capital, where they were more urgently needed to confront the opposition. This gave Bolivia a window of opportunity to initiate a policy of occupation of the unprotected or uninhabited zones in the Chaco Boreal. ${ }^{638}$

Bolivia's policy of expanding fortines soon led to the first serious incident between both countries. To counteract Bolivia's incursions, Paraguay initiated a similar policy of counter-occupation, which soon escalated to dangerous proportions and would, a decade later, lead both countries to war. The first armed clash occurred on February 25, 1927, when (quite ironically) four Paraguayans and their local guide presumably got lost and inadvertently ran into the Bolivian Fortín "Sorpresa." After being taken prisoner, Lt. Rojas Silva, the Paraguayan officer, attempted to escape and was killed by one of the guards. Bolivia officially notified Paraguay of the incident and the tensions escalated to the verge of breaking diplomatic relations.

Argentina extended an offer of good offices, which both countries accepted. In April 1927, therefore, both countries were able to relax their diplomatic posture by signing in Buenos Aires the Díaz León-Gutiérrez protocol. Bolivia and Paraguay agreed to send delegates to solve their differences. In September, a formal conference took place in

${ }^{637}$ Diego Abente, "The Liberal Republic and the Failure of Democracy," The Americas, Vol. 45, No. 4 (April, 1989), pp. 527-529; and Doratioto, "En busca del equilibrio," p. 13.

${ }^{638}$ Querejazu Calvo, Masamaclay, pp. 34-41; Cardozo, Paraguay independiente, pp. 400-401; and Zook, The Conduct of the Chaco War, pp. 43-45. 
Buenos Aires. ${ }^{639}$ The Argentine government, led by Marcelo T. de Alvear, proposed a series of options for peace: first, that Paraguay accepted a direct arbitration on the substantive issues; second, that both countries demilitarized their fortines; and third, that both countries issued a joint declaration stating that their advancements had created a de facto armed situation that granted them no rights, nor could be used in allegations to the arbiter. The parties could not reach an agreement on the type of arbitration to be had, nor on the conditions for demilitarization. Bolivia, for instance, agreed to reduce its troops, but not to abandon the fortines that were already under its control. The final agreement was bitter-sweet, for no formal solution was reached, yet both countries issued a shared declaration accepting that their dispute "would not be resolved but other means other than peaceful ones, except in case of self-defense." ${ }^{\prime 640}$

With the failure of the Buenos Aires conference, the situation became extremely tense for Bolivia and Paraguay, but also for their neighbors. Despite Argentine efforts in restraining both countries, significant changes had occurred during the conference. Bolivia, for example, now denied Paraguay any claims over the Chaco Boreal—a radical departure from previous Bolivian foreign policy attitudes. While Paraguay had tried to "normalize" a certain status quo, or modus vivendi, Bolivian officials and so-called "Chaco experts"

\footnotetext{
${ }^{639}$ See Alberto Virreira Paccieri, Bolivia-Paraguay, 5 de diciembre de 1928: Datos para la historia diplomática (La Paz: Eléctrica, 1932).

${ }^{640}$ On the Buenos Aires Conference of 1927, see Paraguay, Ministerio de Relaciones Exteriores, Libro blanco: Documentos relativos a las conferencias de Buenos Aires sobre la cuestión de límites paraguayoboliviana y algunos antecedentes, 1927-1928 (Asunción: Imprenta Nacional, 1928); Bolivia, Ministerio de Relaciones Exteriores, Actas y documentos de las conferencias de plenipotenciarios bolivianos y paraguayos realizadas in Buenos Aires bajo los auspicios del Gobierno Argentino (La Paz: Escuela Tipográfica Salesiana, 1929); and Bolivia, Ministerior de Relaciones Exteriores, Memoria anual del Ministerio de Relaciones Exteriores y Culto presentada al Congreso Nacional (La Paz: Eléctrica, 19281929).
} 
adopted a stubborn legalistic attitude that rejected the present demarcating lines of the de facto situation in 1928. Paraguay, for its part, was trying to avoid war while also attempting to push back some of the Bolivian outposts located either too close to, or simply inside the, "Hayes zone" of 1879 [see MAPS 9 and 10].

The situation worsened rapidly in the second half of 1928. After both countries intensified reconnaissance missions in the area, a new incident erupted between two neighboring fortines: Vanguardia (Bolivia) and Galpón (Paraguay), located in the northern region of the Chaco, near Bahía Negra. Early on December 5, 1928, the Fortín Vanguardia was surrounded by a considerable Paraguayan force. The entire garrison was soon captured, producing only five casualties. The prisoners were taken back to the Paraguayan Fortín Galpón. Later that same day, both the Bolivian and Paraguayan armies mobilized for war. News of the incident soon made headlines all over the world when Bolivia broke diplomatic relations on December 8. Paraguay immediately reciprocated.

Both incidents, first with Lt. Rojas Silva in Fortín Sorpresa and later with Fortín Vanguardia, showed that the Chaco was a serious and intractable dispute which could erupt into major war at any moment—as it did. Behind curtains, presidents Hernando Siles of Bolivia and Eligio Ayala of Paraguay had been acquiring weaponry and military equipment for years in advance in clear preparation for a confrontation. ${ }^{641}$

\footnotetext{
${ }^{641}$ On the pre-war rearmament and military preparations, see Gustavo A. Riart, El Dr. Luis A. Riart y la defensa del Chaco (Asunción: Riart, 1987); Lorenzo N. Guggiari Livieres, El financiamiento de la defensa del Chaco, 1924-1935: Un desafío al liberalismo económico (Asunción: Arte Nuevo, 1983); Antonio E. González, Preparación del Paraguay para la guerra del Chaco (Asunción: [n/d], 1967), 2 vols.; Fernández, La guerra del Chaco, Vol. 1: pp. 19-57; Arze Quiroga, Documentos, Vol. 2: 19-82; Querejazu Calvo, Masamaclay, pp. 67-68; Dionisio Foianini Banzer, Misión cumplida (La Paz: Fondo Editorial de los Diputados, 2nd ed., [1991] 2002); Luis F. Guachalla, Misión en el Paraguay: Mayo, 1930 - Julio 1931 (La Paz: Imprenta de la Universidad Mayor de San Andrés, 1971); E. Jorge Abastoflor Frey, "Misión Guachalla: Situación militar del Paraguay antes de la guerra del Chaco," Gaceta Académica: Academia Boliviana de Historia Militar (2015), pp. 1-7.
} 
MAP 10 - Logistics of the Chaco War.

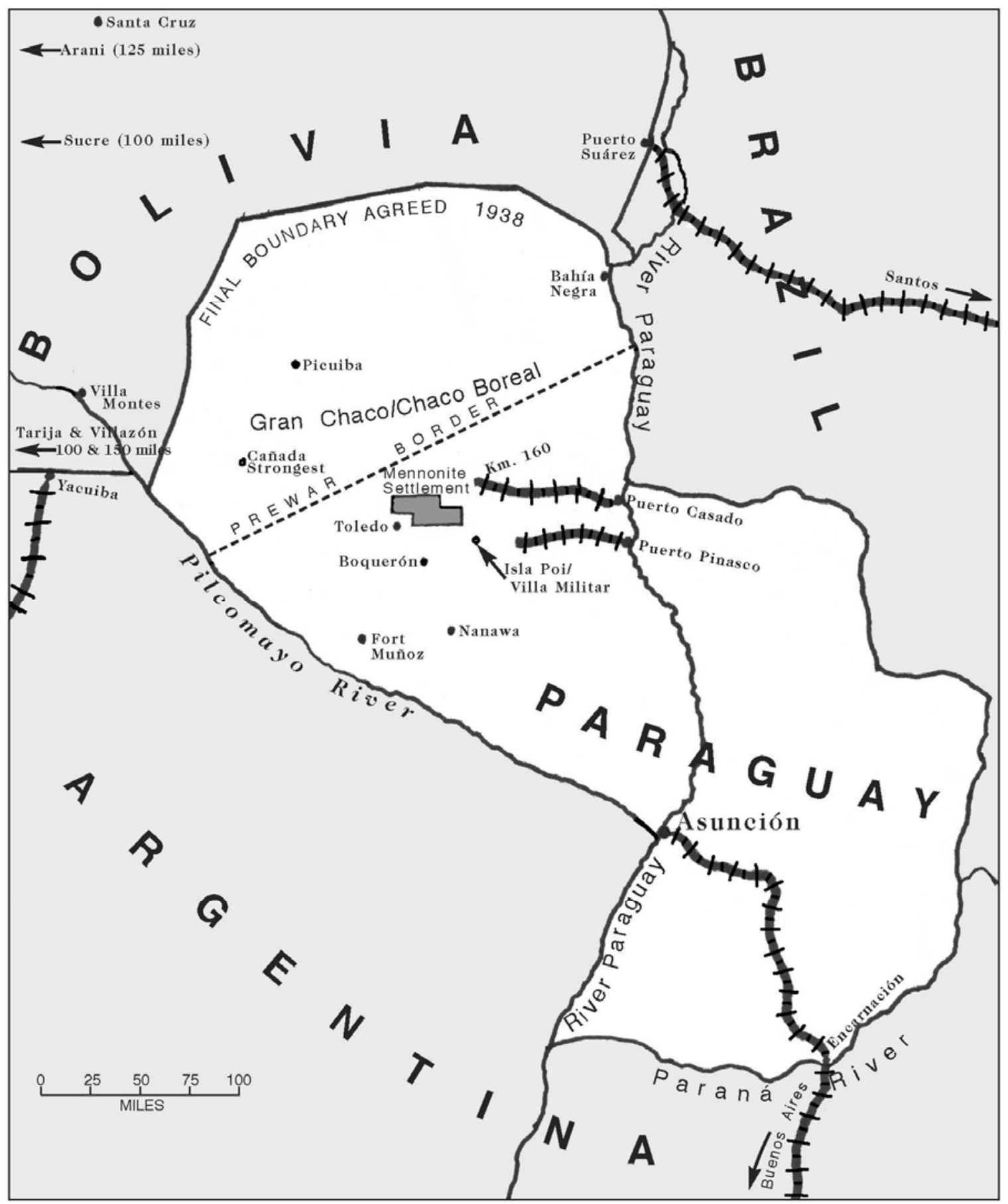

Source: Matthew Hughes, "Logistics and the Chaco War: Bolivia versus Paraguay, 1932-1935," The Journal of Military History, Vol. 69 (April, 2005), p. 427. 
All these preparations were supported by the general public, who in reaction to the incident in December, filled the streets in $\mathrm{La} \mathrm{Paz}$ and Asunción, while the neighboring nations looked with desperation on how two weak and militarily insignificant nations had exacerbated their territorial dispute to the brink of war. On December 14, Bolivian troops captured Fortín Boquerón — a strategic outpost located in the center area of the Chaco [see supra MAP 10]. Shortly after, a second assault captured Fortín Mariscal López. By the end of the day, the two advancing Bolivian companies had pulled back, leaving a small force in Boquerón. The next day, Bolivian airplanes dropped four bombs on Bahía Negra, which did not explode. This episode outraged the Paraguayan people, who demanded war. But Paraguay was yet not ready for one. Its acquisition of armament and equipment had not yet been delivered, so it arranged a small force to adopt defensive positions on those central fortines that could be the next targets of the Bolivian marauding forces.

Coincidentally, the International Conference of American States on Conciliation and Arbitration was meeting in Washington DC and its members decided to extend its good offices, which Bolivia and Paraguay agreed to. During the negotiations (March and September of 1929), however, only moderate success was achieved as not all the issues in the agenda could be solved. The most substantive achievements were those related to the exchange of prisoners, a mutual "forgiveness" and the reestablishment of the status quo ante. Paraguay and Bolivia agreed to normalize their relations and make two clear diplomatic gestures: first, Paraguay would rebuild Fortín Vanguardia, and second, Bolivia would abandon Fortín Boquerón, which could not be occupied right away by Paraguay. ${ }^{642}$

\footnotetext{
${ }^{642}$ See Wood, The United States and Latin America Wars, pp. 21-30; and Russell Cooper, American Consultation in World Affairs: For the Preservation of Peace (Macmillan, 1934), pp. 120-128. The entire documentation of the conference has been published as: United States of America, Department of State,
} 
Back in their respective countries, the delegates who negotiated the agreement were accused of failing to uphold their country's reputation and international honor. Tomás M. Elío, the Bolivian Minister of Foreign Affairs, for example, faced general discontent for not securing a monetary compensation from the Commission of Neutrals, as he had promised. In Paraguay, the final agreement was interpreted as a defeat, for Paraguay looked like the aggressor, while in fact it had been the aggressed. Contrary to Bolivia, which was actively trying to prevent a U.S. intervention by force of arms, Paraguay was trying to precipitate that possibility in order to use it as a guarantee against any Bolivian attack. ${ }^{643}$ However, Bolivia scored some very important points in this negotiation, exposing Paraguayan intransigence on the negotiating table and further adding pressure on the government in Asunción, who now faced an incensed pubic who continued to appeal to war as a solution. ${ }^{644}$

On September 9, 1932, a series of contained and sporadic minor incidents continued to poison bilateral relations and prepared the way for both armies to reach their full potential before the outbreak of the war. It was still a period of rearmament, domestic coalitions, and planning for war. During this transitional stage, however, two important events had a direct impact on the forthcoming confrontation. One was the ousting of the Bolivian president, Hernando Siles, on May 28, 1930, who was replaced by a Council of Ministers and the Chairman of the military government, Carlos Blanco Galindo. But this was a brief interregnum. In March 1931, Daniel Salamanca became President, inaugurating

Proceedings of the Commission of Inquiry and Conciliation: Bolivia and Paraguay, March 13, 1929 September 13, 1929, ed. by Barbara Little (Washington: Sun Book and Job Printing Office, 1929).

${ }^{643}$ Wood, The United States and Latin America Wars, pp. 34-35.

${ }^{644}$ See Bolivia, Memoria anual del Ministerio de Relaciones Exteriores (1928-1929). 
a new period of misfortune for Bolivia. Upon taking office, Salamanca implemented a series of unpopular measures: first, he repressed the political opposition and imposed severe austerity measures; and second, he rekindled a policy of antagonism against Paraguay. It was a recipe for disaster for Bolivia, for the involvement in the war would only deepen the economic problems already endured by the general Bolivian population. ${ }^{645}$

A second major development during this period was Paraguay's acceptance of the offer of good offices extended by the Council of Neutrals, championed by the U.S. The Minister of Foreign Affairs, Gerónimo Zubizarreta, was a seasoned diplomat and knew about Salamanca's reputation as a "hawk," so the acceptance of the good offices was a clever attempt to entangle the recently elected Bolivian president in a web of international mediation led by the U.S. Forced by the situation, and trying not to appear as an intransigent, Bolivia reluctantly accepted the role of the Neutrals as mediators. As part of this agreement, a non-aggression pact was proposed. ${ }^{646}$

Growing unrest in Paraguay, which included a thwarted military coup against President José P. Guggiari and a new incident in the Chaco in September 1931, derailed the Neutrals' efforts to reach an agreement. On April 13, 1932, the Commission of Neutrals made one final exhortation to both countries, expressing its concerns over the multiple

\footnotetext{
${ }^{645}$ See Alvéstegui, Salamanca, Vol. 4; Porfirio Díaz Machicao, Historia de Bolivia: Salamanca, la guerra del Chaco, Tejada Sorzano: 1931-1936 (La Paz: Gisbert, 1955), pp. 15-31; Demetrio Canelas, La guerra del Chaco: Documentos (Cochabamba: Canelas, 1987), pp. 75-225; and Dunkerley, Orígenes del poder militar, pp. 202-215.

${ }^{646}$ On this proceedings, see the extensive documentation published in Paraguay, Ministerior de Relaciones Exteriores, Libro blanco (Asunción: Imprenta Nacional, 1933), Vol. 1; and Bolivia, Ministerior de Relaciones Exteriores, Memoria presentada al Congreso de 1934 (La Paz: [n/d], 1935), pp. 14-58.
} 
reports confirming the secret mobilizations in the Chaco and the acceleration of military preparations and armament procurement. ${ }^{647}$

Although negotiations continued for a few more months, both governments had already convinced themselves that war was "inevitable." Reporting from Buenos Aires, for instance, Vicente Rivarola, Paraguay's representative, captured the same sentiment in Argentina. However, he noted, good reliable sources had confirmed Argentina's support "under the rug" in the upcoming confrontation. ${ }^{648}$ The Argentine representative in London, Manuel E. Malbrán, further reinforced this impression that war was "almost imminent."649 In May, the U.S. Assistant Secretary of State, W. Francis White, who had been presiding over the Committee of Neutrals in Washington, proposed a final project of non-aggression by which both sides would agree not to initiate any military offensive, nor advance their positions further in the Chaco. ${ }^{650}$

On June 15, 1932, while the work of the Committee was still trying to secure the pact, Salamanca ordered Bolivian troops to search for good sources of fresh water in the central Chaco. Mayor Oscar Moscoso, the officer in charge of the operation, warned Salamanca that if any new encounter with Paraguayan troops occurred it could lead to the outbreak of war. However, Salamanca insisted on the order and the Bolivians mobilized to

\footnotetext{
${ }^{647}$ Argentina, Ministerio de Relaciones Exteriores, La política argentina en la guerra del Chaco (Buenos Aires: Kraft, 1937), Vol. 1: p. 263.

${ }^{648}$ Vicente Rivarola, Memorias diplomáticas: El Paraguay en el litigio de límites con Bolivia (Buenos Aires: Ayacucho, 1955), Vol. 2: pp. 80-82.

${ }^{649}$ From M. Malbrán to A. Bioy, London, February 8, 1932, in La política argentina en la guerra del Chaco, Vol. 1: p. 246.

${ }^{650}$ Paraguay, Libro blanco, Vol. 1: pp. 16-165, esp. pp. 38-159; Bolivia, Memoria presentada al Congreso de 1934, pp. 42-53; Argentina, La política argentina en la guerra del Chaco, Vol. 1: pp. 247-352; Rivarola, Memorias diplomáticas, Vol. 2: pp. 88-100; and United States of America, Department of State, Foreign Relations of the United States: Diplomatic Papers, 1932, Vol. 5: pp. 41-55.
} 
take the Pitiantuta (or Chuquisaca) lagoon, near the Paraguayan Fortín Carlos Antonio López. The expedition predictably ended in a confrontation with Paraguayan troops in which their outpost was overcome by a Bolivian assault. After confirmation of the occupation of the fort, Salamanca asked Moscoso to abandon the fort, but the officer replied that it was impossible to do so now, given the arid conditions of the area-water was key. Moscoso suggested a plan for building an alternative fort on the other bank of the lagoon, but the fuse had already been set. ${ }^{651}$

In Asunción, President Guggiari recalled the Paraguayan delegation in Washington, abandoning the Commission of Neutrals conference. Lt. Cnl. J. Félix Estigarribia initiated a successful counter-offensive that retook Fortín Carlos Antonio López. ${ }^{652}$ This marked the beginning of the military stage of the war; a stage which would last for almost three years and cost tens of thousands of lives from countries that were clearly not ready for war.

The war itself developed in two major phases. In the first stage (1932-1934), the Paraguayan forces took the initiative by carrying out a major offensive in the Chaco, during which Pitiantuta and Fortín Carlos Antonio López were retaken. The operation continued towards the center of the Chaco area, occupying other Bolivian outposts like Boquerón, which fell after a bloody encounter. Upon receiving news of the loss of Pitiantuta, Salamanca called a cabinet meeting and demanded almost impossible military feats from his generals, who reacted by trying to carve out some autonomy for themselves in matters of military decision-making. But Salamanca was stubborn and only accommodated slightly

\footnotetext{
${ }^{651}$ See Zook, The Conduct of the Chaco War, pp. 70-71.

${ }^{652}$ Cardozo, Paraguay independiente, pp. 451-416. See also Estigarribia's memoirs: The Epic of the Chaco: Marshal Estigarribia's Memoirs of the Chaco War, 1932-1935, ed. and annotated by Pablo M. Ynsfrán (University of Texas Press, 1950).
} 
to these commonsense demands, further insisting on a full counter-offensive against the southern forts in the Chaco, near the River Pilcomayo. But the incompetence of the President was equally matched by that of his Generals. ${ }^{653}$

When news of the fall of Boquerón reached La Paz, Salamanca ordered General Hans Kundt to retake that strategically important fort for Bolivia. Kundt's preference for clear and frontal attacks contrasted with the outflanking maneuvers of Estigarribia, who at every turn outwitted the Bolivian general. After a series of subsequent encounters and maneuvers for the control of other strategic forts, like Fortín Saavedra, the battle for Fortín Nanawa $^{654}$ represented a horrific disaster for Bolivia. Repeated frontal assaults could not break the Paraguayan defense, and Kundt sealed in that battle not only the deaths of thousands, but also the strategic fate of the war for Bolivia. After the disastrous failure of the Kundt offensive, in which the best Bolivian regulars perished in repeated reckless assaults (more than 2,000 soldiers were lost at Nanawa alone), a new balance in the war emerged. In total, Kundt's frontal assaults cost Bolivia more than 5,000 casualties and 10,000 prisoners, while the Paraguayan losses did not exceed 160 killed and 400 wounded. Without a doubt, the battles for Nanawa were a clear turning point for the war-and for Kundt's generalship.

Despite the tactical blunders committed by Bolivia's command, however, no new forts were lost to the Paraguayans. While the situation still unclear, Estigarribia had adopted a prudent attitude and, after experiencing the carnage of frontal attacks on well-

\footnotetext{
${ }^{653}$ Cf. Arze Quiroga, Documentos; Alvéstegui, Salamanca, Vol. 4; Díaz Machicao, Historia de Bolivia: Salamanca, pp. 32-91.

${ }^{654}$ Known as Fortín Ayala for the Paraguayans.
} 
fortified positions, he decided not to launch an immediate counter-offensive- despite the favorable conditions for doing so. This allowed Kundt's troops to retreat and reorganize. Throughout this initial phase of the war, the Bolivian army counted an important advantage: it had a substantially larger army than the Paraguayans. This meant that, even after such considerable losses in some key strategic battles, La Paz could keep feeding Kundt's war machine. While Kundt awaited reinforcements, therefore, he decided to economize his existing troops and create two strong points of resistance for the eventual Paraguayan advance in Fortín "Km 31" and Fortín Alihuatá.

The subsequent Paraguayan counter-offensive finally came about and, after a series of gruesome battles at Fortines Campo Vía, Alihuatá, and Km 31, the back of the Bolivian army was temporarily broken. At every turn, moreover, the battles not only produced casualties and wounded, but also prisoners. Tens of thousands of them. Vast amounts of weapons and equipment also transferred to the Paraguayans with them, as the Bolivian general retreated frantically. Desertion also became a big problem for La Paz at this point. As Christmas approached, Kundt had a hard time convincing La Paz to accept a 10-day cease-fire suggested by Estigarribia. This truce, however, was finally agreed on December 19,1933 and it was later renewed. ${ }^{655}$ Quite ironically, the first and most brutal phase of the Chaco War ended with an improvised Christmas cease-fire.

The second phase of the war (1934-1935) was a comparatively shorter and less frantic one. It was characterized by smaller and less frequent battles. The general pattern was one of Bolivian retreat and a Paraguayan slow but steady advance towards indisputably

${ }^{655}$ Fernández, La guerra del Chaco, Vol. 3: pp 373-385. 
Bolivian territories located beyond the original area of dispute in the Chaco. In this context, however, Estigarribia's offer of a cease-fire soon became controversial in Paraguay, for it entailed an enormous strategic concession to Kundt by voluntarily halting the Paraguayan offensive, thus allowing the Bolivian commander to reorganize. ${ }^{656}$ After the disaster of Campo Vía, Estigarribia displayed a humanitarian sensibility by not persecuting or killing the scattered Bolivian troops escaping towards the Pilcomayo River. President Ayala justified this decision to the Paraguayan opposition and public opinion by arguing that Paraguay already had its hands full with its 14,000 Bolivian prisoners and adding thousands more would put the country in serious risk of violating international conventions. Paraguay had, according to Ayala, an extremely limited capacity for handling such a high number of prisoners appropriately. ${ }^{657}$ The pace of the war was rapidly accelerating and threatening to get out of control for commanders on the both sides. Both Estigarribia on the field and Ayala in Asunción agreed to take the opportunity of the cease-fire to advance a formal proposal of truce presented to the belligerents.

The general perception at the time of the signing of the Protocol of June 12, 1935, which put into effect a lasting armistice in the Chaco, was that despite the reciprocal offensives and counter-offensives, a certain status quo (or "stalemate") had been reached on the battlefield. The further Bolivia pushed east, the longer the communication and supply lines became. In an inhospitable terrain like the Chaco, it was almost impossible to

\footnotetext{
${ }^{656}$ See Vergara Vicuña, Historia de la guerra del Chaco, Vol. 5: p. 221; Fernández, La guerra del Chaco, Vol. 3: pp. 357-385; René De la Predaja, Wars of Latin America, 1899-1841 (McFarland, 2006), p. 360; cf. Farcau, The Chaco War, pp. 161-162. For the correspondence between Salamanca and Kundt during this critical period of the war, see Arze Quiroga, Documentos, Vol. 3: pp. 137-170.

${ }^{657}$ From E. Ayala to J. Álvarez del Vayo; and from J. Álvarez del Vayo to E. Ayala, both on December 18, 1933, in Paraguay, Libro blanco, Vol. 4: pp. 64-65. See also from J. Álvarez del Vayo to Secretary General of the League of Nations, January 12, 1934, in ibid., Vol. 4: pp. 78-80.
} 
maintain an advantage because the ability to re-supply the offensives on time was severely limited. This applied not just to Kundt's troops, but the Paraguayans too as the further they counter-attacked west, a similar problem emerged for Estigarribia's considerably smaller army. ${ }^{658}$ More territory and forts had to be protected and a substantial change in the topography of the Chaco — closer to the Andes valley—not only gave Bolivians physical advantages but also shortened the supply and communication lines of their larger army. By June 1935, therefore, it was clear for those in power in Asunción and La Paz that little to no further progress could realistically be made in terms of territorial advantages. Paraguay had reached it maximum geographical extension in terms of occupation of the Chaco but had to voluntarily stop its own momentum. Bolivia, previously in general retreat, had managed to contain the Paraguayan advance somewhat, but faced a difficult dilemma between preparing a painfully costly all-out counter-offensive and risk utter defeat, or take a more moderate path assisted by diplomacy and the collaboration of the interested regional neighbors.

The respective public opinion in each country was divided. In La Paz, the general public was incensed by the conduct of the war and demanded a culprit for the Nanawa and Campo Vía disasters. Although large part of the blame rested on Kundt himself, the army generals conspired to depose President Salamanca, who had personally insisted on making such costly strategic (and even tactical) military decisions. A new government, led by José L. Tejada Sorzano, took office on November 28, 1934. This administration would preside

${ }^{658}$ See Shesko, "Mobilizing Manpower for War," pp. 301-309, 329-330. 
over the rest of the war and well into the first year of the peace conference that followed the armistice of June 12, 1935.

In Paraguay, the domestic front was much more convulsed. From August 1932 to February 1936, Paraguay had maintained a relatively stable consensus both politically as well as militarily. Unlike Bolivia, the operative relation between President Ayala and Estigarribia had been a positive one overall. Although pressures were mounting up in Paraguay over the "fateful" decision to slow down the offensive in a key moment of the war, the duo Ayala-Estigarribia gave Paraguay a steady leadership during the most crucial periods of the war, which despite the differences in size and capabilities between both armies, was crucial for Paraguay's military superiority on the battlefield. ${ }^{659}$

Although the Liberal party in Paraguay exercised a hegemony over other political factions, most political battles occurred within the Liberal party itself. In February of 1936, however, a nationalist movement deposed President Eusebio Ayala and initiated the "febrerista" revolution. As it happened with Salamanca's removal in Bolivia, the change in political leadership had a more direct impact on the political and diplomatic front rather than the military one, where strategy and commanders remained the same despite the changes in government. ${ }^{660}$ The conservative, catholic, and anti-communist movement that

${ }^{659}$ Cf. Rogelio Ayala Moreira, Por qué no ganamos la guerra del Chaco (La Paz: Talleres Gráficos Bolivianos, 1959); Alfredo Seiferheld, Estigarribia, veinte años de política paraguaya (Asunción: Laurel, 1983); and Policarpo Artaza, Ayala, Estigarribia y el Partido Liberal (Asunción: Palacios, 3rd ed., [1946] 1988).

${ }^{660}$ On the febrerista impact on the diplomatic negotiations with Bolivia and during the Buenos Aires Conference of Peace, see Juan Stefanich, El 23 de octubre de 1931: Primera batalla por la defensa del Chaco y primer grito de la revolución de febrero de 1936 (Buenos Aires: Febrero, 1959); Stefanich, La diplomacia de la revolución (Buenos Aires: El Mundo Nuevo, 1945); Stefanich, La guerra del Chaco y la misión de la Sociedad de las Naciones (Asunción: [n/d], 1934); cf. Efraím Cardozo, 23 de octubre: Una página de historia contemporánea del Paraguay (Buenos Aires: Guayra, 1956); and Ezequiel González Alsina, El entregador del Chaco (Asunción: Zamphirópolos, 1968). 
put Cnl. Rafael Franco in power from February 17, 1936 to August 13, 1937, shared many of the fascist characteristics of contemporary Europe, but channeled for many in Paraguay a fervent sentiment of nationalism experienced for the first time by the large masses. ${ }^{661}$ Paraguay had risen from the ashes of a 19th-century Paraguay devastated in a war with its neighbors, thus the Chaco War came to represent a contemporary opportunity for a younger generation to reaffirm a sense of self in a new war - a war that they believed Paraguay was close to winning decisively.

In La Paz, a similar view led to the replacement of Tejada Sorzano in May 1936 by a series of military commanders. Between May 1936 and the very end of the peace conference in Buenos Aires, in 1938, Germán Busch and David Toro alternated positions as Chairmen of a Military Junta. ${ }^{62}$ In their view, two promising factors gave them renewed hope: one was the potential plans for enlisting younger Bolivians to the army (and with whom to launch a future offensive against the current Paraguayan positions); and the other was the fact that by pushing back the Paraguayan line the negotiators in Buenos Aires could perhaps obtain more concessions from the intermediaries and from Paraguay itself. In short, although Bolivia was going to the negotiating table after losing some ground in the war, a diplomatic victory on the international front could still be achieved.

\footnotetext{
${ }^{661}$ See Artaza, Ayala, Estigarribia y el Partido Liberal, pp. 145-160; Brezzo and Figallo, La Argentina y el Paraguay, pp. 296-309.

${ }^{662}$ On this period, see Díaz Machicao, Historia de Bolivia: Toro, Busch, Quintanilla: 1936-1940 (La Paz: Juventud, 1957).
} 


\section{Filling the Void: Institutionalizing Order in the 1930s}

During the war (1932-1935), two types of peace negotiations took place. One was centered around the involvement of the United States as a mediator in the conflict; and a second one was the active participation of the League of Nations early in the dispute. The international context, in the aftermath of the First World War, was marked by a growing tension between a new group of powers (Nazi Germany, Fascist Italy, Imperial Japan, and Authoritarian Spain), who had defied the League's legitimacy and tested its effectiveness in Abyssinia and Manchuria. A second group contained free-market, Liberal-democratic nations, and were led by Great Britain and the United States.

In this global context, the U.S. and the League interventions in the Chaco dispute represented an extra-regional effort in institutionalizing order in South America between two of the weakest links in the regional structure of power. Despite the military and economic might of the U.S. at the time, the international financial crisis initiated in the late 1920s had left world markets in profound distress. This global depression also affected South America, given its role as net producer of primary-sector goods and other strategic commodities, like oil, gas, and minerals. ${ }^{663} \mathrm{~A}$ war in South America not only took resources away from a much-needed global economic recovery in the 1930s, but also generated a source of strategic uncertainty that the League was morally and legally bound to attempt to redress, for Bolivia and Paraguay were signatory members. The U.S., for its

\footnotetext{
${ }^{663}$ See Paulo Drinot and Alan Knight, eds., The Great Depression in Latin America (Duke University Press, 2014); and Leslie Bethell, ed., The Cambridge History of Latin America (Cambridge University Press, 1991), Vol. 8.
} 
part, had an interest in maintaining the entire Western Hemisphere free of war and of extraregional interference — so the two would-be pacifiers clashed.

Beyond the League of Nations, there was no other international institutional framework to which states could appeal to for assistance in times of war. Although deeply limited in its own capacity to act effectively in the Chaco dispute, the League was the only "peace machinery" at the time. ${ }^{664}$ There existed an informal normative framework which played an incipient role in the late 1860s and 1870s in Latin America. During the Chaco War, however, these normative frames of references largely supported a restrained conduct in the war, which helped ameliorate some of the intrinsic and unavoidable horrors of war. ${ }^{665}$ Given this "institutional void" in the 1930s, the Peace Conference of Buenos Aires (19351938) became a perfect opportunity for the South American society of states to take the front seat and ultimately triumph where others had failed. During the Peace Conference, South American states came to terms with the issue of "war" as a common regional problem from which no responsible neighbor could approach with detached indifference or rapacious opportunism. This, in turn, prompted a strategic awakening of a regional sense of raison de système, based on the necessity of bringing order and stability to their international relations, according to principles acceptable and tolerable for all.

After an exhausting war, fought in such an inhospitable place as the Chaco Boreal, the two belligerents had become stalled, finding no more room for military maneuvering.

\footnotetext{
${ }^{664}$ Kain, "The Chaco Dispute and the Peace System," Political Science Quarterly, Vol. 50, No. 3 (September, 1935), pp. 321-342.

${ }^{665}$ See, e.g., Zulawski, Unequal Cures, pp. 52-85; Gerardo Céspedes Gutiérrez, “Apuntes sobre la historia de la medicina en la guerra del Chaco (año de 1933)," Archivos Bolivianos de la Historia de la Medicina, Vol. 11, No. 1-2 (enero-diciembre, 2005), pp. 74-88; and Aurelio Melean, La sanidad boliviana en la campaña del Chaco (Cochabamba: Imprenta de la Universidad, 1938).
} 
Bolivia and Paraguay then turned to diplomacy to continue their struggle for the possession of the Chaco. The opportunity was ripe for Argentina to emerge from the diplomatic backstage of the war and propose a collective mediation that would put an end to the conflict for good. Tomás M. Elío, the Bolivian Minister of Foreign Affairs, and Luis A. Riart, his Paraguayan peer, were officially summoned by Carlos Saavedra Lamas, the Argentine Minister of Foreign Affairs, to meet in Buenos Aires to initiate a peace conference. On June 12, 1935, therefore, delegates from La Paz and Asunción signed a protocol that definitely closed the military phase of the war. Now an even bigger battle was about to begin in Buenos Aires, under the eyes of the entire hemisphere and the world. ${ }^{666}$

Despite bringing the military action to an end, the signing of the 1935 protocol generated a larger controversy, which protracted the diplomatic conflict for several years. In contemporary Bolivia and Paraguay, for example, the Protocol of June 12, 1935, is still the subject of polemic commentary in newspapers and certain academic works. When Elío and Riart convened in Buenos Aires in 1935, the armistice that had made possible for the negotiation to take initiate was still fragile and war could return at any moment. It had been

\footnotetext{
${ }^{666}$ The voluminous correspondence and private and confidential documents from this conference have been partially reproduced in Argentina, Ministerio de Relaciones Exteriores, La paz del Chaco, 1935-1939: Compilación de documentos (Buenos Aires: Frigerio, 1939). Other important documentation can be accessed through Argentina, Congreso de la Nación, La paz del Chaco (Buenos Aires: Imprenta del Congreso Nacional, 1938); ibid., Ministerio de Relaciones Exteriores, La política argentina en la guerra del Chaco (Buenos Aires: Kraft, 1937), 2 vols.; and ibid., La neutralidad argentina en el conflicto boliviano-paraguayo (Buenos Aires: Peuser, 1933). Unavoidably, since other confidential and reserved correspondence, telegrams, and memos, remain unpublished, consultation in the national archives of the respective Ministries of Foreign Affairs in Buenos Aires, La Paz, and Asunción (cf. the Bibliography listed at the end of the present dissertation), is necessary for an exhaustive evaluation of the Peace Conference proceedings. Other valuable published documents are United States of America, Department of State, Foreign Relations Between Latin America and the Caribbean States, 1930-1944 (Gale, 2012); ibid., Foreign Relations of the United States: Diplomatic Papers, 1932: Vol. 5 (1948); 1933: Vol. 4 (1950); 1934: Vol. 4 (1951); 1935: Vol. 4 (1953); 1936: Vol. 5 (1954); 1937: Vol. 5 (1954); 1938: Vol. 5 (1956); and ibid., The Chaco Peace Conference: Report of the Delegation of the United States of America to the Peace Conference held at Buenos Aires, July 1, 1935 - January 23, 1939 (Washington DC: Government Printing Office, 1940).
} 
made possible, as well, by the opening of a small window of opportunity given by the advancing Paraguayan troops closer into Bolivian territory and the timely intervention of the A.B.C. mediators.

The pressure on the Bolivian and Paraguayan diplomats, therefore, was enormous. If, at any moment, their respective governments felt that the negotiations in Buenos Aires were leading nowhere, war could still resume - thus shattering all chances of peace. The Bolivian delegation confronted not only a stubborn Paraguayan delegation that was tied by domestic party intrigue and public opinion pressure, and could concede little in order for the formal peace negotiations to advance, but also internal opposition among its own delegation. In this unpromising context, Tomás Elío made a courageous "executive" decision. In the morning of June 8, 1935, Elío, who was a prominent national figure and had served as Chancellor in the late 1920s during the first incidents in the Chaco, decided to sign a protocol despite the prior approval of his government, or the consultation of the rest of the delegation with him in Buenos Aires. ${ }^{667}$ With this decision, if later disavowed by the Bolivian president, Elío was risking more than his reputation and position as head of the delegation. He was also burying his political aspirations for the forthcoming presidential elections in Bolivia. ${ }^{668}$

\footnotetext{
${ }^{667}$ Tomás Manuel Elío's frustration with these multiple obtacles to even initiate the negotiations of peace is well captured in his personal documentation and files, which formed the basis of his book on the subject. See Elío, La guerra y la paz del Chaco. Some years later, the Bolivian Chancellor, Tomás Guillermo Elío, published La paz del Chaco, una decisión política in defense of his father's diplomatic action in defense of peace during the Buenos Aires conference.

${ }^{668}$ Various correspondence exchanges with Bolivian personalities after the war confirm this. See "Papers of the Elío Family," La Paz. See also Gustavo Medeiros Querejazu, Ensayos diplomáticos (La Paz: Ministerio de Relaciones Exteriores y Culto; Academia Diplomática "Rafael Bustillo," 1997), pp. 133-136, 208-212.
} 
Elío's decision generated mixed reactions in Bolivia at first. Although the President ultimately approved his action, some historians and prominent politicians in Bolivia publicly condemned the decision, equating it with the surrendering of all of Bolivia's interests in the Chaco. ${ }^{669}$ The general public, on the contrary, exploded in celebration after the confirmation of the agreement of peace. Although the status quo was momentarily in Paraguay's favor since the Bolivian troops had retreated from the central region of the Chaco, the Paraguayan advance had been effectively stopped - a fragile condition that Elío wanted to maintain at all cost. Rumors of a preparation of a new Bolivian counter-offensive gave critics, such as Bautista Saavedra, who was a member of the Bolivian delegation to the conference in Buenos Aires and former president of Bolivia, reasons to believe that more benefits could have been achieved for Bolivia if only Elío had not been "duped" by the Argentine Minister of Foreign Affaits. Bautista Saavedra wanted to soften the Paraguayan delegation with more of the same "prudent intransigence" he had proposed in earlier meetings. Other members of the delegation, for their part, such as Miguel Mercado Moreira, also criticized Elío's decision as "unnecessarily rushed and naïve." While Saavedra called the episode an "immolation" of Bolivia, Roberto Querejazu Calvo, a prominent Bolivian historian, qualified it as an "entrapment" that led to Bolivia's "surrender." ${ }^{670}$ Several years after this polemic episode, Tomás G. Elío, the Bolivian chancellor's son, looked back at these accusations with a more critical and retrospective

\footnotetext{
${ }^{669}$ See, e.g., Saavedra, El Chaco y la conferencia de paz de Buenos Aires; Mercado Moreira, Historia diplomática de la guerra del Chaco, pp. 212-234; and Querejazu Calvo, Masamaclay, pp. 382-395.

${ }^{670}$ See Saavedra, El Chaco y la conferencia de paz de Buenos Aires, passim, esp. pp. 84, 104; Mercado Moreira, Historia diplomática de la guerra del Chaco, p. 213. Querejazu Calvo, Masamaclay, pp. 389ff. Cf. Elío, La guerra y la paz del Chaco.
} 
eye, arguing that "it [was] easy, at the impetus of popular clamor, to embark a nation in war; the difficult thing [was] to assume the responsibility to put an end to it, especially when there were successes and defeats that penetrated deep into the national consciousness." 671

A careful reconsideration of Elío's personal correspondence, documentation, and notes, however, suggest that far from naïve or "defeatist," his decision had been prudent and far-sighted, justified by the information conveyed to him by the military advisors in the delegation, who had a direct line of communication with the army commanders themselves - thus bypassing the civilian government in La Paz or the other diplomats in the delegation, such as Saavedra or Mercado Moreira. According to several confidential reports, the rumored "new counter-offensive" was not realistically possible without imposing an unbearable burden on the younger generations of Bolivians under the age of twenty. Nor wes there any real evidence, according to these reports, to support the idea of creating a better situation in the Chaco than the fragile one momentarily maintained during the fragile negotiations in Buenos Aires. If any change in the positions had occurred, this would have certainly been in favor of Paraguay — and not Bolivia. More importantly still, the positions of the Paraguayan army at the time were alarmingly close to the city of Santa Cruz and the newly-discovered oil fields in southeast Bolivia. ${ }^{672}$

\footnotetext{
${ }^{671}$ Elío, La paz del Chaco, una decisión política, p. 18.

${ }^{672}$ See "Papers of the Elío Family," La Paz; and "Misión en Argentina y Delegación para negociar la paz del Chaco," Box 5 (1933-1938), ALP/TME, MA-PP, No. 1, 4, 6, 7; Box 6 (1934-1936), ALP/TME, MA-PP, No. 9, 11; Box 7 (1933-1936), No. 1-2; located in the "Tomás Manuel Elío" Archive of Archivo de La Paz, Universidad Mayor de San Andrés, La Paz.
} 
Behind Elío's decision, therefore, there was a carefully calculated assessment of the real strategic situation for Bolivia. It was not ideal, and certainly not in accordance to the plans imagined by the government when the war was declared. Although Elío did not consider the condition of Bolivia in the Chaco as optimal at the time, he also did not think it could be improved by force. He believed that if Bolivia overplayed its hand in Buenos Aires, the whole country would soon have been at risk - and not just the disputed area of the Chaco Boreal. ${ }^{673}$

After the signing of the Protocol, therefore, the Peace Conference focused on turning the provisions of the protocol into a definitive treaty of peace, which would eventually be signed in 1938 and ratified a year later. The central objectives of the Conference were four. First, to resolve the territorial dispute through a direct agreement between the parties, or by arbitration of the International Permanent Court of Justice, in The Hague. Second, to promote the reciprocal return of prisoners captured during the war. Third, to create a Commission to determine the issue of the responsibility of the war-that is to say, which one was the "aggressor." And fourth, to resolve all the practical issues related to the execution of the security provisions and guarantees for the cease-fire. Additionally, the two delegations agreed to an immediate cease-fire and the creation of a Neutral Military Commission, which would deploy in the Chaco to certify the cease-fire and put into effect the truce. The Military Commission played a crucial role in freezing all

${ }^{673}$ Cf. Elío, La guerra y la paz del Chaco, pp. 27-85; and Saavedra, El Chaco y la conferencia de paz de Buenos Aires, p. 88. 
military operations in the disputed zone and in the provisionary demarcation of buffer areas between the armies. ${ }^{674}$

One of the first obstacles faced by the delegates throughout the whole conference, however, was the chronically unstable domestic governments of each party to the negotiation, which created tensions not only between the delegations of Bolivia and Paraguay, but also among their representatives themselves, as determined by their political party affiliation or personal ambitions and reputation. A second source of obstacles was the tense truce between the standing armies in the Chaco, positioned only some miles away from each another, and which excreted enormous pressure on the issues discussed in Buenos Aires. Although the members of each delegation were charged with the prominent objective of elaborating a "good" peace treaty favorable to their respective countries, interpersonal and ideological factors also strained the relation between delegates of the same country. In the Bolivian case, for example, Elío continuously faced the "prudent intransigence" of Bautista Saavedra, a former Bolivian president and prominent member of the delegation. Saavedra's positions were noting but prudent, but very intransigent, suggesting at times extremely inflexible positions even on secondary issues. ${ }^{675}$

In the Paraguayan delegation, too, tensions regularly emerged when the head of the delegation or other members were replaced after a change of government in Asunción. The laborious work, for example, of Gerónimo Zubizarreta during the Ayala administration was

\footnotetext{
${ }^{674}$ On the workings of the Neutral Military Commission, see Estevão Leitão de Carvalho, A paz do Chaco: Como foi efetuada no campo de batalha (Rio de Janeiro: Ministério da Guerra, Biblioteca do Exército, 1958); and Alfredo R. Campos, Misión de paz en el Chaco Boreal (Montevideo: Centro Militar, 1954), 2 vols.

${ }^{675}$ For the personal jousts between Saavedra and Elío on the question o the ratification of the protocal, $c f$. Saavedra, El Chaco y la conferencia de paz de Buenos Aires, p. 88; and Elío, La guerra y la paz del Chaco, pp. $27 \mathrm{ff}$.
} 
threatened by his sudden replacement for Juan Stefanich during the febrerista revolution. ${ }^{676}$ In less than a year, the fall of the revolution in Asunción restored civilian government, and President Félix Paiva named J. Isidro Ramírez as the new head of the Paraguayan delegation in Buenos Aires. ${ }^{677}$

Another factor that the traditional historiography usually accepts as an obstacle during the conference, but which upon closer scrutiny seems to have been a crucial component of the final agreement, is the "controversial" figure of the Argentine Chancellor, Carlos Saavedra Lamas. As the host nation, Argentina was bound to play a central role. However, several written accounts by other participants in the conference often reserve only negative commentary about Saavedra Lamas. For example, he is repeatedly accused by the U.S. delegate, Spruille Braden, of being a petulant and verbose individual, with a high opinion of himself, and who on several occasions let his personality become an obstacle to otherwise promising diplomatic solutions developed by him in the course of the negotiations. ${ }^{678}$ Similar opinions can be found in the Brazilian, or Chilean accounts of the sessions and meetings during the conference. ${ }^{679} \mathrm{It}$ is interesting to note,

${ }^{676}$ Cf. Stefanich, La diplomacia de la revolución; Ayala Queirolo, Paz del Chaco, 2 vols; and Benjamín Vargas Peña, "La guerra y la paz del Chaco: Entrevista Gerónimo Zubizarreta-José Félix Estigarribia," Cuadernos Históricos, Vol. 1, No. 1 (enero-febrero, 1988), pp. 1-62.

${ }^{677}$ See Ramírez, La paz del Chaco; and Paiva Alcorta, La paz del Chaco.

${ }^{678}$ See Spruille Braden, Diplomats and Demagogues (New Rochelle, NY: Arlington House, 1971), pp. 114 192. See also Wood, The United States and Latin American Wars, pp. 52-62, 67-73, 98ff; and Mario Rapoport, "Braden y la guerra del Chaco," Página 12, April 29, 2009.

${ }^{679}$ See Osvaldo González Forster, La neutralidad chilena en el conflicto del Chaco (Santiago: El Imparcial, 1936); and Helder Gordim da Silveira, Argentina x Brasil: A questão do Chaco Boreal (Porto Alegre: EDIPUCRS, 1997); Gordim da Silveira, "A visão militar brasileira da Guerra do Chaco: Projeção geopolítica e rivalidade internacional na América do Sul," Antíteses, Vol. 2, No. 4 (julho-dezembro, 2009), pp. 649667; Francisco Doratioto, "As políticas da Argentina e do Brasil em relação à disputa boliviano-paraguaia pelo Chaco (1926-1938)," in A visão do outro: Seminário Brasil-Argentina (Brasília: Fundação Alexandre de Gusmão, 2000), pp. 439-477; León E. Bieber, "A guerra do Chaco e as relações brasileiro-bolivianas no período 1930-1945: Um caso de reorientação da política exterior do Brasil," Ibero-Amerikanisches Archiv, Neue Folge, Vol. 22, No. 3/4 (1996), pp. 267-288; Luiz A. Moniz Bandeira, “A Guerra do Chaco,” Revista 
however, that the top members of the respective delegations of Bolivia and Paraguay usually do not have such negative views of the Argentine minister. It is mostly those who competed with Saavedra Lamas for a central role as "champions" of the Chaco Peace who had derogatory words saved for his personae. Both Brazil and Chile at some point during the early stages of the dispute tried to host the Peace Conference in their respective capitals. For the neighboring countries, including Argentina, the Bolivia-Paraguay dispute was also a contest of intra-regional prestige and global recognition. In the case of the U.S., it is usually U.S. authors, like Bryce Woods, who fail to objectively assess Braden's own extravagant and idiosyncratic personality and, much like Saavedra Lamas, a very high opinion of himself. A mere glimpse at Braden's anecdotes from the Peace Conference in Buenos Aires suffices to see that perhaps more than contempt, it was envy what motivated his personal antagonism towards Saavedra Lamas - who received the Nobel Peace Prize in 1936 for his efforts in the Chaco Peace Conference in Buenos Aires. ${ }^{680}$

One of the many aspects that made Saavedra Lamas' subtle diplomatic manipulation more a well-planned act than a mere display of his ego is that, in what many observers noted only as a stalling (or filibustering) technique in the duplicity behind Argentina's support for Paraguay, Saavedra Lamas was in reality "testing the waters" for ripe moments during the negotiations to introduce the "right kind" of propositions. Argentina's tacit support of Paraguay during the war, a pseudo-patronage inherited from

Brasileira de Política Internacional, Vol. 41, No. 1 (1998), pp. 161-200; and Moniz Bandeira, Argentina, Brasil y Estados Unidos de la Triple Alianza al Mercosur: Conflicto e integración en América del Sur (Buenos Aires: Grupo Editorial Norma, 2004).

${ }^{680}$ For his personal account of the negotiation, see Carlos Saavedra Lamas, Por la paz de las Américas (Buenos Aires: Gleizer, 1937). 
the end of the Triple Alliance War, gave Saavedra Lamas the upper hand in "reading" the regional strategic context as well as he read Paraguay's internal politics. He was the first diplomat to realize that peace in the Chaco would only come when those- - like the U.S.who professed to be trying to solve the war out of "good-will" or "disinterested" intentions, focused more on the internal political dynamics of the parties and less on the actors at the negotiating table itself. Delegates, after all, were bound by the domestic balances of forces in their respective countries. In the rare case of Elío, it took the Bolivian diplomat several interactions with Saavedra Lamas to come to understand that memorable statesmen always those who know when they should stand above the mass of partisan and ideological antagonisms, and tend for the larger common interest not only of its own constituency but also of the whole context of which that constituency is also a part.

In this sense, each of the four objectives of the conference were able to be achieved precisely because of (rather than "in spite of") the slow and grinding process instituted by Saavedra Lamas, which consisted of stalling and prolonging those situations that, with the manipulated passing of time, could be normalized into more permanent realities (or faits accomplis), accepted by the parties. On the substantive issues, that of Bolivia's quest for a port on the Paraguay River and that of Paraguay's of the portion of the Chaco previously established by international treaties with Argentina and via arbitration, the conference was able to provide a final solution after several rounds of negotiations lasting more than two years. After such arduous negotiations, Paraguay agreed to grant Bolivia a northern portion of the Chaco region, with a small port just north of Bahía Negra. This port, however, had no practical value for navigation in that sector of the river, since is it was only possible to use by smaller ships built for shallower waters - not the kind of ships that could transport 
heavy mineral cargo to the Atlantic Ocean. Paraguay, for its part, managed to secure the main portion of the Chaco region that it had always claimed, yet only poorly maintained.

\section{The Triumph of Pragmatic Solidarity}

The Chaco War and the Peace Conference that followed it offer fertile examples of the interplay between two approaches to solidarity in the Americas: one, led by the United States' unilateral vision of a hemispheric order under its leadership; and another, built out of an impending necessity by the three major states: Argentina, Brazil, and Chile, to reestablish order in their immediate neighborhood. The first victim of the clash between these two competing visions was the League of Nations itself, which was pulled into the region by Argentine and Chilean diplomacy to act as a counterweight to the U.S. "goodneighborly" involvement, but was then swiftly dismissed at the first opportunity when the U.S.' own failed mediation cleared the way for the South American powers to play a larger role in the Chaco dispute themselves. Their guiding principle was always to find South American solutions to South American problems. This strategy necessarily entailed playing one actor against the other and excluding (or severely limiting) the role of the U.S. in the process.

No other South American Chancellery embodied this strategy better than the Argentine one. Argentina's diplomacy, under the personal leadership of Saavedra Lamas, was keen on tilting the region's support towards the U.S. or the League depending on the issues being negotiated and Argentina's convenience. When sanctions or a more coercive approach were deemed necessary to constrain one of the two belligerents, for example, Argentina and its regional partners did not hesitate in soliciting the League's involvement 
to be "the bearer of bad news" for the belligerents A similar approach was followed with the U.S. to expose the limits of its Good Neighbor policy. This offered chances for Chile or Argentina to exert more leverage in the negotiations with their respective "protégés." They put the burden of the 1934 arm-sales embargo imposed on both belligerents, for example, flatly on the U.S., creating "moral hazard" for Washington. This also had the double purpose of "softening" the belligerents before other interventions by Argentina "at the appropriate time." After using the U.S. or the League to test less popular proposals and peace plans, Argentina would unsurprisingly enjoy higher chances of submitting mutually acceptable propositions based on the failure of previous attempts by the U.S. or the League. At the same time, not only would Argentine diplomacy gain prestige and recognition for itself, but the mediation would also get closer to a mutually agreeable and realistic solution. Thus, both Argentine and common regional interests would to be truly served.

Among the A.B.C. countries, however, there was also competition and rivalry. Chile enjoyed over Bolivia the same type of leverage and influence that Argentina had over Paraguay. Both Chile and Argentina were uniquely intertwined with the domestic interests of the two belligerents and, thus, could have a deeper impact on the course of the negotiations by helping shape Bolivia's or Paraguay's internal politics. In this sense, therefore, success in the Peace Conference was not just a matter of adjusting a final treaty to the interests of Bolivia and Paraguay, but also a question of harmonizing the interests of Argentina and Chile inter se. This reality became evident for Washington only after incurring several failures of its own: first in the 1920s, then again in the 1930s as part of the Commission of Neutrals, and lastly in the Buenos Aires Peace Conference itself-being outplayed by Saavedra Lamas. Frustrated with the A.B.C. group's better control of the 
political processes running behind closed doors, the U.S. unsuccessfully tried to develop a parallel channel via the Pan-American conference system. ${ }^{681}$

The United States' interest in the Chaco War had two levels. At the level of government, the U.S. declared its neutrality and championed the three initiatives mentioned above. At the level of private individuals and companies, however, the war offered multiple opportunities for U.S. manufacturers to make large profits by selling weaponry and munition to Bolivia. Although Paraguay counted with the patronage of Argentina, who also provided equipment, loans, and military intelligence, the government deeply resented the U.S. indirect contributions to its enemy, Bolivia. Trying to correct this embarrassing aspect of U.S. foreign policy, President Franklin D. Roosevelt declared an arms embargo on both belligerents. ${ }^{682}$ Argentina and Paraguay maintained that the smuggling of weapons into Bolivia had continued despite the official posture in Washington, and further accusations were levelled at the U.S. Standard Oil Co. in Bolivia, suspected of indirectly financing Bolivia's war effort. ${ }^{63}$

The Good Neighbor policy implemented by the United States during the interwar period and the early 1940s followed a foreign-policy principle that, at least on paper, should have been welcome by all South American nations-and particularly by the two

\footnotetext{
${ }^{681}$ See, e.g., Carlos Saavedra Lamas, La Conferencia Interamericana de Consolidación de la Paz (celebrada en Buenos Aires, del $1^{\circ}$ al 23 de diciembre de 1936) (Buenos Aires: [n/d], 1938).

${ }^{682}$ See United States of America, Foreign Relations of the United States: Diplomatic Papers, 1934, Vol. 4: pp. 290-292. See also Wood, The United States and Latin American Wars, pp. 63-65, 75-76, 367; Charles G. Fenwick, "The Arms Embargo against Bolivia and Paraguay," The American Journal of International Law, Vol. 28, No. 3 (Jul., 1934), pp. 534-538; Manley O. Hudson, "The Chaco Arms Embargo," International Conciliation, Vol. 17 (May, 1936), pp. 217-246; and Rout, Politics of the Chaco Peace Conference, pp. 64-67.

${ }^{683}$ See Michael L. Gillette, "Huey Long and the Chaco War," Louisiana History: The Journal of the Louisiana Historical Association, Vol. 11, No. 4 (Autumn, 1970), pp. 293-311; and Rout, Politics of the Chaco Peace Conference, pp. 64-67.
} 
belligerents. Its main claim was that of the non-intervention into the domestic affairs of other American states and the deepening of cultural, political, and commercial ties between them and the U.S. ${ }^{684}$ In practice, however, this policy was also in tune with the more traditional Monroe Doctrine-and many in fact considered it a mere amendment or corollary to it. ${ }^{65}$ After the radically interventionist approach of prior administrations, such as Woodrow Wilson's in the 1920s, the Good Neighbor policy was a substantial improvement in the tone of U.S. relations with the rest of the American nations. However, Roosevelt's attempts at mediating in the Chaco War were ultimately resented by Bolivia and Paraguay, for despite the non-coercive and non-interventionist aspects of the U.S. policy, the belligerents themselves saw more legitimacy in the action of fellow South American countries, like Argentina or Chile, than in the United States. The belligerents were equally angered by the U.S. refusal to intervene or pressure one another's enemy, and frustrated by even the most minimal insinuation of pressure on themselves. In a speech to the Bolivian Congress, delivered on August 6, 1934, President Salamanca declared that:

The new pacifist doctrine of the American nations makes its grand entrance into the world, with violent steps at the expense of a weak country. The neutrals, with our own consent, exercise nothing more than their good offices, in accordance to international law. They now come forward in the role of tutors and judges, pretending to preside over us in our affairs, exercising a jurisdiction which we have not conferred upon them. These violent acts are done in the name of the American nations, invoking legal principles that condone all violence. Such acts entail the conclusion of the principle of sovereign independence and is based on strength. ${ }^{686}$

\footnotetext{
${ }^{684}$ See Bryce Wood, The Making of the Good Neighbor Policy (Norton, 1967); and Wood, The Dismantling of the Good Neighbor Policy (University of Texas Press, 1985).

${ }^{685}$ See Cooper, American Consultation in World Affairs, pp. 109-191.

${ }^{686}$ Presidential message to the opening sessions of the Bolivian Congress, August 6, 1934, in La política argentina en la guerra del Chaco, Vol. 1: pp. 391-392.
} 
That very same day, Argentina, Brazil, Chile, and Peru issued a joint declaration in a similar line, expressing their desires to "save the interests of peace in America," now severely threatened by "the imminent danger of war" and in protection of their "moral responsibility as members of the same continental family." ${ }^{967}$

In this context, the role played by the League of Nations merits a close examination, for both Bolivia and Paraguay were part of the international organization, while the U.S. was not. The League of Nations first involvement in the Chaco dispute was prompted by the early incident in Fortín Vanguardia, and the inability of the early U.S.-led efforts to prevent the war. ${ }^{688}$ During the early years of the war, Argentina and Chile had also attempted a bilateral mediation, which was later defeated by Bolivia's and Paraguay's loss of confidence in both negotiating states ${ }^{689}$ With the failure of the Commission of Neutrals and the Mendoza Agreements, therefore, two changes took place. On one hand, Chile and Argentina incorporated Brazil and Peru to their subsequent offers of mediation, formalizing the A.B.C.P group - which was successful in the end in brokering the peace between Bolivia and Paraguay. On the other hand, the belligerents themselves saw in the League of Nations a valid alternative interlocutor.

\footnotetext{
${ }^{687}$ Joint declaration by the A.B.C.P countries, August 6, 1934, in ibid., p. 392.

${ }^{688}$ On the involvement of the League of Nations in the Chaco dispute, see La Foy, The Chaco Dispute and the League of Nations; Ronald S. Kain, "The Intervention of the League of Nations in the Chaco Dispute (December 5, 1928 to May 12, 1934)," M.A. Thesis, New York, NY: Columbia University, 1936; Kain, "The Chaco Dispute and the Peace System"; Russell Cooper and Mary Mattison, "The Chaco Dispute: The Development and Phases of the Bolivia-Paraguay Conflict and League Intervention," Geneva Special Studies, Vol. 5, No. 2 (1934), pp. 1-25; Helen P. Kirkpatrick, "The Chaco Dispute: The League and Pan Americanism," Geneva Special Studies, Vol. 7, No. 4 (1936), pp. 21-43; Kirkpatrick, "The League and the Chaco Dispute," Foreign Policy Reports, Vol. 12, No. 9 (July 15, 1936), pp. 110-120; and Liudmila Korableva, "La Liga de las Naciones y la guerra del Chaco: 1932-1935," Estudios Avanzados, Vol. 11 (2009), pp. 29-48.

${ }^{689}$ See Bolivia, Ministerio de Relaciones Exteriores, La conferencia de Mendoza y el conflicto del Chaco (La Paz: Eléctrica, 1933).
} 
However, although the Spring of 1933 was a propitious moment for the League, given the impasse that had emerged in the Chaco, the League of Nations represented a third "formula of peace" to be added to the already complex web of negotiators, good offices, and intermediaries. As Ronald Klein eloquently put it, "too many cooks spoiled the broth. ${ }^{\circ 90}$ The A.B.C.P, the U.S., the Commission of Neutrals, plus the numerous proposals from each, overwhelmed the peace process leading to an inefficient and unproductive overlapping. In the absence of regional or hemispheric formal institutions for conflict resolution, the actors most affected by the geographic proximity of the war, or its economic effects, rushed to fill in the void and thus indirectly helped prolong the war. Even when in coordination with one another, such as in the imposed embargo on arms sales to Bolivia and Paraguay by the U.S. and the League, the U.S. (a non-member) had a stronger interest in keeping the League out of intra-hemispheric affairs. ${ }^{691}$ Although the belligerents were members, the U.S. was not. Thus, the League represented for Washington an unnecessary European meddling in the Americas. Lastly, after the League's determination on the issue of the responsibilities for the war, Paraguay—sanctioned equally as if an aggressor by the League's resolutions - abruptly abandoned the League to avoid any legal sanctions. This defiance further deepened the lack of trust and credibility in the League's capacity for brokering peace between even two small and weak countries in South America. ${ }^{692}$

\footnotetext{
${ }^{690}$ Kain, "The Intervention of the League of Nations," p. 47.

${ }^{691}$ See Calvin L. Christman, "The Chaco Dispute and United States Diplomatic Involvement, 1928-1935," M.A. Thesis, Nashville, TN: Vanderbilt University, 1966, pp. 81-113; and Wood, The United States and Latin American Wars, pp. 361-362.

${ }^{692}$ Paraguay, Ministerio de Relaciones Exteriores, Los orígenes de la guerra del Chaco (Asunción: Imprenta Nacional, 1934).
} 
Despite these numerous hurdles, not all factors in the League's involvement in the Chaco dispute were negligible or unimportant. The work of the League of Nations, through its special commission for the Chaco dispute, helped set the legal ground with which the efforts of the neighbors (the A.B.C. group, plus Peru) and the U.S. were able to implement the Neutral Military Commission in the Chaco to certify the armistice and preside over the demilitarization of both contenders in the Chaco. The prior work of the League also facilitated the later work in the Peace Conference during the negotiation and application of the issue of the liberation and exchange of prisoners. ${ }^{693}$

The history of the Chaco War, and its equally hard-fought peace, shows the strengths and limitations of a regional society of states when it lacks a more formal institutional framework for the maintenance of order. It was only with the creation of the Organization of American States (OAS), in 1948, that such institutional void would finally be filled, thus opening a new chapter in the history of the consolidation of South America's society of states and in the provision of a self-standing regional order for and by its own members.

\section{Testing Alternative Explanations}

The case of the Chaco War offers the possibility to evaluate the competing hypotheses identified in this dissertation. Contrary to the previous case-studies, the Chaco War and its subsequent Peace Conference seem to offer a very fertile ground for most of the seven alternative arguments.

${ }^{693}$ La Foy, The Chaco Dispute and the League of Nations, pp. 138-143. 


\section{H2: The U.S. as a Regional Hegemonic Stabilizer}

The U.S. involvement in the Chaco dispute was a constant feature that came at a moment of great international standing and power for the U.S. Through implementation of the Good Neighbor policy, Roosevelt imprinted an important quota of self-restraint never-beforeseen in the U.S. foreign policy toward the region. Furthermore, the Good Neighbor policy praised the most cherished of diplomatic principles for all Latin American nations: that is non-intervention into the domestic affairs of other countries. Prima facie, therefore, the Chaco War is a case that creates an extremely "easy" test for the $\mathrm{H} 2$ hypothesis. However, as seen in the present chapter, the facts of the case show that not only was U.S. "pacifying" role unsuccessful to prevent, ameliorate, or stop the war, but also that its very participation was contested and repudiated by all the South American nations involved-including at different moments even the belligerents themselves.

This is an extremely important fact when evaluating the relative strength of the $\mathrm{H} 2$ hypothesis. Despite the presence of the two background conditions: preponderance of power and hegemonic willingness to lead, none of the three main expectations for the case obtain. The U.S. failed to suppress war in its own strategic "backyard," despite serious and continuous attempts in institutionalizing through the work of the Commission of Neutrals its role as the central disinterested broker of the peace. This fact is compounded by the fact that the two belligerents were military pygmies in comparison to the U.S. power at the time. Its own version of an inter-American "solidarity" based on the Good Neighbor policy and channeled through the parallel regional conferences, betrayed in fact a deeper wedge of a longer duration between South American countries and the U.S.: that is, the diverging interpretations of the principles expressed in the Monroe Doctrine. While U.S. 
interpretation has always been unilateral, that is via an asymmetrical "tutelage" of the entire hemisphere, the South American nations—-specifically Argentina, Brazil, and Chile—have in contrast defended a version of those same principles in a more multilateral, cooperative, and thus truly "solidaristic" fashion.

These aspects make the failure of the $\mathrm{H} 2$ to explain the Chaco War case all the more spectacular and resounding, and - at least on this single case - show the severe limits in terms of explanatory power. Failure in this case, when seen in a larger perspective with the previous cases, also cast a very long shadow on the overall strength of the hypothesis as a whole when trying to ascertain South America's "long peace" in the 20th century. Although the rise in U.S. power since 1776 to the present, presumably felt more strongly in its own regional area of influence that anywhere else, correlates powerfully with the progressive decline in frequency and ferocity of war in South America, the mismatch between its hypothetical premises and the test results when applied to the historical cases shows that it makes for a poor theoretical explanation of the long peace in South America.

\section{H3: A Balance of Power in the Chaco Boreal}

The second alternative hypothesis is concerned with the balance of power (H3). The Chaco War, and in particular the Peace Conference, shows that considerations about the balance of power in the region were a crucial component of the case. The Chaco war, for example, did not begin until both Bolivia and Paraguay felt they had reached a good-enough level of parity inter se. This can potentially illuminate Paraguay's and Bolivia's reluctance to initiate a war in the 1920s despite similar fortín-related "incidents" occurring during that preliminary period. Mutual fear, that is, interacted with the militarization of the early 1910s 
and 1920 s to produce the outbreak of the war only when the "trigger" of Bolivian reckless policy of deeper penetration in the Chaco created a perception of "threat" to Paraguay's survival. Given that for Paraguay, unlike Bolivia, the Chaco had a crucial economic importance, representing more than two-third of its government revenue, the situation blends itself perfectly for the premises and expectations of the $\mathrm{H} 3$ hypothesis.

In conclusion, therefore, the $\mathrm{H} 3$ argument performs very strongly on at least two of the three main expectations for the case. On the issue of alliances, as well, the fact that Chile's backing of Bolivia and Argentina's support for Paraguay were instrumental in bringing about peace, shows the validity of the third prediction. It was precisely the "right" alignment of Bolivian and Paraguayan interests with those of the two larger regional neighbors, what helps explain the failure of all other peace proposals championed by the U.S., a coalition of neutrals led by the U.S., or the League of Nations itself.

\section{H4: Geopolitics of the South Pacific}

The geopolitical hypothesis (H4), based on the role of geography in making war an impossibility, and thus incentivizing "coping" institutional mechanisms according to crisscrossed geopolitical alliance dynamics, find a very hard test in the Chaco War. Ultimately, the $\mathrm{H} 3$ hypothesis fails in explaining the case because it would be difficult to find a more inhospitable area in the entire western hemisphere for two of the weakest nations to wage a war than the Chaco Boreal. However, in spite of the extremely obtrusive conditions of the terrain and weather, Bolivia and Paraguay managed to wage for almost three years(!) the first "modern" war of the Americas in the 20th century. Failure in this test, is doubly-decisive against the H4 hypothesis. 
Instead of finding the core propositions strongly confirmed, the Chaco War distinctively disproves them. For example, instead of seeing the unique topography of the Chaco Boreal area as making large-scale war impossible, it actually helped two weak states prolong it, for the long pauses imposed on the contenders by the seasons and changing conditions of the area allowed the two countries to rearm, resupply, and return to the fray when weather conditions permitted.

The second expectation is, perhaps, the only one with an incline of confirmation, for the Buenos Aires Peace Conference offered the same type of "coping mechanisms" expected in the $\mathrm{H} 4$ argument. However, this should only be taken partially because the successful institutional "coping mechanism" came after the signing of the armistice (Protocol of June 12, 1935), and not during the war itself. Other factors, apart from the rather regular and predictable topographical and meteorological conditions of the Chaco, pushed the two belligerents towards peace. The same conditions were there before during and after the entire period; however, it was only when the countries had become exhausted with the war effort and a technical deadlock emerged on the battlefield that the confluence of other factors-rather than geopolitics—allowed peace.

Finally, the alliance dynamics according to shatterbelts and checkerboards seems to explain quite well the evolution of the conflict—and even the politics of the diplomatic negotiations. However, upon closer scrutiny, the "facts of the case" seem to suggest that the shelterbelt between Chile-Bolivia, on one side, and Argentina-Paraguay, on the other, was determined more by their historical and cultural past than by "objective" geo-political factors. After all, it was under the same geopolitical scenario that decades earlier Chile fought Bolivia, and Argentina battled Paraguay. The fact that in the Chaco War the so- 
called "shatterbelts" aligned according to that specific patter comes from the inherited semi-tutelage that Argentina and Chile had over their two prior enemies, defeated and occupied after two serious wars. In short, the geopolitical aspects of the Chaco Boreal seem to have made war worse and more protracted, instead of shorter and more limited.

\section{H5: Common Culture}

The H5 hypothesis is premised on two background conditions: the pacifying role of a common legacy of anti-imperialism, and the "triggering" intervention of a foreign power. Although the U.S. was not a foreign power- that is, an extra-hemispheric power, it was considered by the South American countries involved in the Chaco peace process as an extraneous actor with interests that could not be "tuned" to those of the South American region as a whole. The expectation of solving the Chaco dispute in order to remove all possible opportunities for "foreign" intervention of meddling certainly seems to have played a role in the Chaco War case.

But although the general condition and the "trigger" are present, the case-specific expectations obtain only partially or with slight modification. In the case of the "eradication of war," the eloquent and embellished rhetoric of the Peace Conference would certainly support the idea that the architects of peace, like Saavedra Lamas, were intending precisely "the end of all wars" in the Americas. This same notion was an intrinsic component of the U.S. Good Neighbor policy as well. After all, the were no more wars after the Chaco War. At least no more large-scale, interstate ones between neighbors. However, if one looks beyond the rhetorical proclamations and correlates with the historical evolution of the region form there forward, it becomes evident that the correlation is merely coincidental- 
but not causal. After the creation of the OAS, and in all other institutional and legal arrangements in the continent, the use of force ("war") is not banned or eradicated, but merely "tamed" and channeled to fulfill specific objectives, such as self-defense and the application of collective legitimate sanctions on other unruly members. Although war is profoundly curtailed, it remains a factor in intra-hemispheric relations.

Secondly, the Chaco War is certainly not an exemplary case for "unified" action or potential unification against common threats, like the U.S. or war itself. The rivalry dynamics between the U.S. and the League or the A.B.C.P. countries, as well as among the South American countries themselves, makes the Chaco War a poor case for testing the second prediction of the $\mathrm{H} 5$ hypothesis.

Lastly, and quite importantly, the factor of "ideological solidarity" deserves consideration. This expectation, although partly shared with the H1 hypothesis, must be considered as a third contender between $\mathrm{H} 1$ and $\mathrm{H} 2$ propositions about solidaristic cooperation in general. Unlike the $\mathrm{H} 2$ interpretation, however, the ideological component of $\mathrm{H} 5$ clashes with the pragmatic component of the $\mathrm{H} 1$ interpretation. To solve these differences and partial overlapping, it is crucial to consider that in the $\mathrm{H} 5$ argument the expectation is for states to develop a profound security cooperation that is triggered by their common struggle against imperialism and external interventionism. When applied to the Chaco War case, the first factor to consider is that the U.S.-although potentially considered as a "foreign" power-intervened in the case only diplomatically, and not militarily or even coercively. Moreover, this diplomatic intervention was an intervention pro peace, not an intervention of war. These two elements run in the face of the H5 propositions, dealing a devastating blow. If the U.S. was not an aggressor and was only in 
form, yet not in substance, a foreign power to the region, then it becomes illogical and invalid to explain South American states' negative reactions towards the Good Neighbor policy as it applied to the case of the Chaco War.

\section{H6: State-Weakness in the Chaco War}

The H6 argument finds strong applicability to the Chaco War case. As analyzed in the present chapter, the most important factor that helped the peace agreement finally reach a stable and consensual point was the Argentine and Chilean diplomatic readjusting to the domestic conditions in Bolivia and Paraguay. The absence of this factor, as it was seen, also condemned the negotiations led by the U.S. and the League of Nations. In the 1930s, much like in the previous wars of the 19th century, weaker and internally troubled neighbors made for catastrophic regional dynamics of instability and order. The "Holsti dynamics" that chronically pervaded South American throughout the 19th century we also at play in the 1920s; and similarly, they led to international war. Holsti intra-state dynamics do not lead to peace but to externalities and international war. The H6 propositions, however, makes the inverted argument. "Centeno dynamics" are the key for this hypothesis; that is: state-weakness should make war less likely, more limited, and less frequent.

When applied to the Chaco War, however, the dynamic that seems to obtain in the peace process is Centeno's rather than Holsti's. For example, of the few factors that influenced Bolivia and Paraguay positively toward peace and restraint, one must count their military incapacity for war itself. As with the $\mathrm{H} 3$ argument, to understand why the war broke out in the 1930s, and not before, it is important to consider the military, 
logistical, and financial assistance that Chile gave Bolivia-plus the flow of armaments from the U.S. before the arms embargo — and that Argentina gave Paraguay.

In line with Centeno's argument, it was their incapacity for war which made the difference between the 1870-1920s and the 1932-1935 period. But even when considering this factor, Bolivia and Paraguay expended their "artificial" military capacity (including here also their demographics and "manpower") in the short time-span of two years and nine months. Unable to find ways to maintain the high-intensity of "modern" war, and with the withdrawal of their allies' military patronage, both belligerents had no other option but to sue for peace.

In summation, the H6 hypothesis finds in the Chaco War a highly-unique and highly-certain case study, for the involved parties had to choose peace reluctantly given their exhaustion after years of war. Even if the fighting was interrupted by the weather or the terrain. The particular geography of the region raised the costs for war $(c f . \mathrm{H} 4)$, yet it only led to peace when the flow of allied support, both in political capital and war materiel, ran dry. That is, geographical factors alone cannot account well neither for the outcome, nor the process, of the Chaco War when it is not correlated with the technological capacity of the states to overcome those geopolitical costs and the level of political involvement and support of the neighboring states indirectly affected by the outcome of the conflict.

\section{H7: A "Liberal Peace" in the South Pacific?}

The final alternative hypothesis articulates three specific predictions, based on two distinctive conditions: one as a "background" and another as a "trigger." When applied to the Chaco War case, these two conditions are present, for in Paraguay and Bolivia civilian, 
democratically elected governments were in office. Moreover, both nations subscribed to Liberal principles of free-trade and participated in similar international organizations, like the League of Nations. Unlike the previous case-studies from the 19th century, where these background conditions applied — if at all—partially or with modifications, in the early 20th century, the League of Nations represented the historical summum of the Liberal aspirations in world politics. Both Bolivia and Paraguay were signatories of the Covenant, thus making the application and testing of the $\mathrm{H} 7$ argument more appropriate than in past case-studies. This means that the "trigger" of the "convergence" of the similar Liberal values could also be counted as active and present in the 1930s.

The case-specific predictions, however, interrupt all expectations of wide explanatory power for the $\mathrm{H} 7$ argument. For example, as seen with $\mathrm{H} 5$, the eradication of war inter se, is the first element to be discarded, for Bolivia and Paraguay did not consider at any moment of the dispute to minimize or reduce their levels of aggression to one another because of the confluence of similar democratic regimes, or a similar predisposition towards the maximization of commercial profits over military costs. Not even their shared membership to the League of Nations seems to have restrained the two countries, norquite interestingly - empower that international organization in any significant way. If anything, one should count the Chaco War as one more example of the League's weakness in preventing, and much less stopping, international war. Although the war was fought by two of the weakest members, the Chaco War also contributed to the collapse of the League after the cases of Abyssinia and Manchuria.

In conclusion, war was nor prevented between two democratic and Liberal members of the League of Nations, during an international period of stress for the League, 
but also of world depression and distress. The League, in this scheme, failed to act as an "institutional supplement" or to help the parties in the avoidance of their security externalities — as expected in the $\mathrm{H} 7$ argument. Paradoxically, it was democratic openness that weakened the civilian administrations in Bolivia and Paraguay, leading to either military governments that continued the war or to virulent "popular" participation in strong support for the war. Even more challenging, it was under a democratically-elected administration in Bolivia that the country precipitated the outbreak of hostilities in 1932, and with military governments or juntas that the most substantive peace agreements were achieved. The fact that Argentine President, Agustín P. Justo, had acceded to power in 1930 via a coup, further complicates the strength of the $\mathrm{H} 7$ argument as a whole. If not a feeling of inter-democracy solidarity and Liberal values, then what exactly moved Argentina to mediate and help stop a war precisely when his protégé state, Paraguay, was close to achieve military victory?

\section{Some Preliminary Conclusions}

For both contenders, the war was devastating. The hardships of the terrain and the logistics of combat, joined the lack of fresh water supplies, famine, and sickness. Scurvy and diphtheria plagued both armies at war. Although the overall conduct of the war was limited within pre-established legal and normative constraints, several episodes of execution of wounded and non-wounded prisoners were known during and after the war. Mass desertion became increasingly common as the war moved to its second stage before military exhaustion and attrition in the arid Chaco. The technological conditions also helped make 
the Chaco War more devastating for those "on the ground" than otherwise expected in a war between two of the poorest and militarily weakest of South American nations.

Although an incipient normative framework was in place, no regional equivalent institutional architecture existed, apart from the League of Nations - discredited by its ineffectiveness in the Abyssinia and Manchuria cases. The League's view was juridical, while the A.B.C.P group focused on confluence of pragmatic interests and solidarity. This contrasted with the U.S. "disinterested" participation, premised too strongly on a unilateral interpretation of the Monroe Doctrine and other sentiments of "Pan-American" solidarity.

When contrasted with the alternative explanations, the $\mathrm{H} 1$ or international society argument does not seem to explain perfectly or exhaustively every aspect of the war or the peace negotiation. However, it does seem to perform holistically better than almost all its alternatives. That is, while the alternative explanations account unproblematically for only one or a few of the case-specific predictions, the international society seems to out-perform them by explaining precisely the other alternatives" "paradoxes" or dead-ends.

One of the best performing alternatives is the H6, followed closely by the H3 hypothesis. The historical specifics of the Chaco War case, however, make both H3 and H6 incompatible inter se. It is here that the international society can help bridge them by accommodating some of their strengths into a larger, encompassing perspective. 


\section{CONCLUSION}

\section{“ORDERED ANARCHY” IN SOUTH AMERICA ${ }^{694}$}

The study of a war is also the study of its peace. The main question proposed at the very onset of this study was what the main causes of South America's stable order were. More specifically, what explains South America's contemporary regional order in the absence of traditional sources of international peace found in other regions of the world. These guiding questions are important for the exploration of the paradoxical presence of external peace amid internal violence in Latin America. Since the so-called "long peace" obtains in the 20th century, after the end of the Chaco War in 1938, the main question of this dissertation points to the exploration of the historical preconditions that made such a paradoxical peace possible in the first place.

The main argument advanced in this study is that the explanation of the 20thcentury phenomenon of the "long peace" in South America is rooted in the emergence of a "society of states" in the mid-1860s, and in its long-term process of consolidation thereafter. This dissertation, therefore, has only focused on the origins and the earliest stages of consolidation of this regional society of states until the 1930s. A future study that continues with the historical process post 1930s can complement the application of the main theoretical argument presented here. The argument suggests that a society of states emerged in South America only after the formation of a system of independent and

${ }^{694}$ The term is borrowed from Edward E. Evans-Pritchard, The Nuer: A Description of the Modes of Livelihood and Political Institutions of a Nilotic People (Clarendon Press, 1940), pp. 6, 181. 
autonomous states in the relatively short period running from 1810 to 1860 . After this initial condition, two other background conditions emerged in the mid-1860s: one was the far-sightedness of the governing elites, who struggled with the pacification of their domestic orders and the externalities of the domestic orders of the neighboring states. This dynamic was further "triggered" or activated by an uneven process of strategic awakening across the region, forcing leading elites to link their respective states' "national interests" with those of the region as a whole. The confluence of these two dynamics further produced an interest in creating and upholding a regional "order" among autonomous peers, rather than other alternative forms of organization. These generated three interlocking sets of practices: first, the taming of war; second, the progressive institutionalization of order via formal and informal legal and diplomatic arrangements; and third, a pragmatic solidarism among members of the society of states.

The main argument, therefore, entails a series of relevant analytical and practical implications. First, it argues that the "long peace" phenomenon cannot be understood without the proper consideration of the regional dynamics of the 19th century. Contemporary studies of South America's peculiar international relations often neglect the 19th century, or merely make assumption about it that are not always warranted or accurate. With surprising regularity, for example, otherwise well-developed theoretical arguments discussing South America's long peace leave the historical preconditions of this phenomenon unexplored. The focus is placed, therefore, on factors located "inside" the long peace itself. That is, on factors that are present betwee the late 1930s and now. The 19th century, therefore, is normally brushed aside as an unimportant, "war-stricken" period. 
This generalized neglect of the 19th century regularly leads scholars to two related problems. On one hand, it can potentially blind the researcher from considering causes that may have long-term effects- for which a historical approach would be better suited. And on the other, it can lead to interpretations of the 19th century based on poor or simplistic notions that can assume it as inherently violent, and thus also as irrelevant for the study of peace.

The main argument explored in this dissertation tackles these potential problems head on. In this sense, it offers a historical exploration of four "hard" case-studies that point to the presence of a regional "society of states" and its tangible effects on the evolution of the quality of the region's interstate relations. South America's society of states formed after the struggle for independence in the Americas produced a system of independent states, which further consolidated during the second half of the 19th century. These four historical cases studies, analyzed in Chapters $2-5$, are considered "hard tests" (or "least likely" cases) because, first of all, they were major wars. In fact, they were the largest military conflicts in the entire history of the region. As such, they acts as "stress tests" for an analysis centered on the historical preconditions of a long interstate peace. At the same time, the absence of any major war in South America after 1938 makes the exploration of the prior wars all the more compelling in the search for historical, potentially hidden, sources of peace that may have been dormant or operating with a very long-term effect. The potential for "lessons learned" from the conduct of those wars must also be contemplated, when one considers the presence of of ruling elites that lived through at least three of the four major wars of the region. Between the 1860s and the early 1880 s, which is the period where the Guano War, the Paraguayan War, and the War of the Triple Alliance 
took place, political figures like Domingo F. Sarmiento, Benjamín Vicuña MacKenna, José V. Lastarria, Bartolomé Mitre, Mariano I. Prado, or Álvaro Covarrubias, among many others, moved in and out of political role in government, as diplomats or advisers, or simply as narrators of the events.

These four case studies were explored using historical analysis and process-tracing methods, making use of multiple primary and secondary sources. In application of these methods, the main argument was contrasted with six other competing arguments to have a more solid appreciation of its relative strength vis-à-vis the empirical record and the other contending explanations (see TABLE 4, p. 148). In contrast with the international society approach (or H1), the second contender (or H2) maintains that the long peace was caused by the pacifying role of the U.S., who through a preponderance of power and a willingness to "lead" can generate three distinctive sets of practices, or causal-mechanism: the suppression of war, an institutional tutelage, and a solidarity based on the leadership of the hegemon itself.

The third contending argument (H3) proposes that a balance of power could also explain the long peace by way of an unintended equilibrium of power between states. This is premised on a short-sightedness of ruling elites that is most prominent when the survival of the state is at stake. The three sets of causal-mechanisms identified by $\mathrm{H} 3$ are the use of war as a regulating mechanism for restraining others, the primacy of mutual fear and selfhelp behavior, and the forming of essentially dynamic alliances based on pure power calculations only.

The fourth contender (H4) sustains that geopolitics can offer a better alternative explanation for the long peace. This is premised on the rather fixed geopolitical factors of 
the region, marked by vast open spaces in between the main centers of power and other factors that can raise the costs of war, and thus, dampen war's frequency and intensity. When the topography constrains states, then the costs of waging large-scale war far outweigh the technological capabilities of states. In such conditions, there are three expected mechanisms: first, the impossibility of states to wage war inter se; followed by the instrumental use of regional institutions as a coping mechanism; and lastly, the formation of "shatterbelts" and "checkerboards" as intra-regional dynamics.

The fifth contender (H5) argues that the long peace can be explained by the "agglutinating" role of a common culture, based on a shared legacy of anti-imperialism against foreign interventionist powers. In this view, member states look to the eradication of war among one another, the (re-)unification into a larger political entity to provide security for all based on a solidarity that is underpinned by the sharing of an anti-imperialist ideology or culture.

The last two contenders stipulate that the internal make-up of states can explain the long peace. The sixth contender (H6) argues that the long peace is the result of state incapacity or "weakness" that emanates from serious domestic security constraints. These constraints can produce externalities that spill-over onto other neighboring states. States sharing these problems cannot wage or sustain large-scale war inter se, even if intended, nor remain idle on the wayside. Their incapacity for war, therefore, leads them to develop regional organizations as supplements or coping mechanism to solve collectively their diplomatic differences and avoid or contain further externalities.

The last contender, the "Liberal Peace," argues that the sharing of Liberal republican values can explain the long peace via the elimination of war among Liberal 
republican and free-trade loving member states, and the institutionalization of that separate peace on a regional or international level.

In this context, and building upon the preliminary conclusions at the end of each case-study chapter, the main findings from the overall study are the following:

1. The proposition of the emergence of a society of states in South America in the secondhalf of the 19th century, and the related argument about its progressive consolidation in the 1930s, as the main explanation of the region's "long peace" in the 20th century is widely supported by a series of case-specific assessments, which are visible only from a long-term perspective cutting across the four selected cases. In that regard, the H1 argument outperforms all other alternative explanations on a one-to-one basis. While isolated aspects of each case study can be enriched by one, or a combination, of the contending arguments (H2-H7), no single argument, nor stable combination of them, survives a cross-case comparison, such as the one performed in this dissertation. Only the $\mathrm{H} 1$ seems to hold its ground across the four selected case studies.

2. When considered as a whole, therefore, the strength of the international society argument is evident by its capacity to explain the progressive qualitative change in the international relations of South America, in its transition from the mid-19th century to the early 20th century. Its strength is also clear in its superior capacity to explain satisfactorily a large number of "highly-certain" intra case-study tests (mostly "hooptests"). Although "doubly-decisive tests" are hard to find in general, and even harder to pass, the international society argument scores some important points in the cases of the Guano War, the Paraguayan War, and the Chaco War. In the first two cases, for example, the international society argument offers a solid explanation of the mayor 
dynamics at play in those simultaneous wars-finding explanations for dynamics that confound other contenders (i.e., scoring high on the "unique" side of the tests). Similarly, for the cases of Ecuador and Chile in the Guano War. The behavior of these two countries towards Peru in 1865-1866 cannot be consistently explained by any of the other alternative hypotheses, except perhaps partially by H5. In the case of Bolivia's behavior towards Chile, it can also only be partially explained by a handful of alternatives arguments apart from H1. Perhaps only H6. On the issue of the alliance of Argentina and the Brazilian Empire, only the H1 hypothesis can unproblematically explain the underlying motivations for the Argentine-Brazilian rapprochement, which overlooked "regime type" considerations and a long history of intra-regional rivalry and mutual suspicion in the River Plate area.

3. When contrasted with all four case studies, the H2 hypothesis ("U.S. hegemonic stability" in the Americas) is the weakest-performing alternative explanation. Across the board, the U.S. did show an increasing willingness to act as an impartial arbiter, mediator, and "good neighbor." This, moreover, correlated strongly with its ascent to great power status towards the later 19th century and early 20 th century. That reached its apex during the 1930s in its sustained efforts to mediate the Chaco dispute. However, not only were all U.S. offers of mediation flatly rejected by those to whom the olive blanch of peace was extended (i.e., Francisco S. López in the Paraguayan War), or postponed and eventually turned down (Paraguay in the Chaco War), but they also provoked a generalized animosity in almost all the South American states. Although extending good offices and proposing peace, South American countries resented the patronage or "tutelage" implicit in the U.S. mediations. These feelings 
were intensified by the unilateral U.S. interpretation of the Monroe Doctrine and its guiding principles for "hemispheric inoculation" from European meddling. The momentary "absence" of the U.S. during the two conflicts of the 1860s, provoked by its civil war, further helped instill in the South American countries a shared sense of urgency and fragility. Their successive "victory" against Spain in the Guano War, however, reinforced countries like Chile in their appreciation for the protection of regional order from a multilateral, rather than unilateral and submissive, way-as implied in a U.S. leadership. Despite the popular representation of Latin America as the proverbial "backyard" of the U.S., the evidence analyzed in the case studies shows a radically different story, marked by active and self-conscious South American states and state-leaders in full exercise of their roles as deserning and autonomous political actors - despite the vast disparities in economic and military power deparating the U.S. from its sister American republics.

4. Of the four case studies explored, the Chaco War stands out as the most important in support of the international society argument. Popularly seen as "the lowest point of Pan-Americanism" in the history of the Hemisphere, the history of the Chaco War and its Peace Conference, however, emerges as the strongest point of the incipient society of states formed in the fulcrum of the second half of the 19th century. Its regional identity was further reaffirmed and formalized in the A.B.C.(P.) group at the very beginning of the 20th century, after the signing of the "May Pacts," which would eventually play a crucial role in developing an active diplomatic profile for the region in the U.S.-Mexican war, as well as in later initiatives like the Contadora Group, which helped atenuate conflict in Central America during the Cold War. Through the artful 
diplomatic maneuvering of the Argentine Chancellor and secretary general of the Chaco Peace Conference, the meddling efforts of the U.S. and those of the League of Nations took a back seat in the 1930s as South American states struggled to find South American solutions to problems of their own making. The Chaco War, therefore, while for many contemporary observers represents the failure of a hemispheric view of ideological "cooperation" by way of failing to prevent the Chaco War, from the vantage point of the international society approach it offers the highest point of a sense of American "solidarity" that is pragmatic at its core and devoid of all empty rhetoric of transnational cultural, pan-national, or ideological continental unity. In short, it showcases the ultimate triumph of "pragmatic solidarty," or a view of inter-state cooperation premised on basic common interests, rather than common culture, regimetype, or ideology.

5. The most challenging case study for the international society argument appears to be the case of the War of the Pacific. While Chile and its neighbors did adjust their behavior to the precepts of "civilization" as understood in the late 19th century, incurring important strategic costs along the way, the war also showed the "ugly" (or more violent) side of international society. Although logically in accordance with the expectations of $\mathrm{H} 1$, the "civilized" components of international society can at times take violent expressions when the protection of the regional order and stability of the entire system is at risk (i.e., the Triple Alliance against Paraguay). As discussed in Chapter 1, societies of states do not seek the erradication of war among its members, but simply tame and multilateralize the use of force through legitimating institutional channels. In the War of the Pacific, Chile reacted to a regional conext that risked to 
encircle it in a web of alliances and pacts indirectly aimed against Chile's interest. It seems that a traditional security-dilemma dynamic was fueled by the internal "weakness" of Bolivia and its caudillos bárbaros, then erupting in a war that nobody intended, but which all needed to win. The behavior of key regional players, such as Argentina and Brazil, further support the idea of a regional strategic environment that escapes mere power-political, self-aggrandizing foreign policy dyamics. The struggle for resources behind the War of the Pacific shows the staying power of classical shortsightedness when driven by elite greed, mutual fear, and a sense of cultural superiority (in these cases, by Bolivian and Peruvian leaders). But it also helps to reinforce the roles that self-restraint, institutionalization, and "pragmatic solidarity" play in containing aggression and spill-over effects in times of war under the overarching presence of a regional society of states.

In each successive chapter, the South American society of states transitioned through four difference struggles: First, through a struggle for the confirmation of its independence against Spain - a foreign or extra-regional monarchy. Second, through a struggle for the protection of the status quo and the Platine equilibrium against a destabilizing internal force. Third, through a struggle based on the acquisition of resources and the resolution of inherited territorial ambiguities in a context of rapidly growing intra-regional competition, fueled by work markets and foreign investors' private interests. And finally, the triumph of a common vision of regional order championed by the A.B.C.P. group countries during the Chaco Peace Conference and thereafter-successful in bringing about peace where all other, stronger actors, had failed. 
Contrary to traditional and widely popular representations of an "Americanist" solidarity and cooperation — promulgated since the Cold War by the Latin American leftthe notion of a "pragmatic solidarity" contained in the international society approach offers one of the most interesting conceptual innovations for further debate and analysis. It is a offers a new lens with which to re-interpret the history of international relations in the Americas. In the "Americanist" view of solidarity, international relations should follow a sentiment of continental unity, liberty from foreign oppression, and be inherently peaceful. From the vantage point of this vision of a patria grande (pan-latin-american nation) one cannot but despair in frustration when reviewing the history of South America in the late 19th and the early 20th centuries. But when solidarity is understood in such an ideological sense, it imprints a strong bias towards (peaceful) "cooperation," and thus quickly reveals itself as a normative aspiration that has never been achieved in the past, nor could possibly be in the future. "Americanists" of this kind are thus bound to be professional pessimists. But when solidarism is understood in the "pragmatic" sense, however, it helps to reinterpret the long record of "cooperation failures" of the American states in more realistic terms, closer to how the elites and political actors at the time understood their actions. In a society, just like in a family, members do not always have to agree to be part of the whole. And sometimes, "failures" could be important lessons with large implications for the road ahead.

In conclusion, one of the important findings of the historical review of these four case studies is that the "long peace" in South America can be better understood in its historical dimension, rather than in a more presentist fashion. When seen in this light, therefore, instead of interpreting the 20th century as a "radical departure" from the region's 
past, relevant historical connections, traditions, and enduring features come to life, revealing dynamics that were previously ignored by more traditional analysis. Using the international society approach to re-interpret the origins and evolution of a longer "long peace" in South America—one with roots that extend far beyond the pre-1930s threshold— allows one to better comprehend the seemingly paradoxical dynamic of internal violence and external peace.

Deeply rooted in the historical dynamics of internal insecurity and violent contestation, the nation-states which formed and consolidated toward the end of the 19th century carried onto the 20th century more than mere institutional weakness. Entire generations of diplomats and decision-makers, among other states officials and political elites, first acquired and later embodied over the long span of the 19th century certain patterned practices for conducting their foreign affairs in conditions of internal and external weakness. Through regional socialization and some very painful experiences of war, South American officials institutionalized those same lessons into forms of state behavior that seem to have survived well into the 21 st century. Such a "diplomatic strategic culture" has allowed, not just military governments from the 1930s up to the early 1990s to maintain South America's paradox and perpetuate a regional society of states that prioritizes order among its members more than peace among its citizens. It has also allowed civilians in democratically elected governments consolidated in the 1990s to continue this same regional legacy under radically different global conditions. If this present condition of relative order in South America—however fragile—is to be preserved and even perhaps deepened, then the strategic and moral quality of those individuals in positions of power will have to match the quality of the society of states of which they are, also, members. 


\section{BIBLIOGRAPHY}

\section{PRIMARY SOURCES}

(a) UNPUBLISHED MANUSCRIPTS

ARGENTINA:

-Archivo del Ministerio de Relaciones Exteriores y Culto, Buenos Aires.

-Archivo General de la Nación, Buenos Aires.

-Documentos del Dr. Rufino de Elizalde, Instituto Ravignani, Buenos Aires.

-Museo Mitre, Buenos Aires.

BOLIVIA:

-Archivo Central Histórico del Ministerio de Relaciones Exteriores y Culto, La Paz.

-Archivo de La Paz, Universidad Mayor de San Andrés, La Paz.

-Papers of the Elío Family, La Paz.

BRAZIL:

-Arquivo Histórico do Itamaraty, Ministério das Relações Exteriores, Rio de Janeiro.

CHILE:

-Archivo General Histórico del Ministerio de Relaciones Exteriores, Santiago.

-Archivo Nacional, Santiago.

ECUADOR:

-Archivo Histórico del Ministerio de Relaciones Exteriores y Movilidad Humana, Quito.

PARAGUAY:

-Archivo Nacional de Asunción, Asunción.

-Biblioteca Nacional del Paraguay, Asunción.

PERU:

-Archivo Central del Ministerio de Relaciones Exteriores, Lima.

-Biblioteca Nacional del Perú, Lima.

URUGUAY:

-Archivo Histórico Diplomático del Ministerio de Relaciones Exteriores, Montevideo.

-Archivo General de la Nación, Montevideo.

(b) NEWSPAPERS

El Federalista (Venezuela).

El Ferrocarril (Chile).

El Mercurio de Valparaíso (Chile).

El Semanario (Paraguay).

La Nación Argentina (Argentina). 


\section{(c) GOVERNMENT PUBLICATIONS}

ARgentinA. Congreso de la Nación. La paz del Chaco (Buenos Aires: Imprenta del Congreso Nacional, 1938).

- Ministerio de Relaciones Exteriores. Correspondencia cambiada con la legación del Perú en la República Argentina sobre el Tratado Continental celebrado en Santiago de Chile, en setiembre 15 de 1856 (Buenos Aires: Bernheim y Boneo, 1862).

- Correspondencia diplomática entre el gobierno del Paraguay y la legación de los Estados Unidos de América y el Cónsul de S. M. el Emperador de los franceses (Buenos Aires: Imprenta Buenos Aires, 1868).

. Documentos oficiales de Bolivia relativos a la cuestión del Pacífico (Buenos Aires: Imprenta del Pueblo, 1879).

. Documentos relativos a la declaración de guerra del gobierno argentino al del Paraguay (Buenos Aires: Imprenta de la Nación Argentina, 1864).

—. La neutralidad argentina en el conflicto boliviano-paraguayo (Buenos Aires: Peuser, 1933).

—. La paz del Chaco, 1935-1939: Compilación de documentos (Buenos Aires: Frigerio, 1939).

- $\frac{}{2 \text { vols. }}$. La política argentina en la guerra del Chaco (Buenos Aires: Kraft, 1937).

- Memoria presentada [...] al Congreso Nacional (Buenos Aires: [n/d], 1864-1884).

BOLIVIA. Ministerio de Relaciones Exteriores. Actas y documentos de las conferencias de plenipotenciarios bolivianos y paraguayos realizadas in Buenos Aires bajo los auspicios del Gobierno Argentino (La Paz: Escuela Tipográfica Salesiana, 1929).

- Bolivia-Paraguay: Exposición de los títulos que consagran el derecho territorial de Bolivia, sobre la zona comprendida entre los ríos Pilcomayo y Paraguay, ed. by Ricardo Mujía (La Paz: El Tiempo, 1914). 5 vols.

—. El enclaustramiento de Bolivia es un problema de América (La Paz: Ministerio de Relaciones Exteriores y Culto, 1963). —. La conferencia de Mendoza y el conflicto del Chaco (La Paz: Eléctrica,

Mediación de Estados Unidos en la guerra del Pacífico: Bolivia (La Paz: Imprenta de la Unión Americana, 1880). 
- Memoria anual del Ministerio de Relaciones Exteriores y Culto presentada al Congreso Nacional (La Paz: Eléctrica, 1928-1931, 1940).

- Memoria que el ex-Secretario General de Estado y actual Ministro de Gobierno, Justicia y Relaciones Exteriores de la República de Bolivia presenta a la Asamblea Nacional Constituyente reunida en 1868 (La Paz: Imprenta Paceña, [1868]).

—. Memoria presentada al Congreso de 1934 (La Paz: [n/d], 1935).

—. Notas y el memorándum de Bolivia contra el tratado de arbitraje argentino-paraguayo de 1876 (La Paz: Escuela Tipográfica Salesiana, 1929).

BRAZIL. Ministério das Relações Exteriores. Correspondência e documentos officiales relativos á missão especial do Conselheiro José Antônio Saraiva ao Rio da Prata em 1864 (Bahia: Typographia do Diario, 1872).

—. Relatório da repartição dos negócios estrangeiros apresentado á Assambléa Geral Legislativa (Rio de Janeiro: Laemmert, 1864-1873).

—. Fundação Alexandre de Gusmão. A missão Varnhagen nas repúblicas do Pacífico 1863 a 1867 (Rio de Janeiro, 2005). 2 vols.

CHILE. Cámara de Senadores. Sesiones secretas de la Cámara de Senadores celebradas durante la guerra (Santiago: Imprenta Nacional, [1881]).

Ministerio de Guerra. Boletín de la guerra del Pacífico, 1879-1881 (Santiago: Bello, 1979).

. Ministerio de Relaciones Exteriores. Las conferencias en Arica: Documentos relativos a la mediación ofrecida por el gobierno de los Estados Unidos de Norte América para poner fin a la guerra entre Chile, Perú i Bolivia (Santiago: Imprenta Nacional, 1880).
- . Memoria presentada [...] al Congreso Nacional (Santiago: Imprenta Nacional, 1864-1884). junio de 1872).

Colombia. Documentos referentes a la reunión en Panamá del Congreso Americano, iniciada y promovida por el Gobierno de Colombia en favor de la institución del arbitraje (Bogotá: Rivas, 1881).

- Secretaría de lo Interior y Relaciones Exteriores. Memoria de la Secretaría de lo Interior y Relaciones Exteriores de Colombia (Bogotá: [n/d], 1865).

ECUADOR. Ministerio de Relaciones Exteriores. Exposición del Ministerio del Interior y Relaciones Exteriores dirigida a las Cámaras Legislativas del Ecuador en 1865 (Quito: Imprenta Nacional, 1865). 
Informe del Ministro del Interior y Relaciones Exteriores dirigido a las Cámaras Legislativas del Ecuador en 1867 (Quito: Imprenta Nacional, 1867).

La guerra del Pacífico: Cartas cambiadas entre el plenipotenciario del Perú, señor Doctor Don Juan Luna y el prócer de la Independencia, señor Doctor Don Antonio L. Guzmán. Documentos relativos a las conferencias de Arica. Circulares de la Secretaría de Relaciones Exteriores del Perú. Despachos de la legación peruana en las repúblicas de la antigua Colombia (Quito: Rivadeneira, 1880).

La guerra del sur del Pacífico III: Actitud de la República Argentina. Gran sesión en el Congreso Argentino, condenando la política de Chile. Desaprobación por el Senado Argentino del último tratado con Chile. El bombardeo de puertos indefensos condenado por Chile y por toda la América en 1866 (Quito: Sanz, 1879).

Great BritaIn. Foreign Office. British Documents on Foreign Affairs-Reports and Papers from the Foreign Office. Confidential Print. Part I: "From the Mid-Nineteenth Century to the First World War"; Series D, Latin America, 1845-1914, ed. by George PHILIP (Bethesda, MD: University Publications of America, 1991). 9 vols.

. Correspondence Respecting Hostilities in the River Plate: Confidential F.O. 420: 18-19-20-22-26 [HC-PP] (London: Harrison, 1865-1870). 5 vols. . Correspondence Respecting the War Between Chile and Spain: Confidential F.O. 420: 21-22 [HC-PP] (London: Harrison, 1866-1867). 2 vols. . Papers Relating to the Seizure of the Chincha Islands by a Spanish Squadron [HC-PP] (London: Harrison, 1864). 2 vols.

PARAguAY. Ministerio de Relaciones Exteriores. Correspondencia confidencial entre el Exmo. Sr. Presidente de la República del Paraguay y el de la Confederación Argentina en 1863 y 1864 (Asunción: Imprenta Nacional, [1867] 1886).

Correspondencias cambiadas entre el Ministerio de Relaciones Esteriores de la República y el señor Charles A. Washburn sobre la conspiración fraguada contra la Patria y el gobierno en combinación con el enemigo, y el atentado de asesinato a la personal del Exmo. Señor Mariscal López por Nacionales y Extrangeros (Luque: Imprenta Nacional, 1868).

Correspondencias oficiales relativas a los sucesos de la República Oriental del Uruguay cambiadas entre los Exmos. Sres. Ministros de Relaciones Exteriores de la República del Paraguay y de la Confederación Argentina (Asunción: Imprenta Nacional, 1864).

Exposición de la causa del Paraguay en su conflicto con Bolivia, presentada a la XV Asamblea de la Sociedad de las Naciones reunida en setiembre de 1934 (Asunción: Imprenta Nacional, 1934). 


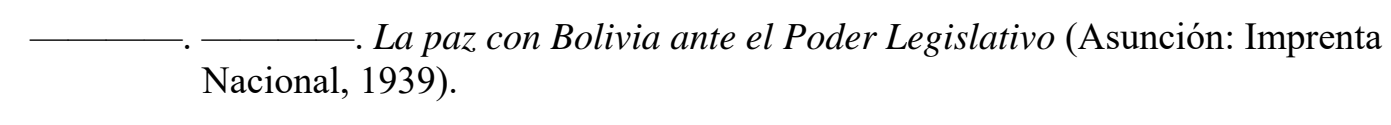

—. Libro blanco (Asunción: Imprenta Nacional, 1933-1934). 5 vols.

—. Libro blanco: Documentos relativos a las conferencias de Buenos Aires sobre la cuestión de límites paraguayo-boliviana y algunos antecedentes, 1927-1928 (Asunción: Imprenta Nacional, 1928).

—. Los orígenes de la guerra del Chaco: Memorándum presentado el 8 de marzo de 1934 (Asunción: Imprenta Nacional, 1934).

PERU. Colección de los tratados, convenciones, capitulaciones, armisticios y otros actos diplomáticos y políticos celebrados desde la independencia hasta el día, precedida de una introducción que comprende la época colonial. Vol. 6, por Ricardo ARANDA (Lima: Imprenta del Estado, 1896).

Ministerio de Relaciones Exteriores. Catálogo de documentos sobre la guerra de las repúblicas aliadas contra España: 1866 (Lima: Ministerio de Relaciones Exteriores del Perú; Red de Archivos Diplomáticos Iberoamericanos, 2012).

[Accessible at: https://apps.rree.gob.pe/portal/catalogoradi.nsf].

—. Confederación Perú-Boliviana (1835-1839). Recopilación y prólogo de Carlos Ortiz de Zevallos Paz-Soldán (Lima: Archivo Diplomático del Perú IX, 19721974). 2 vols.

- Congresos americanos de Lima: Recopilación de documentos precedida de Prólogo por Alberto Ulloa (Lima: Archivo Diplomático del Perú II-III; Imprenta Torres Aguirre, 1938). 2 vols.

\footnotetext{
. Correspondencia diplomática relativa a la cuestión del Paraguay, publicada por orden de S. E. el Jefe Supremo Provisorio para ser presentada al Congreso Constituyente (Lima: El Progreso, 1867).

- Correspondencia diplomática relativa a la cuestión española, publicada por orden de S. E. el Jefe Supremo Provisorio para ser presentada al Congreso Constituyente (Lima: El Imprenta del Estado, 1867).
—. Cuestión entre el Perú y la España (Lima: Imprenta del Gobierno, 1864).
—. Documentos relativos a la cuestión española: Edición oficial (Lima: Imprenta del Estado, 1866).
—. Memorándum sobre la actitud del gobierno de los Estados-Unidos de Norte-América en el Pacífico, presentado a las cancillerías del Plata por la legación peruana (Buenos Aires: Coni, 1882).
-. Memoria que el Ministro de Relaciones Exteriores presenta a la Legislatura Ordinaria de 1864 sobre los asuntos de España (Lima: [n/d], 1864).


. Memoria que el Ministro de Relaciones Exteriores presenta al Congreso Extraordinario de 1879, sobre el conflicto suscitado por Chile contra las Repúblicas del Perú y Bolivia (Lima: [n/d], 1879).

—. Perú y España: Exposición de algunos puntos importantes de la cuestión actual entre los dos países (Lima: Alfaro, 1865).

United STATES OF AMERICA. Department of State. Foreign Relations Between Latin America and the Caribbean States, 1930-1944 (Farmington Hills, MI: Gale, 2012).

. Foreign Relations of the United States [...] (Washington DC: Government Printing Office, 1880-1884).

Foreign Relations of the United States: Diplomatic Papers, (Washington DC: Government Printing Office, 1948-1956), 1932: Vol. 5; 1933: Vol. 4; 1934: Vol. 4; 1935: Vol. 4; 1936: Vol. 5; 1936: Vol. 5; 1937: Vol. 5; 1938: Vol. 5.

Papers Relating to the War in South America and Attempts to Bring About Peace. Executive Document No. 79, 47th Congress, 1st Session (Washington DC: Government Printing Office, 1882).

The Chaco Peace Conference: Report of the Delegation of the United States of America to the Peace Conference held at Buenos Aires, July 1, 1935 January 23, 1939 (Washington DC: Government Printing Office, 1940).

. Proceedings of the Commission of Inquiry and Conciliation: Bolivia and Paraguay, March 13, 1929 - September 13, 1929, ed. by Barbara LITTLE (Washington: Sun Book and Job Printing Office, 1929).

URUguAY. Ministerio de Relaciones Exteriores. Documentos diplomáticos: Misión Saraiva (Montevideo: Imprenta de la Reforma Pacífica, 1864).

. . Documentos diplomáticos relativos a la detención del paquete argentino "Salto" en las aguas de la República Oriental del Uruguay por el vapor de guerra nacional Villa del Salto (Montevideo: Menéndez, 1863).

- Negociaciones entre el gobierno oriental del Uruguay i el ministro diplomático de Chile sobre el consulado chileno en Montevideo y la venta de presas (Buenos Aires: Imprenta de Buenos Aires, 1866).

—. Publicación oficial del negociado entre el Ministerio de Relaciones Esteriores y el Sr. Enviado Estraordinario y Ministro Plenipotenciario de la República de Chile, con motivo de su pretensión sobre venta de presas que las fuerzas navales chilenas pudieran hacer a la España (Montevideo: La Tribuna, 1865).

Reclamaciones de la República Oriental del Uruguay contra el Gobierno Imperial del Brasil (Montevideo: El País, 1864). 


\section{(d) Other Published Documents, CorResPondence, AND MEMoirs}

AguirRe, Nataniel. Bolivia en la guerra del Pacífico (Cochabamba: El Heraldo, 1883).

Aguirre Lavallén, Joaquín. Guerra del Pacífico: Pacto de tregua 1884. Documentos reservados inéditos (La Paz: Los Amigos del Libro, 1987).

Ahumada Moreno, Pascual. Guerra del Pacifico: Recopilación completa de todos los documentos oficiales, correspondencias i demás publicaciones referentes a la guerra que ha dado a luz la prensa de Chile, Perú i Bolivia, conteniendo documentos inéditos de importancia (Valparaíso: Imprentas del Mercurio; Americana; Progreso, 18841891). 8 vols. and Appendix.

ALFONSO, José. La legación chilena en el Plata y el ministro de relaciones esteriores a propósito del folleto de don Gaspar Toro (Valparaíso: Imprenta del Mercurio, 1879).

ARANGuiz Donoso, Horacio. "Cartas políticas de don Domingo Santa María a don José Francisco Vergara (1878-1882): Recopilación, prólogo y notas,” Estudios de Historia de las Instituciones Políticas y Sociales, Vol. 1 (1966), pp. 313-370.

Archivo del Coronel Doctor Marcos Paz (La Plata: Universidad Nacional de La Plata, 1959_ 1966). 7 vols.

Archivo del General Mitre: Documentos y correspondencia (Buenos Aires: Biblioteca de "La Nación," 1911-1914). 28 vols.

ARZE QuiRogA, Eduardo. Documentos para una historia de la guerra del Chaco: Archivo Daniel Salamanca (La Paz/Cochabamba: Don Bosco/Universitaria, 1951-1974). 4 vols.

AYala QueIRolo, Víctor. Paz del Chaco: Gestión Dr. Gerónimo Zubizarreta (Asunción: La Casa del Libro, 1976-1996). 2 vols.

Azevedo, Walter A. de. “A 'Diplomacia Oriental en el Paraguay' do Dr. D. Luis Alberto de Herrera (Algumas notas)," Crítica Jurídica, Histórica, Política y Literaria, Tomo XVII, No. 48-50 (1928), pp. 141-151.

. “A ‘Diplomacia Oriental en el Paraguay' do Dr. D. Luis Alberto de Herrera (Continuación)," Crítica Jurídica, Histórica, Política y Literaria, Tomo XVIII, No. 51-53 (1928), pp. 21-35.

"As missões Sagastume e Carreras, ao Paraguay (contribuições documentaes)," La Revista Americana de Buenos Aires, Año VII, Tomo XXVIII, No. 76 (agosto, 1930), pp. 25-40.

"As missões Sagastume e Carreras, ao Paraguay (contribuições documentaes)," La Revista Americana de Buenos Aires, Año VII, Tomo XXVIII, No. 77 (septiembre, 1930), pp. 153-168. 
“As missões Sagastume e Carreras, ao Paraguay (contribuições documentaes)," La Revista Americana de Buenos Aires, Año VII, Tomo XXIX, No. 78 (octubre, 1930), pp. $17-32$.

“As missões Sagastume e Carreras, ao Paraguay (contribuições documentaes)," La Revista Americana de Buenos Aires, Año VII, Tomo XXIX, No. 79 (noviembre, 1930), pp. 161-176.

“As missões Sagastume e Carreras, ao Paraguay (contribuições documentaes)," La Revista Americana de Buenos Aires, Año VII, Tomo XXX, No. 81 (enero, 1931), pp. 161-176.

"As missões Sagastume e Carreras, ao Paraguay (contribuições documentaes)," La Revista Americana de Buenos Aires, Año VII, Tomo XXXI, No. 82 (febrero, 1931), pp. $33-48$.

BENíTEZ, Luis G. Cancilleres y otros defensores de la República (Asunción: [n/d], 1994). 2 vols.

BRADEN, Spruille. "A Résumé of the Role Played by Arbitration in the Chaco Dispute," The Arbitration Journal, Vol. 2, No. 4 (October, 1938), pp. 387-395.

Diplomats and Demagogues (New Rochelle, NY: Arlington House, 1971).

Brezzo, Liliana M. (ed.). La guerra del Paraguay en primera persona: Testimonios inéditos. Fondo Estanislao Zeballos (Asunción: Tiempo de Historia, 2015).

BURR, Robert N. and Roland D. HUSSEY (eds.) Documents on Inter-American Cooperation (University of Pennsylvania Press, 1955). 2 vols.

BURTON, Richard F. Letters from the Battle-fields of Paraguay (London: Tinsley, 1870).

CAIVAno, Tomasso. Storia della guerra D’America fra il Chilì il Perù e la Bolivia (Torino: Loescher, 1882-1886). 2 vols.

CAMPos, Alfredo R. Misión de paz en el Chaco Boreal (Montevideo: Centro Militar, 1954). 2 vols.

CANÉ, Miguel. Prosa ligera (Buenos Aires: Casa Vaccaro, 1919).

CANElAS, Demetrio. La guerra del Chaco: Documentos (Cochabamba: Canelas, 1987).

"Cartas enviadas por don José Victorino Lastarria durante su misión en el Río de La Plata, 18651866," Revista Historia, No. 7 (1968), pp. 313-330.

"Carta sobre la cuestión con España," Revista Chilena, Año IV, Tomo XI, No. 38 (diciembre, 1920), pp. 248-253.

[CARVE, Luis]. "Negociaciones de paz en 1863-65," Revista Histórica [Montevideo], Tomo V, No. 13 ( $1^{\circ}$ trimestre, 1912), pp. 408-473. 
. "Negociaciones de paz en 1863-65," Revista Histórica [Montevideo], Tomo V, No. 15 ( $3^{\circ}$ trimestre, 1912), pp. 618-639.

- "Negociaciones de paz en 1863-65," Revista Histórica [Montevideo], Tomo VI, No. 16 (4 $4^{\mathrm{o}}$ trimestre, 1912), pp. 125-154.

CENTENO, Francisco. “1864: Misión del Coronel Sarmiento a Chile y Perú,” in Virutas históricas (1810-1928). Vol. 1 (Buenos Aires: Menéndez, 1929), pp. 92-100.

. "El Doctor Elizalde," Revista de Derecho, Historia y Letras, Año IX, Tomo XXVII (1907), pp. 442-449.

- "La diplomacia argentina en el Pacífico: Guerra hispano-americana de 1865," Revista de Derecho, Historia y Letras, Año XIX, Tomo LVII (1917), pp. 368-390.

. "Las montoneras: Invasión a Salta por el célebre montonero Felipe Varela," Revista de Derecho, Historia y Letras, Año XXIII, Tomo LXVIII (1921), pp. 111-119, 259-268, 366-394, 476-482.

. "Las montoneras: Invasión a Salta por el célebre montonero Felipe Varela," Revista de Derecho, Historia y Letras, Año XXIII, Tomo LXIX (1921), pp. 99-109, 381-403.

. "Las montoneras: Invasión a Salta por el célebre montonero Felipe Varela," Revista de Derecho, Historia y Letras, Año XXIII, Tomo LXX (1921), pp. 99-108, 237-259.

CERRUTI, Fidelo E. Peru and Spain, being a Narrative of the Events Preceding and Following the Seizure of the Chincha Islands, with an Analysis of the Despatch of Señor Salazar y Mazarredo [...] (London: Williams and Norgate, 1864).

CORREIA, Manoel F. "Saque de Assumpção e Luque atribuído ao exército brazileiro na guerra do Paraguay: Refutação," Revista Trimensal do Instituto Historico e Geographico Brazileiro, Tomo LIX, Parte I ( $1^{\circ}$ e $2^{\circ}$ trimestres, 1896), pp. 369-393.

Correspondence Between señor don José Antonio García y García, Minister of Peru, and the Hon. William H. Seward, Secretary of State of the United States (New York, NY: Gresham, 1869).

Correspondence Between the Brazilian and Argentine Governments Respecting the Treaties Concluded between Brazil and the Republic of Paraguay and the Withdrawal of Troops from the Island of Atajo (London: Reynell, 1872).

"Correspondencia de don Rafael Sotomayor con don Aníbal Pinto, sobre la guerra del Pacífico," Revista Chilena, Tomo XV (1922), pp. 178-194, 285-294.

“Correspondencia militar de la División Oriental, 1866-1869," Boletín Histórico del Estado Mayor del Ejército [Montevideo], No. 145-148 (1975), pp. 1-160.

Correspondencia Mitre-Elizalde (Buenos Aires: Universidad de Buenos Aires, 1960). 
Courcelle Seneuil, Jean G. Agresión de España contra Chile (Santiago: Imprenta del Ferrocarril, 1866).

- La guerra entre España y Chile: Los neutrales y el derecho de jentes (Santiago: Imprenta de la República, 1866).

DALENCE, Zenón. Informe histórico del servicio prestado por el cuerpo de ambulancias del Ejército Boliviano; desde su creación en Tacna hasta la repatriación de su última sección de heridos. presentado al Supremo Gobierno y a los Comités de la Asociación Internacional de la "Cruz Roja” (La Paz: La Tribuna, 1881).

DAVIS, Arthur H. Martin T. McMahon, diplomático en el estridor de las armas (Asunción: Litocolor, 1985).

DE HerRerA, Luis A. La diplomacia oriental en el Paraguay: Correspondencia oficial y privada del doctor Juan José de Herrera, Ministro de Relaciones Exteriores de los gobiernos de Berro y Aguirre. Vol. 1 (Montevideo: Barreiro y Ramos, 1908).

. La diplomacia oriental en el Paraguay [...]. Vol. 2 (Montevideo: El Arte, 1911).

—. La diplomacia oriental en el Paraguay [...]. Vol. 3: “Buenos Aires, Urquiza y el Uruguay" (Montevideo: [n/d], 1919).

_. La diplomacia oriental en el Paraguay [...]. Vol. 4: "La clausura de los ríos” (Montevideo: [n/d], 1920).

. La diplomacia oriental en el Paraguay [...]. Vol. 5: “El drama del 65 (la culpa mitrista)" (Montevideo: [n/d], 2nd ed., [1926] 1927).

De la Puente Candamo, José A. and José De la Puente Brunke (eds.). El estado en la sombra: El Perú durante la ocupación chilena. Documentos administrativos (diciembre de 1881 - julio de 1882) (Lima: Fondo Editorial de la Pontificia Universidad Católica del Perú, 2016).

DE la ReZA, Germán A. (comp.). Documentos sobre el Congreso Anfictiónico de Panamá (Caracas: Fundación Biblioteca Ayacucho, 2010).

Delgado, Luis H. Guerra entre el Perú y Chile, 1879; de la Historia del General Mariano Ignacio Prado con documentos originales e inéditos (Lima: Ariel, 1965).

—. Guerra entre el Perú y España, 1866; de la Historia del General Mariano Ignacio Prado con documentos originales e inéditos (Lima: Ariel, 1965).

DENNIS, William J. Documentary History of the Tacna-Arica Dispute (New York, NY: Kennikat Press, 1927).

- Tacna and Arica: An Account of the Chile-Peru Boundary Dispute and of the Arbitrations by the Unites States (Yale University Press, 1931). 
Documentos relativos a la campaña del Pacífico (1863-1867): Archivo Álvaro de Bazán, sección expediciones (Madrid: Museo Naval, 1966-1994). 3 vols.

Documentos relativos a la mediación de la Francia i la Gran-Bretaña i de los Estados Unidos en la guerra entre las repúblicas aliadas del Pacífico i la España (Santiago: Imprenta Nacional, 1867).

Donoso, Ricardo. José Antonio Soffia en Bogotá (Bogotá: Instituto Caro y Cuervo, 1976).

ECHENIQUE GANDARILlaS, José M. El tratado secreto de 1873: Su documentación (Santiago: Cervantes, 1921).

El derecho de la guerra según los últimos progresos de la civilización (recopilación oficial) (Santiago: [n/d], 1879).

El doctor Rufino de Elizalde y su época vista a través de su archivo (Buenos Aires: Universidad de Buenos Aires, 1969-1974). 4 vols.

ELío, Tomás G. La paz del Chaco, una decisión política (La Paz: Plural, 2nd ed., [1988] 2011).

ELío, Tomás M. La guerra y la paz del Chaco (La Paz: Plural, 2nd ed., [1959] 2011).

“Episodios de la guerra de Chile con España,” Revista Historia, No. 5 (1966), pp. 217-237.

Epistolario de Alberto Blest Gana (1856-1916) (Santiago: DIBAM; Centro de Investigaciones Diego Barros Arana, 2011). 2 vols.

ESTIGARRIBIA, José F. The Epic of the Chaco: Marshal Estigarribia's Memoirs of the Chaco War, 1932-1935, ed. and annotated by Pablo M. YNSFRÁn (University of Texas Press, 1950).

ESTRADA, Genaro. Las relaciones entre México y Perú: La misión de Corpancho (México DF: Archivo Histórico Diplomático Mexicano No. 4, Secretaría de Relaciones Exteriores, 1923).

Exposición de la Legación del Ecuador en el Perú, confiada al Excmo. Sr. Dr. D. Benigno Malo en los años de 1866 i 1867, con un prólogo i un apéndice por el Doctor Don Vicente Paz (Lima: Imprenta del Diario Oficial, 1883).

Exposición de los actos agresivos contra el Perú, ejecutados por el Almirante de la escuadra española, D. Luis H. Pinzón (Lima: El Mercurio, 1864).

FoIANINI BAnZeR, Dionisio. Misión cumplida (La Paz: Fondo Editorial de los Diputados, 2nd ed., [1991] 2002).

FUENTES, Manuel A. Refutación al discurso pronunciado en el Senado español, por el Ministro de Estado D. J. F. Pacheco (Lima: El Mercurio, 1864). 
Gill AguinagA, Juan B. La Asociación Paraguaya en la guerra de la Triple Alianza (Asunción: ServiLibro, [1959] 2011).

GuACHALla, Luis F. Jayucubás: Comentarios y crónicas de la guerra del Chaco (La Paz/Cochabamba: Los Amigos del Libro, 1978).

_. Misión en el Paraguay: Mayo, 1930 - Julio 1931 (La Paz: Imprenta de la Universidad Mayor de San Andrés, 1971).

GuZMÁn PALOMino, Luis. Historia general de la guerra del Pacífico. Vol. 3: "Compendio histórico y recopilación de partes y documentos de la guerra del Pacífico” (Lima: Milla Batres, 1980).

HERnÁNDEZ PinZÓn, Luis. Diario de la navegación practicada al Océano Pacífico con las fragatas y goleta Resolución, Triunfo y Covadonga (Madrid: Museo Naval de Madrid, [1864]). Doc. No. 976, Code of Ref.: BMDB20160046090).

HuRTAdo, J. Nicolás. La legación de Chile en el Perú desde abril hasta setiembre de 1864 i el conflicto peruano-español (Santiago: Librería del Mercurio, 1872).

Informes inéditos de diplomáticos extranjeros durante la guerra del Pacífico: Alemania, Estados Unidos de Norteamérica, Gran Bretaña (Santiago: Bello, 1980).

Jus. La guerra de Chile ante el Derecho de Gentes (Valparaíso: Julio Real y Prado, 1880).

La cuestión Talambo ante La América (Lima: Imprenta del Comercio, 1864).

LAMAS, Andrés. Tentativas para la pacificación de la República Oriental del Uruguay, 18631865 (Buenos Aires: Imprenta de la Nación Argentina, 1865).

La misión Lavalle en Chile y el tratado secreto de 1873: Correspondencia oficial del enviado extraordinario y ministro plenipotenciario del Perú en Chile, don José A. de Lavalle, con el ministro de relaciones de ese país, durante su misión cerca del gobierno de Chile, en 1879, según los documentos originales que existen en el archivo del Ministerio de Relaciones Exteriores (Santiago: Imprenta Nacional, 1924).

LARRAÍn DE CASTRO, Carlos J. La misión Lastarria, 1865-1866 (Santiago: El Imparcial, 1940).

LASTARria, José V.; Álvaro Covarrubias, Domingo SANTA MaríA and Benjamín ViCuÑa MACKENNA, Colección de ensayos i documentos relativos a la unión i confederación de los pueblos hispano-americanos (Santiago: Imprenta Chilena, 1862).

LAVALle, José A. de. Mi misión en Chile en 1879 y anexos (Lima: Instituto de Estudios Histórico-Marítimos del Perú, 1994).

Leitão de CARVAlHo, Estevão. A paz do Chaco: Como foi efetuada no campo de batalha (Rio de Janeiro: Ministério da Guerra, Biblioteca do Exército, 1958). 
LE LÉON, Eugène. Souvenirs d'une mission à l'armée chilienne: Batailles de Chorrillos et de Miraflores (avec un résumé de la guerre du Pacifique et des notes) (Paris: Baudoin, 1883).

LIRA URQUIETA, Pedro. "La guerra con España en la correspondencia de don Álvaro Covarrubias con don José Ramón Lira," Boletín de la Academia Chilena de la Historia, Vol. 25 (1 semestre, 1958), pp. 149-169.

Logan, Cornelius A. and Francisco GARCía CALDERón. Mediación de los Estados Unidos de Norte América en la guerra del Pacífico (Buenos Aires: Imprenta de Mayo, 1884).

MARKHAM, Clements R. The War Between Peru and Chile, 1879-1883 (London: Gilbert and Rivington, 1883).

MARTÍNEZ, Marcial. La Unión Americana (Santiago: Imprenta de la Libertad, 1868).

MASTERMAn, George F. Seven Eventful Years in Paraguay: A Narrative of Personal Experience Amongst the Paraguayans (London: Sampson Low, Son and Marston, 1870).

MATTA, Manuel A. Documentos para un capítulo de la historia diplomática de Chile en su última guerra con España (Santiago: Imprenta del Ferrocarril, 1872).

MC Evoy, Carmen. Armas de persuasión masiva: Retórica y ritual en la guerra del Pacífico (Santiago: Centro de Estudios Bicentenario; Universidad Andrés Bello, 2010).

- Chile en el Perú: La ocupación a través de sus documentos, 1881-1884 (Lima: Fondo Editorial del Congreso del Perú, 2016).

MEDINACELI, Benedicto. El voto de guerra: Colección de artículos publicados durante la campaña de los españoles en el Pacífico (Sucre: Siglo XIX, 1866).

. Sistema político que toca observar a Bolivia en la cuestión hispano-peruana (Cochabamba: Gutiérrez, 1864).

[MESONES, Luis]. La diplomacia y el congreso (Turin: Imprenta de l'Italie, 1864).

Milla Batres, Carlos. Historia general de la guerra del Pacífico. Vol. 4: "Recopilación de partes y documentos de la guerra del Pacífico, 1879-1883” (Lima: Milla Batres, 1980).

Miró Quesada SosA, Aurelio. "Preliminares del tratado de Ancón (correspondencia IglesiasLavalle, enero-setiembre 1883), Revista Histórica [Lima], Vol. 33 (1981), pp. 9-44.

NAVARRO, Joaquim. "Informe confidencial sobre la República de Paraguay (inédito)," Revista Nacional [Buenos Aires], Vol. 20, Tomo I, No. 1 ( $3^{\circ}$ serie, 1894), pp. 166-185, $193-$ 209. 
NúÑEZ, Rafael. "El Congreso Internacional de Panamá," in La reforma política en Colombia: Colección de artículos publicados en "La Luz” de Bogotá, "El Porvenir" y "El Impulso” de Cartagena, de 1878 a 1884 (Bogotá: La Luz, 1886), pp. 38-43.

OCHOA, José V. Diario de la campaña del ejército boliviano en la guerra del Pacífico (Lima: La Casa del Libro Viejo, 2012).

“Órdenes de la División Oriental: Guerra del Paraguay, 1865-1868,” Boletín Histórico del Estado Mayor del Ejército [Montevideo], No. 145-148 (1975), pp. 161-216.

ORIBE STEMMER, Juan. El umbral de la Triple Alianza: Correspondencia de los representantes diplomáticos británicos en el Río de la Plata y documentos complementarios de la región, enero 1864 - agosto 1865 (Montevideo: Banda Oriental, 2nd ed., rev. and enlarged, [2008] 2013).

ORTIZ Benites, Juan (comp.). El New-York Herald y la guerra del Pacífico (Lima: La Casa del Libro Viejo, 2013).

- Sesiones secretas del Senado de Chile durante la guerra del Pacífico: Marzo de 1879 a septiembre de 1880 (Lima: La Casa del Libro Viejo, 2013).

PAIVA AlCoRTA, Félix. La paz del Chaco: Documentos para el estudio de las tratativas que concluyeron en el Tratado de Paz, Amistad y Límites con Bolivia (Archivo Dr. Félix Paiva) (Asunción: El Lector, 1983).

PALleja, León de. Diario de la campaña de las fuerzas aliadas contra el Paraguay (Montevideo: El Pueblo, 1865-1866). 2 vols.

“Papeles de don Domingo Santa María: La ocupación de las Islas Chinchas en 1864," Revista Chilena de Historia y Geografía, Año VIII, Tomo XXVII, No. 31 (3º trimestre, 1918), pp. 84-92.

Papeles de López: O, el tirano pintado por sí mismo y sus publicaciones (Buenos Aires: Imprenta Americana, 1871).

Papeles del Tirano del Paraguay tomados por los aliados en el asalto de 27 de diciembre de 1868 (Buenos Aires: Imprenta Buenos Aires, 1869).

PARDO Y BARREDA, José. Historia del tratado "secreto" de alianza defensiva entre el Perú y Bolivia (Lima: Milla Batres, 1979).

PeZET, Juan A. Exposición del General don Juan Antonio Pezet, ex-Presidente del Perú (Paris: Berger, 1867).

Protesta del pueblo orureño contra el ultraje inferido a la soberanía nacional del Perú, a nombre de la Reina de España, por su escuadra, al mando del Almirante Pinzón (Oruro:

Vargas, 1864). 
QueRejazu CALvo, Roberto (comp.). Oposición en Bolivia a la Confederación Perú-boliviana: Cartas del vicepresidente Mariano Enrique Calvo y el presidente Andrés Santa Cruz (Sucre: Excma. Corte Suprema de Justicia de la Nación, 1996).

RAMÍREZ, J. Isidoro. El panamericanismo, el arbitraje y la agresión boliviana en el Chaco: Un examen documental (Santiago: [n/d], 1933).

_. La paz del Chaco: Defensa de la línea de hitos (Asunción: Intercontinental, [1942] 2011).

ReBAUdI, Arturo. Guerra del Paraguay: La conspiración contra S. E. el Presidente de la República, Mariscal don Francisco Solano López (Buenos Aires: Constancia, 1917).

—. Guerra del Paraguay, un episodio: ¡Vencer o morir! (Buenos Aires: Constancia, 1918).

- La declaración de guerra de la República del Paraguay a la República Argentina: Misión Luis Caminos-misión Cipriano Ayala-declaración de Isidro Ayala (Buenos Aires: Serantes, 1924).

Ríos VALDIVIA, Alejandro. "La misión Lavalle," Anales de la Universidad de Chile, Año 2, Serie 2 (enero-diciembre, 1924), pp. 413-559, 856-1002.

Rivarola, Vicente. Memorias diplomáticas: El Paraguay en el litigio de límites con Bolivia (Buenos Aires: Ayacucho, 1952-1957). 3 vols.

Rivarola Coello, Vicente. Cartas diplomáticas: Eusebio Ayala-Vicente Rivarola. Guerra del Chaco (Buenos Aires: Industria Gráfica del Libro, 1982).

RodrígueZ Alcalá, Guido and José E. AlCÁZAR. Paraguay y Brasil: Documentos sobre las relaciones binacionales, 1844-1864 (Asunción: Tiempo de Historia, 2007).

SAAVedrA, Bautista. El Chaco y la conferencia de paz de Buenos Aires (Santiago: Nascimiento, 1939).

SAAVEDRA LAMAS, Carlos. La Conferencia Interamericana de Consolidación de la Paz (celebrada en Buenos Aires, del $1^{\circ}$ al 23 de diciembre de 1936) (Buenos Aires: [n/d], 1938).

—. Por la paz de las Américas (Buenos Aires: Gleizer, 1937).

SANTA CRUZ, Oscar de (comp.). El General Andrés de Santa-Cruz, Gran Mariscal de Zepita y el Gran Perú (La Paz: Escuela Tipográfica Salesiana, 1924).

SARMIENTO, Domingo F. Obras. Tomo XXXIV: “Cuestiones americanas” (Buenos Aires: Imprenta Mariano Moreno, 1900).

Sarmiento-Mitre: Correspondencia, 1846-1868 (Buenos Aires: Museo Mitre, 1911). 
SCAVONE Yegros, Ricardo (comp.). Colombia ante la guerra del Paraguay contra la Triple Alianza: Documentos oficiales, artículos periodísticos y otros escritos contemporáneos (Asunción: Tiempo de Historia, 2015).

SEeBER, Francisco. Cartas sobre la guerra del Paraguay, 1865-1866 (Buenos Aires: Rosso, 1907).

SosA, Jaime. Negociaciones diplomáticas entre el Brasil, la República Argentina y el Paraguay: Misión del ciudadano paraguayo Jaime Sosa a Río de Janeiro (Buenos Aires: La Tribuna, 1875).

SOTOMAYOR VALDÉS, Ramón. La legación de Chile en Bolivia desde setiembre de 1867 hasta fines de 1870 (Santiago: Imprenta Chilena, 1872).

SPILA DA SUBIACO, Benedetto. Il Chilì nella guerra del Pacifico: Missionario emerito del Chilì (Roma: Cuggiani, 2nd ed., enlarged, [1883] 1886).

STEFAnICH, Juan. El 23 de octubre de 1931: Primera batalla por la defensa del Chaco y primer grito de la revolución de febrero de 1936 (Buenos Aires: Febrero, 1959).

—. La diplomacia de la revolución (Buenos Aires: El Mundo Nuevo, 1945). La guerra del Chaco y la misión de la Sociedad de las Naciones (Asunción: [n/d], 1934).

Stewart SellitTi, Yolanda C. Memorias del doctor Guillermo Stewart: Jefe de la Sanidad Militar durante la guerra del '70 (Asunción: Intercontinental, 2015).

THOMPSON, George. The War in Paraguay; with a historical sketch of the country and its people and notes upon the military engineering of the war (London: Longmans Green, 1869).

URIBE, José A. Anales diplomáticos y consulares de Colombia (Bogotá: Imprenta Nacional, 1900-1920). 6 vols.

URIBURU, Dámaso E. Guerra del Pacífico: Episodios, 1879 a 1881 (Buenos Aires: Compañía Sud-Americana de Billetes de Banco, 1899).

URRUTIA CERUTI, Jaime. Informes de los cónsules franceses en Lima, 1842-1877 (Lima: Instituto Francés de Estudios Andinos; Instituto de Estudios Peruanos, 2015).

VACCA, Juan E. Notas de la pasada guerra del Chaco, e informaciones de cosas vistas, oídas y vividas en la zona de operaciones (Buenos Aires: Círculo Militar, 1938).

VANZINA, Alberto. Cenni sulla Repubblica del Chilì e sulla guerra col Perù e colla Bolivia (Torino: Tipografia Legale, 1881).

VARAS, Antonio. Correspondencia de don Antonio Varas: Cuestiones americanas (Santiago: Taller Imprenta, 1929). 
- Correspondencia de don Antonio Varas sobre la guerra del Pacífico (Santiago: Imprenta Universitaria, 1918).

VARAS VeLÁSQUEZ, Miguel. "Algunas cartas y documentos sobre el conflicto hispano-peruano (1864-1865),” Revista Chilena, Año XII, No. 95-96 (marzo-abril, 1928), pp. 171240 .

—_. "Algunas cartas y documentos sobre la guerra entre Chile-Perú y España (18651866)," Revista Chilena, Año XII, No. 97 (mayo, 1928), pp. 494-549.

—. "Páginas americanas: Chile y el Ecuador, 1855: Algunas cartas y documentos," Revista Chilena, Año XII, No. 100-101 (agosto-septiembre, 1928), pp. 911-964.

VARGAS PEÑA, Benjamín. "La guerra y la paz del Chaco: Entrevista Gerónimo Zubizarreta-José Félix Estigarribia," Cuadernos Históricos, Vol. 1, No. 1 (enero-febrero, 1988), pp. 162.

VARIGNY, Charles V. de. La guerra del Pacífico (Santiago: Cervantes, [1881] 1922).

VÁsquez Sagastume, José and José A. SARAIVA. "Preliminares da guerra do Paraguay: Rectificación histórica. El Dr. Vásquez Sagastume e resposta do Conselheiro José Antônio Saraiva," Revista Trimensal do Instituto Historico e Geographico Brazileiro, Tomo LIX, Parte I ( $1^{\circ}$ e $2^{\circ}$ trimestres, 1896), pp. 262-367.

Washburn, Charles A. The History of Paraguay, with Notes of Personal Observations, and Reminiscences of Diplomacy under Difficulties (Boston, MA: Lee and Shepard, 1871). 2 vols.

WHIGHAM, Thomas L. and Juan M. CASAL (comps.). La diplomacia estadounidense durante la guerra de la Triple Alianza: Escritos escogidos de Charles Ames Washburn sobre el Paraguay, 1861-1871 (Asunción: ServiLibro, 2015).

Wu Brading, Celia. Diplomacia y cañones en la guerra del Pacífico: Testimonios británicos de la ocupación de Lima, enero de 1881 (Lima: Biblioteca Nacional del Perú, 2016).

Yrigoyen, Pedro. La adhesión de la República Argentina al tratado de alianza defensiva Perúboliviano de 1873 (Lima: Sanmartí, 1919).

—. La alianza Perú-boliviana-Argentina y la declaratoria de guerra de Chile (Lima: Sanmartí, 1921).

YRIGOYEN, Pedro; DiPlomÁtico X and Javier PRADO. "Tratado de alianza argentino-peruano de 1873,” Revista de Derecho, Historia y Letras, Año XXI, Tomo LXIII (1919), pp. 206230, 401-417.

. "Tratado de alianza argentino-peruano de 1873," Revista de Derecho, Historia y Letras, Año XXI, Tomo LXIV (1919), pp. 76-89. 
Zubizarreta Ugarte, José M. La paz del Chaco. Tomo I: “Antecedentes del conflicto” (Buenos Aires: Buschi, 1974).

\section{(e) DisSERTATIONS AND THESES}

AmAYo, Enrique. "British Policy in the War of the Pacific: Chile vs. Peru and Bolivia, 18791884. A Chapter of Free Trade Expansion in the Pax Britannica Period," Ph.D. Dissertation, Pittsburgh, PA: University of Pittsburgh, 1985. [Published].

BARRIO, Cesar de Oliveira Lima. "O intervencionismo do Império brasileiro no Rio da Prata: Da ação contra Rosas e Oribe à Tríplice Aliança," Ph.D. Dissertation, Brasília: Universidade de Brasília, 2011.

BECK, William F. "A Comparison of British and United States Relations with Chile, 1879-1883: A Study in Diplomatic History," Ph.D. Dissertation, Pittsburgh, PA: University of Pittsburgh, 1942.

Brown, Stephen D. "The Power of Influence in United States-Chilean Relations," Ph.D. Dissertation, Madison, WI: University of Wisconsin-Madison, 1983.

Caballero Aquino, Ricardo. "The Economic Reconstruction of Paraguay in the Postwar Period: Politics and Property in the Era of General Caballero, 1869-1904," Ph.D. Dissertation, Carbondale, IL: Southern Illinois University at Carbondale, 1980. [Published].

CAMPOS ARRUdÃO, Bias. "Ending the War of the Triple Alliance: Obstacles and Impetus," M.A. Thesis, Austin, TX: University of Texas at Austin, 1981.

ChANG HuAYANCA, Antonio J. "Entre la espada y la pared: La administración del Gral. Juan Antonio Pezet frente a la crisis diplomática con España (1863-1865)," Lic. Thesis, Lima: Universidad Nacional Mayor de San Marcos, 2013.

Christman, Calvin L. "The Chaco Dispute and United States Diplomatic Involvement, 19281935," M.A. Thesis, Nashville, TN: Vanderbilt University, 1966.

CoRTADA, James W. “Conflict Diplomacy: United States-Spanish Relations, 1855-1868," Ph.D. Dissertation, Tallahassee: FL, The Florida State University, 1973.

Crosby, Kenneth W. "The Diplomacy of the United States in Relation to the War of the Pacific, 1879-1884," Ph.D. Dissertation, Washington DC: George Washington University, 1949.

FEBRES-CORDERO CARILLO, Francisco. "La anexión y la guerra de restauración dominicana desde las filas españolas (1861-1865),” Ph.D. Dissertation, Ríp Piedras: Universidad de Puerto Rico, 2008. 
Fornos PeÑALBA, José A. "The Fourth Ally: Great Britain and the War of the Triple Alliance," Ph.D. Dissertation, Los Angeles, CA: University of California, 1979.

HENDERSON, Donald C. "A Comparative Study in the Application of the Monreo Doctrine in Two Selected Instances," East Lansing, MI: Ph.D. Dissertation, Michigan State University, 1964.

HERSCH, Robert C. “American Interest in the War of the Triple Alliance, 1865-1870," Ph.D. Dissertation, New York, NY: New York University, 1974.

HoLland, Emmett J. “A Historical Study of Bolivian Foreign Relations, 1935-1946,” Ph.D. Dissertation, Washington DC: The American University, 1967.

Hughes, Lawrence R. "General Martin T. McMahon and the Conduct of Diplomatic Relations Between the United States and Paraguay," M.A. Thesis, Boulder, CO: University of Colorado, 1962.

JefFs CAStro, Leonardo. “Chile y la guerra del Chaco,” Ph.D. Dissertation, Santiago: Universidad de Santiago de Chile, 2011.

KAIN, Ronald S. "The Intervention of the League of Nations in the Chaco Dispute (December 5, 1928 to May 12, 1934)," M.A. Thesis, New York, NY: Columbia University, 1936.

KLEIN, Herbert. "The Impact of the Chaco War on Bolivian Society," Ph.D. Dissertation, Chicago, IL: The University of Chicago, 1963. [Published].

LACASSE, Geoffrey. "Trace of Oil: The Search for the Initiating Factor of the Chaco War," M.A. Thesis, Burnaby, BC: Simon Fraser University, 1987.

LÓPEZ MUÑOZ, Ricardo. "El americanismo en Chile ante la expansión política y militar europea sobre Hispanoamérica (1861-1871), P Ph.D. Dissertation, Santiago: Universidad de Chile, 2011.

MAAS, Ellis R. "The Role of Uruguay in the Mediation of the Chaco War," Ph.D. Dissertation, Lincoln, NE: University of Nebraska, 1958.

Martín GonZÁlez, Félix E. “The Longer Peace in South America, 1935-1995,” Ph.D. Dissertation, New York, NY: Columbia University, 1998. [Published].

MCINTYRE, David. "The Longest Peace: Why Are There So Few Interstate Wars in South America?” Ph.D. Dissertation, Chicago, IL: The University of Chicago, 1995.

MCLYNN, Frank J. "General Urquiza and the Politics of Argentina, 1861-1870," Ph.D. Dissertation, London: University of London, 1976.

MEIERDING, Emily L. "No Blood for Oil? The Dynamics of Interstate Petroleum Disputes," Ph.D. Dissertation, Chicago, IL: The University of Chicago, 2010. 
Page, A. Nayland. "United States Diplomacy in the Tacna-Arica Dispute, 1884-1929," Ph.D. Dissertation, Norman, OK: The University of Oklahoma, 1958.

PHILLIPS, Richard S. "Bolivia in the War of the Pacific, 1878-1884," Ph.D. Dissertation, Charlottesville, VA: University of Virginia, 1973.

RiBAS MiRANDA, José A. “'Diplomata mais amante do seu paiz que das suas commodidades': Atuação de Francisco Adolfo de Varnhagen nas Repúblicas do Pacífico, 1863-1865," M.A. Thesis, Porto Alegre: Pontifícia Universidade Católica do Rio Grande do Sul, 2013.

RICHARDS, Carolyn A. H. "Chilean Attitudes Toward the United States, 1860-1867," Ph.D. Dissertation, Stanford, CA: Stanford University, 1970.

Ross, Carl A. "Chile and its Relations with the United States during the Ministry of Thomas Henry Nelson, 1861-1866," Ph.D. Dissertation, Athens, GA: University of Georgia, 1966.

RUBILAR LUENGO, Mauricio E. "La política exterior de Chile durante la guerra y postguerra del Pacífico (1879-1891): Las relaciones con Estados Unidos y Colombia. Diplomacia, opinión pública y poder naval," Ph.D. Dissertation, Valladolid: Universidad de Valladolid, 2012.

SAUNDERS, John H. "Diplomacy under Difficulties: United States Relations with Paraguay during the War of the Triple Alliance," Ph.D. Dissertation, Athens, GA: University of Georgia, 1966.

SCHAEFER, Robert H. "The Paraguayan War and the Platine Balance of Power," M.A. Thesis, Portland, OR: Portland State University, 1975.

SHESKO, Elizabeth. "Conscript Nation: Negotiating Authority and Belonging in the Bolivian Barracks, 1900-1950,” Ph.D. Dissertation, Durham, NC: Duke University, 2012.

SMITH, Betty W. "James G. Blaine and United States Mediation in the War of the Pacific," M.A. Thesis, East Lansing, MI: Michigan State College of Agriculture and Applied Science, 1955.

TERRADAS, Nicolás. "El dilema de la seguridad en América del Sur: Una revisión del debate sobre la 'larga paz' sudamericana," M.A. Thesis, Buenos Aires: Universidad Torcuato Di Tella, 2010.

VAN AKEN, Mark J. "Origins of the Pan-Hispanic Movement to 1866," Ph.D. Dissertation, Berkeley, CA: University of California, 1955. [Published]

VARLEY, Michael G. "Aftermath of the War of the Pacific: A Study in the Foreign Policy of Chile, 1891-96," Ph.D. Dissertation, Cambridge: University of Cambridge, 1969.

WILGuS, A. Curtis. "James G. Blaine and the Pan-American Movement," M.A. Thesis, Madison, WI: University of Wisconsin, 1921. 


\section{GENERAL BIBLIOGRAPHY}

ABASTOFLOR FREY, E. Jorge. "Misión Guachalla: Situación militar del Paraguay antes de la guerra del Chaco," Gaceta Académica: Academia Boliviana de Historia Militar (2015), pp. 1-7.

ABeCiA VALDIVIESO, Valentín. Las relaciones internacionales en la historia de Bolivia (La Paz: Los Amigos del Libro, 2nd ed., [1979] 1986). 3 vols.

ABENTE, Diego. "Constraints and Opportunities: Prospects for Democratization in Paraguay," Journal of Interamerican Studies and World Affairs, Vol. 30, No. 1 (Spring, 1988), pp. 73-104

"Foreign Capital, Economic Elites and the State in Paraguay during the Liberal Republic, 1870-1936," Journal of Latin American Studies, Vol. 21, No. 1 (February 1989), pp. 61-71.

—. "The Liberal Republic and the Failure of Democracy," The Americas, Vol. 45, No. 4 (April, 1989), pp. 525-546.

. "The War of the Triple Alliance: Three Explanatory Models," Latin American Research Review, Vol. 22, No. 2 (1987), pp. 47-69.

ABREU, Sergio. La vieja trenza: La alianza porteño-lusitana en la cuenca del Plata (1800-1875) (Montevideo: Planeta, 2nd ed., [2013] 2014).

ACEVEDO, Eduardo. Anales históricos del Uruguay (Montevideo: Barreiro y Ramos, 1933). 6 vols.

Acosta, Gustavo. Posguerra contra la Triple Alianza: Aspectos políticos e institucionales (1870-1904) (Asunción: ServiLibro, 2013).

ADLER, Emanuel and Michael N. BARNETT (eds.). Security Communities (Cambridge University Press, 1998).

ALBERDI, Juan B. El crimen de la guerra. Edición crítico-genética de Élida Lois (San Martín: Universidad Nacional de San Martín, [1870] 2007).

—_. El Imperio del Brasil ante la democracia de América (Paris: Rochette, 1869).

—. Las disensiones de las repúblicas del Plata y las maquinaciones del Brasil (Montevideo: Imprenta Tipográfica a Vapor, 1865).

- Obras completas de Juan Bautista Alberdi (Buenos Aires: La Tribuna Nacional, 1886-1887). 8 vols.

AlCÁZAR, Moisés. Drama y comedia en el Congreso: Cónicas parlamentarias (La Paz: Juventud, 3rd ed., rev., [1957] 1980). 
ALjovín DE LoSADA, Cristóbal. "La Confederación Perú-boliviana, 1836-1839: Política interna o externa," Investigaciones Sociales, Año V, No. 8 (2001), pp. 65-79.

. "Perú y la guerra del Paraguay, 1864-1870," in La guerra del Paraguay:

Historiografías. Representaciones. Contextos, ed. by Horacio CRESPO, Juan M.

PALACIO and Guillermo PALACIOS (México DF: El Colegio de México, 2012), pp. 363-382.

Alonso PiÑEIRO, Armando. La misión diplomática de Mitre en Rio de Janeiro-1872 (Buenos Aires, Institución Mitre, 1972).

AlvéSTegui, David. Bolivia y el Paraguay: La cuestión de límites (La Paz: Renacimiento, 1926).

- Salamanca: Su gravitación sobre el destino de Bolivia (La Paz/Cochabamba: Talleres Gráficos Bolivianos/Canelas, 1957-1970). 4 vols.

AMARILla FRETES, Eduardo. La liquidación de la guerra de la Triple Alianza contra el Paraguay (negociaciones diplomáticas) (Asunción: Imprenta Militar, 1941).

AMAYO, Enrique. “A guerra do Paraguai em perspectiva histórica," Estudos Avançados, Vol. 9, No. 24 (1995), pp. 255-268.

—. La política británica en la guerra del Pacífico (Lima: Horizonte, 1988).

ANDRADE, Olímpio de Souza. Joaquim Nabuco e o Pan-americanismo (São Paulo, Editora Nacional, 1950).

ANDRESKI, Stanislav. Military Organization and Society (University of California Press, 2nd ed., enlarged, [1954] 1968).

. "On the Peaceful Disposition of Military Dictatorships," Journal of Strategic Studies, Vol. 3, No. 3 (1980), pp. 3-10.

- Wars, Revolutions, Dictatorships: Studies of Historical Contemporary Problems from a Comparative Viewpoint (London: Frank Cass, 1992).

ARAÚZ, Celestino A. Panamá y sus relaciones internacionales (Panamá: Editorial Universitaria, 1994). 2 vols.

Araúz, Celestino A. and Patricia PIZZurno Gelós. El Panamá colombiano (1821-1903) (Panamá: Primer Banco de Ahorros; Diario La Prensa de Panamá, 1993).

- Relaciones entre Panamá y los Estados Unidos: Historia del canal interoceánico desde el siglo XVI hasta 1903 (Panamá: Autoridad del Canal de Panamá, 1999).

ARCHER, Christon I. (ed.). The Wars of Independence in Spanish America (Wilmington, DE: Scholarly Resources, 2000). 
ARIAS, Enrique D. and Daniel M. GoldSTEIN (eds.). Violent Democracies in Latin America (Duke University Press, 2010).

ARMAS ASÍN, Fernando. "Financiar la guerra: Planes fiscales, lucha política y crisis inflacionaria en el Perú (1879-1880),” Revista Histórica [Lima], Vol. 25, No. 2 (2001), pp. 49-97.

ARMSTRONG, David. Revolution and World Order: The Revolutionary State in International Society (Oxford University Press, 1993).

ARRIGHI, Jean-Michel. La OEA y el derecho internacional (México DF: Porrúa, 2015).

ArtaZA, Policarpo. Ayala, Estigarribia y el Partido Liberal (Asunción: Palacios, 3rd ed., [1946] 1988).

ARZE QUIROGA, Eduardo. Las relaciones internacionales de Bolivia, 1825-1990 (La Paz: Los Amigos del Libro, 1991).

AUZA, Néstor T. “Apertura de relaciones diplomáticas en el Pacífico: Misión Cané en Venezuela y Colombia," Revista Histórica [Buenos Aires], Tomo VI, No. 17 (1991), pp. 165236.

. "La mediación argentina en la guerra del Pacífico, 1880-1882," Res Gesta, No. 33 (enero-diciembre, 1994), pp. 43-81.

—. La misión Sarmiento en Chile y Perú y el Congreso Americano, 1864-1865 (Buenos Aires: Histórica, 2007).

—. Santiago Estrada y el conflicto de límites con Chile (Buenos Aires: Estrada, 1965).

ÁviLA, Federico. Bolivia en el concierto del Plata (México DF: Cultura, 1941).

Ayala Moreira, Rogelio. Por qué no ganamos la guerra del Chaco (La Paz: Talleres Gráficos Bolivianos, 1959).

BADER, Thomas M. "The Chancellery and the Change-Purse: A Skeptic's View of the Applicability of a 'Balance of Power' Concept to 19th Century South America," Proceedings of the Pacific Coast Council on Latin American Studies, Vol. 3 (1974), pp. 45-54.

BÁKULA, Juan M. La política internacional entre el Perú y Colombia (Bogotá: Temis, 1988).

Perú, entre la realidad y la utopía: 180 años de política exterior (Lima: Fundación Academia Diplomática del Perú, 2002). 2 vols.

. Perú y Ecuador: Tiempos y testimonios de una vecindad (Lima: CEPEI, 1992). 3 vols.

BALDRICH, Alonso. "El problema del petróleo y la guerra del Chaco," Revista Americana de Buenos Aires (septiembre, 1934), pp. 9-46. 
BARBA, Enrique M. "La alianza secreta de 1873 entre Bolivia y Perú: Tentativa para obtener la anexión argentina," Revista de Historia de América, No. 22 (diciembre, 1946), pp. $273-351$.

. "Las relaciones exteriores con los países americanos," in Historia de la Nación Argentina (desde los orígenes hasta la organización definitiva en 1862). Vol. VII: "Rosas y su época” (Buenos Aires: Imprenta de la Universidad, 1950), pp. 281-368.

BARLETTA, Michael and Harold TRINKUNAS. "Regime Type and Regional Security in Latin America: Toward a 'Balance of Identity' Theory," in Balance of Power: Theory and Practice in the 21st Century, ed. by Tazha V. PAUL, James J. WIRTZ and Michel FORTMANN (Stanford University Press), pp. 334-359.

BARRERA AguilerA, Óscar J. "La guerra del Chaco como desafío al Panamericanismo: El sinuoso camino a la conferencia de paz de Buenos Aires, 1934-1935," Anuario Colombiano de Historia Social y de la Cultura, Vol. 38, No. 1 (enero-junio, 2011), pp. 179-217.

BARRERO, Francisco U. Conducción político-diplomática de la guerra con Paraguay (La Paz: El Siglo, 1979).

BARrio, Cesar de Oliveira Lima. A missão Paranhos ao Prata (1864-1865): Diplomacia e política na eclosão da guerra do Paraguai (Brasília: Fundação Alexandre de Gusmão, 2010).

BARros, Jaime de. “A defesa coletiva da América," Cultura política: Revista mensal de estudos brasileiros, Vol. 1, No. 3 (maio, 1941), pp. 11-20.

—. "A diplomacia brasileira e a defesa da América," Cultura política: Revista mensal de estudos brasileiros, Vol. 3, No. 31 (agosto, 1943), pp. 65-76.

. "A diplomacia brasileira e a defesa da América," Cultura política: Revista mensal de estudos brasileiros, Vol. 3, No. 34 (novembro, 1943), pp. 107-111.

- "A política do Brasil no América," Cultura política: Revista mensal de estudos brasileiros, Vol. 1, No. 1 (março, 1941), pp. 34-41.

- A política exterior do Brasil: 1930-1940 (Rio de Janeiro: Departamento de imprensa e propaganda, 1941).

BARros Borgoño, Luis. La cuestión del Pacífico y las nuevas orientaciones de Bolivia (Santiago: Artes y Letras, 2nd ed., [1922] 1922).

BARROS VAN BUREN, Mario. Chile y la guerra de secesión: La misión Astaburuaga en los Estados Unidos (Santiago: Editorial Universitaria, 1992).

—. Historia diplomática de Chile, 1541-1938 (Barcelona: Ariel, 1970). 
BASADRE, Jorge. "Antecedentes de la guerra con Chile," in Historia del Perú. Vol. 7: "Perú republicano” (Lima: Mejía Baca, 1980), pp. 9-160.

—. Chile, Perú y Bolivia independientes (Barcelona: Salvat, 1948).

—. Historia de la República del Perú (1822-1933) (Lima: El Comercio, 2005). 18 vols.

—. Reflexiones en torno a la guerra de 1879 (Lima: Campodónico, 1979).

BAStert, Russell H. “A New Approach to the Origins of Blaine's Pan American Policy,” The Hispanic American Historical Review, Vol. 39, No. 3 (August, 1959), pp. 375-412.

"Diplomatic Reversal: Frelinghuysen's Opposition to Blaine's Pan-American Policy in 1882," The Mississippi Valley Historical Review, Vol. 42, No. 4 (March, 1956), pp. 653-671.

Battaglino, Jorge. "The Coexistence of Peace and Conflict in South America: Toward a New Conceptualization of Types of Peace," Revista Brasileira de Política Internacional, Vol. 55, No. 2 (July-December), pp. 131-151.

BEACH, Derek and Rasmus B. Pedersen. Causal Case Study Methods: Foundations and Guidelines for Comparing, Matching, and Tracing (University of Michigan Press, 2016).

. Process-Tracing Methods: Foundations and Guidelines (University of Michigan Press, 2013).

BÉCKER, Jerónimo. Historia de las relaciones exteriores de España durante el siglo XIX (apuntes para una historia diplomática) (Madrid: Jaime Ratés/Voluntad, 1924-1926). 3 vols.

BEISNER, Robert L. From the Old Diplomacy to the New: 1865-1900 (Arlington Heights, IL: Harlan Davidson, 2nd ed., [1986] 1992).

Belgrano, Mario. "España y el conflicto del Pacífico, 1864-1867," in Contribuciones para el estudio de la historia de América: Homenaje al Doctor Emilio Ravignani (Buenos Aires: Peuser, 1941), pp. 515-549.

. "La cuestión de la nacionalidad y el tratado con España de 1863," Anuario de Historia Argentina, Vol. 2 (1940), pp. 47-64.

BeníTEZ, Luis G. Historia diplomática del Paraguay (Asunción: [n/d], 1972).

BenNetT, Andrew. "Process Tracing and Causal Inference," in Rethinking Social Inquiry: Diverse Tools, Shared Standards, ed. by Henry E. BRADY and David COLLIER (Lanham, MD: Rowman \& Littlefield, 2nd ed., [2004] 2010), pp. 207-219.

BenNetT, Andrew and Jeffrey T. CHECKEL. "Process Tracing: From Philosophical Roots to Best Practices," in Process Tracing: From Metaphor to Analytic Tool, ed. by Andrew BENNETT and Jeffrey T. CHECKEL (Cambridge University Press, 2015), pp. 1-37. 
BenNetT, Andrew and Jeffrey T. CHECKel (eds.). Process Tracing: From Metaphor to Analytic Tool (Cambridge University Press, 2015).

Bethell, Leslie. "Brazil and Latin America," Journal of Latin American Studies, Vol. 42, No. 3 (August, 2010), pp. 457-485.

. "The Paraguayan War (1864-1870)," University of London, Institute of Latin American Studies, Research Paper No. 46 (1996), pp. 1-41.

Bethell, Leslie and José Murilo De CARVAlHo. "Brazil from Independence to the Middle of the Nineteenth Century," in The Cambridge History of Latin America. Vol. 3: "From Independence to c. 1870,” ed. by Leslie BETHELL (Cambridge University Press, 1985), pp. 679-746.

BeVERINA, Juan. La guerra del Paraguay (1865-1870): Resumen histórico (Buenos Aires: Círculo Militar, 1973).

- La guerra del Paraguay: Las operaciones de la guerra en territorio argentino y brasileño (Buenos Aires: Ferrari, 1921). 7 vols.

BIDABeHERE, Fernando A. Mitre diplomático (Buenos Aires: Porter, 2nd ed., [1966] 1967).

. "Un episodio diplomático en la vida de Mitre," Historia, Vol. 13, No. 47 (abril-junio, 1967), pp. 99-101.

BIEBER, León E. “A guerra do Chaco e as relações brasileiro-bolivianas no período 1930-1945: Um caso de reorientação da política exterior do Brasil," Ibero-Amerikanisches Archiv, Neue Folge, Vol. 22, No. 3/4 (1996), pp. 267-288.

BLACKEMORE, Harold. "Chile from the War of the Pacific to the World Depression, 1880-1930," in The Cambridge History of Latin America. Vol. 5: “c. 1870 to 1930,” ed. by Leslie BeTHELl (Cambridge University Press, 1986), pp. 499-551.

Blanlot Holley, Anselmo. Historia de la paz entre Chile i el Perú, 1879-1884 (Santiago: Universo, 2nd ed., [1909] 1910).

- “¿Quién descubrió el tratado secreto Perú-Boliviano de 1873?” Revista Chilena, Año II, Tomo VII, No. 9 (diciembre, 1918), pp. 5-23.

Bonilla, Heraclio. Guano y burguesía en el Perú (Lima: FLACSO, 3rd ed., [1974] 1994).

. "El problema nacional y colonial del Perú en el contexto de la guerra del Pacífico," Desarrollo Económico, Vol. 20, No. 77 (abril-junio, 1980), pp. 49-70.

- "La dimensión internacional de la guerra del Pacífico," Desarrollo Económico, Vol. 19, No. 73 (abril-junio, 1979), pp. 79-92. 
- "La emergencia del control norteamericano sobre la economía peruana: 1850-1930," Desarrollo Económico, Vol. 16, No. 64 (enero-marzo, 1977), pp. 581-600.

- "Peru and Bolivia from Independence to the War of the Pacific," in The Cambridge History of Latin America. Vol. 3: "From Independence to c. 1870," ed. by Leslie BETHELl (Cambridge University Press, 1985), pp. 539-582.

—. Un siglo a la deriva: Ensayos sobre el Perú, Bolivia y la guerra (Lima: Instituto de Estudios Peruanos, 1980).

Bosch, Beatriz. "Los desbandes de Basualdo y Toledo," Revista de la Universidad de Buenos Aires, Vol. 4, No. 1 (1959), pp. 213-245.

- "Urquiza y la guerra de la Triple Alianza," Boletín de la Academia Nacional de la Historia, Vol. 34, No. 2 (1963), pp. 819-835.

—. Urquiza y su tiempo (Buenos Aires: EUDEBA, 1971).

BowdEn, Brett. Civilization and War (Cheltenham: Edwards Elgar, 2013).

- The Empire of Civilization: The Evolution of an Imperial Idea (The University of Chicago Press, 2009).

Box, Pelham H. The Origins of the Paraguayan War (New York, NY: Russell \& Russell, [1930] 1967).

BRAUn MENÉNDEZ, Armando. Mitre y la cuestión de límites argentino-chilena (Buenos Aires: Emecé, 1957).

Brezzo, Liliana M. and Beatriz J. Figallo. La Argentina y el Paraguay: De la guerra a la integración (Rosario: Instituto de Historia, Facultad de Derecho y Ciencias Sociales del Rosario; Pontificia Universidad Católica Argentina, 1999).

Bull, Hedley. "International Theory: The Case for a Classical Approach," World Politics, Vol. 18, No. 3 (April, 1966), pp. 361-377.

- The Anarchical Society: A Study of Order in World Politics (Columbia University Press, 1977).

BuLl, Hedley (ed.). Intervention in World Politics (Clarendon Press, 1984).

BuLL, Hedley and Adam WATSON (eds.). The Expansion of International Society (Oxford: Clarendon Press, 1984).

BúLneS, Gonzalo. Guerra del Pacífico. Vol. 1: “De Antofagasta a Tarapacá” (Valparaíso: Universo, 1912).

—. Guerra del Pacífico. Vol. 2: “De Tarapacá a Lima” (Valparaíso: Universo, 1914). 
- Guerra del Pacífico. Vol. 3: “Ocupación del Perú: La Paz” (Valparaíso: Universo, 1919).

BURR, Robert N. "Argentina and Chile," in Conflict in World Politics, ed. by Steven L. SPIEGEL and Kenneth N. WALTZ (Cambridge, MA: Winthrop, 1971), pp. 155-176.

- By Reason or Force: Chile and the Balancing of Power in South America, 1830-1905 (University of California Press, 1965).

- "Commentary on the Papers of Professors Hann and Bader," Proceedings of the Pacific Coast Council on Latin American Studies, Vol. 3 (1974), pp. 55-72.

—. "The Balance of Power in Nineteenth-Century South America: An Exploratory Essay," The Hispanic American Historical Review, Vol. 35, No. 1 (February, 1955), pp. 37-60.

- The Stillborn Panama Congress: Power Politics and the Chilean-Colombian Relations during the War of the Pacific (University of California Press, 1962).

BustiLlo, Ignacio P. La misión Bustillo (más antecedentes de la guerra del Pacifico) (Sucre: Bolívar, 1919).

Bustos, Carlos. Chile y Bolivia, un largo camino: De la independencia a Monterrey (Santiago: RIL; ADICA, 2004).

ButTERFIELD, Herbert. "Raison d'État: The Relations Between Morality and Government," The First Martin Wight Memorial Lecture delivered in the University of Sussex on 23 April 1975.

BUTTERFIELD, Herbert and Martin Wight (eds.). Diplomatic Investigations: Essays in the Theory of International Politics (Harvard University Press, 1966).

BuZAN, Barry and Ole WłVER. Regions and Powers (Cambridge University Press, 2003).

BUZAN, Barry and Richard LiTTLE, International Systems in World History: Remaking the Study of International Relations (Oxford University Press, 2000).

CABAllero Aquino, Ricardo. La segunda república paraguaya 1869-1906: Política, economía y sociedad (Asunción: Centro de Investigación y Documentación, 1986).

—. La tercera república paraguaya: 1936-19 (Asunción: El Lector, 1988).

CADY, John F. Foreign Intervention in the Rio de la Plata, 1838-50: A Study of French, British, and American Policy in Relation to the Dictator Juan Manuel Rosas (New York, NY: AMS Press, 1969).

CAILlET-BOIS, Ricardo R. "1864, un año crítico en la política exterior de la presidencia de Mitre,” Boletín de la Academia Nacional de la Historia, Vol. 17 (1946), pp. 47-80. 
“Argentina y la intervención europea en México en 1862," Historia Mexicana, Vol. 12, No. 4 (abril-junio, 1963), pp. 552-594.

-. Cuestiones internacionales (1852-1966) (Buenos Aires: EUDEBA, 1970).

CAJÍAS DE LA VeGA, Fernando. "Bolivia y la guerra de la Triple Alianza," in La guerra del Paraguay: Historiografías. Representaciones. Contextos, ed. by Horacio CRESPO, Juan M. PALACIO and Guillermo PALACIOS (México DF: El Colegio de México, 2012), pp. 383-397.

CAMPBELL, Charles S. The Transformation of American Foreign Relations: 1865-1900 (New York, NY: Harper, 1976).

CAPDEVILA, Luc. Una guerra total: Paraguay 1864-1870. Ensayo de historia del tiempo presente (Buenos Aires: SB edición, CEADUC, [2007] 2010).

"Droit et coutumes dans la guerre de la Triple Alliance (1864-1870): Le sort des prisonniers de guerre," Nuevo Mundo Mundos Nuevos [online], Débats, 2016. [Accessible at: https://journals.openedition.org/nuevomundo/69668]

. "Guerra, estado y nación en América austral en la década de 1860: La contienda de la Triple Alianza. Periferias e identidades colectivas," in El poder y la sangre: Guerra, estado y nación en la década de 1860, ed. by Guillermo PALACIOS and Érica PANI (México DF: El Colegio de México, 2014), pp. 199-218.

CÁRCANO, Ramón J. Guerra del Paraguay: Orígenes y causas (Buenos Aires: Viau, 1939).

. Guerra del Paraguay: Acción y reacción de la Triple Alianza (Buenos Aires: Viau, 1941). 2 vols.

"La diplomacia de la Triple Alianza," Revista Americana, Ano I, No. 2 (novembro, 1909), pp. 161-178.

. "La misión Mitre al Brasil (abril-diciembre 1972)," Anales de la Faculta de Derecho y Ciencias Sociales, Tomo III, $1^{\circ}$ parte $\left(2^{\circ}\right.$ serie, 1913$)$, pp. 5-189.

Cardoso, Fernando H. and Enzo Faletto. Dependency and Development in Latin America (University of California Press, 2nd ed., [1971] 1979).

CARDOZO, Efraím. 23 de octubre: Una página de historia contemporánea del Paraguay (Buenos Aires: Guayra, 1956).

- Aspectos de la cuestión del Chaco (Asunción: Imprenta Nacional, 1932).

- El Chaco en el régimen de las intendencias: La creación de Bolivia (Asunción: Imprenta Nacional, 1930).

- El Chaco y los virreyes: La cuestión paraguayo-boliviana según documentos de los archivos de Buenos Aires y de Río de Janeiro (Asunción: Imprenta Nacional, 1934). 
- El Imperio del Brasil y el Río de la Plata: Antecedentes y estallido de la guerra del Paraguay (Buenos Aires: Librería del Plata, 1961).

. Hace 100 años: Crónicas de la guerra de 1864-1870 (Asunción: El Lector, 2nd ed., [1967] 2010). 4 vols.

—. Paraguay independiente (Asunción: ServiLibro, [1949] 2011).

"Urquiza y la guerra del Paraguay," Investigaciones y Ensayos, Vol. 2 (enero-junio, 1967), pp. 141-165.

. Vísperas de la guerra del Paraguay (Buenos Aires: El Ateneo, 1954).

CAmacho Arango, Carlos. El conflicto de Leticia (1932-1933) y los ejércitos de Perú y Colombia (Bogotá: Universidad Externado de Colombia, 2016).

CANTILO, José M. Canciller Cantilo: La diplomacia argentina al servicio de la paz (Buenos Aires: Histórica, 2005).

CANTIR, Cristian. "'Savages in the Midst': Revolutionary Haiti in International Society (17911838)," Journal of International Relations and Development, Vol. 20, No. 1 (January 2017), pp 238-261.

CASAL, Juan M. "La interpretación dominante en Uruguay sobre los orígenes de la guerra de la Triple Alianza," Diálogos (Maringá. Online), Vol. 19, No. 3 (setembro-dezembro, 2015), pp. 929-953.

. "Una 'diplomacia difícil': El ministro Washburn, Estados Unidos y la guerra del Paraguay," in La guerra del Paraguay: Historiografías. Representaciones. Contextos, ed. by Horacio CRESPO, Juan M. PALACIO and Guillermo PALACIOS (México DF: El Colegio de México, 2012), pp. 335-362.

. "Uruguay and the Paraguayan War: The Military Dimension," in I Die with My Country: Perspectives on the Paraguayan War, 1864-1870, ed. by Hendrik KRAAY and Thomas L. WHIGHAM (University of Nebraska Press, 2004), pp. 119-139.

CASTAÑo PAREJA, Yoer J. “'La diplomacia secreta': La participación de Colombia en el conflicto entre Perú y España por las islas guaneras," Historia y Sociedad, No. 24 (enero-junio, 2013), pp. 189-214.

CAstro de SouzA, Luiz de. “A medicina na guerra de Paraguai: Mato-Grosso (I)," Revista de História, Vol. 37, No. 75 (1968), pp. 145-173.

. “A medicina na guerra de Paraguai: Mato-Grosso (II)," Revista de História, Vol. 38, No. 78 (1969), pp. 383-414.

. "A medicina na guerra de Paraguai: Mato-Grosso (III)," Revista de História, Vol. 40, No. 81 (1970), pp. 113-136. 
. "A medicina na guerra de Paraguai: Mato-Grosso (IV)," Revista de História, Vol. 41, No. 83 (1970), pp. 111-136.

. “A medicina na guerra de Paraguai: Mato-Grosso (v)," Revista de História, Vol. 42, No. 85 (1971), pp. 129-146.

CAVELIER, Germán. Política internacional de Colombia (Bogotá: Universidad Externado de Colombia; Facultad de Finanzas, Gobierno y Relaciones Internacionales, 1997). 4 vols.

CAVIERES FigueROA, Eduardo. "Las frustraciones de la Unión Americana: La guerra del Paraguay. Estado y sociedad en los conflictos del Cono Sur, 1860-1880," in La guerra del Paraguay: Historiografías. Representaciones. Contextos, ed. by Horacio CRESPO, Juan M. PALACIO and Guillermo PALACIOS (México DF: El Colegio de México, 2012), pp. 299-322.

CAYO, Percy. "Algunas reflexiones acerca del tratado peruano-boliviano de 1873." Revista del Instituto de Estudios Histórico-Marítimos del Perú, No. 2 (1979), pp. 93-109.

. "La guerra con Chile," in Historia del Perú. Vol. 7: "Perú republicano” (Lima: Editorial Juan Mejía Baca, 1980), pp. 161-302.

. "Las conferencias de Lackawanna," Revista Histórica [Lima], Vol. 32 (1979), pp. 7397.

Centeno, Miguel Á. Blood and Debt: War and the Nation-State in Latin America (The Pennsylvania State University Press, 2002).

- "Latin American Independence and the Double Dilemma," Latin American Politics and Society, Vol. 50, No. 3 (Fall, 2008), pp. 147-161.

. "Limited War and Limited States," in Irregular Armed Forces and Their Role in Politics and State Formation, ed. by Diane E. DAVIS and Anthony W. PEREIRA (Cambridge University Press, 2003), pp. 82-95.

- Warfare in Latin America (Hampshire: Ashgate, 2007). 2 vols.

CEnteno, Miguel Á. and Agustín E. Ferraro (eds.). State and Nation Making in Latin America and Spain: Republics of the Possible (Cambridge University Press, 2013).

Centeno, Miguel Á. and Elaine EnRIQUeZ (eds.). War and Society (Cambridge: Polity, 2016).

CEnturión, Carlos R. El conflicto del Chaco Boreal: Gestiones diplomáticas (Asunción: La Colmena, 1937). 2 vols.

CERDa CATAlán, Alfonso. La guerra entre España y las repúblicas del Pacífico, 1864-1866: El bombardeo de Valparaíso y el combate naval del Callao (Providencia [Chile]: Editorial Puerto de Palos, 2nd. ed., [1977] 2004). 
"La guerra entre España y las repúblicas del Pacífico, 1864-1866. Primera Parte: Antecedentes diplomáticos, militares y económicos," Revista Histórica [Santiago], Año LXXI, Tomo XLIX, No. 145-147 (noviembre, 1977), pp. 1-210.

. "La guerra entre España y las repúblicas del Pacífico, 1864-1866. Segunda Parte: La lucha armada," Revista Histórica [Santiago], Año LXXIV, Tomo LIII, No. 157-159 (abril, 1981), pp. 1-208.

"La guerra entre España y las repúblicas del Pacífico, 1864-1866. Segunda parte: La lucha armada," Revista Histórica [Santiago], Año LXXV, Tomo LIV, No. 160-162 (abril, 1982), pp. 1-197.

—. "La misión de Jacinto Albístur al Perú en 1865," Revista Histórica [Santiago], Año LXIX, Tomo XLVII, No. 139-141 (noviembre, 1975), pp. 1-46.

CERVo, Amado L. O Parlamento brasileiro e as relações exteriores (1826-1889) (Brasília: Universidade de Brasília, 1981).

CÉSPEDES GUTIÉRREZ, Gerardo. "Apuntes sobre la historia de la medicina en la guerra del Chaco (año de 1933)," Archivos Bolivianos de la Historia de la Medicina, Vol. 11, No. 1-2 (enero-diciembre, 2005), pp. 74-88.

CHECKEL, Jeffrey T. "Mechanisms, Process, and the Study of International Institutions," in Process Tracing: From Metaphor to Analytic Tool, ed. by Andrew BENNETT and Jeffrey T. CHECKEL (Cambridge University Press, 2015), pp. 74-97.

CHECKEL, Jeffrey T. and Andrew BENNETT. "Beyond Metaphors: Standards, Theory, and the 'Where Next' for Process Tracing," in Process Tracing: From Metaphor to Analytic Tool, ed. by Andrew BENNETT and Jeffrey T. CHECKEL (Cambridge University Press, 2015), pp. 260-275.

Chesterton, Bridget M. (ed.). The Chaco War: Environment, Ethnicity, and Nationalism (London: Bloomsbury, 2016).

Chiavenatto, Julio J. A guerra do Chaco (leia-se petróleo) (São Paulo: Brasiliense, 1980). Genocídio americano: A guerra do Paraguai (São Paulo: Brasiliense, 1979).

CHILD, Jack. "Geopolitical Thinking in Latin America," Latin American Research Review, Vol. 14, No. 2 (1979), pp. 89-111.

- Geopolitics and Conflict in South America: Quarrels Among Neighbors (New York: Praeger, 1985).

"Interstate Relations in Latin America: Peaceful or Conflictual?" International Journal, Vol. 43 (Summer, 1988), pp. 378-403. 
. Unequal Alliance: The Inter-American Military System, 1938-1978 (Boulder, CO: Westview Press, 1980).

CID, Gabriel. "Entre el diseño interno y la amenaza externa: La oposición al régimen portaleano y la Confederación Perú-boliviana," Revista Histórica (separata) [Santiago], Tomo XLV (2011-2012), pp. 69-96.

- La guerra contra la Confederación: Imaginario nacionalista y memoria colectiva en el siglo XIX chileno (Santiago: Universidad Diego Portales, 2011).

CLARK, Ian. Waging War: A New Philosophical Introduction (Oxford University Press, 2nd ed., [1988] 2015).

CochetTi, María L. La neutralidad "activa” argentina en la guerra del Pacífico: La promoción del tráfico de armas hacia los ejércitos de Bolivia y Perú (Buenos Aires: FLACSO; Universidad de San Andrés; Universidad de Barcelona, 2006).

Coerver, Don M. and Linda B. HALl. Tangled Destinies: Latin America and the United States (University of New Mexico Press, 1999).

COKER, William S. "The War of the Ten Centavos: The Geographic, Economic, and Political Causes of the War of the Pacific," The Southern Quarterly, Vol. 7, No. 2 (1969), pp. $113-129$.

CoLl, Alberto R. The Wisdom of Statecraft: Sir Herbert Butterfield and the Philosophy of International Politics (Duke University Press, 1985).

COLLIER, David. “Understanding Process Tracing," PS: Political Science and Politics, Vol. 44, No. 4 (2011), pp. 823-830.

COLLIER, Simon. "Chile from Independence to the War of the Pacific," in The Cambridge History of Latin America. Vol. 3: "From Independence to c. 1870," ed. by Leslie Bethell (Cambridge University Press, 1985), pp. 583-613.

COLLIER, Simon and William F. SATER. A History of Chile, 1808-2002 (Cambridge University Press, 2nd ed., [1996] 2004).

CONTRERAS, Manuel E. "Debt, Taxes, and War: The Political Economy of Bolivia, c. 19201935," Journal of Latin American Studies, Vol. 22, No. 2 (May, 1990), pp. 265-287.

CoONEY, Jerry W. "Economy and Manpower: Paraguay at War, 1864-69," in I Die with My Country: Perspectives on the Paraguayan War, 1864-1870, ed. by Hendrik KRAAY and Thomas L. Whigham (University of Nebraska Press, 2004), pp. 23-43.

COOPER, Russell M. American Consultation in World Affairs: For the Preservation of Peace (New York, NY: Macmillan, 1934). 
COOPER, Russell M. and Mary MATTISON. "The Chaco Dispute: The Development and Phases of the Bolivia-Paraguay Conflict and League Intervention," Geneva Special Studies, Vol. 5, No. 2 (1934), pp. 1-25.

COPELAND, Dale. "A Realist Critique of the English School," Review of International Studies, Vol. 29, No. 3 (July, 2003), pp. 427-441.

—. The Origins of Major War (Cornell University Press, 2013).

COROMINAS, Enrique V. Historia de las conferencias interamericanas, desde el Congreso de Panamá hasta la Conferencia Interamericana de Caracas, en 1954 (Buenos Aires: Propulsión, 1959).

—. La práctica del hispanoamericanismo (Madrid: Arba, 1952).

—. Paz y seguridad americana (Buenos Aires: El Ateneo, 1950).

CORSELLI, Rodolfo. La guerra americana della Triplice Alleanza contro il Paraguay (Modena: Tipografia della R. Accademia di Fanteria e Cavalleria, 1938).

CORTADA, James W. "Diplomatic Rivalry between Spain and the United States over Chile and Peru, 1864-1871," Inter-American Economic Affairs, Vol. 27, No. 4 (Spring, 1974), pp. $47-57$.

. "España y Estados Unidos ante la cuestión mexicana: 1855-1868," Historia

Mexicana, Vol. 27, No. 3 (enero-marzo, 1978), pp. 387-426.

_. "Spanish Foreign Policy, 1846-1875," in Spain in the Nineteenth-Century World, ed. by James W. CORTADA (Westport, CT: Greenwood Press, 1994), pp. 23-43.

CORTÉs DíAZ, Milton. "La diplomacia chilena y el conflicto del Chaco (1928-1938)," Revista Encrucijada Americana, Vol. 8, No. 1 (2016), pp. 95-111.

COTE, Stephen C. “A War for Oil in the Chaco, 1932-1935," Environmental History, Vol. 18 (October, 2013), pp. 738-758.

"Bolivian Oil Nationalism and the Chaco War," in The Chaco War: Environment, Ethnicity, and Nationalism, ed. by Bridget M. CHESTERTON (London: Bloomsbury, 2016), pp. 157-176.

- Oil and Nation: A History of Bolivia's Petroleum Sector (West Virginia University Press, 2016).

CRESPO, Horacio; Juan M. PALACIO and Guillermo PALACIOS (eds.). La guerra del Paraguay: Historiografías. Representaciones. Contextos (México DF: El Colegio de México, 2012).

Cuevas Cancino, Francisco M. Del Congreso de Panamá a la Conferencia de Caracas, 18261954 (Caracas: [n/d], 1976). 
DA Mota Menezes, Alfredo. A guerra é nossa: A Inglaterra não provocou a Guerra do Paraguai (São Paulo: Contexto, 2012).

—. Guerra do Paraguai: Como construímos o conflito (São Paulo: Contexto, 1998).

DAVIS, William C. The Last Conquistadores: The Spanish Intervention in Peru and Chile, 18631866 (The University of Georgia Press, 1950).

DE ARAúJo, Johny S. "El Imperio de Brasil, los estados platinos en el prólogo de la guerra de 1865," Caravelle, No. 108 (2017), pp. 135-148.

De HerrerA, Luis A. Antes y después de la Triple Alianza (Montevideo: Adroher, 1951-1952). 2 vols.

-. El Uruguay internacional (Paris: Grasset, 1912).

—. La misión Ponsonby (comentario) (Montevideo: Barreiro y Ramos, 1930). 2 vols.

DE LA FUENTE, Ariel. Caudillo and Gaucho Insurgency during the Argentina State-Formation Process (La Rioja, 1853-1870) (Duke University Press, 2000).

. "Federalism and Opposition to the Paraguayan War in the Argentine Interior: La Rioja, 1865-67," in I Die with My Country: Perspectives on the Paraguayan War, 1864-1870, ed. by Hendrik KRAAY and Thomas L. WHIGHAM (University of Nebraska Press, 2004), pp. 140-153.

De La PedRAJA, René. Wars of Latin America, 1899-1841 (Jefferson, NC: McFarland, 2006).

- Wars of Latin America, 1948-1982: The Rise of the Guerillas (Jefferson, NC: McFarland, 2013).

. Wars of Latin America, 1982-2013: The Path to Peace (Jefferson, NC: McFarland, 2013).

DE LA REZA, Germán A. “De las autonomías a la pluralidad de las repúblicas: ¿Destino ineluctable?” Política y Cultura, No. 33 (primavera 2010), pp. 9-34.

- El ciclo confederativo: Historia de la integración latinoamericana en el siglo XIX (Lima: Fondo Editorial de la Universidad Nacional Mayor de San Marcos, 2012).

- "El Congreso Anfictiónico de Panamá (1826): Determinaciones hispanoamericanas de su desenlace," Revista de Historia de América, No. 134 (enero-junio, 2004), pp. 185216.

. "La asamblea hispanoamericana de 1864-1865, último eslabón de la anfictionía," Estudios de Historia Moderna y Contemporánea de México, No. 39 (enero-junio, 2010), pp. 71-91. 
. "La dialéctica del fracaso: el Congreso americano de Lima (1847-1848) y su desenlace," Cuadernos Americanos, Vol. 134, No. 4 (octubre-diciembre, 2010), pp. $11-26$.

. "La diplomacia itinerante: Del Pacto de Familia al Congreso Americano de Lima (1831-1848)," Fuentes Humanísticas, Vol. 22, No. 40 (enero-junio, 2010), pp. 55-69.

. "¿Necesidad o virtud? Razones y alcances de los tratados continentales hispanoamericanos de 1856," Histórica, Vol. 38, No. 1 (2014), pp. 61-83.

Del CAMPo Rodríguez, Juan. Por la República y por la Reina: Una visión histórica del conflicto de 1864-1871 entre España y la alianza peruano-chilena ([Lima]: Asociación de Funcionarios Diplomáticos en Actividad, [2003]).

Delgado De CARVAlHo, Carlos. História diplomática do Brasil (Brasília: Edições do Senado Federal, [1959] 2016).

De MARCo, Miguel Á. Corresponsales en acción: Crónicas de la guerra del Paraguay. La Tribuna, 1865-1866 (Buenos Aires: Histórica, 2003).

- La armada española en el Plata (1845-1900) (Rosario: Universidad Católica Argentina, 1981).

. La guerra del Paraguay (Buenos Aires: Booket, 2nd ed., [1995] 2013).

. "La sanidad militar argentina en la guerra con el Paraguay (1865-1870)," Revista Histórica [Buenos Aires], Vol. 3, No. 9 (julio-diciembre, 1981), pp. 55-86.

DESCH, Michael C. "War and Strong States, Peace and Weak States?" International Organization, Vol. 50, No. 2 (Spring, 1996), pp. 237-268.

- "Why Latin America May Miss the Cold War: The United States and the Future of Inter-American Security Relations," in International Security and Democracy: Latin America and the Caribbean in the Post-Cold War Era, ed. by Jorge I. DoMínGUEZ (University of Pittsburgh Press, 1998), pp. 245-265.

DE QUEIRÓZ, Silvânia. Revisando a revisão: “Genocídio americano: a guerra do Paraguai” (Porto Alegre: FCM editora, 2014)

DeUTSCH, Karl W. (et al.). Political Community and the North Atlantic Area: International Organizations in the Light of Historical Experience (Princeton University Press, 1957).

DíAz MaChICAO, Porfirio. Historia de Bolivia: Salamanca, la guerra del Chaco, Tejada Sorzano: 1931-1936 (La Paz: Gisbert, 1955).

—. Historia de Bolivia: Toro, Busch, Quintanilla: 1936-1940 (La Paz: Juventud, 1957).

DiEz DE MedinA, Eduardo. Apuntes sobre tópicos internacionales (La Paz: Arnó, 1919). 
- De un siglo al otro: Memorias de un hombre público (La Paz: Tejerina, 1955).

. Diplomacia y política internacional (La Paz: [n/d], 1949).

- La cuestión del Pacifico y la política internacional de Bolivia (La Paz: Litografías e Imprentas Unidas, 1923).

—. Por los derechos de Bolivia: Conferencias (La Paz: Arnó, 1933).

—. Problemas internacionales (La Paz: [n/d], 1936).

DomíngueZ, Jorge I. "Boundary Disputes in Latin America," Peaceworks, No. 50, United States Institute of Peace (September, 2003), pp. 1-45.

"International Cooperation in Latin America: The Design of Regional Institutions by Slow Accretion," in Crafting Cooperation: Regional International Institutions in Comparative Perspective, ed. by Amitav ACHARYA and Alastair I. JOHNSTON (Cambridge University Press, 2007), pp. 83-128.

DomíngueZ, Jorge I. (ed.). International Security and Democracy: Latin America and the Caribbean in the Post-Cold War Era (University of Pittsburgh Press, 1998).

DonADío, Alberto. La guerra con el Perú (Medellín: Hombre Nuevo, 2nd ed., [1995] 2002).

Donoso Rojas, Carlos and Gonzalo Serrano Del Pozo (eds.). Chile y la guerra del Pacífico (Santiago: Centro de Estudios Bicentenario; Universidad Andrés Bello, 2011).

Donoso Rojas, Carlos and Jaime Rosenblit B. (eds.). Guerra, región y nación: La Confederación Perú-boliviana, 1836-1839 (Santiago: Universidad Andrés Bello; Centro de Investigaciones Diego Barros Arana, 2009).

DORATIOTO, Francisco. “A ocupação político-militar brasileira do Paraguai (1869-76)," in Nova história militar brasileira, ed. by Celso CASTRO, Vito IZECKSOHN and Hendrik KRAAY (Rio de Janeiro: FGV; Bom Texto, 2004), pp. 209-235.

. "As políticas da Argentina e do Brasil em relação à disputa boliviano-paraguaia pelo Chaco (1926-1938)," in A visão do outro: Seminário Brasil-Argentina (Brasília: Fundação Alexandre de Gusmão, 2000), pp. 439-477.

- "En busca del equilibrio: La política exterior paraguaya entre 1920 y 1925," Cena Internacional, Vol. 8, No. 1 (junho, 2006), pp. 4-19.

. "La política del Imperio del Brasil en relación al Paraguay, 1864-1872," Estudios Paraguayos, Vol. 26-27, No. 1-2 (2008), pp. 7-21.

. "La rivalidad argentino-brasileña y la reorganización institucional del Paraguay (1869-1870)," Historia Paraguaya: Anuario del Instituto Paraguayo de Investigaciones Históricas, Vol. 37 (1997), pp. 219-254. 
. Maldita guerra: Nova história da guerra do Paraguai (São Paulo: Companhia Das Letras, 2nd ed., [2002] 2015).

. "Tentativas de paz na guerra do Paraguai,” Navigator, Vol. 11, No. 21 (2015), pp. $119-131$.

DOTTA OSTRIA, Mario. Oligarquías, militares y masones: La guerra contra el Paraguay y la consolidación de las asimetrías regionales (1865-1870) (Montevideo: Ediciones de la Plaza, 2nd ed., [2011] 2011).

Doyle, Don H. (ed.). American Civil Wars: The United States, Latin America, Europe, and the Crisis of the 1860s (The University of North Carolina Press, 2017).

DOZER, Donald M. Are We Good Neighbors? Three Decades of Inter-American Relations, 1930 1960 (University of Florida Press, 1959).

. "The Challenge to Pan Americanism," unpublished manuscript, Arizona State University, Center for Latin American Studies, 1972.

DRAGO, Mariano. "Una controversia de Mitre y Sarmiento sobre política intercontinental," Revista del Museo Mitre, No. 9 (1956), pp. 97-118.

DUARTE, María A. "Entre Ríos y la amenaza de invasión paraguaya a Santa Fe: Año 1865," Trabajos y Comunicaciones, No. 6 (1956), pp. 67-80.

DUNKERLEY, James. Orígenes del poder militar: Bolivia, 1879-1935 (La Paz: Plural, 2006).

EBel, Roland H., Raymond TARAS and James D. Cochrane. Political Culture and Foreign Policy in Latin America: Case Studies from the Circum-Caribbean (State University of New York Press, 1991).

ENCINA, Francisco A. "El proyecto de alianza perú-boliviana-Argentina de 1873-75 y la iniciativa de don Abdón Cifuentes en la adquisición de los blindados chilenos," Boletín de la Academia Chilena de la Historia, Año IV, No. 9 ( $2^{\circ}$ semestre, 1937), pp. 7-32.

ERICKSON, Amanda. "Latin America is the World's Most Violent Region: A New Report Investigates Why," The Washington Post, April 25, 2018.

ESQUIVEL MolinA, Manuel. "Un caso de panamericanismo práctico: La solidaridad continental de 1856," Revista de los Archivos Nacionales [Costa Rica], Vol. 20, No. 1-6 (enerojunio, 1956), pp. 143-147.

Escobari CusiCANQui, Jorge. Historia diplomática de Bolivia (La Paz: Plural, 6th ed., [1975] 2013). 2 vols. 
ESPINOSA MORAGA, Oscar. "Arturo Prat, agente confidencial de Chile en Montevideo (5 de noviembre de 1878 - 16 de febrero de 1879)," Boletín de la Academia Chilena de la Historia, Vol. 17, No. 42 (1ºmestre, 1950), pp. 65-80.

_. Bolivia y el mar, 1810-1964 (Santiago: Nascimento, 1964).

—. El aislamiento de Chile (Santiago: Nascimento, 1961).

_. El precio de la paz chileno-argentina, 1810-1969 (Santiago: Nascimento, 1969). 3 vols.

—. La postguerra del Pacífico y la Puna de Atacama, 1884-1899 (Santiago: Nascimento, 1958).

- "Las cuestiones de límites chileno-argentinas," Boletín de la Academia Chilena de la Historia, Vol. 18 (1ºmestre, 1951), pp. 55-106.

"Los pactos de mayo," Boletín de la Academia Chilena de la Historia, Vol. 19, No. 46 (1 $1^{\circ}$ semestre, 1952), pp. 5-52.

. Presencia del Brasil (1500-1973) (Santiago: Nascimento, 1974).

EsPosito, Gabriele. Armies of the War of the Pacific, 1879-83: Chile, Peru and Bolivia (Oxford: Osprey, 2016).

Armies of the War of the Triple Alliance, 1864-70: Paraguay, Brazil, Uruguay and Argentina (Oxford: Osprey, 2015).

- The Chaco War, 1932-35: South America's Greatest Modern Conflict (Oxford: Osprey, 2011).

ESTEBAN-INFANTES Y MARTÍN, Emilio. Expediciones españolas (siglo XIX) (Madrid: Instituto de Cultura Hispánica, 1949).

ETCHEPAREBORDA, Roberto. "Enfrentamiento argentino-brasileño al finalizar la guerra del Paraguay: Un episodio de espionaje en el Río de la Plata en 1874," Investigaciones y Ensayos, Vol. 10 (enero-junio, 1971), pp. 131-158.

- Historia de las relaciones internacionales argentinas (Buenos Aires: Pleamar, 1994).

"La política externa argentina, 1870-1920," Anuario del Departamento de Historia, Año II-III, No. 2 (Córdoba: Universidad Nacional de Córdoba, Facultad de Filosofía y Humanidades, 1964-1965), pp. 167-261.

—_ "Las tensiones en el Plata vistas a través de la información diplomática (1907-1910)," Investigaciones y Ensayos, Vol. 17 (julio-diciembre, 1971), pp. 91-114.

Evans, Henry C. Chile and Its Relations with the United States (Duke University Press, 1927). 
FABRY, Mikulas. Recognizing States: International Society and the Establishment of New States Since 1776 (Oxford University Press, 2010).

FANO, Marco. El cónsul, la guerra y la muerte ([Rome]: HSH, 2nd ed., [2012] 2016).

"El Río de la Plata y la guerra del Paraguay en los archivos italianos," in Paraguay en la historia, la literatura y la memoria: Actas de las II Jornadas Internacionales de Historia del Paraguay en la Universidad de Montevideo, ed. by Juan M. CASAL and Thomas L. WHIGHAM (Asunción: Tiempo de Historia; Universidad de Montevideo, 2011), pp. 165-172.

. El partido de la paz ([Rome]: Fano, 2016).

—_. "El 'partido de la paz' en Río de Janeiro," in Paraguay: Investigaciones de historia social y política. III Jornadas Internacionales de Historia del Paraguay en la Universidad de Montevideo (Asunción: Tiempo de Historia; Universidad de Montevideo, 2013), pp. 147-156.

. Il rombo del cannone liberale ([Rome]: Fano, 2010). 3 vols.

FARCAU, Bruce W. "Civilians and the War of the Pacific, 1879-1884," in Daily Lives of Civilians in Wartime Latin America, ed. by Pedro SANTONI (Westport, CT: Greenwood Press, 2008), pp. 147-171.

. The Chaco War: Bolivia and Paraguay, 1932-1935 (Westport, CT: Praeger, 1996).

. The Ten Cents War: Chile, Peru, and Bolivia in the War of the Pacific, 1879-1884 (Westport, CT: Praeger, 2000).

FAWCETt, Louise and Andrew HURRELl (eds.). Regionalism in World Politics: Regional Organization and International Order (Oxford University Press, 1994).

FAZAL, Tanisha N. "Dead Wrong? Battle Deaths, Military Medicine, and Exaggerated Reports of War's Demise,” International Security, Vol. 39, No. 1 (Summer, 2014), pp. 95-125.

FERMANDOIS, Joaquín and Mariana PERRY. "El factor internacional en la conciencia del estadonación: Chile entre Argentina y Brasil, 1889-1902," in Estado y nación en Chile y Brasil en el siglo XIX, ed. by Ana M. STUVEN and Marco A. VILlELA PAMPLONA (Santiago: Ediciones Universidad Católica de Chile, 2009), pp. 209-226.

FERNÁNDEZ, Carlos J. La guerra del Chaco (Buenos Aires/Asunción: [n/d], 1955-1987). 7 vols.

FERnÁNDEZ BengoeCheA, Teresa. Carlos Saavedra Lamas: Un obrero de la paz (Buenos Aires: Dunken, 2007).

FERNÁNDEZ VALDÉS, Juan J. Chile y Perú: Historia de sus relaciones diplomáticas entre 1819 y 1879 (Santiago: Cal \& Canto, 1997). 
- Chile y Perú: Historia de sus relaciones diplomáticas entre 1879 y 1929 (Santiago: RIL; ADICA, 2004).

. "El tratado de Ancón," Boletín de la Academia Chilena de la Historia, Año LXVII, No. 110 ( $2^{\circ}$ semestre, 2000), pp. 81-103.

—. "El tratado secreto peruano-boliviano de 1873 y la diplomacia brasileña," Boletín de la Academia Chilena de la Historia, Año XXIII, No. 55 (2ºmestre, 1956), pp. 5-18.

—. La República de Chile y el Imperio del Brasil: Historia de sus relaciones diplomáticas (Santiago: Bello, 1959).

—_. "Los pactos de mayo y la diplomacia británica," Boletín de la Academia Chilena de la Historia, Año XXXII, No. 73 (2ºmestre, 1965), pp. 99-131.

FERrARI, Gustavo. Conflicto y paz con Chile, 1989-1903 (Buenos Aires: EUDEBA, 1969).

FINNEMORE, Martha. "Exporting the English School?" Review of International Studies, Vol. 27, No. 3 (July, 2001), pp. 509-513.

FINOT, Enrique. La guerra del Chaco y los Estados Unidos (La Paz: América, 1935).

Nueva historia de Bolivia: Ensayo de interpretación sociológica (La Paz: Gisbert, 3rd ed., [1946] 1964).

FLEMES, Daniel. "Creating a Regional Security Community in Southern Latin America: The Institutionalisation of the Regional Defence and Security Policies," Working Papers: Global and Area Studies, Deutsches Übersee-Institut [Hamburg], No. 13 (December, 2005), pp. 1-35.

FLICKEMA, Thomas O. "The Settlement of the Paraguayan-American Controversy of 1859: A Reappraisal," The Americas, Vol. 25, No. 1 (July, 1968), pp. 49-69.

—_. "Sam Ward's Bargain': A Tentative Reconsideration,” The Hispanic American Historical Review, Vol. 50, No. 3 (August, 1970), pp. 538-542.

FoOTE, Nicola and René D. HARDER Horst (eds.). Military Struggle and Identity Formation in Latin America: Race, Nation, and Community during the Liberal Period (University Press of Florida, 2010).

FortnA, Page; John J. MeARSHEIMER and Jack S. Levy. "Review Symposium: Has Violence Declined in World Politics?" Perspectives on Politics, Vol. 11, No. 2 (June, 2013), pp. 566-577.

FRAZER, Robert W. "Latin-American Projects to Aid Mexico during the French Intervention," The Hispanic American Historical Review, Vol. 28, No. 3 (August, 1948), pp. 377388. 
"The Role of the Lima Congress, 1864-1865, in the Development of PanAmericanism," The Hispanic American Historical Review, Vol. 29, No. 3 (August, 1949), pp. 319-348.

FREEDMAN, Lawrence. "Defining War," in The Oxford Handbook of War, ed. by Julian LINDLEY-FRENCH and Yves BOYER (Oxford University Press, 2012), pp. 17-29.

GARAVAgliA, Juan C. "De Caseros a la guerra del Paraguay: El disciplinamiento de la población campesina en el Buenos Aires postrosista (1852-1865)," Illes i Imperis, No. 5 (2001), pp. 53-80.

. "Guerra y finanzas en la Argentina unificada, 1864-1872: La guerra del Paraguay y la misión De la Riestra en Londres," Quinto Sol, Vol. 20, No. 3 (septiembre-diciembre, 2016), pp. 1-33.

"Las fuerzas de guerra argentinas durante el conflicto de la Triple Alianza, 18651871," in A 150 años de la guerra de la Triple Alianza contra el Paraguay, ed. by Juan C. GARAVAGLiA and Raúl O. FradKIN (Buenos Aires: Prometeo, 2016), pp. $105-130$.

GARAVAglia, Juan C. and Raúl O. FrAdKIN (eds.). A 150 años de la guerra de la Triple Alianza contra el Paraguay (Buenos Aires: Prometeo, 2016).

GARAVAglia, Juan C.; Juan PRo RUIZ and Eduardo ZIMMERMANN (eds.). Las fuerzas de guerra en la construcción del estado: América Latina, siglo XIX (Rosario: Prohistoria, 2012).

García Mellid, Atilio. Proceso a los falsificadores de la historia del Paraguay (Buenos Aires: Theoria, 1963-1964). 2 vols.

GARCía SAlAZAR, Arturo. Historia diplomática del Perú (Lima: Rivas Berrio, 1930). Resumen de historia diplomática del Perú: 1820-1884 (Lima: Sanmartí, 1928).

GARnER, William R. The Chaco Dispute: A Study of Prestige Diplomacy (Washington DC: Public Affairs Press, 1966).

GAT, Azar. The Causes of War and the Spread of Peace: But Will War Rebound? (Oxford University Press, 2017).

[G. H. S.]. "El general Mitre y la guerra de Chile con España," Revista Chilena, Año IV, Tomo XI, No. 39 (marzo, 1920), pp. 432-435.

GIL, Enrique. Evolución del panamericanismo: El credo de Wilson y el panamericanismo (Buenos Aires: Menéndez, 1933).

GILLETTE, Michael L. "Huey Long and the Chaco War," Louisiana History: The Journal of the Louisiana Historical Association, Vol. 11, No. 4 (Autumn, 1970), pp. 293-311. 
GoldSteIn, Joshua S. Winning the War on War: The Decline of Armed Conflict Worldwide (New York, NY: Plume, 2012).

GONZÁLEZ, Antonio E. Historia integral de la guerra del Chaco, 1932-1935 (Asunción: El Lector, 2nd. ed. [1941] 2011). 2 vols.

_. Preparación del Paraguay para la guerra del Chaco (Asunción: El Gráfico, 1957). 2 vols.

GonZÁLEZ AlsinA, Ezequiel. El entregador del Chaco (Asunción: Zamphirópolos, 1968).

GONZÁLEZ ForSTER, Osvaldo. La neutralidad chilena en el conflicto del Chaco (Santiago: El Imparcial, 1936).

GonZÁlez PiZArro, José A. S. La política de España en América bajo Isabel II (Navarra: Newbook, 1999).

GonZÁlez PiZARRo, José A. and Daniel PAROdi REVOREDO. "Una gesta común: La alianza peruana-chilena contra España, 1864-1866," in Las historias que nos unen: Episodios positivos en las relaciones peruano-chilenas, siglos XIX y XX, ed. by Sergio GONZÁLEZ and Daniel PARODI (Santiago: RIL, 2013), pp. 105-149.

GoRdim DA SilveIRA, Helder. Argentina x Brasil: A questão do Chaco Boreal (Porto Alegre: EDIPUCRS, 1997).

“A visão militar brasileira da Guerra do Chaco: Projeção geopolítica e rivalidade internacional na América do Sul," Antíteses, Vol. 2, No. 4 (julho-dezembro, 2009), pp. 649-667.

GRABENDORFF, Wolf. "Interstate Conflict Behavior and Regional Potential for Conflict in Latin America," Journal of Interamerican Studies and World Affairs, Vol. 24, No. 3 (August, 1982), pp 267-294.

. "Tipología y potencial de conflictos en América Latina," Nueva Sociedad, No. 59 (marzo-abril, 1982), pp. 39-46.

GRAHAM, Richard. "Brazil from the Middle of the Nineteenth Century to the Paraguayan War," in The Cambridge History of Latin America. Vol. 3: "From Independence to c. 1870," ed. by Leslie BETHELL (Cambridge University Press, 1985), pp. 747-794.

GrAnZIERA, Rui G. A guerra do Paraguai e o capitalismo no Brasil: Moeda e vida urbana na economia brasileira (São Paulo: HUCITEC, 1979).

GRAY, John. "Delusions of Peace,” Prospect (October, 2011), pp. 40-44.

GREz PÉREZ, Carlos E. La agresión de Bolivia en el Chaco y el “uti possidetis” (Santiago: Neupert, 1932). 
- Los intentos de unión hispano americana y la guerra de España en el Pacífico (Santiago: Nascimento, 1928).

GRIFFIN, Charles C. Latin America: An Interpretation of Main Trends in Its History (Cornell University Press, 1944).

_. "The States of Latin America," in The New Cambridge Modern History, Vol. XI, ed. by Francis H. HINSLEY (Cambridge University Press, 1962), pp. 516-541.

GUERRERO YOACHAM, Cristián. "Chile y Estados Unidos: Relaciones y problemas, 1812-1916," in Cientocincuenta años de política exterior chilena, ed. by Walter SÁNCHEZ and Teresa PEREIRA (Santiago: IEI; Editorial Universitaria, 1977), pp. 65-82.

—. "Chile y la guerra de secesión de los Estados Unidos: 1861-1865," Boletín de la Academia Chilena de la Historia, Vol. 42-43, No. 89 (1975-1976), pp. 97-267.

"La misión de Vicuña Mackenna a los Estados Unidos (1865-1866), Atenea, Vol. 454 (1986), pp. 239-275.

GUMUCIO GRANIER, Jorge. Estados Unidos y el mar boliviano: Testimonios para la historia (La Paz: Plural; Instituto PRISMA, 3rd ed., [1985] 2005).

GUTIÉRREZ, Alberto. La guerra de 1879 (Paris: Bouret, 1912).

GuZMÁn, Santiago V. El derecho de conquista y la teoría del equilibrio en la América Latina (Buenos Aires: Coni, 1881).

- El doctor Arce y su rol en la política boliviana: Examen de sus opiniones concernientes a la celebración de la paz entre Bolivia y Chile (La Paz: Imprenta de la Unión Americana, 1881).

—. Los Estados Unidos y el conflicto del Pacífico: Nueva faz de la cuestión según la opinión norte-americana (Buenos Aires: Coni, 1882).

GuZMÁn Polanco, Manuel de. Un ecuatoriano ilustre: Vicente Piedrahita. Páginas de la diplomacia ecuatoriana (Quito: Casa de la Cultura Ecuatoriana, 1965).

HANN, John H. "Burr's Model Applied: The Balance of Power in the Rio de La Plata, Brazil's Role," Proceedings of the Pacific Coast Council on Latin American Studies, Vol. 3 (1974), pp. 31-44.

HARDY, Osgood. "South American Alliances: Some Political and Geographical Considerations," Geographical Review, Vol. 8, No. 4/5 (October-November, 1919), pp. 259-265.

HARRISON, Simon. The Mask of War: Violence, Ritual and the Self in Melanesia (Manchester University Press, 1993).

HeALY, David. James G. Blaine and Latin America (University of Missouri Press, 2001). 
Henderson, Peter V. N. Gabriel García Moreno and Conservative State Formation in the Andes (University of Texas Press, 2008).

HERBST, Jeffrey. States and Power in Africa: Comparative Lessons in Authority and Control (Princeton University Press, 2nd ed., [2000] 2014).

. "War and the State in Africa," International Security, Vol. 14, No. 4 (Spring, 1990), pp. 117-139.

HEREDIA, Edmundo A. El imperio del guano: América Latina ante la guerra de España en el Pacífico (Córdoba: Alción, 1998).

. "Intervencionismo, unidad latinoamericana y pensamiento liberal: La Liga Continental, 1856-1862," Ciclos, Año III, Vol. 3, No. 4 (1ºmestre, 1993), pp. 75102.

. "Sarmiento en Lima," Boletín del Instituto Rivera-Agüero, No. 15 (1988), pp. 199212.

Herken Krauer, Juan C. "Crecimiento económico en el Paraguay: La herencia de las dos guerras: 1864-1870/1932-35," in: Estado y Economía en Paraguay, 1870-2010, ed. by Fernando MASI and Dionisio BORDA (Asunción: Centro de Análisis y Difusión de la Economía Paraguaya, 2010), pp. 22-54.

HeRKen KRAuer, Juan C. and María I. GIMÉNEZ DE Herken. Gran Bretaña y la guerra de la Triple Alianza (Asunción: Arte Nuevo, 1983).

HERRERA LEÓN, Fabián. La política mexicana en la Sociedad de Naciones ante la guerra del Chaco y el conflicto de Leticia, 1932-1935 (México DF: Secretaría de Relaciones Exteriores, 2009).

Holden, Robert H. Armies without Nations: Public Violence and State Formation in Central American, 1821-1960 (Oxford University Press, 2004).

Holsti, Kalevi J. Peace and War: Armed Conflicts and International Order, 1648-1989 (Cambridge University Press, 1991).

- Taming the Sovereigns" Institutional Change in International Politics (Cambridge University Press, 2004).

- "Theorising the Causes of Order: Hedley Bull's The Anarchical Society," in Theorising International Society: English School Methods, ed. by Cornelia NAVARI (New York, NY: Palgrave Macmillan, 2009), pp. 125-147.

. The State, War, and the State of War (Cambridge University Press, 1996).

HOWARD, Michael. The Invention of Peace and the Reinvention of War (London: Profile Books, rev. and enlarged ed., [2000] 2001). 
Hughes, Matthew. "Logistics and the Chaco War: Bolivia versus Paraguay, 1932-1935," The Journal of Military History, Vol. 69 (April, 2005), pp. 411-437.

HUNER, Michael K. "Saving Republics: General Martin Thomas McMahon, the Paraguayan War and the Fate of the Americas (1864-1870)," Irish Migration Studies in Latin America, Vol. 7, No. 3 (March, 2010), pp. 323-338.

HurRell, Andrew. “An Emerging Security Community in South America?” in Security Communities, ed. by Emanuel ADLER and Michael N. BARNETT (Cambridge University Press, 1998), pp. 228-264.

- "Hegemony and Regional Governance in the Americas," in Regionalism and Governance in the Americas: Continental Drift, ed. by Louise FAWCETT and Mónica SERRANO (Basingstoke: Palgrave Macmillan, 2005), pp. 185-207.

"International Society and the Study of Regimes: A Reflective Approach," in Regime Theory and International Relations, ed. by Volker RITTBERGER (Oxford University Press, 1993), pp. 49-72.

. On Global Order: Power, Values, and the Constitution of International Society (Oxford University Press, 2007).

. "Security in Latin America," International Affairs, Vol. 74, No. 3 (July, 1998), pp. 529-546.

. "Working with Diplomatic Culture: Some Latin American and Brazilian Questions," paper presented at the ISA Annual Convention, Montreal (March, 2004).

IBARRA CIFUENTES, Patricio. "Vivir la guerra en cautiverio: Prisioneros en la guerra del Pacífico," in Chile y la guerra del Pacífico, ed. by Carlos DONOSO RoJAS and Gonzalo SeRRANO DEL POZO (Santiago: Centro de Estudios Bicentenario; Universidad Andrés Bello, 2011), pp. 155-174.

IZECKSOHN, Vitor "Recrutamento militar no Rio de Janeiro durante a guerra do Paraguai," in Nova história militar brasileira, ed. by Celso CASTRO, Vito IZECKSOHN and Hendrik KRAAY (Rio de Janeiro: FGV; Bom Texto, 2004), pp. 179-235.

- "Resistência ao recrutamento para o exército durante as guerras civil e do Paraguai: Brasil e Estados Unidos na década de 1860," Estudos Históricos, No. 27 (2001), pp. 84-109.

- Slavery and War in the Americas: Race, Citizenship, and State Building in the United States and Brazil, 1861-1870 (University of Virginia Press, 2014).

IZECKSOHN, Vitor and Peter M. BEATTIE. "The Brazilian Home Front during the War of the Triple Alliance, 1864-1870," in Daily Lives of Civilians in Wartime Latin America, ed. by Pedro SANTONI (Westport, CT: Greenwood Press, 2008), pp. 123-145. 
JACKSON, Robert H. Quasi-States: Sovereignty, International Relations and the Third World (Cambridge University Press, 1995).

- The Global Covenant: Human Conduct in a World of States (Oxford University Press, 2000).

JACKSON, Robert H. and Carl G. ROSBERG. "Why Africa's Weak States Persist: The Empirical and the Juridical in Statehood," World Politics, Vol. 35, No. 1 (October, 1982), pp. 124.

JACOBS, Alan M. "Process Tracing the Effects of Ideas," in Process Tracing: From Metaphor to Analytic Tool, ed. by Andrew BENNETT and Jeffrey T. CHECKEL (Cambridge University Press, 2015), pp. 41-73.

JARA ROMÁN, Marcelo and Felipe LÓPEZ PÉREZ. "Guerra y diplomacia: La legación chilena en los Estados Unidos de Colombia (1879-1880)," in Los nuevos estados latinoamericanos y su inserción en el contexto internacional, 1821-1903 (Morelia: Universidad Michoacana de San Nicolás; Universidad Stedhal-Grenoble 3, 2012), pp. 407-435.

. "La legación diplomática chilena en los Estados Unidos de Colombia (1879)," Si Somos Americanos: Revista de Estudios Fronterizos, Vol. 14, No. 1 (enero-junio, 2014), pp. 101-123.

JEFFS CASTRO, Leonardo. "Combatientes e instructores militares chilenos en la guerra del Chaco," Universum, Vol. 19, No. 1 (2004), pp. 58-85.

- Encuentros y desencuentros: Chile y Bolivia 1928-1935 (Santiago: Peña Andina, 2005).

- "Las relaciones chileno-paraguayas durante la guerra del Chaco (1932-1935)," Bicentenario: Revista de Historia de Chile y América, Vol. 7, No. 2 (2008), pp. 97127.

- "Logros, frustraciones y desafíos en la historia de las relaciones chileno-bolivianas, desde la firma del Tratado de 1904 hasta nuestros días", in Bolivia y Chile: Propuestas de integración para el siglo XXI, ed. by Marcela TAPIA LADINO (Iquique: Universidad Arturo Prat, Instituto de Estudios Internacionales, 2004), pp. 115-122.

"Los esfuerzos de Argentina, Brasil y Chile por la paz durante la guerra del Chaco," paper presented at the X Congreso Argentino-Chileno de Estudios Históricos e Integración Cultural, Universidades de Los Lagos and La Frontera, Pucón, April, 2013.

- "Opiniones chilenas sobre la guerra del Chaco," in Actas del II Encuentro de Intelectuales Chileno-Boliviano y del V Seminario Internacional de Integración SubRegional, Vol. 2, Año II, Iquique (Septiembre 27-29, 2000), pp. 1-12. 
JERVIS, Robert. System Effects: Complexity in Political and Social Life (Princeton University Press, 1997).

JOAS, Hans and Wolfgang KNÖBL. War in Social Thought: Hobbes to the Present (Princeton University Press, 2013).

JONES, Charles A. American Civilization (London: Institute of Latin American Studies, 2007).

"Another American Social Science: International Relations in the Western Hemisphere," in Cooperation and Hegemony in U.S.-Latin American Relations: Revisiting the Western Hemisphere Idea, ed. by Juan P. SCARFI and Andrew R. Tillman (New York, NY: Palgrave Macmillan, 2016), pp. 33-70.

- "Exile as an Institution of South American International Society, 1808-1881," paper presented at the III Global International Studies Conference of the World International Studies Committee, Porto, August 17-20, 2011, pp. 1-46.

. "Foundations of South American International Society," paper presented at the annual meeting of the American Political Science Association, Boston, July, 2008, pp. 1-38.

"Hierarchy and Resistance in American State-Systems, 1400-1800 CE," in The Balance of Power in World History, ed. by Stuart J. KAUFMAN, Richard LITTLE and William C. WOHLFORTH (New York, NY: Palgrave Macmillan, 2007), pp. 176-198.

. "International Relations in the Americas during the Long Eighteenth Century, 16631820," in International Orders in the Early Modern World, ed. by Shogo SUZUKI, Yongjin ZHANG and Joel QUIRK (New York, NY: Routledge, 2014), pp. 118-137.

"War in the Twenty-first Century: An Institution in Crisis," in The Anarchical Society in a Globalized World, ed. by Richard LITTLE and John WILLIAMS (Basingstoke: Routledge, 2006), pp. 162-188.

JOVER, José M. Política, diplomacia y humanismo popular en la España del siglo XIX (Madrid: Turner, 1976), pp. 84-138.

KACOWICZ, Arie M. "Blood and Debt: War and the Nation-State in Latin America [review]," Estudios Interdisciplinarios de América Latina y el Caribe, Vol. 15, No. 2 (juliodiciembre, 2004), pp. 214-216.

. "Compliance and Non-compliance with International Norms in Territorial Disputes: The Latin American Record of Arbitrations," in The Impact of International Law on International Cooperation: Theoretical Perspectives, ed. by Eyal BENVENISTI and Moshe HIRSCH (Cambridge University Press, 2004), pp. 194-215.

. "Stable Peace in South America: The A.B.C. Triangle, 1979-1999," in Stable Peace Among Nations, ed. by Arie M. KACOWICZ, Yaacov BAR-SimAn-Tov, Ole ELGSTRÖM and Magnus JERNECK (Lanham, MD: Rowman \& Littlefield, 2000), pp. 200-219. 
- The Impact of Norms in International Society: The Latin American Experience, 18812001 (University of Notre Dame Press, 2005).

- Zones of Peace in the Third World: South America and West Africa in Comparative Perspective (State University of New York Press, 1998).

KAHHAT, Farid. "Balance of Power, Democracy and Foreign Policy in South America's Southern Cone," Documentos de Trabajo del CIDE, No. 103 (diciembre, 2003), pp. 1-21.

KaIN, Ronald S. "Behind the Chaco War," Current History, Vol. 42, No. 2 (August, 1935), pp. 468-474.

. "The Chaco Dispute and the Peace System," Political Science Quarterly, Vol. 50, No. 3 (September, 1935), pp. 321-342.

KAY, Adrian and Phillip BAKER. "What Can Causal Process Tracing Offer to Policy Studies? A Review of the Literature," The Policy Studies Journal, Vol. 43, No. 1 (2015), pp. 121.

KeELEY, Lawrence H. War Before Civilization: The Myth of the Peaceful Savage (Oxford University Press, 1996).

KELLY, Philip. Checkerboards and Shatterbelts: The Geopolitics of South America (University of Texas Press, 1997).

Kendall, Lane C. "Andrés Santa Cruz and the Peru-Bolivian Confederation," The Hispanic American Historical Review, Vol. 16, No. 1 (February, 1936), pp. 29-48.

KIERNAN, Victor G. "Foreign Interests in the War of the Pacific," The Hispanic American Historical Review, Vol. 35, No. 1 (February, 1955), pp. 14-36.

KING, Gary; Robert O. KeOHANE and Sidney Verba, Designing Social Inquiry: Scientific Inference in Qualitative Research (Princeton University Press, 1994).

KIRKPATRICK, Helen P. "The Chaco Dispute: The League and Pan Americanism," Geneva Special Studies, Vol. 7, No. 4 (June, 1936), pp. 21-43.

. "The League and the Chaco Dispute," Foreign Policy Reports, Vol. 12, No. 9 (July 15, 1936), pp. 110-120.

Kittleson, Roger. "The Paraguayan War and Political Culture: Rio Grande do Sul, Brazil, 1865-80," in I Die with My Country: Perspectives on the Paraguayan War, 18641870, ed. by Hendrik KRAAY and Thomas L. WHIGHAM (University of Nebraska Press, 2004), pp. 105-118.

KLARÉn, Peter F. "The Origins of Modern Peru, 1880-1930," in The Cambridge History of Latin America. Vol. 5: “c. 1870 to 1930,” ed. by Leslie BETHELL (Cambridge University Press, 1986), pp. 587-640. 
KLEIN, Herbert. “American Oil Companies in Latin America: The Bolivian Experience," InterAmerican Economic Affairs, Vol. 18, No. 2 (Autumn, 1964), pp. 47-72.

- "Bolivia from the War of the Pacific to the Chaco War, 1880-1932," in The Cambridge History of Latin America. Vol. 5: “c. 1870 to 1930,” ed. by Leslie BeTHELl (Cambridge University Press, 1986), pp. 553-586.

—. Parties and Political Change in Bolivia, 1880-1952 (Cambridge University Press, 1969).

_. "Prelude to the Revolution," in Beyond the Revolution: Bolivia since 1852, ed. by James M. MALLOY and Richard S. THORN (University of Pittsburgh Press, 1971), pp. $25-51$.

Klein, Herbert and José A. PeRES-CAJías. "Bolivian Oil and Natural Gas under State and Private Control, 1920-2010,” Bolivian Studies Journal, Vol. 20 (2014), pp. 141-164.

KLEINPENNING, Jan M. G. "Strong Reservations About 'New Insights into the Demographics of the Paraguayan War'," Latin American Research Review, Vol. 37, No. 3 (2002), pp. $137-142$.

KolBert, Elizabeth. "Peace in Our Time," The New Yorker, Vol. 87, No. 30 (October 3, 2011), pp. $75-78$.

KOLINSKI, Charles J. Independence or Death! The Story of the Paraguayan War (University of Florida, 1965).

KoRABLEVA, Liudmila. “La Liga de las Naciones y la guerra del Chaco: 1932-1935,” Estudios Avanzados, Vol. 2 (2009), pp. 29-48.

KRAAY, Hendrik. "Patriotic Mobilization in Brazil: The Zuavos and Other Black Companies," in I Die with My Country: Perspectives on the Paraguayan War, 1864-1870, ed. by Hendrik KRAAY and Thomas L. WHIGHAM (University of Nebraska Press, 2004), pp. $61-80$.

. "Slavery, Citizenship and Military Service in Brazil's Mobilization for the Paraguayan War," Slavery and Abolition, Vol. 18, No. 3 (December, 1997), pp. 228-256.

. "“The Shelter of the Uniform': The Brazilian Army and Runaway Slaves, 18001888," Journal of Social History, Vol. 29, No. 3 (Spring, 1996), pp. 637-657.

KraAY, Hendrik and Thomas L. WhighaM. I Die with My Country: Perspectives on the Paraguayan War, 1864-1870 (University of Nebraska Press, 2004).

KRIEG, William L. Bolivia's Quest for the Sea (U.S. Department of State Report, Department of State, Washington DC: Office of External Research, 1993).

- Legacy of the War of the Pacific (U.S. Department of State Report, Department of State, Washington DC: Office of External Research, 1974). 
KUMAR, Radha. "Demography and Warfare," in The Oxford Handbook of War, ed. by Julian LINDLEY-FRENCH and Yves BOYER (Oxford University Press, 2012), pp. 603-616.

Kupchan, Charles A. How Enemies Become Friends: The Sources of Stable Peace (Princeton University Press, 2010).

LABOUGle, Raúl de. "Mitre y la política exterior argentina," Mayo: Revista del Museo de la Casa de Gobierno, No. 8 (1960), pp. 115-139.

LACONICH, Marco A. La paz del Chaco: Un pueblo traicionado (Montevideo: Editorial Paraguay, 1939).

LACOSTE, Pablo. "Americanismo y guerra a través de El Mercurio de Valparaíso (1866-1868)," Anuario de Estudios Americanos, Tomo LIV, No. 2 (1997), pp. 567-591.

LA FoY, Margaret. The Chaco Dispute and the League of Nations (Ann Arbor, MI: Bryn Mawr, 1941 [1946]).

LAKE, David A. and Patrick M. MoRgAn (eds.). Regional Orders: Building Security in a New World (The Pennsylvania State University Press, 1997).

LAWLER, Andrew. “The Battle Over Violence," Science, Vol. 336, No. 6083 (May 18, 2012), pp. 829-830.

. "Civilization's Double-Edged Sword," Science, Vol. 336, No. 6083 (May 18, 2012), pp. 832-833.

LeIVA VIVAS, Rafael. Posición de Centroamérica en la guerra del Pacífico (Tegucigalpa: Editorial Universitaria, 1989).

LEMKE, Douglas. Regions of War and Peace (Cambridge University Press, 2004).

LEONARD, Thomas M. "The New Pan Americanism in U.S.-Central American Relations, 19331954," in Beyond the Ideal: Pan Americanism in Inter-American Affairs, ed. by David SHEININ (Westport, CT: Praeger, 2000) pp. 95-113.

LeUCHARS, Chris. To the Bitter End: Paraguay and the War of the Triple Alliance (Westport, CT: Greenwood Press, 2002).

LEWIS, Paul H. "Paraguay from the War of the Triple Alliance to the Chaco War, 1870-1932," in The Cambridge History of Latin America. Vol. 5: “c. 1870 to 1930,” ed. by Leslie BETHELl (Cambridge University Press, 1986), pp. 475-496.

- "Paraguay since 1930," in The Cambridge History of Latin America. Vol. 8: "Latin America since 1930: Spanish South America”, ed. by Leslie Bethell (Cambridge University Press, 1991), pp. 233-266. 
LinKLATER, Andrew. The Problem of Harm in World Politics: Theoretical Investigations (Cambridge University Press, 2011).

. Violence and Civilization in the Western States-Systems (Cambridge University Press, 2017).

LITTLE, Richard. "British Neutrality versus Offshore Balancing in the American Civil War: The English School Strikes Back,” Security Studies, Vol. 16, No. 1 (2007), pp. 68-95.

- The Balance of Power in International Relations: Metaphors, Myths and Models (Cambridge University Press, 2007).

LITTLE, Walter. "International Conflict in Latin America," International Affairs, Vol. 63, No. 4 (October, 1987), pp. 589-601.

"Military Power in Latin America: An Overview," University of Liverpool, Institute of Latin American Studies, Working Paper No. 4 (1986), pp. 1-91.

LIVIERES GugGiARI, Lorenzo N. El financiamiento de la defensa del Chaco, 1924-1935: Un desafío al liberalismo económico (Asunción: Arte Nuevo, 1983).

LoBO, Hélio. Antes da guerra: (A missão Saraiva ou os preliminares do conflicto com o Paraguay) (Rio de Janeiro: [n/d], 1914).

Ás portas da guerra: (Do ultimatum Saraiva, 10 de agosto de 1864, á Convenção da Villa União, 20 de fevereiro de 1865) (Rio de Janeiro: Imprensa Nacional, 1916).

LóPEZ, Jacinto. Historia de la guerra del guano y el salitre; o guerra del Pacífico entre Chile, Bolivia y el Perú (New York, NY: De Laisne \& Rossboro, 1930).

LÓPEZ-ALVES, Fernando. State Formation and Democracy in Latin America, 1810-1900 (Duke University Press, 2000).

. "The Latin American Nation-state and the International," in Thinking International Relations Differently, ed. by Arlene B. TICKNER and David L. BLANEY (New York, NY: Routledge, 2012), pp. 161-180.

LóPeZ Maldonado, Ulpiano. Del Congreso de Panamá a la Conferencia de Caracas, 18261954 (Quito: Imprenta del Ministerio de Educación, 1955).

LÓPEZ-OCÓN CABRERA, Leoncio. "La comisión científica del Pacífico: De la ciencia imperial a la ciencia federativa," Bulletin de l'Institut Français d'Études Andines, Vol. 32, No. 3 (2003), pp. 479-515.

LÓPEZ-OCón CABrera, Leoncio and Miguel Á. Puig SAMPER Mulero. "Los condicionantes políticos de la Comisión Científica del Pacífico: Hispanoamericanismo y nacionalismo en la España bajoisabelina (1854-1868)," in Estudios sobre historia de la ciencia y de la técnica, Vol. 2 (Valladolid: Junta de Castilla y León, 1988), pp. 615-629. 
LUHNOW, David. "Latin America is World's Most Violent Region,” The Wall Street Journal, April 11, 2014.

LunA TOBAR, Alfredo. El Ecuador en la independencia del Perú (Quito: Banco Central del Ecuador, 1986).

LYNCH, John. "The River Plate Republics from Independence to the Paraguayan War," in The Cambridge History of Latin America. Vol. 3: “From Independence to c. 1870,” ed. by Leslie BETHELL (Cambridge University Press, 1985), pp. 615-676.

MAESTRI, Mário. A guerra no papel: História e historiografia da guerra do Paraguai (18641870) (Porto Alegre: FCM Editora, 2013).

- "A intervenção do Brasil no Uruguai e a guerra do Paraguai: A missão Saraiva," Revista Brasileira de História Militar, Ano IV, No. 13 (abril, 2014), pp. 3-23.

"As espadas do Império: A guerra do Paraguai e a gênese de um exército nacional profissional," Diálogos (Maringá. Online), Vol. 19, No. 3 (setembro-dezembro, 2015), pp. 981-1016.

- La guerra sin fin: La Triple Alianza contra el Paraguay. La campaña ofensiva, 18641865 (Asunción: Intercontinental, 2017).

. La guerra sin fin: La Triple Alianza contra el Paraguay. La campaña defensiva, 18661870 (Asunción: Intercontinental, 2018).

- Mar del Plata: Dominação e autonomia no Sul da América: Argentina, Brasil, Uruguai (1810-1864) (Porto Alegre: FCM Editora, 2016).

MAgnaterRA, Oscar J. La guerra de la Triple Alianza: Desde la diplomacia del patacón al lenguaje del cañón (Buenos Aires: Dunken, 2002).

MAHONEy, James. "Process Tracing and Historical Explanation," Security Studies, Vol. 24, No. 2 (2015), pp. 200-218.

. "The Logic of Process Tracing Tests in the Social Sciences," Sociological Methods \& Research, Vol. 41, No. 4 (2012), pp. 570-597.

MALlon, Florencia. The Defense of Community in Peru's Central Highlands: Peasant Struggle and Capitalist Transition, 1860-1940 (Princeton University Press, 1983).

MANN, Michael. "Have Wars and Violence Declined?" Theory and Society, Vol. 47, No. 1 (February, 2018), pp. 37-60.

- States, War and Capitalism: Studies in Political Sociology (Oxford: Basil Blackwell, 1988). 
MARES, David R. "Constructing Real Peace and Security in Latin America: Minimizing the 'Moral Hazard' Character of Security Institutions," Pensamiento Propio, No. 36/37, Año 17 (julio-diciembre, 2012), pp. 157-174.

- Latin America and the Illusion of Peace (London: The International Institute for Strategic Studies, 2012).

. "Making War to Make the State [review]," Georgetown Journal of International Affairs, Vol. 4, No. 1 (Winter/Spring, 2003), pp. 143-146.

- "Regional Conflict Management in Latin America: Power Complemented by Diplomacy," in Regional Orders: Building Security in a New World, ed. by David A. LAKE and Patrick M. Morgan (The Pennsylvania State University Press, 1997), pp. $195-218$.

. Violent Peace: Militarized Interstate Bargaining in Latin America (Columbia University Press, 2001).

MARES, David R. and David S. PALMER. Power, Institutions, and Leadership in War and Peace: Lessons from Peru and Ecuador, 1995-1998 (University of Texas Press, 2012).

MARCUS, Elliot A. "Chile and Hispanic-American Solidarity, 1810-1830," The Americas, Vol. 7, No. 4 (April, 1951), pp. 463-474.

. "Chile and Hispanic-American Solidarity, 1830-1865," The Americas, Vol. 9, No. 2 (October, 1952), pp. 177-200.

MARTín, Félix E. "External Peace, Internal Violence: The Obsolescence of the Latin American Military," Hemisphere, Vol. 16 (Spring, 2006), pp. 6-9.

. Militarist Peace in South America: Conditions for War and Peace (New York, NY: Palgrave Macmillan, 2006).

MC Evoy, Carmen. "Chile en el Perú: Guerra y construcción estatal en Sudamérica, 1881-1884," Revista de Indias, Vol. 66, No. 236 (2006), pp. 195-216.

- "De la mano de Dios: El nacionalismo católico chileno y la guerra del Pacífico, 18791881," Revista Histórica [Lima], Vol. 28, No. 2 (2004), pp. 83-136.

- Guerreros civilizadores: Política, sociedad y cultura en Chile durante la guerra del Pacífico (Santiago: Universidad Diego Portales, 2011).

MC Evoy, Carmen and Ana M. STUVEn (eds.). La república peregrina: Hombres de armas y letras en América del Sur, 1800-1884 (Lima: Instituto Francés de Estudios Andinos; Instituto de Estudios Peruanos, 2007).

MCLynN, Frank J. "Consequences for Argentina of the War of the Triple Alliance, 1865-1870," The Americas, Vol. 41, No. 1 (July, 1984), pp. 81-98. 
"Political Instability in Cordoba Province during the Eighteen-Sixties," Iberoamerikanisches Archiv, Neue Folge, Vol. 6, No. 3 (1980), pp. 251-269.

. "The Argentine Presidential Election of 1868," Journal of Latin American Studies, Vol. 11, No. 2 (November, 1979), pp. 303-323.

. "The Causes of the War of the Triple Alliance: An Interpretation," Inter-American Economic Affairs, Vol. 33, No. 1 (Autumn, 1979), pp. 21-43.

. "The Frontier Problem in Nineteenth Century Argentina," History Today, Vol. 30 (January, 1980), pp. 28-32.

. "The Ideological Basis of the Montoneros Risings in Argentina during the 1860s," The Historian, Vol. 46, No. 2 (February, 1984), pp. 235-251.

- "The Montoneros Risings in Argentina during the Eighteen-Sixties," Canadian Journal of History, Vol. 15, No. 1 (1980), pp. 49-66.

. "Urquiza and the Montoneros: An Ambiguous Chapter in Argentina History," Iberoamerikanisches Archiv, Neue Folge, Vol. 8, No. 3 (1982), pp. 283-295.

MEARSHEIMER, John J. "Back to the Future: Instability in Europe after the Cold War," International Security, Vol. 15, No. 1 (Summer, 1990), pp. 5-56;

- The Tragedy of Great Power Politics (New York, NY: Norton, 2001).

. "Why We Will Soon Miss the Cold War," The Atlantic Monthly, Vol. 266, No. 2 (August, 1990), pp. 35-50.

Medeiros Querejazu, Gustavo. Ensayos diplomáticos (La Paz: Ministerio de Relaciones Exteriores y Culto; Academia Diplomática “Rafael Bustillo," 1997).

MeIERDing, Emily L. "Dismantling the Oil Wars Myth," Security Studies, Vol. 25, No. 2 (2016), pp. 258-288.

. "Do Countries Fight Over Oil?" in The Palgrave Handbook of the International Political Economy of Energy, ed. by Thijs VAN DE GRAAF (et al.) (London: Palgrave Macmillan, 2016), pp. 441-460.

MerCAdo MoreIra, Miguel. El Chaco Boreal: Litigio boliviano-paraguayo (La Paz, Atenea, 1929).

—. Historia diplomática de la guerra del Chaco (La Paz: [n/d], 1966).

—. Historia internacional de Bolivia (La Paz: Atenea, 2nd ed., enlarged, [1916] 1930).

Miller, Benjamin. States, Nations, and the Great Powers: The Sources of Regional War and Peace (Cambridge University Press, 2007). 
Millington, Herbert. American Diplomacy and the War of the Pacific (Columbia University Press, 1948).

MiLlington, Thomas. Colombia's Military and Brazil's Monarchy: Undermining the Republican Foundations of South American Independence (Westport, CT: Greenwood Press, 1996).

MolineU, Harold. U.S. Policy Toward Latin America: From Regionalism to Globalism (Westview Press, 2nd ed., [1986] 1990).

Moniz BANDEIRA, Luiz A. A expansão do Brasil e a formação dos estados na Bacia do Prata: Argentina, Uruguai e Paraguai (Da colonização à Guerra da Tríplice Aliança) (Rio de Janeiro: Civilização Brasileira, 4th ed., rev. and enlarged, [1985] 2012).

“A Guerra do Chaco," Revista Brasileira de Política Internacional, Vol. 41, No. 1 (1998), pp. 161-200.

Argentina, Brasil y Estados Unidos de la Triple Alianza al Mercosur: Conflicto e integración en América del Sur (Buenos Aires: Grupo Editorial Norma, 2004).

—. La formación de los estados en la cuenca del Plata: Argentina, Brasil, Uruguay, Paraguay (Buenos Aires: Grupo Editorial Norma, 2006).

MORRIS, Michael and Víctor MiLláN (eds.). Controlling Latin American Conflicts: Ten Approaches (Boulder, CO: Westview Press, 1983).

Mosk, Sanford A. "Latin America and the World Economy, 1850-1914," Inter-American Economic Affairs, Vol. 2, No. 3 (Winter, 1948), pp. 53-82.

Murilo de CARVAlho, José. A Construção da ordem-Teatro de Sombras (Rio de Janeiro: Civilização Brasileira, 2014).

. "La década de 1860 en Brasil: política y guerra," in El poder y la sangre: Guerra, estado y nación en la década de 1860, ed. by Guillermo PALACIOS and Érica PANI (México DF: El Colegio de México, 2014), pp. 219-233.

"Political Elites and State Building: The Case of Nineteenth-Century Brazil," in Constructing Culture and Power in Latin America, ed. by Daniel H. LEVINE (University of Michigan Press, 1993), pp. 403-428.

MURILLO RIVERA, Fernando. "La solidaridad americana en el pensamiento internacionalista de Andrés Bello," in Quinto Centenario, No. 10 (Madrid: Editorial Universidad Complutense, 1986), pp. 19-61.

NAVARI, Cornelia (ed.). Theorising International Society: English School Methods (New York, NY: Palgrave Macmillan, 2009).

NAZER AHUMADA, Ricardo. "El 'saqueo' de Lima durante la guerra del Pacífico," in Chile y la guerra del Pacífico, ed. by Carlos DONOSO RoJAS and Gonzalo SERRANO DEL POZO 
(Santiago: Centro de Estudios Bicentenario; Universidad Andrés Bello, 2011), pp. $117-154$.

Novo y Colson, Pedro de. Historia de la guerra de España en el Pacífico (Madrid: Fortanet, ed. de lujo, 1882).

NuERMBERGER, Gustave A. "The Continental Treaties of 1856: An American Union 'Exclusive of the United States'," The Hispanic American Historical Review, Vol. 20, No. 1 (February, 1940), pp. 32-55.

NUNES FERREIRA, Gabriela. Centralização e descentralização no Império: O debate entre Tavares Bastos e visconde de Uruguai (São Paulo: Editora 34, 1999).

- Rio da Prata e a consolidação do Estado Imperial (São Paulo: HUCITEC, 2006).

OcAmpos CABAllero, Augusto. Emancipación y diplomacia: Misión de Solano López en Madrid (Asunción: Editora Ricor Grafic, 1995).

OELSNER, Andrea. "Consensus and Governance in Mercosur: The Evolution of the South American Security Agenda," Security Dialogue, Vol. 40, No. 2 (2009), pp. 191-212.

"(De)Securitisation Theory and Regional Peace: Some Theoretical Reflections and a Case Study on the Way to Stable Peace," EUI Working Papers, RSCAS No. 27 (October, 2005), pp. 1-21.

. "Friendship, Mutual Trust and the Evolution of Regional Peace in the International System," Critical Review of International Social and Political Philosophy, Vol. 10, No. 2 (June, 2007), pp. 257-279.

- International Relations in Latin America: Peace and Security in the Southern Cone (London: Routledge, 2005).

. "Pluralistic Security Communities in Latin America," in Routledge Handbook of Latin American Security, ed. by David R. MARES and Aire M. KACOWICZ (New York, NY: Routledge, 2016), pp. 173-184.

- "Procesos de paz y no-democracias: La estabilización de la paz en el Cono Sur," Revista Argentina de Ciencia Política, No. 7/8 (septiembre, 2004), pp. 55-72.

OFFNER, John L. An Unwanted War: The Diplomacy of the United States and Spain over Cuba, 1895-1898 (The University of North Carolina Press, 1992).

OLIVEIRA-CÉZAR, María. "La guerra de la sed, el conflicto por el Chaco: Causas, preparativos y desarrollo de la contienda bélica (1932-1935)," Todo es Historia, No. 581 (diciembre, 2015), pp. 6-25.

"La política cultural de la Argentina en el Paraguay en los años previos a la guerra del Chaco," América: Cahiers du CRICCAL, No. 39 (2010), pp. 147-156. 
Oneto y Viana, Carlos. La diplomacia del Brasil en el Río de la Plata (Montevideo: Librería de la Universidad, 1903).

ONUF, Nicholas G. World of Our Making (Routledge: [1989] 2012).

OSTRIA GUTIÉRREZ, Alberto. La doctrina del no-reconocimiento de la conquista en América (Rio de Janeiro: Borsoi, 1938).

—. The Tragedy of Bolivia: A People Crucified (Belmont, MA: American Opinion, 1961).

- Una obra y un destino: La política internacional de Bolivia después de la guerra del Chaco (Buenos Aires: López, 2nd ed., rev. and enlarged, [1946] 1953).

—. Una revolución tras los Andes (Santiago: Nascimento, 1944).

OTERo MuÑoz, Gustavo. Un hombre y una época: La vida azarosa de Rafael Núñez (Bogotá: Biblioteca de Historia Nacional, Vol. LXXXIII, 1951).

Otterbein, Keith F. How War Began (Texas A\&M University Press, 2004).

- The Anthropology of War (Long Grove, IL: Waveland, 2009).

PALACIOS, Guillermo. "De imperios y repúblicas: Los cortejos entre México y Brasil, 18221867,” Historia Mexicana, Vol. 51, No. 3 (enero-marzo, 2002), pp. 559-618.

- Intimidades, conflictos y reconciliaciones: México y Brasil, 1822-1993 (México DF: Secretaría de Relaciones Exteriores, 2001).

PALACIOS, Guillermo and PANI, Érica (eds.). El poder y la sangre: Guerra, estado y nación en la década de 1860 (México DF: El Colegio de México, 2014).

PARENT, Joseph M. Uniting States: Voluntary Union in World Politics (Oxford University Press, 2011).

PARODi Revoredo, Daniel. "La continuidad de la alianza perú-boliviana a través de las publicaciones del diario oficial El Peruano (Arequipa 1882-883)," Revista del Archivo General de la Nación [Peru], No. 17 (1998), pp. 191-223.

- La laguna de los villanos: Bolivia, Arequipa y Lizardo Montero en la guerra del Pacífico (1881-1883) (Lima: Institut Français d'Études Andines; Fondo Editorial de la Pontificia Universidad Católica del Perú, digital edition, [2001] 2015).

PASQUALI, Patricia S. “Americanismo y conflictos domésticos en el Rosario de 1864," Res Gesta, No. 29 (1991), pp. 185-192.

PATTEE, Richard. Gabriel García Moreno y el Ecuador de su tiempo (México: Jus, 1944). 
_- "García Moreno y la política internacional ecuatoriana," Boletín de la Academia Nacional de la Historia (Quito), Vol. XVII, No. 50-53 (enero-junio, 1939), pp. 185208.

—. La República Dominicana (Madrid: Cultura Hispánica, 1967).

PAUL, Tazha V. (ed.) International Relations Theory and Regional Transformation (Cambridge University Press, 2012).

PAZ SOldÁn, Mariano F. Narración histórica de la guerra de Chile contra el Perú y Bolivia (Buenos Aires: Imprenta y Librería de Mayo, 1884).

PECENY, Mark. “The Inter-American System as a Liberal 'Pacific Union'?” Latin American Research Review, Vol. 29, No. 3 (1994), pp 188-201.

PeÑAlBA, José A. F. "Draft Dodgers, War Resisters and Turbulent Gauchos: The War of the Triple Alliance Against Paraguay,” The Americas, Vol. 38, No. 4 (April, 1982), pp. 463-479.

Peñaloza Cordero, Luis. Nueva historia económica de Bolivia: La guerra del Pacífico (La Paz: Los Amigos del Libro, 1984).

PeÑA VILlamiL, Manuel. Eusebio Ayala y su tiempo (Asunción: [n/d], 1993).

. "Las relaciones paraguayo-argentinas durante el conflicto del Chaco (1925-1935)," Historia Paraguaya: Anuario del Instituto Paraguayo de Investigaciones Históricas, Vol. 33 (1994), pp. 169-199.

. "Los corsarios sudistas en la guerra de la Triple Alianza," Historia Paraguaya, No. 11 (1966), pp. 147-155.

Peres Costa, Wilma. A espada de Dâmocles: O exército, a guerra do Paraguai e a crise do Império (São Paulo: HUCITEC, 1996).

- "Los tormentosos años 60 y la crisis de la monarquía en Brasil: Guerra, esclavitud e imaginarios políticos," in El poder y la sangre: Guerra, estado y nación en la década de 1860, ed. by Guillermo PALACIOS and Érica PANI (México DF: El Colegio de México, 2014), pp. 235-257.

. "Revisitando as reverberações de uma 'guerra maldita'-A guerra do Paraguai e a crise do Império," in A 150 años de la guerra de la Triple Alianza contra el Paraguay, ed. by Juan C. Garavaglia and Raúl O. Fradkin (Buenos Aires: Prometeo, 2016), pp. 61-94.

PÉREZ CONCHA, Jorge. Ensayo histórico-crítico de las relaciones diplomáticas del Ecuador con los estados limítrofes (Quito: Gobierno del Ecuador, 2008), 2 vols.

PÉrez del Castillo, Álvaro. Bolivia, Colombia, Chile y el Perú: Diplomacia y política, 18251904 (La Paz: Los Amigos del Libro, 1980). 
PÉREZ StOCCO, Sandra. "La neutralidad argentina en la guerra del Chaco," Época-Revista de Historia, No. 5 ( $1^{\circ}$ semestre, 2012), pp. 55-87.

_. La paz del Chaco: Carlos Saavedra Lamas y la participación de la Cancillería argentina (1932-1938) (Mendoza: Jagüel, 2014).

Pereyra, Carlos. Francisco Solano López y la guerra del Paraguay (Madrid: América, 1919).

Pereyra Plasencia, Hugo. "La negociación diplomática del tratado de Ancón," Revista Histórica [Lima], Vol. 39, No. 2 (2015), pp. 153-170.

PERINA, Rubén M. "Los desafíos de la Carta Democrática Interamericana," Estudios Internacionales, Año 44, No. 173 (septiembre-diciembre, 2012), pp. 7-36.

- The Organization of American States as the Advocate and Guardian of Democracy: An Insider's Critical Assessment of Its Role in Promoting and Defending Democracy (Lanham, MD: University Press of America, 2015).

PERKINS, Dexter. A History of the Monroe Doctrine (Boston, MA: Little Brown, 1955). . The Monroe Doctrine, 1826-1867 (Baltimore, MD: The Johns Hopkins Press, 1933).

PETERSON, Harold F. Argentina and the United States, 1810-1960 (State University of New York, 1964).

"Efforts of the United States to Mediate in the Paraguayan War," The Hispanic American Historical Review, Vol. 12, No. 1 (February, 1932), pp. 2-17.

PIKE, Fredrick B. Chile and the United States, 1880-1962: The Emergence of Chile's Social Crisis and the Challenge to United States Diplomacy (University of Notre Dame Press, 1963).

- The United States and the Andean Republics: Peru, Bolivia, and Ecuador (Harvard University Press, 1977).

PINKER, Steven A. The Better Angels of Our Nature: Why Violence Has Declined (New York, NY: Viking, 2011).

PINKER, Steven A.; Bradley A. THAYER; Jack S. Levy and William R. THOMPSON. "The Forum: The Decline of War," International Studies Review, Vol. 15, No. 3 (September, 2013), pp. 396-419.

PION-BERLIN, David. "Sub-regional Cooperation, Hemispheric Threat: Security in the Southern Cone," in Regionalism and Governance in the Americas: Continental Drift, ed. by Louise FAWCETT and Mónica SERRANO (New York, NY: Palgrave Macmillan, 2005), pp. 211-227. 
Pivel Devoto, Juan E. Historia de los partidos políticos en el Uruguay (Montevideo: García \& Cía., 1942).

Pivel Devoto, Juan E. and Alcira RANiERI. Historia de la República Oriental del Uruguay (1830-1930) (Montevideo: Medina, 1966).

Pletcher, David M. The Awkward Years: American Foreign Relations Under Garfield and Arthur (University of Missouri Press, 1962).

Plesur, Milton. America's Outward Thrust: Approaches to Foreign Affairs, 1865-1890 (Northern Illinois University Press, 1971).

POMER, León. Cinco años de guerra civil en la Argentina (1865-1870) (Buenos Aires: Amorrortu, 1985).

- Conflictos e intervenciones extranjeras en la cuenca del Plata (1810-1890) (Buenos Aires: Instituto Superior Dr. Arturo Jauretche, 2012).

- La guerra del Paraguay: Estado, política y negocios (Buenos Aires: Colihue, 3rd ed., [1968] 2008).

PONS MuZzo, Gustavo. Historia del conflicto entre el Perú y España (1864-1866) (Lima: Iberia, 1966).

PORCELl, Luis A. Argentina y la guerra por el Chaco Boreal (Buenos Aires: Centro Editor América Latina, 1991).

PREUSS, Ori. Bridging the Island: Brazilians' Views of Spanish America and Themselves, 18651912 (Iberoamericana Vervuert, 2011).

Querejazu CAlvo, Roberto. Aclaraciones históricas sobre la guerra del Chaco (La Paz: Juventud, 1995).

. Aclaraciones históricas sobre la guerra del Pacífico (La Paz: Juventud, 1995).

—. Bolivia y los ingleses (1825-1948) (La Paz: Los Amigos del Libro, 1973).

—_. "El tratado de alianza defensivo perú-boliviano de 1873 y la misión de Serapio Reyes Ortiz de 1879," Historia y Cultura, Vol. 3 (1978), pp. 245-257.

- Guano, salitre, sangre: Historia de la guerra del Pacífico (la participación de Bolivia) (La Paz: GUM, 3rd ed., [1979] 1998).

—. Guerras del Pacífico y del Chaco, similitudes y diferencias (Cochabamba: Los Amigos del Libro, 1982).

- Masamaclay: Historia política, diplomática y militar de la guerra del Chaco (La Paz: GUM, 4th ed., [1965] 2008). 
RAMOS, Jorge A. Historia de la nación latinoamericana (Buenos Aires: Peña Lillo, 2011).

REAL DE AZÚA, Mario F. "La misión diplomática del peruano Manuel Corpancho, 1862-1863," Historia Mexicana, Vol. 28, No. 1 (julio-septiembre, 1978), pp. 62-81.

REBER, Vera B. “A Case of Total War: Paraguay, 1864-1870," Journal of Iberian and Latin American Studies, Vol. 5, No. 1 (July, 1999), pp. 15-40.

. "Comment on 'The Paraguayan Rosetta Stone'," Latin American Research Review, Vol. 37, No. 3 (2002), pp. 129-136.

. "Response to Whigham and Potthast," The Hispanic American Historical Review, Vol. 70, No. 4 (November, 1990), pp. 677-678.

. "The Demographics of Paraguay: A Reinterpretation of the Great War, 1864-70," The Hispanic American Historical Review, Vol. 68, No. 2 (May, 1988), pp. 289-319.

RESENDE-SANTOS, João. "Anarchy and the Emulation of Military Systems: Military Organization and Technology in South America, 1870-1930," in Realism: Restatements and Renewal, ed. by Benjamin FrANKEL (London: Frank Cass, 1996), pp. 193-260.

. Neorealism, States, and the Modern Mass Army (Cambridge University Press, 2007).

RESTREPO SALAZAR, Juan C. and Luis I. BETANCUR. Economía y conflicto colombo-peruano (Bogotá: Villegas, 2001).

RIART, Gustavo A. El Dr. Luis A. Riart y la defensa del Chaco (Asunción: Riart, 1987).

RIBAS MIRANDA, José A. "Peso da neutralidade: Varnhagen e o Governo Imperial ante a crise das ilhas Chincha (1864-1865)," Anais Eletrónicos do X Encontro Internacional da ANPHLAC, 2012, pp. 1-11.

RICHARD, Nicolas (ed.) Mala guerra: Los indígenas en la guerra del Chaco (1932-35) (Asunción and Paris: ServiLibro; CoLibris, 2008).

RiCHARD, Nicolas; Luc CAPDEVILA and Capucine BoIDIN (eds.). Les guerres du Paraguay aux XIXe et XXe siècles (Paris: CoLibris, 2005).

RICUPERO, Rubens. A diplomacia na construção do Brasil, 1750-2016 (Rio de Janeiro: Versal, 2017).

RIPPY, J. Fred. "Latin America and the Foreign Policy of the United States," Inter-American Economic Affairs, Vol. 2, No. 4 (Spring, 1949), pp. 69-73.

RIPSMAN, Norrin M. "Two Stages of Transition from a Region of War to a Region of Peace: Realist Transition and Liberal Endurance," International Studies Quarterly, Vol. 49, No. 4 (December, 2005), pp. 669-694.

RIVA AGÜERO, José de la. La unión perú-boliviana (Lima: El Inca, 1918). 
Rock, David. "Argentina Under Mitre: Porteño Liberalism in the 1860s,” The Americas, Vol. 56, No. 1 (July, 1999), pp. 31-63.

RoDAs EgUINO, Justo. La guerra del Chaco: Interpretación de política internacional americana (Buenos Aires: Bernabé, 1938).

RodrígueZ GonZÁLEZ, Agustín R. La campaña del Pacífico, 1862-1871 : España frente a Chile y Perú (Madrid: Real del Catorce, 2nd ed., [1999] 2016).

RosA, José M. La guerra del Paraguay y las montoneras argentinas (Buenos Aires: Punto de Encuentro, [1973] 2008).

Rout, Leslie B. Politics of the Chaco Peace Conference, 1935-1939 (The University of Texas Press, 1970).

RuIZ MorenO, Isidoro. "El tratado de paz del Chaco del 21 de julio de 1938," Historia Paraguaya, Vol. 38 (1998), pp. 179-191.

"La neutralidad argentina en la guerra del Chaco," Revista de la Universidad Nacional de Córdoba, Año XXI, No. 3/4 (mayo-junio, 1934), pp. 155-192.

SÁBATO, Hilda. "Arms and Republican Politics in Spanish America: The Critical 1860s," in American Civil Wars: The United States, Latin America, Europe, and the Crisis of the 1860s, ed. by Don H. DoYLE (The University of North Carolina Press, 2017), pp. 185-203.

. Buenos Aires en armas: La revolución de 1880 (Buenos Aires: Siglo XXI, 2008).

"La fuerza de las armas: Estado, guerra y revoluciones en la Argentina de la década de 1860," in El poder y la sangre: Guerra, estado y nación en la década de 1860, ed. by Guillermo PALACIOS and Érica PANI (México DF: El Colegio de México, 2014), pp. 259-277.

. Republics of the New World The Revolutionary Political Experiment in NineteenthCentury Latin America (Princeton University Press, 2018).

SÁENZA HAYES, Ricardo. Miguel Cané y su tempo (1851-1905) (Buenos Aires: Kraft, 1955).

SAGREDO BAEZA, Rafael. "Guerra y honor: Chile y Perú contra España (1864-1866)," in El poder y la sangre: Guerra, estado y nación en la década de 1860, ed. by Guillermo PALACIOS and Érica PANI (México DF: El Colegio de México, 2014), pp. 313-337.

SAlas Olivari, Miriam. El presupuesto, el estado y la nación en el Perú decimonónico y la corrupción institucionalizada, 1823-1879 (Lima: Instituto de Estudios HistóricoMarítimos del Perú, 2016).

- Historia marítima del Perú. Vol. 11(4): “La República: 1879 a 1883” (Lima: Instituto de Estudios Histórico-Marítimos del Perú, 2011). 
"Perú, Bolivia y Chile: En el trazado de sus respectivos estados, naciones y relaciones tripartitas, desde la fundación de las repúblicas al tiempo previo de la guerra del Pacífico, 1810-1879," in Ni vencedores ni vencidos: La guerra del Pacífico en perspectiva histórica, ed. by José CHAUPIS TORRES; Eduardo CAVIERES FIGUEROA and Juan ORTIZ BENITES (Lima: La Casa del Libro Viejo, 2016), pp. 25-50.

SALINAS VegA, Luis. "Tentativas de Chile en 1879 para separar a Bolivia de la alianza peruana," Revista Chilena, Año IV, Tomo X, No. 33 (julio, 1920), pp. 277-287.

SALLES, Ricardo. Guerra do Paraguai: Escravidão e cidadania na formação do exército (São Paulo: Paz e Terra, 1990).

. "La guerra de Paraguay, la cuestión servil y la cuestión nacional en Brasil," in Estado y nación en Chile y Brasil en el siglo XIX, ed. by Ana M. STUVEN and Marco A. VILlELA PAMPLONA (Santiago: Ediciones Universidad Católica de Chile, 2009), pp. $113-138$.

SÁNCHEZ ANDRÉS, Agustín. "La intervención española en el Pacífico Sur en el contexto de la política latinoamericana de España, 1863-1866," in El poder y la sangre: Guerra, estado y nación en la década de 1860, ed. by Guillermo PALACIOS and Érica PANI (México DF: El Colegio de México, 2014), pp. 339-364.

SÁNCHEZ NiETO, W. Alejandro. "Whatever Happened to South America's Splendid Little Wars?" Small Wars \& Insurgencies, Vol. 22, No. 2 (May, 2011), pp. 322-351.

SANTA MARÍA, Ignacio. “Chile y Argentina en 1864,” Revista Chilena, Año V, Tomo XIII, No. 46 (octubre, 1921), pp. 5-32.

“Chile y Argentina en 1864," Revista Chilena, Año V, Tomo XIII, No. 47 (noviembre, 1921), pp. 113-128.

SANTOS NeUmANN, Eduardo and Luiz A. GRIJÓ (org.). O continente em armas: Uma história da guerra no sul do Brasil (Rio de Janeiro: Apicuri, 2010).

SANZ, Luis S. "La historia diplomática desde la presidencia de Mitre, 1862, hasta 1930," in Historia argentina contemporánea, 1862-1930. Vol. 2: "Historia de las instituciones y la cultura: Primera sección” (Buenos Aires: El Ateneo, 1964), pp. 293-359.

SARMIENTO, Domingo F. Facundo; o civilización i barbarie en las pampas arjentinas (Buenos Aires: [n/d], 4th ed., [1845] 1868).

SATER, William F. Andean Tragedy: Fighting the War of the Pacific, 1879-1884 (University of Nebraska Press, 2007).

- Chile and the United States: Empires in Conflict (University of Georgia Press, 1991).

- Chile and the War of the Pacific (University of Nebraska Press, 1986). 
. The Heroic Image in Chile: Arturo Prat, Secular Saint (University of California Press, 1973).

SCAVONE Yegros, Ricardo. Después de la guerra: Las relaciones paraguayo-bolivianas desde el Tratado de Paz hasta 1952 (Asunción: ServiLibro, 2013).

- Las relaciones entre el Paraguay y Bolivia en el siglo XIX (Asunción: ServiLibro, 2004).

SCHEINA, Robert L. Latin America: A Naval History, 1810-1987 (Annapolis, MD: Naval Institute Press, 1987).

. Latin America's Wars (Dulles, vA: Brassey 2003). 2 vols.

SchMitT, Peter A. Paraguay y Europa, 1811-1870 (Asunción: 2nd ed., [1963] 1990).

Schouenborg, Laust. The Scandinavian International Society: Primary Institutions and Binding Forces, 1815-2010 (New York, NY: Routledge, 2014).

SCHULZ, Carsten-Andreas. "Civilisation, Barbarism and the Making of Latin America's Place in 19th-Century International Society," Millennium, Vol. 42, No. 3 (2014), pp. 837-859.

SCHWELLER, Randall L. Unanswered Threats: Political Constraints on the Balance of Power (Cornell University Press, 2006).

SECADA, Alexander G. de. "Arms, Guano, and Shipping: The W. R. Grace Interests in Peru, 1865-1885,” Business History Review, Vol. 59, No. 4 (Winter, 1985), pp. 597-621.

SECKINGER, Ron L. "South American Power Politics during the 1820s," The Hispanic American Historical Review, Vol. 56, No. 2 (March, 1976), pp. 241-267.

- The Brazilian Monarchy and the South American Republics, 1822-1831: Diplomacy and State Building (Louisiana State University Press, 1984).

SEIFERHELD, Alfredo M. Economía y petróleo durante la guerra del Chaco: Apuntes para una historia económica del conflicto paraguayo-boliviano (Asunción: El Lector, 1983).

—. Estigarribia, veinte años de política paraguaya (Asunción: Laurel, 1983).

SHESKO, Elizabeth. "Mobilizing Manpower for War: Toward a New History of Bolivia's Chaco Conflict, 1932-1935," The Hispanic American Historical Review, Vol. 95, No. 2 (May, 2015), pp. 299-334.

SICKER, Martin. The Geopolitics of Security in the America: Hemispheric Denial from Monroe to Clinton (Praeger, 2002).

SiLes GuevarA, Juan. "Juan de la Cruz Benavente y la participación de Bolivia en la Cuádruple Alianza contra España de 1866," in Revisiones Bolivianas (La Paz: Camarlinghi, 1969), pp. 77-101. 
. "La última misión diplomática chilena y el comienzo de la guerra del Pacífico," Anales de la Academia Boliviana de la Historia, 1973-1979 (La Paz: Academia Boliviana de la Historia, 1980), pp. 250-267.

SiNN BRUNO, Juan E. La política americanista de Chile y la guerra con España, 1864-1866 (Santiago: Editorial Universitaria, 1960).

SMALl, Melvyn and David J. Singer. Resort to Arms: International and Civil Wars, 1816-1980 (Beverly Hills: Sage, 1982).

SMITH, Geoffrey. "The Role of José M. Balmaceda in Preserving Argentina Neutrality in the War of the Pacific," The Hispanic American Historical Review, Vol. 49, No. 2 (May, 1969), pp. 254-267.

SMith, Joseph. Illusions of Conflict: Anglo-American Diplomacy Toward Latin America, 18651896 (University of Pittsburgh Press, 1979).

SOARES, Álvaro Teixeira. Diplomacia do Império no Rio da Prata (até 1865) (Rio de Janeiro: Editôra Brand, 1955).

—. O drama da Tríplice Aliança (1865-1876) (Rio de Janeiro: Editôra Brand, 1956).

SOBREVILlA PEREA, Natalia. "Conflicto regional, guano y poder," in Más allá de la dominación y la resistencia: Estudios de historia peruana, siglos XVI-XX, ed. by Paulo DRINOT and Leo GARÓFALO (Lima: Instituto de Estudios Peruanos, 2005), pp. 181-214.

—. The Caudillo of the Andes: Andrés de Santa Cruz (Cambridge University Press, 2011).

ST. JoHn, Ronald B. "Hacia el mar: Bolivia's Quest for a Pacific Port," Inter-American Economic Affairs, Vol. 31, No. 3 (Winter, 1977), pp. 41-73.

—. La política exterior de Perú (Lima: Asociación de Funcionarios del Servicio Diplomático del Perú, 1999).

—. "Same Space, Different Dreams: Bolivia's Quest for a Pacific Port," The Bolivian Research Review, Vol. 1, No. 1 (July, 2001), pp. 1-21.

STRAUSS, Norman T. "Brazil after the Paraguayan War: Six Years of Conflict, 1870-6," Journal of Latin American Studies, Vol. 10, No. 1 (May, 1978), pp. 21-35.

SUÁREZ, José L. Diplomacia universitaria americana: Argentina en el Brasil (Buenos Aires: Escoffier, Caracciolo, 1918).

SvAmPA, Maristella. Civilización y barbarie: El dilema argentino (Buenos Aires: Taurus, 2010).

TASSO Fragoso, Augusto. "A paz com o Paraguai despois da guerra da Tríplice Aliança," Revista do Instituto Histórico e Geográfico Brasileiro, Vol. 174 (1939), pp. 1-334. 
- História da guerra entre a Tríplice Aliança e o Paraguai (Rio de Janeiro/São Paulo: Freitas Bastos, 2nd ed., [1934] 1956-1960). 5 vols.

TATE, Edward N. "Britain and Latin America in the Nineteenth Century: The Case of Paraguay, 1811-1870," Ibero-Americanisches Archiv, Neue Folge, Vol. 5, No. 1 (1979), pp. 39 70.

TERÁN GÓMEZ, Luis. Bolivia frente a los pueblos del Plata (La Paz: Arnó, 1936).

TERRADAS, Nicolás. “The 'Long Peace' in Latin America: Transcending the Security Dilemma?" paper presented at the CLAS Tri-University Graduate Student Conference, Miami (March, 2018).

—_. "The Quest for Order in Anarchical Societies: Anthropological Investigations," International Studies Review [forthcoming]. https://doi.org/10.1093/isr/viy078.

THIES, Cameron. "Public Violence and State Building in Central America," Comparative Political Studies, Vol. 39, No. 10 (December, 2006), pp. 1263-1282.

. "The Construction of a Latin American Interstate Culture of Rivalry," International Interactions, Vol. 34, No. 3 (2008), pp. 231-257.

"War, Rivalry, and State Building in Latin America," American Journal of Political Science, Vol. 29, No. 3 (July, 2005), pp. 451-465.

TiCKNer, Arlene B. and Mônica Herz. "No Place for Theory? Security Studies in Latin America," in Thinking International Relations Differently, ed. by Arlene B. TICKNER and David L. BLANEY (New York, NY: Routledge, 2012), pp. 92-114.

TILLY, Charles. Coercion, Capital, and European States, AD 990-1992 (Oxford: WileyBlackwell, rev. and enlarged ed., [1990] 1992).

"International Communities, Secure or Otherwise," in Security Communities, ed. by Emanuel ADLER and Michael N. BARNETT (Cambridge University Press, 1998), pp. $397-412$.

. "States, State Transformation, and War," in The Oxford Handbook of World History, ed. by Jerry H. BENTLY (Oxford University Press, 2011), pp. 176-194.

. "War Making and State Making as Organized Crime," in Bringing the State Back In, ed. by Peter B. Evans, Dietrich RueschenMEYER, and Theda SKOCPOL (Cambridge University Press, 1985), pp. 169-191.

TILly, Charles (ed.). The Formation of National States in Western Europe (Princeton University Press, 1975).

TJARKS, Germán O. "Nueva luz sobre el origen de la guerra de la Triple Alianza," Revista de Historia [Costa Rica], Vol. 1, No. 1 (1975), pp. 21-84. 
TORO JIMÉNEZ, Fermín. Una misión diplomática en Venezuela, 1866 (Caracas: Facultad de Derecho, Universidad Central de Venezuela, 1971).

TORRE REYes, Carlos de la. Piedrahita, un emigrado de su tiempo (Quito: Casa de la Cultura Ecuatoriana, 1968).

Townshend, Charles (ed.), The Oxford Modern History of War (Oxford University Press, 2nd ed., [1997] 2005).

TREVERTON, Gregory F. "Interstate Conflict in Latin America," in The United States and Latin America in the 1980s, ed. by Kevin J. MIDDLEBROOK and Carlos RICO (University of Pittsburgh Press, 1986), pp. 565-590.

TRILlo AUQUI, Gerardo. "Buenos Aires y la guerra del Pacífico: Actores subalternos en la ocupación de Lima," Diálogo Andino, No. 48 (2015), pp. 55-64.

TRUE, Jacqui. “Are War and Violence Really in Decline?” Australian Journal of International Affairs, Vol. 68, No. 5 (2014), pp. 487-494.

TYLER, Alice F. The Foreign Policy of James G. Blaine (Hamden, CT: Archon Books, 1965).

VALLADÃO, Alfredo. Brasil e Chile na época do Império, amizade sem exemplo (Rio de Janeiro: Olympio, 1959).

VAN AKEN, Mark J. King of the Night: Juan José Flores and Ecuador: 1824-1864 (University of California Press, 1989).

VAn EverA, Stephen. Guide to Methods for Students of Political Science (Cornell University Press, 1997).

VARAS VelÁSQUEZ, Miguel. “El Congreso Americano celebrado en Lima en 1864,” Revista Chilena de Historia y Geografía, Año XI, Tomo XXXVII, No. 42 (2º trimestre, 1921), pp. $72-100$.

- "Un capítulo de la historia de la guerra con España, 1864-1866," Revista Chilena de Historia y Geografía, Año X, Tomo XXXIII, No. 37 (1º trimestre, 1920), pp. 173-202.

VARgas Ugarte, Rubén. Historia general de la guerra del Pacífico. Vol. 1: "La cuestión del salitre: La guerra naval y la campaña del sur” (Lima: Milla Batres, 1979).

- Historia general de la guerra del Pacífico. Vol. 2: "La toma de Lima y la campaña de la Breña” (Lima: Milla Batres, 1979).

VÁZQUEZ-MACHICADO, Humberto. "James G. Blaine y la guerra del Pacífico," in Obras completas de Humberto Vázquez-Machicado y José Vázquez-Machicado. Vol. VII (La Paz: Don Bosco, 1988), pp. 281-288. 
- "Para una historia de los límites entre Bolivia y el Brasil," in Obras completas de Humberto Vázquez-Machicado y José Vázquez-Machicado. Vol. I (La Paz: Don Bosco, 1988), pp. 1-490.

. “Melgarejo y la Triple Alianza," Revista Khana, Vol. 4/5, No. 21/24 (1956-1957), pp. $226-231$.

. "Un litigio de fronteras en la América del Sud: Bolivia-Paraguay," in Obras completas de Humberto Vázquez-Machicado y José Vázquez-Machicado. Vol. VII (La Paz: Don Bosco, 1988), pp. 167-237.

VÁZQUEZ-MACHICADO, José. "La diplomacia boliviana y la tragedia de Maximiliano en México: Una gestión generosa de Melgarejo ante Juárez," in Obras completas de Humberto Vázquez-Machicado y José Vázquez-Machicado. Vol. VII (La Paz: Don Bosco, 1988), pp. 723-746.

Vergara Vicuña, Aquiles. Historia de la guerra del Chaco (La Paz: Imprentas Unidas, 19401944). 7 vols.

VICTORICA, Julio. “Los Estados Unidos y el Paraguay: Mediación argentina en 1859," Revista de Derecho, Historia y Letras, Año III, Tomo VII (1900), pp. 365-379.

. "Reminiscencias históricas: El General Urquiza, los Estados Unidos y el Paraguay," Revista de Derecho, Historia y Letras, Año II, Tomo VI (1900), pp. 389-402.

- "Reminiscencias históricas: Origen de la guerra con el Paraguay," Revista de Derecho, Historia y Letras, Año II, Tomo VI (1900), pp. 167-182.

Vicuña Mackenna, Benjamín. Diez meses de misión a los Estados Unidos de Norte América como ajente confidencial de Chile (Santiago: Imprenta de la Libertad, 1867). 2 vols.

- Historia de la guerra de Chile con España (de 1863 a 1866) (Santiago: Victoria, 1883).

—. Historia de la campaña de Tacna y Arica, 1879-1880 (Santiago: Rafael Jover, 1881).

—. Historia de la campaña de Tarapacá (Santiago: Rafael Jover, 1880). 2 vols.

—. Historia de la campaña de Lima, 1880-1881 (Santiago: Rafael Jover, 1881).

VIDAURRETA, Alicia. “Alberdi y el Paraguay: su amistad con Gregorio Benítez," Revista Histórica [Buenos Aires], Vol. 3, No. 9 (julio-diciembre, 1981), pp. 161-218.

“Al margen de la guerra del Paraguay," Trabajos y Comunicaciones, Vol. 18 (1968), pp. $243-261$.

- "Conflictos entre política y grupos de presión: Argentina y los aliados del Pacífico, 1872-1883," Revista de Historia de América, No. 105 (enero-junio, 1988), pp. 7-44. 
. "La Argentina y la guerra del Pacífico," Revista de Indias, Vol. XLV, No. 175 (enerojunio, 1985), pp. 111-159.

VILABOY, Sergio G. "La dramática historia de la guerra del Pacífico (1879-1883) y de sus consecuencias para Bolivia," Revista Izquierdas, No. 15 (abril, 2013), pp. 193-213.

- Paraguay: De la independencia a la dominación imperialista, 1811-1870 (La Habana: Editorial de Ciencias Sociales, 1984).

VILlACRÉS Moscoso, Jorge W. Historia diplomática de la República del Ecuador (Guayaquil: Programa Editorial de la Biblioteca de la Muy Ilustre Municipalidad de Guayaquil, 3rd ed., [1989] 2007).

- "El rol del Ecuador en el ofrecimiento de la mediación de la cuádruple alianza de la guerra entre el Paraguay y la Triple Alianza," Boletín de la Academia Nacional de Historia, Vol. 51, No. 112 (julio-diciembre, 1968), pp. 200-208.

. "La posición del Ecuador en el seno del Congreso Americano de 1864," Revista de la Universidad de Guayaquil, Vol. 7, No. 4 (enero-diciembre, 1965), pp. 19-45.

VILlafañe Gomes SANTOS, Luís C. "A missão especial nas repúblicas do Pacífico e Venezuela,” Textos de História, Vol. 2, No. 3 (março, 1994), pp. 123-147.

"As consequências da guerra da Tríplice Aliança na definição da identidade brasileira," Militares e Política, No. 3 (julho-dezembro, 2008), pp. 42-58.

. "Brasil: Americano, Latino-Americano ou Sul-Americano?" Cuadernos del CLAEH, Año 28, Vol. 1, No. 90 (2 $2^{\text {a }}$ serie, 2005), pp. 87-107.

. "Do estadista ao diplomata: As instruções da missão especial nas repúblicas do Pacífico e na Venezuela," Cadernos do Centro de História e Documentação Diplomática, Fundação Alexandre de Gusmão, Ano III, No. 5 (2ºmestre, 2004), pp. 431-453.

- "Duarte da Ponte Ribeiro - O fronteiro-mor do Império," Revista do Instituto Histórico e Geográfico Brasileiro, Ano 174, No. 461 (outubro-dezembro, 2013), pp. 449-460.

. Duarte da Ponte Ribeiro: Pionero de la diplomacia y amistad entre Brasil y Perú (Lima: Embajada de Brasil, 2012).

. "Identities in the Empire of Brazil: Constructing the Other," in Explorations on Subjectivity, Borders, and Demarcation: A Fine Line, ed. by Raúl A. GALOPPE and Richard WeINER (Lanham, MD: University Press of America, 2005), pp. 25-46.

- O Brasil entre a América e a Europa: O Império e o interamericanismo (do Congresso do Panamá à Conferência de Washington) (São Paulo: Editora UFPR, 2003). 
. “O Império Brasileiro e as repúblicas do Pacífico, 1822-1889," Revista Cena Internacional, Vol. 3, No. 2 (2001), pp. 133-152.

. "O Império Brasileiro: Guerras e nacionalismo," Prohistoria, Año 7, No. 7 (2003), pp. $87-106$.

- O Império e as repúblicas do Pacífico: As relações do Brasil com Chile, Bolívia, Peru, Equador e Colômbia (1822-1889) (Curitiba: Editora UFPR, 2002).

—. "Varnhagen e a América do Sul," in Varnhagen (1816-1878): Diplomacia e pensamento estratégico, ed. by Sérgio E. Moreira Lima (Brasília: Fundação Alexandre de Gusmão, 2016), pp. 199-242.

VINCENT, R. John. Human Rights and International Relations (Cambridge University Press, 1986).

. Nonintervention and International Order (Princeton University Press, 1974).

VIRREIRA PACCIERI, Alberto. Bolivia-Paraguay, 5 de diciembre de 1928: Datos para la historia diplomática (La Paz: Eléctrica, 1932).

VON VERSEN, Max. "História da guerra do Paraguai e episódios da viagem na América do Sul," Revista do Instituto Histórico e Geographico Brasileiro, Tomo LXXVII, Parte II (1913), pp. 5-270.

WADDELL, David A. G. "International Politics and Latin American Independence," in The Cambridge History of Latin America. Vol. 3: “From Independence to c. 1870," ed. by Leslie BETHELl (Cambridge University Press, 1985), pp. 197-228.

Wagner de ReYnA, Alberto. Historia diplomática del Perú, 1900-1945 (Lima: Ediciones Peruanas, 1964). 2 vols.

- Historia marítima del Perú. Vol. 7: La intervención de las potencias europeas en Latinoamérica, 1864 a 1868 (Lima: Instituto de Estudios Histórico-Marítimos del Perú, 4th ed., [1975] 1981).

. "La misión de Manuel Montt y el Congreso de Lima de 1864," Anales de la Universidad de Chile, Año 116, No. 109-110 (enero-junio, 1958), pp. 440-479.

- "La misión Martínez ante el gobierno de Pezet (mayo-octubre de 1865)," Revista Histórica [Lima], Vol. 20 (1953), pp. 326-338.

- "La misión Santa María en el Perú (octubre 1865-enero 1866)," Apartado del Boletín de la Academia Chilena de la Historia (Santiago: Imprenta Universitaria, 1952), pp. $1-48$.

- "La ocupación de las islas de Chincha y las relaciones chileno-peruanas," Boletín de la Academia Chilena de la Historia, Vol. 17, No. 50 (1954), pp. 5-70. 
- Las relaciones diplomáticas entre el Perú y Chile durante el conflicto con España, 1864-1867 (Lima: Sol, 1963).

—. Los límites del Perú (Lima: Sol, 2nd ed., [1961] 1962).

WALDNER, David. "Process Tracing and Qualitative Causal Inference," Security Studies, Vol. 24, No. 2 (2015), pp. 239-250.

"What Makes Process Tracing Good? Causal Mechanisms, Causal Inference, and the Completeness Standard in Comparative Politics," in Process Tracing: From Metaphor to Analytic Tool, ed. by Andrew BENNETT and Jeffrey T. CHECKEL (Cambridge University Press, 2015), pp. 126-152.

WALTZ, Kenneth N. Theory of International Politics (Reading, MA: Addison-Wesley, 1979).

WARREN, Harris G. Paraguay and the Triple Alliance: The Postwar Decade, 1869-1878 (University of Texas Press, 1978).

WATson, Adam. Diplomacy: The Dialogue Between States (Routledge, 1983).

"New States in the Americas," in The Expansion of International Society, ed. by Hedley BULL and Adam WATSON (Oxford: Clarendon Press, 1984), pp. 127-141.

- The Evolution of International Society: A Comparative Historical Analysis (New York, NY: Routledge, 1992).

. The Limits of Independence: Relations Between States in the Modern World (Routledge, 1997).

__ "Systems of States," Review of International Studies, Vol. 16, No. 2 (1990), pp. 99109.

WeISIGER, Alex. Logics of War: Explanations for Limited and Unlimited Conflicts (Cornell University Press, 2013).

WendT, Alexander. Social Theory of International Politics (Cambridge University Press, 1999).

"Why a World State is Inevitable," European Journal of International Relations, Vol. 9, No. 4 (2003), pp. 491-542.

WeRnECK DA Silva, José L. As duas faces da moeda: A política externa do Brasil monárquico (1831-1876) (Rio de Janeiro: Universidade Aberta, 1990).

WHEELER, Nicholas J. Saving Strangers: Humanitarian Intervention in International Society (Oxford University Press, 2000).

WHIGHAM, Thomas L. "Aspectos claves de la larga resistencia paraguaya: Disciplina militar, cohesión burocrática, y la ego manía indomada del Mariscal López," in A 150 años de 
la guerra de la Triple Alianza contra el Paraguay, ed. by Juan C. GARAVAGLIA and Raúl O. FrADKIN (Buenos Aires: Prometeo, 2016), pp. 11-52.

"Brazil's 'Balloon Corps': Pride, Desperation, and the Limits of Military Intelligence in the Triple Alliance War," Luso-Brazilian Review, Vol. 52, No. 2 (2015), pp. 1-18.

La guerra de la Triple Alianza (Asunción: Taurus, 2010-2012). 3 vols.

"Protesta, desilusión y primeras tentativas de lograr la paz: La crítica a la Triple Alianza (1866)," in Paraguay en la historia, la literatura y la memoria: Actas de las II Jornadas Internacionales de Historia del Paraguay en la Universidad de Montevideo, ed. by Juan M. CASAL and Thomas L. WHIGHAM (Asunción: Editorial Tiempo de Historia and Universidad de Montevideo, 2011), pp. 239-249.

"Silva Paranhos and the Construction of a Post-Lopista Paraguay," Journal of Iberian and Latin American Studies, Vol. 21, No. 3 (2015), pp. 221-241.

The Paraguayan War: Causes and Early Conduct (University of Calgary Press, 2nd ed., [2002] 2018).

. "The Paraguayan War: A Catalyst for Nationalism in South America," in I Die with My Country: Perspectives on the Paraguayan War, 1864-1870, ed. by Hendrik KRAAY and Thomas L. WHIGHAM (University of Nebraska Press, 2004), pp. 178-198.

. The Politics of River Trade: Tradition and Development in the Upper Plata, 17801870 (University of New Mexico Press, 1991).

. The Road to Armageddon: Paraguay versus the Triple Alliance, 1866-70 (University of Calgary Press, 2017).

Whigham, Thomas L. and Barbara POTTHAST. "Refining the Numbers: A Response to Reber and Kleinpenning," Latin American Research Review, Vol. 37, No. 3 (2002), pp. 143-148.

- "Some Strong Reservations: A Critique of Vera Blinn Reber's 'The Demographics of Paraguay: A Reinterpretation of the Great War, 1864-70'," The Hispanic American Historical Review, Vol. 70, No. 4 (November, 1990), pp. 667-675.

"The Paraguayan Rosetta Stone: New Insights into the Demographics of the Paraguayan War, 1864-1870," Latin American Research Review, Vol. 34, No. 1 (1999), pp. 174-186.

WIGHT, Martin. Systems of States (Leicester University Press, 1977).

"Western Values in International Relations," in Diplomatic Investigations: Essays in the Theory of International Politics, ed. by Herbert BUTTERFIELD and Martin WIGHT (Harvard University Press, 1966), pp. 102-104.

Wilgus, A. Curtis. "James G. Blaine and the Pan American Movement," The Hispanic American Historical Review, Vol. 5, No. 4 (November, 1922), pp. 662-708. 
Williams, John H. “A Swamp of Blood: The Battle of Tuyutí," Military History, Vol. 17, No. 1 (April, 2000), pp. 58-64.

. "Foreign Técnicos and the Modernization of Paraguay, 1840-1870," Journal of Interamerican Studies and World Affairs, Vol. 19, No. 2 (May, 1977), pp. 233-257.

- The Rise and Fall of the Paraguayan Republic, 1800-1870 (University of Texas Press, 1979).

WILson, Joe F. The United States, Chile and Peru in the Tacna and Arica Plebiscite (Washington, DC: University Press of America, 1979).

WooD, Bryce. Aggression and History: The Case of Ecuador and Peru (UMI, 1978).

—. The Dismantling of the Good Neighbor Policy (University of Texas Press, 1985).

—. The Making of the Good Neighbor Policy (Columbia University Press, 1961).

—. The United States and Latin American Wars, 1932-1942 (Columbia University Press, 1966).

Woods, David J. The Bombardment of Paradise (Geneva: WTA Publishing, 2011).

YePES, Jesús M. Del Congreso de Panamá a la Conferencia de Caracas, 1826-1954: El genio de Bolívar a través de la historia de las relaciones interamericanas (Caracas: Cromotip, 1955). 2 vols.

—. El Panamericanismo y el derecho internacional (Bogotá: Imprenta Nacional, 1930).

YNSFRÁN, Pablo M. La expedición norteamericana contra el Paraguay, 1858-1859 (Buenos Aires: Guarania, 1954). 2 vols.

_. "Sam Ward's Bargain with President Lopez of Paraguay," The Hispanic American Historical Review, Vol. 34, No. 3 (August, 1954), pp. 313-331.

ZooK, David H. The Conduct of the Chaco War (New York, NY: Bookman, 1960).

. Zarumilla-Marañón: The Ecuador-Peru Dispute (Bookman, 1964).

ZuletA, María C. Los extremos de Hispanoamérica: Relaciones, conflictos y armonías entre México y el Cono Sur, 1821-1990 (México DF: Secretaría de Relaciones Exteriores, 2008).

. "Los primeros años de YPFB y las encrucijadas de la industria petrolera boliviana en sus orígenes, 1936-1945. Notas preliminares," H-industri@, Año 5, No. 8 (1 ${ }^{\circ}$ semestre, 2011), pp. 1-24. 
NICOLÁS TERRADAS

Born in Olavarría, Buenos Aires, Argentina

2002-2007

B.A., International Relations

UNICEN

Tandil, Buenos Aires, Argentina

2007-2010

M.A., International Studies

Torcuato Di Tella University

Buenos Aires, Argentina

2011-2013

M.A., International Studies

Florida International University

Miami, Florida, United States of America

2011-2018

$\mathrm{Ph}$.D. Candidate, International Relations

Florida International University

Miami, Florida, United States of America

2011-2013

Fulbright Scholar

U.S. Dept. of State; Fulbright Commission Argentina

2013-2017

Teaching Assistant

Department of Politics and International Relations

School of International and Public Affairs

Florida International University

2018-2019

Teaching Fellow

Honors College, Florida International University

\section{PUBLICATIONS AND PRESENTATIONS}

"The Quest for Order in Anarchical Societies: Anthropological Investigations," International Studies Review [forthcoming].

"From Burr to Bull to Bulwark against Empire: Rethinking the Balance of Power in Nineteenth Century South America, 1864-1884."

- ISA’s 60th Annual Convention, March 28, 2019, Toronto, Canada.

"In the National Interest: An English School Approach to Foreign Policy" (with Onur Erpul).

- ISA's 59th Annual Convention, April 4, 2018, San Francisco, California, U.S.A.

"The Role of 'Diplomatic Culture' in the Creation and Maintenance of Regional Order." - ISA's 59th Annual Convention, April 4, 2018, San Francisco, California, U.S.A. 